; 


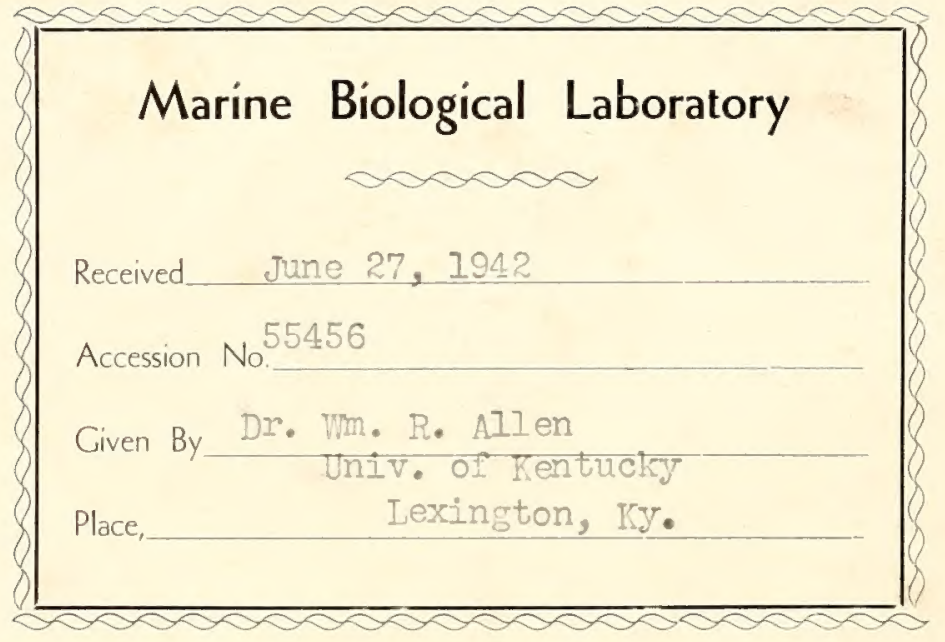




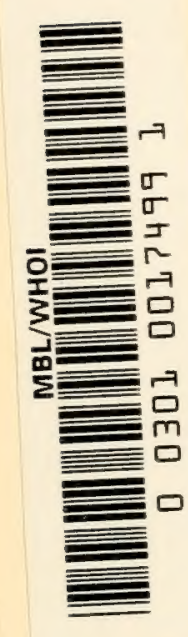



CELEBRATING THE SEVENTY-FIFTH ANNIVERSARY OF THE UNIVERSITY OF KENTUCKY AND HONORING THE PRESIDENTS WHO HAVE SERVED THE UNIVERSITY FOR THREE-QUARTERS OF A CENTURY

$\begin{array}{ll}\text { JOHN AUGUSTUS WILLIAMS } & 1866-1867 \\ \text { JOSEPH DESHA PICKETT } & 1867-1869 \\ \text { JAMES KENNEDY PATTERSON } & 1869-1910 \\ \text { JAMES GARRARD WHITE acting. } & 1910 \\ \text { HENRY STITES BARKER } & 1910-1917 \\ \text { PAUL PRENTICE BOYD acting } & 1917 \\ \text { FRANK LEROND MCVEY } & 1917-1940 \\ \text { THOMAS POE COOPER acting } & 1940-1941 \\ \text { HERMAN LEE DONOVAN } & 1941-\end{array}$

THIS BOOK IS PUBLISHED UNDER A GRANT FROM THE MARGARET VOORHIES HAGGIN TRUST ESTABLISHED IN MEMORY OF HER HUSBAND JAMES BEN ALI HAGGIN 




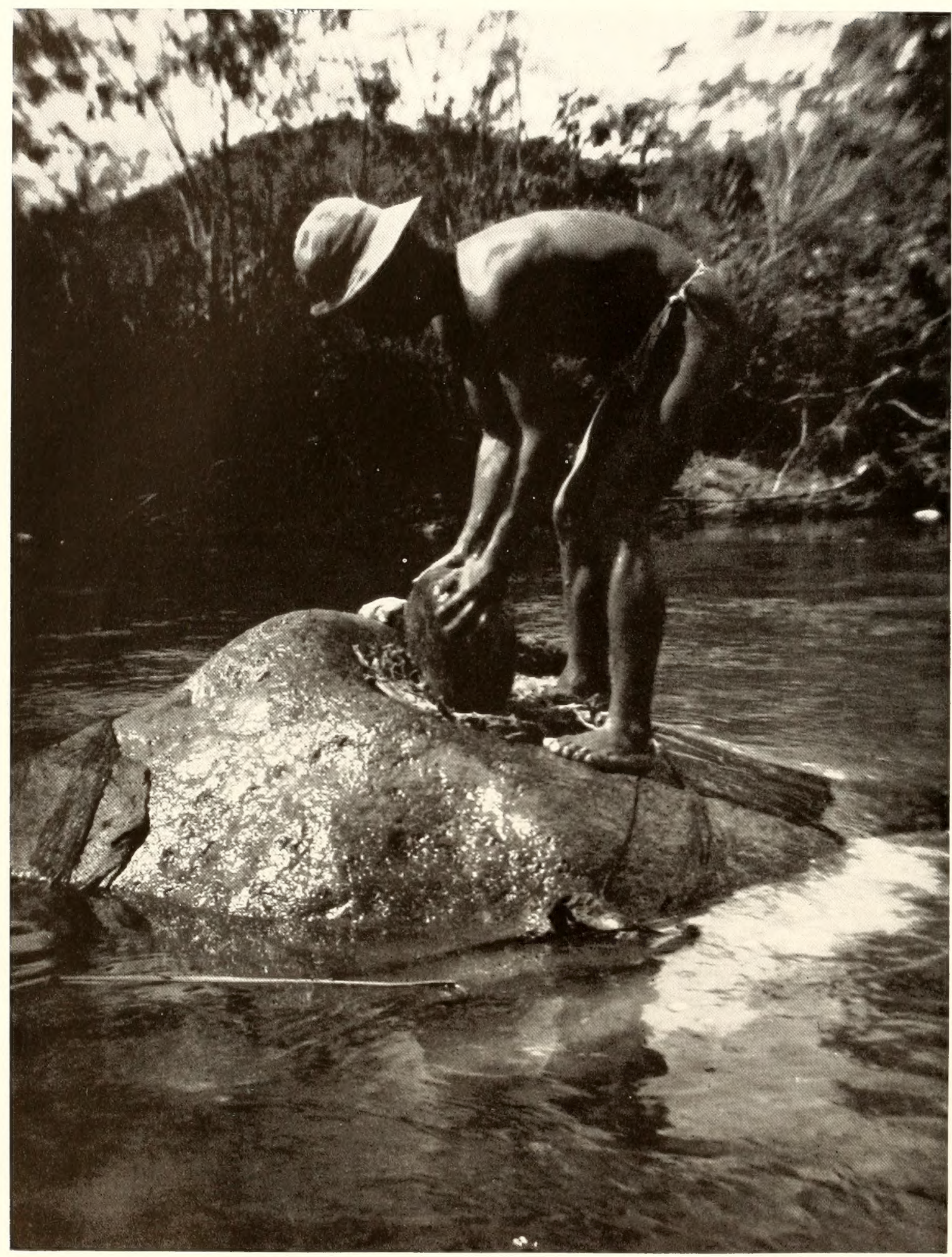

PLATE I

Poisoning the Rio Chanchomayo for Fish, Using the Root of Cube

This small channel of the river has been partially cut off by a rough rock-and-branch dam to reduce the flow, then the root is bruised between rocks, and the alkaloid sap washed out into the water, giving it the milky appearance seen in the photograph. 


\title{
FISHES
}

$\mathrm{OF}$

\section{WESTERN SOUTH AMERICA}

I. The Intercordilleran and Amazonian Lowlands of Peru

II. The High Pampas of Peru, Bolivia, and Northern Chile

With a Revision of the Peruvian Gymnotidae, and of the Genus ORESTIAS

\author{
CARL H. RIGENMANN \\ Late Dean of the Graduate School, and Professor of Zoology, \\ Indiana University \\ WILLIAM RAY ALLEN \\ Professor of Zoology, \\ University of Kentucky
}

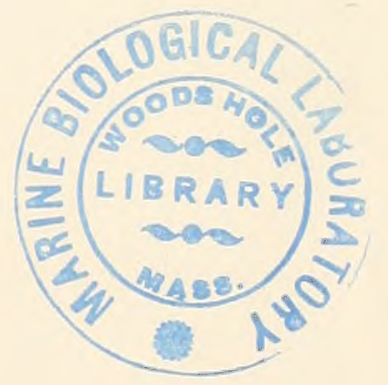

1942

THE UNIVERSITY OF KENTUCKY 
Copyright 1942

BY UNIVERSITY OF KENTUCKY

Composed and Phinted at the

WAVERLY PRESS, INC.

Baltimore, Mo., U. S. A. 


\section{TABLE OF CONTENTS}

LIST OF ILLUSTRATIONS. . . . . . . . . . . . . . . . . . . .

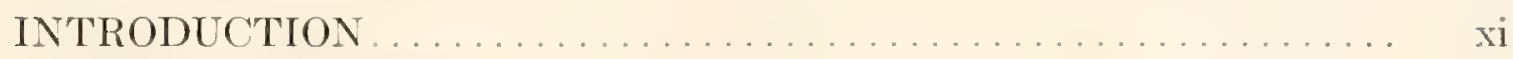

ACKNOWLEDG

NARRATIVE OF THE EXPEDITIONS .................. 1

Chronologi and Itinerart . . . . . . . . . . . . . . . . . . 10

HISTORY OF ICHTHYOLOGICAL EXPLORATION IN PERU ...... 18

THE INLAND FISHERIE

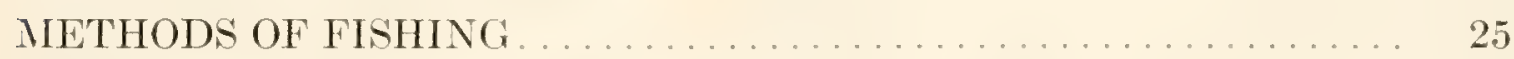

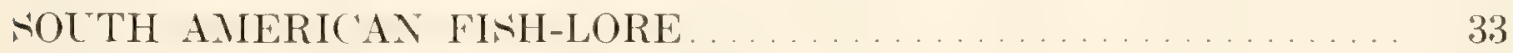

DISTRIBT TION OF THE FISHEN . . . . . . . $\ldots \ldots \ldots \ldots \ldots \ldots \ldots \ldots \ldots$

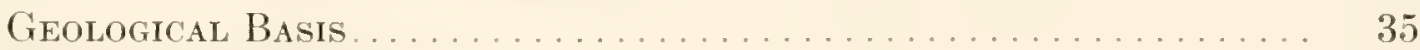

Geographic Regions............................. 38

Faunal Lists of Principal River firsteais. . . . . . . . . . . . . . . . 43

Distribution Tables............................. 53

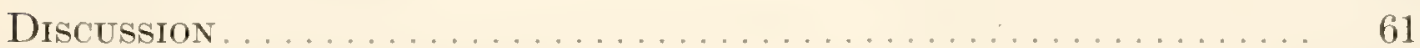

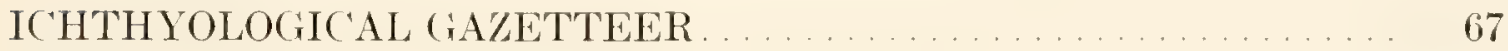

ANNOTATED LIST OF THE SPECIES . . . . . . . . . . . . . 82

A Review of the Literature and Lore of the Candirú. . . . . . . . 142

A Revien of the Literature and Lore of the Piranhas. . . . . . . . 242

A Revision of the Peruvian Grmnotidae . . . . . . . . . . . . . . 312

An Account of the Paiche, Arapaima ................... 336

Revision of the (ienus Orestial . . . . . . . . . . . . . . . . . . . 346

Mimicry. . . . . . . . . . . . . . . . . . . . . . . . . . 384

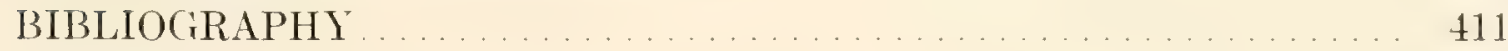

PLATES . . . . . . . . . . . . . . . . . . . . . . 431

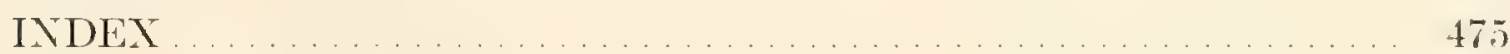

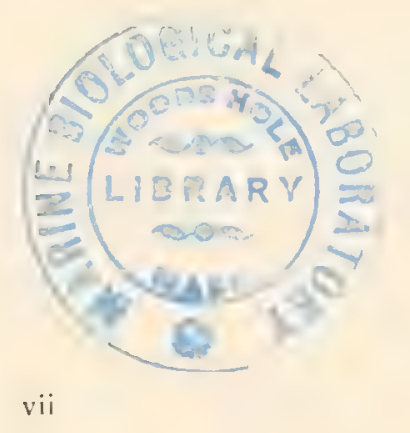

55456 


\section{LIST OF ILLUSTRATIONS}

Fig. 1. The Van of the Fishing Fleet ..................... 3

Fig. 2. The Fishing Fleet, Lake Titicaca .................... 4

Fig. 3. The Upper R. Mantaro . . . . . . . . . . . . . . . . . . . . . 6

Fig. 4. Dynamiting the R. Molino ...................... 8

Fig. 5. Marketing Orestias, Puno ....................... 9

Fig. 6. The upper R. Poopó . . . . . . . . . . . . . . . . . . . . 12

Fig. 7. L. Poopó, Bolivia .......................... 14

Fig. 8. L. Ascotan, Chile, with V. Ollagïe ................ 16

Fig. 9. R. Loa, Chile . . . . . . . . . . . . . . . . . . . . . 21

Fig. 10. The upper R. Huallaga . . . . . . . . . . . . . . . . . . . . 23

Fig. 11. A Fish-trap, Huánuco . . . . . . . . . . . . . . . . . . . 26

Fig. 12. Poisoning the Chanchomayo . . . . . . . . . . . . . . . 29

Fig. 13. R. Azupizú, typical stream of montaña . . . . . . . . . . . 33

Fig. 14. Headpiece; ancient Peruvian textile . . . . . . . . . . . . . . . 82

Fig. 15. R. Pichis at Puerto Bermudez . . . . . . . . . . . . . . . 95

Fig. 16. Lower Pachitea; fishing canoe. . . . . . . . . . . . . . . . . . . 103

Fig. 17. R. T'eayali; a fuel stop . . . . . . . . . . . . . . . . . . . . . 116

Fig. 18. R. Pachitea; launch ('ocamita . . . . . . . . . . . . . . . . . 131

Fig. 19. R. Pacaya ... . . . . . . . . . . . . . . . . . . . . 152

Fig. 20. Fishing Camp on the Pacaya ................... 167

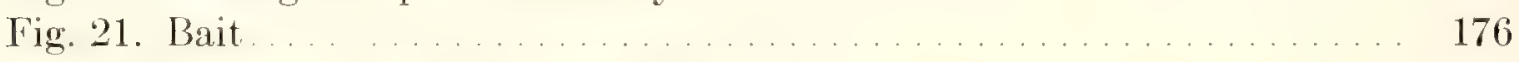

Fig. 22. Catching Candirú without Tackle ................... 190

Fig. 23. Fishing with Tarafa . . . . . . . . . . . . . . . . . . . . 199

Fig. 24. An Hour's Catch with Tarafa . . . . . . . . . . . . . . . 207

Fig. 25. Peruvian Fish-Weir . . . . . . . . . . . . . . . . . . 217

Fig. 26. Entrance to the Same. . . . . . . . . . . . . . . . . . 227

Fig. 27. "Facilities" for Amazonian Travel . . . . . . . . . . . . . 236

Fig. 28. Mouth of the R. Itaya, Iquitos . . . . . . . . . . . . . 250

Fig. 29. The Amazon at Iquitos . . . . . . . . . . . . . . . . . . 261

Fig. 30. The lower R. Huallaga . . . . . . . . . . . . . . . . . . . . 272

Fig. 31. Seining the R. Huallaga ....................... 281

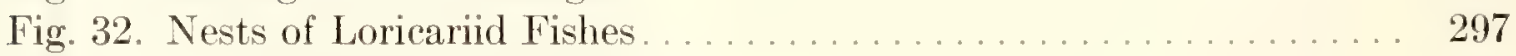

Fig. 33. A Fisherman's Barricade . . . . . . . . . . . . . . . . . . 306

Fig. 34. The Marañon and Pongo de Manseriche . . . . . . . . . . . . . 311

Fig. 35. Swift Waters of R. Marañon. . . . . . . . . . . . . . . . 323

Fig. 36-39. Preparing Arapaima for drying. . . . . . . . . . . . . 336-341

Fig. 40. Drying Arapaima . . . . . . . . . . . . . . . . . . . . . 343

Fig. 41. Deck-cargo of Arapaima meat .................... 344

Fig. 42. Gigging for Orestias, L. Umayo . . . . . . . . . . . . . . . . 347

Fig. 43. Drying-method for small fish . . . . . . . . . . . . . . 359

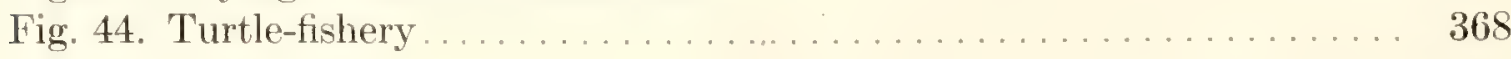


Fig. 45. Foraging for Turtle-meat and eggis

Fig. 46. Deck-load of Turtle . . . . . . . . . . . . . . . . . . . . . . 391

Fig. 47. The Fishing-fleet, Para, Brazil . . . . . . . . . . . . . . . 402

Fig. 48. Tailpiece; Embarcation . . . . . . . . . . . . . . . . . . . 409

Plate I, Poisoning the Chanchomayo

Frontispiece

Plate II, Fig. 1. Bunocephahus haggini; fig. 2. Bunocephalus bifidus; fig. 3. Bunocephalus retropinnis

Plate III, Fig. 1. Microglanis zonatus; fig. 2. Spine of same; figs. 3 and 4. Chasmocranus peruanus; fig. 5. Pimelodella peruana.

Plate IV, Fig. 1. Brachyplatystoma jumense; fig. 2. Pimelodus jivaro; fig. 3. Pimelodus leptus; fig. 4. Duopalatinus peruanus.

Plate V, Fig. 1. Trachycorystes galeatus; fig. 2. Tympanopleura nigricollis, female; fig. 3. Tympanopleura nigricollis, male; fig. 4. Centromochlus gyrimus: fig. 5. Pimulodus altiximus:

Plate VI, Fig. 1. Chactostoma lineopunctata; fig. 2. Hemiancistrus arenarius; fig. 3. Tympanopleura nigricollis, male; fig. 4. Tympanopleura alta. 441

Plate VII, Figs. 1 and 2. Conthopomus agassizii

Plate VIII, Figs: 1 and 2. Harttia filamentissima; figs. 3 and 4. Harttia microps

Plate IX. Fig. 1. Huttiu microps.

Plate X, Figs. 1 and 2. Ancistrus occloi; fig. 3. Rhamdia riojue; fig. 4. Pimelodella roccae; fig. 4a. pectoral spine of same.

Plate XI, Figs. 1 7. Astroblepus munoi

Plate XII, Fig. 1. Corydoras zygatus; fig. 2. Corydoras stenocephalus; fig. 3. Corydoras episcopi; fig. 4. Corydoras leucomelas.................

Plate XIII, Fig. 1. Otocinclus macrospitus; fig. 2. Pimelodella montana; figs. 3-5. Pygidium atochae; figs. 6-7. Astroblepus praeliomum.

Plate XIV, Fig. 1. Curimata murieli; fig. 2. Curimata reticulata; fig. 3. Psectrogaster cisandinus; fig. 4. Gasteropelecus coronatus; fig. 5. Carnegiella strigata; fig. 6. Bryconamericus osgoodi; fig. 7. Aparciodon pongoense.

Plate XV, Fig. 1. Apteronotus anas; fig. 2. Oedemognathus exodon; fig. 3. lips and teeth of same

Plate XVI, Fig. 1. Sternarchogiton porcinum; figs. 2 and 5. Eigenmannia conirostris; figs. 3 and 4. Rhabdolichops longicaudatus............

Plate XVII, Fig. 1. Orestias incae; fig. 2. Orestias humboldti; figs. 3 and 4. Orestias pentlandii; fig. 5. Orestias curieri

461

463

Plate XVIII, Figs. 1 and 2. Orestias luteus; fig. 3. Orestias olinaceus; fig. 4. radiograph of Orestias agassizii; fig. 5. radiograph of Orestias pentlandi.

Plate XIX, Fig. 1. Orestias silustani; figs. 2-5. Orestias albus . . . . . . . . . .

Plate XX, Fig. 1. Orestias elegans; fig. 2. Orestias empyraens; figs. 3-8. Orestias agassizii. . . . . . . . . . . . . . . . . . . . . .

Plate XXI, Fig. 1. Orestias mülleri; fig. 2. Orestias owenii; fig. 3. Orestias jussiei; fig. 4. Orestias tschudii. .

Plate XXII, Figs. 1 and 2. Rivulus urophthalmus; fig. 3. Amplove alleni; figs. 4-7. Aequidens hercules; fig. 8. Acaronia trimaculata. 



\section{INTRODUC'TION}

The present report had its inception as a proposed Part II of The Fishes of Northwestern South America. Part I consisted of the studies made by C. H. Eigenmann, Arthur W. Henn, Charles E. Wilson, and others upon the fishes of Colombia, Ecuador, and the Pacific slopes of Peru (Eigenmann, 1922b). Later the Fishes of Chile appeared (Eigenmann, 1927), as a separate monograph. Meanwhile the results of the studies of N. E. Pearson made on the Mulford Expedition, extending our work southeastward to tie up with the explorations of J. D. Haseman, were published as "Part II" (Pearson, 1924).

The work of the Irwin Expedition of Indiana University, in Collaboration with the University of Illinois, 1918-1919, was devoted (a) to the completion of the above-named studies on west coast fishes; (b) the Chilean monograph; and (c) the fishes of the highlands of the Peruvian, Bolivian, and Chilean Andes. The first and second-named objectives were carried out principally by Prof. Eigenmann. Through the generous cooperation of the University of Illinois I was able to have a part in the expedition, giving my time principally to the third objective named above. Through the first portion of the journey Prof. Eigenmann was accompanied by his daughter Adele; on the second portion he was unaccompanied. After trying his hand at exploration in the highlands, at Oroya, 12000 feet, and about Cerro de Pasco, 9000-14000 feet, and descending the Urubamba from La Raya, 14000 down to Santa Ana, 3000 feet, Dr. Eigenmann found he must relinquish the high mountains in my favor by reasons of health. For the remainder of the time my apportionment was the third objective mentioned above.

In addition to studies of fishes, I collected parasitological materials for the University of Illinois; earthworms and freshwater sponges being also on the list of desiderata.

Later, 1920, I was sent as traveling fellow of Indiana University to continue exploration on down the eastern slopes of the Andes to the Amazon. Collections made on that, the "Centennial", expedition are the principal basis of the present volume.

After my return some time remained which could be devoted to a study of certain groups. For several years these collections were given intermittent attention by Prof. Eigenmann and a number of his students. A few species were described by Myers, and by Eigenmann and Pearson. The Characins were combed through for materials to complete the monograph of that family. My Doradidae were studied by Eigenmann and used in his monograph of that nematognath group.

By 1925 a not inconsiderable amount of material had been studied and partially put in writing. This included the first draft of descriptions of many new species, and records and notes on most of the Nematognathi. 
During the winter of 1925-26 Professor Eigenmann, while enroute to Florida in vain search of health, mislaid this rough manuscript on board a train. $\mathrm{He}$ never saw it again, nor resumed work on the collection, his death occurring not long afterward, April 24, 1927, after a year at San Diego. The missing papers were brought to light by Mr. George F. Scheer, in January, 1928, in a repository for lost and found articles in the offices of the Baltimore and Ohio Ry. at Indianapolis. By him they were forwarded to President W. L. Bryan and by him to me. During the ensuing summer (1928) I spent five or six weeks making a careful recheck of the manuscript with the collections in the Indiana University Museum and continuing with the study of parts not covered by the manuscript.

While working in the Iquitos region I employed as assistant, mayordomo and interpreter a Barbado-Peruvian, Percival Morris. With the training which I was able to give him, he continued making local collections for a year after my departure. These were brought by him personally to New York at the end of that time, and form a substantial part of the fruits of the Centennial Expedition.

Two by-products of the Irwin and Centennial Expeditions, not of ichthyological character, should be mentioned:

Cubé, a fish-poison and insecticide used in the interior of Peru, and discussed more at length on later pages, was introduced into the United States, and subsequently has become an important source of rotenone.

A method of caring for photographic materials in the tropics was designed, and improved by more or less accidental discoveries in the field. The method was described on my return (Allen, 1922b) and later accounts indicate that it has now come into general use.

The Indiana University collections of Jordan and of Eigenmann were sold in the Autumn of 1929 to the California Academy of Sciences, and were removed without loss or impairment under the painstaking care of Dr. Barton W. Evermann, Mr. H. Walton Clark, and Mr. Alvin Seale, to Golden Gate Park, San Francisco, where I was able to visit them again in the summer of 1940.

For a consideration of the regions visited during the Irwin Expedition, consult Eigenmann, 1922b. The following pages narrate briefly my participation in that enterprise, and continue with the story of the Centennial Expedition. If Stefansson appropriately designates a certain area of the polar sea as the pole of inaccessibility, perhaps I may be permitted to nominate this region east of the Peruvian Andes as the Equator of Inaccessibility, the scene of the following explorations. 


\section{ACKNOWLEDGMENTS}

In undertaking a work of this nature there is cause for astonishment at the number of helping hands extended all along the way, without which much less could be accomplished. I wish to acknowledge the many kinds of assistance given me, such as letters of introduction, shelter, transportation, and aid in obtaining local personnel for the work of collecting. The list will be incomplete at best; it could be extended by repeating certain names mentioned by Doctor Eigenmann, 1922b, in his narrative of the Irwin Expedition.

President William Lowe Bryan of Indiana University; whose ready and sympathetic assistance was always in the background

Dr. Henry B. Ward of the University of Illinois who provided for my expenses on the Irwin Expedition

Sr. Victor Pezet, Peruvian Consul at New Orleans, and his brother. Perurian Embassador at Washington for introductions and advice

Mr. W. L. Morkill of the Peruvian Corporation at Lima who provided free transportation on railroads and steamship lines for personnel and equipment

Mr. L. S. Blaisdell of the Southern Railway of Peru who placed not only transportation but the railroad employes at my disposal

Mr. W. A. Corry of the Southern Railway who gave me the benefit of his experience as engineer throughout southern Peru

Mr. N. B. Roper and other members of the Backus and Johnson Company for the use of their mining establishments as headquarters

Numerous members of the Cerro de Pasco Mining Company's staffs at Lima, Oroya, La Fundición, and Cerro de Pasco, together with nearly the entire staff of the C. de P. Railway

MI. J. D. Feehan, General Manager, Central Railway who assisted in working out itineraries

Sr. Victorio Repetto, Huanuco, agent of the Durand interests

Don Augusto Durand, proprietor of La Prensa, Lima, and of the coca plantations which were my headquarters for some weeks

Sr. Ricardo Tello y Devotto, then of Huánuco, now of Huancayo, for valuable guidance

Mr. A. S. Kalenborn and Mr. Berrien of Oroya who gave much help with collecting

Sr. Emilio B. Béraun, Administrador of the Hda. San Juan who was my host for two weeks

Sr. Aguiles A. Rubina, Prefect of Dept. of Puno, who arranged my itinerary through his provinces

Sr. Antonio Stroebel, Puno, who provided introductions and loaned me his favorite servant. 
Pedro Vasques, my majordomo, cook, interpreter, guide, friend

Messrs. R. S. Shepherd and J. M. Howell of the Puno Adventist Mission, authors of many favors, introductions, etc.

Sr. Francisco P. Valcárcel, who made my collecting at Lake Umayo pleasant and profitable at the family estate, Hatun Colla

Mr. Nathaniel G. Grundy who was my host and guide at his mining establishment, Maravillas on the $\mathrm{R}$. de Lampa

Don Daniel S. Bustamante, Minister of Public Instruction and Agriculture, La Paz, who opened to me the official resources of his department of government

Sr. M. V. Ballivián, scholar and scientist, who interested the above in my enterprise

Sr. Jorge R. Cornejo V., engineer of the tin mines and smelter, Poopó, who was my host, guide, and counsellor

Dr. A. Gieseke, Cuzco, now of Lima, Rector of the University of Cuzco, patron of all scientific enterprises visiting Peru

Mr. Lycett, Cebollar, Chile, superintendent of the B.C.C., who personally conducted me to the fish haunts of Lake Ascotan

Sr. Ricardo A. Espinosa, Director de Gobierno, Lima; Sr. Enrique Lagarre, Director of Fomento, Lima; Sr. Antonio Cashof, Minister of War; various members of the Foreign Office, including the Minister, all of whom provided me with indispensible letters of introduction to their subordinates in the interior

Dr. Carlos Rospigliosi y Vigil, Colonel of the Medical staff of the Peruvian Army, member of the staff of the Military Hospital at Lima, Professor of Zoology, University of San Marcos, Director of its Museum, who made representations before the government departments in my behalf

Don César Ruiz y Pastor, Prefect of the Dept. of Loreto, who made available many resources of his inland provinces

Señores Valle Riestra, Perené Colony; H. F. Bardalez Hernández, Iquitos; Julio A. Battistini, Hda. Ytalia, Rio Ucayali; Sr. Medina, Hda. Bretaña, R. Puinagua, were my hosts for periods of varying length

Capt. Manuel Curiel, Oficial de Cavallería, Comandante of the Military District of the Lower Ucayali, gave me the advantage of his knowledge of Indian affairs and his patronship of the indigenous tribes, in procuring assistance

The Brothers Juan and Ecuador Praeli of Tarma and La Merced lent assistance in fishing, in equipment, and in establishing the necessary credits for travel in the interior

Mr. W. J. Dennis, then of the Methodist Mission School, Huancayo, gave very material assistance in obtaining supplies of the fish poison, cubé

Mr. Francis A. Mitchell, Americo-Peruvian, Yurimaguas, gave much help in obtaining necessary facilities for work there

Percival Morris, Barbado-Peruvian, was my aide during the weeks spent at Iquitos, and did collecting according to my instructions for a year after my visit

Senhora Snethlage, Curator of the Natural History Museum, Para, Brazil, obligingly forwarded mail and cablegrams sent in her care 
In addition, numerous subprefects, gobernadors, private citizens, foreign residents were the donors of many services, large and small

The Eli Lilly Company of Indianapolis provided a complimentary kit of tropical medicines which pretty well cared for our needs on both expeditions. Further adrice and assistance with health problems were given at Lima by the national Instituto Higienico

To Dr. G. S. Myers, Stanford University, and to Dr. Carl L. Hubbs and Joe K. Neel of the University of Michigan, my thanks are due for bibliographical assistance. I must acknowledge the valued help of Mrs. IV. R. Allen in proofreading, and that of Miss Barbara Allen in map-making.

To Dr. Thomas Barbour of the Museum of Comparative Zoology, and to Dr. Robert C. Miller and the late Mr. Howard Walton Clark of the California Academy of Sciences thanks are due for the loan of specimens.

Under the hand of Mrs. Dorothy VanCleave Lincicome the Atkinson drawings were restored from engraver's proof, most of the originals having been lost. 



\section{NARRATIVE OF THE EXPEDITIONS}

The general account of the Irwin Expedition was published by Eigenmann (1919a, 1920a, and 1922b). My own part in the undertaking covers the areas which we have under consideration here, and may be extracted as follows (Allen, 1920):

... All members of the party reached Lima, Peru, in August, 1918. My chief activities were the collection of parasitic materials, and the collection of the fishes of the Titicaca basin. ... As an introductory procedure I worked about Lake Junin in Central Peru and spent more than a month along the Huallaga from its sources near 14000 feet down to 2000 feet.

After early September the writer proceeded independently of the others, first to Lake Junin and the Rio Huallaga, later to Lake Titicaca. Lake Junin (Chinchaycocha) is a shallow, mud-bottomed lake near Cerro de Pasco. It is surrounded by great areas of marsh and lies in the midst of an extensive peaty pampa at more than 13500 feet elevation. It forms the source of the Rio Mantaro, one of the principal tributaries of the Ucayali, and this in turn one of the three principal tributaries of the Amazon. The inhabitants regard it as the true source of the Amazon, an honor it shares with a score of high Andean rivers.

The pampa is a bleak area upon which virtually nothing grows except certain native sessile rosette-plants, representing several families, but principally composites. These constitute the pasturage of the few sheep and llamas that can be maintained. Everywhere in the Peruvian Andes there is a remarkable climatic difference between elevations of 12000 and those of 13000 feet. Though Lake Titicaca is five hundred miles farther from the equator than Junin, there, at 12500 feet, an extensive agriculture is practised. Wheat, barley, and potatoes are rarely seen at elevations of 13000 feet, and the Junin pampa will produce none of them. At midday temperatures may be quite high. But nights are always cold, and the passing of a cloud over the face of the sun will cause the fisherman to assume his coat. At equal elevation at Cebollar, Chile, a diurnal temperature variation of $65^{\circ} \mathrm{F}$. was encountered.

While the elevation is too great to allow more than a few land plants, there is still an abundance of aquatic vegetation. The lake bottom is deeply covered with mud and flocculent organic debris. Ceratophyllum, Potamogeton, and Philotria are abundant. The exposed roots of the shore plants at the water's edge are covered with great quantities of green fresh-water sponge, of which adequate collections were made.

The fish are of only two species, but very numerous in individuals; they are: the bagre, a Pygidium, catfish, which the inhabitants say ascends the rivers to spawn; and the challhua, an Orestias.

The fish are only slightly susceptible to dynamiting. It affected only those nearest the explosion. Nost of these instead of rising to the surface as was expected sank into the ooze at the bottom and were lost. At first one is inclined to attribute this to the great elevation, and the decrease of about twofifths of the atmospheric pressure. But the fishes here are apparently in as perfect adjustment to the existing hydrostatic pressure as at any other eleva- 
tion, and ought therefore to respond in a similar way. It was disconcerting to eruise (in a motor launch kindly loaned by an American Gun Club at La Fundición) among the reedy embayments and lagoons, seeing vast numbers of fish in clear water, unable to interest them in hook and line, unable to manipulate a seine, or to dynamite successfully, and the fish always out of reach of a dipnet. The Peruvian came to the rescue. With a hardihood inherent in the dwellers of the bleak pampas he stepped into the water to his thighs, supporting his weight on the rhizomes and roots of plants. Here he searched among stems for the fishes, and found them.

Very large frogs, Cyclorhamphus culeus Garman [Telmatobius culeus] were found fairly abundant in the lake and its tributaries. They were much parasitized, especially with small Cestodes....

The marshes and reedy islands surrounding Lake Junin harbor a multitude of birds, especially ducks, coots and grebes. Seldom may one look out upon the lake without sighting the smoke of fires in the bulrushes employed by the Indians to reveal the nests of birds. The eggs are a highly prized addition to the scanty diet, though scorched by the fire or in a state of partial incubation.

Six weeks were spent upon the Huallaga river and some of its affluents. The highway from Cerro de Pasco to Huánuco follows the river from its origin, a group of springs below Cerro at 14000 feet. Between Cerro and Huánuco, a distance of seventy miles, both river and road descend to an elevation of 6000 feet. In its upper course the river is mostly a series of rapids. No fish were encountered above Ambo at an elevation of probably 7500. They are said to occur at San Rafael during the lower stages of the river. This village has an elevation of 9000 or more. At Huánuco several species occur.

Collecting was continued seventy miles below Huánuco as far as the Cayumba rapids, at 1800 or 2000 feet. These constitute an effective barrier to the tropical fishes of the lower courses of the Huallaga. Not more than six species occur [immediately] above the rapids. A native river man was able to enumerate and describe thirty-six species occurring from Cayumba to Tingo Maria, the ensuing forty miles. . .

On the ridge of Punta de Esperanza, altitude 9000 feet, and thirty miles northeast of Huánuco, the trail abruptly enters the tropical forest, which from this point on entirely envelopes the mountains. On the forested east slope the rainy season was well under way, in sharpest contrast with the barren west slope and ranges back of it.

Comparatively few of the mountain slopes have been cleared and placed under cultivation (chiefly to coca). At San Juan, one of the estates of Dr. Augusto Durand, I was hospitably sheltered for ten days while engaged in collecting the parasites of tropical birds.

... work was begun in southern Peru in mid-November. The ensuing four months were devoted to the Titicaca-Poopó basin of Peru, Bolivia, and Northern Chile.

... For want of riding animals four trips were taken on foot, aggregating 200 miles, in order to reach some of the rivers and lakes of the Titicaca-Poopó Valley. The first trip was from Puno to Yunguyo, paralleling the shore of Lake Titicaca. ... The second trip extended from the port of Moho, at the northeast corner of the lake, northwestward to Tirapata. . . Laguna Salinas is too saline for fishes. In fact nothing living was found in it except certain phyllopod crustacea, Artemia salina reported for the first time from the continent, though found in all other continents). These were very abundant, and in all stages of development simultaneously. Flamingoes were feeding constantly in the lake. 
Lake Umayo, five leagues inland from Puno, is very rich in several species of Orestias. It abounds also in freshwater sponges, which form masses covering the roots of aquatic plants and exposed bowlders to a depth of one-fourth inch or more. Thanks to the hospitality of Sr. Francisco P. Valcarcel I was able to obtain excellent collections there, and to visit the ruins of Silustani and Hatun-colla. ...

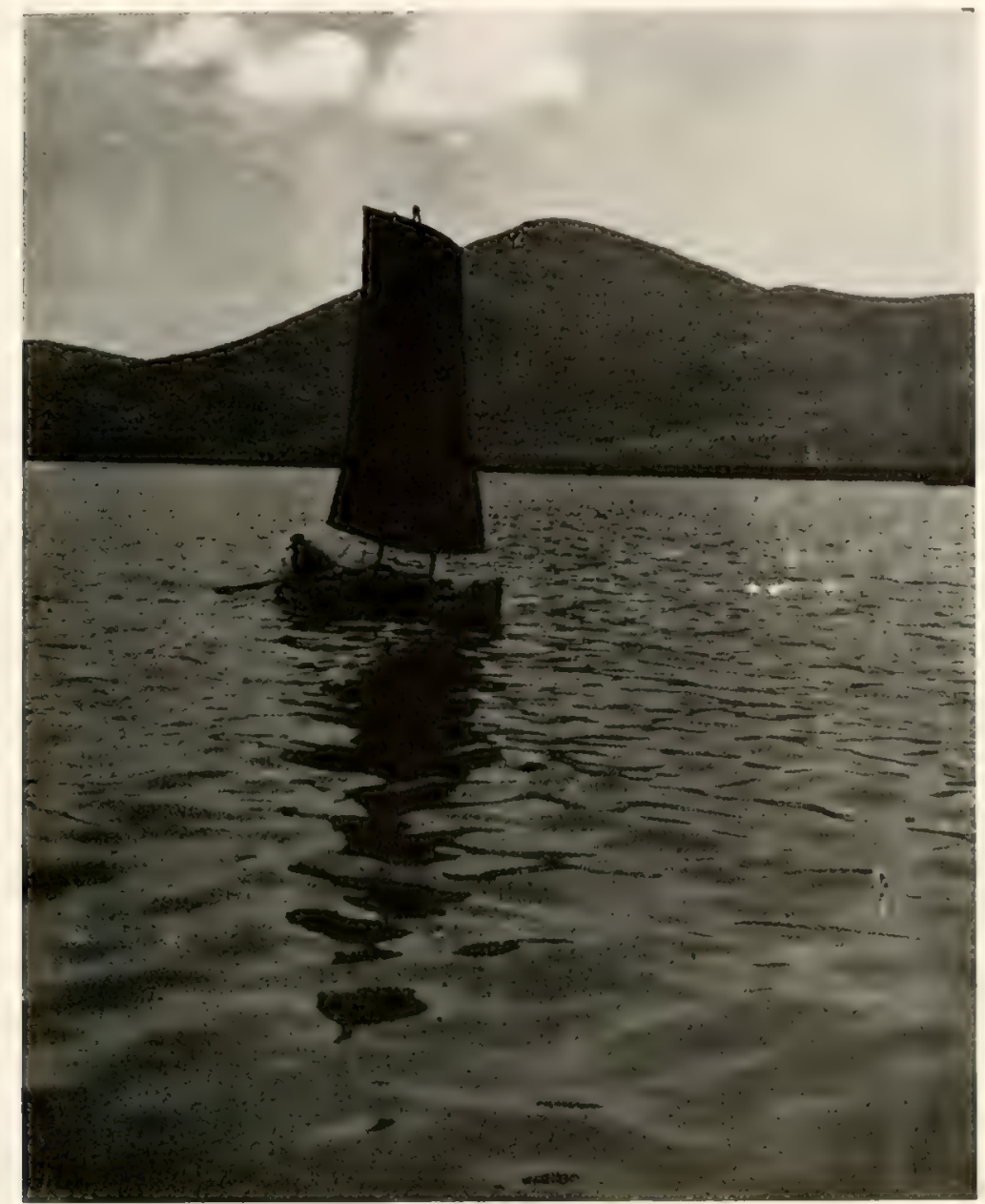

Fig. 1. The VAN OF THE FISHING-FLEeT from Capachica arrives at Puno, Lake Titicaca. Laden with fish, fagots, taqui (dried dung), and scanty produce, the Indian farmer-fisherman-shepherdsailor sails his grass-boat with the daily trade-winds. The winds blow here at this great elevation with much the same punctuality as at sea, enabling the inhabitants to arrive and depart on schedule.

Lake Poopó at 12000 feet elevation in the Bolivian highlands, is nearly unapproachable, hence... nearly total lack of native facilities... The lake shores are extremely flat. The fluctuations in level carry the shore line back and forth more than a mile from season to season. I was able to wade more than a mile out into the lake at its lower level before reaching water above the knees. In addition to the seasonal fluctuations there are changes in level of shorter periods, apparently diurnal. They are probably due to wind rather 
than to the existence of a seiche. Though more than fifty miles long and half as wide, the lake has a maximum known depth of thirteen feet.

The literature is flatly contradictory as to the salinity of the water of Lake Poopó. It is in fact quite salt and nonpotable. However, I was able to subsist four days upon strong tea made with it. So far as observed the salt has no effect upon the fish fauna. The Rio de Juli in Peru is considerably more saline, yet is inhabited by the same fish as the nearby freshwater creeks.

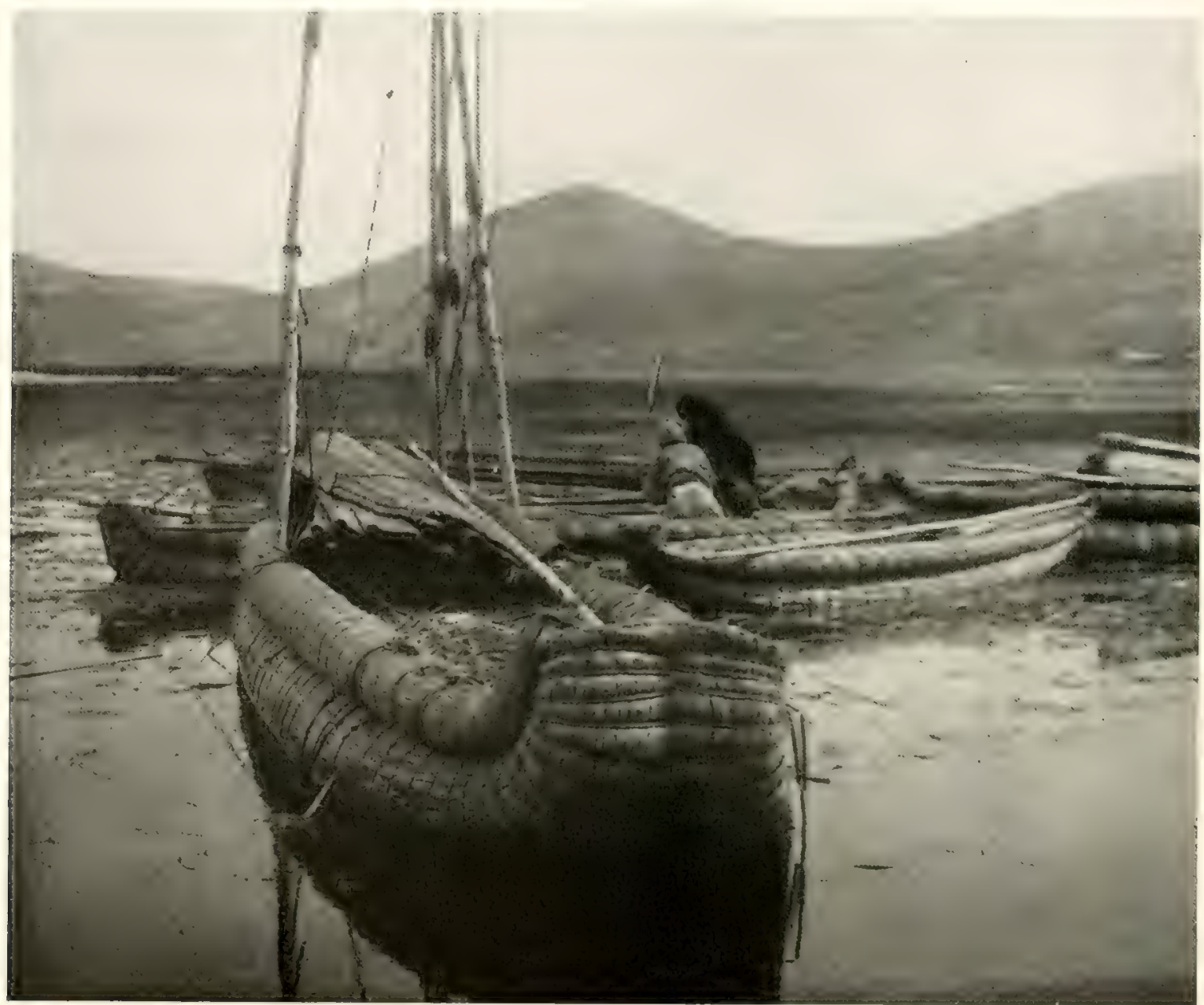

FIG. 2. THE FISHING FLEET, LAKE TITICACA. "Grass"-boats, or balsas made of reeds, the sole means of local transport on the lake. 'The masts are of spliced, imported poles, the sails and tackle of the same $i c h u$-grass used in binding the rolls of the hull. The furled sail becomes a shelter. The cargo has gone ashore to the Puno market.

Even Lake Titicaca is slightly salt, at least locally. This is not evident to the taste in most places... Other rivers vary seasonally in saline content. $R$. de Lampa in the rainy season has no taste of salt. But Mr. F. H. Grundy reports that at Maravillas during the dry season the Indians scrape salt off the rocks of its bed. Lake Poopó is probably less salt than it would be did its surplus not overflow annually into the Salar de Coipasa. Here, as at Laguna Salinas, and elsewhere, salt is recovered on a commercial scale by leaching it out of the salty earth. 
In the Rio de Poopo occurs a spring of superheated steam and water. This water mingles with and is gradually tempered by the water of the river. Small suches were observed in water of considerably more than $100^{\circ} \mathrm{F}$. The same phenomenon occurs at Aguas Calientes in southern Peru.

At the same altitude as the Titicaca-Poopó altiplane the so-called Lake Ascotan is hemmed off by a ring of volcanoes. It is about twenty-five miles in extent and lies just within the border of Chile. It consists for the most part of muddy deposits of lime salts. Numerous pools and sluggish streams appear throughout, and drain away by seepage. At the bases of volcanoes along the eastern margin are many warm and cold springs. These are only slightly brackish. Small Orestias are everywhere abundant here, though there is no communication with the outside.

Between Ascotan and the coast at Antofagasta lie vast volcanic areas and the nitrate belt. Only one river which might support fish occurs - the Loa. But at Calama (elevation 7000 feet) it was found to be totally devoid of them. This is reported to be due to a waterfall twenty-five kilometers downstream, below which coastal forms were said to exist.

... with one exception few parasites were obtained from the many hundreds dissected... resident in the cranial cavity of nearly every Orestias examined, not only in Lake Titicaca itself, but in tributary lakes and streams.

In the lakes of the altiplane the great quantity of bird life in the broad plant zone of the littoral is noteworthy. There are many coots, cormorants, grebes, ducks, flamingoes, ibises, lapwings, and gulls. I estimated that there were not fewer than 10,000 wading birds per mile of the shore at the southern end of Lake Poopó.

... The smaller Orestias, hispe and carache sometimes occur in remarkable concentration, especially in the meadow ponds of the pampas. Frequently scores of them may be dipped up with a single swoop of the dipnet. Even a roadside sheep-washing pool, without outlet and very muddy, contained a multitude of isolated, pallid carachitos. In the same pools occur also rast numbers of small Dytiscid beetles. As a result ... no fish were found which did not have the fins more or less abbreviated.

After the lapse of a year I found myself back in Peru, this time as representative of Indiana University alone. The following extract is a brief account of the "Centennial Expedition", occurring as it did in the university's centennial year and that of the Republic of Peru. As it turned out the enterprise was finally reduced to a one-man expedition (Allen, 1921b; a fuller account, Allen, 1921a).

Between June, 1918, and June, 1919, the Irwin Expedition of Indiana University as a part of its work collected the fishes in the highlands of Peru, particularly in the Urubamba valley from the headwaters at La Raya, elevation 14,150 feet, to Santa Ana, 3,000 feet. This work was done by Dr. C. H. Eigenmann and Miss Adele Eigenmann. Collections were made in the upper Huallaga basin between its headwaters about Cerro de Pasco and Goyllarisquisga down to near Tingo Maria, 1,800 feet, mostly by the present writer. Further collections were made from Lake Junin, 13,500 feet, near Cerro de Pasco, in the Mantaro basin to Huancayo, 10,500 feet, by myself and the Eigenmanns. Collections were also made from the headwaters of the Tarma River at Tarma, 10,000 feet, down to La Merced, about 2,500 feet, by the Eigenmanns. The Irwin Expedition thus collected in the headwaters of the

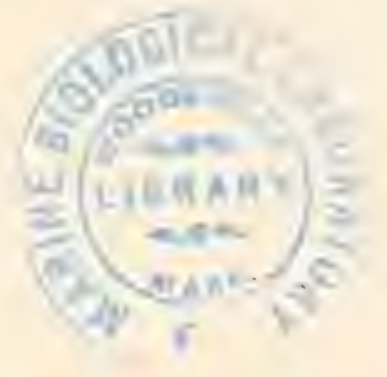


Huallaga and Ucayali Rivers from their sources to the neighborhood of 2,000 feet above sea level.

In May of 1920 I started on the so-called Centennial Expedition of Indiana University to carry the survey of the fish fauna to the lower levels of the rivers of eastern Peru. The expedition was assisted by a grant from the Bache Fund of the National Academy of Sciences, and by the hearty cooperation of the Peruvian government, which provided free transportation and other assistance within Peru.

The writer traveled alone, so far as the English-speaking personnel of the expedition is concerned, depending solely upon local aid. At times help was volunteered by interested individuals or solicited from the local authorities,

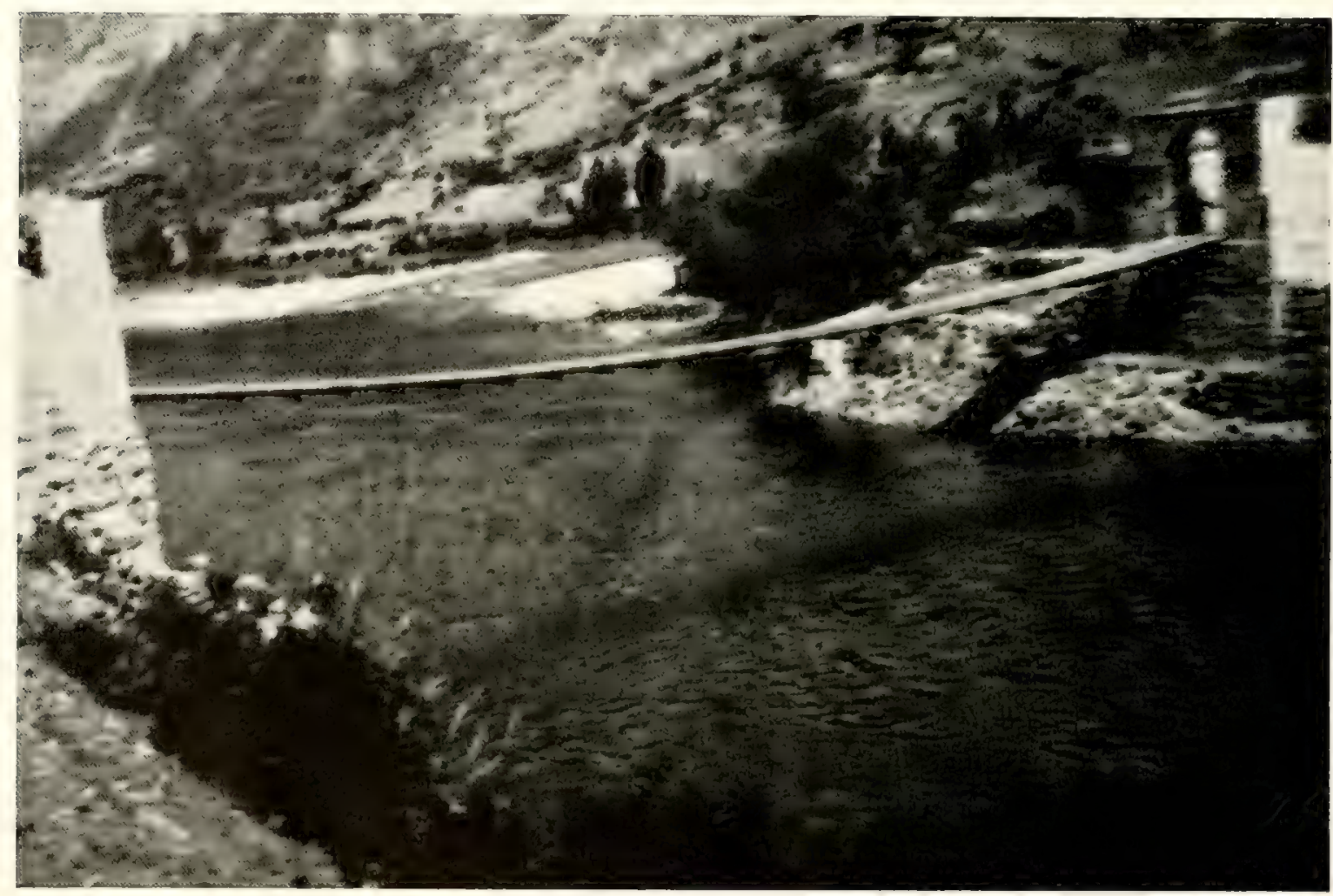

FIG. 3. The upper Mantaro near Jauja, about 11000 feet above sea level. This portion of the river pertains to the temperate life zone, and to the area of the upland fish fauna.

civil and military. Three weeks of the initial portion of the trip (from the Perené to the Ucayali) were spent in company with Professor J. Chester Bradley and Dr. W. T. M. Forbes, of the Cornell Entomological Expedition.

The plan of the present expedition has been to collect as exhaustively as possible the fishes of a few suitable, representative localities in the basins of the above-named rivers, comprised for the most part within the great Department of Loreto. Entering by Lima, Tarma and La Merced, the writer began where the Irwin Expedition left off two years ago, and crossed to the head of navigation of the Pichis-Pachitea-Ucayali system by the Via Central. Ten days were required to traverse the final 200 kilometers of this atrocious trail. It is an endless succession of mudholes, yet the principal and almost sole means of communication between coastal Peru and her transandine provinces. 
No real hardship is involved in making this journey, thanks to the series of government tambos, or shelter houses, at convenient distances, which cater very well to those who come well recommended. This is otherwise a region entirely devoid of inhabitants.

Ten days were spent at Puerto Bermudez. 'Two days by canoe brought the party to a point on the Pichis to which the steam mail launch could ascend. Thenceforward travel was chiefly by launches, mail and commercial, which abound in Loreto; the shorter trips into tributary streams and lakes were made in dugouts. A month was devoted to the vicinity of Contamana on the lower Ucayali, a fortnight to the Puinahua and Pacaya, and an equal period to the region of Iquitos. The markets of Iquitos are in season very well supplied with fresh fish of great variety. Another month was spent in cruising the upper Marañon from Iquitos to the Pongo de Manseriche, and the tributaries Tigre and Morona. A three-week sojourn in and about Yurimaguas allowed an examination of the lower Huallaga, the third of four great rivers of Peruvian Amazonia. I had during the Irwin Expedition collected on the upper portion of this river.

These streams, the Ucayali, Marañon, and Huallaga, are comparable in size to the Ohio at flood stage. All arise in the Andes and form a vast confluent flood plain parallel to the mountains, and 500-600 miles in extent. Though 2,000-2,500 miles from the mouth of the Amazon, this plain is only 400 feet above sea level. In all this stretch there is very little topographic relief. The annual fluctuation in level of the Amazon at Iquitos is 40 feet. The annual inundation therefore extends far inland from the rivers. Large numbers of cut-off lakes (cochas) with their connecting cañas form a network throughout the system, which becomes one body of water with the coming of winter rains. Most of them are dead-water bayous of varying dimensions. There are almost no brooks - all depressions (quebradas) only serving to receive the backwater of the rivers. The smaller tributary rivers vary greatly in their flow at all seasons, fluctuating both with the local rainfall and with the level of the outlet. A stream flowing very rapidly now may display almost no current within a few hours, or vice versa.

The extent of the navigable portion of the streams in Peru is much greater than in most Brazilian streams. Many of the latter are interrupted not far from their mouths by impassible rapids. The Brazilian river basins are sharply separated from each other by chains of hills. To the Loretan the slightest rise is a cerro mountain. Any stretch of terrain not inundated is an altura. Every riffle is a pongo - rapid. Within the past few years even the redoubtable Pongo de Manseriche, by which the Maranon breaks through its last chain of the Andes, has been passed by no fewer than five steam launches. It has always been risked by raft and canoe.

The above conditions allow many species of fish from the lower Amazon to become distributed to the very foot of the Andes, and throughout oriental Peru. One finds many fishes extending from one extremity of Loreto to the other.

With the annual subsidence of the water there is of course everywhere a local sorting of species according to preferred habitat. Thus in a given stream one may not obtain more than two, three, or half a dozen species at the same time. Rarely are more than this number brought up in a single haul of a seine. (Bates called attention to this fact seventy years ago.) The cochas usually produce more species, but spaced pretty well apart. To get them all one must draw the seine many times in various parts of the lake. The common 
fish that one is obliged to reject may surfeit even one's native helpers. There is a pretty rigid assorting of fishes into river and lake forms, despite the fluvial origin of the lakes, and despite the inundations.

The great diversity of arboreal animals on the land is paralleled in the water by the large number of families of fishes and of aquatic mammals represented. The region is yet virtually tourist-free. One may journey by steamers and launches without seeing much of the teeming life of forest and river,

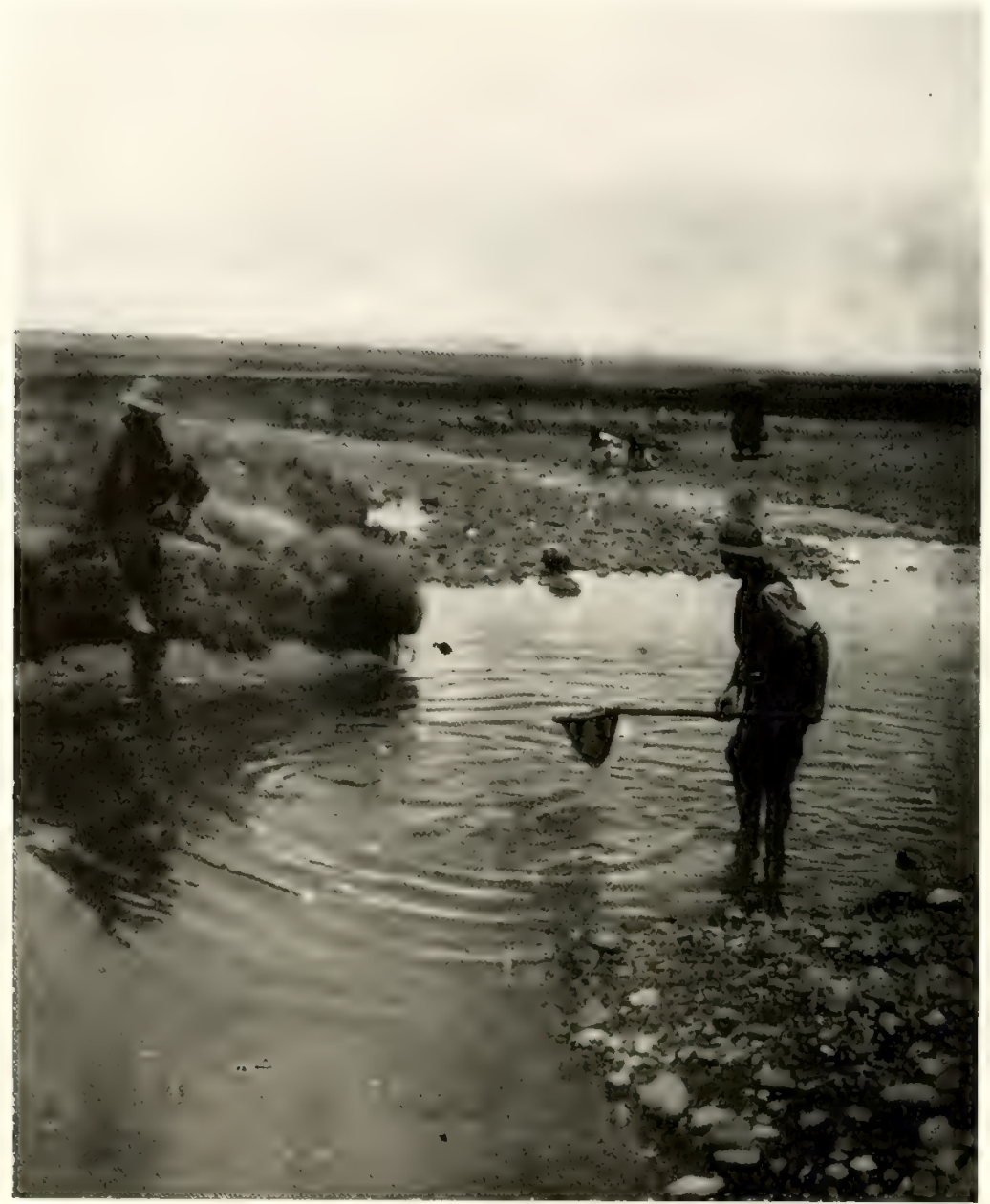

Fig. 4. Dynamiting The Rio DE MOLino, along the western shore of Lake Titicaca. Using the dipnet is Pedro Vasquez, assistant, cook, foreman, interpreter.

or of primitive human life. Only in the tributary streams, traveling by canoe, does one encounter them. Here the dolphin, manatee, otter, alligator, capybara, tapir, etc., still abound, and one comes surprisingly near seeing all the animals which he had hoped to encounter.

The year 1920 was remarkable for its unusual rainfall. Not only was the curve for the depth of the Amazon at Iquitos higher throughout April and May than for many years, but also throughout the dry season. The lowest stage reached was some seven feet higher than the mean minimum depth.

The exceptional inundation of April and May had destroyed much of the 
crops. There was a serious shortage of all staples (plantains, beans, yucca, rice, etc.) and considerable hardship among the improvident. At no time were the sand bars of the Maranon or Amazon exposed. This of course affected the fishing industry. Seining was made much more difficult, while throw-net fishing was probably increased, due to the concentration of the mijanos, schools of shore fish. Much of the time the fish had taken to the monte, or thicket, when the overflow of cocha and quebrada reached into the forest. While the fish are in the woods, the Loretan abandons his diet of fresh fish, and resorts to his supply of the dried.

Certain fishes are very abundant. But there is an increasing scarcity of others. The famed pirumucu (paiche of Peru) has undoubtedly been exter-

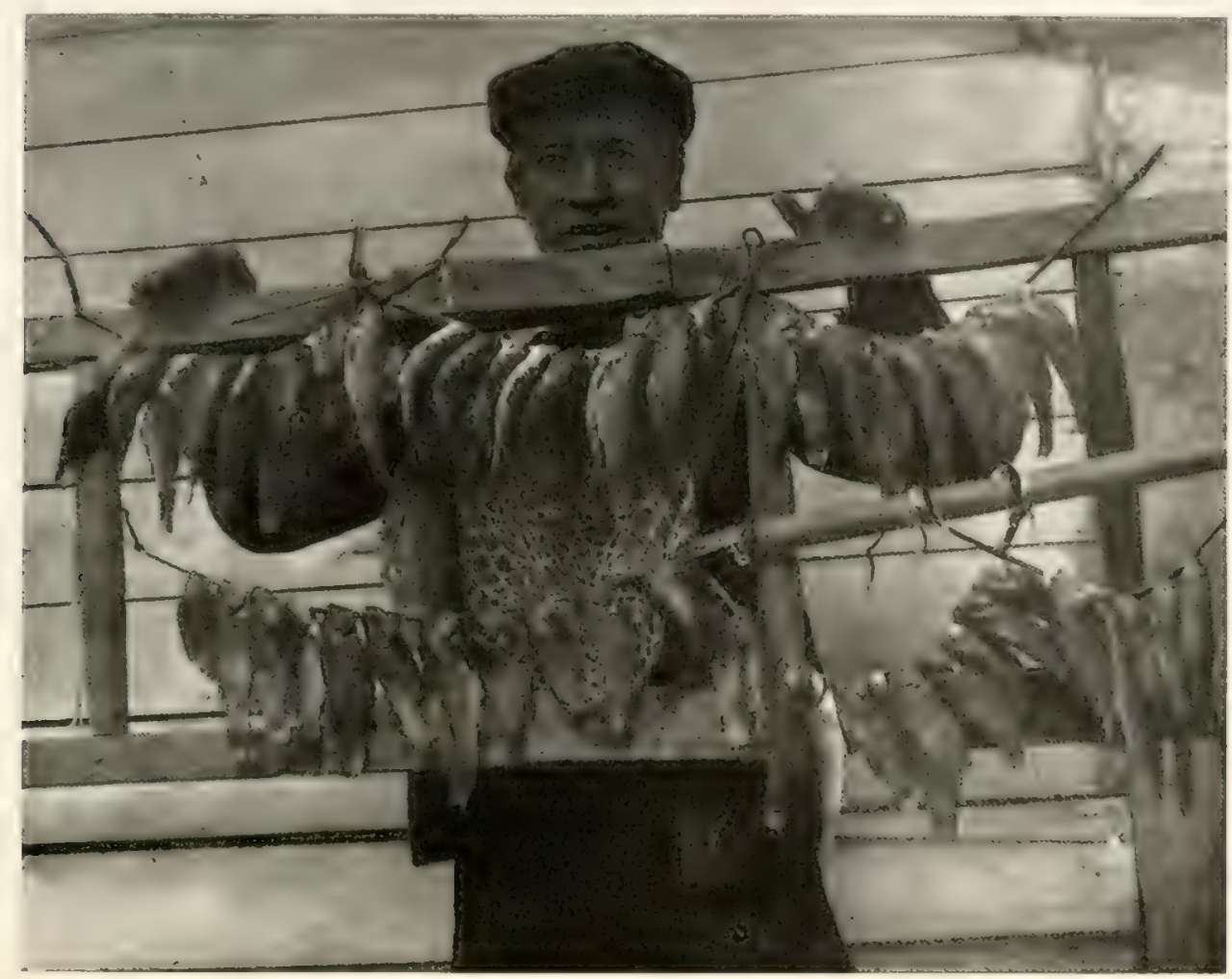

FIG. 5. Marketing Orestias, Puno, Lake Titicaca. Each string of fish worth five centavos, the whole valued at thirty centavos (about 15c). Strung on the tough blades of a native flag.

minated from certain regions. In the Chanchomayo dynamiting has greatly reduced the river fishes. The government has now found it possible to prevent the sale of dynamite to the poor thereabout, but has found no way of curbing the practise of dynamiting on the part of the wealthy and influential. Poisoning streams wholesale by means of the crushed root of the native poison plant cube is prohibited by law. But this method continues to prevail wherever cube is available, notably in the tributaries of the Huallaga, the smaller of which are nearly depopulated of fish.

Some birds are also rapidly becoming scarce, especially the egrets, whose plumes are marketed. Two brothers Hoyle of Contamana have secured recently a government monopoly of the plume trade of the Ucayali. They are bound by its terms to develop the fisheries of the Ucayali, first as a means 
of rearing fish to feed the egrets, and secondarily for the sake of restocking the streams. How to enforce respect of their charter, and how to develop a fisheries industry from nothing, without experience, are two large problems confronting the concessionaires. They do not seem to regard it a difficult matter to secure a revocation of the American law forbidding the importation of egret to this country.

Seventy years ago Bates predicted the rapid extinction of the turtles of the Amazon. In spite of an enormous consumption of turtles and eggs that has continued from that day to this, they are still very abundant. Petroleum has replaced turtle oil since that time, but turtle eggs, meat, and viscera continue to be favorite articles of food.

An effort was made by the expedition to confirm the widespread urinophilous reputation of the candiri (carnero of Peru). A Briggs' lead-in trap properly baited was frequently placed in rivers in the hope that it might demonstrate such a tropism. This was never successful. Nor did careful inquiry ever lead to the finding of an authentic case of parasitism of man by this fish. That it is strongly tropic to flesh or blood has been demonstrated.

The Oriente of Peru was not found by the writer to be, as we are encouraged to believe, wholly a land of dismal forests, swamps, noxious animals, and fevers. All these elements are present in quantity, certainly, but by no means universally distributed. Only once have I seen a large boa, and very few small snakes. Mr. Mitchell of Yurimaguas states that he has seen but four boas in twenty years' residence in Amazonia. Some rivers, e.g., the Pacaya, are full of alligators, but many rivers have almost none. Only one region visited, that of the upper Maranon, was badly infested with fever. Insect pests were numerous, and of many sorts, but not so intolerable as often represented by travelers.

The realization of Humboldt's dream does not seem imminent. Such difficulties as those of transportation, climate, inundation, and an untaught, unambitious population, must be overcome before Peruvian Amazonia shall come to her own.

\section{CHRONOLOGY AND ITINERARY OF THE IRWIN AND CENTENNIAL EXPEDITIONS}

June 18, 1918 Left Bloomington, Indiana, with Professor C. H. Eigenmann and daughter, Adele; June 19, Arr. New Orleans; June 19-July 23 Awaiting passports at New Orleans and Bay Saint Louis; July 24 Released by State Department, sailed on S.S. Carrillo; July 26 Arr. Havana, Cuba; 28 Departed Havana; August 1, 1918 Arrived Cristobal-Colon, C.Z.; 5 Transited Panama Canal; 9 Landfall Payta, Peru; 10 Eten, Pacasmayo; 11 Salaverry; 12 Callao and Lima; 13-18 Making contact with officials, arranging letters, permits; 16-17 Fishing Rio Rimac at Lima; 18 Sunday excursion and reconnaissance of upper Rio Rimac to Rio Blanco; 20 Fishing above Cerro San Cristobal in Rimac; 22 Enroute to Chosica; 23-25 Fishing between trains in middle Rimac; 26 Enroute to Rio Blanco; 26-27 Adjustment to high elevation; 28 Train to Oroya; 29-30 Preparing equipment for dividing forces; 31 Train to Junin. 
September 1, 1918 Via locomotive to Duck House on Lake Chinchaycocha; 2 To Smelter in search of facilities and assistance; 3 Return to Duck House; 4 Duck hunting for parasites, Lake Chinchaycocha; 5-6 Fishing with dynamite, seine, dipnet, collecting Spongillids; 7 Duck House to Zigzag, fishing branch of Mantaro, collecting earthworms, return to Oroya; 8-9 (With C.H.E.) collecting Rio de Oroya and Rio Mantaro; 10 Preparations for trips to Chanchomayo and Huánuco; 11 Oroya to Cerro de Pasco; 12-13 Packing and securing transportation to Huánuco; 14-16 Cerro de Pasco to Huánuco by horse; 17-21 Huánuco Awaiting baggage and arranging accommodations in the "interior"; 22 Horseback Huánuco to Cochas; 23-24 Cochas to San Juan (Don Augusto Durand's coca hacienda and manufactory); 25 Preparations for carriers and foot-travel to the Huallaga; 26 Via foot-trail to Chinchavitoc at mouth of Rio Chinchao; 27-28 Rained in, walked to Cuevas at foot of the Cayumba rapids, dynamiting river; 29-30 Fishing, collecting parasitological materials.

October 1, 1918 Seining and dynamiting Chumatagua, return to Chinchavitoc; 2 Chinchavitoc to Hacienda San Juan, dynamiting and seining the Rio Chinchao enroute; 3-12 Collecting parasitological materials from birds, snakes, etc. at San Juan; 13-15 Enroute, mostly afoot San Juan to Cochas; 16-25 Cochas to Huánuco, convalescing from fever, fishing Rio Huallaga, Rio Tingo, and Huancachupa Creek; 26-29 Huánuco to Cerro de Pasco, fishing Rio Huallaga and a tributary at Ambo; 30 Fever, packing; 31 Cerro de Pasco by rail to Junin, damming creek, tributary to Lago Chinchaycocha, fishing, collecting parasites.

November 1, 1918 By train Junin to Tilarnioc, collecting fish and birds for parasites, train to Oroya; 2 Oroya to Lima by train; 3-7 Preparations for southern trip; 8-11 S. S. Maipo to Mollendo, boat-train to Arequipa; 12 Arequipa; 13 Train Arequipa to Puno; 14-20 Collecting at Puno mole, Puno Bay; shores of island in bay; 21 Train Puno to Sumbay; 22 Fishing gorge of upper Rio Chili, Sumbay by train to Maravillas and fishing Crucero Alto enroute; 23 Fishing the outlet of Lakes Lagunillas and Saracocha into Rio de Lampa, walked to Santa Lucia and freight-train to Maravillas; 24 Net fishing and poisoning millrace, etco about Maravillas, train to Puno; 25 Puno to Cuzco by train; 26 Sightseeing, the Eigenmanns arriving in evening from Urubamba trip; 27 ('uzco to Puno; 28 30 Preparing stores, etc. for overland trip to Bolivia.

December 1-3, 1918 Same; 4 Hunting birds for Parasitology about the bay; 5 Afoot with burro train Puno to Chucuito; 6 Hunting, fishing about Chucuito; 7 Chucuito to Acora, shooting birds enroute; 8 Acora to Ilave; 9 Dynamiting and seining Rio de Ilave, bird parasites; 10 Ilave to Juli, fishing Rio Caminaque enroute with roadside ponds and marshy areas; 11 Caring for parasites and collections at Juli, first collecting from open part of Lake Titicaca; 12 Juli to Pomata, fishing at noon in Rio de Molino; 13 Hunting birds and plankton Pomata Bay; 14 Pomata to Yunguyo, camping beside mole; 15 Shooting birds for parasites; 16 Mainly collecting parasites, at nightfall boarded coastwise steamer, Coya, found Dr. and Mrs. F. M. Chapman aboard; 17 Aboard S. S. Coya, Copacabana; 18 Guaqui, Bolivia, boat train to La Paz, joining the Eigenmanns and the Chap- 
mans; 19 Boat train to Guaqui, rejoining the Coya, and following eastern shores of Lake Titicaca; 20 Puerto Acosta and Moho port, set up camp in Adventist school; 21-23 Shooting birds, collecting parasites of birds, toad, fishes, collecting Oligochaets, Crustacea, spending one afternoon getting my assistant, Pedro Vasquez, out of Moho jail; 24-25 Waiting promised burros engaged by Gobernador; 26 Up at 4:30, enroute via Vilque Chico to Huancané; 27 Fishing and collecting

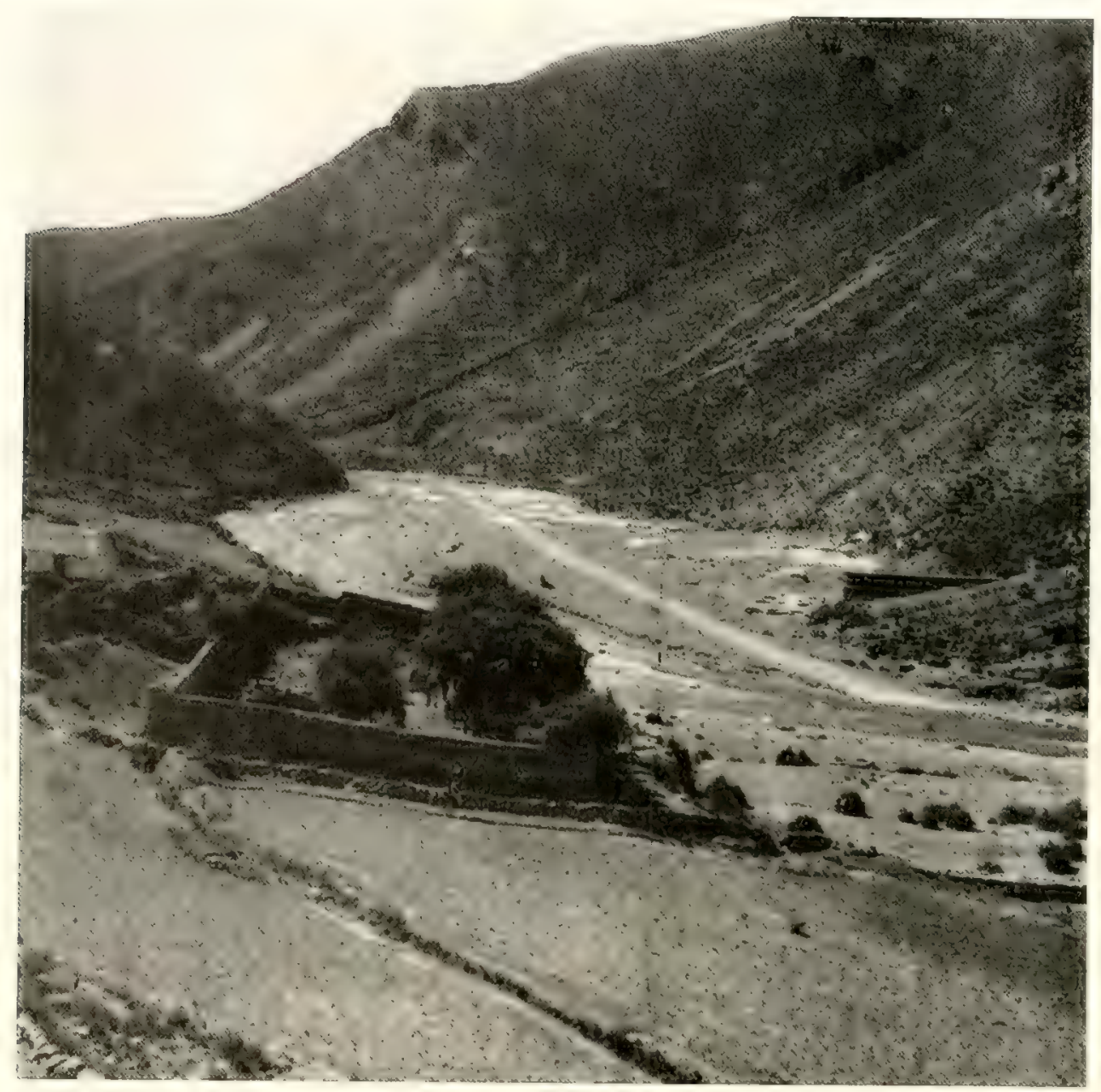

Fig. 6. Upper course of Rio de Poopó, Bolivia, about 13000 feet altitude. Thermal springs seen at foot of slope on right are sufficiently hot to be used for cooking, but their outlet is occupied by Pygidium at temperatures decidedly warm to the touch (above 100 degrees F.).

Crustacea in roadside pools and wet meadows, Huancané; 28 Continued rain and flood waters, dynamiting and seining at ford of Rio de Huancané; 29 Rio de Huancané to near village of Chupa, emergency camp; 30 One league further to Chupa, camping on North shore of Lake Arapa, Gobernador and villagers coming out and helping with seine; 31 Hunting birds, Crustacea, seining.

January 1, 1919 Burro train and afoot Chupa to Laguna Salinas, fishing enroute in small Rio de Chupa; 2 Fishing Laguna Salinas from balsa, no fish present 
due to high salinity, salt works, collected first known specimens (fide A. S. Pearse) of Artemia salina, the brine shrimp, from South America, although known from all other continents; 3 Collecting freshwater Crustacea; 4 Enroute Laguna Salinas to Azángaro, official visits; 5 Fishing Rio de Azángaro, shooting birds; 6 Azángaro to Tirapata; 7 Dissecting birds; 8 Dynamiting Rio de Pujara and its smaller tributary, Rio de Porque, train to Puno; 9 Laboratory work, packing, engaging animals; 10 Puno to Lake Umayo, invited to be guest of Señor Valcarcel at Hacienda Chingarani; 11 Fishing Lake Umayo, Spongillids, Crustacea, Oligochaeta, parasites; 12 Return to Puno; 13 Collecting Lago Verde and headwaters of Rio Vilcanota at La Raya and Aguas Calientes; 14 Laboratory work on specimens and preparations for Bolivian trip; 15 Same; 16 Train to Juliaca, fishing Rio de Lampa and ponds and ditches along the Cuzco railway line; 17 Collecting Crustacea from bayous near Juliaca; train to Puno, aboard the S. S. Inca for night trip across Lake Titicaca to Guaqui; 18 Collecting at Guaqui mole, Lake Titicaca, dissecting for parasites; 19 Guaqui to La Paz by train, exploring; 20-25 Making contacts with Señor Ballivian, and through him the ministers of government, for official assistance, packing, preparations for trips; $26 \mathrm{La} \mathrm{Paz}$ to Oruro by train; 27-28 Official calls at prefecture, etc., mountain climbing, collecting, dissecting; fishing Rio de Eucalyptus; 29 Oruro to Poopó village, burro train and afoot to Choro; 30 Choro to shores of Lago Poopó, camping on mud flat; 31 Tent flooded in night, fishing with seine from balsa.

February 1, 1919 Earthworms, Crustacea, sponges, parasites; 2 Getting transportation and part way on return to Choro; 3 To Choro, to Poopó, and to shelter of tin mine works nearby; 4 Fishing small Rio de Poopó and adjacent hot springs; 5 Poopó to Pazña by train; 6 Collecting Rio de Pazña, hunting, collecting parasitological materials; 7 Train Pazña to Challapata, collecting in Rio de Challapata, a brook; 8 Hunting land birds and their parasites; 9 Fishing, collecting birds and parasites, Crustacea, at lower end of Lake Poopó; 10 Dissecting birds, train to Uyuni; 11 Organizing; 12 Enroute to Antofagasta, Chile, dropping Pedro Vasquez to collect at Rio Grande de Lipez; 13 Interviews with officials regarding facilities; 14 By rail to Calama, Chile; 15 Reconnaissance of Rio Loa; 16 Train to Uyuni, Bolivia; 17 Return Uyuni to Cebollar, Chile, on Lago Ascotan, at home of Mr. Lycett; 18 Ford track-car and mules 14 kilometers to freshwater pools and streams; 19 Packing and collecting parasites and Entomostraca, to Uyuni, Bolivia, by train; 20 Uyuni to Potosi, Bolivia, dropping Pedro Vasquez at Rio Mulato enroute to collect; 21 Return via Rio Mulato to Uyuni; 22 Train Uyuni to rail terminus at Atocha, fishing Rio de Atocha; 23-24 Collecting, train to Uyuni, international train for Oruro and Cochabamba; 25 Reconnaissance of Cochabamba, train to Oruro; 26 Train to La Paz; 27 Train for Arica, Chile, dropping Pedro Vasquez at Calacoto to collect the Rio Mauri; 28 Vacationing at Arica.

March 1, 1919 Reconnoitering for fishing grounds; 2-3 Found one pond 9 kilometers up the roadstead and railroad toward Tacna, by train to Bolivia in evening; 4 Picked up Pedro Vasquez with collections at Calacoto, on to Viacha; 5 Fishing the turbid Rio Colorado and adjacent bayous on pampa; 6 Train to Guaqui; 7 Hunting near Guaqui, fishing ditches along railroad; 8 Fishing Rio de 
Tiahuanaco and ponds at village of Tiahuanaco; 9 Aboard S.S. Coya Guaqui, Bolivia, to Puno, Peru; 10-11 Closing up affairs at Puno, packing, soldering, ship-

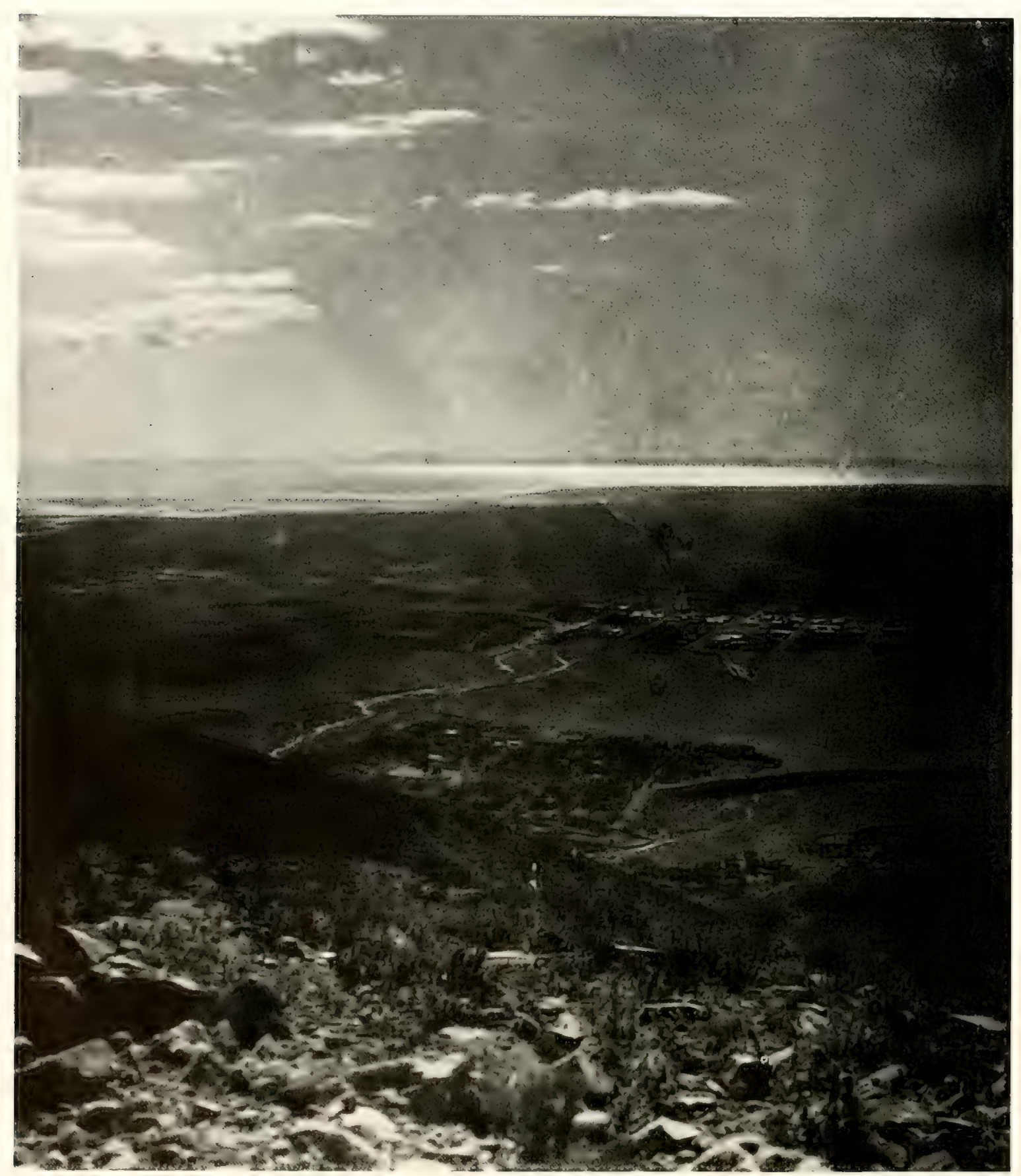

Fig. 7. Lake Poop', Bolivia, seen at about seven miles, from a mountain top above Challapata, elevation above 12000 feet. The Rio de Challapata winds about the old town and passes the new (railroad) town. Its course indicates the extreme flatness of this allurial plain. The lake, although having a length of fifty miles, is not known to have a greater depth than about thirteen feet.

ping collections; $13-14$ Train to Lagunillas, collecting in chain of lakes at 14000 feet elevation; 15 Train to Arequipa; 16 Train to Mollendo; 17 Waiting for S. S. 
Huasco; 18 Aboard S.S. Huasco for Callao; 20 Arrived Lima; 20-April 9 Delayed in Lima awaiting funds.

April 10, 1919 Aboard S.S. Limari for Cristobal; 16 Arr. Cristobal, C.Z.; 18 Aboard S.S. Santa Marta, via Colombian ports and Port Royal to New York; May 3, arrived Bloomington, Indiana.

\section{Centennial Expedition}

May 9, 1920 Left Bloomington, Indiana; 10-11 Outfitting and preparations for sailing, New Orleans; 12 Sailed on S.S. Parismina; 17 Arr. Cristobal-Colon; 20 Aboard S.S. Ucayali; 21 Transiting Panama Canal; 24-25 Loading cargo at Guayaquil, Ecuador; 26 Payta, Peru; 27 Eten, Pacasmayo; 28 Huanchuco, Salaverry; 29 Callao, Lima; 30-31 Arranging with Customs, bank, consuls, Minister of Foreign Relations, Professors Tello and Rospigliosi, Peruvian Corporation, War Department, and Department of Fomento.

June 1-5 Continued; 6 Fishing with poison at Callao in mouth of Rio Rimac; 7-8 Geographical Society, Hermanos Praeli, etc., packing; 9 Train to Rio Blanco; 10 Adjustment to elevation; 11 Poisoning Rio Blanco without results, train to Huancayo; 12-13 Visiting native shops to buy their stocks of cubé, the native fish poison; 14 Return Huancayo to Oroya; 15 Oroya to Tarma, reconnaissance; 16-18 Waiting baggage via 'Tilarnioc, fishing Rio de Tarma; 19-20 Baggage arrived, repacking for transportation by mule, and arranging for same; 21-22 Tarma by muleback and packtrain to San Ramón and La Merced; 23-24 Fishing creek with cubé; 26-28 Fishing Rio Chanchomayo about La Merced, damming, dynamiting, seining, poisoning; 29-30 Repacking and organizing transport.

July 1, 1920 La Merced to La Peruvian on the Rio Perené; united the 'Centennial Expedition' with the 'Cornell Expedition' for the ensuing three weeks; 2 Hda. La Peruvian of the Peruvian Corporation to the first tambo of the Via Central, Yapaz; 3 Yapaz to Tambo Eneñas, $30 \mathrm{~km}$., and over the summit of the Cadena de la Sal at 6000 feet; 4 Poisoning creek at Eneñas; 5 Eneñas to Tambo Dos de Mayo, Km. 71; 6 Tambo Dos de Mayo to Tambo Porvenir; 7 Tambo Porvenir to Tambo San Nicolas; 8 Tambo San Nicolas to Tambo Azupizú, 14 km., fishing in Rio Palcazu; 9 Tambo Azupizú to Tambo Miriatirani; 10 Tambo Miriatirani to banks of Rio Aguachini, held by rain and flood waters; 11 Ferried Rio Aguachini by raft, to Puerto Yessup, dugout canoe Puerto Yessup to Puerto Bermudez; 12-18 Fishing Rio Pichis, Rio Chiviz, and small streams; 19 Resumed travel down Pichis by canoe, camp on sand-bar; 20 Canoe journey continued, reached the Cocamita, going aboard with the mail and baggage, down Pichis and Pachitea, camping on sand-bar; 21 Continuing down Rio Pachitea, hook and line fishing; 22 To mouth of Rio Pachitea, transfering to larger steam launch Louis, towing the larger Verdun; 23 Aground on sand-bar most of the day on the Rio Ucayali; 24 Arrived Contamana, headquarters for four weeks. Rented an unused water-front house, moved in; 25-26 Preliminary arrangements, hiring boys; $27-31$ National Holiday, boys resigned, no facilities.

August 1, 1920 Organizing trip upriver; 2 Mail launch Verdun to Nueve Ytalia, guest of Señor Julio Battistini; 3-4 Fishing Lago Cashiboya; 5 Upriver to 
village Maqueria, fishing in cutoff lake; 6-7 Fishing at Nueva Ytalia, waiting for overdue launch; 8 Rowboat down to Contamana; 9-10 Buying alcohol, packing, preserving specimens; 11 Joined party to reconnoitre site for village when present site will have been removed by the river; 12-14 Packing and waiting for launch; 15 Aroused by whistle of the Louis at 2:15 a.m., unable to embark, as she takes the East channel, I the West; 16 Castnet fishing with army lieutenant and two Chama Indians in Cocha de Contamana; 17 Repairing seines; 18 Fishing oxbow lake Tupishka with lieutenant, soldiers, and Indians; 19 Waiting for launch Melita,

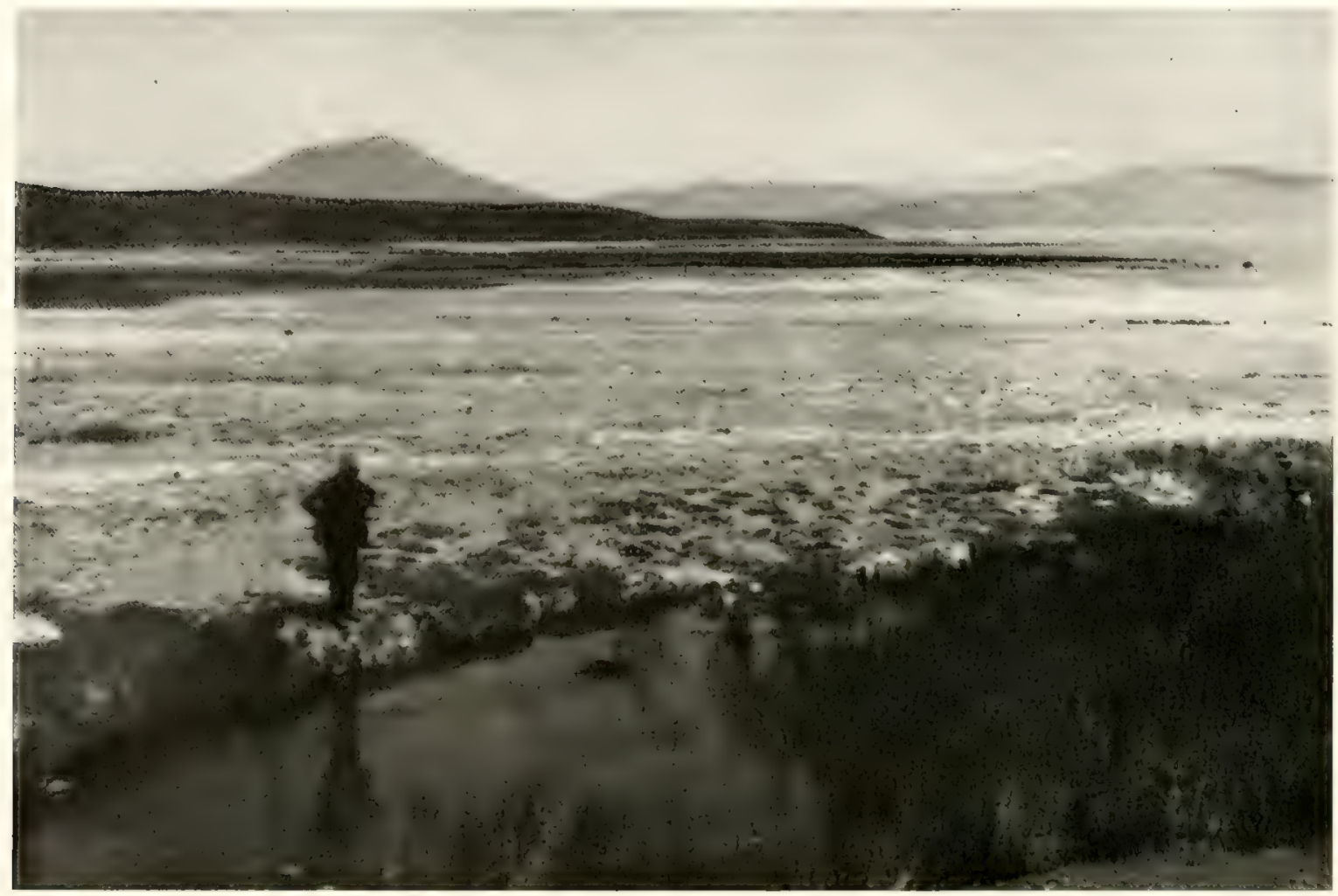

FIG. 8. Lake Ascotan, Chile. Partly lake, partly dry and encrusted with salts, and wholly enclosed within a ring of volcanic peaks, Ollaguë at one extreme, San Pedro and San Pablo at the other, near 13000 feet elevation. Inhabited by Orestias agassizii similar to those of the Bolivian side of the peaks. They show considerable adaptability to saline waters, but are most abundant in freshwater springs such as this.

delayed by storm; 20-21 Aboard Melita, delaying to trade; 22-23 Fishing sand bars of Ueayali near anchorages of Melita at various trading points, Orellana, Inahuaya, etc.; 24 With three men and castnet took boatload of fishes in schools, ascending the river along the shore, transferred to launch Rosa to take the western route; 25 Aboard Rosa entered the Puinagua, or West Fork, arrived Bretaña at 5:00 p.m.; 26 Guest of Señor Medina, javelin fishing in mouth of Rio Pacaya; 27 Mending nets, preparing for trip up Rio Pacaya; 28 With host, nephew, three peons enroute up Rio Pacaya in large dugout; 29 Up the cutoff Lake Yarinacocha to its upper extremity; 30-31 Hook, javelin, castnet fishing, visiting weirs in the back-waters and cañas (furo, in Brazil). 
September 1, 1920 Fishing about the mouth of Yarinacocha; 2-3 Seining enroute down the Rio Pacaya to Bretañ; 4-7 Packing, preserving, collecting parasites, fishing at Bretaña, in the back-waters of the Pacaya; 9 Waiting for the overdue launch Lovie; down the Puinagua; 9 Down the lower Ucayali, waters greatly swollen, little fishing, to mouth of river on Rio Marañon; 10 Down the Marañon to Iquitos; 11-17 Buying fishes in market, packing, contracting for a run of redistilled, high-proof alcohol, changing alcohols; 18-19 Guest of Senor Layet, my distiller, and his wife at their Hda. Iça up the Rio Itaya, poisoning in clear, woodland streams; 20-28 Collecting in ponds and brooks near Iquitos, Marañon, Nanay, and cutoff lake Moronacocha, preserving, packing, and shipping fishes, preparations for next cruise; 29 Boarded the launch-transport Hercules on its tour of the frontier posts; 30 Getting equipment stored and adjusted to a crowded launch.

October 1-2, 1920 Up the Rios Marañon and Tigre to the outpost on the Ecuadorian frontier; 3-6 Up the Marañon against swollen and turbid waters, with poor fishing; 7-10 On up the Alto Marañon; 11 Obtained an additional supply of fishpoison; 12-13 Poisoning small woodland streams with cubé; 14-16 Continuous travel up the Rio Morona; 17 Seining Gosulimacocha; 18 Landing and embarking troops and officers, with their supplies, much rain, descending swollen Rio Morona; 19-20 Replacing broken propeller shaft, on down Morona; 21-22 Up Alto Marañon to Puerto Melendez, river bank-full, swift, and turbid, no fishing; 23 Poisoning creek across from Pto. Nelendez, aboard the Hercules, and on down the Marañon; 24-25 Continuing down Alto Marañon to mouth of Rio Huallaga, left the Hercules; 26 Awaiting the launch for the Huallaga, Adolfo; 27 Arrived late at Yurimaguas on the Huallaga; 28 Rented vacant store in which to live three weeks, official visits to subprefect and gobernador; 29-30 Preparation for work, getting helpers; 31 Fishing at Lago Sanango upriver from Y urimaguas.

November 1-2, 1920 Seining bars of Rio Paranapura, entering Huallaga just below city; 3-4 Poisoning creeks in forest inland from city; 5-6 Seining pasture ponds, rains, indoor work; 7 Trying swift waters of Rio Shanusi above city, seining bars of the Huallaga itself; 8-13 Rain, hiring men, buying cubé, short trips between rains; 14-17 Photography, preparing specimens, packing; 18 Boarded launch Adolfo; 19-21 Aboard the launch enroute to Iquitos, stopping frequently to trade; 22-28 Buying fishes in Iquitos market, packing, shipping, developing film; 29December 6 Aboard river S.S. Säo Salvador Iquitos to Manaos, Brazil.

December 7-8, 1920 Manaos, buying fishes; 9-13 Manaos to Para, Brazil, at the mouth of the Amazon; 14-17 Para, sightseeing, visiting museum, etc.; 18-January 2, 1921 Aboard the freighter Hubert of the Booth Line, Para to New York. 


\section{HISTORY OF ICHTHYOLOGICAL EXPLORATION IN PERU}

Much of the territory is so remote and so difficult of access that transportation problems have kept the traveler out, and the products of the country in. Natural resources have yet, providentially, to be exploited in many regions; only those most easily removed, most in demand, or commanding the highest prices on world markets, such as gold, quinine, coca, or rubber, have successfully overcome these barriers. Just as soon as rubber or quinine were established on a paying basis in the Orient, their native South American provinces ceased to meet competition. Cotton, lumber, Brazil nuts, ivory nuts, etc. do well only when the demand abroad is very high. There has never yet occurred a world demand for such perishables as fish sufficient to overcome the costs of packing and shipping, despite their great abundance.

Very few attempts have been made to explore the region in a scientific way. Nearly all the collecting has been done by laymen, incidentally, with the usual result that there is only one specimen of a kind, or specimens are improperly preserved, with no information as to habitat, habits, or exact localities. Conversely, the descriptions are often written by men who have never seen their subjects in a living state, and whose work is done in the shelter of an overseas museum. No one has done for fishes what Bates was able to accomplish for the Lepidoptera during his eleven years' residence, and devotion solely to that subject.

The 1830's were marked by the expedition of von 'Tschudi, but the results not of great value since he dealt with the entire fauna of Peru.

During the 1840's Castelnau made his well-known expedition to the interior of Peru and down the Amazon, giving much the greater time to Brazil, dividing his time between various branches of Zoology, and one section of his report to fishes.

The 1860's found John Hauxwell in that region which has been under dispute among Colombia, Brazil, Ecuador and Peru, the lower Peruvian Amazon about Pebas and the Rio Ambyiacu. He was in correspondence with Bates in Brazil and with Cope in Philadelphia.

During this decade, Edward Bartlett transmitted specimens from Xeberos and the Huallaga to Günther at the British Nuseum; also specimens were recorded by Günther from Higgins, the localities the same. This decade may be considered the most noteworthy in Brazilian ichthyology by reason of the Thayer Expedition led by Louis Agassiz. The main expedition traveled up the Amazon as far as Manaos, and one of its members just missed our territory, Bourget having been sent by the emperor, Dom Pedro II as far as Tabatinga.

At about this time Cope received a collection from Robert Perkins, taken "between the Huallaga and the Rio Negro." Also Prof. James Orton made his first geological and biological excursion, traveling from Quito down the Napo to the 
Peruvian Amazon. His fish collections constitute the largest part of Cope's material, and the largest collection made in Peru prior to our own.

The 1870 's will be noted principally for two projects, the first being the two journeys of James Orton. He again descended the Napo to the Amazon, thence to Nauta, Lima, Arequipa and Lake Titicaca, his material from Nauta and Pebas reported on by Cope and Gill. His work came to an untimely end with his death at Puno, Lake Titicaca. While working about Puno, I frequently passed the lonely islet in Puno Bay where lie his remains, a happier resting-place with its reedy shores and the plaintive voices of the waterfowl than the sacred but now crumbling crypts of the Pumo Pantheon.

The year 1875 brought Alexander Agassiz and Samuel Garman on a survey of Lake Titicaca, from January 1 to March 5, their work dealing in part with the fishes. While at Puno I met an old man who had been errand-boy for that expedition, and who told naive reminiscences of the event, which loomed large in his memory.

Small collections of fishes from Amable Maria, Tambillo, and Monterico on the Tulumayo were published by Steindachner.

About 1880 Clarence Buckley made "rich collections" at three localities in eastern Ecuador, Sarayacu, Canelos, and Pallatanga. The materials were worked up mainly by Boulenger. Some of it, disposed of to a dealer, found its way to Steindachner, including some new species.

At approximately the same time a Dr. A. Stübel traveled via the Huallaga, collecting enroute. Steindachner received 121 specimens from him, assigned to 55 species. Also at this period Steindachner received from a Herr Stolzmann a collection of fishes from the basin of the Rio de Huambo and its tributary the Rio de Totora, Callacate, etc., of the middle Huallaga basin. His artist now visited the settlement of Monterico (Custos L. Taczanowski) obtaining some of its scanty fauna.

During the 1890's, and reported by Boulenger, collections were made by Dr. Enrico Festa in Ecuador, entering the Rio Santiago, the principal tributary of the Alto Marañon, which is in our territory.

As reported upon by Regan, 1903, the new century opens with a collection of fishes in the British Museum made by a Mr. Ockenden on a journey via Tirapata to the Marcapata valley. A species of Orestias was described from this material by Boulenger, 1902.

Mr. P. O. Simons was the collector of a group of fishes in the U. S. National Museum from the Perené and elsewhere.

Dr. Austin Davis dispatched a collection of the fishes of the Cerro de Pasco region to the U. S. National Museum, partially reported upon by Evermam and Radcliffe.

Early in the second decade of the present century some incidental collecting was done in the upper and middle Urubamba valley to Santa Ana and the Rio Comberciato by Edmund Heller and E. C. Erdis of the Yale-National Geographic Society Expedition. The results of that collecting appear elsewhere in this paper. At about that time the British Museum received a collection of fishes of the Rio Ucayali, made by W. Mounsey, reported by Regan in 1913. Also Miss Lola E. Vance (Mrs. Jacob Lievense) collected in the Rio Tarma from Tarma to La Mereed. 
The end of the decade saw two of the Indiana University expeditions into this area, the Irwin Expedition, 1918-1919, and the Centennial, 1920-1921, discussed elsewhere in this paper. The Mulford Expedition, as reported in Eigenmann, $1922 \mathrm{~b}$, crossed our route and continued the survey down the Beni and Mamoré. In 1923 Dr. N. E. Pearson added the valuable chapter of Peruvian ichthyology dealing with the fishes of the upper Marañon and overland between that river and the Pacific via Cajamarca.

Myers (1936b) indicates that the United States National Museum has received a valuable collection of fishes made in eastern Peru in 1935 by Mr. William G. Scherer. This material remains unworked, except the one or two striking examples which he picked out for immediate publication. Mr. Scherer is continuing his collections about Pebas and the Ambyiacu for the Stanford Museum.

1937 (Fowler, 1939), is marked by an important collection of fishes made by Mr. William C. Norrow and associates, chiefly about Contamana on the lower Ucayali. Unfortunately a still larger part of this collection was lost in transit. Surviving the accident Fowler reports 319 specimens, 106 species, of which 22 are new, with 5 new genera.

This account is incomplete. A scattering of specimens has found their way into various museums without being reported, such as a collection by J. B. Steere. I have elsewhere listed a small collection made by E. G. Squier in 1865 from Lake Umayo.

The close of the career of Professor Eigenmann would appear to be an appropriate moment in History for an assay of the status of neotropical ichthyology, for he gave more years of his life to that subject than any other has done, despite what others would have considered insuperable discouragements. I shall not attempt, however, more than a brief categorical outline of some of the convictions which have forced themselves upon me during this study.

Although large collections exist, there is still great lack of material for the careful revision of many groups, a centralized collection many times larger than any now under one roof, and representing many more localities, from all parts of South America. It is unfortunate that Eigenmann passed before the era of liberal spending. He would have envisioned, and perhaps have realized such a program. No museum or institution is at present carrying out a systematic attack upon such an enterprise. There is little collaboration among scholars in the field, little unanimity of purpose, no undivided interest on the part of any man. There is even a conviction on the part of some ichthyologists that the citizenry is not asking this service, although the initiative must arise from the scholar himself. The personnel in field and museum needs to be enlarged. It now devolves upon American institutions to take the lead, due to the impairment of those abroad.

A second type of work which should be undertaken at this time is that of making exhaustive collections in certain small, selected areas. This has almost never been undertaken; the long series of visits to Pebas is nearer this objective than any other, but has always been in the hands of untrained amateurs. It is highly important that a trained personnel spend a period of years, from season to season, in these areas, with all needed equipment to work up their collections on the spot, from living fishes as well as dead. 
Corollary to the last-named objective, the field laboratories should undertake studies of life-histories, food-habits, ecology, parasites, etc., almost untouched phases of the subject, except for recent Brazilian efforts.

In the highlands of Peru and Chile some new temperate-zone forms have been introduced. Chile has had considerable success with the European brown trout, even well down toward sea-level, in the South.

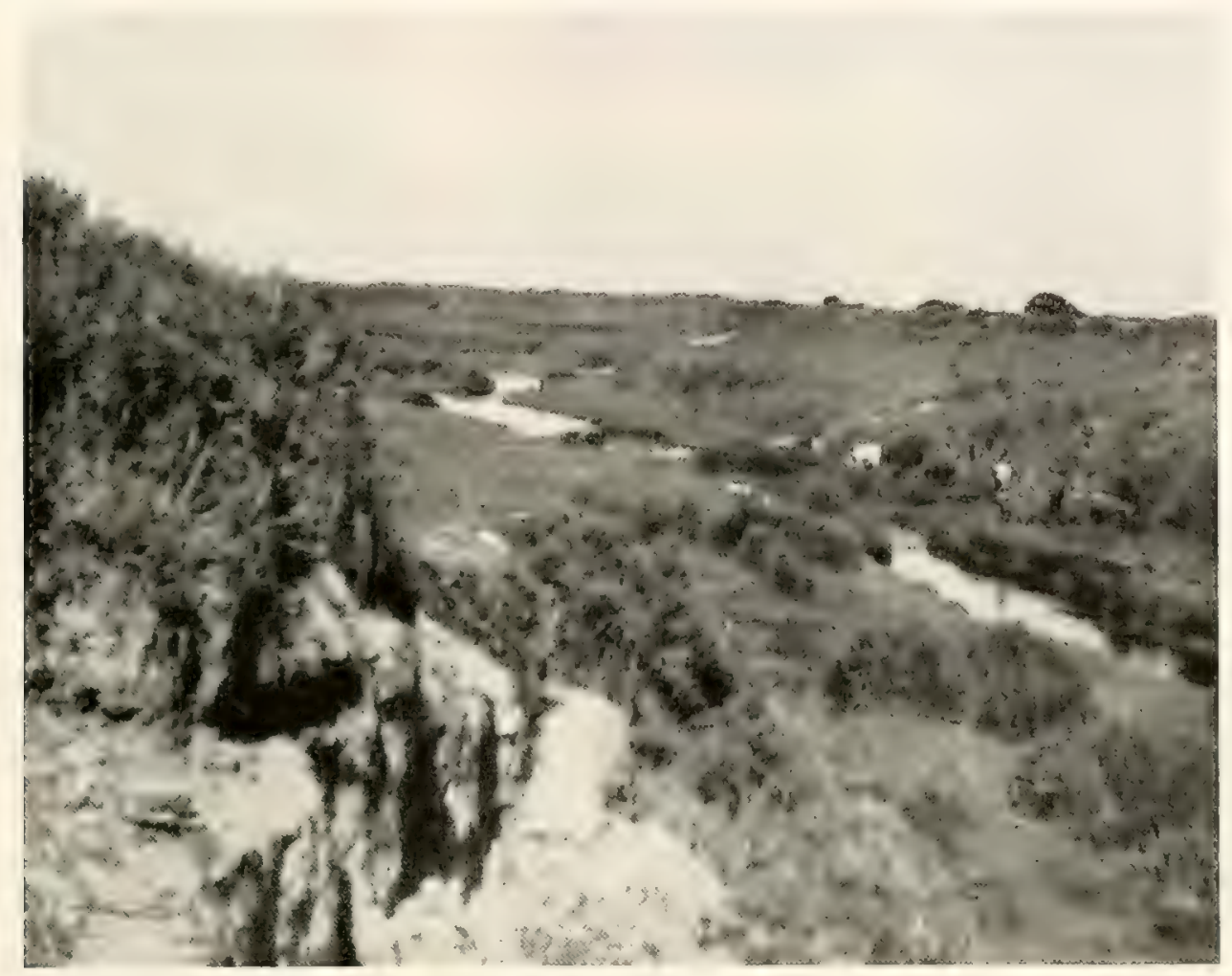

FIG. 9. Rio Loa, Chile, and bordering irrigated lands. At this point near Calama found to be devoid of fishes. Elevation about 7000 feet.

For some years the Rainbow trout has been a member of the fauna of the upper Mantaro, introduced by the U. S. Bureau of Fisheries and members of the Cerro de Pasco Company's staff. The situation there has been modified further by the impounding of the waters of Lake Chinchaycocha. What biological effects this has had on that lake since my visit would be interesting to know.

Proposals for the impounding of Lake Titicaca, raising or lowering it, have been made. To do so would greatly affect the biological constitution of it. Such an event may not transpire for many years, but that long-deferred thoroughgoing biological survey should be made. A suggestion was made by Garman as long ago as $\mathbf{1 8 7 5}$ that the lake be used for a large-scale experiment on the introduction of better economic species. Recently an effort has been made to do this, when two million whitefish eggs, and many thousands of lake trout eggs were sent for release there. They also, if successful, will materially alter the biology of the lake and its tributaries, even before a survey can be made of the original fauna, and life histories of Orestias species, etc. be determined under original conditions. 


\section{TIE FISIIERIES OF WEST-CENTRAL SOUTH AMERICA}

The streams of South America are unparalleled for length, width, depth, volume, number and variety of tributaries, and for the intricate network of halfexplored backwater channels-unequalled therefore in the opportunity they have presented to the ichthyfauna for the evolution of species and of populations. The part that fishes have played in the daily lives of the human population is consequently very large. This is true chiefly as a source of food, but also in a variety of other ways, such as the handicrafts, folklore, and religion. Travelers have sometimes reported that this is true, but have brought back little circumstantial information. Few books deal with fishes or fisheries to greater length than a paragraph or as much as a few pages.

Beals uses the word fish at least six times (1934) but makes no mention of fishes. Koebel, writing from the economic point of view, makes the scantiest mention of fisheries and the possibility of their development. He says naively (1915, 233), writing of the native dependence on fish as food: "it is said that the Amazon contains a freshwater replica of every salt water fish from the whale downwards ... the manatee of a size to be hunted by the Indian with the harpoon ... but with the growth of inland communications it is possible that the demand will spring up, in which case no doubt the neglected industry of fish will gain a much-needed impetus."

Enoch, trained observer, student of natural resources, hasn't so much as a line on this particular resource, while Domville-Fife in a book on the economic life of Brazil, gives one brief paragraph to the fisheries of Uruguay, including freshwater and marine.

Whitbeck $(1926,233)$ in an economic geography, finds room for an account of the vanishing and picturesque vicuna, but makes only passing mention of the fisheries of the coast, none of those of the interior. He discusses the oft-described Sunday market of Huancayo, but hasn't a word for the shopping habits of all Amazonia; gives all the credit for the production of guano to the birds, none to the fishes who sacrifice their all.

Those pioneer students of natural resources, Herndon and Gibbon, make numerous allusions to fishing, few to fisheries, and as to fishes, they only repeat a few matters told them by the natives. For example, Gibbon thus reports nine kinds found at the outlet of Lake Titicaca and absent at Puno; that there are more kinds in the limpid east side than in the shallow northwest corner.

Squier $(146,148$, and 173) says "the waters of Titicaca hide a variety of strange fishes which contribute to support a population necessarily scanty". Conversely Bandelier (page 48) reports the Indian population of Titicaca Island not much addicted to fishing. He mentions the occurrence of twelve kinds including bogas and suchis. Means (page 134) gives weight to Peñalosa's account (1586) of the Uru tribe and its dependence on fish and "roots of wild plants" (no doubt the 
potato). Bowman alludes to the small numbers of native andean groups dependent on fishing, the Urus of the Desaguadero, and a small tribe on the Chilean coast.

Martin $(1905,171)$ says the Para market affords few appetizing fish, but countless turtles (page 214). Mozans $(1911,506)$ quotes Agassiz as to the vast numbers of Amazon fishes yet marks their total absence aboard the steamers of that river,

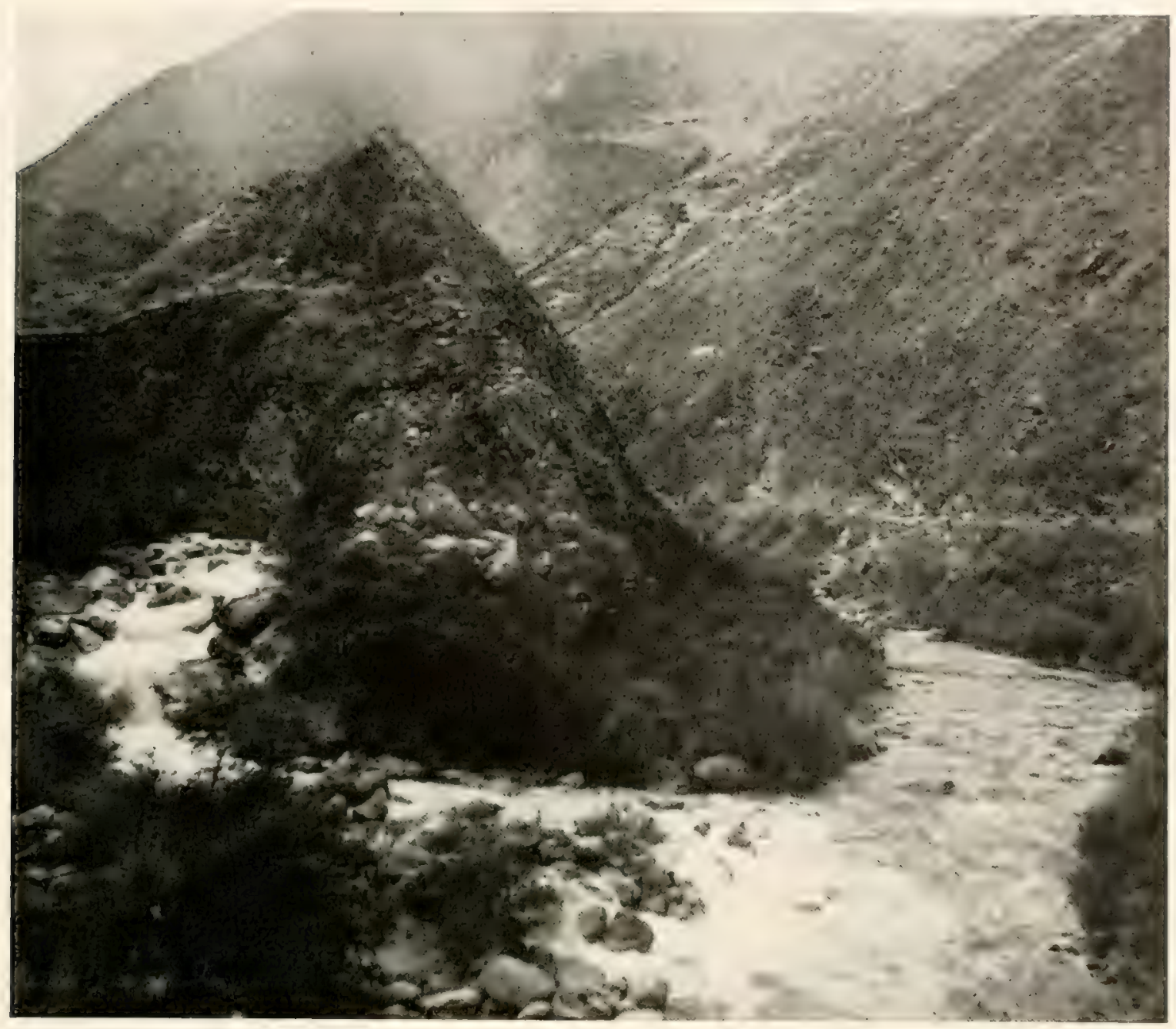

FIG. 10. The upper Rio Huallaga. Looking upstream to the right. On the left enters a tributary fed by melting glacial ice from the Eastern Cordillera, its milky waters diffusing into the darker main stream. The road from Cerro de Pasco to Huánuco on the mountain side at the right. Waters similar to this continue for many miles, separating the lowland fish fauna from that of the highlands.

quoting a steward to the effect that they are too expensive. McGovern (page 54) says that although the Amazon is the angler's paradise, it was seldom that they were given fresh fish, every meal consisting of salted pirarucú, with a flavor like rancid soap. Medina (Lee trans., 1934) frequently points out the dependence of the early explorers upon fresh fish and dried, and the dried flesh of manatee.

In all Raimondi's wide travels, the fisheries resources seem never to have 
reached the threshold of his consciousness, although undoubtedly sometimes a constant article of diet. They were perhaps a sort of manna, no more worthy of a place in his three great volumes than the sunshine. An encyclopedia should render more space to so important a matter, but the South American Encyclopedia (Koebel, ed., IV, 1506) has only to say that fish is expensive in the markets and that Amazonia exports less than a million kilos of this, its greatest resource.

Nash $(1926,80)$ laments the excessive fishing of the breeding adult, and of young fishes, of the Atlantic coast.

In spite of the almost universal mention of fisheries by travelers, the accounts we have would attach a very minor importance to them. Yet they are the greatest single food resource of the lowlands. I note that travelers who set forth into the interior with a superabundance of supplies which they often enumerate, frequently meet with disaster and are thrown on the resources of the country. Thus you read more and more about fishes as you approach the final chapters; the fishing stories are directly proportional to their dependence on the country.

Often the native populations spend a good part of the dry season on lengthy fishing trips, as described formerly by Bates, Herndon, and others. Whitney (page 117) could not understand why the fishing was done during the low-water season. It is a very common experience in travel along the rivers to pass temporary shelters on the sand-bars, or at the edge of the forest, built of poles or of cane, with palm-thatch. Here families or male members of families are camping or have camped. Nearby are the palm-thatch platforms on poles where the drying of the catch is done.

The whole of the white man's civilization in the interior is centered about the river. The entire population is distributed along the water-courses, either on the main streams or on the web of backwater chamels. The larger towns, such as Iquitos, Contamana or Yurimaguas lie on the more navigable rivers, and various villages such as Xeberos are on the banks of secondary streams and bayoux, off the beaten path. The indigenous tribes are still farther removed toward the upper reaches of the secondary streams. From the Andes to the Atlantic scarcely a road is to be found, except the local footpaths through the forest from one settlement to another. Most of the white man's dwellings face the streams, the portal of each at the river bank. Here he maintains a floating dock, which is a raft of a size proportional to the volume of his business. Here his fleet is tied up, often consisting of canoes of various sizes. The largest may exceed thirty feet in length and require four to eight paddlers; the smallest light, shallow craft for local use. The largest montarias are often canopied over amidships. On the raft-landing of each farm is maintained working-space for gutting fish, sometimes also the drying platforms. Here the huckster-boats (lanchas) tie up for long hours, bartering with the patron for his fire wood, cotton, tagua-nuts, dried paiche, or other products. Now and then a pig is purchased for consumption on board. The raft is often provided with a bathhouse, or at least a bathing-place. Here guests are met and from here they depart. 


\section{METHODS OF FISHING}

The student of fishes and of fisheries is also much interested in the methods by which fishing is done. Radcliffe rightly remarks that there is little information to be had concerning Peruvian fishing before the Conquest. The writings of the Conquistadores and their more literate companion Church Fathers are devoid of allusions to this and to other ethnic matters. Their mission was rather to learn what was wrong with the native ways of life and to reform them. It is doubtful if many unique, indigenous fishing practises survive without change to our day, except among the most isolated tribes of the tropical forests of the far interior. Among various practises it may be impossible wholly to determine which are native to the country. It is highly probable that certain methods have evolved in various parts of the world independently, and some of them are no doubt the common inheritance of various peoples from before their present distribution about the earth. The blow-gun as a hunting weapon was invented among the tribesmen of both hemispheres; why not also the throw-net? Of methods in use in central South America, we have an excellent list from Haseman (1911c).

I often found my own equipment inadequate for certain fishes or certain localities, and was obliged to resort to local assistance. The people frequently considered my gear a joke.

Tet-fishing has taken various forms in South America, but in the interior seems nowhere the principal dependence, as in other parts of the world. Except in marine fishing large nets are almost unknown, although, as described by Ogilvie $(1922,165)$ seines are employed to some extent in Lake Titicaca, operated from balsa to balsa. In the lowland streams of the interior, my seines were rapidly cut to pieces. Gill-nets would be destroyed in a single setting, and most fishes caught in them eaten by predators. In mountain streams no form of net could be operated among the rocks. Tolten, however (page 255), alludes to the use of large nets for shoals of traira, and Up de Graff finds the Antipas fishing with nets of fiber, having floats of balsawood.

The throw-net is a special type of netting practised here as in many parts of the world. The inhabitants construct their own from cotton fiber, using various names for them, Paez calling them tarraya, elsewhere known as iarafa. The Peruvians were much interested in mine, scorning the pocket, or bolsilla around the margin.

In the Lima region with only the pejerrey and the camerones available, the local fishermen work upstream among the rocks with a small semicircular dipnet formed on a bow-like frame. This is pushed ahead, flat side down, held against the knees, while the fisherman reaches upstream, turning the rocks, the current sweeping his catch into the net between his feet.

For work among the pondweed in the Rio Ilave, I found a local custom of fish- 
ing with a square net similar to the above, but mounted on a curved pole which would enable the operator to rock the net up and down, forcing it through the tangle of plant.

Many authors allude to bow-and-arrow fishing, (Whitney, page 95; Bates, page 77 ; Fleming, page 153 ; McGovern, page 234; Orton, page 478, et. seq.; Grubb, page 34). The method is practised chiefly in central Brazil up to the border of our territory. Grubb describes a method of using bow and arrow with the aid of a lure, made of white bark, cut in the form of a fish, whose details are drawn in

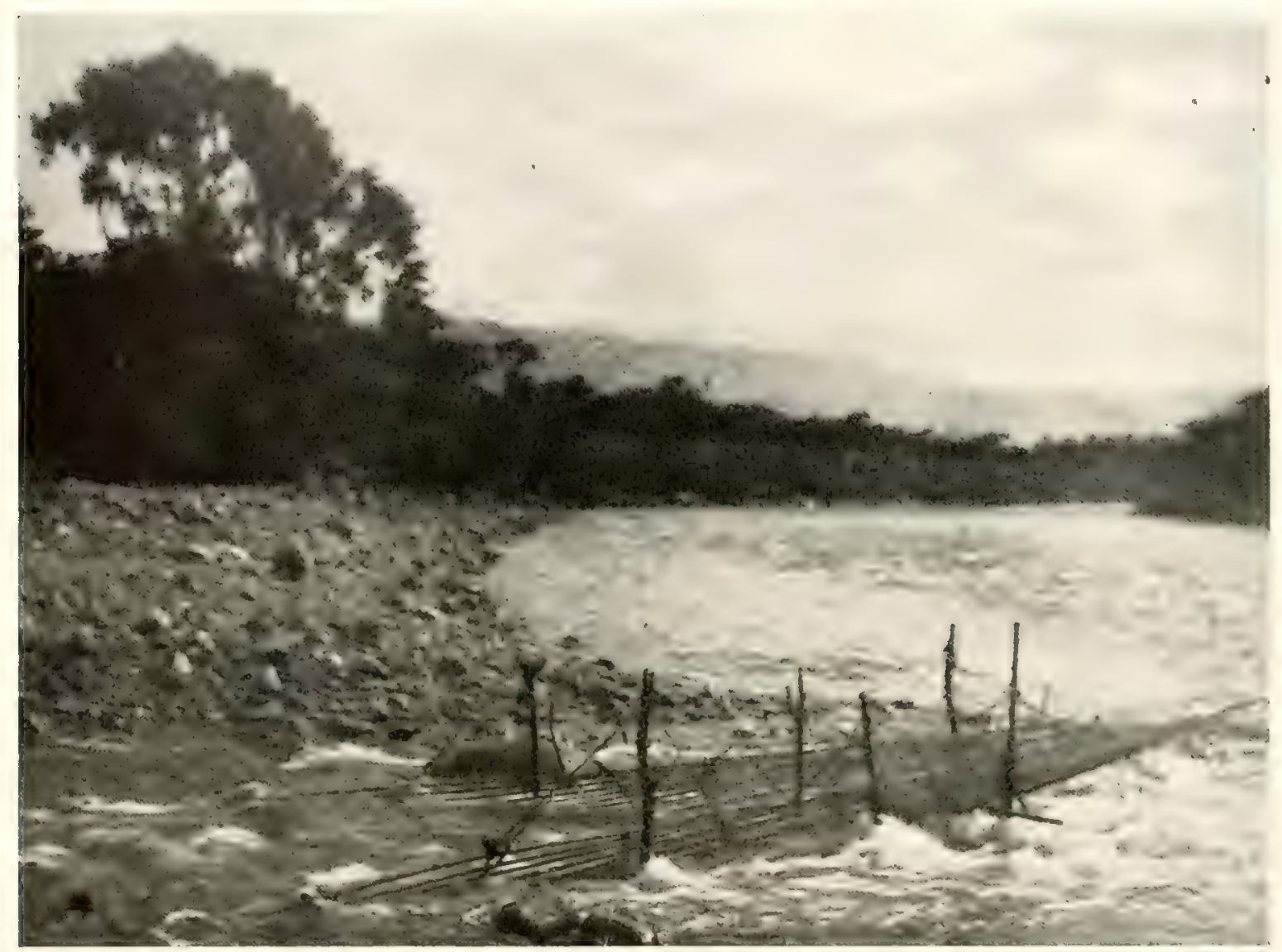

FIG. 11. Fish-trap in the mouth of the Rio de Tingo, or Rio de Higueros, at Huánuco on the Rio Huallaga.

charcoal. Herndon describes a fishing arrow with detachable head. His companion, Gibbon (page 193) not only describes, but gives an elaborate drawing of a system of bow-and-arrow fishing used by the Yuracaré tribe. It consists of a series of logs or large poles supported just above the water, and used as runways from which the barefoot fisherman could discharge his shafts into the quiet waters below, recovering them with his catch wherever they came near his footlogs.

Hook-and-line methods are little employed in regions I visited, nor did I find fishhooks as ready a medium of exchange with the simple heathen in the traditional manner, as I had hoped. In fact, due to the corrosive effects of climate and the 
voracious ways of certain fishes, the lifetime of a fishook is brief. MeGovern, however, page 234, finds the inhabitants of the Uaupés using bone hooks made in evident imitation of the metal ones; Orton found hooks used to some extent (page 478). André describes an implement known as the robador. It was a weighted line, with a row of bare hooks. Thrown among a school of fishes, one or more of the hooks would meet with its prey a sufficiently large number of times.

Harpooning is practised in this as in other parts of the world. I was interested to observe three modifications of the method. The first was a homemade "gig", three stout wires sharpened and bound to a pole in the Neptunian manner. Such an implement was seen in use both in the Titicaca region, and on Chinchaycocha, where it was a frogging rather than a fishing weapon. Neither the tines nor the pole are native products of the highlands, and must be gotten through trade. In one of the best early accounts, however, Bandelier (page 48) quotes Father Cobo, as early as 1683, Historia del Mundo Nuevo, II, 227, as to the use of the fisga. This was then a three-pronged harpoon, which they "used in the right hand while swimming in pursuit of the fish with the left". Bandelier justly remarks that swimming in these waters for as much as fifteen minutes would be impossible. I never observed anyone swimming in or about the lake, even for a moment, nor wading longer than necessary.

A second type of harpoon was a two-pronged iron javelin with a shaft consisting of the stem of a cane, of considerable strength, and extreme lightness, used for fishes of moderate size, thrown, not jabbed.

The third type, however, was a much heavier one, with a wooden shaft of some eight feet in length, capable of floating. A detachable, barbed iron head with a length of cord completed it. Its special usefulness was in taking the larger Pimelodids and the pirarucu. Orton (page 478) alludes to the spearing of such fishes. André (page 75) found a combination of gigging of mullet with the luring by torchlight, about the mangroves of Guiana.

Various forms of trapping are practised. Whitney gives a photograph of a type having numerous variants (opp. page 116). It consists of bamboo canes, lashed together, and brought toward a point, like a funnel. Staked in the riffles of a stream, it is capable of retaining small fishes unable to make way against a strong current. (Fig. 11). Elsewhere Whitney (page 95) describes a triangular trap made of slats of cakouri palm, such as I frequently saw used for floors. The fishes are taken out of it by hand. MacCreagh (opp. page 369) also figures such a trap used in the Rio Negro region. Tolten (page 235) refers to a wicker baskettrap for "bony-scaled" catfish, and others refer to basket traps set in waterfalls.

An interesting trap was being used on the eastern shore of Lake Titicaca. Made of wicker, its warp was a rope of plaited, native ichu-grass. A cord of the same material was used to lower the device from a buoy. Its bottom consisted of a funnel-shaped lead-in for the entrance of the victim.

Roth (page 15, fig. 10 and page 16, fig. 11) and (Kahn, page 88) describe spring-traps intended to be baited, and as a refinement of the principle, a springbasket trap. 
In the backwaters of the Ucayali and Pacaya rivers I observed the use of weirs of two types:

The first was nothing more than a fence-like line of brush, palm fronds, etc. thrust into the bottom across the shoals of the quiet backwaters, forming a light barricade. They could be expected to halt rather than hold large fishes, especially Arapaima. The operator of the device stationed himself in his dugout alongside the barrier. A large fish in its efforts to break through would agitate the fence sufficiently to direct the aim of his harpoon. (Fig. 33).

The second type of weir is of more stable, more permanent and effective construction. (Figs. 25 and 26). It is a pole fence of considerable height, allowing for the rise and fall of water from season to season, bound together with lianas. As the preceding it is placed across the narrower passages of backwater channels, from bank to bank. At mid-channel a tight pound, or four-sided enclosure, of similar structure, is built. At the front-center of this a gate is suspended so as to swing inward freely, not outward. During the oncoming rainy season and rising waters, larger fishes, seeking passage upstream in the usual manner, nose their way along the barrier, find the gate, enter, and are unable to escape from the pound. As needed, the inhabitants get their fresh fish by clinging barefoot to the stringers around the top of the fence, and spearing the day's selection from above.

Kahn (1931, page 88) has given us the story of the cumaru, a fish which feeds on the explosive seeds of the plant walaba on the bank. The fish has learned to wait nearby for this food, and to recognize the popping of the seed-pods, in answer to which they come rushing to be first. The Djukas have learned to imitate the popping with a sharp handclap so as to lure the cumaru within striking distance.

A most unusual fishing method is described by Orton (page 478), and by Paez (page 416). Both had seen Indians wading and dragging canoes, lashing the water with branches. Fishes in panic would frequently make the wrong turn and leap into the canoes. I am well prepared to believe this story from the number of times I have seen fishes leap inboard when disturbed by the ordinary paddling movement.

Fishing in holes with the bare hands is sometimes done, as I had caught bullheads in boyhood; this is mentioned in a previous section, concerning the taking of Orestias in Lake Chinchaycocha. White (Beebe, page 481, et. seq.) describes the drives of Arowona into shallow water where they could be picked up by hand.

Almost as extreme a case of fishing without tackle is that described by Paez (page 153). Fishes were taken in the fresh hide from the head of an ox. To this they would cling tenaciously until pulled out of water. In my observation this occurred only in the case of Hemicetopsis (q.v.), not worth taking for food.

André and others allude to the employment of dynamite in fishing. In parts of the country near enough to mining centers to make dynamite available, I found the population not more averse to its use than here at home. Many sections were found greatly depleted of fishes, and available dynamite was freely alleged as the reason. I found it a convenience at times when other methods failed, and with reluctance carried it well-packed in my saddle-bags, or baggage.

Many authors describe at more or less length the use of poisons of various 
kinds. In all parts of the world occur mineral and plant substances whose introduction into natural waters affects fishes. Mr. O. L. Shields, Valley Station, Kentucky volunteered information recently, "that people in a nearby county are in the

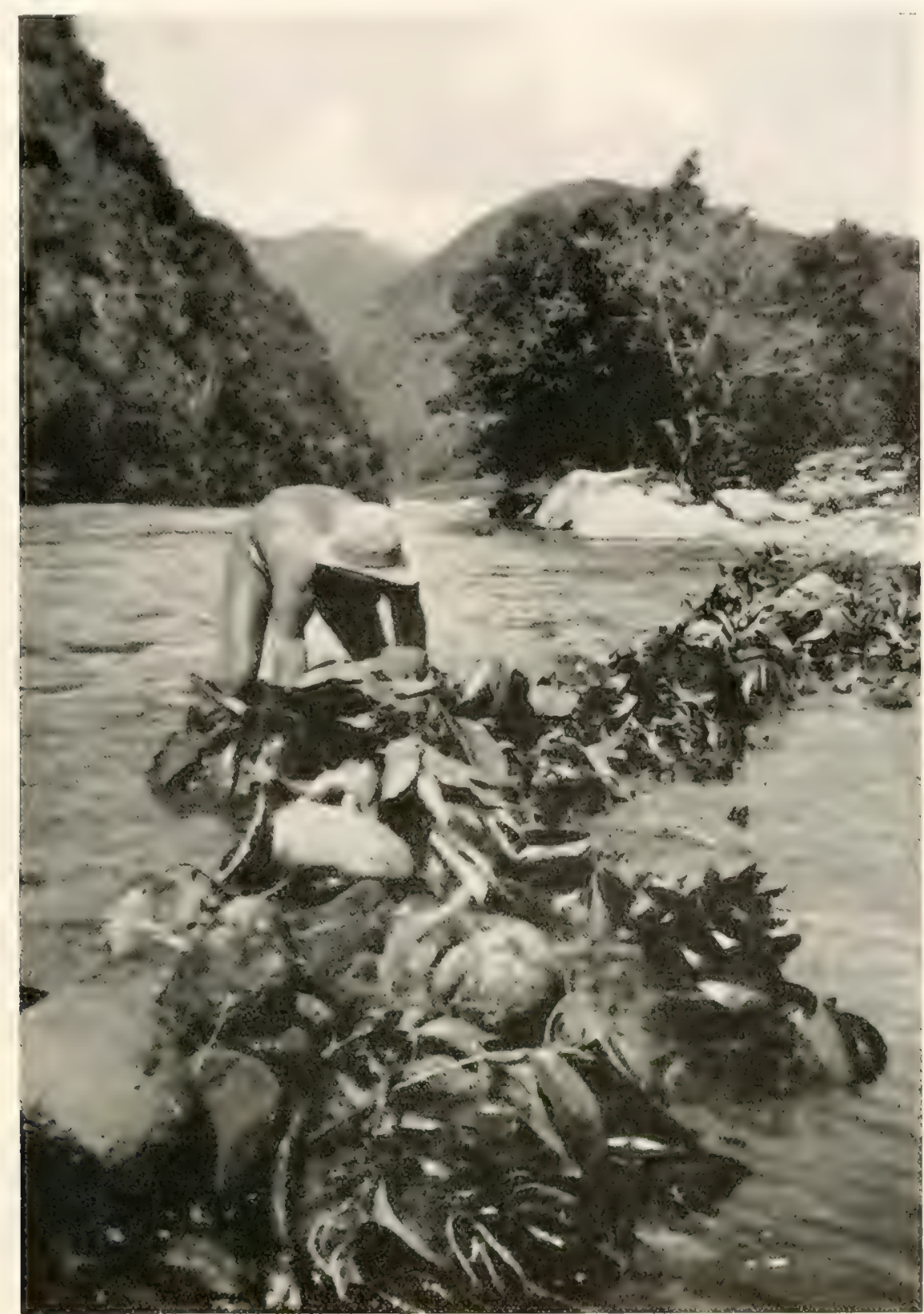

Fig. 12. Fish-poisoning. This was the first step preparatory to poisoning an arm of the Rio Chanchomayo. By means of the brush dam the flow of water was reduced. The actual poisoning shown in the Frontispiece.

habit of throwing walnut hulls into the creeks, and dead fish come to the surface". Furthermore. "this is done whenever a mess of fish is wanted." South America seems to have more than a reasonable share of these deleterious substances. Bates 
observed the introduction into streams of a poisonous liana (Paullinia pinnata), prepared by crushing into a pulp. Under the rather commonly used name timbó Orton discusses it (page 169). Kingston's "liana" (page 465), "poured from a calabash" is probably the same. Fleming observed the Indians whipping the water with a bush, name forgotten (page 153).

One or more species of the leguminous genus Lonchocarpus have been reported as fish-poisons from a wide area. By im Thurn (page 233) L. densiflorus is designated as the agent employed by Guiana Indians, who create pools for poisoning by constructing dams. In my own observation temporary dams were constructed of rock, brush, and earth (Fig. 12), not for creating pools, but to divert much of the water of a stream for the opposite purpose of reducing the volume to be poisoned. Im Thurn gives the name haiari (Arawak) to the plant. Three others he names are: connami (Clibadium aspersum), the seed of which is employed; haiari-balli (Mullera moniliformis); and yarro-conalli (Tephrosia toxicaria), used by the Macusis. Kahn was informed of a Lonchocarpus, the juice of which his Djukas extracted for poisoning, and which they call nekku.

Orton's list of fish poisons includes an 'evergreen bush, Jacquinia armillaris, and MacCreagh refers to the thorny-boled tree solyman and bush-barbasco (as though he had knowledge also of a vine-barbasco). Paez (page 432) mentions a poison only occasionally referred to by others, cuna, a Venezuelan name. It has a clover-like leaf, and a turnip-like bulb, and is obviously the Oxalis of other regions.

The various authors give accounts of the matter which seem to be founded largely upon hearsay rather than careful observation. The name barbasco is loosely applied to several plants in different regions, of very different nature, the name being no more specific than the word "poison". Thus Paez calls it a vine (page 432), as does Up de Graff (page 204), while Grubb (page 34) calls it a crushed liana.

Eigenmann (1912, page 39, figs. 10 and 11) took advantage of the custom of using timbó in British Guiana.

On our arrival "on the hill" in Central Peru we were informed of the use by the inhabitants of a poisonous root called cubé (pronounced koo-bay), or barbasco. It was, furthermore, known to be imported by the people of the mountain region from the tropical lowlands for use as an insecticidal dip for stock. But due to its misapplication in the unlawful poisoning of streams, it was officially contraband, not only as to use, but even to possession and sale. We canvassed Oroya, Cerro de Pasco, and Junin in the hope of obtaining it for collecting purposes, but of course no one thus approached by strangers had ever heard of it. When Prof. Eigenmann reached Huancayo, and formed the acquaintance of Mr. Dennis, the director of the Methodist Mission school, the latter was able to make the necessary contacts. At his magic words, little stocks of cubé began to come forth from beneath counters and back rooms in the little shops all around the town. With this supply we were enabled to collect in many streams of the highlands which otherwise would have yielded nothing.

Two years later, returning via Lima and Oroya enroute to the lowlands of the interior, I also stopped off at Huancayo, and also visited Mr. Dennis. Again 
with him I canvassed the tiendas of Huancayo, and his magic formula with my form of palmistry elicited a fair supply of the root for my journey.

Neanwhile Prof. Eigenmann, on his return home, had communicated to Dr. N. E. McIndoo, U. S. Bureau of Entomology, the story of cubé, which, of course would interest that bureau for its known insecticidal properties. We were requested to obtain a supply for analysis and testing. This also through MIr. Demnis I was able to do. The result of their analysis has had far-reaching consequences. The root proved to be so rich in rotenone that it was recommended as a substitute for Derris, and has been developed in recent years on a large commercial scale.

Our interest in the root was of course its effectiveness as an agent for fishcollecting. The supply which we obtained in the high Andes, far from its point of origin, was always well-dried, the roots gnarled, shrunken, yellowish in color. Later in the interior the roots which I obtained fresh, still in the sap, well rounded out, smooth, resembled the others much as new potatoes resemble last year's crop toward the end of winter. Many persons, seeing we had a supply, volunteered information about it. There was a general opinion that the old dry roots are the more potent. I am inclined to agree, but for the reason that the water-extraction of the powdery alkaloid is easier and more complete than from the juicy, fresh root.

The manner of using the roots consists, first of thoroughly crushing them, either in the open, or in a bag, improvised in our case from our supply of cheesecloth; then of further crushing and kneading the bag with its contents under the water to be poisoned, washing out the alkaloid in a milky stream. (See Frontispiece.) Afterward the thoroughly macerated residue may be broadcast into the water.

During the preparation, either between rocks, or by use of a cudgel (beetle, in the words of Marcoy) on a stump, a fine, yellow dust of the dried sap is liberated. The operator must work with much care, for the powder gets into the air and materially impedes respiration. In high elevations with reduced oxygen this proved to be serious indeed. We had a very fair demonstration upon ourselves of the effect which the extract has upon the fish, causing it to struggle to the surface where it may gasp for air. If the dosage is high enough it results in death to fishes, and the more active they are the more susceptible. If speedily washed downstream, the fishes have opportunity to recover.

Domville-Fife's allusion (page 210), "pounding a certain root and placing the flour so made in a bag, suspended by a cord in the river" may refer to cubé. The method is similar, but the amount needed to poison a river would be very great. Of course the word "rio" often applies to very small streams, since there seems to be no well-used equivalent of the word "creek". Orton's (page 169) description of the process makes certain that he had the same plant in mind.

Paez says barbasco is a vine, and that either vine or root is crushed with a mallet. He says that when fishes are to be poisoned with cuna, they are first baited with maize-meal mush, then the poison administered in a mixture with the mush, pastelike. Thus it would appear to be a stomach poison, while cubé has its effect through the gills.

Herndon (pages 161 and 193) and Marcoy (II, 179) describe regular and peri- 
odic fishing-parties of entire villages, gala events, on which streams and lakes were thoroughly poisoned and the whole fish-population removed, by the use of barbascum. The fishes when in their last struggles were retrieved by baskets used as dipnets, larger ones by bow and arrow.

Today there are statutes and decrees forbidding the use of poisons, and the practise no longer takes place in the open, except in the remotest districts. Yet the opposition to it arises more from the fears of cattle owners than from motives of conservation.

Europeans sometimes hesitate to eat fish taken in this manner, but no one is ever harmed by doing so. 


\section{SOUTH AMERICAN FISH-LORE}

As in other regions of the world, fishes have been looked upon through the ages, by primitive peoples, with an interest often religious, often superstitious, and with certain mystic properties attributed to them. Thus they are commonly subjects of art, in common with other forms of animal life. Means (pages 74-77) shows examples of early Peruvian ceramic work decorated with fishing scenes-

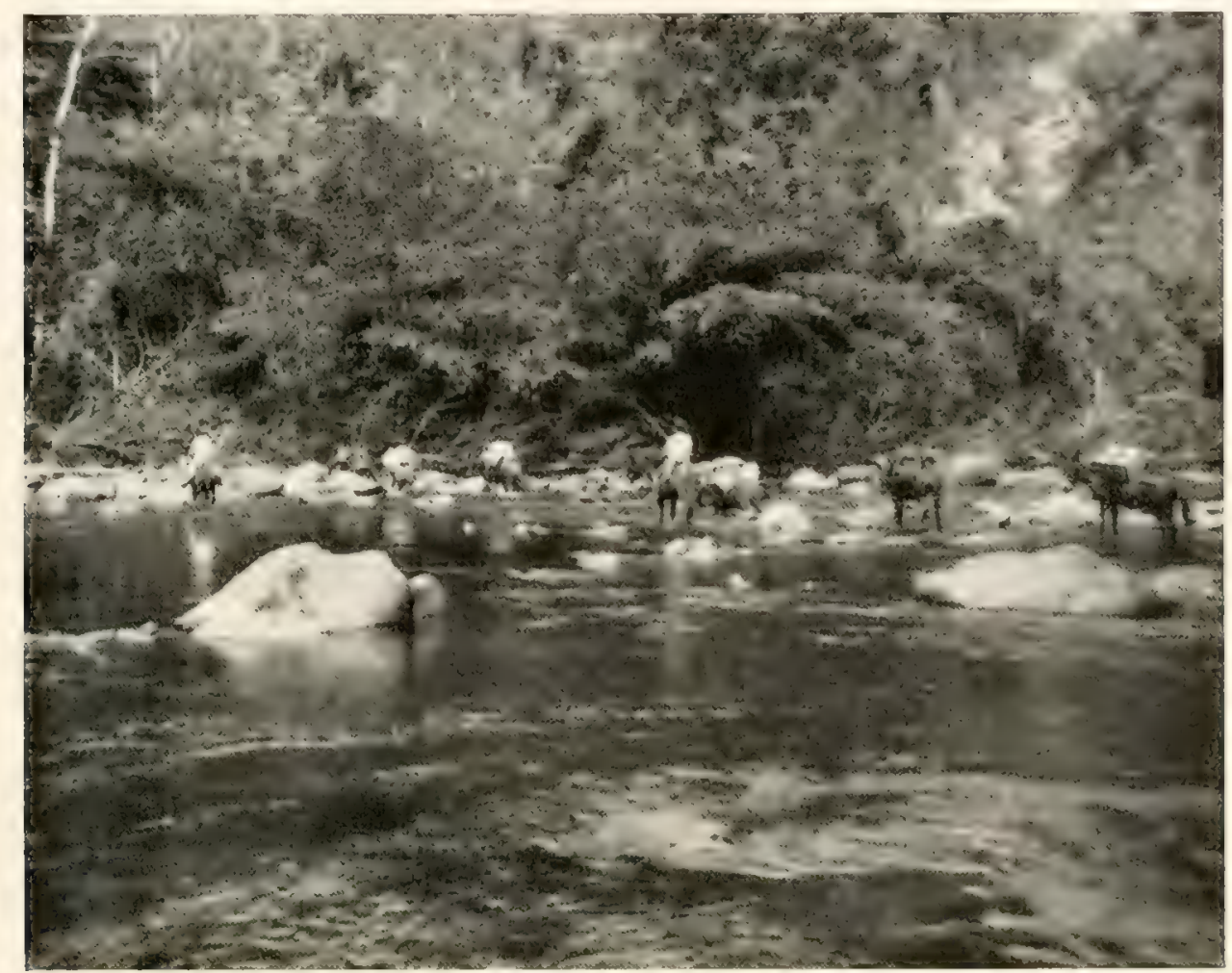

FIG. 13. The Rio Azupizu, a principal tributary of the P'ichis-Pachitea-Ueayali complex. My pack-train fording the river on the Via Central.

even with hook and line! Enock, Andes and Amazon, (page 217) alludes to the use of the fish symbol of Viracocha, the ranking pre-Inca deity. He finds in Viracocha a parallel to the Chaldean god of beginnings, Dagon. Padre Techo, 1608, Historia de la Provincia Jesuitica del Paraguay (see Church, page 255) says that among the Guaycurús every man selected from among a number of eligible species one who was to be the patron and protector of his life. When offered fish of this species as food, he would refuse it as taboo.

The significance to the peoples of the interior of the fish life is well exemplified in the many names of streams and places, especially the latter. The story of the Inca's relays of rumers for supplying his table with fresh fish from the coast, wherever he might be in his mountain realm, is one to appeal to the imagination. 
A wide-spread story has survived in northern Peru and Ecuador that the volcanoes Caraguayrazo and Imbabura once housed underground reservoirs and streams inhabited by fishes. About 1700, during eruptions, it was generally believed that these waters were spewed up mingled with volcanic mud and steam, and the fishes rained upon the surrounding slopes for miles about. The story was accepted by so good a man of science as James Orton $(1875,132,143)$, and not definitely denied by Edward Whymper (1891), although a much more logical explanation of the occurrence is that the fishes were inhabiting the crannies of surface streams, and were killed by the mud and ash of the eruption. Paez (page 420) knew of the episode and passed it on without raising doubts; but then he also transmits as true the story of his father's having seen a rain of fishes (bocachica) which he had seen in youth. I found persons in northern and central Peru who knew of blind fishes living in the caves. This may be true, and the tradition may have no connection with the fishes of the volcanoes.

Paez gives us a fish-tale which is one of the best emanating from the continent, partly for its brushing elbows with history as well as a true light on natural history. Simon Bolivar, the great Liberator, was taking a brief pasear in a canoe with a friend, idling along in a holiday mood. The friend slyly splashed the great man with his paddle. "Damn it, Compañero, let us pull back. Even the fish are hostile in this country."

Medina (Lee trans., 1934, 189) may be credited with the following narrative, which unfortunately loses effect in the absence of the background of heroic adventure of the first discovery of the Amazon, out of which it must be lifted. Padre Carbajal's journal of Orellana's pioneering crew names many witnesses.

On the deck of the ship which they had constructed in the wilderness, Mexía, their first crossbowman, leveled his weapon to bring down a bird. A vital and necessary nut fell out of the firing mechanism of the crossbow, and overside into the river, putting the bow out of commission. Contreras meanwhile was fishing from the deck nearby. Casting his hook into the river he pulled in a fish of five spans length. This was passed to the cook, and when the latter dressed it for cooking, there was the missing nut in its belly. The last remaining crossbow was restored to usefulness. To be interpreted only as a special act of Providence, the episode once again revived the courage of the crew. 


\title{
DISTRIBUTION OF THE FISHES
}

\author{
GEOLOGICAL BASIS OF DISTRIBUTION
}

In $n o$ part of the world do distributional studies present more interesting correlations between the hydrography and topography on the one hand, and the facts of plant and animal distribution on the other. Whether we accept or reject the Archhelenis theory to account for the beginnings of certain families of freshwater fishes in South America, we still have ample evidence of the part played by the old land masses, Archiguyana and Archibrazil.

\section{(1) The Origin of the Land Forms}

Throughout much of the Palaeozoic Era and the early Mesozoic, the portion of the South American continent with which we are concerned existed as an immense geosyncline, or trough, of greater or less extent below sea level. The older Paleozoic continents existed at that time farther eastward where the matured highlands of Brazil and the Guianas are today. Materials originating in the eastern highlands probably contributed to the upbuilding of the immense depths of sedimentary formations in this western trough. The Brazilian and Guiana highlands were doubtless then of much greater height and more rugged form where now reduced to maturity. There is less evidence that an additional nearby continent existed on the Pacific side which might have added its contributions to the upbuilding of the many thousand feet of andean sedimentary rocks. At any rate the formations are there, derived from adjacent highlands, of enormous horizontal and vertical magnitude, requiring a correspondingly great total of submerged area of sea bottom, now a lofty mountain system. Either great deeps existed over a long period of time, or, more probably a long series of shorter periods of subsidence accompanied by aggradation were occurring and recurring throughout the period. This period of accumulation of sedimentary formations may be considered the first step. It is closely paralleled by events in the northern hemisphere, with the older Appalachian system contributing to a great syncline in the western ocean while weathering to maturity, and the new, rugged Rocky Mountain system rearing itself along the lines of the syncline, bearing aloft the sedimentary accumulations formed in it.

In the middle Mesozoic a second step has begun. Diastrophic rearrangements of enormous magnitude were in order in many parts of the earth. In this area they continued intermittently throughout the Cretaceous, culminating in a series of folds of the old geosyncline forming mountain chains. This phase was completed by the end of that period, and the youthful Andes of the early Cenozoic were born. then of moderate elevation. (Schuchert and Dunbar, page 354.)

The third stage appears to have been a period of comparative diastrophic inactivity through the earlier half of the Cenozoic, at least in much of the region, 
especially the central portion. This allowed time for a weathering down of the Andes to a peneplane and to a mature topography. That elevations were not great appears to be certain, for they were insufficient to cut off moisture-laden winds, and the weathering was more or less equal on the two flanks.

A fourth phase during the Pliocene and Pleistocene consists of a second and rapid period of uplifting; this is a final chapter which continues on down to our time. (See Schuchert and Dumbar, page 411.) No other series of events would seem logically to explain the present topography, the apparent anomaly of a mountain system with immense areas of more or less level and matured relief at the top, with the most rugged and immature approaches from the flanks.

The rapidity of the recent phases is well brought out by the fact that the Titicaca-Poopó basin has not had sufficient time to find an outlet to the outside, and has become well base-leveled internally. A similarly elevated intercordilleran basin, the Pampa de Junin, has had a similar history, but for an unknown time has been pirated by the Rio Mantaro and drains to the outside.

\section{(2) Geological Agencies}

In establishing the present relief, it is probable that every known type of geological agent has somewhere had a part in the sculpture of the details.

\section{(a) Weathering}

a. Frost: Freezing rarely occurs in elevations below 12000 feet, commonly in many areas of 13500 feet; in many spots permanently above 16000 feet. Thus freezing and thawing are effective principally in the high puna. The critical points vary with precipitation, with latitude, with the slope (isolation). Bosworth has shown the heat of the sun to be a direct agent in the cleavage of pebbles, aside from freezing and thawing.

b. Ice: Permanent ice fields furnish the principal sources of the water in certain streams, growing and diminishing with the season, with intermittent stream action. Many traces of direct ice erosion are evident in the higher elevations.

c. Rainfall: Mountains of such extreme height erected across the path of the moisture-laden Southern Trade Winds have inevitably resulted in the greatest inequality in precipitation. Two hundred inches per year are common for the eastern slopes. But it would not be an exaggeration to put the figure at an inch per two-hundred years in the rain-shadow of the western slopes. As a result the streams of the Pacific slope are of scant volume at any time, and often dry, very declivitous, short, and direct, while those of the Atlantic side have maintained throughout their history basins of great length and gorges of great depth to the interior of the ranges.

d. Wind: On the western slopes the action of the wind may be read directly from the topography, in the absence of, and out of competition with, rainfall. First, this is effected directly by the wind-distribution of sand and earth, forming dunes, etc.; second, the wind-borne sand is a tool, responsible for the etching of the details of many areas, especially on the western scarp. 


\section{(b) Vulcanism}

Along the borders of the western Andes are large areas in which the details of the upthrust formations are blotted out by lava beds and volcanic peaks. In Ecuador (outside our area) this also holds good for the Eastern Cordillera, along the Atlantic scarp. Central and Northern Peru have few volcanic areas, Southern Peru and Northern Chile many. They are largely responsible for the surface configurations where they occur.

\section{(c) Diastrophism}

The latest phases of the upthrust from the paleozoic sea may be seen in the Eastern Cordillera of Bolivia, which stands in magnificent relief (22000 feet) above Lake Titicaca (12500 feet) with the most youthful contours, and with a snowcapped granitic core. Thus the cordilleras are variously crowned with volcanic peaks, with sedimentary formations often on edge, or with granitic formations. Upon these the winds, frost, rainfall, etc. work their varied effects.

\section{(d) Aggradation}

On the western slopes we find many minute areas in which water has been the principal constructive agent, but few large areas, and no extremely large ones. Due to the deep sea close inshore and the small volume of the rivers, delta formations are very small. Inland the rivers are of youthful to extremely youthful form, with room only for very small playas at infrequent intervals. Such a cove in the hollow of the hills may be remote, yet if suited to crops is sure to be occupied, even though of few acres, or even of fractional acreage. The mouths of rivers are the largest - the Rimac, the Santa, the Tambo, or the Camaná. (See Johnson's aerial photographs.)

The eastern slope on the contrary is aggraded terrain, or alluvial land, from the Andes to the mouths of the rivers. With a maximum precipitation, and having from 2600 to 3000 miles in which to make its final thousand feet of descent, it does so with an extremely slight gradient, and the well-known inundation. The valley land of the Amazon is the repayment on the old palaeozoic account which the Andes are making to Brazil for the materials borrowed from its eastern ranges. (Johnson, pages 144-150.)

The result of the interplay of these varied forces upon the varied substratum described above is a profound variation in the geographic and ecological regions and subregions. Add to these factors those of climate, elevation, latitude; clothe the land with the most diversified vegetation, and we have the background of a most heterogeneous fauna, aquatic as well as terrestrial.

\section{(3) Major Topographic Features}

The Andes arise from the depths of the Antarctic, an island at a time, until the mainland is reached at the Straits of Magellan. 
Coming northward through Chile we encounter a single range of mountains most of the way, and elevations increasing from 3000 feet in the South to passes of 17000-18000 feet in middle Chile, and Aconcagua at 23000 feet. In the latitude of northern Chile and southern Bolivia a new range begins to rise out of the Argentine plain and run in a parallel line. The Chilean range becomes the Western Cordillera, and the new one the Eastern. In southern Bolivia, the valley between these cordilleras is raised to more than 12000 feet by an immense volcanic area which blocks the exit, and holds back the waters of the Titicaca-Poopó basin from creating an exit southward. The western range on the Bolivian-Chilean border is largely obliterated by volcanic formations, while the eastern rises higher and higher to a crest of 22000 feet north of La Paz, and the great Sierra Nevada overlooking Lake Titicaca. North of that lake the two cordilleras draw nearer together until the Nudo de Vilcanota is reached, tying them together by transverse ridges running East and West, elevation above 14000 feet.

Departing northward from this high intercordilleran bridge, the ranges swing more northwestward, continuing at great elevations, and separated by great gorges. From here we may recognize three ranges. The westernmost, the Occidental, is separated from the Central by the Rio Apurimac, and the Eastern from the Central Cordilleras by the Vilcanota and the Urubamba rivers. Unlike the southern intercordilleran basin, these of the middle section of Peru have made or retained their water-gaps to the outside, draining to the Amazon. The three cordilleras approach one another again and form a third transverse bridge, the Nudo de Pasco, draining north and south. Northward of Cerro de Pasco the three ranges are separated as before, by the rivers Marañon and Huallaga, not to reunite within our territory, but to be bridged across further northward, at the Nudo de Ampato of Ecuador.

At about the eastern extremity of the Nudo de Pasco a chain of mountains strikes eastward toward the Amazon valley, contrary to the usual trend of the ranges elsewhere. This is the Cadena de los Cerros de la Sal.

\section{(4) Geographic Regions of West-Central South America}

With the physical background described above, the terrain is seen to be of a maximum relief, with its axis transverse to the course of prevailing winds, and, although wholly within the Torrid Zone, should have given rise to distinct biogeographical provinces. The accompanying diagram (Table I) is an attempt to analyze the geological, or rather, physiographical basis for such provinces. First of all we must recognize the north-south lines of demarcation mentioned in all the books, the Western Cordillera and the Oriental, and the three resulting general regions, the Coast, the Sierra, and the Montaña trending northwest-southeastward. In the fifteen hundred miles here considered, extending nearly from the Equator to the Tropic of Capricorn, latitude becomes a factor, and at the same time two great physical barriers are set up in an east-west direction, the Nudo de Pasco and the Nudo de Vilcanota mentioned above, the former above 14000 feet, the latter nearly as much.

The coastal provinces are not sharply divided, yet are sufficiently unlike that 
you can very well identify in many a photograph the region from which it has come. Region A, the Northwest, is noteworthy for its recently elevated terraces, outwash plains, or tablazos, and dunes. The Western (B) presents a land of immense dry canyons of the Rimac and Santa, with somewhat extensive deltas. The Southwest (C) presents upland dunes and lava fields, with volcanic cones, and approaching topographic maturity as against the youthful west-central section. Part I of this work has dealt with the Coast; we are here dealing with portions of the remaining six.

Throughout most of the north-central region (D) the heights of the cordilleras are moderate. The western range forms the continental divide, drops from a height near Cerro de Pasco of nearly 20000 feet to the northern passes of 8000 feet, soaring again toward the volcanic heights of Ecuador. At the southwestward extremity of this region the Marañon has its source in Lake Lauricocha and other nearby lakes, at 17000 feet, rapidly traversing its gorge north-northwestward to emerge through its water-gap, the Pongo de Manseriche, upon the Amazonian plain. The Marañon eastwardly skirts the Central Cordillera, which also trends north-northwest from the Cerro de Pasco, reaching elevations of only 15000-16000 feet, but falling away to 2000 feet to allow the emergence of the river. Next eastward is the Rio Huallaga, which also has its birth on the northern slopes of Cerro de Pasco at 14000 feet altitude, traveling northward between the Central and Eastern Cordilleras, passing around the end of the latter, as it fades out into the plain, to become a tributary of the Marañon in northern Peru. The Eastern Cordillera falls away rapidly to the north from its 15000-16000 feet at Cerro de Pasco to mountains of 8000-10000 feet about Huánuco, then lower to the hills about the Pampa de Sacramento. This northern province is mostly one of immense gorges with abrupt lofty mountains. As rapidly as the ranges were elevated, the intercordilleran rivers kept pace with their erosive work, from Cretaceous time to the present.

A similar region is that designated as $\mathrm{E}$, the Central. It also is bounded by the Eastern and Western Cordilleras, the latter still the continental divide, at the northern extremity bounded by the Nudo de Pasco, at the southern by the Nudo de Vilcanota. The Western Cordillera remains consistently at elevations 16000 to 18000 feet or above; the Eastern has here overtaken the Western, often surpassing it in elevation, interposing a barrier of extreme magnitude to the moistureladen winds and to plant and animal distribution. Bowman graphically describes the assortment of climates from tropical lowlands to permanent ice-fields (1916).

At the north of this region the Rio Mantaro, arising on the southern flank of the Nudo de Pasco, within the pampa de Junin, flows southeastward to join the Apurimac, where with united forces they break through the Central Cordillera. The Apurimac, having arisen in Laguna Villafrio, southern Peru, near Cailloma, courses northwestward between the Western and Central Cordilleras to the junction with the Mantaro. Then known as the Ene, and having penetrated the Central Cordillera, it travels between the latter and the Eastern Cordillera in search of a weak point in the last barrier toward the Atlantic. Here it is joined by the Urubamba which drains all of the southeast section. The high mountains 

Trupm:al, lowland flood plains

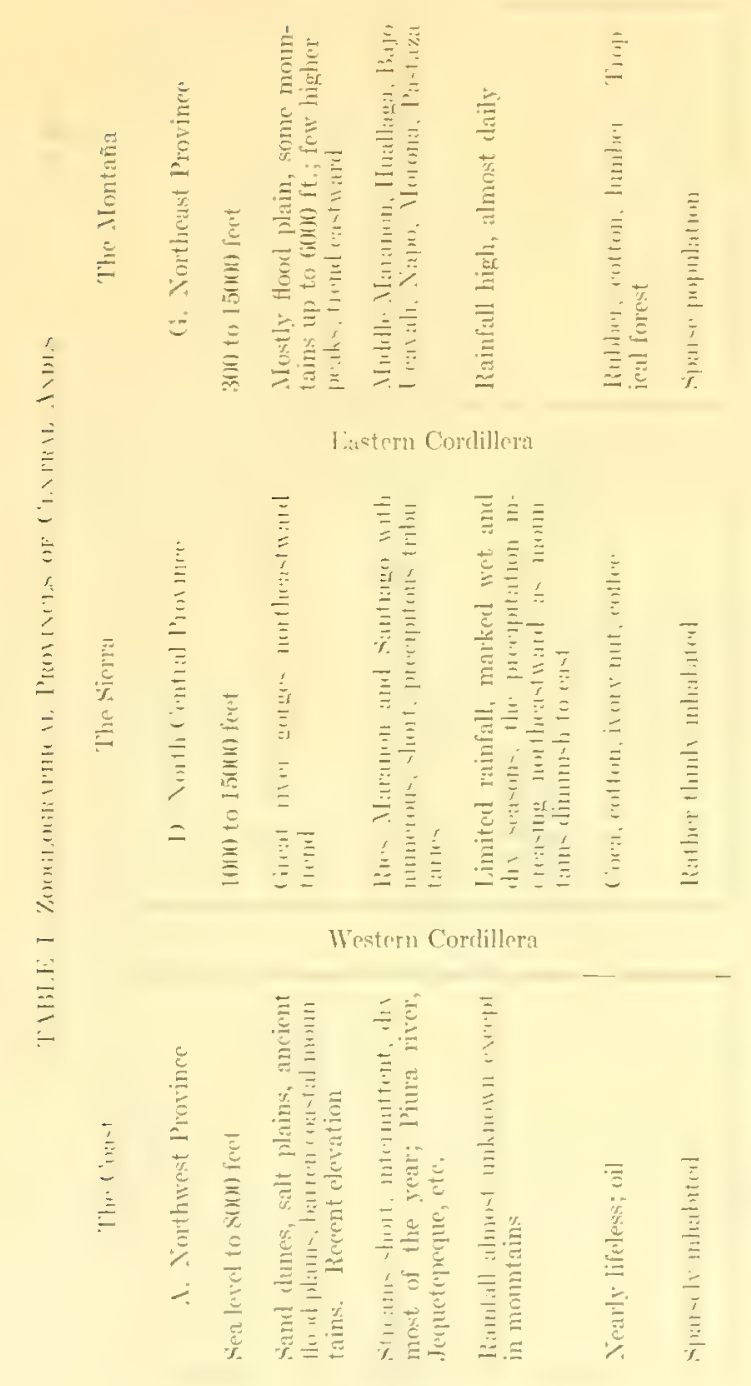

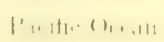

Tropical lowland flood plains and elcrated prasslands

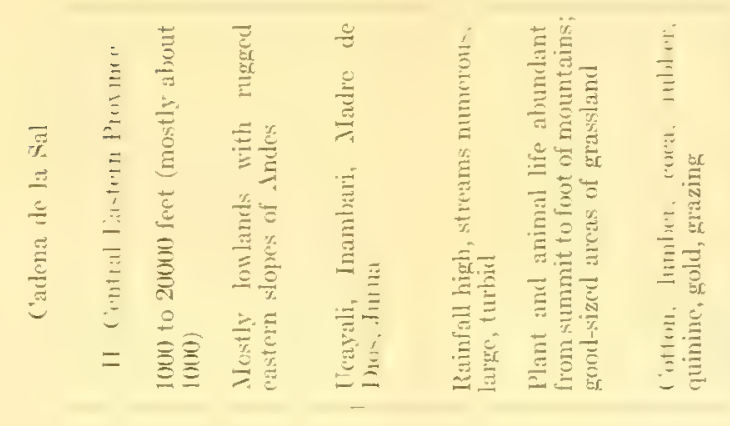

Eastern Cirrillera

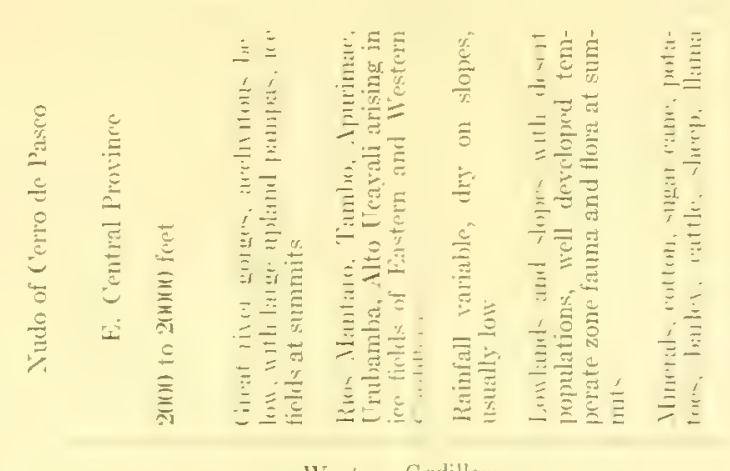

Western Curdillera

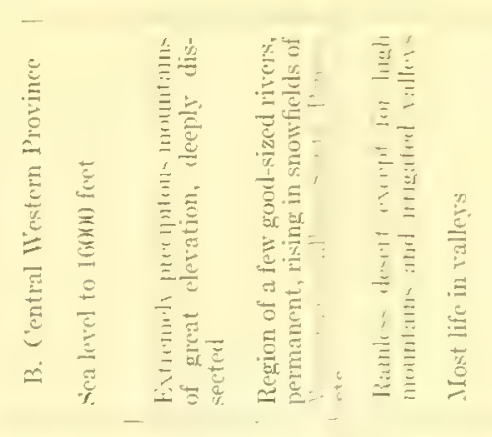

Pacific cean

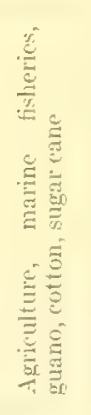

Trumal lowlands of Bolivis
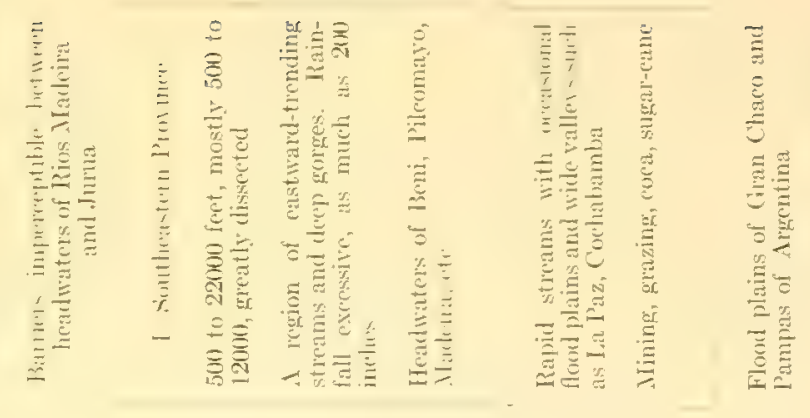

Fiastern Cordillera

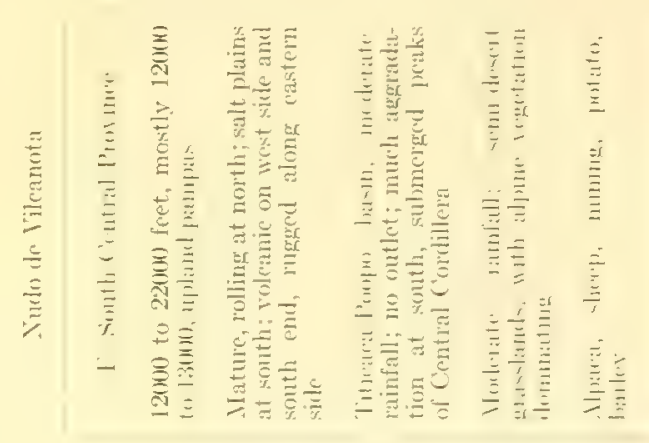

Western Cordillera
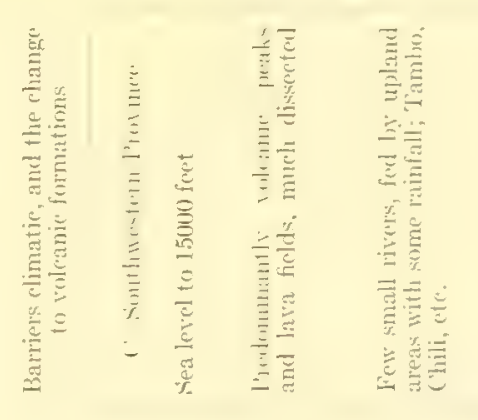

l'acific oren 
of the Eastern range cast a broad rainshadow upon the valleys giving rise to great variation in the amounts of precipitation received in various sections.

Climbing southeastward by the Urubamba and its tributary the Vilcanota river, we come out upon the southern intercordilleran bridge, the Nudo de Vilcanota, where, at La Raya, 14153 feet, we see the mingling of the waters of the Atlantic-bound Vilcanota with the headwaters of streams of the Titicaca basin. Here we enter the south-central region $(\mathrm{F})$.

The same impenetrable Western Cordillera here forms the barrier toward the Pacific, but from here well down into Chile the outlines of the sedimentary formations are blotted out by volcanoes and volcanic formations, while the Eastern ranges, the Cordillera Real, have climbed to their highest elevations, and to the most elevated and most youthful portion of the entire Andean system. The snowcapped Sierra Nevadas fringing Lake Titicaca and attaining to heights of 2000022000 feet, culminating in Sorata and Illimani, the crowning glory of the continent, are granitic intrusions which have disrupted and upended the adjacent sedimentary formations of the region. Thus the Region $\mathrm{F}$ is unlike any other in being bounded by volcanic formations on the one hand and by igneous on the other. In this region the Central Cordillera had long been regarded as missing, but now its outlines are thought to be discernible in the alluvial plains of the Poopó basin as a series of low hills rising abruptly from the level pampa, partly lost by reason of their diminishing height, and partly by the burial of much of it through the processes of aggradation. Elsewhere the erosive action of streams has kept pace with the uplift of the mountains, creating the gorges and water gaps draining to the Atlantic. But in this section, no stream has done so. In the southern direction, toward the streams of Argentina, the most logical outlet, the intercordilleran valleys have been cut off, not by another bridge or Nudo, but by a series of volcanic formations. Hence the story of the Titicaca-Poopó basin has been, despite its great altitude, one of aggradation. One stream alone, the Rio La Paz, has actually penetrated the highest portion of the Cordillera Real and at this geological period is in the act of pirating the glacial waters of the western slopes which belong to the Titicaca drainage, escaping to the Atlantic side by way of an abrupt arroyo 1300 feet deep in the detritus of the pampa and a canyon 7000 feet deep through the cordillera.

The northern section of this area with its moderate precipitation drains through a number of small rivers entering the lake from north, west, and east. It is a terrain of moderate relief above the 12500 feet of the lake, rolling and mature. Titicaca itself occupies a constricted middle portion of its basin, and is bordered by alternating hills and aggraded valleys becoming marshy on much of the lake shore at the north and west. Its great depth with its contours unlike the surrounding aggraded terrain encourage the belief that it may have been formed by block faulting. In various places I have observed the sedimentary formations near its shores, much distorted and displaced, often standing on edge, and rising many feet above the pampa. This is especially noteworthy at the northeast and southwest corners. 
Lake Poopo, the recipient of the waters of Titicaca through the Desaguadero, in turn spills over into the flat salt marshes of Coipasa where there is sufficient area to provide for the evaporation of the excess.

Region $\mathrm{G}$, the northernmost one of the Montaña extends from the crest of the Eastern Cordillera. It may be characterized by the great size and number of its network of streams, a plexus of active and backwater rivers, channels, oxbowlakes, etc. All the eastern rivers of the region trend northward to the Maranon. parallel to the cordilleras, while those of Oriental Ecuador enter the same river from the northwest, spread out fanwise. It is a region of high rainfall, high humidity, and high temperature. Except for good-sized areas of grassland such as the Pampa de Sacramento, it is a tropical forest. Navigation is practicable to good-sized steamers for many hundreds of miles of the Marañon, Huallaga, and Ucayali.

Region $\mathrm{H}$ is the least explored, consisting of rather broken terrain about the headwaters of the Juruá, the Purus, etc., and except for the eastward slopes of the cordillera is tropical lowland forest. It is difficult of access by trail, and very remote from bases in Brazil for approach by river.

Region I consists of the Atlantic slopes of the Eastern Cordillera in Bolivia, very rugged terrain, but largely explored for minerals. The summits are often more mature and are used, together with the limited hillside lands and valley floors for agriculture. Rough trails follow the precipitous streams to the lowlands. This area was explored for fishes by $\mathrm{X}$. E. Pearson on the MIfford Expedition. (1924.)

The barriers separating the oriental regions are slight, and not effective for land forms. In fact the climatic zones follow vertical cleavage much more sharply than horizontal. All three of the Atlantic provinces are sparsely populated. Cotton, ivory nut, and rubber are typical products of the lowlands; coca, balsa-wood, sugar-cane and quinine of higher terrain.

\section{FAUNAL LISTS OF THE PRINCIPAL RIVER SYSTEMS LOWER MARAÑON \\ Pongo de Manseriche to Tabatinga}

Bunocephalus aleuropsis

$\begin{array}{ll}\because & \text { melas } \\ " & \text { haggini } \\ " & \text { coracoideus }\end{array}$

Callophysus macropterus

Pimelodina flavipinnis

Microglanis zonatus

Zungaro zungaro

Chasmocranus peruanus

Rhamdia quelen

$\begin{array}{ll}\text { " } & \text { bathyura } \\ . \quad \text { humilis } \\ \text { dorsalis }\end{array}$

Pimelodella puruensis

" lateristriga

" buckleyi

" hasemani

" cristata

" cyanostigma

Pimelodus pictus

" jivaro

" clarias

Goeldiella eques

Pseudoplatystoma fasciatum

Phractocephalus hemiliopterus

Sciades marmoratus 
Brachyplatystoma juruense

Sorubim lima

Platystomatichthys sturio

Hemisorubim platyrhynchos

Sorubimichthys planiceps

Perugia agassizii

Centromochlus heckelii " steindachneri

، gyrinus

Trachycorystes galeatus $\begin{array}{ll}\text { " } & \text { isacanthus } \\ \text { ". } & \text { brevibarbus } \\ & \text { coracoideus }\end{array}$

Auchenipterus nuchalis brachyurus?

Epapterus dispilurus

Megalodoras irwini

Centrodoras brachiatus

Pterodoras granulosus

Platydoras costatus

Agamyxis pectinifrons " flavopictus

Amblydoras hancocki " monitor

Anadoras grypus " nauticus

Hypodoras forficulatus

Physopyxis lyra

Pseudodoras niger

Trachydoras nattereri atripes

Hemidoras stenopeltis " morrisi

Opsodoras parallelus " humeralis " orthacanthus

Ageneiosus ucayalensis " brevifilis

Tympanopleura nigricollis alta

Hypophthalmus edentatus Hemicetopsis candiru Pseudocetopsis ventralis

Pariolius armillatus

Pareiodon microps

Henonemus punctatus

Pseudostegophilus nemurus

Apomatoceros alleni

Urinophilus diabolicus

Tridens melanops
Callichthys callichthys

Hoplosternum littorale

“. $\quad$ thoracatum

Decapogon adspersum

Corydoras ambiacus

. acutus

" amphibelus

" paleatus

. episcopi

Dianema longibarbis

Brochis coeruleus

Chaenothorax bicarinatus

$$
\text { " semiscutatus }
$$

Osteogaster splendens

Canthopomus agassizii

Hypostomus emarginatus

Hemiancistrus arenarius

Pterygoplichthys gibbiceps

$$
\text { " multiradiatus }
$$

Lasiancistrus heteracanthus

Chaetostoma sericea

$$
\text { " variola }
$$

Xenocara latifrons

Ancistrus hoplogenys

Hypoptopoma gulare

Otocinclus vestitus

$$
\text { " thoracatum }
$$

Loricaria acuta

$$
\begin{array}{ll}
\text { “ } & \text { brunnea } \\
\text { ، } & \text { konopickyi } \\
\text { ، } & \text { maculata } \\
\text { “. } & \text { nudirostris } \\
\text { “ } & \text { punctata } \\
\text { ، } & \text { macromystax } \\
\text { ، } & \text { cataphracta }
\end{array}
$$

Hemiodontichthys acipenserinus

Harttia microps

$$
\text { " brevirostris }
$$

Sturisoma rostrata

$$
\text { " güntheri }
$$

Farlowella smithi

Acrobrycon ipanquianus

Phenacogaster pectinatus

Astyanax asymmetricus
" bimaculatus
" maximus
. fasciatus
" abramis 
Bryconamericus diaphanus phoenicopterus

Ctenobrycon hauxwellianus Hemigrammus schmardae

$$
\text { " pulcher }
$$

Hyphessobrycon robustulus

$$
\begin{array}{ll}
\text { ". } & \text { innesi } \\
. & \text { loretoensis } \\
\text { peruvianus }
\end{array}
$$

Moenkhausia oligolepis

$$
\begin{array}{ll}
\text {.. } & \text { atahualpiana } \\
. . & \text { bondi } \\
. . & \text { comma } \\
& \text { ovalis }
\end{array}
$$

Bario steindachneri

Tetragonopterus argenteus

Stethaprion erythrops chalceus

$$
\text { "chryseum }
$$

Ephippicharax orbicularis

Serrasalmus spilopleura

$$
\begin{array}{ll}
\text {. } & \text { rhombeus } \\
\text {. } & \text { maculatus } \\
\text { humeralis }
\end{array}
$$

Rooseveltiella nattereri

Metynnis luma alta

Piarctus nigripimnis

Colossoma oculus

$$
\begin{array}{ll}
\text { ". } & \text { bidens } \\
\text {. herniarium }
\end{array}
$$

Mylossoma duriventre

Brycon cephalum

$$
\text { " albiscopum }
$$

$$
\begin{array}{ll}
\text { ". } & \text { stiibelii } \\
\text { ". } & \text { capito } \\
\text { ". } & \text { erythropterum } \\
& \text { erym }
\end{array}
$$

Iguanodectes tenuis

Piabucus dentatus

Charax pauciradiata

$$
\text { " limaesquamis }
$$

$$
\text { .. tectifer }
$$

Roeboides myersii

$$
\text { " bicornis }
$$

Cynopotamus gulo

Chalcinus angulatus

$$
\begin{array}{ll}
\text { ". } & \text { albus } \\
\text {. } & \text { rotundatus } \\
& \text { elongatus }
\end{array}
$$

Coscinoxyron culter

Clupeacharax anchoveoides
Copeina argyrops

Pyrrhulina melanostoma

$$
\begin{aligned}
& \text { " laeta } \\
& \text {.. lugubris }
\end{aligned}
$$

Odontostilbe fugitiva

Aphyocharax pusillus

$$
\text { ، } \quad \text { filigerus }
$$

Gasteropelecus coronatus

Thoracocharax stellatus

Carnegiella strigata pectorosus

Paragoniates alburnus

Rhaphiodon rulpinum

Cynodon gibbum

Hydrolicus scomberoides

$$
\text { " pectoralis }
$$

Xiphostoma maculatum

Acestrorhynchus abbreviatus

$$
\text { ". } \quad \text { falcirostris }
$$

Chalceus macrolepidotus

Plethodectes erythrurus

Hoplias malabaricus

Hoplerythrinus unitaeniatus

Erythrinus erythrinus

Hemiodus microlepis

Anisitsia amazonum

Apareiodon pongoense

Poecilobrycon eques

Characidium etheostoma

$$
\text { " steindachneri }
$$

Potamorhina pristigaster

Psectrogaster amazonicus

Curimatella meyeri

$$
\text { cisandinus }
$$

Curimata spilura

$$
\begin{array}{ll}
\text {. } & \text { bimaculata } \\
\text {. } & \text { asperastetha } \\
\text {.. } & \text { leucisca } \\
\text {. } & \text { ciliata } \\
\text {.. } & \text { cyprinoides } \\
\text {. } & \text { hypostoma } \\
\end{array}
$$

Anodus laticeps

$$
\begin{array}{ll}
\text { " latior } \\
\text { elongatus }
\end{array}
$$

Eigenmannina melanopogon Laemolyta taeniata 
Anostomus trimaculatus

Schizodon fasciatum

Rhytiodus microlepis

$$
\text { " argenteofuscus }
$$

Leporinus friderici

$$
\begin{array}{ll}
\text { ". } & \text { bimaculatus } \\
\text { ". } & \text { maculations } \\
\text { " } & \text { holostictus } \\
\text { ". } & \text { multifasciatus } \\
& \text { hypselonotus }
\end{array}
$$

Leporellus vittatus

Prochilodus nigricans

$$
\begin{array}{ll}
\text { " } & \begin{array}{l}
\text { ortonianus } \\
\text { cephalotes }
\end{array} \\
\text { " } & \text { theraponeura } \\
\text { ". } & \text { amazonensis } \\
\text { " } & \text { insignis } \\
& \text { rubrotaeniatus }
\end{array}
$$

Sternopygus macrurus

Steatogenys elegans

Hypopomus brevirostris

Eigenmannia virescens

$$
\text { " } \quad \text { troscheli }
$$

Rhabdolichops longicaudatus

Sternarchorhynchus oxyrhynchus

Sternarchorhamphus macrostomus

Apteronotus albifrons

$$
\begin{array}{ll}
\text { "، } & \text { leptorhynchus } \\
" & \text { anas } \\
" & \text { bonapartii } \\
& \text { hasemani }
\end{array}
$$

Sternarchella schotti

Porotergus gimbeli

$$
\text { " terminalis }
$$

Stemarchogiton nattereri

$$
\text { ". porcinum }
$$

Oedemognathus exodon

Adontosternarchus sachsi

Rhamphichthys rostratus

$$
\text { " balaenops }
$$

Gymnotus carapo

Symbranchus marmoratus
Lycengraulis batesii

Amplova alleni

Pristigaster cayanus

Ilisha altamazonica

"iquitensis

" deaurata

Osteoglossum bicirrhosum

Arapaima gigas

Rivulus urophthalmus

$$
\text { " micropus }
$$

Potamorrhaphis guianensis

Tylosurus amazonicus

Monocirrhus mimophyllus

Plagioscion squamosissimum

$$
\text { " auratum }
$$

Chaetobranchus flavescens

Acaronia trimaculata

Uaru amphiacanthoides

Astronotus ocellatus

Aequidens tetramerus

$$
\begin{array}{cl}
\text { ". } & \text { dorsigerus } \\
\text { ، } & \text { mariae } \\
\text { ". } & \text { vreniferus } \\
\text { ". } & \text { subocularis } \\
\text { ". } & \text { hercules }
\end{array}
$$

Cichlaurus bimaculatus

$$
\begin{array}{ll}
\text { ". } & \text { severus } \\
\text { autochthon }
\end{array}
$$

Mesonauta festivum

Acarichthys heckelii

Biotodoma cupido

Geophagus surinamensis

$$
\text { .. jurupari }
$$

Apistogramma amoenum

Cichla ocellaris

Batrachops cyanonotus

Crenicichla saxatilis

$$
\begin{array}{ll}
\text { "، } & \text { anthurus } \\
\text { " } & \text { geayi } \\
& \text { johanna }
\end{array}
$$

Pterophyllum scalare

Achirus achirus

Achiropsis nattereri

Colomesus psittacus

Lower UCAYALI Basin

Potamotrygon hystrix

Callophysus macropterus

Zungaro zungaro
Rhamdia sebae

$$
\text { " mounseyi }
$$

Piramutana piramuta 
Pimelodella buckleyi

$$
\begin{array}{ll}
\text { " } & \text { hartwelli } \\
\text {. } & \text { boliviana } \\
& \text { peruana }
\end{array}
$$

Pimelodus pictus

$$
\begin{array}{ll}
“ & \text { clarias } \\
" & \text { leptus } \\
" & \text { altissimus }
\end{array}
$$

Duopalatinus peruanus

Pseudoplatystoma fasciatum Sorubim lima

Platystomatichthys sturio

Hemisorubim platyrhynchos

Perugia agassizii

Centromochlus heckelii

Auchenipterus nuchalis

Pseudauchenipterus nodosus

Epapterus dispilurus

Centrodoras brachiatus

Pterodoras granulosus

Liosomadoras morrowi

Amblydoras hancocki

Anadoras grypus

Pseudodoras niger

Trachydoras nattereri

Doras punctatus

Opsodoras hemipeltis

" humeralis

" orthacanthus

Hassar ucayalensis

Leptodoras linnelli

Ageneiosus ucayalensis

Hypophthalmus edentatus

Hemicetopsis candiru

Pseudostegophilus nemurus

Vandellia plazai

Urinophilus erythrurus

Callichthys callichthys

Hoplosternum thoracatum "s shirui

Corydoras aeneus

" armatus

، elegans

. $\quad$ stenocephalus

". episcopi

. leucomelas

Hypostomus emarginatus

" phrixosoma

Hemiancistrus ucayalensis

Monistiancistrus carachama

Pterygoplichthys gibbiceps

" multiradiatus
Parancistrus aurantiacus

Lasiancistrus pictus

Chaetostoma furcata

$$
\text { lineopunctata }
$$

Ancistrus temminckii

" airhosis

Hypoptopoma thoracatum

" joberti

. carinatum

Loricaria wolfei

" brumnea

“. chanjoo

" maculata

". ucayalensis

. cashibo

. petleyi

" morrowi

. carinata

“. clavipinna

Harttia filamentissima

Sturisoma rostrata

" nigrorostrum

Farlowella amazona

Astyanax bimaculatus

" maximus

Ctenobrycon hauxwellianus

Moenkhausia simulata " ovalis

Knodus megalops

Tetragonopterus argenteus

Stethaprion erythrops

Serrasalmus elongatus

" humeralis

Rooseveltiella nattereri " alta

Metynnis luna

Myleus setiger

Piaretus nigripinnis

Colossoma bidens

Mylossoma aureum

Myloplus levis

$$
\begin{array}{ll}
\text { " } & \text { duriventre } \\
& \text { albiscopum }
\end{array}
$$

" rubripinnis

Brycon melampterum

" erythropterum

Charax limaesquamis

$$
\text { ". gibbosus }
$$

Roeboides myersii

. affinis

“ bicornis

Cynopotamus gulo 
Salminus affinis

Chalcinus angulatus elongatus

Coscinoxyron culter

Pyrrhulina eleanorae

Gasteropelecus sternicla

Thoracocharax pectorosus

Rhaphiodon vulpinum

Hydrolicus scomberoides

Acestrorhynchus abbreviatus

$$
\begin{aligned}
& \text { " falcirostris } \\
& \text { " cachorro }
\end{aligned}
$$

Chalceus macrolepidotus

Hoplias malabaricus

Hoplerythrinus unitaeniatus

Hemiodus microlepis

Pterohemiodus atranalis

Psectrogaster amazonicus

$$
\text { " cisandinus }
$$

Curimatella alburna

Curimata leucisca

" ciliata

" cyprinoides

" reticulata

" hypostoma

" hypostoma hastata

" murieli

" melaniris

Curimatoides ucayalensis

Anodus laticeps

$$
\begin{aligned}
& \text { " latior. } \\
& \text { " elongatus }
\end{aligned}
$$

Anostomus ucayalensis

Schizodon fasciatum

Rhytiodus microlepis

Leporinus friderici

$$
\text { "wolfei }
$$

Prochilodus nigricans

$$
\begin{array}{ll}
" & \text { theraponeura } \\
& \text { amazonicus }
\end{array}
$$

Potamotrygon hystrix

Bunocephalus bicolor

$$
\begin{array}{ll}
" 6 & \text { knerii } \\
\text { " } & \text { bifidus }
\end{array}
$$

Pseudopimelodus raninus

Rhamdia quelen

Pimelodella buckleyi

$$
\text { " } \quad \text { hasemani }
$$

Prochilodus caudofasciatus

Sternopygus macrurus

Eigenmannia virescens troscheli

Sternarchorhamphus mülleri

Apteronotus bonapartii

Sternarchella schotti

Adontosternarchus sachsi

Rhamphichthys marmoratus

Electrophorus electricus

Amplova alleni

Pristigaster cayanus

Osteoglossum bicirrhosum

Arapaima gigas

Potamorrhaphis guianensis

Tylosurus amazonicus

Monocirrhus mimophyllus

Plagioscion squamosissimum

$$
\text { “ auratum }
$$

Chaetobranchus flavescens

Uaru amphiacanthoides

Astronotus ocellatus

Equidens tetramerus

$$
\text { " } \quad \text { mariae }
$$

Cichlaurus bimaculatus

$$
\text { " severus }
$$

Mesonauta festivum

Biotodoma cupido

Geophagus surinamensis

$$
\text { " jurupari }
$$

Apistogramma ambloplitoides

Cichla ocellaris

Batrachops nemopterus

Crenicichla saxatilis

$$
\text { ، } \quad \text { johanna }
$$

Pterophyllum scalare

Achirus achirus

Achiropsis nattereri

Lower Huallaga

Pimelodus pictus

$$
\text { " } \quad \text { ornatus }
$$

Pseudoplatystoma fasciatum

Sorubim lima

Sorubimichthys gigas

Perugia agassizii

Centromochlus heckelii

Trachycorystes galeatus 
Auchenipterus nuchalis

Platydoras costatus

Doras punctatus

Opsodoras stïbelii

Leptodoras acipenserinus

Ageneiosus brevifilis

Hypophthalmus edentatus

Hemicetopsis candiru

Pygidium taczanowskii

Henonemus punctatus

$$
\text { “ macrops }
$$

Acanthopoma annectens

Urinophilus erythrurus

Astroblepus sabalo

$$
\begin{aligned}
& \text { " longifilis } \\
& \text {.. taczanowskii }
\end{aligned}
$$

Callichthys callichthys

Hoplosternum littorale

$$
\text { " thoracatum }
$$

Decapogon adspersum

Corydoras armatus

$$
\text { . zygatus }
$$

Canthopomus agassizii

Hypostomus emarginatus

Hemiancistrus arenarius

Panaque dentex

Pterygoplichthys punctatus

Acanthicus hystrix multiradiatus

Chaetostoma taczanowskii

$$
\text { ". } \quad \text { branickii }
$$

Ancistrus hoplogenys

$$
\text { . temminckii }
$$$$
\text { " cirrhosus }
$$

Hypoptopoma thoracatum

\section{Loricaria lanceolata}

$$
\begin{aligned}
& \text { " stübelii } \\
& \text {. punctata } \\
& \text { “ lamina } \\
& \text {.. cataphracta }
\end{aligned}
$$

Harttia filamentissima

Sturisoma rostrata

$$
\text { " güntheri }
$$

Farlowella smithi

Hemibrycon jelskii

Astyanax longior maximus

Bryconamericus osgoodi

Creagrutus peruanus

Ctenobrycon hauxwellianus

Moenkhausia bondi
Moenkhausia ovalis

Tetragonopterus argenteus

Stethaprion erythrops

Serrasalmus elongatus

$$
\begin{array}{ll}
\text { ". } & \text { rhombeus } \\
\text { ". } & \text { maculatus } \\
& \text { humeralis }
\end{array}
$$

Rooseveltiella alta

Metymnis luna

$$
\text { " hypsauchen }
$$

Mylossoma duriventre

$$
\text { " albiscopum }
$$

Charax amazonum

Roeboides myersii

$$
\text { "affinis }
$$

Chalcinus angulatus

$$
\begin{array}{ll}
. . & \text { angulatus vittatus } \\
\text {." } & \text { albus } \\
& \text { elongatus }
\end{array}
$$

Aphyocharax pusillus

Gasteropelecus coronatus

Thoracocharax stellatus

Rhaphiodon vulpinum

Cynodon gibbum

Hydrolicus scomberoides "6 pectoralis

Xiphostoma maculatum

Acestrorhynchus falcirostris

Hoplias malabaricus

$$
\text { falcatus }
$$

microlepis

Erythrinus erythrinus

Psectrogaster amazonicus cisandinus

Curimatella meyeri

Curimata bimaculata

" dobula

" aspera

، rutiloides

“ leucisca

“. hypostoma

. robustula

“. simulata

Anodus laticeps

" latior

Laemolyta taeniata

Schizodon fasciatum

Leporinus friderici
" megalops
“ trifasciatus
، hypselonotus 
Prochilodus nigricans

Hypopomus brevirostris

Eigenmannia virescens

Sternarchorhamphus macrostomus

Sternarchogiton poreinum

Gymnotus carapo

Symbranchus marmoratus

Lycengraulis batesii

Pristigaster cayanus

Osteoglossum bicirrhosum

Rivulus urophthalmus

Tylosurus amazonicus

Astronotus ocellatus

Aequidens tetramerus
Aequidens dorsigera

" mariae

Cichlaurus bimaculatus

" severus

Geophagus jurupari

Cichla ocellaris

" temensis

Batrachops reticulatus

Crenicichla lucius

" geayi ، johanna

Achirus achirus

Achiropsis nattereri

Colomesus psittacus

\section{ECUadorean Lowlands}

Bunocephalus knerii

Pseudopimelodus pulcher

Nannoglanis fasciatus

Nannorhamdia longicauda

Pimelodella buckleyi

Centromochlus perugiae

Hemicetopsis plumbeus

Pygidium knerii

Henonemus punctatus

Astroblepus boulengeri

Chaetostoma dermorhyncha

$$
\text { " microps }
$$$$
\text { . brevis }
$$

Ancistrus occidentalis

$$
\text { " cirrhosus }
$$

Loricaria filamentosa

$$
\text { " lanceolata }
$$$$
\text { " simillima }
$$

Farlowella knerii
Astyanax fasciatus

Creagrutus mülleri

Charax pauciradiata

Cynopotamus knerii

Paragoniates alburnus

Leptagoniates steindachneri

Piabucina unitaeniata

$$
\text { longata }
$$

Parodon buckeyi

Characidium fasciatum

Curimata nasa

$$
\text { " dobula }
$$

Leporinus striatus

Sternopygus macrurus

Sternarchorhynchus oxyrhynchus

Apteronotus albifrons

Gymnotus carapo

Aequidens vittatus

Crenicichla saxatilis

\section{Alto Marañon Above Pongo de Manseriche}

Pseudopimelodus pulcher

Chasmocranus quadrizonatus

Imparfinis bolivianus

Nannorhamdia longicauda

Pimelodella gracilis

Pimelodus ornatus

Hemicetopsis plumbeus

Pygidium taczanowskii

Astroblepus longifilis

$$
\begin{array}{ll}
\text { ". } & \text { supramollis } \\
\text {.. } & \text { labialis } \\
\text { peruanus }
\end{array}
$$

Hypostomus plecostomus
Chaetostoma brevis

$$
\text { " mollinasa }
$$

Loricaria puganensis

Hemibrycon helleri

$$
\text { " jelskii }
$$

Astyanax bimaculatus

$$
\text { " maximus }
$$

Bryconamericus caucanus

Creagrutus beni alfredae

Microgenys lativirgatus

Hemigrammus paipayensis 
Moenkhausia crisnejas

Knodus moenkhausii

" breviceps

Brycon stolzmanni
Cynopotamus gulo

Prochilodus nigricans

Sternopygus macrurus

Apteronotus hasemani

Rio Santiago Upper Marañon, Festa Collection

Rhamdia humilis

(Rhamdia parvus)

(Cetopsis macroteronema)

Pygidium knerii

(Pygidium taenium)

Astroblepus prenadilla

(Astroblepus festae)

(Chatostomus platycephalus)

Chaetostomus microps

Chaetostomus dermorhynchus
(Bryconamericus rutilis)

(Hemibrycon polyodon)

(Brycon atricaudatus)

(Brycon striatulus)

Salminus affinis

Piabucina elongata

Prochilodus nigricans

Sternarchus albifrons

Acara syspilus

Crenicichla saxatilis

Species in parentheses not recorded from our area elsewhere

Moyobamba, Chachapoyas Huallaga Basin

Rhamdia riojae

Astyanax longior

maximus
Bryconamericus osgoodi

Hyphessobryeon sp.

Crenicichla lucius

\section{Rio Huambo, Rio Totora Middle Hullaga}

Pygidium taczanowskii

Astroblepus sabalo

$$
\begin{array}{ll}
\text { ". } & \text { longifilis } \\
\text { ، } & \text { peruanus } \\
\text { taczanowskii }
\end{array}
$$

Chaetostoma taczanowskii
Chaetostoma branickii

Hemibrycon jelskii microps

Creagrutus peruanus

\section{Alto Huallaga Above Cayumba Rapids}

Pimelodella montana

Pygidium taczanowskii

Astroblepus sabalo

$$
\begin{array}{ll}
\text { ". } & \text { prenadilla } \\
\text { ". } & \text { longiceps } \\
& \text { praeliorum }
\end{array}
$$

Chaetostoma taczanowskii .. marmorescens

Othonocheirodus eigenmanni

Hemibrycon huambonicus

Astyanax bimaculatus

Orestias empyraeus

Tarma, Chanchomayo, Perené Valley

Rhamdia quelen " pentlandi

Pseudodoras niger

Pygidium oroyae

Astroblepus sabalo "6 praeliorum

Ancistrus bufonius

Hemibrycon jelskii
Astyanax bimaculatus maximus

Ceratobranchia obtusirostris

Bryconacidnus ellisi

Creagrutus peruanus

Salminus affinis

Prochilodus caudofasciatus 


\section{Rio Pichis}

Corydoras aeneus

Chaetostoma lineopunctata

Ancistrus temminckii

Astyanax bimaculatus

$$
\text { maximus }
$$

Moenkhausia simulata

Knodus megalops

Tetragonopterus argenteus

Serrasalmus humeralis
Brycon melampterum Curimata hypostoma Prochilodus nigricans Sternopygus macrurus Electrophorus electricus Tylosurus amazonicus Equidens tetramerus Crenicichla saxatilis " geayi

\section{Middle and Upper Urubamba}

Rhamdia duquei riojae

Pimelodella roccae

Pygidium dispar

$$
\text { " rivulatum }
$$

Astroblepus sabalo

$$
\text { " mancoi }
$$

Chaetostoma taczanowskii

Ancistrus occloi

Hemibrycon helleri

$$
\text { " huambonicus }
$$

Acrobrycon ipanquianus

Astyanax bimaculatus
Astyanax maximus

Ceratobranchia binghami

Bryconamericus grosvenori

$\begin{array}{ll}، & \text { pachacuti } \\ ، \quad & \text { alfredae }\end{array}$

Creagrutus peruanus

Sternopygus macrurus

Apteronotus albifrons

Orestias mülleri

$$
\begin{array}{ll}
" & \text { owenii } \\
" & \text { jussiei } \\
& \text { rospigliosii }
\end{array}
$$

Titicaca-Poopó-Ascotan Basin

Pygidium rivulatum

Orestias agassizii

“ mülleri

" humboldtii

" tschudii

" pentlandii
Orestias cuvieri

" luteus

" albus

" olivaceus

" silustani

" incae 
TABLE II. Distribution of Lowland Fishes

Omitting those known from only a single locality

Potamotrygon hystrix

Bunocephalus knerii

$$
\text { ، bifidus. }
$$

Callophysus macropterus

Pimelodina flatripinnis

Zungaro zungaro

Pseudopimelodus raninus

Rhamdia quelen

$$
\text { ". sebae. }
$$

Imparfinis bolivianus

Piramutana piramuta.

Pimclodella purtuensic

$$
\begin{array}{ll}
. & \text { lateristriga } \\
. & \text { huckleyi } \\
. & \text { hasemani } \\
. & \text { boliviana. } \\
\text { “ } & \text { rristata } \\
\text { " } & \text { gracilis... }
\end{array}
$$

Pimelodus pietur

$$
\text { " clarias... }
$$

Goeldiella eques.

Pseudoplatystoma fasciatum

Phractocephalus hemiliopterus.

Bratchyplat ristomai juruense

Sorubim lima

Platystomatichthresturio

Hemisorubim platyrhynchos.

Sorubimichthys planiceps

Perugiat atgisizizii

Centromochlus heckelii

'Trachycorystes galeatus.

Auchenipterus nuchalis.

Pseudauchenipterus nodosus

Evapterus dispilurus

Megaloxloras irwini

Centrodoras brachiatus.

Pterodoras gramulosis.
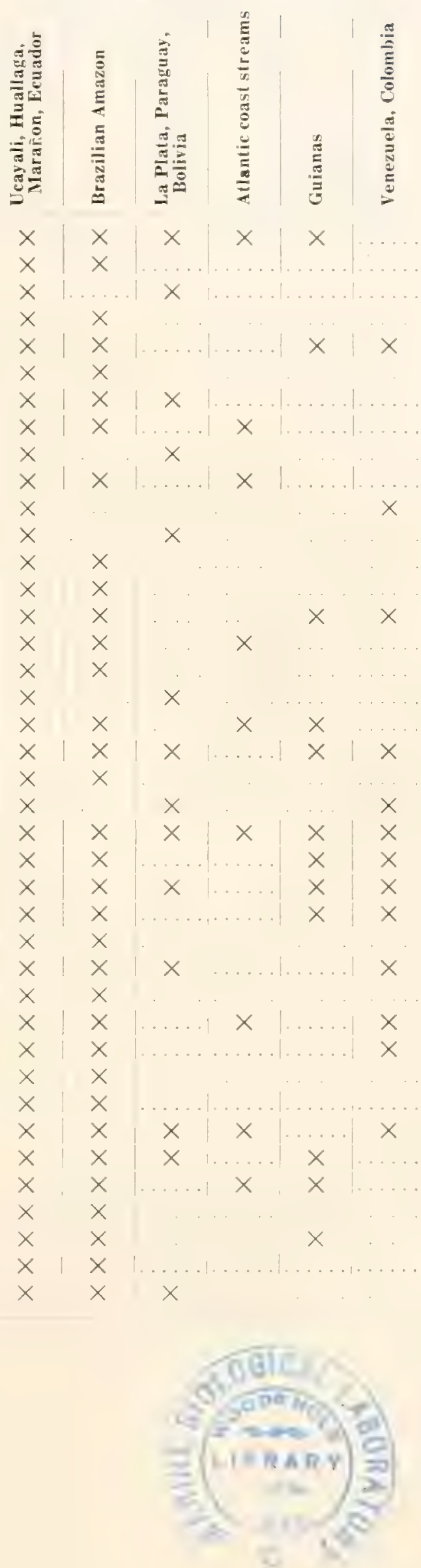
TABLE II.-Continued

Platydoras costatus

Amblydoras hancockii.

Anadoras grypus.

Pseudodoras niger

Trachydoras nattereri. atripes

Doras punctatus

Hemidoras stenopeltis.

Opsodoras humeralis.

Leptodoras linnelli

Ageneiosus ueayalensis

$$
\text { "6 brevifilis. }
$$

Hypophthalmus edentatus.

Hemicetopsis candiru

Pygidium knerii

$$
\text { plumbeus. }
$$

Henonemus punctatus

$$
\text { macrops. }
$$

Pseudostegophilus nemurus

Vandellia plazai.

Urinophilus orythrurus

Astroblepus longiceps.

Callichthys allichthys

Hoplosternum littorale.

Decapogon adspersum

$$
\text { thoracatum }
$$

Corydoras aeneus.

$$
\begin{aligned}
& \text { " armatus. } \\
& \text {. } \\
& \text {." pagans. } \\
&
\end{aligned}
$$

( )steogaster splendens.

Canthopomus agasizii

Hypostomus emarginatus

$$
\text { plecostomus }
$$

Pter'rgoplichthys githiceps

Acanthicus hystrix

$$
\text { punctatus. }
$$

multiradiatus

Ancistrus hoplogenys

$$
\begin{array}{ll}
\text { " bufonius. . } \\
\text { " temminckii. } \\
\text { " cirrhosus. . }
\end{array}
$$

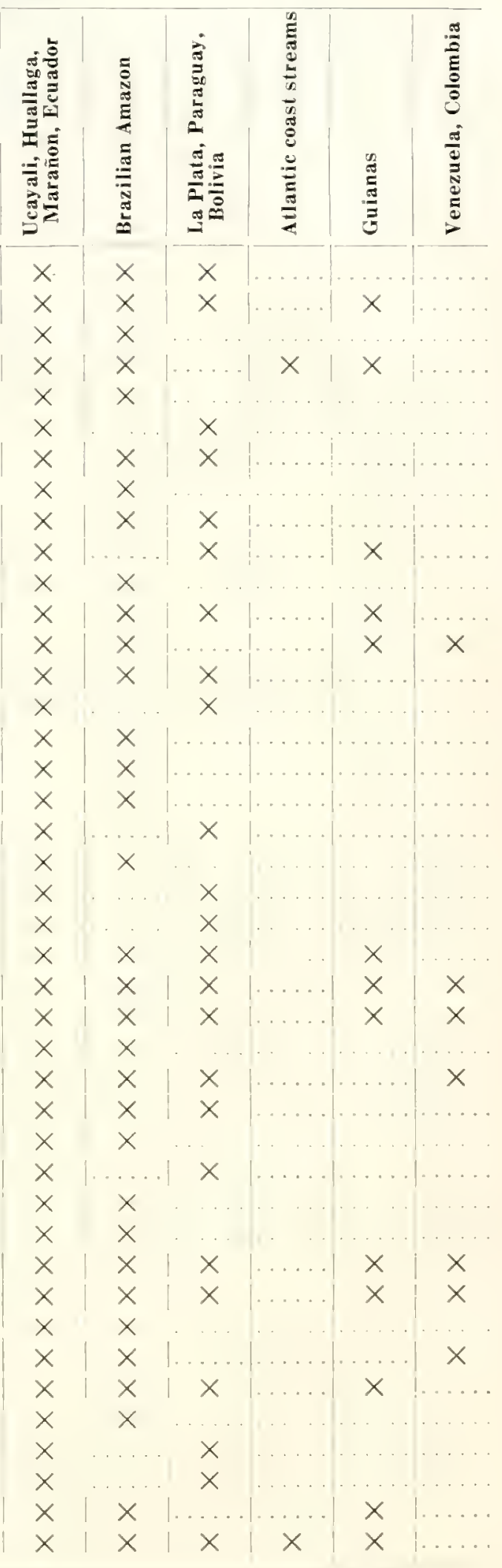


TABLE II.-Continued

Hypoptopoma thoracatum

$$
\text { ". } \quad \text { joberti ... }
$$

Loricaria filamentosa.

$$
\begin{aligned}
& \text { " lanceolata. } \\
& \text { ". acuta. } \\
& \text {. brunnea. } \\
& \text {.. konopickyi..... } \\
& \text { “ trpus. } \\
& \text { ، maculatio } \\
& \text { " evansii } \\
& \text {. nudirostris..... } \\
& \text { " punctata...... } \\
& \text {.. carinata } \\
& \text {. cataphracta }
\end{aligned}
$$

Hemiodontichthys acipenserinus.

Sturisoma rostrata

$$
\text { " güntheri...... }
$$

Farlowella kneri.

$$
\text { " amazona. . }
$$

Hemibrycon huambonicus

Phenacogaster pectinatus.

Astyanax bimaculatus. .

$$
\text { "6 fasciatus. }
$$

Hemigrammus sehmardar

Moenkhausia oligolepis

$$
\text { " bondi. }
$$

Bario steindachneri.

Tetragonopterus argenteus

$$
\text { " chalceus. }
$$

Sitrothaprion erythrops

Ephippicharax orbicularis.

Serrasalmus spilopleura.

$$
\begin{array}{cl}
\text { “ } & \text { elongatus. } \\
\text {, } & \text { rhombeus. } \\
\text {, } & \text { maculatus } \\
\text {. } & \text { humeralis. }
\end{array}
$$

Rooseveltiella nattereri.

Metynnis hypsauchen

Myleus setiger.

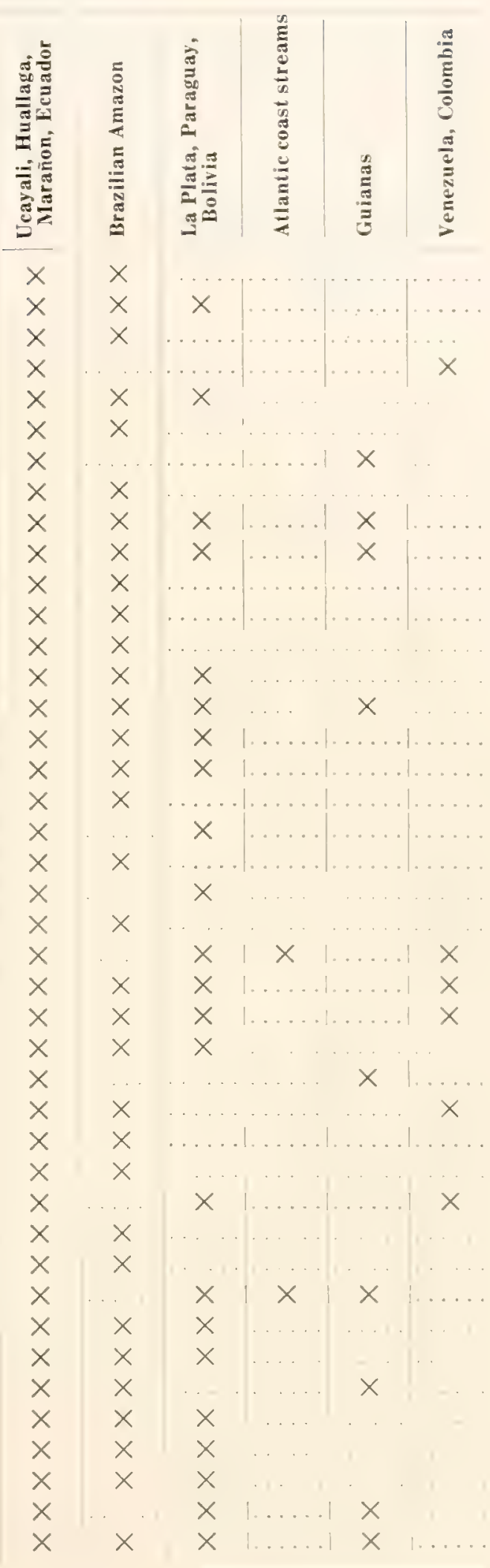


TABLE II.-Continued

Piaretus nigripinni.

Colossoma bidens

Mylossoma aureum

$$
\text { " } \quad \text { duriventre. }
$$

Myloplus rhomboidalis

$$
\text { " levis...... }
$$

Iguanodectes tenuis

Piabucus dentatus.

Charax gibbosus

Roeboides affinis

Cynopotamus knerii

Chalcinus angulatus

$\begin{array}{cc}\text { " } & \text { rittatus. } \\ \text { " } & \text { albus........... } \\ \text { " } & \text { rotundatus. . . . . . . . . . . }\end{array}$

Coseinoxyron culter

Clupeacharax anchoveoides

Pyrrhulina lugubris

Aphyocharax allowmus.

Gasteropelecus sternicla

Thoracocharax stellatus.

Carnegiella strigata

Paragoniates alburnus

Rhaphiodon vulpinum.

Cynodon gibbum

Hydroliens seomberoides

Acestrorhynchus falcatus

$$
\text { " microlepis. }
$$

Chalceus macrolepidotus

Plethodectes ery thrurus

Piabucina unitaeniata

Ioplias malabaricus.

Hoplery thrinus unitaeniatus

Erythrinus ery thrinus

Hemiodus mircrolepis

Anisitsia amazonum

Characidium fasciatum

Potamorhina pristigaster

Psectrogaster amazonicus

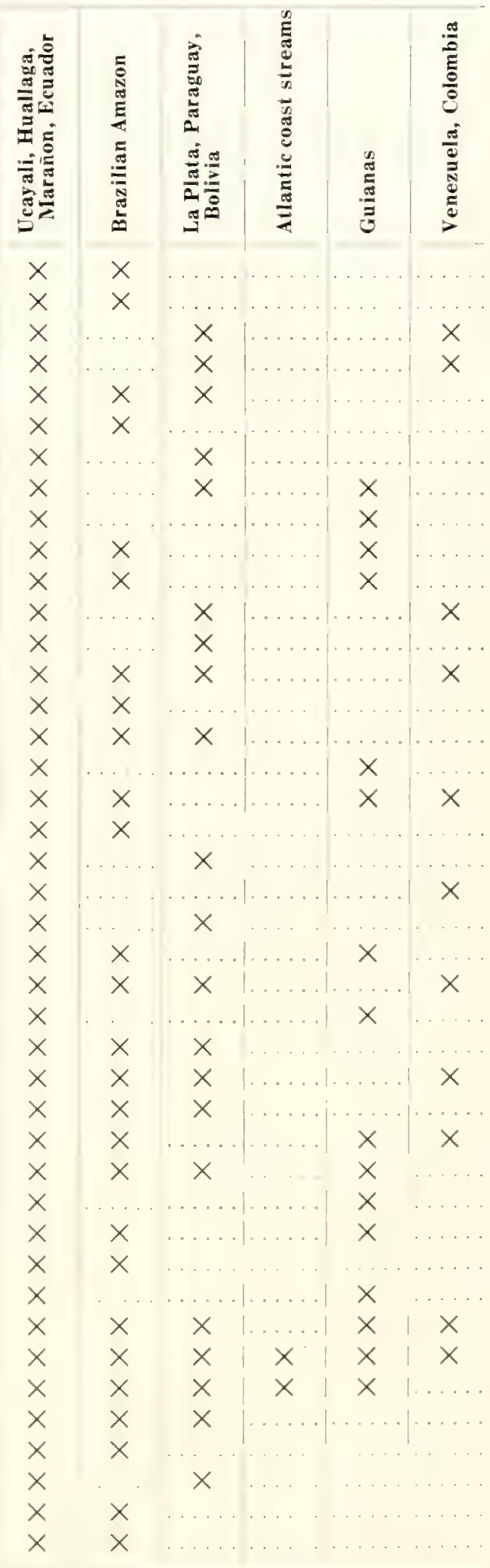


TABLE II.-Continued

C'urimatella alburna

Curimata spilura.

" bimaculata.

" rutiloides.

" cyprinoides.

Anodus laticeps....

. latior.

" elongatus.

Anostomus trimaculatus

Schizodon fasciatum.

Rhytiodus microlepis.

Leporinus friderici

$$
\text { argenteofuscus. . }
$$

، bimaculatus

“. striatus

“ mülleri.

" megalepis

“ maculatus

" trifasciatus

“ hypselonotus.

Leporellus vittatus

Prochilodus nigricans

$$
\text { " } \begin{aligned}
& \text { amazonensis... } \\
& " \\
& \text { insignis...... }
\end{aligned}
$$

Sternopygus macrurus

Steatogenys elegans.

Hypopomus brevirostris

Eigenmannia virescens

Sternarchorhynchus oxyrhynchus

Stemarchorhamphus mülleri.

Apteronotus albifrons

$$
\text { " leptorhynchus }
$$

Stemarehella schotti.

Porotergus gimbeli

Sternarchogiton nattereri

Adontostermarchus sachsi

Rhamphichthrs botratus mamoratus

Girmotus carapo.

Electrophorus electriass

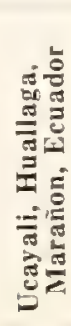

है

Eี

$\times$

$x$

$\times$

$x$

$x$

$x$

$x$

$\times$

$x$

$x$

$x$

$x$

$x$

$x$

$x$

$x$

$x$

$x$

$x$

$x$

$x$

$x \quad x$

$x \quad x$

$x \quad x$

$x \quad x$

$x \quad x$

$x$

$x$

$x$

$x$

$x$

$x$

$x$

$x$

$x$

$x$

$x$

$x$

$x$

$x$

$x$
$x$

$x$
$x$

$x$

$x$

$x \quad x$

$x$

$x$

$x$

$x$

$x$

$x$

x

$x$

$x$

$x$

$x$

$x$

$x$

$x$

$x$

$x$

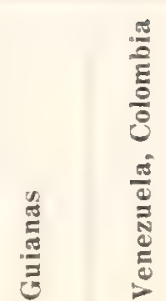

$x$

$x \quad x$

$x \quad x$

$x$

$x$

X

$x$

$\times \quad \times \quad x$

$x$

$\times$

$\times$

$\times \quad x$

$x \quad x$

$x$

$x \quad x$

$\times \quad x$

$x$
$x$
$x$
$x$
$x$
$x$
$x$
$x$
$x$
$x$
$x$
$x$
$x$
$x$
$x$
$x$
$x$
$x$
$x$
$x$
$x$
$x$
$x$
$x$
$x$
$x$
$x$
$x$
$x$
$x$
$x$


TABLE II.-Concluded

Symbranchus marmoratus.

Lycengraulis batesii .

Pristigaster cayanus

Ilisha altamazonica.

Osteoglossum bicirrhosum

Arapaima gigas.

Rivulus urophthalmus.

$$
\text { micropus }
$$

Potamorrhaphis guanensis

Tylosurus amazonicus

Plagioscion squamosissimum

$$
\text { auratum }
$$

Chaetobranchus flavescens.

Acaronia nassa .

Uaru amphiacanthoides

Astronotus ocellatus.

Aequidens tetramerus

$$
\text { dorsigerus. }
$$$$
\text { mariae. }
$$

Cichlaurus bimarulatus.

$$
\begin{array}{ll}
\text { " } & \text { severus.... } \\
\text {. } & \text { temporalis. } \\
\text { autochthon }
\end{array}
$$

Mesonauta festivum

Acarichthys heckelii.

Biotodoma cupido

Geophagus surinamensis

$$
\text { jurupari. }
$$

Apistogramma amoenum

Cichla ocellaris

$$
\text { temensis }
$$

Batrachops reticulatus.

Crenicichla saxatilis. .

$$
\text { ". } \quad \text { jeayi... }
$$

Pterophyllum scalare

Achirus achirus.

Achiropsis nattereri

Colomesus psittacus

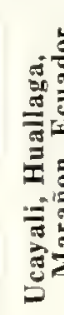

$x$

$x$

$x$

$x$

$x$

$x$

$x$

$x$

$x$

$x$

$x$

$\times$

$\times$

$x$
$x$

$x$

$x$

$x$

$\times$

$x$

$x$

$x$

$x$

$x$

$x$

$x$

$\times$

$\times$

$\times$

$x$

$x$

$x$

$x$

$x$

$x$

$x$

$x$

$x$

$x$

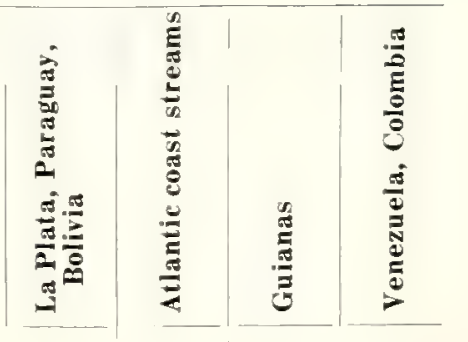

$\times|\times| \ldots|\times| \times$

\begin{tabular}{l|l|l|l|l|}
$x$ & $\ldots$ & $\ldots$ & $\ldots$ & $\ldots$ \\
$x$ & $\ldots$ & $x$ & $x$ & $\ldots$
\end{tabular}

$x$

$x$

$x$

$x$

$\times$

$\times$

$\times$

$x$

$\ldots|x| x \mid x$

$\times \quad \times \quad \ldots \ldots \times$

$\times|\times| \ldots \ldots|\times| \times$

$\times$

$x$

$\times$

$x$

$\ldots$

$\times$

$x$

$x$

$x$

$x$

$x$

$x$

$\times$

$x$

$x$

$x$

$x$

$x$

$x$

\begin{tabular}{l|l}
$x$ & $x$
\end{tabular}

$\times$

$x$

$\times$

$\times$

$\times$

$x$

$\stackrel{x}{\times}$

$x$

$\times$

$x$

$x$

$x$

$\times|\ldots| \times|\times| \times$

$\ldots \times x$

$\times \mid \times$

$\ldots \ldots \ldots \ldots \ldots$

$x|\ldots \ldots| \ldots|x| x$

\begin{tabular}{l|l|l|l|l} 
& $\times$ & $\times$ & $\times$ & $x$
\end{tabular}

$x$

$\times$ 
Table ili. Distribution of Cordilleran Fishes

Pseudopimelodus pulcher.

Chasmocranus quadrizonatus.

Rhamdia duquei

\begin{tabular}{|c|c|c|c|c|c|c|c|c|}
\hline 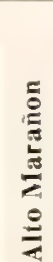 & 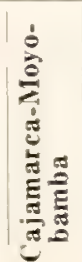 & 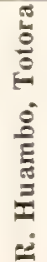 & 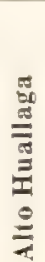 & 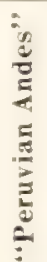 & 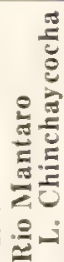 & 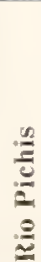 & 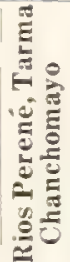 & 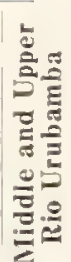 \\
\hline
\end{tabular}

Rhamdia quelen

Rhamdia riojae.

?Rhamdia pentlandi.

Imparfinis bolivianus.

Nannorhamdia longicauda

Pimelodella roceae.
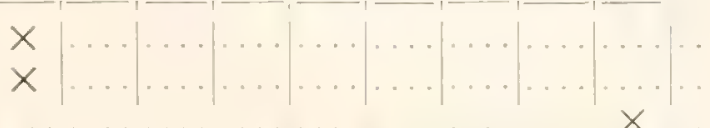

$$
\begin{aligned}
& \text {.. montana } \\
& \text {. gracilis. }
\end{aligned}
$$

Pimelodus ornatus

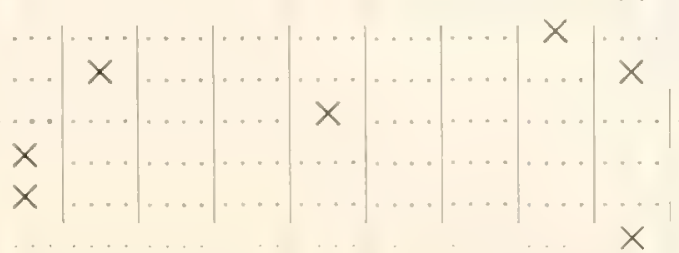

Pseudodoras niger.

Hemicetopsis plumbeus

Prgidium fuscum

$$
\begin{array}{ll}
\text {. } & \text { dispar..... } \\
\text {.. } & \text { rivulatum. } \\
\text { " } & \text { taczanows. . . }
\end{array}
$$

Astroblepus sabalo...

$$
\text { .. } \quad \text { prenadilla. }
$$

Astroblepus supramollis.

$$
\begin{array}{ll}
\text {.. } & \text { labialis.... } \\
\text {.. } & \text { peruanus .. } \\
\text {. } & \text { simonsii..... } \\
\text {. } & \text { taczanowskii } \\
\text {. } & \text { mancoi.... } \\
. & \text { longiceps... } \\
. & \text { pracliorum. }
\end{array}
$$

Corydoras aeneus

Hypostomus plecostomus.

Chaetostoma taczanowskii

$$
\begin{aligned}
& \text { " lineopunctata } \\
& \text {.. marmorescens } \\
& \text {.. branicliii. } \\
& \text {.. microps. } \\
& \text {.. maculata } \\
& \text { “ brevis. } \\
& \text { mollinasa. }
\end{aligned}
$$

Ancistrus bufonius

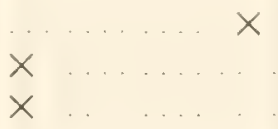

$x$

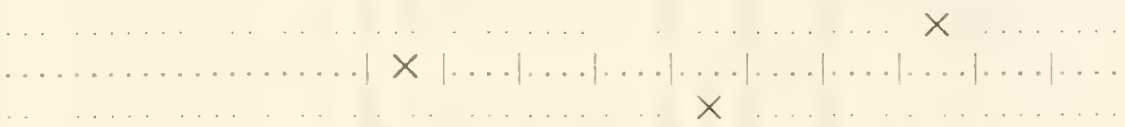

$$
\begin{array}{ll}
\text {.. } & \text { occloi .... } \\
& \text { temminckii }
\end{array}
$$


TABLE III.-Continued

Loricaria puganensis. .

Othonocheirodus eigenmanni

Hemibrycon tridens.

$$
\begin{array}{ll}
\text { " } & \text { helleri...... } \\
\text { " } & \text { huambonicus. } \\
& \text { jelskii ...... }
\end{array}
$$

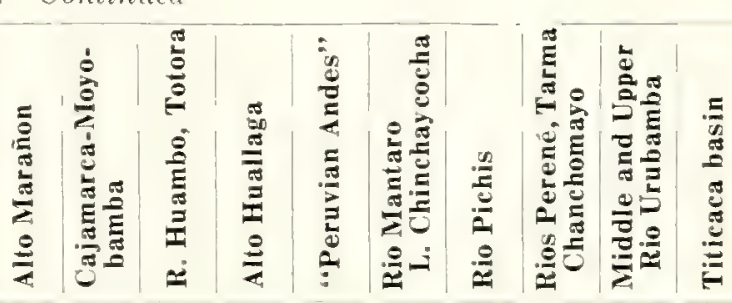

Acrobrycon ipanquianus

Astyanax bimaculatus

$$
\begin{aligned}
& \text {. } \\
& \text {. mangior. }
\end{aligned}
$$

$\times|\ldots| \ldots|\ldots| x$

Ceratobranchia obtusirostris.

$$
\text { " binghami. }
$$

Bryconamericus grosienori.

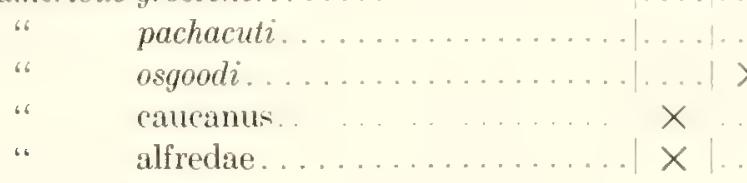

Bryconacidnus ellisi

C'reagrutus peruanus.

$$
\text { 66 beni..... }
$$

Microgenys lativirgatus

Hemigrammus paipayensis.

Hyphessobrycon sip.

Mornkhausia simulata

$$
\text { " crisncjas }
$$

Knodus moenkhausii .

$$
\text { " hrevieeps }
$$
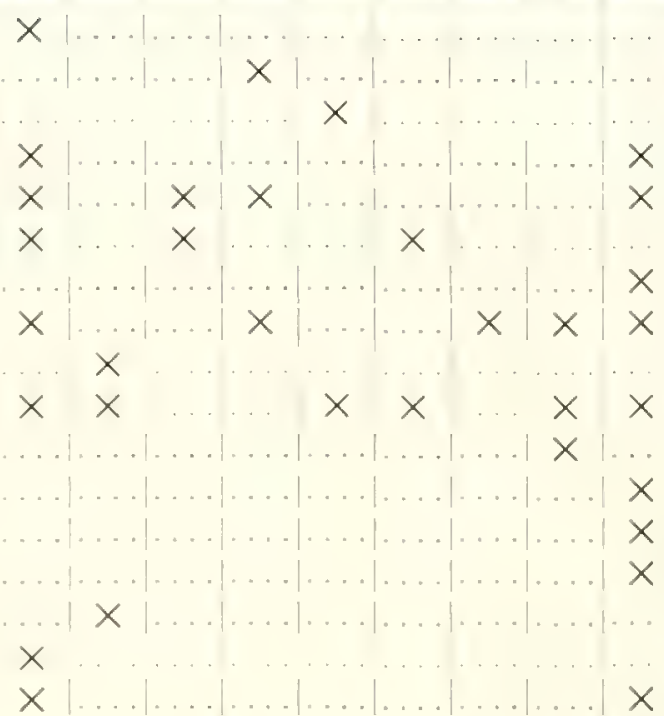

Tetragonopterus argenteus

Brycon melampterum

$$
\text { " stolzmamni }
$$

Salminus affini

Cynopotamus gulo

Lebiasina bimaculata

Curimata hypostoma

Prochilodus nigricans.

$$
\text { " caurlofasciatus }
$$

Sternopygus materurus.

Apteronotus hasemani

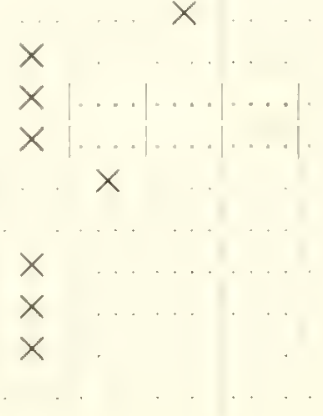


TABIE III.-Concluded

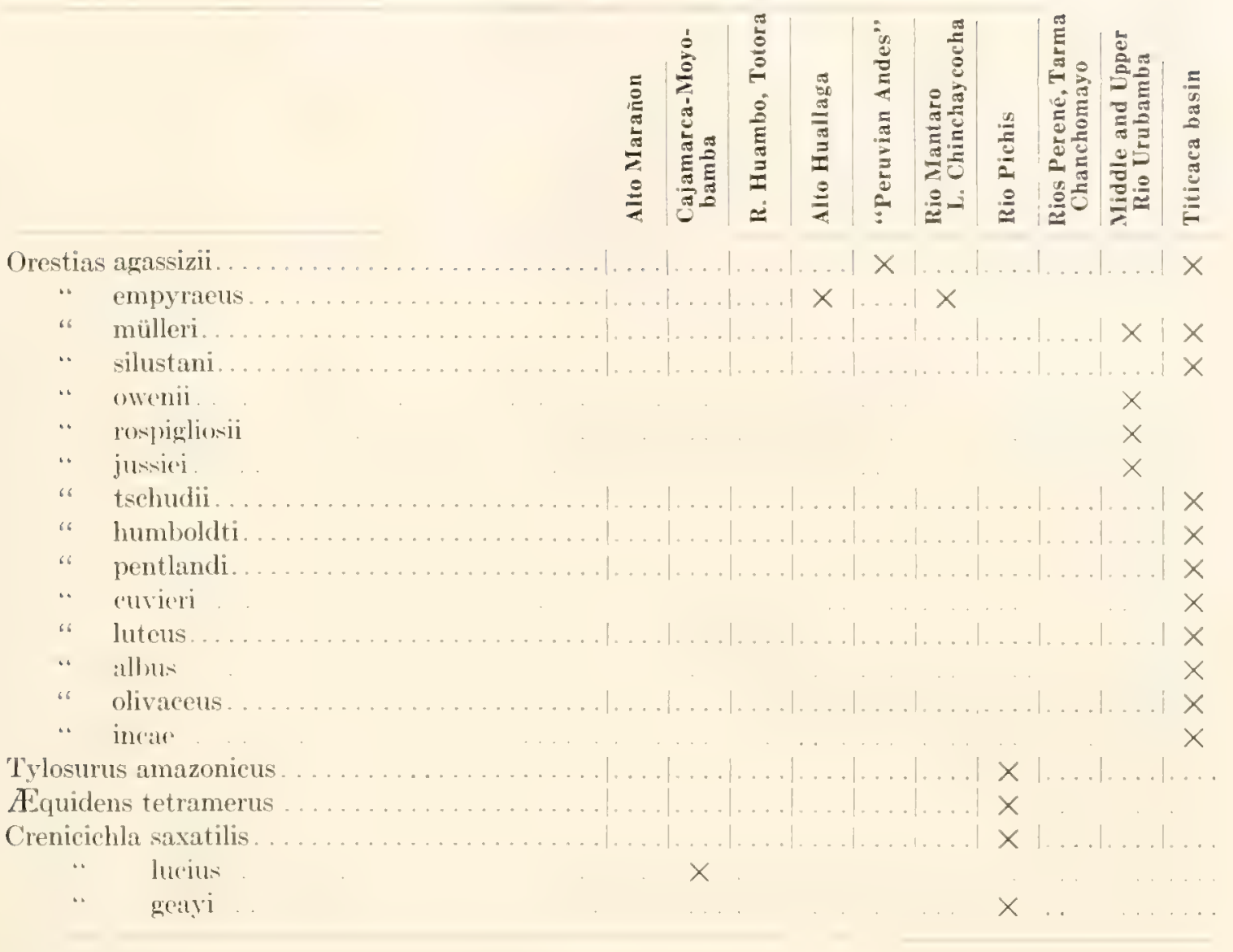

Species italicized in Table III are from unique localities; Hemibrycon helleri doubtfully identical; Astroblepus praeliorum from streams arising in the same area.

\section{DISCUSSION}

The evidences and the conclusions concerning distribution in other regions of South America are discussed by Eigenmann (1909, 1912, 1922, etc.) Since so large a part of the freshwater fauna of the continent belongs to only a few families several of which are represented also in Africa, and since certain Geological facts lend support to the theory, he considered the demonstration sufficiently complete that the fishes of South America have their nearest kinship with those of the Eastern Hemisphere. Whether an Archhelenis-Archiplata continent existed all at one time or piecemeal, a freshwater communication with Africa appeared to be the most logical explanation of the facts. Rejection of the theory seems to permit only one alternative, the much broader assumption of many cases of close parallelism, purely fortuitous, between the fishes of the two continents.

The present discussion has to do with the youngest major portion of South America, antedated through long geological periods by the freshwater areas of Brazil and the Guianas. Regardless of the earliest beginnings of the ichthyfauna, the migration routes into this area from the older streams are discernible (Eigen- 
mann, 1922b, d; 1923a). Although most of the stocks passed through periods in which they inhabited the eastern highlands, it was not until the Amazon developed its great freshwater basin that it became the greatest hatchery of species known. From there Haseman (1912), Pearson (1937b) have traced the highways of dispersal in various directions, while Eigenmann, 1. c., found that the fishes of the Pacific slopes had to traverse a circuitous route around the low northern Andes of Colombia to reach their present habitats.

Pearson finds two major sources of the population of the Paraguay, the Guaporé, and of the Bolivian headwaters of the Madeira, the latter more nearly resembling the upper Amazonian fauna. Our fishes from the upper Peruvian Amazon and its tributaries should therefore exhibit close kinship with those of Bolivia, and they do. This is true, not only for the lowland species, but we find a number of fishes such as the Hemibrycons inhabiting regions of intermediate elevation in the tropical rain forests of both Peru and Bolivia. In Peru as in Bolivia and La Plata, the changes in a fauna as we proceed from the Amazon southward are similar, that is, changes mostly by subtraction. None of these facts aid in explaining the origins of the respective families, nor do we find any facts which would support Haseman's theory as to a North American origin of Characin fishes.

The present study differs from those previously made: in the age of the formations which determine the types of habitat; in the large-scale topographic relief; and in the length of the period of occupancy. Like most of the continent, it is part of a unit uncontaminated from north, west, or south, and having its only family ties with the East. Numerous families are of tropical South American origin, and are confined to that continent, such as: Loricariidae, Astroblepidae, Callichthyidae, Aspredinidae, Hypophthalmidae, Pygidiidae, Gymnotidae; also numerous characin subfamilies.

The fauna has developed with the continent itself, and despite the youthfulness of our region, sufficient time has elapsed to differentiate the Pacific slope fishes completely from those of the Atlantic side, at least to species, and sometimes to distinct genera.

The upthrust of the Andes as described above has created barriers more rapidly than weathering processes could smooth them down. This has resulted in the creation of: (a) the land-locked Titicaca-Poopó basin, and of numerous areas, large and small, throughout our area, having mature topography and high elevation, plains, lakes, marshes; (b) a second, subtropical, zone to which some of the inhabitants of the first zone have escaped; (c) a zone of still lower elevation to which certain genera of Amazonian fishes have been able to ascend; and (d) the tropical lowlands, richly and abundantly populated from the various centers of dispersal of the Amazon system.

The first and most elevated zone is occupied almost exclusively by fishes descended from those which were elevated with the mountains themselves. The second zone consists of limited localities with suitable terrain to encourage the further evolution of highland fishes, such as the Astroblepus of southern Ecuador. The third zone whose extent is to be described below is marked off from those above by greater or less extent of rapids, and represents the farthest reach of a 
few scattered pioneer types from the lowland. The fourth zone presents, apparently, the limitless waters of the tropical lowlands, with its opportunities for an aggressive or resourceful species. To this zone belong the greater part of the characin and catfish faunas, which have responded to the opportunity in an unparalleled way. Events have transpired in such a way as to permit not a few marine or estuarine fishes to become readjusted to the fresh waters of the new habitats, so that the uppermost Amazon remote from the sea has its stingrays, its flatfishes, puffers, anchovies, etc., as well as its otter, porpoises, and manatees. At Cayumba rapids, 3000 miles from the ocean, even a crab was found, elevation 1800 feet.

Table II shows at least qualitatively the degrees of relationship between our area and other major systems. Unique species are not given, not being of value for comparison. As should be expected most, 201, of the lowland fishes given in the table belong to the Brazilian Amazon also. The entire Amazon is a unit from its mouth to the point where it was an inland sea washing the foothills of the Andes. One-hundred ten, less than half the 246 lowland Peruvian species, have also surmounted the low barriers of the upper Madeira to the Beni, Mamoré, and Paraguay.

Pearson, 1937b, in a total of 485 species from Bolivia (including also mountain species and uniques) finds 316 common to the Paraguay, 229 found in the Amazon. The Guiana fauna has no less than 97 species reaching the lowlands of Peru, indicating a not very remote separation biologically. There is little doubt that the 68 species mutual to lowland Peru and Venezuela or westward show only the lack of exploration of the farther reaches of the Orinoco.

The streams of the Atlantic seaboard are short and disconnected, and lie on the farther slopes of the Brazilian plateau, and our table lists only some 26 of their species in the lowlands of Peru.

The fishes of the highlands are almost wholly distinct from those of other regions. The intent of Table III is, therefore, not to make comparisons with outside areas, but to analyze the distribution within the region itself. Uniques are included.

The Maranon and Santiago boast the largest number of known species, 34, in elevations mostly 3000-4000 feet. It will be noted that most of them are either lowland species or closely allied to them, obviously derived from the Amazon fauna, which has met with considerable success in passing barriers formerly considered impassible. The greatest obstacle to passage upstream is to be met at the point of emergence from the intercordilleran valley upon the Amazonian plain, the watergap known as the Pongo de Manseriche. When I visited it, I was informed that a number of steam launches had succeded in ascending the rapids, while the books tell of numbers of canoe-parties making their way through the pongo safely. It has therefore not constituted a very formidable barrier to lowland fishes. The larger Pimelodus-types, flying-fishes, pirarucu, and fishes of great size, quiet waters, marshy habitats, etc, have not made the ascent. The smaller, intrusive or sucking-mouthed types, and mountain types of Characin, such as Hemibrycon, have done better, including two Gymnotids.

The Pichis river is a good example of a lowland stream deeply invading the 
highlands, and certain other lowland fishes have readily made their way there, such as Bario or Tetragonopterus argenteus. Ease of access has made it equally desirable to fishes and to the canoes and launches of the Via Central.

The Tarma-Chanchomayo-Perené drainage is one with numerous rapids and much difficulty of ascent; thirteen species were taken, nine of them lowland forms.

The middle Huallaga has been represented by such small and casual collections that we might be misled into believing that few aggressive lowland forms have populated it from below; probably many more will be found than the ten listed from R. Huambo and R. de Totora. Juan Mesa, a riverman, was able to name for me offhand more than twenty which he had known at Tingo Maria at the mouth of the Monzón. My collecting in the troubled waters of the Upper Huallaga (from Cayumba rapids at 2000 feet to 14000 feet) and Dr. Eigenmann's collections in the sources of its tributary, the R. Yanahuana produced a total of thirteen species. The Cascada de Cayumba I found to be a much more precipitous hazard than the Pongo de Manseriche, and, I believe, satisfactorily accounts for our total of only thirteen species above it, as against 34 of the Alto Maranon.

The middle Urubamba is guarded from the invasion of lowland fishes by the formidable Pongo de Mainique, which I did not visit. (Bowman, 1916.) Yet it is far from being fish-proof, since 22 species have been recovered from the river above this point, 15 of which should be classed as lowland forms, seven from the upper reaches of the river and its tributaries. From the number of lowland forms it should be rated between the Maranon and the Huallaga as to ease of invasion. It must also be remembered that the headwaters of the Urubamba and those of the Marañon are at about the same elevation, but that the former has about twice the distance in which to climb a stair of equal height. Except for extreme barriers, the longer streams should have the more abundant fauna. Unfortunately the records from the Apurimac, which should give light on this point, are very scanty.

Our collections show that only the genera Orestias, Pygidium, Astroblepus, with some Chaetostoma, belong to the fauna of the high Andes. The center of dispersal of Astroblepus appears to be in the lower elevations of the Andes of Southern Ecuador, diminishing in species southward. Pygidium centers farther south, some 26 species having been collected north of our area, some 39 southward, most of them following the crests of the ranges.

Aside from the climbers mentioned above, we have the same types of Characins recurring in the Urubamba as in the North, such as the Astyanax-HemibryconBryconamericus group, and the same Apteronotus and Sternopygus. Most of the remainder are uniques.

The Titicaca basin has produced most of the Orestias. Except for the two which have arisen in central Peru (Province E) and three in the upper Urubamba valley, the genus is still limited to that basin.

Orestias is the only clear-cut endemic genus of the upland pampas of the Andes; Astroblepus is probably so, but has representatives well down toward sealevel. There is more doubt about the widely dispersed Pygidium. While Othonocheirodus, our Hemibrycon, Ceratobranchia, Bryconamericus, and Creagrutus are 
spoken of as mountain genera, they pertain to the fauna of the rapid rivers of the tropical rain forest, elevations of a few hundred feet to 5000 or 6000 .

Prior to the National Geographic Society's collections and our own the following fishes had been listed from the upper and Middle Urubamba:

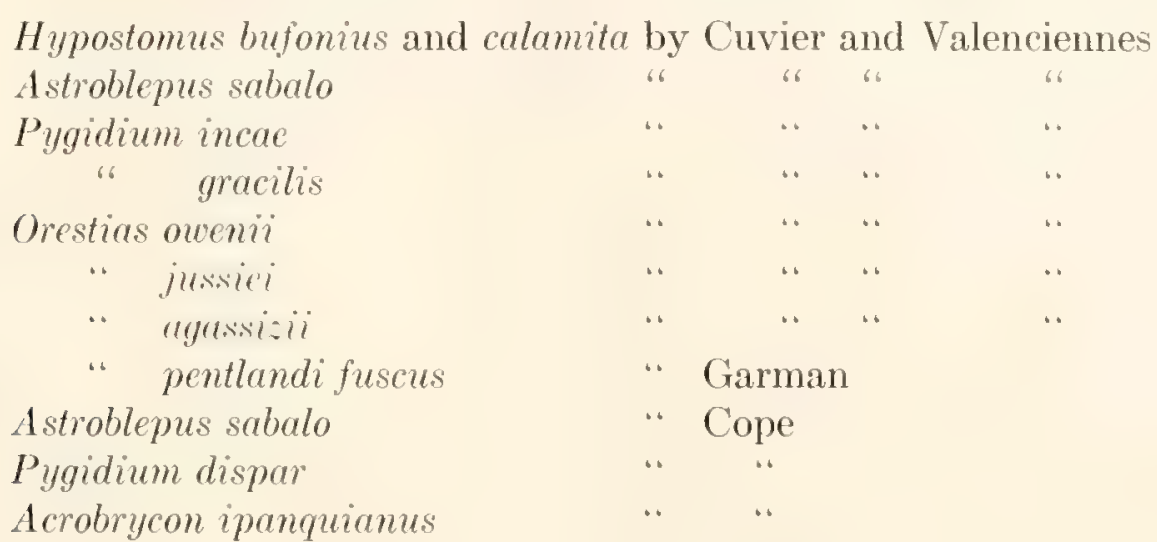

The distribution of the mountain fishes by genera rather than by species may be more graphic and illuminating:

$\begin{array}{lll}\text { Astroblepus } & \text { Andes Urubamba to Panama and Mérida } & 300-13400 \text { feet } \\ \text { Ancistrus } & \text { Rio Chagres to Guiana and Buenos Aires up to } 9000 \text { feet } \\ \text { Pygidium } & \text { mountains Punta Arenas to Panama } & 0-14000 \text { feet } \\ \text { Pimelodella } & \text { Panama to Buenos Aires } & 0-6000 \text { feet } \\ \text { Bryconamericus } & \text { Costa Rica to Buenos Aires } & 0-4000 \text { feet } \\ \text { Acrobrycon } & \text { Eastern slopes Bolivia, Peru } & 4000-8000 \text { feet } \\ \text { Hemibrycon } & \text { Urubamba to Panama and Trinidad } & 0-11500 \text { feet } \\ \text { Creagrutus } & \text { " " ". Guianas } & 0-4000 \text { feet } \\ \text { Ceratobranchia } & \text { Southern Peru to Chanchomayo } & 2000-3500 \text { feet } \\ \text { Astyanax } & \text { Texas to Buenos Aires } & 0-3500 \text { feet } \\ \text { Orestias } & \text { Mantaro to northern Chile } & 9000-15000 \text { feet }\end{array}$

Steinmann (as quoted in Eigenmann, 1909, III, 372) holds that as late as the Tertiary the Titicaca basin was a body of water or a deep valley draining normally southeastward to the southern tributaries of the Amazon. The rapid rise of the Eastern Cordillera interrupted its outlet, creating its closed system of drainage. Looking at the topography from the pampa above the La Paz gorge, you would be inclined to take that view of it, although an equally alluring solution is presented south of Uyuni by the intercordilleran valley now closed by volcanic action. For the following reasons I should prefer to regard the Titicaca basin as a closed one for a much longer period.

Prior to the extreme present elevation of the Eastern Cordillera the interior valley should have had much greater rainfall, as the lower eastern ranges of the time would have been less effectual in cutting off the southeastem trade-winds. If an open way to the Atlantic existed then along the path of the moisture-laden winds, it would have been kept open. Northward of this, the present valleys of the Urubamba, Apurimac, etc., have maintained an outlet despite the rise of high 
ranges eastward and the creation of large areas having a dry climate at their headwaters.

The existence of terraces showing that Lake Titicaca was once much larger, extending as far as Pucará, and that the Desaguadero is paralleled by the shorelines of an ancient strait, were pointed out by Agassiz in 1875 (q. v.). The present shrunken lake is evidence of a progressively drier climate with the upthrust of the Bolivian cordillera. That it has been in more or less continuous existence from the date of its rise from the sea is indicated by the considerable saline deposits on the land, and the brackish character of the waters of Lake Poopó. The terraces 300-400 feet above the lake are much higher than the present pampa which holds back the exit of the lake through the Rio La Paz. This goes to show that when they were formed the $\mathrm{La} \mathrm{Paz}$ area was much higher, and that the cutting down of the La Paz gorge through the soft, alluvial formations is of subsequent occurrence. The fishes of the lake gained admittance to this closed system from the parent sea itself, rather than via an Amazonian tributary, and their lack of kinship with other fishes of the continent would lead to the same conclusion.

In the above paper Eigenmann says that while isolation is a necessary condition to species-formation, there is insufficient isolation in Lake Titicaca itself to have given rise to so many species. That has been one of the puzzling questions in the present study. We find perhaps the most complete, if not the longest, isolation to be that of Lake Ascotan, Chile, yet, except for color, its fishes differ little from those of the great lake. On the other hand, the nearby Lake Umayo, rather well separated, has been prolific of species not yet found in the greater, parent body. Furthermore, our collecting records show that there is an assortment of species with depth, and between the lake and its tributary streams, the nearest thing to isolation I can suggest. But, here as elsewhere, we do not often find more than one or two species in any particular locality.

For a long time I was troubled to answer the question as to the distribution of Orestias agassizii, supposedly existing all the way from the Nudo de Pasco in the north to Lake Ascotan a thousand miles to the south in the Chilean Andes, connected by a terrain dissected to a depth of many thousand feet by the Mantaro, Apurimac, and Urubamba, an effective barrier except perhaps about the high passes of the volcanic western cordillera. How could a species maintain its integrity against such odds? There seemed to be a tentative answer in our finding the species even at the extreme elevation of 14660 feet in the pass Crucero Alto. But now after a careful restudy of all my specimens and comparison with those from the California Academy of Sciences, I find that the species are distinct in central and southern Peru. The confusion arises from the close resemblance of the immature stages, for the adults are quite unlike. We may look to the Crustacea for additional evidence of the marine origin of Lake Titicaca, for seven species of Orchestiids exist there.

Resumé: In the total absence of species derived from southern invaders, only Astroblepus from the northward, no Pacific slope forms scaling the extreme heights, we have only two primary sources of the fishes of the cordilleras and interandine valleys. These are the aggressive species from the Amazon and the endemic upland forms. 


\section{ICHTHYOLOGICAL GAZETTEER}

The recently completed sheets of the American Geographical Society's Millionth Map are in the more settled areas a very good source of information as to the terrain and places. The "Mapa General del Peru", published by Carlos Fabbri, Lima, is especially good on the current usages in naming streams in Peru.

South American geographical nomenclature has suffered from the not uncommon evils of ambiguity, fashion, indefiniteness, and translation. The Peruvian often says to the traveler, "Oh yes, you are from the United States.-From New York?" Conversely collectors not infrequently record their specimens as from South America, or Brazil, or the Ucayali.

Some of the practical difficulties which I have experienced in interpreting locality records will be of no less interest to others, and the following is a more or less complete statement of them.

(1) The name of the nearest large town or village is used. E. g. Iquitos for all Loreto; or Quito for the entire hinterland of Ecuador.

(2) The names of private estates, sometimes duplicated in various regions, with no explanation from the collector, and subject to the caprices of future owners in changing names.

(3) Similar duplications in the names of streams, such as four tributaries of the Huallaga named Cachiyacu; or Rio Grande, Rio Colorado, etc., so often repeated.

(4) Names used interchangeably, sometimes Indian and Spanish, such as Poopó and Aullagas, or Junin and Chinchaycocha.

(5) Name changing with political power. Puerto Pardo on the Morona was Puerto Leguia when I visited it, and is again Puerto Pardo today. Punta Arenas became Magallanes, then reverted as before.

(6) Confusion of spelling: the use of $\mathrm{Gu}$ or $\mathrm{Hu}, \mathrm{J}$ or $\mathrm{X}, \mathrm{B}$ or $\mathrm{V}, \mathrm{Y}$ or $\mathrm{Ll}$, mayo or mayu, yaco or yacu; various renderings into other languages of local names; lack of standardization of spelling, the distinguished geographer Raimondi no less than others spelling the same words in a variety of ways.

(7) Confusion in the extent of a stream under the same name. Often when two streams converge, not one, but both names are exchanged for a third. E. g. the Chanchomayo and Paucartambo unite as the Perené.

(8) The removal of a town to a new location, on account of a railroad (as Challapata), the encroachments of a river (Contamana).

(9) Compounded names, such as San Juan de la Frontera de los Chachapoyos.

The following list of place names concerned with ichthyological collections and locality records is an attempt at identifying and stabilizing them.

The symbols used are as follows:

*Collections made by Allen;

**Collections made by Eigenmann;

***Collections made by others and studied by us. 
Names without symbols are places from which we have seen no specimens. In a few instances names are included although no specimens were obtained, when the regions named were vainly explored and it is certain fishes do not occur, such as Oruro.

AcorA: village inland from Chucuito, near L. Titicaca and Puno bay, on Camino Real, the ancient road from Bolivia (Upper Peru) and Puno to the capital city of Cuzco; a flat pampa country with poorly drained ditches; elevation 12600 feet. ${ }^{*}$

Aguachini: small river on the Via Central, emptying into the Pichis near Puerto Yessup; usually a clear mountain stream, fordable; during freshets must be ferried by raft.*

Aguas Calientes: many warm or hot springs go by the name. In particular, (1) near sources of Rio Poopó, Bolivia,* inland from the village of Poopó; (2) warm, boggy springs in the La Raya pass, ${ }^{*}$ and forming the source of the Rio Vilcanota; others nearby on the other side of the pass, at the headwaters of streams forming the northern extremity of Titicaca basin.

Amable Maria: presumably an estate, on or about the middle course of Rio Tulumayo, eastern-central Peru.

Amazon, Amazons, Amazonas: (1) upper Marañon, Alto Marañon, Intercordilleran Marañon, from the source at some 16000 feet elevation on the knot uniting the western and central Cordilleras down to Lago Lauricocha and the gorge of the Maranon, bending abruptly eastward and escaping to the Amazonian plain at the Pongo de Manseriche (q.v.).*** Its largest tributary the Rio Santiago.

(2) Alto Marañon; this name applied also to that portion of the river from the Pongo de Manseriche to the mouth of the Ucayali**

(3) Bajo Marañon; from the junction of the Alto Marañon with the Ucayali to the Brazilian border.*

(4) Peruvian Amazon or Amazons; includes all three of the above sections.*

(5) Solimoes; from the Peruvian border to the mouth of the Rio Negro (others say the mouth of the nearby Rio Madeira). The Brazilians insist that the Amazon as such heads at this point, although it continues in a very direct line for some 1500 miles further upstream.***

(6) Amazon; lower Amazon, Bajo Amazon; from the mouth of the Rio Negro to the sea, in the Brazilian sense. In the broader sense, all the four sections named above.***

The northern Peruvians claim the name for the entire river.

The southern Peruvians hold out for a nomenclature which would establish the sources of the Amazon at the head of the Rio Apurimac in southwestern Peru, since it, together with the Ucayali, constitutes the longest course.

Амво: village on western bank of the upper Huallaga, some fifteen miles above Huánuco, and at the junction of the Rio Huacar (Yanahuanca). Marks the most elevated point where fishes were obtained on the Huallaga, at near 7000 feet elevation.*

Ambyiacu, Rio: small, lowland stream entering the Peruvian Amazon from 
the left at Pebas; site of much collecting by Orton and Hauxwell, and recently by Mr. Scherer. Alternative spelling, Ampiyacu.

Angascancha: a lake three miles northeast from the Smelter (q.v.), where collections were made by Dr. A. Davis (Evermann and Radcliffe.)

Angostura: Cuzco valley, on Rio Huatanay (q.v.).**

Antofagasta: city in north-central Chile, southern limit of this report, 23 S. latitude, on Pacific coast; terminus of the La Paz railway system, and center of the nitrate belt.

Apurimac, Rio: most remote tributary of the Amazon, arising in southern Peru at Lago Villafrio, near Cailloma, Dept. of Arequipa, flowing northwestward to unite with the Mantaro and forming the Ene, thence joining the Tambo and flowing to join the Urubamba and forming the Ucayali.

Arapa: village and lake of the same name, some ten miles north of Lake Titicaca; the lake with numerous reedy embayments.*

Arica: city, formerly Bolivian, now Chilean, on the Pacific coast. Rainless, arid, without streams. Few very small, brackish beach-pools.*

Ascotan, Lago: in northern Chile, on La Paz railway, elevation above 12000 feet; a saline pampa some twenty-five miles in length, encircled by volcanic peaks, both active and extinct. During the dry season, its waters reduced to bayoux, some of them spring-fed and rather fresh.*

Aтосна: river on eastern slope of Bolivia, tributary to the Rio Grande; at that time terminus of the Bolivian-Argentine railway. A wide stream in a canyon with walls much eroded; many channels appearing and again losing themselves in the rocky canyon floor.*

Aullagas, Lago; see Poopó.*

AzÁngaro: village, river, and province, Dept. of Puno, Peru, on the rather level terrain of the Titicaca basin, and to the north of the lake; the river a small, sluggish, meandering stream entering Rio Ramiz, and thence to the lake**

Azupizu: sixth rest-house (tambo) of the Via Central, in the valley of Rio Palcazu; a small river of the name flowing to the Palcazu.*

BALsAs: village on the intercordilleran Maranon, at the crossing of the northern trail from Cajamarca to Moyobamba. Elevation 3500 feet. (Pearson, 1937.)^{* * * *}$

Barranca: village on left bank of Alto Marañon below the Rio Morona, named for the high river banks.*

Blanco, Rio: railway station, and small stream entering Rio Rimac at 11000 feet elevation on the western slope of the western cordillera; glacial sources.*

Breta ̃a: hacienda of S. Medina on east bank of Rio Puinagua at the mouth of Rio Pacaya.*

Cachiyaco (Cachiyacu): copious affluent of Rio Paranapura, which enters the Rio Huallaga at Yurimaguas; Dist. Balsa Puerto, Prov. Alto Amazonas, Dept. Loreto, and enroute to Moyobamba (means salt river). Herndon calls it Cachiyacu all the way to Yurimaguas. Orton, Cope, Herndon, Mozans.

CACHIyco: (2) another stream entermg the Yanayacu near Caymarache; (3) 
a stream entering the Huallaga near 'Tocache; (4) a tributary of the R. Mayo near Jacinto, Dist. of Moyobamba.

Cajamarca: city, province, and department of northern Peru; the city on the watershed drained by the $R$. Jequetepeque to the Pacific, and by the Rio Cajamarca and Rio Crisnejas to the Marañon. (Pearson.)***

Calacoto: village in Bolivia, near Rio Desaguadero, on the Arica-La Paz railway and Rio Mauri.*

Calama, Chile: city on La Paz railway near Chuquicamata copper mines, and on Rio Loa; Smithsonian Solar Observatory nearby at that time.*

Callacate: near Rio de Totora, Omia Dist., Prov. Chachapoyas. Hda. de Callacate, near Cutervo, west of Chota, Dept. Cajamarca.

Caminaque (or Zapatilla?): good-sized creek meandering through the pampa; arises in western cordillera, enters L. Titicaca near Juli.*

Campucila, Lago: west of Cuzco (Valenciennes); elevation 14000 feet.

Canelos: station on the upper Pastaza, left branch (Rio Bombonasa); near Sarayacu. (Boulenger).

CAPACHICA: point of land extending from near Chucuito into Lake Titicaca, enclosing Puno bay, on the south.*

CASAPALCA: mining center western Cordillera, near Oroya; small lake near the mines, perhaps the highest point at which fishes have been known to live. (See Crucero Alto.).**

Cashiboya, Lago: cutoff lake of the Ucayali, communicating with the latter by a narrow channel. Above Contamana; named for the Cashibo tribe.*

Cayumba, Cascada DE: series of broken falls of the Rio Huallaga at about 1800 feet elevation, between the Rio Monzón and Rio Chinchao; the river's greatest barrier to lowland life. The Rio de Cayumba enters from the West directly above the falls.*

Cebollar: a Chilean station on the La Paz railway and on the border of Lago Ascotan.*

Cerro de Pasco: city and provincial capital on the Nudo de Pasco which bridges the central and eastern cordilleras at above 14000 feet elevation. Mining center (Cerro de Pasco Copper Corporation); terminus of C. de P. railway; point of departure for the Huallaga river, which has its source along the side of the Nudo near the city.***

Challapata: old and new villages; Rio de Challapata; southeastern corner of Lake Poopó, Bolivia, five miles distant; antimony mining; elevations above 12000 feet.*

Chaldhuacocha: (meaning fish-lake) near Quishuarcancha, terminus of one spur of the railway to Goyllarisquisga, northwest of Cerro de Pasco, elevation 13200 feet.

Chanchomayo, Rio: river formed near San Ramón, eastern-central Peru, by the union of the Rios Oxabamba, Palca, and Tulumayo; passes La Merced; unites with the Paucartambo at the Perené colony to form the Rio Perené****

CHilt, Rıо: small, swift, turbid; arising in western cordillera, flowing south- 
westward through mostly volcanic terrain, forming great gorges through most of its course. Its upper courses fished without results by Allen (1918) and Pearson (1921); about Arequipa by Eigenmann and daughter (1918). Principal source of water for the city and irrigated valley of Arequipa.***

Chinchao, Rio: small, rapid, precipitous, rising in the central cordillera, flowing eastward to the Rio Huallaga above Cayumba rapids. Subject to the frequent flood-stages of the tropical rain forest; at other times clear.*

Chinchavitoc, Chinchavisto, Chinchavito: mouth of the Rio Chinchao river on the Huallaga. A small playa, or outwash, on the East bank, with a onefamily settlement and bananal. Ferry service on the foot-trail to the Monsón. Elevation about 2000 feet.*

Chinchaycocha, Lago: a clear, mountain lake on the Pampa de Junin of central Peru, elevation 13500 feet; dimensions about six miles East and West, twenty miles long; boggy, rushy shore-line sheltering immense numbers of Orestias, green sponge, and nesting ducks. Now used for impounding waters for the Cerro de Pasco smelter at Oroya, and doubtless much altered ecologically. Also known as Lago Junin.*

Chinchero, Lago: small lake a short distance north of Cuzco.**

Chivis, Rro: tributary to Rio Pichis at Puerto Bermudez; small, turbid river from the foothills, navigable some distance by canoe.*

CHoro: an adobe village on the mud flats near the mouth of the Rio Desaguadero and head of Lake Poopó**

Chosica: village on the Central railway at 3000 feet elevation, along the course of the Rio Rimac; mouth of Rio Santa Eulalia a short distance above; good fishing holes at the hydroelectric dam. The river larger here than at Lima, due to the withdrawal of water for irrigation.*

Снота: village and province, Dept. Cajamarea, on small Rio Llaucan, which enters the Marañon below Balsas; elevation of village 8580 feet. (Boulenger, 1898.)

Chucuito: village and bay, southern arm of Puno bay, Lake Titicaca; shallow water and reed-grown shoreline; much fishing, especially for Orestias pentlandi. An historic name for the region in colonial times, and for the main, northern body of Lake Titicaca. A former center of missionary activity.

Chumatagua: large creek or small river arising on the western front of the eastern cordillera and entering the Huallaga above the Cayumba rapids. Deeply entrenched; I saw numerous fine large specimens of ammonites weathered out of its cliffs.*

CHupa: village and cerro near the head of Lake Arapa, north of Lake Titicaca; the conical mountain a landmark for many miles in every direction. RIo DE CHupA: a small stream encircling the mountain from the northward, near Laguna Salinas, and entering Lake Arapa on a flat pampa with numerous sloughs.*

Chupapa, Rio de: a small tributary of the upper Urubamba at Santa Ana.**

Cochabamba: Bolivian city above 8000 feet elevation on eastern slope, in the center of a wide agricultural valley; mining center.* 
Cochas: hacienda of Don Mario Durand, fifteen miles below Huánuco**

Colorado, Rio: numerous streams. For the present report, a small stream, elevation 12500 feet, near Viacha, on the Bolivian pampas, Titicaca basin; a flat, winding, turbid stream with numerous bayoux, some of them permanent.*

Comberciato, Rio: a small tributary of the middle Urubamba, elevation 1800 feet, entering from the west, thirty miles above the Pongo de Mainique. Visited by Heller on the Yale-National Geographic expedition. (Bowman.)***

Contamana and Cocha de Contamana: small city on the right bank of the Rio Ucayali, provincial capital. The lake large, irregular, not clearly of the ox-bow type, being much larger than the nearby river in all dimensions; bluffy at its eastern extremity; the water clear, deep, rushy-bordered, triangular in outline; developing waves of considerable size and some wave-terracing.*

COPACABANA: village and peninsula, the latter almost dividing Lake Titicaca. except for the straits of Tiquina; the village a good fishing center, site of the famous church and shrine of Nuestra Senora de Copacabana.*

Crisnejas, Rio: arises near Cajamarca and enters the Marañon above Balsas. (Pearson, 1937.)***

Crucero Alto: a pass in the western cordillera of southern Peru, traversed by the Southern railway enroute to Cuzco and Puno; elevation 14666 feet, the highest point except one where fishes were found, that is the ditches along the railroad track produced numerous small Orestias.*

Cunvas: one of several rock shelters at the foot of cliffs below the Cascada de Cayumba, on the Huallaga, elevation 1800 feet; Juan Mesa volunteered information on one which contains water and blind fishes.*

Culcur: collections made by J. T. Zimmer, 1922. Location unknown.

Culpani: above Santa Ana on the upper Urubamba.**

Cuzco: city and department, southern Peru, $307 \mathrm{~km}$. from Juliaca by rail; ancient capital, and headquarters of the Eigenmanns for the exploration of the Urubamba and valley of Cuzco; elevation 11700 feet.**

Desaguadero, Rio: outlet of Lago Titicaca into Lake Poopó, Bol. Volume of water extremely variable with season; elevation 12500-12200.*

Dos de Mayo: third tambo, or shelter house, on the Via Central, at Km 71 . on the shoulder of a mountain of the Cadena de la Sal, overlooking great valleys of the tropical forest.*

Duck House: flag-stop on eastern shore of Lake Chinchaycocha; small clubhouse maintained mostly by Anglo-american employes of the Cerro de Pasco company.*

ENEÑAS: second government tambo, or shelter-house on the Via Central, over the summit of the Cadena de la Sal, in a small valley cleared of tropical forest and planted to cane.*

Eucalyptus and Rro de Eucalyptus: village and small river, on the pampa of the Titicaca-Poopó basin and on the La Paz railway near Oruro, Bolivia, the river flowing to the Desaguadero; a flat, winding creek. Also point of departure of the Mulford expedition (Pearson, 1924.)*

Fundición, LA: see Smelter. 
Gosulmacocha: cutoff channel of the Rio Morona; muddy, flat, lowland cocha along the base of the andean foothills.*

Goyllarisquisga: coal mines and railway terminus, valley of Rio Yanahuanca, north of Cerro de Pasco; elevation 13700 feet.**

Grande, Rio, de Lipez: southwestern Bolivia, elevations above 12000 feet: a small stream rising in southern border of the Titicaca-Poopó-Coipasa basin, among volcanic peaks, draining northward into saline pampa along the Chilean border.*

Guaqui (Huaqui), Bolivia: La Paz railway terminus, port, and village on the southern shore of Lake Titicaca (Uinamarca); much shallow, reedy shore line, with lagoons, and delta land about the mouth of the Rio de Tiahuanaco.*

Guasacona: see Huasacuna.

Guatanai: see Huatanay.

Hermita, hacienda (?): near Oropesa, above Cuzco.**

Huallaga: large river rising in a series of springs on the northern slope of Cerro de Pasco, at about 14000 feet elevation, flowing generally northward between the Central and Eastern Cordilleras to Huánuco, thence eastward through a water gap, and again northward between the cordilleras to pass around the lomas which form the end of the broken Eastern Cordillera, to flow into the Marañon. Its principal barrier to lowland fishes is the Cascada de Cayumba (q.v.) at about 1800 feet elevation. In its upper reaches it is paralleled by an ancient highway following the valley to Huánuco. The middle course down into the tropical belt has mule trails gradually fanning out in several directions and ending in foot trails through the forest. In the lower portion, the river is reached by water only, except for trails from Cajamarea and Moyobamba.*

Huanbo, Rro: river in the province of Chachapoyas, Dept. of Amazonas, district of Omia; abbreviation for Huambo Pucayacu, which flows to the middle Huallaga; elevations 4000-5000 feet. (Steindachner.)

HuANCACHUPA creek: a small tumultuous stream from the eastern slope of the Central Cordillera to the Huallaga a league above Huánuco.*

Huancané, city and bay, the latter an extensive northern arm of Lake Titicaca; nearby the Rio de Huancané, which enters the Rio Ramiz, a small, sluggish pampa stream with poorly drained terrain.*

Huancayo, Dept. Junin, Peru; regional, departmental, and provincial capital; elevation 11000 feet; wide agricultural and pastoral valley of the Rio Mantaro, on the Central railway, $124 \mathrm{~km}$. south of Oroya.**

HuÁNuCo: city and departmental capital; 6000 feet elevation on the middle Huallaga.*

HuARACACA: a small river at the northeastern corner of the Pampa de Junin. (Evermann and Radcliffe.)

Huasacuna (Guasacona): farm in the province of Azángaro, Dept. of Puno, famous for its dairy products.

Huatanay, Rio: arises in the mountains bordering the valley of Cuzco, crosses the valley and city eastward to the Rio Urubamba; saline. Also Laguna Huatanay (Hutana) near Cuzeo.** 
HUAYPO: village of upper Urubamba valley.**

ICA: hacienda, soapworks, and chalet of Senor Layet, $4-5 \mathrm{~km}$. from Iquitos, left bank Rio Itaya.* Also a locality where collections were made by W. James, not determined.

Ilave, Rio DE; village: the stream flowing from the Western Cordillera to Lake Titicaca; 30-40 yards wide, rocky, with bluffy channel in the Pampa de Ilave; formed by the union of the Rio San Antonio and Rio Blanco. The village midway between Puno and Yunguyo.*

INAHUAYA: village on the Bajo Ucayali.*

Iquitos: city and metropolis of Loreto, oriental Peru; left bank of the Amazon, about 2300 miles from its mouth, and less than 100 from the Brazilian border; present head of navigation available to seagoing ships; port of entry.*

Iscuchaca: point on the Rio Huatanay (q.v.).**

ItAya, Rio: small, rather sluggish lowland river, entering the Amazon from the westward just above Iquitos.*

JAUJA: small, colonial town in the valley of the Mantaro, between Oroya and Huancayo; elevation above 11000 feet.**

Jeveros (Jeberos, Xeveros): see Xeberos.

JULI: city, ancient provincial capital, about 13000 feet elevation, about one mile from the west shore of Lake Titicaca; on the old Camino Real of colonial days from Cuzco to Sucre and La Paz. Rio de Juli a small stream near the city from the foothills of the Western Cordillera.*

Juliaca : capital province San Román, junction Southern railway, near northwest corner Lake Titicaca; important market, including fishes; Rio de Lampa and lagoons adjacent.*

JunIN, city, river, battlefield, pampa, lake, department: (1) the city a business and transportation center for the bleak, upland mining and grazing section; (2) the river draining the southern section of the pampa;* (3) the battlefield the most decisive in the War of Independence; (4) the pampa an extensive plain forming the headwaters of the Mantaro, elevations 13500 feet and above:* (5) the lake a fine mountain body, some six miles by twenty before inundation for storage (see Chinchaycocha) $*^{*}(6)$ the department with its eapital at Huancayo.*

Laguna Salinas: village one day's walk north of Chupa, and in the foothills bordering the Titicaca basin, province of Azángaro, department of Puno, elevation near 13000 feet; salt-works. Lake of same name nearby, quite saline, without fish, inhabited only by a few algae and Artemia salina.*

LAGUNillas: an alpine lake 14000 feet above sea level, on Southern railway, Dept. Puno; with Saracocha (q.v.) draining the upper basin of the Rio de Lampa. Railway station nearby of same name.*

LA Merced: village eastern-central Peru, on Rio Chanchomayo, elevation near 2500 feet, $96 \mathrm{~km}$. from Oroya; tropical life-zone with sugar-cane and coffee.***

LAMPA, RIO DE: begins as a small creek, the outlet of Lagunillas and Saracocha, flows eastward to Juliaca, and enters Lake Titicaca as a small river; its basin the route of the Southern railway; its lower course marshy, with numerous bayoux.* 
LANGUI: village, province of Canas, Dept. Cuzco, above 12000 feet elevation on Sicuani-Yauri highway. River of same name adjacent.**

LA PAZ: capital of Bolivia, and divided by stream of same name; elevation 11000 feet. The stream deeply entrenched in a canyon which has pirated a section of the eastern border of the Titicaca basin.*

La Peruvian: Peruvian Corporation's hacienda on the Perené.*

LA RAyA: (see Aguas Calientes); pass over the Nudo de Vilcanota connecting the headwaters of the Rio Vilcanota (Atlantic drainage) with those of the Rio de Pucará (Titicaca basin); traversed by the Southern railway.*

Leguia, Puerto (renamed during the Leguia administration; formerly Puerto Pardo); military outpost at Ecuadorean frontier four days by launch up the Rio Morona.*

LIPEz: see Rio Grande de Lipez.*

LOA, Rio: a small Chilean river arising in the volcanic section of the Andes near Ascotan, eleration 12000-13000 feet, draining circuitously to the Pacific; mostly diverted for mining and irrigation.*

MANAOS: our final collecting ground; central Amazon, state of Upper Amazonas, some ten miles up the Rio Negro.* Ana.**

Mandor PAMPA: on the right bank of the upper Urubamba, above Santa

Manseriche, Pongo DE: canyon through which the Alto Marañon breaks the last barrier of the Andes to the Amazonian plain; formerly regarded as the greatest barrier, but at the time of my visit had been negotiated by steam launch no fewer than five times, frequently by raft in the downstream direction.*

Mantaro, Rio: its headwaters in the Pampa de Junin, and several streams entering Lago Chinchaycocha; flows southeastward between eastern and western cordilleras, via Oroya, Jauja, and Huancayo; a good-sized, clear, rock-bedded stream. During recent years successfully stocked with North American rainbow trout by the U. S. Bureau of Fisheries and the Cerro de Pasco Company. Used. for hydroelectric purposes at the Oroya smelter and the copper mining district.***

Maqueria: small village above Contamana, near Cashiboya lake and village, on the right bank of the Ucayali. Also the name of the nearby cutoff lake formed by the Ucayali, with clear, brown water and much decayed vegetation.*

Marañon, Rio: see Amazon.*

Maravillas: station on Southern railway, smelter, mine, near 14000 feet elevation, Rio de Lampa valley, southern Peru.*

MARCAPATA: river and valley of, in the eastward extension of the province of Quispicanchis, Dept. Cuzco, flowing eastward to the Rio Inambari and Madre de Dios; reached by road from Urcos in the Cuzco valley.

Mauri, Rro: tributary of the middle course of Rio Desaguadero.*

Media Luna: on the upper Rio Urubamba.**

Melendez, Puerto: military outpost just below the Pongo de Manseriche on the Peruvian Amazon.*

Miriatirani: seventh government tambo, or rest-house, on the Via Central, 
in the valley of the lower Azupizu, in the northern foothills of the Cadena de la Sal.*

Моно: village, port, bay, and provincial capital, northeast corner of Lake Titicaca; old and new village, the latter at the SS. landing on the fjord-like, granitebordered bay.*

Molino, Rio DE: small, sluggish, meandering creek entering western side of Lake Titicaca above Pomata, from western cordillera.*

Monterico: a farm at the confluence of the Pulperia and Apurimac rivers, 75 miles from Huanta, province of Huanta, Dept. Ayacucho, elevation 2723 feet.

Morona, Rio: small, navigable river of Ecuadorean and Peruvian lowlands, skirting the eastern foothills of the Andes; the first of the left-hand tributaries of the Amazon east of the mountains.*

Moronacocha: cutoff lake derived from the Nanay, in the rear of Iquitos; deep, clear, bluffy bank used as a summer resort.*

Mоговамва: city and provincial capital on the Rio Mayo, tributary of the Huallaga, Dept. San Martin; on northern overland trail Cajamarca to the Huallaga.

Mulato, Rro de: good-sized stream of the Bolivian pampas, arising in the foothills of the Eastern Cordillera, entering Lake Poopó near the southeastern corner.*

NANay, Rio: river entering Amazon just below Iquitos, from the Ecuadorean foothills to the northwest; navigable to larger launches of the Iquitos fleet.*

Napo, Rio: large Ecuadorean and Peruvian tributary of the Amazon below Iquitos, discovered by the first conquistador expedition to the Amazon, conducted by Pizarro and Orellana. On the route to Quito.

NAUTA: former village, former port, and one-time metropolis of Loreto, before the arrival of the larger Brazilian river steamboats; left bank Peruvian Amazon, just above the confluence with the Ucayali. (Orton, Herndon, and various earlier travelers.)

Nueva Ytalia: puesta, or chacara of Sr. Julio Battistini on right bank of Ucayali above Contamana, adjoining the channel of the Lago Cashiboya, my headquarters for a week.*

OCCOpATA, Rio: a small branch of the upper Urubamba.**

Ollantaitambo: village, Incaic ruins, upper Rio Urubamba. (Bowman.)**

Orellana: small town, on high right bank of Rio Ucayali below Contamana.*

Oroya: village, new and old (the former largely Anglo-American) on Rio Mantaro at 12000 feet elevation between Eastern and Westem cordilleras, central Peru; smelter and hydroelectric plant of the Cerro de Pasco Copper Co; Old Oroya down the river a short distance. Rio de Oroya a very small stream descending the slopes of the Eastern Cordillera to the Mantaro at Old Oroya; the last half mile very precipitous, and among many boulders. (See Pygidium oroyae.)***

Oruro: city and department of the Poopó valley of Bolivia; $18 \mathrm{~S}$. latitude; above 12000 feet elevation; mining center.*

PACAYA, RIO: small, sluggish, brown river in lowlands, arising in the lomas of the northern part of the Eastern Cordillera, and emptying by more than one outlet to the Puinagua and Bajo Ucayali; densely forested and sparsely inhabited by 
Cocama Indians; during rainy season known to have chamnels in communication with the lower Huallaga.*

PaChachaca: near Huancayo.**

PAchitea, Rio: moderately small river, navigable to small steam craft; formed by the union of the Pichis and the Palcazu; its junction with Alto Ucayali gives rise to the Bajo Ucayali.*

PAIPAY, Rio: a small, deeply entrenched stream, Dept. Cajamarca, flowing down eastern slope of Western Cordillera into the Rio Crisnejas near its junction with the upper Maranon; elevation about 4000 feet. (Pearson 1937a, pl. xii, fig. 1. $)^{* * *}$

PALCA: village on Via Central below Tarma; Rio de Tarma unites with Rio de Palca, and the latter with the Tulumayo to form the Chanchomayo.***

Palcazu, Rio: swift, boulder-strewn, clear stream becoming deeper in lower course, and uniting with the Pichis to form the Pachitea.*

Pampa ditches on Camino Real along the western shores of Lake Titicaca; sluggish streams and marshy areas with much plant, water snails, Dytiscid beetles, and Orestias agassizii; pampa de Acora and pampa de Ilave, elevation 12600$12800{ }^{*}$

Pampayacu, Hacienda de: mouth of Rio Chinchao.*

PARANAPURA, Rio: small river skirting the foothills northwest of Yurimaguas, entering the Huallaga just below that city; well-populated district; canoe navigation; numerous sand bars. (Mozans: Andes and Amazons.)*

PastazA, Rio: largest northern tributary of the Peruvian Amazon above Iquitos.*

PAZÑA, village and river: the latter a small, winding stream on the pampa of Lake Poopó; arises on the western slope of the Eastern Cordillera of Bolivia, entering the lake on the East; above 12000 feet.*

Pebas (Pevas): village, monastery on left bank of Amazon $100 \mathrm{~km}$. below Iquitos, at the junction of Rio Ambyiacu. The best-collected small area within the scope of this report. (Orton, Cope, etc.)

Perené, Rio: formed near San Luis de Shuaro and La Peruvian by the union of the Chanchomayo and the Paucartambo; elevation 2000 feet.*

Perni: elevation 800 meters; near Huaraz; location and drainage unknown. (Regan, 1912.)

Pichis, Rio: small river with many sand bars, navigable to canoe, and intermittently to small steam launches; arising in the Cadena de la Sal, flowing northward to the Pachitea; the terminus of the Via Central, or Pichis Trail.*

Piedra Blanca: chacara and ford on lower Rio Chinchao.*

Pochochacra: village on the Rio de Oroya, near Oroya, Dept. Junin, elevation 14796 feet.

Pocobanba, Lago: near Cerro de Pasco, elevation 13700 feet; collections made by Miss Adele Eigenmann and Mr. Emerson.**

Pomata, city and bay: southwestern comer Lake Titicaca; bay shallow with much pondweed, a shelter for much fish and bird life.*

Pongo de Manseriche: rapid and water-gap of the Peruvian Amazon. 
where it penetrates the foothills of the Andes of northern Peru; formerly regarded as impassible, but I was reliably informed of five successful passages made by steam launch in favorable stages. Rather numerous rafts have traveled through the pongo downstream. Pearson has shown, and Festa before him, that it is not so formidable a barrier to fishes. (Pearson, 1937a; Boulenger, 1898-99.)*

Poopó: village, river, lake of the Bolivian highlands. The village a tinmining center with ancient Spanish smelter. The river arising on the western slopes of the Eastern Cordillera and entering the lake from the East; deeply entrenched in a region of greatly displaced sedimentaries, hot springs, and the like. Lake Poopó (Aullagas), elevation 12200 feet, the outlet of the Titicaca basin through the Rio Desaguadero; very shallow, 25 by 50 miles in extent, overflowing into salars, or salt plains in the rainy season; water brackish.*

Poroy: village of the upper Rio Urubamba.**

Porque, Rio DE: small tributary of the Rio de Pucará at Tirapata, upper Titicaca basin.*

Porvenir, Tambo: fourth shelter house government-sponsored, on the Via Central, in a saddle of the Cadena de la Sal; tropical belt. *

Potosi : Bolivian mining town just outside the Poopó basin and over the divide of the Eastern Cordillera on the Atlantic side; famous silver mountain of colonial times; former market for the scanty fisheries products of the Bolivian highlands.*

PUCARÁ: village near 13000 feet elevation in the upper Titicaca basin. Rio de Pucará, a small stream rising at La Raya and entering Lake Titicaca at the north through the lower Ramiz; numerous riffles, holes, and clay barrancas; considerable local fishing industry.*

Puerto Acosta, Bolivia: village, lake port on eastern shore of Lake Titicaca, at the foot of the Sorata range.*

Puerto Bermudez: military post, wireless telegraph station, tambo, and terminus of the Via Central with its accompanying telephone line; at the junction of the Chivis with the Pichis river; $205 \mathrm{~km}$. from La Merced (128 mi.).*

Puerto Melendez: military outpost left bank Peruvian Amazon at the foot of the Pongo de Manseriche.*

Puerto Yessup: eighth tambo, and one of the two termini of the Via Central on the banks of the Rio Pichis, the head of canoe navigation.*

Punnagua: lateral channel of the Rio Ucayali on the left, near Sarayacu, reentering far below, forming an island claimed to be the largest in Amazonia except Marajó. One of the mouths of the Pacaya enters the Puinagua. (Puinahua.)*

Puno: city, bay, department; the city on the bay, an arm of Lake Titicaca; at 12500 feet above sea level, $494 \mathrm{~km}$. from Mollendo on the Pacific coast (306 miles). Principal market for lake fisheries. The bay, some 12 miles by 18, is relatively shallow, with quite shallow, rushy borders, sheltering many Orestias and much bird life.*

Puquiura: 9500 feet elevation, near Nusta España on the Rio Vilcabamba, which is tributary to the Urubamba about ten miles above Santa Ana.

Pusoc: on the upper Marañon above Balsas, 3700 feet in altitude. (Pearson, 1937 a, pl. xii, fig. 2.)*** 
Rimac, Rio: its sources in the glacial streams of the Westem Cordillera, central Peru, descending 15000-16000 feet in little more than 100 miles to the Pacific at Callao; its principal tributaries of like origin, the Rios Blanco and Santa Eulalia. Our stations were Rio Blanco, Matucana, Chosica, Lima and Callao.***

Rozmaiu, in "Upper Peru" (may mean something like Rosmayo or Rosmayu, the suffix meaning river in Quichua) probably in our area two specimens in British Museum collected by Rosenberg. (Regan, 1904.)

Sanango, Lago: large cutoff lake near the Huallaga and comnected with it by a narrow channel, above Yurimaguas; clear, weedy, productive of fish.*

SAN JUAN, HDA.: the cocal, coca plantation, and fabrica, manufactory, of Dr. Augusto Durand, proprietor of the Prensa of Lima, at near 4000 feet elevation on the wide shoulder of the eastern slope of the Central Cordillera, overlooking the gorge of the Huallaga, below Huánuco.*

San Miguel: estate or village of the upper Urubamba.*

San Nicolas, Tambo: the fifth on the Via Central.*

SAN RAMón: village at the confluence of Rio Palca with the Tulumayo, forming the Chanchomayo.***

Santa AnA: village on the middle Urubamba, the hacienda of Sr. Carlos Duque; elevations of about 3000-3400 feet; Rio de Santa Ana, a creek entering the Urubamba there; the farthest point reached by the Eigenmanns on the Urubamba.**

Santa Lucia: village on Southern railway and Rio de Lampa, Dept. Puno; mining and grazing district; above 13000 feet.*

SAnta Rosa: small tributary of the middle Urubamba above Santa Ana.**

SARACOCHA: lower and smaller of the lakes forming the head of Rio de Lampa, 14000 feet, on Southern railway.*

SARAYACU: village on the left bank of the Bajo Ucayali, $80 \mathrm{~km}$. (50 miles) below Contamana. A second Sarayacu on Rio Bombanasa, a tributary of the Pastaza, in eastern Ecuador. (Boulenger, 1887.)

SAYLLA: in the Cuzco valley.**

Shanusi, Rio: small, turbulent stream entering the Huallaga just above Yurimaguas.*

Suelter: former location of the Cerro de Pasco smelter near that city, when coal was employed for smelting.

Sumbay: station of the Southern railway, elevation 13000 feet; deep canyon of Rio Chili in volcanic rock, rapid stream found to be without life.****

TABAtinga: frontier station and village on left bank of Amazon at PeruvianBrazilian border. Upward limit of collections by Bourget of the Thayer expedition.

TAmBillo: presumably an estate near Rio Tulumayo (q.v.)

TARMA: city, provincial capital, and river, eastern slope of central Peruvian Andes, on the Via Central, elevation 8000 feet; sources of Rio de Tarma high meadows at near 14000 feet; deeply entrenched in a gorge; the Tarma water supply tributary springs. $* * * * * * *$

TianuANaco (Tiaguanacu): village on stream of same name on the Bolivian 
pampa bordering Lake Titicaca at the south; the river entering the Lake at Guaqui. Ruins.*

Tigre, Rio: small, navigable river rising in Ecuador, entering the Peruvian Amazon from the northwest, near Nauta.*

Tilarnioc: station on the Cerro de Pasco railway; a small stream tributary to the upper R. Mantaro.***

Tingo, Rio: a small river also called Higueros (Herndon) entering the Huallaga from the northwest; many channels and braided type of stream in dry season; a rocky torrent in the wet season; trail follows river up to village of Higueros and to Huánuco Viejo.*

Tingo de PAUCA: junction of Rio Crisnejas (q.v.) with the upper Maranon, elevation about 3800 feet. (Pearson, 1937a.)***

Tinta: village of upper Urubamba or Vilcanota, below Sicuani, 11400 feet elevation (Cope, Orton.)

Tirapata: village on Southern railway, Cuzco division, and on the Rio de Pucará**

TITICACA, LAKE: highest large lake and largest high lake of the world; area 2050 square miles; depths down to 600 feet or more; maximum length 120 miles; maximum width 40 miles; elevation 12500 feet; traversed by Peruvian-Bolivian boundary; its northern body the larger, known as Lago Chucuito, nearly constricted off from the southern portion, Lago Uinamarea, at the straits of Tiquina. Navigated by the Inca direct between railway termini at Puno, Peru, and Guaqui, Bolivia; two smaller coastwise trading steamers; another added recently.*

Torontoy: village of upper Rio Urubamba, elevation 8000 feet.**

Totora, Rio de: enters Rio Huambo (q.v.) near village of Omia, province of Chachapoyas, Dept. Amazonas; also village of same name. (Steindachner.)

Tuctu: near Morococha, Dept. Junin; 14400 feet elevation; explored by Miss Haywood and Mr. A. S. Kalenborn.**

Tulumayo, Rio: small, precipitous mountain river joining with Rio Palca to form the Chanchomayo at San Ramón.

Tupishka, Lago: west of Rio Ucayali, opposite Contamana, of contours similar to the river; waters in circulation, high, turbid.*

Tusi creek: near Pocabamba (q.v.)**

UCAYALI, Rio: greatest all-Peruvian river, and greatest Peruvian affluent of the Amazon, of the order of the Ohio or the Missouri; receiving most of the drainage of the central and southern sections of Peru, entering the Amazon at Nauta; navigable many hundred miles to good-sized launches of moderate draught; flat, meandering, turbid; within tropical lowlands. ${ }^{*}$

Uinamarca, Laguna: See Titicaca and Guaqui.*

Umayo (Humayo), Lago: lake five leagues from Puno, northwest, four miles in length, near 13000 feet elevation; sites of the ruins Silustani and Atuncolla.*

Urcos, LAgo: near 13000 feet, near Rio Vilcanota and south of Cuzco; the lake which, by legend, contains the mammoth chain of gold.**

Urubamba, Rio: important northward-flowing stream of southern Peru, beginning as the Vilcanota and entering the Ucayali. Also known as the Santa 
Ana. Extremely precipitous, with magnificent gorges, especially noteworthy at Macchu Picchu and at the Pongo de Mainique; the latter the most formidable barrier, the gateway to the lowlands, with cliffs almost sheer, 2000 feet in height. Pueblo Urubamba, on the upper river above Ollantaytambo. (Bowman.)**

UruHuasi: below Macusani; Rio San Gabian, tributary of $\mathrm{R}$. InambariMadre de Dios; another on the Apurimac 24 leagues from Cuzco.

UyunI: Bolivian city at southern extremity of Titicaca-Poopó basin; railway center and headquarters for collecting trips in southern Bolivia and Chile; above 12000 feet; Salar de Uyuni, saline plain.*

VERDE, LAGo: small lake at La Raya and headwaters of the Vilcanota.*

Via Central: (Pichis trail); road and trail from Oroya to the head of canoe navigation on the Rio Pichis; traversing the Cadena de la Sal, elevation 6000 feet, through tropical and subtropical zones, $205 \mathrm{~km}$. (128 miles) from La Merced to Puerto Bermudez; 9-12 days by mule; with numerous shelter houses conveniently spaced in an area otherwise total wilderness except at the beginning. ${ }^{*}$

Vilcanota, Rio: river arising at La Raya, descending rapidly to form the Urubamba; cordillera of same name skirting it on eastern side; Nudo de Vilcanota bridging the eastern and western ranges at La Raya.**

Vilque Chico: village at head of bay of Huancané, at northern end of Lake Titicaca; many shallow areas and weedy shore-line.*

Xeberos: colonial and modern village in the delta country between the lower Huallaga and the Alto Marañon; described as an El Dorado, land of contentment and plenty, and out of lines of travel.

Yahuarmagui (Yahuarmayo?): farm, province of Convención, Dist. Vilcabamba, Dept. Cuzco; tropical.

YahUARMAYo, Rio: small tributary of the Rio Inambari, province Carabaya, Dept. Puno; entering from the right, flowing westward, north of Macusani.

YANAHUANA? Or YanAhUANCA ? (doubtfully identical): village, and river, arising in western cordillera, near Goyllarisquisga, and flowing northeastward to the Huallaga at Ambo; elevations 7000-10000 feet.

Yanamate, Lago: small lake near Cerro de Pasco.

YAPAZ (LlapAz): first tambo, or shelter house, on Via Central.*

YARINACOCHA (LlaninACOCHA): a cutoff lake, rather shallow and clear, entered from right bank of Rio Pacaya by a long, narrow channel.*

Yunguro: village and bay, on Lake Titicaca at the narrow isthmus forming the base of the Peninsula of Copacabana; mole built out into shallow, weed-grown bay; shipping point for sheep and alpaca wools.*

YuRIMAguas: head of navigation on Rio Huallaga; town, provincial capital, cotton port; elevation 570 feet; eastern terminus of trails from Pacasmayo and Cajamarca over the mountains; between the mouths of Rios Shanusi and Paranapura.*

ZIGZAG: a switchback on the Cerro de Pasco railway, used to follow up a small tributary canyon of the Rio Mantaro in reaching the Pampa de Junin.* 


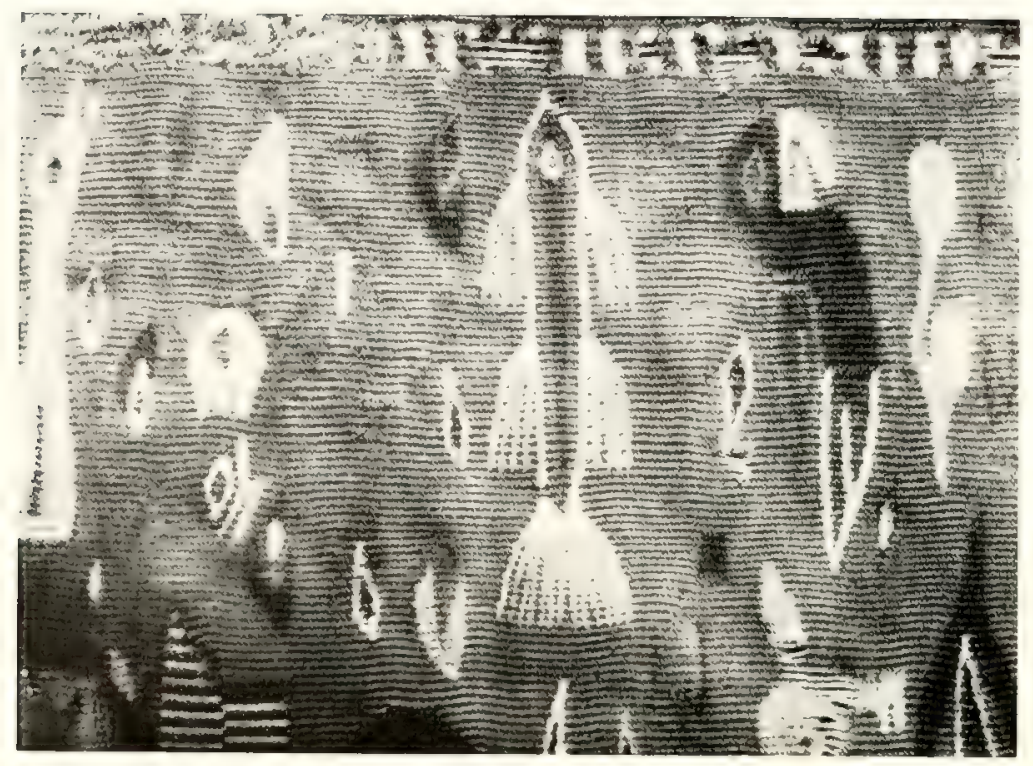

FIG. 14

\section{ANNOTATED LIST OF THE SPECIES}

With some exceptions the following pages do not present full bibliographies or full synonymies of the genera and species. Reference is made, however, to the papers under the following categories:

1. original descriptions of the genera and species

2. principal changes in name

3. the more comprehensive works and monographs

4. those especially pertinent to the area.

The accession numbers used here are those of the Indiana University Museum, and retained by the Museum of the California Academy of Sciences, the institution to which the Jordan and Eigenmann collections were sold in 1929. Their removal from Bloomington to Golden Gate Park constitutes not only an epoch in ichthyological history, but a most noteworthy accomplishment in the technique of handling and transporting a large collection.

\section{Subclass: SELACHII \\ Order: BATOIDEI \\ Family I: Dasyatidae}

\section{Subfamily: POTAMOTRYGONINAE}

Pelvis bearing a blade-like, median, forward-projecting cartilage.

\section{Genus 1: POTAMOTRYGON Garman}

Tacniura Müller and Henle, 1837, Bericht. I. Preuss. Akad. Wiss., 117.

Potamotrygon Garman, 1877, Proc. Boston Soc. Nat. Hist., XIX, 210. 


\section{Type: Pastinaca humboldtii Roulin}

The fresh waters of South America

Mouth papillose, teeth in more than twenty-five rows, tail spiny, length of spines irregular, one or more long.

\section{Potamotrygon hystrix (Müller and Troschel)}

Pastinaca humboldtii Roulin, 1829, Amer. Sci. Nat., XVI, 104, pl. iii;

Duméril, 1865, Hist. Nat. Poiss., I, 625.

Trygon hystrix Müller and Henle, 1841, Syst. Beschr. Plagiostomen, 167;

Valenciennes, in D'Orbigny, 1847, Voy. Amer. Merid., V, ii, 11, pl. xv, La Plata to the Amazon :

Castelnau, 1855, Anim. Amér. Sud, Poiss., 103;

Günther, 1870, Cat. Fish. Brit. Mus., VIII, 482.

Potamotrygon humboldtii Garman, 1877, Proc. Boston Soc. Nat. Hist, 210;

Eigenmann, 1910, Rept. Princeton Univ. Exped. Patagonia, II I, 378.

Potamotrygon hystrix Eigenmann and Kennedy, 1903, Proc. Acad. Nat. Sci. Phila., 498;

Fowler, 1939 (1940), Proc. Acad. Nat. Sci. Phila., XCI, 221, Contamana.

Trygon mülleri Castelnau, 1855, Anim. Amér. Sud, Poiss., 102, pl. xlviii, fig. 2.

\section{Guianas to La Plata and Rio de Janeiro}

$16137,2,108$ and $232 \mathrm{~mm}$., Rio Ucavali, near Orellana, Allen, August, 1920.

$16138,2,123$ and $240 \mathrm{~mm}$., creek, Yurimaguas, Allen, November, 1920.

16139, 3, about $180 \mathrm{~mm}$., Yarinacocha, Allen, August, 1920.

The three specimens numbered 16139 were given birth when the mother was taken by seine. Yolk sacs were still attached, but nearly used up. Two males and a female.

The only selachian species collected, it represents the sole species of its class (which is almost completely marine) at this remote distance from the sea, and one of a considerable number of fishes owing their origin to the salt water era in the history of the Amazon.

\section{Order NEMATOGNATHI, the Catfishes}

Fishes without scales, naked or with bony plates; first four vertebrae united to form Weberian apparatus; subopercle lacking; maxillary reduced to mere basis for barbel; teeth in villiform bands; dorsal fin usually present and above or before ventrals; adipose fin usually present, variable; air bladder present, large, united to Weberian ossicles; first dorsal and pectoral fins usually extremely developed. These fishes find their greatest numbers of species and individuals in the freshwaters of South America; there as elsewhere they are noteworthy for extreme tenacity of life.

\section{Family II: Aspredinidae}

Nematognath fishes having vestigial opercle; body expanded forward to form distinct trunk and tail regions, much depressed; neural spines of the coalesced vertebrae forming a ridge from the occipital region to the dorsal fin; caudal verte- 
brae greatly compressed, their neural spines freely expanded; gill opening a mere slit; air bladder well developed; adipose fin lacking; nares distal; dorsal fin very short; pectoral strongly spined.

\section{Subfamily: BUNOCEPHALINAE}

Differing from the Aspredininae in the short tail, with the anus equidistant from snout and end of caudal, anal rays not exceeding eleven in number.

\section{Genus 2: BUNOCEPHALUS Kner}

Bunocephalus Kner (part), 1855, Sitzb. KK. Akad. Wiss. Wien, XVII, 95;

Bleeker, 1863, Nederl. Tijdsch. Dierk., I, 118, verrucosus;

Eigenmann and Eigenmann, 1890, Occ. Papers Cal. Acad. Sci., I, 14;

Eigenmann, 1910, Rept. Princeton Univ. Exped. Patagonia, III, 379.

\section{Type: Platystacus verrucosus Bloch}

Peruvian Amazon to Surinam

Aspredinids having short tails, well-developed dorsals, head depressed and without knobs, six barbels. Bony protuberances upon dorsal surface; pectorals with serrations both anterior and posterior.

\section{Bunocephalus BICOLOR Steindachner}

Bunocephalus bicolor Steindachner, 1882 (1883), Denksch. KK. Akad.

Wiss. Wien, XLVI, 8, pl. ii, figs. 1-1b, Rio Huallaga, 1 specimen, $100 \mathrm{~mm}$;

Eigenmann and Eigenmann, 1890, Occ. Papers Cal. Acad. Sci., I, 17;

Eigenmann, 1910, Rept. Princeton Univ. Exped. Patagonia, III, 380.

The Amazons

15411 and 15840, several, about 99 mm., creek, Yurimaguas, Allen, November, 1920.

\section{Bunocephalus knerit Steindachner}

Bunocephalus knerii Steindachner, 1882 (1883), Denksch. KK. Akad.

Wiss. Wien., XLVI, 9, pl. ix, figs. 2-2b;

Boulenger, 1887, Proc. Zool. Soc. London, 278, Canelos;

Eigenmann and Eigenmann, 1889, Proc. Cal. Acad. Sci., (2), II, 48;

Eigenmann and Eigenmann, 1890, Occ. Papers Cal. Acad. Sci., I, 19;

Eigenmann, 1910, Rept. Princeton Univ. Exped. Patagonia, III, 380.

Rio Huallaga and Canelos to Cudajas

\section{Bunocephalus aleuropsis Cope}

Bunocephalus aleuropsis Cope, 1870, Proc. Amer. Phil. Soc., XI, 568, Pebas;

Eigenmann and Eigenmann, 1890, Occ. Papers Cal. Acad. Sci., I, 19;

Eigenmann, 1910, Rept. Princeton Univ. Exped. Patagonia, III, 380.

Known only from the types taken at Pebas, and in the collections of the Philadelphia Academy of Sciences. 


\section{Bunocephalus melas Cope}

Bunocephalus melas Cope, 187t, Proc. Acad. Nat. Sei. Phila., NXVI, 132, Nauta;

Cope, 1878, Proe. Amer. Phil. Soc., XVII, 681, Nauta;

Eigenmann and Eigenmann, 1890, Oce. Papers Cal. Acad. Sci., I, 18, Peruvian Amazon;

Eigenmann, 1910, Rept. Princeton Unir. Exped. Patagonia, III, 380.

Known only from the Peruvian Amazon.

15841, 1, 37 mm., Rio Morona, Allen, October, 1920.

A small number of the specimens listed or described below were collected in Brazil by Dr. John Haseman for the Carnegie Museum, where his material was in charge of Professor Eigenmann, at the time Curator of Fishes there. Haseman's types and all but a few duplicates were returned to the Carnegie Museum.

\section{Bunocephalus retropinnis Eigenmann, sp. nov.}

\section{Plate II, fig. 3}

14332, 2, cotypes, 86 mm., Cacequi, Brazil, Haseman, Feb. 1909.

Extralimital.

Distinguished by the backward position of the dorsal, the origin of which is sometimes nearer the caudal than the snout.

Head $5-5.5$; depth $5.5-6 ;$ D. $5 ;$ A. 8 , width at origin of pectorals 3 in the length; depth of head $6.5-7$; distance between snout and pectoral $4-4.25$ in the length; nuchal plate narrow, terminating in a knob, sloping forward from knob to a point between the posterior end of the bases of the pectorals; two lower knobs between the larger knob and the dorsal fin; snout truncate, general shape not unlike that of a guitar; coracoid processes converging, about equal to the space between their bases; interorbital equal to snout and eye; maxillary barbels reaching just beyond the base of the last pectoral ray; mental barbels reaching the postmentals which reach in turn beyond the gill-opening. Teeth minute, feeble; a large pectoral pore; dorsal rays coterminous; caudal rounded, a little longer than the head; anal rounded, its basis about 7 in the length; rentrals distinctly behind origin of dorsal, reaching to, or nearly to, the anal; pectoral spines not reaching ventral.

No parts showing great prominence.

General color gray, sides and back spotted, dorsal dark at base, becoming speckled and rusty toward margin; caudal light at basis, shading into marble, the extreme margin light; anals hyaline or marbled toward the tips, the pectoral similar to the predorsal area.

15415, 1, 85 mm., Uruguayana, Brazil, Haseman, February, 1909.

This specimen, probably belonging to retropinnis, had the origin of the dorsal slightly in advance of the middle; the coracoid processes flaring outward toward their tips; the ventral just reaching the anal. 


\section{Bunocephalus bifidus Eigenmann, sp. nov.}

Pl. II, fig. 2

Bunocephalus bifidus Eigenmann, in Pearson, 1924, Ind. Univ. Studies, XI, no. 64, 9, Lake Rogagua (nom.nud.)

15412, 5, type and cotypes, 40-47 mm., creek, Yurimaguas, Allen, November, 1920.

15413, 2, 40 and 44 mm., lagoon, Lago Rogagua, Bolivia, Pearson, November, 1921.

This Bunocephalus was named and not described in the Pearson report. Clearly differentiated from all other species of Bunocephalus by the bifid postmental barbel.

Head 5.5 ; depth about 8 ; D. 5 ; A. 7-9; width at base of pectoral $3.66-3.8$ in the length; depth of head 2 in the distance between snout and pectoral; distance between snout and dorsal 2.6 in the length; nuchal plate a thin, low crest, entire, or with very slightly indented margin; dorsal knob scarcely, if at all, distinct; tail slender (Plate II); coracoid processes short, scarcely reaching the middle of the short pectoral spine, their length scarcely half the distance between their bases; interorbital equals snout and eye; teeth very minute.

Maxillary barbel reaching to or beyond base of pectoral; mental barbels about reaching the postmentals; postmental barbels bifid, one of the rami always shorter; pectoral pore large.

Dorsal rounded or the first ray longest; caudal slightly rounded, 4 in the length; anal basis $5-7$ in the length; pectoral spines not near reaching ventrals, not quite equal to the head length.

Ashen, dorsal and posterior part of the caudal black, margined with light and with a few light spots; basal portion of caudal lighter; pectorals, ventrals, and anal spotted or mottled. Back in front of the dorsal and two or three spots behind the dorsal ashen; sides dark with fine vertical light lines.

The specimens from Rogagua are lighter in color than the rest. The postmental barbels have a scale-like bract at their base, in one of the specimens; the left barbel with a short outer branch near its base, the right one a small wart in place of it; in the second specimen only the bracts are present besides the barbel. The vertical white lines on the sides are largely due to large, white papillae.

\section{Bunocephalus Haggini Eigenmann and Allen, sp. nov.}

$$
\text { Pl. II, fig. } 1
$$

15408, 1, 94 mm., type, Amazon at Iquitos, Allen, September, 1920.

15979 , 4, 45-115 mm., paratypes, Iquitos, Norris, 1922.

$15409,2,68$ and $69 \mathrm{~mm}$., Maciel, Brazil, Haseman, 1909

15 $110,1,61 \mathrm{~mm}$., Santarem, Brazil, Haseman, 1909.

Head 4.6; depth at tip of coracoid process 7 or 8 ; D. 5 ; A. 7 or 8 ; width at base of pectorals $3-3.3$; head depressed, its depth about 2 in the distance between the snout and pectoral; distance between snout and dorsal 2.2-2.5 in the length; nuchal plate a thin crest with two feeble knobs, a separate knob in front of the dorsal; crests on head all low; snout truncate; tail tapering; coracoid processes very 
slightly converging, longer $(16 \mathrm{~mm}$.) in type and large specimens than the space between their bases $(11 \mathrm{~mm}$. in type); the processes shorter than the space in the smallest; interorbital equals the snout plus the eye; maxillary barbel reaching to or a little beyond origin of pectoral; teeth feeble or none; a large pectoral pore.

Dorsal rays nearly coterminous; caudal rounded, equals distance between snout and pectoral; anal rounded, its base 5.5-6.6 in the length; ventrals not reaching the anal; pectoral spines much longer than the head, reaching beyond coracoid process, to the ventrals; both margins with strong hooks. A rhomboidal area in front of the dorsal, including the entire top of the head, lilac to brown; two blotches of similar color behind the dorsal; the body dark, with a few small light spots, barbels banded; fins black with a few lighter spots, the tips narrowly light.

Near coracoideus, differing as indicated above.

\section{Bunocephalus coracoideus (Cope)}

Dysichthys coracoideus Cope, 1874, Proc. Acad. Nat. Sci. Phila., XXVI, 133, Nauta;

Cope, 1878, Proc. Amer. Phil. Soc, XVII, 681, Nauta;

Eigenmann and Eigenmann, 1890, Occ. Papers Cal. Acad. Sci., I, 20;

Eigenmann, 1910, Rept. Princeton Univ. Exped. Patagonia, III, 380. Bunocephalus bicolor Haseman (part), 1911, b, Ann. Carnegie Mus., VII, 321.

Cope erected the genus Dysichthys upon the supposed absence of all barbels except the maxillary. Haseman examined the types and says that all barbels are present, although minute in small specimens and increasing with age.

Known only from the types collected at Nauta, in the Nuseum of the Philadelphia Academy, and from Haseman's specimens at Pittsburgh.

\section{Family III : Pimelodidae}

A family of many genera and species, many individuals, widely dispersed, many of extreme size, both large and small. Catfishes with nares remote, with six barbels, and with well-developed adipose; teeth villiform, in bands. In common with the Siluridae having the reduced maxillaries, the margins of the upper jaws formed by the premaxillaries alone. Gill-membranes usually free from the isthmus, but sometimes freely united across it; nares widely separated, without barbels.

\section{Subfamily: CALLOPHYSINAE}

Distinguished from the Ariinae by the well-developed adipose, the six barbels, and the widely spaced nares; from the nearby Pimelodinae by the incisor-like teeth, which form a double series above, and a single series below.

\section{Genus 3: CALLOPHYSUS Müller and Troschel}

Callophysus Müller and Troschel, 1849, Horae Ichth., III, 1, sp.;

Bleeker, 1863, Nederl. Tijdsch. Dierk., I, 101, macropterus;

Eigenmann and Eigenmam, 1890, Occ. Papers Cal. Acad. Sci., I, 94;

Eigenmann, 1912, Mem. Carnegie Mus., V, 148. 
Pimelotropis Gill, 1859, Proc. Acad. Nat. Sci. Phila., 196, lateralis = macropterus.

Pseudocallophysus Bleeker, 1863, Nederl. Tijdsch. Dierk., I, 102, ctenodus = macroptenus.

\section{Type: Pimelodus macropterus Lichtenstein}

The Amazons northward

Only one series of teeth in lower jaw, two in the upper, the inner much the smaller and more or less concealed; first dorsal and pectoral rays not spine-like nor longer than the following rays; adipose long and narrow; wedge-shaped fontanel between the eyes and a circular one at the base of the occipital crest.

\section{Callophysus macropterus (Lichtenstein)}

Pimelodus macropterus Lichtenstein, 1819, Wiede. Zool. Mag., I, iii, 59, Brazil.

Callophysus macropterus Müller and Troschel in Schomburgk, 1848, Brit. Guiana, 629, Essequibo; Günther, 1864, Cat. Fish. Brit. Mus., V, 137;

Eigenmann and Eigenmann, 1890, Occ. Papers Cal. Acad. Sci., I, 95;

Eigenmann, 1910, Rept. Princeton Univ. Exped. Patagonia, III, 382;

Eigenmann, 1912, Mem. Carnegie Mus., V, 148;

Fowler, 1939 (1940), Proc. Acad. Nat. Sci. Phila., XCI, 222, Contamana.

Pimelotropis lateralis Gill, 1859, Proc. Acad. Nat. Sci. Phila., 196.

Callophysus lateralis Günther, 186t, Cat. Fish. Brit. Mus., V, 136;

Steindachner, 1876, Sitzb. KK. Akad. Wiss. Wien, LXXIV, 105, Tabatinga;

Cope, 1878, Proc. Amer. Phil. Soc., XVII, 676, Peruvian Amazon;

Regan, 1913, Ann. Mag. Nat. Hist., (8), XII, 281, Rio Ucayali.

Pimelodus ctenodus Castelnau, 1855, Anim. Amér. Sud, Poiss., 35.

\section{Amazon valley northward to Caribbean}

\section{Subfamily: PIMELODINAE}

That division of the family having a free union of gill-membranes and teeth in villiform bands.

\section{Genus 4: PIMELODINA Steindachner}

Pimelodina Steindachner, 1876, Sitzb. KK. Akad. Wiss. Wien, LXXIV, 101 ;

Eigenmann and Eigenmann, 1890, Occ. Papers Cal. Acad. Sci., I, 101;

Eigenmann, 1910, Rept. Princeton Univ. Exped. Patagonia, III, 383.

Type: Pimelodina flavipinnis Steindachner

Throughout Amazon valley

A genus distinguished for its elongated, nearly conical snout projecting beyond lower jaw; teeth weak and in narrow bands; adipose fin long; dorsal and pectoral fins with first rays elongated and articulated; dorsal and anal fins emarginate.

\section{Pimelodina flavipinnis Steindachner}

Pimelodina flavipinnis Steindachner, 1876, Sitzb. KK. Akad. Wiss. Wien, LXXIV, 102, pl. xiii, fig. 2, Para; 
Eigenmann and Eigenmann, 1890, Oce. Papers Cal. Acad. Sci., I, 101;

Eigenmann, 1910, Rept. Princeton Unir. Exped. Patagonia, III, 383.

The Amazon from Peru to Para

15759, 1, 315 mm., Manaos, Brazil, Allen, December, 1920.

15952, 1, $275 \mathrm{~mm}$. . Iquitos, Morris, 1922.

\section{Genus 5: MICROGLANIS Eigenmann}

Microglanis Eigenmann, 1912, Mem. Carnegie Mus., V, 155.

Type: Microglanis poecilus Eigenmann

Small Pimelodids having a very broad, naked head, very short occipital crest not approximating the dorsal fin; premaxillary teeth lacking a backward-projecting angle on the sides. Our collections extend the range from the Guianas to the upper Marañon.

12. Microglanis zonatus Eigenmann and Allen, sp. nov.

Plate III, figs. 1 and 2

15890, 1, $2+$ mm., type, Rio Morona (?), Allen, 1920.

This minute specimen might be Microglanis poecilus Eigenmann if it were not for the hooks on the anterior edge of the pectoral spine. In two of the cotypes of M. poecilus the anterior hooks of the pectoral spine are in part retrorse, part antrorse, the hook on the dividing line near the center of the spine being Y-shaped, the outer arm being antrorse like the hooks toward the end of the spine, the inner being retrorse like the hooks toward the base of the spine. In the specimen of the present species the hooks are all retrorse on one of the pectoral spines, and all but the ultimate one on the other spine. (Plate III, fig. 2.)

Length of base of caudal $19 \mathrm{~mm}$; width of head equal to its length, $5.5 \mathrm{~mm}$.; snout $2 \mathrm{~mm}$., interorbital $3 \mathrm{~mm}$., eye $1 \mathrm{~mm}$., dorsal spine $3 \mathrm{~mm}$., pectoral $4 \mathrm{~mm}$. ; D. I, 6; A. 9 (?); maxillary barbel reaching a little beyond tip of humeral spine; outer mental barbel a little beyond base of pectoral; color as in poecilus; snout variegated; top of head dark, the dark area continued as a bar to the lower angle of the opercle; a light bar from pectoral across opercle to opposite pectoral; a dark bar from humeral process to humeral process, joined above to similar bar from base of all but the last dorsal ray to the level of the humeral process; a Y-shaped band encircling the body near origin of anal, the anterior arm of the $\mathrm{Y}$ continued as a quadrate spot on the back, the posterior arm narrowly continued across the adipose, the lower arm across the anal; a narrow black band across the base of the caudal rays continued forward on the caudal peduncle, a narrow arm of the continued portion meeting its fellow at the anterior end of the dorsal fulcra of the caudal; margin of the dorsal white, a submarginal dark band; base of spine colorless, bases of the dorsal rays except the last black, the basal black united with the submarginal band in front; a wedge-shaped hyaline area with a few dots between the basal and 
submarginal band from the second ray back; irregular cross-bars on the caudal becoming more intense backward; anal speckled, with the black cross-band in front; ventrals speckled; pectorals speckled, with a dark band across its middle.

\section{Genus 6: ZUNGARO Bleeker}

Zungaro Bleeker, 1863, Nederl. Tijdsch. Dierk., I, 101, zungaro;

Eigenmann, 1910, Rept. Princeton Univ. Exped. Patagonia, III, 384.

Pseudopimelodus Eigenmann and Eigenmann (part), 1890, Occ. Papers Cal. Acad. Sci., I, 112.

\section{Type: Pimelodus zungaro Humboldt}

La Plata and upper Amazon basins

Restricting Pseudopimelodus to the raninus-group of species, and retaining Bleeker's genus Zungaro, it may be characterized as having an intermaxillary band of teeth with a backward-projecting angle; the eye small and anterior; dorsal and pectoral spines short with thick cord of skin covering and prolonging them. Head as wide as long, frontal very narrow, occipital process short and notched at the tip for the reception of the much longer dorsal plate.

\section{Zungaro Zungaro (Humboldt)}

Pimelodus zungaro Humboldt, 1833, Obs. Zool., II, 170, pl.xlvi, fig. 1, Marañon;

Cuvier and Valenciennes, 1840, Hist. Nat. Poiss, XV, 160.

Zungaro zungaro Bleeker, 1863, Nederl. Tijdsch. Dierk., I, 101;

Eigenmann, 1910, Rept. Princeton Univ. Exped. Patagonia, III, 384.

Pseudopimelodus zungaro Eigenmann and Eigenmann, 1888, Proc. Cal. Acad. Sci., (2), I, 122 ;

Eigenmann and Eigenmann, 1890, Oce. Papers Cal. Acad. Sci., I, 112.

Pimelodus bufonius Cuvier and Valenciennes, 1840, Hist. Nat. Poiss., XV, 155;

Cope, 1878, Proc. Amer. Phil. Soc., XVII, 675, Peruvian Amazon.

Throughout upper Amazon and La Plata

Popularly known throughout Loreto as the zungaro. Other large Pimelodinae given the same name, sometimes qualified by such an adjective as blanco or negro. Often seen, but not collected, mostly by reason of the size and attendant difficulty of preservation.

\section{Genus 7: PSEUDOPIMELODUS Bleeker}

Pseudopimelodus Bleeker, 1858, Ichth. Arch. Ind. Siluri, 196, sp.;

Bleeker, 1863, Nederl. Tijdsch. Dierk., I, bufonius = zungaro;

Eigenmann and Eigenmann, 1890, Oce. Papers Cal. Acad. Sci., I, 108.

Type: Pimelodus raninus Cuvier and Valenciennes

Rio Magdalena everywhere to Rio de La Plata

Head rather broad and not produced; teeth well developed, vomer edentulous; head covered by skin, neither plated nor granulated; eye beneath skin, without free orbital margin; intermaxillary teeth without angle projecting backward; adipose fin short; barbels terete. 


\section{Pseudopimelodus pulcher Boulenger}

Pimelodus (Pseudopimelodus) pulcher Boulenger, 1887, Proc. Zool. Soc. London, 276, pl. xxi, fig. 1, Canelos.

Pseudopimelodus pulcher Eigenmann and Eigenmann, 1890, Occ. Papers Cal. Acad. Sci., I, 111 ;

Pearson, 1937a, Proc. Cal. Acad. Sci., (4), XXIII, 92, Tingo de Pauca, Alto Marañon.

Batrachoglanis pulcher Eigenmann, 1910, Rept. Princeton Univ. Exped. Patagonia, III, 383.

Eastern Ecuador and Upper Marañon

\section{Pseudopimelodus Ranivus (Cuvier and Valenciennes)}

Pimelodus raninus Cuvier and Valenciennes, 1840, Hist. Nat. Poiss., XV, 157, Rio de Janeiro.

Pseudopimelodus raninus Steindachner, 1882 (1883), Denksch. IKL. Akad. Wiss. Wien, XLVI, 4, one specimen, $100 \mathrm{~mm}$, Rio Huallaga;

Eigenmann and Eigenmann, 1890, Occ. Papers Cal. Acad. Sci., I, 111.

Batrachoglanis raninus Gill, 1858, Ann. Lyceum Nat. Hist. N. Y., VI, 389;

Eigenmann, 1910, Rept, Princeton Univ. Exped. Patagonia, III, 383.

Rio Huallaga to the Guianas and Rio de Janeiro

\section{Genus 8: CHASMIOCRANUS Eigenmann}

Chasmocephalus Eigenmann, 1910, Rept. Princeton Univ. Exped. Patagonia, III, 384, preoccupied. Chasmocranus Eigenmann, 1912, Mem. Carnegie Mus., V, 160.

\section{Type: Chasmocranus longior Eigenmann}

The Guianas to the upper Marañon and southeastern Brazil

Cranial roof naked, fontanel narrow and reaching base of occipital, interrupted in interorbital region and again back of eye level; occipital crest short and narrow; eye superior, without free orbital margin. First rays of dorsal and pectoral soft; origin of ventrals nearly under the origin of the dorsal; adipose fin low and free from caudal; anal short; caudal forked. Premaxillary tooth-area subrhomboidal, its outer posterior angle extending caudally. Snout not prolonged, barbels not flattened.

\section{Chasmocranus quadrizonatus Pearson}

Chasmocranus quadrizonatus Pearson, 1937a, Proc. Cal. Acad. Sci., (4), XXIII, 93, Tingo de Pauca and Pusoc, upper Marañon, two specimens, types.

17. Chasmocranus peruanus Eigenmann and Pearson, sp. nov.

Plate III, figs. 3 and 4

15869, 2, cotypes, 60 and 63 mm., Puerto Melendez below Pongo de Manseriche, Rio Marañon, Allen, October, 1920.

Related to $C$. longior from which it differs in possessing a deeply forked caudal, a narrower head, and longer barbels.

Head 4.66-4.8; depth 8 and $9 ;$ D. 7 ; A. 10; eye 4.25 and 5 ; width of the head 
1.33 in its length; eye about equal to the interorbital width; head slightly convex; tail compressed; tip of the occipital crest nearer the origin of the dorsal than the tip of the snout; anterior nostril much nearer the snout than to the posterior nostril; mouth subterminal, the upper jaw slightly the longer; depth of the premaxillary band of teeth 2 times in its length; maxillary barbels extending slightly beyond the origin of the ventrals, outer mentals to the base of the pectorals, inner mentals to the gill opening; distance of the dorsal from the tip of the snout 2.6 times in the length; origin of the ventrals below the second dorsal ray; origin of the anal posterior to the origin of the adipose; adipose fin 3.5 in the length; caudal rather deeply forked, the upper lobe the longer, considerably longer than the head.

Brownish, a dark humeral spot, otherwise unmarked.

\section{Genus 9: NANNOGLANIS Boulenger}

Nannoglanis Boulenger, 1887, Proc. Zool. Soc. London, 278, pl. xxi, fig. 3, Canelos;

Eigenmann and Eigenmann, 1890, Occ. Papers Cal. Acad. Sci., I, 146;

Eigenmann, 1910, Rept. Princeton Univ. Exped. Patagonia, III, 385.

\section{Type: Nannoglanis fasciatus Boulenger \\ Eastern Ecuador to southeastern Brazil}

Anal short, having only 8 rays; dorsal entirely behind the vertical from the ventrals; dorsal lacking a pungent spine; fontanel continued to the base of the occipital process which does not reach the dorsal plate; head longer than broad, but not produced into an elongated snout; vomer and palatine edentulous; narial barbels wanting; eye superior; head enclosed in skin; adipose large, caudal truncate.

\section{Nannoglanis Fasciatus Boulenger}

Nannoglanis fasciatus Boulenger, 1887, Proc. Zool. Soc. London, 278, pl. xxi, fig. 3, Canelos; Eigenmann and Eigenmann, 1890, Oce. Papers Cal. Acad. Sci., I, 147;

Eigenmann, 1910, Rept. Princeton Univ. Exped. Patagonia, III, 385.

Eastern slopes of Ecuador, piedmont zone

Genus 10: RHAMDIA Bleeker

Pimelodus Lacépède, 1803, Hist. Nat. Poiss., V, sp.;

Cuvier, 1817, Règne Animal, II, 203, sp.;

Günther, 1864, Cat. Fish. Brit. Mus., V, sp.

Rhamdia Bleeker, 1858, Ichth. Arch. Ind. Siluri, I, 197, 207, sp;

Bleeker, 1863, Nederl. Tijdsch. Dierk., I, 101, queleni;

Eigenmann and Eigenmann, 1890, Occ. Papers Cal. Acad. Sci, I, 116;

Eigenmann, 1910, Rept. Princeton Univ. Exped. Patagonia, III, 385.

\section{Type: Pimelodus quelen Quoy and Gaimard}

\section{Mexico to La Plata and Peru}

Fontanel terminating at the eye level; occipital process not reaching dorsal plate; top of head enclosed in skin, not granulated; head longer than broad, snout 
not produced; barbels terete or flat. Fontanels obsolescent, occipital obsolete; free orbital margin.

\section{Rhamdia duquei Eigenmann and Pearson, sp. nov.}

\section{Bagre}

, 36, type and paratypes, 48-135 mm., Rio Urubamba, Santa Ana, Eigenmann, November, 1918 .

Very closely related to $R$. micayi, from which it differs in the shorter adipose.

Head 4-4.25; depth 5.87 ; D. I, 6 ; A. 12 ; eye $6-7$; interorbital $3.5-4$ in the head; width of the head in its length 1.4; flat above, the surface covered with thin skin, the surface of the bones striate; frontal fontanel not extending past the eye; occipital fontanel present in the young, remaining in the adults as a circular depression; occipital process extending $\frac{2}{5}$ of the distance from its base to the origin of the dorsal; eye elliptical, 1.5-1.8 in the interorbital width; teeth of the upper jaw in an uninterrupted band, the depth 7 or slightly less in the width; gill-rakers simple, slender, 3-6; maxillary barbels compressed or filiform, extending to the middle of the ventrals or slightly beyond; outer mental barbels to slightly beyond the base of the pectorals, inner mentals slightly beyond the gill opening; pores on the head regularly distributed; pectoral spine $2-2.5$ in the head, the posterior margin slightly roughened, the anterior margin with 8 conspicuous recurved teeth in a specimen of $100 \mathrm{~mm}$.; ventral inserted below the last dorsal ray; anal fin higher than long, the tips reaching to below the end of the adipose when depressed; distance of the dorsal fin from the snout 2.8-3 times in the total length. Dorsal spine pungent, 3.2-3.6 times in the head, its anterior margin rough; adipose fin separated from the dorsal by a distance equal to or slightly greater than the base of the dorsal, 3.5-3.8 in the total length; caudal deeply forked; the lower lobe rounded, broader than the upper.

Color brown; humeral region darker; predorsal line dark; a dark area on the top of the head; dorsal with a light, transparent band, chromatophores above the band collected along the posterior edge of the interradial membrane; the other fins dusky.

For Don Carlos Duque of Santa Ana, whose hospitality and active participation have contributed to the success of this expedition and others in the Urubamba valley. Name supplied by W.R.A.

\section{Rhamdia Quelen (Quoy and Gaimard)}

Pimelodus quelen Quov and Gaimard, 1824, Toy. Uran. Zool., pl. xlix, figs. 3-4.

Rhamdia quelen Eigenmann and Eigenmann, 1888, Proc. Cal. Acad. Sci., (2), I, 126, Brazil;

Eigenmann and Eigenmann, 1890, Oce. Papers Cal. Acad. Sci., I, 127.

Pimelodus queleni Günther, 1864, Cat. Fish. Brit. Mus., V, 123, Brazil.

Rhamdia queleni Bleeker, 1863, Tederl. Tijdsch. Dierk., I, 101.

Amazons to the basin of Rio de la Plata

15791, many, 50-282 mm., creeks at Yurimaguas, Allen, November, 1920.

15792, 157 and $172 \mathrm{~mm}$., Iquitos, Allen, 1920. 
15793, 1, 95 mm., La Merced, Allen, July, 1920.

15870,1 , Puerto Melendez, Pongo de Manseriche, Allen, October, 1920, too small for certain determination.

Near $R$. sebae, from which it differs most consistently in the barbel length, a character variable itself in some localities. Width of body less than depth, becoming compressed strongly toward the tail; head flattened dorsally; occipital process reaching half way to dorsal spine; large pores occurring in patches on the head; in the young, maxillary barbels reaching the posterior third of the adipose, but shortened with age; mental barbels falling short of pectorals, post-mentals beyond the base of the pectorals.

\section{Rhamdia sebae (Cuvier and Valenciennes)}

Pimelodus sebae Cuvier and Valenciennes, 1840, Hist. Nat. Poiss., XV, 169.

Pimelodus (Rhamdia) sebae Steindachner, 1876, Sitzb. KK. Akad. Wiss. Wien, LXXIV, 68.

Rhamdia sebae Eigenmann and Eigenmann, 1888, Proe. Cal. Acad. Sci., (2), I, 126;

Eigenmann and Eigenmann, 1890, Oce. Papers Cal. Acad. Sci., I, 123;

Fowler, 1914, Proc. Acad. Nat. Sci. Phila., LXVI, 258;

Fowler, 1915, Proc. Acad. Nat. Sci. Phila., LXVII, 209;

Fowler, 1939 (1940), Proc. Acad. Nat. Sci. Phila., XCI, 222, twelve, 120-214 mm., Contamana.

Magdalena basin to that of Rio Janeiro; throughout the Amazon

\section{Rhamdia mounseyi Regan}

Rhamdia mounscyi Regan, 1913, Ann. Mag. Nat. Hist., (8), XII, 281, seven, 75-135 mm., Rio Ucayali.

Known only from the types from an unnamed locality on the Rio Ucayali.

\section{Rhamdia bathyurus (Cope)}

Pimelodus bathyurus Cope, 1878, Proc. Amer. Phil. Soc., XVII, 674, Peruvian Amazon.

Rhamdia bathyurus Eigenmann and Eigenmann, 1888, Proc. Cat. Acad. Sci., (2), I, 124, Rio Marañon;

Eigenmann and Eigenmann, 1890, Occ. Papers. Cal. Acad. Sci., I, 122;

Eigenmann, 1910, Rept. Princeton Univ. Exped. Patagonia, III, 385.

Known only from the Cope specimens from the Marañon.

\section{Rhamdia humisis (Günther)}

Pimelodus humitis Günther, 1864, Cat. Fish. Brit. Mus., V, 129, Venezuela.

Rhamdia humitis Eigenmann and Eigenmann, 1888, Proc. Cal. Acad. Sci., (2), I, 126;

Eigenmann and Eigenmann, 1890, Occ. Papers Cal. Acad. Sci., I, 127;

Eigenmann, 1910, Rept. Princeton Univ. Exped. Patagonia, III, 385.

Venezuela to the Marañon 


\section{Rhamdia riojae Fowler}

Plate $\mathbf{X}$, fig. 3

?Thamdia dorsalis Gill, 1870, Proc. Acad. Nat. Sci. Phila., 94, upper Amazon.

Pimelodus humitis Cope, non Günther, 1878, Proc. Amer. Phil. Soc., XVII, 674, Rioja, near Moyobamba, Peru.

Rhamdia riojae Fowler, 1915, Proc. Acad. Nat. Sci. Phila., 2, Rioja, erected on Cope's specimens of $P$. humilis.

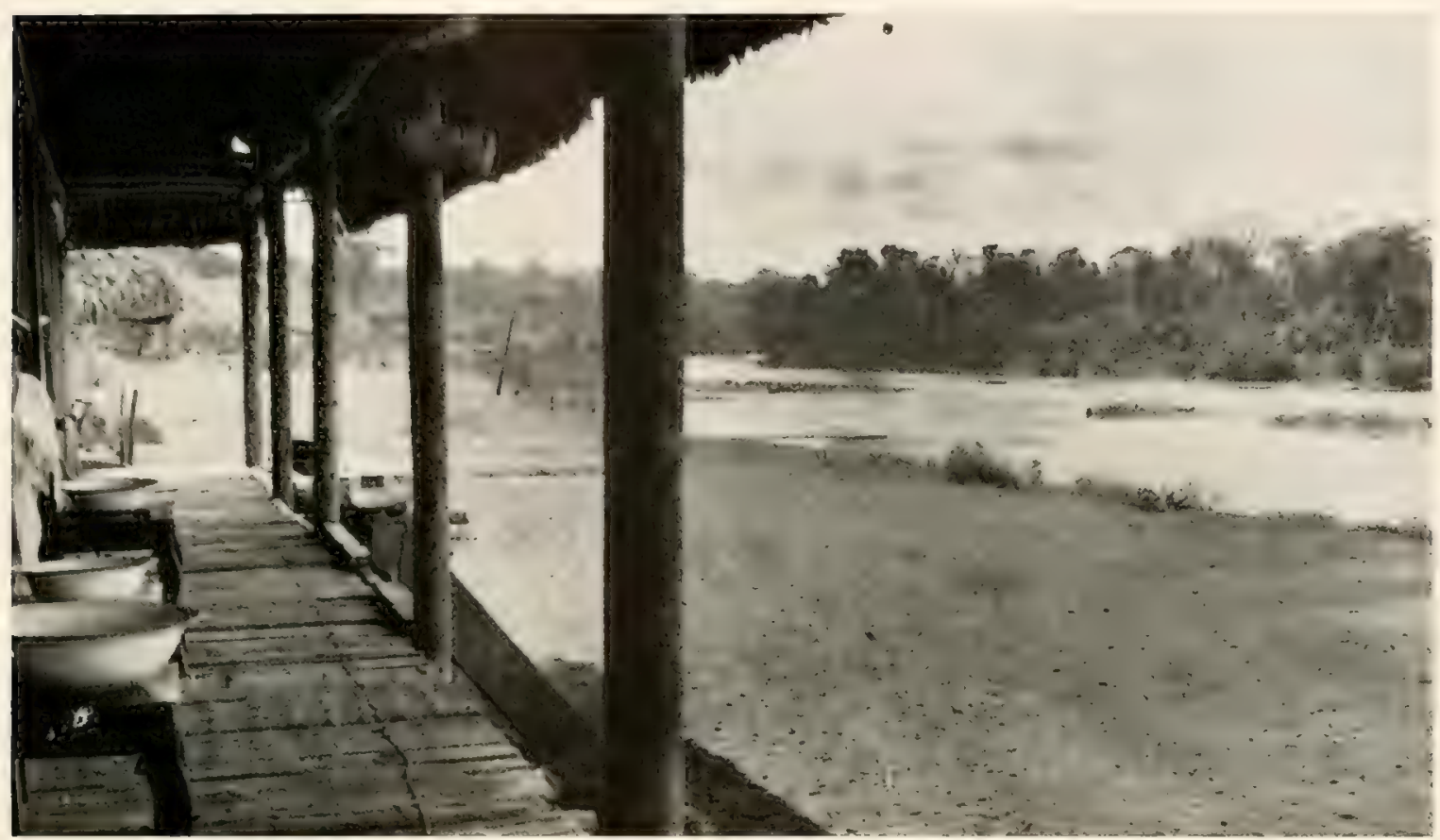

Fig. 15. Puerto Bermudez, Rio Pichis. The head of launch navigation during the rainy season, and the end of the Via Central. The spreading deciduous tree on the further bank is the dominant species of the forest, the silk cotton, or kapok tree. From the rerandah of the government tambo, or rest-house.

Along eastern fringe of Peruvian Andes

MI.C.Z., 1, 1800 feet, Rio Comberciato, Edmund Heller.

M.C.Z., 11, 1800 feet, Rio Comberciato, Edmund Heller.

M.C.Z., 2, 3400 feet, Rio Comberciato, Edmund Heller.

C.M., 2, Rio Comberciato, Edmund Heller.

C.M., 2, Santa Ana, Rio Urubamba, Edmund Heller.

C.M., 2, Rio Comberciato, Edmund Heller.

I.U.M., 6, Rio Comberciato, Edmund Heller.

The Comberciato specimens measure 93-192 mm, those from Santa Ana 70-109 mm.

Head 4.2-4.3; depth 5.66-6.33; D. I, 6 in eighteen specimens, I, 7 in two; A. 13-14; adipose fin 3.33-4; distance between dorsal and adipose one third to one half the length of the adipose. Maxillary barbel extending about to tip of ventrals, rarely to origin or middle of anal; eye 6-7 in the head, $2.3-3$ in snout, $1.66-2.33 \mathrm{in}$ interorbital; snout longer than interocular width; depth of caudal peduncle 9-9.5 in the length; width of head $0.66-0.8 \mathrm{in}$ its length; depth of premaxillary band of teeth $6-8$ in its width. 
Of nearly uniform depth from occiput to anal. Pores of head inconspicuous, not aggregated; a small fontanel at base of occipital process; premaxillary band of teeth very little wider at sides than at middle; outer mental barbels extending to about middle of pectorals; dorsal a little higher than long; caudal deeply cleft, but not to its base, the lower lobe much the broader; pectoral spine nearly half as long as the head.

Uniform ash color; a series of translucent areas near basal portion of dorsal.

This species differs from the $R$. humilis of Günther in ways pointed out by Cope long ago, and by Fowler.

\section{Rhamdia pentlandi (Cuvier and Valenciennes)}

Pimelodus pentlandi Cuvier and Valenciennes, 1840, Hist. Nat. Poiss., XV, 183, pl. 435, tributaries of Lake Titicaca;

Steindachner, 1876, Sitzb. KK. Akad. Wiss. Wien, LXXIV, 48 (reprint page), Monterico, Tulumayo;

Steindachner, 1882 (1883), Denksch. KK. Akad. Wiss. Wien, XLVI, 25 (reprint page), Rio de Huambo.

Rhamdia pentlandi Eigenmann and Eigenmann, 1888, (2), I, 126;

Eigenmann and Eigenmann, 1890, Occ. Papers Cal. Acad. Sci., I, 127;

Eigenmann, 1910, Rept. Princeton Univ. Exped. Patagonia, III, 386.

\section{Peruvian Andes}

Its occurrence in a tributary of Lake Titicaca seems very questionable, as well as the identity of Steindachner's material from northern-central Peru with that collected in the South by Pentland.

Native name Kuntsche applied to this species (Steindachner).

\section{Rhamdia dorsalis Gill}

Rhamdia dorsalis Gill, 1870, Proc. Acad. Nat. Sci. Phila., XXII, 94, Marañon or Napo basin;

Eigenmann and Eigenmann, 1890, Occ. Papers Cal. Acad. Sci., I, 135;

Eigenmann, 1910, Rept. Princeton Univ. Exped. Patagonia, III, 386.

Oriental Peru or Ecuador; known only from the types

\section{Genus 11: IMPARFINIS Eigenmann and Norris}

Imparfinis Eigenmann and Norris, 1900, Revista Mus. Paulista, IV, 351.

Type: Imparfinis piperatus Eigenmann and Norris

Southeastern Brazil to Upper Marañon

A genus of doubtful validity. "Cheeks to opercle covered with thin skin; head depressed; anal short; dorsal spine not pungent; eye small, without free margin." (Gosline). 


\section{Imparfinis bolivianus Pearson}

Imparfinis bolivianus Pearson, 1924, Ind. Univ. Studies, no. 64, 12, pl. ii, fig. 3, Huachi, Bolivia; Pearson, 1937a, Proc. Cal. Acad. Sci., (4), XXIII, 92, Pusoc, Upper Marañon.

\section{Intercordilleran streams of eastern Peru and Bolivia}

\section{Genus 12: PIRANIUTANA Bleeker}

Piramutana Bleeker, 1863, Tederl. 'Tijdsch. Dierk., I, 99;

Eigenmann and Eigenmann, 1890, Occ. Papers Cal. Acad. Sci., I, 186.

\section{Type: Bagrus piramuta Bleeker}

Amazon and tributaries

Top of head and occipital processes granulated, covered with skin; occipital processes separated a little from dorsal plate; the teeth cardiform and forming an uninterrupted band on vomer and palatines; maxillary barbels flattened and bandlike.

\section{Piramutana piramuta (Bleeker)}

Bagrus piramuta Iiner, 1857, Sitzb. KK. Akad. Wiss. Wien, XIVI, 382.

Piramutana piramuta Bleeker, 1863, Nederl. Tijdsch. Dierk., I, 99;

Günther, 186t, Cat. Fish. Brit. Mus., T, 111;

Eigenmann and Eigenmann, 1890, Occ. Papers Cal. Acad. Sci., I, 186;

Fowler, 1939 (1940), Proc. Acad. Nat. Sci. Phila., XCI, 22t, two, 233 and 248 mm., Contamana.

The Amazon and its tributaries

\section{Genus 13: NANNORHAMDIA Regan}

Nannorhamdia Regan, 1913, Ann. Mag. Nat. Hist., (8) XII, 467;

Eigenmann, 1922, Mem. Carnegie Mus., IX, 39.

\section{Type: Nannorhamdia spurrelli Regan \\ Colombian streams to oriental Bolivia}

Closely allied to Rhamdia and especially to Chasmocranus, differing from the former in the much larger frontal fontanel and the large occipital fontanel, with the upper margin of the orbit free; differing from the latter in the narrower band of premaxillary teeth without the backward-projecting angle; the dorsal and pectoral spines much feebler than in Rhamdella.

\section{Nannorhamdia longicauda (Boulenger)}

Pimelodus longicauda Boulenger, 1887, Proc. Zool. Soc. London, 275, pl. xx, fig. 2, Canelos. Rhamdia longicauda Eigenmann and Eigenmann, 1888, Proc. Cal. Acad. Sci., (2), I, 126; Eigenmann and Eigenmann, 1890, Occ. Papers Cal. Acad. Sci., I, 135; Eigenmann, 1910, Rept. Princeton Univ. Exped. Patagonia, III, 386; Pearson, 1937a, Proc. Cal. Acad. Sei., (4), XXII, 92, forty-one specimens from Paipay and Tingo de Pauca, upper Marañon. 


\section{Inter-cordilleran streams of northern Peru and Ecuador}

Noteworthy for the great prolongation of the upper caudal lobe.

\section{Genus 14: PIMELODELLA Eigenmann and Eigenmann}

Pseudorhamdia Steindachner, non Pseudorhamdia Bleeker, 1876, Sitzb. KK. Akad. Wiss. Wien, LXXIV, 46, lateristriga.

Pimelodella Eigenmann and Eigenmann, 1888, Proc. Cal. Acad. Sci.,(2), I, 131, cristatus;

Eigenmann and Eigenmann, 1890, Occ. Papers Cal. Acad. Sci., I, 147;

Eigenmann, 1910, Rept. Princeton Univ. Exped. Patagonia, III, 338;

Eigenmann, 1917, Mem. Carnegie Mus., VII, 251-255, pls. xxxiii and xxxiy;

Eigenmann, 1922, Mem. Carnegie Mus., IX, 28 and 41.

Type: Pimelodus cristatus Müller and Troschel

Panama and Pacific coast of Ecuador to La Plata

Differing from the nearby Pimelodus in the remote nares; the persistent frontal and parietal fontanels; the occipital process narrow and uniform in width throughout, and extending to the dorsal plate; head covered with non-granular skin; anal short (11-15 rays), less than adipose; dorsal and anal rounded; maxillary barbels well-developed, reaching to end of pectoral or beyond the caudal; mental barbels two pairs, sometimes attached in a straight line transversely; pectoral spine shorter than its rays.

\section{Pimelodella puruensis Fowler}

Pimelodella puruense Fowler, 1915, Proc. Acad. Nat. Sci. Phila., 21t, fig. 4, Peruvian Amazon. Pimelodella puruensis Eigenmann, 1917, Mem. Carnegie Mus., VII, 240.

\section{Peruvian Amazon}

A species known only from the type specimen, $52 \mathrm{~mm}$. in length, which is possibly the young of another species; upper caudal lobe not strongly developed, but equal to lower; pectoral spine smooth in front, with about nine thorns on inner margin; no lateral band; maxillary barbels reaching origin of ventrals.

\section{Pimelodella roccae Eigenmann Plate X, figs. 4 and $4 \mathrm{a}$}

Pimelodella roccae Eigenmann, 1917, Mem. Carnegie MIus, VII, 240, nom. nud.

Pearson, 1924, Ind. Univ. Studies, no. 64, 14, Beni basin, Bolivia, nom. mud.

Middle Urubamba and Beni basin of Bolivia

, M.C.Z., type, 182 mm., paratype, 118 mm., Rio Comberciato, 1800 feet elevation, Edmund Heller.

Description of the type: head 4.5-5; depth 5.33-5.66; D. I, 6 ; A. 12 ; adipose fin 3 in the length; maxillary barbel extending to the base of the anal in the larger, to its tip in the smaller; outer mental barbel to near tip of pectoral; eye 6 in the head, 2.75 in the snout, 1.5 in the interorbital; interorbital 4 in the head; depth of 
caudal peduncle 10-11 in the length; length of head in the type $30.5 \mathrm{~mm}$; dorsal spine $21 \mathrm{~mm}$.; pectoral spine $23 \mathrm{~mm}$.; dorsal spine roughened near the tip in front, its posterior margin smooth; basal two thirds of pectoral spine with about twelve small hooks and a ridge of coalesced hooks (nine hooks in the paratype and no ridge); humeral process extending not quite to middle of pectoral spine in the type, beyond middle in the paratype. Caudal deeply forked, upper lobe much the longer, about 3.5 in the length.

Type with obscure lateral band; the paratype plain ashy.

Pearson's Bolivian specimens have the upper caudal lobe not much produced; maxillary barbels reaching beyond tip of ventrals; numerous minute teeth on the pectoral spine. The specimens collected in forest pools are of dark color, and the maxillary barbels reaching to or slightly beyond the anal.

For the Inca Rocca, the first of the great Incas, proclaimed sovereign by the people, under direction of his mother, Siuyacu, the ladies of the court having an active part in shaping history, then as always.

\section{Pimelodella lateristriga (Müller and Troschel)}

Pimelodus lateristrigus Müller and Troschel, 1849, Horae Ichth., III, 3.

Pimelodas lateristriga Günther, 1861, Cat. Fish. Brit. Mus., V, 118.

Pimelodella lateristriga Eigenmann and Eigenmann, 1888, Proc. Cal. Acad. Sci., (2), I, 133, Brazil;

Eigenmann and Eigenmann, 1890, Occ. Papers. Cal. Acad. Sci., I, 156;

Eigenmann, 1910, Rept. Princeton Univ. Exped. Patagonia, III, 389;

Eigenmann, 1917, Xem. Carnegie Mus., VII, 245.

Atlantic drainage Maranon and Parahyba northward

15867, 2, 121 and 135 mm., Puerto Melendez, Alto Marañon, Allen, October, 1920.

\section{Pimelodella BuChleyi (Boulenger)}

Pimelodus lateristriga Cope, non Müller and Troschel, 1872, Proc. Acad. Nat. Sci. Phila., 270, Rio Ambyiacu, two, $160 \mathrm{~mm}$.

Pimelodus buchleyi Boulenger, 1887, Proc. Zool. Soc. London, 275, pl. xx, fig. 1, two, $150 \mathrm{~mm}$, Canelos.

Pimelodella buckleyi Eigenmann and Eigenmann, 1888, Proc. Cal. Acad. Sci., (2), I, 133, Brazil; Eigenmann and Eigenmann, 1890, Occ. Papers Cal. Acad. Sci., I, 158; Eigenmann, 1910, Rept. Princeton Univ. Exped. Patagonia, III, 389; Eigenmann, 1917, \em. Carnegie Mus., VII, 240.

Amazon and tributaries, Peru to Rio Parahyba

15860, 7, 67-129 mm., Rio Ucayali, Contamana, Allen, August, 1920.

15861, 1, $92 \mathrm{~mm}$, creek, Yurimaguas, Allen, November, 1920.

\section{Pimelodella hartwelit Fowler}

Pimelodella hartwelli Fowler, 1939 (1940), Proc. Acad. Nat. Sci. Phila., XCI, 222, figs. $4-7$.

One specimen, the type, Contamana. 


\section{Pimelodella hasemani Eigenmann}

Pimclodella lateristriga Eigenmann and Eigenmann (part), 1890, Oce. Papers Cal. Acad. Sci., I. 156 Pimelodella hasemani Eigenmann, 1917, MIem. Carnegie MIus., VII, 241, pl. xxx, fig. 1.

\section{Valleys of the upper Amazon and Madeira}

15862, 6, 93-120 mm., Rio Morona, Allen, October, 1920.

15863, 9, 43-77 mm., creek Rio Morona, Allen, October, 1920.

$15864,4.60-122 \mathrm{~mm}$., Rio Huallaga, Yurimaguas, Allen, November, 1920.

15865, 8, 63-78 mm., Rio Paranapura, Yurimaguas, Allen, November", 1920.

\section{Pimelodella boliviana Eigenmann}

Pimelodella boliviana Eigenmann, 1917, Mem. Carnegie Mus., VII, 245, pl. xxxi, fig. 2, Santa Cruz de la Sierra, Bolivia.

Peruvian and Bolivian piedmont

15866, 7, 60-92 mm., Lago Cashiboya, Allen, August 1920.

38. Pimelodella cristata Müller and Troschel

Pimelodus cristatus Müller and Troschel, in Schomburgk, 1848, Brit. Guiana, 628;

Müller and Troschel, 1849, Horae Ichth., III, 4, Essequibo;

Günther, 1864, Cat. Fish. Brit. Mus., V, 117 ;

Steindachner, 1882 (1883), Denksch. KK. Akad. Wiss. Wien, XLVI, 4, Rio Huallaga.

Pimelodella cristatus Eigenmann and Eigenmann, 1888, Proc. Cal. Acad. Sci.., (2), I, 132;

Eigenmann and Eigenmann, 1890, Occ. Papers. Cal. Acad. Sci., I, 150.

Pimelodus agassizii Steindachner, 1876, Sitzb. KK. Akad. Wiss. Wien, LXXIV, 99, Peruvian Amazon.

Pimelodus ophthalmicus Cope, 1878, Proc. Amer. Phil. Soc., XVII, 675, Peruvian Amazon.

Pimelodella cristata Eigenmann, 1910, Rept. Princeton Lniv, Exped. Patagonia, III, 388;

Eigenmann, 1917, Mem. Carnegie Mus., VII, 236.

Whole of Amazon basin southward to C. San Roque

15958

, Iquitos, Morris, 1922.

39. Pimelodella montana Allen, sp. nov.

Plate XIII, fig. 2

17830, 5, 86-91 mm., standard length, Rio Huallaga, Huánuco, Allen, October, 1918.

While the Pimelodellas are generally fishes of moderate elevation, hitherto known to reach occasionally up to 1800 feet, the present species was collected at three times that height above sea level. Near cristata on the basis of the structure of the pectoral spine, but differing in the dark head and lateral band.

Head 4.3-4.5; depth 5.3-5.4; adipose fin 3.2-3.7 in the length, tapering toward the head, the latter half being of about uniform depth; D. I, 6, truncate; P. I, 8-9; V. 7; A. 8-9. Pectoral spine 1.8 in head, serrae on its hind margin smooth and not retrorse, strongest on the middle third, diminishing proximally, and wanting on the distal fourth; serrae of its cephalic margin strong on the distal half, diminishing to the point of extinction on the proximal half. 
Pectorals reaching middle of dorsal, dorsal beyond base of ventral, ventral to the middle point between the anus and anal fin, end of anal not to end of adipose, caudal bifurcated more than half its length.

Eye 4 in head; in interorbital space 1.2-1.5; $1.4-1.5$ in the snout; width of head in its length 1.6: mouth 2.4-2.7 in the length of the head; maxillary barbels reaching to the adipose; outer mental barbels not nearly to ventrals; inner mental to pectorals.

Color darker than other species, nearly black on head to light brown below. Blue-black line from opercle along lateral line to middle caudal rays.

Name in allusion to its mountainous habitat.

40. Pimelodella peruana Eigenmann and Myers, sp. nov.

Plate III, fig. 5

15868, 1, $52 \mathrm{~mm}$., type, Inahuaya, Rio Ucayali; also paratype from same locality, very minute, Allen, August 22, 1920.

Allied to $P$. transitoria, $P$. hartii, and $P$. meeki.

Head 4.66 in length to basal of caudal; adipose 4.25 in the same, reaching just past vertical of tip of appressed anal fin. Distance from snout to dorsal 3 in length to base of caudal. Eye 4.16 in head length; interorbital 4.5 in same; width of head somewhat greater than snout plus eye; snout equals $\frac{4}{5}$ of postorbital part of head; width of occipital process 3 in its length.

Anterior border of pectoral spine with three weak serrations near the end, and numerous very evident rugosities near the basal part; posterior border with ten strong thorns, the first being proximal of the third serration of the anterior border; pectoral spine equals head less opercle, slightly longer than the dorsal spine; the latter not attenuated.

Maxillary barbels extending past tip of ventrals, but not quite reaching to anal fin.

Dorsal I, 6 ; A. I, 12; no mucous pores on head; caudal lobes equal, 1.25 in the length of the head.

Coloration silvery, with a darkish lateral-line streak and a humeral spot; supraoccipital dark; dorsal plain.

\section{Pimelodella Cyanostigma (Cope)}

Rhamdia cyanostigma Cope, 1870, Proc. Amer. Phil. Soc., XI, 569, Pebas;

Eigenmann and Eigenmann, 1890, Oce. Papers Cal. Acad. Sei., I, 164.

Pimelodus cyanostigma Cope, 1878, Proc. Amer. Phil. Soc., XVII, 675;

Eigenmann, 1910, Rept. Princeton Univ. Exped. Patagonia, III, 388.

Pimelodella cyanostigma Fowler, 1915, Proc. Acad. Nat. Sci. Phila., 218;

Eigenmann, 1917, Mem. Carnegie Mus., VII, 242.

Known only from the types from Pebas, in the Philadelphia Academy collections. Nay be a Rhamdia, inasmuch as the pectoral spines are broken off. Native helpers must be watched carefully to forestall this type of mutilation, when collect- 
ing, done in the interest of safety. Specimens in the markets are invariably marred in this respect, although perfect otherwise.

\section{Pimelodella gracilis (Cuvier and Valenciennes)}

Pimelodus gracilis Cuvier and Valenciennes, 1840, Hist. Nat. Poiss., XV, 181;

Valenciennes, 18t7, Voy. d'Orbigny, atlas II, pl. ii, fig. 5;

Günther, 1864, Cat. Fish. Brit. Mus., V, 121.

Pimelodella gracilis Eigenmann and Eigenmann, 1888, Proc. Cal. Acad. Sci., (2), I, 132;

Eigenmann and Eigenmann, 1890, Oce. Papers Cal. Acad. Sci., I, 153;

Eigenmann, 1910, Rept. Princeton Univ. Exped. Patagonia, III, 389;

Eigenmann, 1917, Mem. Carnegie Mus., VII, 238;

Pearson, 1937a, Proc. Cal. Acad. Sci., (4), XXIII, 92, Tingo de Pauca and Pusoc, upper Marañon.

\section{La Plata to the Orinoco}

\section{Genus 15: PIMELODUS Lacépède}

Pimelodus Lacépède, 1803, Hist. Nat. Poiss. V, polygeneric $s p$;

Cuvier, 1817, Règne Anim., II, 203 (restricted to species having only a single band of teeth in the upper jaw);

Swainson, 1837, Fish. Amph. Rept., II, 305, quadrimaculatus;

Eigenmann and Eigenmann, 1890, Occ. Papers Cal. Acad. Sei, I, 162;

Eigenmann, 1910, Rept. Princeton Univ. Exped. Patagonia, III, 388;

Eigenmann, 1912, Mem. Carnegie Mus., V, 171.

Type: Pimelodus maculatus Lacépède (Silurus quadrimaculatus Bloch)

All South America southward to La Plata and westward to the Andes

Edentulous palate (teeth on pterygoid in one species); vomerine teeth in small patches or wanting; fontanel not extending past the eyes; humeral process broad and not spine-like; crown of the head granulose; dorsal I, 6; dorsal and pectoral spines stout; eye with free orbital margin; barbels terete.

\section{Pimelodus pictus Steindachner}

Pimelodus pictus Steindachner, 1876, Sitzb. KK. Akad. Wiss. Wien, LXXIV, 96, Peruvian Amazon; Eigenmann and Eigenmann, 1888, Proc. Cal. Acad. Sci., (2), I, 13t, Hyavary;

Eigenmann and Eigenmann, 1890, Occ. Papers Cal. Acad. Sci., I, 170;

Eigenmann, 1910, Rept. Princeton Univ. Exped. Patagonia, III, 388.

\section{Peruvian tributaries of Amazon to Hyavary}

15754, 9, 97-105 mm., Rio Huallaga, Yurimaguas, Allen, November, 1920.

15755, 1, 105 mm., Rio Paranapura, Yurimaguas, Allen, November, 1920.

15756, 1, $92 \mathrm{~mm}$., mouth Rio Pacaya, Allen, August, 1920.

15757, 3, 9t-10t mm., Rio Morona, Allen, August, 1920.

Steep profile flattened on interorbital region; postorbital region much rounded transversely; occipital process keeled; head bones granular; premaxillary band of teeth projecting; vomerine teeth in small patches; eye $3.5 \mathrm{in}$ head, 1.33 in the snout, 1.2 in the interorbital; maxillary barbels extending slightly beyond base of adipose or to the caudal; mental barbels to the base of the pectoral; postmental to the tip 
of the pectoral. Distance of the dorsal spine from the snout 2.5 in the length; dorsal spine equal to head, serrated on its posterior margin, slightly so near the tip on front margin, finely granular below; distance of the adipose fin from the dorsal equals length of adipose and is contained 6 times in the length. Caudal deeply forked, longer than head; pectoral spine strongly serrated on both sides, the serrations a little stronger on the inner side. Silvery below, brownish above; faint darker areas on the back, bases and tips of dorsal rays, tip of adipose, caudal lobes black.

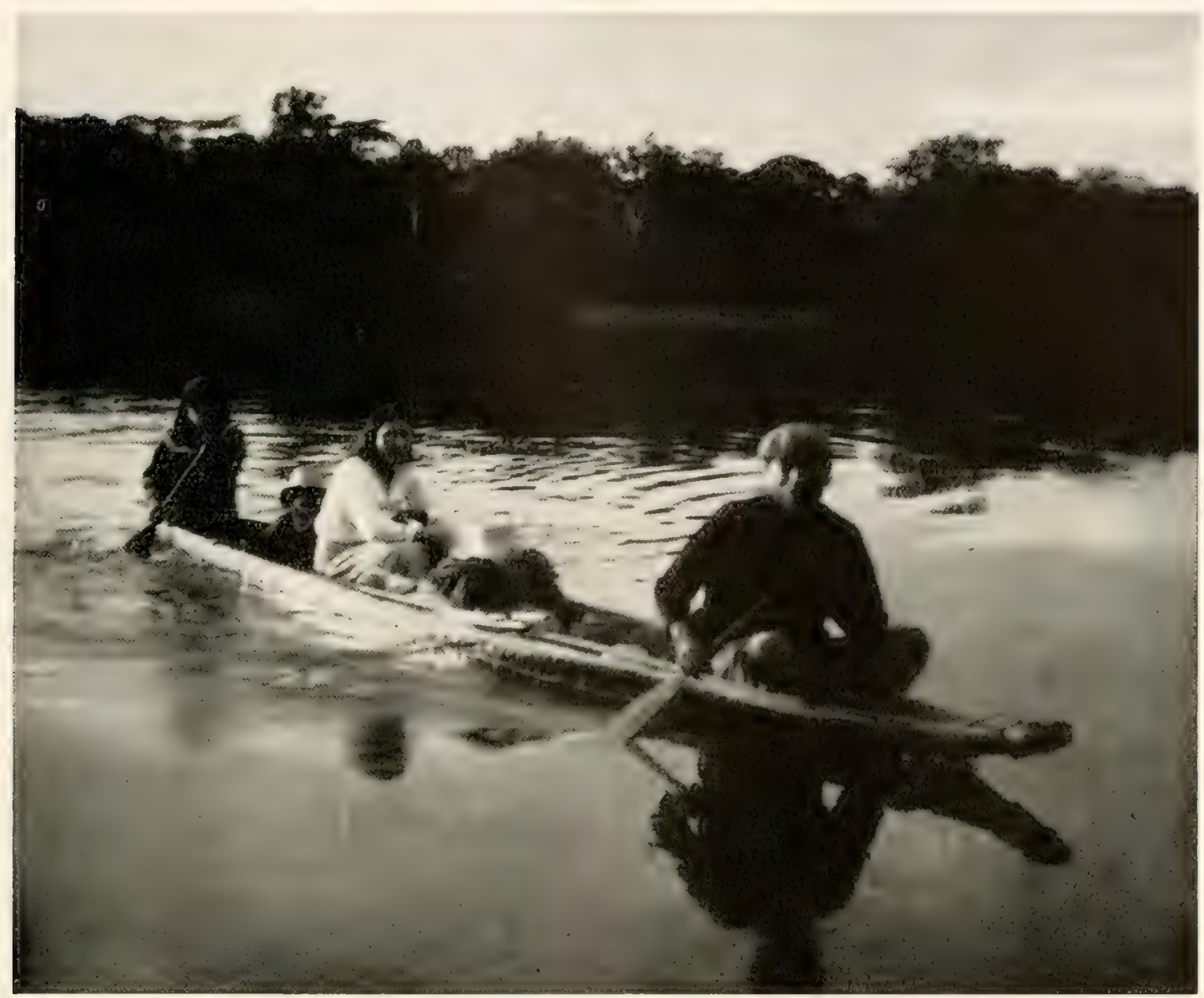

Fig. 16. The lower Pachitea river. Such craft of the lighter type are used for local travel, for fishing, hunting, etc.

\section{Pimelodus ornatus Kner}

Pimelodus ornatus Kner, 1857, Sitzb. KK. Akad. Wiss. Wien, XXVI, 411, fig. 18, Surinam to Rio Negro;

Günther, 1864, Cat. Fish. Brit. Mus., V, 116, Para;

Eigenmann and Eigenmann, 1888, Proc. Cal. Acad. Sci., (2), I, 134;

Eigenmann, 1910, Rept. Princeton Univ. Exped. Patagonia, III, 388;

Eigenmann, 1912, Mem. Carnegie Mus.; V, 175;

Pearson, 1937a, Proc. Cal. Acad. Sci., (4), XXIII, 92, Pusoc, upper MIarañon.

Pimelodus ornata Eigenmann and Eigenmann, 1890, Occ. Papers Cal. Acad. Sci., I, 168. 


\section{Peruvian Amazon to Paraguay and the Caribbean}

15753, 1, 175 mm., Rio Paranapura, Yurimaguas, Allen, November, 1920.

Nearly straight profile, snout projecting; premaxillary band of teeth nearly double the width of the mandibular; dorsal spine short, not nearly reaching tip of last ray, conspicuous dark spot on anterior half; caudal rounded.

\section{Pimelodus clarias (Bloch)}

Silurus clarias Bloch, 1795, Ausl. Fische, pl. xxxv, figs. 1 and 2.

Pimelodus clarias Lacépède, 1803, Hist. Nat. Poiss., V, 93;

Castelnau, 1855, Anim. Amér. Sud, Poiss., 34, Rio Ucayali;

Steindachner, 1882 (1883), Denksch. KK. Akad. Wiss. Wien, XLVI, 1, one specimen from the Huallaga;

Eigenmann and Eigenmann, 1888, Proc. Cal. Acad. Sci., (2), I, 134;

Eigenmann and Eigenmann, 1890, Oce. Papers Cal. Acad. Sci., I, 171, (with five subspecies described but unnamed);

Eigenmann, 1910, Rept. Princeton Univ. Exped. Patagonia, III, 388.

Pseudorhamdia piscatrix Cope, 1870, Proc. Amer. Phil. Soc., XI, 569;

Cope, 1872, Proc. Acad. Nat. Sci. Phila., XXIII, 262, Ambyiacu;

Cope, 1878, Proc. Amer. Phil. Soc., XVII, 674, Peruvian Amazon.

All South America La Plata northward, Andes eastward

(All measurements are to end of middle caudal rays).

$15799,4,183-210 \mathrm{~mm}$., Rio Pachitea, Allen, July, 1920.

15800, 3, 121-150 mm., Gosulimacocha, Rio Morona, Allen, September, 1920.

$15851,6,157-214 \mathrm{~mm}$., Iquitos, Allen, September, 1920.

15852, 3, 177-196 mm., Lago Sanango, Yurimaguas, Allen, November, 1920. Dorsal spine longer than head in two.

15853, 6, 151-186 mm., Manaos, Brazil, Allen, December, 1920.

15854, 5, 90-127 mm., Rio Ueayali, Contamana, Allen, August, 1920.

15855 , 10, 59-92 mm., Lago Cashiboya, Allen, August, 1920.

15856, 1, $88 \mathrm{~mm}$., Rio Marañon below mouth of Pastaza, Allen, October, 1920.

15857, 2, 73-84 mm., Rio Ucayali, near Orellana, Allen, August, 1920.

Differing from pictus in the want of brown bars on the caudal. Anal emarginate; no conspicuous dark area on dorsal, but sides may be variously streaked or plain; profile steep, snout narrow and not sharply snouted; pectoral spine with anterior margin nearly smooth, dorsal spine weakly serrate.

Surface feeders, often seen acting as scavengers of waste thrown from the boatlandings and decks of steam launches. Recognizable in their muddy habitat from the long, plumbeous to black barbels which break the surface-film and lie along the surface, moving in serpentine fashion ahead of, and about, the fish.

\section{Pmelodus leptus Eigenmann and Pearson, sp. nov.}

Plate IV, fig. 3

15858, 1, type, 175 mm., Rio Pachitea, Allen, July, 1920.

Closely related to $P$. westermanni and $P$. altissimus, from which it differs in possessing a slightly larger eye, longer adipose, and longer barbels. 
Head 5 ; depth 5.9 ; D. 1,6 ; A. 10 ; eye 4 ; interorbital 3.5 ; width of the head 1.45 in its length, moderately convex above; occipital bone with lines radiating anteriorly and posteriorly from the fontanel; occipital fontanel $\frac{1}{3}$ the length of the eye and $\frac{1}{3}$ as wide as long; the top of the head covered with thin skin; frontal fontanel not quite extending to above the posterior margin of the pupil; eye elliptical, its length only slightly less than the interorbital space; mouth inferior, small; no teeth on the intermaxillary; the lower jaw with a band of fine teeth set in a fleshy cushion; gill membranes separate to below the anterior margin of the eye; gill rakers slender, simple, $\frac{1}{2}$ the length of the gill filament, $\delta+16$; maxillary barbels slightly compressed, extending more than the length of the head beyond the end of the middle caudal rays; outer mental barbels reaching considerably beyond the base of the ventrals, inner mentals beyond the middle of the pectorals; the pectoral and dorsal spines weak, all broken and the tips missing; the basal portion of the posterior margin of the pectoral spine with several weak thorns, the anterior margin slightly roughened; second dorsal ray extending considerably beyond the origin of the adipose when depressed; first soft rays of the pectorals not near reaching base of ventrals; ventrals not reaching anal by a distance equal to one half their length; anal slightly emarginate; distance of the origin of the dorsal from the tip of the snout 3 times in the total length; adipose fin separated from the dorsal by a distance equal to $\frac{2}{3}$ the base of the dorsal, its length 2.9 in the total length; caudal lobes broken and missing.

Iridescent; a dark spot just in front of the origin of the dorsal; dorsal fin with chromatophores on the interradial membrane.

\section{Pimelodus Jivaro Eigenmann and Pearson, sp. nov. \\ Plate IV, fig. 2}

15859, 3, cotypes, $105 \mathrm{~mm}$., Creek, Rio Morona, Allen, October, 1920.

15813, a, 2, 85 and 98 mm., Creek, Rio Morona, Allen, October, 1920.

Close to $P$. clarias, from which it differs by possessing a shorter head, a higher dorsal fin, a longer adipose, and caudal peduncle less deep.

Head 4.2 ; depth 4.75 ; D. I, 6 ; A. 12 ; eye 4 ; interorbital 3.8 to 4 ; width of the head 1.5 in its length, convex above, the surface of the bones granulate; frontal fontanel ending above the posterior edge of the pupil; occipital fontanel remaining as an oval depression; eye elliptical, its length equal to the interorbital width; mouth inferior; most of the band of the intermaxillary teeth exposed, the depth 7 times in the width; no teeth on vomer; gill rakers slender, simple, one half the length of the gill filament, 4-12; maxillary barbels compressed, their length $1 \frac{1}{2}$ times the total length or slightly greater, outer mentals reaching to the origin of the anal, the inner mentals to the middle of the pectoral spine; pectoral spine $\frac{4}{5}$ the length of the head, the posterior margin in the larger specimen has 20 strong, pointed, recurved teeth, the anterior edge with as many smaller teeth; the longest ray of the pectoral almost reaching the base of the ventral; ventrals almost to anal; the anal high, emarginate, the highest ray almost twice as long as the anal base; distance of the origin of the dorsal from the tip of the snout $2 \frac{1}{2}$ times in the total length; dorsal 
spine pungent, its anterior edge smooth, the posterior border with spines, its length 1.1 times the length of the head; adipose fin separated from the dorsal by a distance equal to ${ }_{5}^{3}$ the base of the dorsal, its length $3 \frac{1}{2}-3 \frac{2}{3}$ times in the total length; caudal deeply forked, the lobes narrow.

Iridescent; humeral region darker; dorsal fin with the chromatophores collected on the interradial membranes; border of the adipose with many chromatophores.

For the dominant indigenous tribe of the region, the "head-hunters", or Jivaros. Name supplied by W.R.A.

48. Pimelodus altissimus Eigenmann and Pearson, sp. nov.

Plate V, fig. 5

15797, 1, type, $182 \mathrm{~mm}$. to end of middle caudal rays, Rio Ucayali, near Orellana, Allen, August, 1920.

Characterized by the very long and very high adipose. Closely related to $P$. altipinnis, from which it differs by possessing a much higher dorsal spine, longer pectoral spines, and a steeper predorsal profile.

Head 5 ; depth 4.85 ; D. I, 6 ; A. 12 ; eye 5.66 ; interorbital 3.5 ; width of the head 1.38 in its length; convex above, the surface of the bones granulate; frontal fontanel ending above the posterior margin of the eye; occipital fontanel completely grown over; eye elliptical, its length 1.5 times in the interorbital; mouth inferior, the upper jaw projecting somewhat beyond the lower, exposing one half of the band of intermaxillary teeth; intermaxillary band of teeth 3.5 times as broad as deep; no teeth on vomer; maxillary barbels compressed, their length 1.33 times the total length, outer mentals reaching slightly beyond the end of the middle caudal rays, the inner mentals slightly beyond the base of the ventrals; pectoral spine almost as long as the head, serrated along the posterior and anterior margins, 36 hooks along the inner margin; pectorals not quite reaching base of ventrals; ventrals not quite to the anal; distance of the origin of the dorsal from the tip of the snout 3.2 times in the total length; dorsal spine pungent, the anterior margin smooth, the posterior margin with a few very weak spines, its length 1.4 times in the length of the head; origin of the adipose immediately behind the base of the dorsal, its length 2.28 in the total length; caudal deeply forked, the lower lobe much narrower than the upper.

Iridescent, an oblong dark spot above the tip of the humeral process; dorsal with the chromatophores thickest on the interradial membrane, the border of the adipose with many chromatophores.

Genus 16: GOELDIELLA Eigenmann and Norris

Goeldiella Eigenmann and Norris, 1900, Revista Mus. Paulista, IV, 353;

Eigenmann, 1910, Rept. Princeton Univ. Exped. Patagonia, III, 388;

Eigenmann, 1912, Mem. Carnegie Mus., V, 177. 
Type: Pimelodus eques Müller and Troschel

Range, that of the unique species

Differing from the nearby Pimelodus and Pimelodella in the unequally lobed and rounded caudal fin, giving it an oblique form.

\section{Goeldiella eques (Mïller and Troschel)}

Pimelodus eques Müller and Troschel in Schomburgk, 1848, Reisen, III, 628; Eigenmann and Eigenmann, 1890, Oce. Papers Cal. Acad. Sci., I, 166. Goeldiella eques Eigenmann and Norris, 1900, Revista Mus. Paulista, IV, 353;

Eigenmann, 1910, Rept. Princeton Univ. Exped. Patagonia, III, 388;

Eigenmann, 1912, Mem. Carnegie Mus., V, 177.

Entire Amazon and northward

15968, 4, 97-185 mm., Iquitos, Morris, 1922.

Head flat; a deep groove from the maxillary barbel to beneath the eye; anal fin peculiar in the rounded form of the free margin, the eighth ray the highest, 2 in the head; dorsal spine rather weak, 1.6 in the head; pectoral spine longer, 1.4 in head, and stronger; strong extrorse teeth on anterior border, and retrorse on the posterior. Gill-membrane edged with white; brownish general color, marbled with darker; a dark spot on shoulder sometimes continued across back, in front of dorsal spine, and backward as lateral band to caudal.

\section{Genus 17: DUOPALATINUS Eigenmann and Eigenmann}

Duopalatinus Eigenmann and Eigenmann, 1888, Proc. Cal. Acad. Sci., (2), I, 136;

Eigenmann and Eigenmann, 1890, Occ. Papers Cal. Acad. Sci., I, 200;

Eigenmann, 1910, Rept. Princeton Univ. Exped. Patagonia, III, 391.

Type: Platystoma cmarginatum Cuvier and Valenciennes Rio São Francisco to the Ucayali

Similar to Brachyplatystoma, differing in that the vomerine and palatine patches of teeth, although uniform, are widely separated; caudal deeply forked, lobes long and pointed; head narrowed at gape; adipose longer than anal.

50. Duopalatinus peruanus Eigenmann and Allen, sp. nov.

$$
\text { Plate IV, fig. } 4
$$

15798, 1, type, $176 \mathrm{~mm}$., to end of middle caudal rays, Rio Puinagua, mouth of Rio Pacaya, Allen, August, 1920.

Head 3.6 ; depth 5 ; D. I, 6 ; A. I, 9 ; head broader than deep, its width equal to its length less the opercle, its depth about equal to the length of the snout; eye with a free margin, a little nearer the end of the opercle than to the tip of the snout, 7 in the head, 2.25 in interorbital; maxillary barbel extending past tip of caudal; outer mental barbel extending to the ventrals; inner mental barbels slightly beyond 
origin of pectorals; gill membranes free from each other and from the isthmus; mouth broad, premaxillary teeth in a rounded band; mandibular band tapered backward; teeth of the roof of the mouth in two vomerine patches, two palatine patches, and two pterygoid patches; lower jaw much shorter.

Lateral line with a series of ossicles diminishing toward the end of the dorsal.

Occipital process extending to the lower plate; fontanel extending to near the posterior margin of the eye.

Dorsal falcate, the spine with feeble hooks behind, slightly roughened in front, equal to snout and eye; first ray considerably longer than the spine; adipose dorsal 3.66 in the length, beginning at the tip of the last dorsal ray; caudal very de eply forked, the upper ray prolonged, nearly equal to the combined dorsal and adipose; anal truncate; pectoral short and broad, the spine short, heavy, pungent, the outer surface rough; the inner surface serrate, the spine about two thirds as long as the dorsal spine, the first ray about equal to the length of the dorsal spine.

Tip of dorsal dark; no distinet markings.

\section{Genus 18: PSEUDOPLATYSTOMA Bleeker}

Platystoma Agassiz, 1829, Sel. Gen. et Spec. Pisc. Bras., 23, sp.

Sorubim Spix, 1829, Sel. Gen. et Spec. Pise. Bras., pls. xii-xv.

Pseudoplatystoma Bleeker, 1863, Nederl. Tijdsch. Dierk., I, 97;

Eigenmann and Eigenmann, 1890, Occ. Papers Cal. Acad. Sci., I, 207;

Eigenmann, 1910, Rept. Princeton Univ, Exped. Patagonia, III, 391;

Eigenmann, 1912, Mem. Carnegie 入Ius., V, 182.

Hemiplatystoma Bleeker, 1863, Nederl. Tijdsch. Dierk., I, 97, tigrinum.

\section{Type: Silurus fasciatus Linnaeus (part) \\ Throughout Amazons, to Surinam}

Head greatly depressed; top of head bony; occipital processes meeting, or nearly meeting, dorsal plate; fontanel extending from the middle of the snout to behind the eyes and continued as a groove to the occipital; width of mouth about equal to the greatest width of the head; upper jaw a little longer than the lower; jaw teeth uniform; vomerine teeth constricted in the middle line, and with palatine teeth in more or less confluent patches, the two forming a comma-shaped area on each side of the palate; gill-rakers short, spinose, not overlapping; caudal deeply cleft, the lobes rounded, with the rays much branched; branchiostegals 14-15; barbels short.

\section{Pseudoplatystoma fasciatum (Linnaeus)}

Silurus fasciatus Linnaeus, 1766, Syst. Nat., ed. xii, I, 505;

Bloch, 1794, Ausl. Fische, VIII, 30, pl. 366;

Bloch and Schneider, 1801, Syst. Ichth., 382.

Pimelodus fasciatum Lacépède, 1803, Hist. Nat. Poiss., V, 94, 99, 100.

Platystoma fasciatum Cuvier and Valenciennes, 1840, Hist. Nat. Poiss., XV, 14;

Günther, 1864, Cat. Fish. Brit. Mus., V, 107;

Cope, 1878, Proc. Amer. Phil. Soc., XVII, 674, Peruvian Amazon; 
Steindachner, 1882 (1883), Denksch. KK. Akad. Wiss. Wien, XLVI, 4, one specimen, 320 mm., Rio Huallaga;

Pseudoplatystoma fasciatum Bleeker, 1863, Nederl. Tijdsch. Dierk., I, 97;

Eigenmann and Eigenmann, 1890, Oce. Papers Cal. Acad. Sci., I, 208;

Eigenmann, 1910, Rept. Princeton Univ. Exped. Patagonia, III, 391;

Eigenmann, 1912, Mem. Carnegie Mus., V, 182;

Fowler, 1939 (1940), Proc. Acad. Nat. Sci. Phila., XCI, 224, Contamana.

Platystoma punctifer Castelnau, 1855, Anim. Amér. Sud, Poiss., t0, pl. xix, fig. 2, Amazon.

La Plata northward to the Magdalena, Orinoco, and Guiana

15763, 2, about 270 and $296 \mathrm{~mm}$., Manaos, Allen, December, 1920.

$15764,1,163 \mathrm{~mm}$., Lago Cashibova, Allen, August, 1920.

, 1, $450 \mathrm{~mm}$., Amazon, Iquitos, Allen, 1920.

Head 3.16; eye small, 14 in head, exactly centered from front to back, 3.3 in flat interorbital space; latter 4.8 in length of head; fontanel long, sharply pointed forward, deep in the middle, less sharp posteriorly, not reaching occipital process; mouth wide, equals isthmus of snout just before the eye, 3.16 in length of head. Occipital process an elongate triangle, its divided tip nearly in contact with the sharply acute anterior angle of the dorsal plate, whose posterior margin forms an are, the entire plate being arrow-shaped. Branchiostegals not entering upper leg of membrane or lateral aspect of head, leaving that portion of opercle a loose flap, but rays prominent below. Barbels three pairs, the narials extending nearly to end of head; the inner pair of mental barbels reach beyond the level of the eye, the posterior pair, inserted posterior and lateral to the preceding, thick, wiry, flattened on one side, taper to a fine filament reaching to the middle of the pectoral fins. Nares with the anterior pair at the edge of the snout guarded by a white flap directed forward; the posterior pair separated by a space one fourth the length of the snout from the preceding, and more than half the interorbital space apart, guarded by similar flaps turned backward.

Prominent patches of sensory canals appear as the skin dries; a narrow band of canals follows the lateral line from the base of the caudal fin forward; beneath the dorsal fin this band widens out so as to form a cornucopia with its mouth at the opercular aperture, where its width is equal to that of the interorbital space; a goodsized patch of canals occurs in the inter- and post-narial region, another forms a narrow area on the preorbital region; a fan-shaped suborbital is confluent with a post-orbital; two large patches occupy the forward border of the opercle. Many of the canals anastomose into a network, and terminate in minute white pustules. The produced premaxillary exposes many of its minute teeth beyond the border of the mandible.

Snout much flattened, its depth contained four times in its width at the level of the posterior nares; greatest width of head contained 2.23 in its length; posterior part of the head trapezoidal in section, becoming a rounded equilateral triangle before the dorsal fin, body tapering with but slight compression to the caudal, the latter part of the trunk being oval throughout.

Ventral, anal, and caudal fins thickened and fleshy; D. I, 6; its spine slender, pointed, long, its fine retrorse hooks limited to a few at the tip, mostly enclosed in 
the skin; pectoral spine much stouter, about I, 9 ; adipose short, just exceeding the interorbital, its depth 2.5 in its length, very fleshy; caudal broad, full, its lobes deeply cleft, and rounded.

Color in alcohol a rich, soft brown becoming nearly black in the middle of the white-bordered bands, and a lighter, diffuse brownish on head and caudal fin, yellow on other median fins, and nearly white on paired fins which are low and horizontal. Bands about 20 in number cross the back and reach the points of widest diameter, mostly beyond the lateral line, and diminishing toward the caudal; continued upward brokenly on the adipose. Series of spots on the dorsal rays not so dark, numerous irregular rows on the caudal fin, fewer and smaller on the anal; the paired fins unmarked.

\section{Genus 19: PHRACTOCEPHALUS Agassiz}

Phractocephalus Agassiz, 1829, Sel. Gen. et Spec. Pisc. Bras., 22, bicolor = hemiliopterus;

Eigenmann and Eigenmann, 1890, Oce. Papers Cal. Acad. Sci., I, 188;

Eigenmann, 1910, Rept. Princeton Univ. Exped. Patagonia, III, 390;

Eigenmann, 1912, Mem. Carnegie Mus., V, 178.

\section{Type: Silurus hemiliopterus Bloch and Schneider}

The range that of the single species

Large nematognath fishes having rather short body and very broad head; upper portion of head with granulations arranged in a vermiculated pattern; occipital process broad, semicircular, rounded on its caudal margin, not reaching to dorsal plate; latter broadly reniform; adipose fin somewhat rayed distally; vomerine teeth contiguous to palatine, in large pentagonal patches; barbels subterete; caudal forked.

\section{Phractocephalus hemiliopterus (Bloch and Schneider)}

Silurus hemitiopterus Bloch and Schneider, 1801, Syst. Ichth., 385.

Phractocephalus hemiliopterus Cuvier and Valenciennes, 1840, Hist. Yat. Poiss, XV, 3, pl. 421 ; Castelnau, 1855, Anim. Amér. Sud, Poiss., 47, pl. xv, fig. 4;

Güther, 186t, Cat. Fish. Brit. Mus., V, 110;

Cope, 1878, Proc. Amer. Phil. Soc., XVII, 674, Peruvian Amazon;

Eigenmann and Eigenmann, 1890, Occ. Papers Cal. Acad. Sci., I, 188;

Eigenmann, 1910, Rept. Princeton Univ. Exped. Patagonia, III, 390;

Eigenmann, 1912, Mem. Carnegie Mus., V, 178.

Phractocephalus bicolor Agassiz, 1829, Sel. Gen. et Spec. Pisc. Bras., 23.

Amazon and Marañon northward

15951, 1, 310 mm., Iquitos, Morris, 1922.

Specimens of appropriate size for preservation were not collected by Allen. The largest, about four feet in length, was harpooned on the Rio Puinagua at Bretana, in the eddy at the outlet of the Rio Pacaya. Others approaching that size were seen at the Iquitos market. 
Genus 20: SCIADES Müller and Troschel

Sciades Müller and Troschel, 1819, Horae Ichth., III, 8, sp;

Bleeker, 1858, Ichth. Arch. Ind. Siluri, 62 and 66, pictus;

Eigenmann and Eigenmann, 1890, Oce. Papers Cal. Acad. Sci., I, 190;

Eigenmann, 1910, Rept. Princeton Unir. Exped. Patagonia, III, 390.

Type: Bagrus pictus Müller and Troschel

\section{The Amazons}

Differentiated from other genera chiefly by the longer dorsal fin with its 10 or 11 rays; and by the smaller patches of palatine teeth remote from the vomerine and transversely arranged.

\section{Sciades marmoratus Gill}

Sciades marmoratus Gill, 1870, Proc. Acad. Nat. Sci. Phila., XXII, 95, Napo or Marañon basin; Eigenmann and Eigenmann, 1890, Oce. Papers Cal. Acad. Sci., I, 192;

Eigenmann, 1910, Rept. Princeton Univ. Exped. Patagonia, III. 390.

Known from specimens taken at Tabatinga and upstream.

\section{Genus 21: BRACHYPLATYSTOMA Bleeker}

Platystoma Cuvier and Valenciennes, 1810, Hist. Nat. Poiss., XV, sp., preoccupied in Diptera;

Brachyplatystoma Bleeker, 1863, Nederl. Tijdsch. Dierk., I, 97, vaillanti;

Eigenmann and Eigenmann, 1890, Occ. Papers Cal. Acad. Sci., I, 194;

Eigenmann, 1910, Rept. Princeton Univ. Exped. Patagonia, III, 390;

Eigenmann, 1912, Mem. Carnegie Mus., V, 179.

Type: Platystoma vaillanti Cuvier and Valenciennes

Amazonia to Guiana and Parahyba

Distinguished from other Pimelodinae by the long, slender, depressible premaxillary teeth; vomerine and palatine teeth villiform; caudal forked deeply; head naked; occipital process short, indistinct, and not reaching the dorsal fin in the adult.

\section{Brachyplatystoma juruense (Boulenger) \\ Plate IV, fig. 1}

Platystoma jumense Boulenger, 1898, Trans. Zool. Soc. London, XIV, 421, pl. xxxix, Rio Juruá. Brachyplatystoma juruense Eigenmann, 1910, Rept. Princeton Univ. Exped. Patagonia, III, 390.

\section{Rio Juruá and Iquitos}

$15953,1,286 \mathrm{~mm}$. to base of middle caudal rays, Iquitos, Morris, 1922.

Head 4 ; depth 5.33 ; D. I, 6 ; A. 5 .

Head depressed, profile to base of occipital process straight, the process not nearly reaching dorsal plate; anterior margin of eye near center of the head; eye 8 in snout, 16 in length of head, 4.5 in interorbital; maxillary barbel flat, reaching to 
base and middle of ventrals; mental barbels just beyond base of pectorals, postmentals to tip of pectorals; groove of fontanel scarcely perceptible; top of head and sides reticulate; opercle with reticulations radiating from its upper anterior corner; premaxillary band of teeth of nearly uniform width, the inner teeth as usual depressible; vomerine patches transversely ovate, the narrow lateral ends in contact with the smaller comma-shaped palatine patches; body villose, velvety, the nap longest in a band along the middle of the sides.

Pectorals lanceolate; the first ray equals the length of the head less the opercle, reaching the ventrals; dorsal very slightly emarginate, the longest ray equal to the length of the first pectoral ray; base of the adipose longer than the base of the dorsal or anal, equal to the length of the snout and eye; caudal very deeply forked, the outer rays very greatly prolonged into filaments; lower ray with its filament 595 $\mathrm{mm}$. long, that is about twice the length of the fish to the base of the middle caudal rays; anal emarginate, the longest ray about reaching the tip of the last, equal to the length of the snout; ventrals less pointed than the rest of the fins, a little less than head without opercles.

Top of head dark ashen, with a small light spot in the middle, immediately in front of the eye; eight or nine dark ashen bars, the first two nearly vertical, the rest extending obliquely downward and forward, the bars somewhat narrower than the light interspaces; the bars not quite symmetrical on the two sides, the one under the dorsal and the one following it joined to form a $\mathrm{Y}$ on the left side, the corresponding bars on the right side separate. Caudal faintly spotted, the other fins uniform in color.

This species has been known hitherto from the type $190 \mathrm{~mm}$. over all. The caudal filaments are of more uniform length, and the dorsal profile at the dorsal fin less arched in the type.

\section{Brachyplatystoma goeldi Eigenmann and Bean}

Brachyplatystoma goeldii Eigenmann and Bean, 1907, Proc. U. S. Nat. Mus., XXXI, 659.

Brachyplatystoma filamentosum Eigenmann (part), 1910, Rept. Princeton Univ. Exped. Patagonia, III, 390.

\section{Peruvian Amazon}

15775, 4, 117-208 mm. to end of middle caudal rays, Iquitos, Allen, September, 1920.

\section{Genus 22: SORUBIM Spix}

Platystoma Agassiz, 1829, Sel. Gen. et Spec. Pise. Bras., sp., preoccupied.

Sorubim Spix, 1829, Sel. Gen. et Spec. Pisc. Bras., 24;

Bleeker, 1863, Nederl. Tijdsch. Dierk., I, 22, lima;

Eigenmann and Eigenmann, 1890, Occ. Papers Cal. Acad. Sci., I, 212;

Eigenmann, 1910, Rept. Princeton Univ. Exped. Patagonia, III, 392.

Pseudoplatystoma Eigenmann (part), 1912, Mem. Carnegie Mus., V, 182. 
Type: Silurus lima Bloch and Schneider

La Plata via Amazons to the Magdalena

A genus of one widely distributed species. Greatly prolonged upper jaw and extremely flattened head; mouth as wide as the widest part of the head; eyes lateral; teeth on the roof of the mouth in four patches forming a horse-shoe, vomerine patches confluent, maxillary band wider than deep; barbels fleshy; adipose fin shorter than anal; dorsal spine midway between snout and posterior extremity of adipose; first lateral line plates broad and thin. Fishes often of very large size.

\section{Sorubim lima (Bloch and Schneider)}

Silurus lima Bloch and Schneider, 1801, Syst. Ichth., 384.

Platystoma lima Agassiz, 1829, Sel. Gen. et Spec. Pisc. Bras., 24.

Sorubim lima Spix, 1829, Sel. Gen. et Spec. Pisc. Bras., 24;

Günther, 186t, Cat. Fish. Brit. Mus., V, 105;

Günther, 1869, Proc. Zool. Soc. London, 423, Bartlett coll.;

Cope, 1878, Proc. Amer. Phil. Soc., XVII, 674, Peruvian Amazon;

Steindachner, 1882 (1883), Denksch. KK. Akad. Wiss. Wien, LXVI, 4, four specimens 150-230 mm., Rio Huallaga;

Eigenmann and Eigenmann, 1890, Occ. Papers Cal. Acad. Sci., I, 213;

Eigenmann, 1910, Rept. Princeton Unir. Exped. Patagonia, III, 392;

Regan, 1913, Ann. Mag. Nat. Hist., (8), XII, 281, Rio Ucayali;

Fowler, 1939 (1940), Proc. Acad. Nat. Sci. Phila., ICI, 225, Contamana.

La Plata drainage to the Magdalena

$15766,1,177 \mathrm{~mm}$., creek, Yurimaguas, Allen, October, 1920.

15767, 3, 230-25t mm., Rio Paranapura, Yurimaguas, Allen, October, 1920.

15768, 2, 172 and $177 \mathrm{~mm}$., Rio Ucavali, Contamana, Allen, July, 1920.

$15769,2,260$ and $280 \mathrm{~mm}$., Rio Ucayali, near Orellana, Allen, August, 1920.

$15770,3,139-145$ mm. Lago Cashiboya, Allen, August, 1920.

$15771,1,214 \mathrm{~mm}$., Rio Pachitea, Allen, July, 1920.

$15773,1, \quad$, Nouth of Rio Pacaya, Allen, September, 1920

15955, 1, $167 \mathrm{~mm}$. ., Iquitos, Morris, 1922.

Steindachner reports a native name chullu-coclla for this species.

\section{Genus 23: PLATYSTOMATICHTHYS Bleeker}

Platystoma Kner (part), 1857, Sitzb. KK. Akad. Wiss. Wien, XXVI, 395, fig. 9, sp.

Platystomatichthys Bleeker, 1863, Nederl. Tijdsch. Dierk,, I, 98;

Eigenmann and Eigenmann, 1890, Oce. Papers Cal. Acad. Sci., I, 217;

Eigenmann, 1910, Rept. Princeton Univ. Exped. Patagonia, III, 392.

\section{Type: Platystoma sturio Kner}

Range that of the unique species

The most extreme of the genera having elongated and flattened snouts, differing from Sorubim mainly in the much greater emphasis of this character, the mouth being 1.5 in the greatest width of the head; teeth of upper jaw in an arrow-shaped patch; palatine patches ovate longitudinally, and widely separated from the romerine patch; maxillary barbels wiry or ossified more than half their length and ex- 
tending far beyond the caudal fin of the fish; eye superior; adipose longer than anal; upper jaw as in Sorubim much produced, and toothed over its entire ventral surface; caudal deeply forked, the lobes pointed and equalling or surpassing half the body length.

\section{Platystomatichthys sturio (Kner)}

Platystoma sturio Kiner, 1857, Sitzb. KK. Akad. Wiss. Wien, XXVI, 395. Platystomatichthys sturio Bleeker, 1863, Nederl. Tijdsch. Dierk., I, 98;

Eigenmann and Eigenmann, 1890, Occ. Papers Cal. Acad. Sci., I, 218;

Eigenmann, 1910, Rept. Princeton Univ. Exped. Patagonia, III, 392.

Fowler, 1939 (1940), Proc. Acad. Nat. Sci. Phila., XCI, 225, figs. 8-10, one, Contamana.

The Amazon system

1565t, 1, $280 \mathrm{~mm}$. to end of middle caudal rays, Iquitos, Allen, September, 1920.

\section{Genus 24: HEMISORUBIM Bleeker}

Platystoma Cuvier and Valenciennes (part), 1840, Hist. Nat. Poiss., XV, 27, preoccupied in Diptera. Hemisorubim Bleeker, 1863, Nederl. Tijdsch. Dierk., I, 97, platyrhynchos;

Eigenmann and Eigenmann, 1890, Oce. Papers Cal. Acad. Sci., I, 205;

Eigenmann, 1910, Rept. Princeton Univ. Exped. Patagonia, III, 391;

Eigenmann, 1912, Mem. Carnegie Mus., V, 181.

\section{Type: Platystoma platyrhynchos Cuvier and Valenciennes}

Peruvian Amazon and São Paolo northward

Among the long-headed genera of Pimelodinae, Hemisorubim is distinguished for the protraction of the lower jaw beyond the upper, the latter being thin and sharply truncate; intermaxillary band of teeth constricted in the center; vomerine patch single and much wider than the above, lying close to the large palatine patches; width of the mouth at its angle 1.5 in the greatest width of the head; mental barbels approximated and near the edge of the lip; occipital process shorter than the dorsal plate and reaching it; postorbital region striate and granulate; sides of head and snout reticulated.

\section{Hemisorubim platyrhynchos (Cuvier and Valenciennes)}

Platystoma platyrhynchos Cuvier and Valenciennes, 18t0, Hist. Nat. Poiss., XV, 27; Castelnau, 1855, Anim. Amér. Sud, Poiss., 40.

Hemisorubim platyrhynchos Bleeker, 1863, Nederl. Tijdsch. Dierk., I, 97;

Eigenmann and Eigenmann, 1888, Proc. Cal. Acad. Sci, (2), 1, 138;

Eigenmann and Eigenmann, 1890, Occ. Papers Cal. Acad. Sci., I, 151;

Eigenmann, 1910, Rept. Princeton Univ. Exped. Patagonia, III, 391;

Fowler, 1939 (1940), Proc. Acad. Nat. Sci. Phila., XCI, 224, Contamana. Hemisorubim platyrhynchus Günther, 1864, Cat. Fish. Brit. Mus., V, 109;

Cope, 1878, Proc. Amer. Phil. Soc., XVII, 67t, Peruvian Amazon. 


\section{Marañon to the Orinoco and Paraguay}

15656, 1, $238 \mathrm{~mm}$., Iquitos, Allen, 1920.

$15760,1,300 \mathrm{~mm}$. to base of caudal, Manaos, Allen, December, 1920.

15761, 1, $227 \mathrm{~mm}$., Contamana, Allen, August, 1920.

$15762,1,129 \mathrm{~mm}$. . Lago Cashiboya, Allen, August, 1920.

15956, 1, $253 \mathrm{~mm}$., Iquitos, Morris, 1922.

\section{Genus 25: SORUBIMICHTHYS Bleeker}

Platystoma Agassiz (part), 1829, Sel. Gen. et Spec. Pisc. Bras., sp.

Sorubim Spix (part), 1829, Sel. Gen. et Spec. Pisc. Bras., sp.

Sorubimichthys Bleeker, 1863, Nederl. Tijdsch. Dierk., I, 98, jandia = spatula;

Eigenmann and Eigenmann, 1890, Occ. Papers Cal. Acad. Sci., I, 214;

Eigenmann, 1910, Rept. Princeton Univ. Exped. Patagonia, III, 392.

\section{Type: Platystoma spatula Agassiz}

\section{Orinoco and Amazon systems}

Snout much projected and very broad; eyes superior; teeth of upper jaw in a very deep band, those of roof of mouth in two patches; barbels fleshy; adipose shorter than anal.

\section{Sorubinichthys planiceps (Agassiz)}

Platystoma planiceps Agassiz, 1829, Sel. Gen. et Spec. Pisc. Bras., 25, Rio Negro to upper Amazon; Cuvier and Valenciennes, 1810, Hist. Nat. Poiss., XV, 19, Brazil.

Sorubimichthys planiceps Eigenmann and Eigenmann, 1888, Proc. Cal. Acad. Sci., (2), I, 139;

Eigenmann and Eigenmann, 1890, Oce. Papers Cal. Acad. Sci., I, 215;

Eigenmann, 1910, Rept. Princeton Univ. Exped. Patagonia, III, 392.

Sorubimichthys ortoni Gill, 1870, Proc. Acad. Nat. Sci. Phila., XXII, 94, Napo or Marañon basin.

Amazon and Orinoco basins

\section{Sorubimichthys gigas (Gïnther)}

Platystoma gigas Günther, 1872, Ann. Mag. Nat. Hist., X, 449, Huallaga.

Sorubimichthys gigas Eigenmann and Eigenmann, 1888, Proc. Cal. Acad. Sci., (2), I, 139;

Eigenmann and Eigenmann, 1890, Occ. Papers Cal. Acad. Sci., I, 217;

Eigenmann, 1910, Rept. Princeton Univ. Exped. Patagonia, III, 392.

\section{Rio Huallaga}

May be identical with $S$. planiceps.

$$
\text { Subfamily: LUCIOPIMELODINAE }
$$

With air-bladder reduced and separated from the skin by a fatty layer, not forming a pseudo-tympanum; divided anteriorly into two small lobes.

\section{Genus 26: PERUGIA Eigenmann and Norris}

Perugia Eigenmann and Norris, 1900, Revista MLus. Paulista, IV, 355;

Driver, 1919, proc. Amer. Phil. Soc., IVIII, 448-456;

Eigenmann, 1922, Mem. Carnegie Mus., IX, 34. 


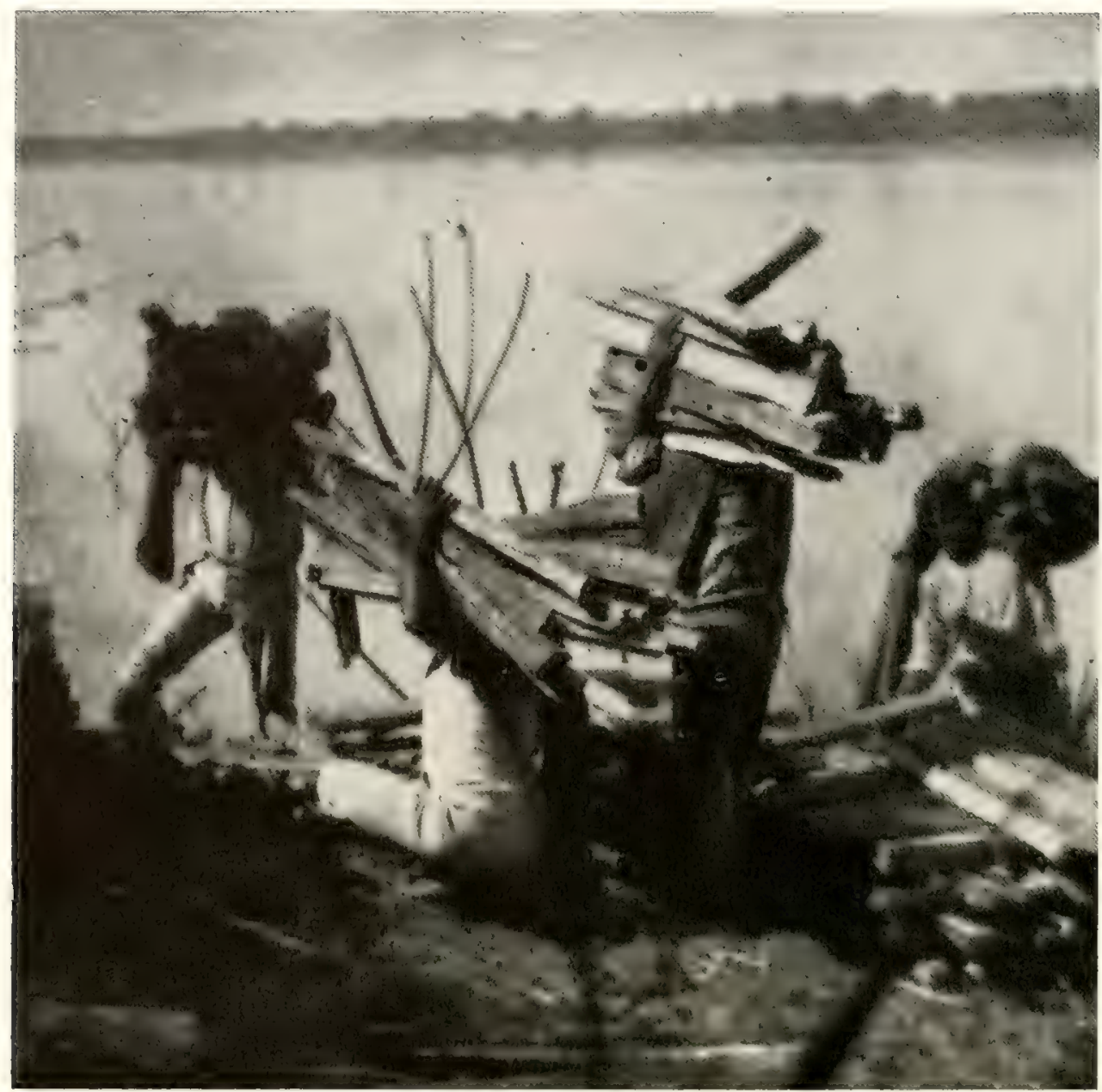

FIG. 17. The Rio Ucayali; a fuel-stop.

Type: Pinirampus agassizi Steindachner

Rio Magdalena to La Plata

Nares remote; gill-membranes free from isthmus; spines of dorsal and pectoral fins weak and lacking pungeney, remaining rays graduated backward; mouth slightly inferior, jaws subequal; palatines edentulous; head small, but much longer than broad; eye large and in middle of head; jaw teeth strong, without backwarddirected angle; mental barbels two pairs; occipital fontanel wanting or reduced to a pore; occipital process narrow, reaching about half way to the dorsal, where it meets a floating interneural attached to the interneural which supports the first dorsal ray.

The generic distinctness of agassizi was recognized by the Eigenmanns in the 1890 monograph, where it was listed under an unnamed genus in the absence of specimens, to be rescued ten years later by Eigenmann and Norris, reduced to synonymy in 1910, and again revived by Driver nine years later and placed in a distinct subfamily with Luciopimelodus. 


\section{Perugia agassizil (Steindachner)}

Pinirampus agassizii Steindachner, 1876, Sitzb. KK. Akad. Wiss. Wien, LXXIV, 57, pl. xii, Para.

?- agassizii Eigenmann and Ligenmann, 1890, Oce. Papers Cal. Acad. Sci., I, 183.

Perugia agassizii Ligenmann and Norris, 1900, Revista Mus. Paulista, IV, 355;

Eigenmann, 1922, Mem. Carnegie Mus., IX, 34.

Luciopimelodus agassizii Ligenmann, 1910, Rept. I'rinceton Univ. Exped. Patagonia, III, 383.

The Amazons

$15657,1,245 \mathrm{~mm}$., Iquitos, Allen, 1920.

$15658,2,169$ and $175 \mathrm{~mm}$., Marañon above mouth of Huallaga, Allen, October, 1920.

15736, 1, 335 mm., Rio Huallaga, Yurimaguas, Allen, November, 1920.

15758, 5, 204-275 mm., Rio Ucayali, near Orellana, Allen, August, 1920.

$1577+, 1,420 \mathrm{~mm} .$, Minaos, Allen, December, 1920.

\section{Subfamily: AUCHENIPTERINAE}

Pimelodidae with both maxillary and mental barbels and lacking lateral plates; gill-membranes united to each other and to the isthmus; nares remote and without barbels; free air-bladder, cervical vertebrae modified, but without lateral processes.

\section{Genus 27: CENTROMOCHLUS Kner}

Centromochlus Kner, 1857 (1858), Sitzb. KK. Akad. Wiss. Wien, XXVI, t30; Eigenmann and Eigenmann, 1890, Oce. Papers Cal. Acad. Sci., I, 266; Eigenmann, 1910, Rept. Princeton Univ. Exped. Patagonia, III, 395; Eigenmann, 1912, Mem. Carnegie Mus., V, 197.

\section{Type: Centromochlus megalops Kner \\ Peru to Guianas and Rio de Janeiro}

Mental barbels arranged by pairs; adipose fin shorter than the short anal which has only $7-11$ rays; mouth terminal, jaws equal; caudal forked; V. 6 ; palatine teeth absent, vomerine occasionally present; D. I, 4-5; humeral process present; occipital process firmly united to dorsal plate; head naked and usually granular.

\section{Centromochlus heckelit (Filippi)}

Auchenipterus heckelii Filippi, 1853, Guer. Rev. et Mag. Zool., 166.

Centromochlus heckelii Günther, 186t, Cat. Fish. I3rit. Mus., V, 197; Cope, 1878, Proc. Amer. Phil. Soc., XVII, 677, Pentian Amazon; Eigenmann and Eigenmann, 1888, Proc. Cal. Acad. Sci., (2), I, 156;

Eigenmann and Eigenmann, 1890, Occ. Papers Cal. Acad. Sci., I, 267; Eigenmann, 1910, Rept. P'rinceton Univ. Exped. Patagonia, III, 395.

Fowler, 1939 (1940), Proc. Acad. Nat. Sei. Phila., XCI, 231, Contamana, one, $71 \mathrm{~mm}$,

\section{Amazon system}

15660, 5, 77-120 mm., Rio Morona, Allen, October, 1920.

15781, 1, $94 \mathrm{~mm}$., Rio Huallaga, Yurimaguas, Allen, October, 1920.

$15782,2,70$ and $90 \mathrm{~mm}$., mouth Rio Pacaya, Allen, August, 1920.

15783, 2, 97 and $95 \mathrm{~mm}$., Iquitos, Allen, September, 1920.

15889, 4, 67-103 mm., Rio Ueayali, near Orellana, Allen, August, 1920. 


\section{Centromochlus steindachneri Gill}

Centromochlus steindachneri Gill, 1870, Proc. Acad. Nat. Sci. Phila., XXII, 95, Napo or Marañon; Eigenmann and Eigenmann, 1890, Occ. Papers Cal. Acad. Sci., I, 268;

Eigenmann, 1910, Rept. Princeton Univ. Exped. Patagonia, III, 395.

Reported only from the Marañon or its tributaries.

15903, 2, 74 and 77 mm., Pebas, University of Michigan Museum.

\section{Centromochlus perugrae Steindachner}

Centromochlus perugiae Steindachner, 1882 (1883), Denksch. KK. Akad. Wiss. Wien, XLVI, 29, pl. vii, figs. 2-2a, Canelos;

Eigenmann and Eigenmann, 1890, Occ. Papers Cal. Acad. Sci., I, 270;

Eigenmann, 1910, Rept. Princeton Univ. Exped. Patagonia, III, 395.

Known only from the Canelos specimens.

65. Centromochlus grrinus Eigenmann and Allen, sp. nov.

Plate V, fig. 4

15795, 1, 55 mm., type, brook near Rio Itaya, Iquitos, Allen, September, 1920.

Head 4.3 ; depth 3.5 ; D. I, 6 ; A. 12; P. I, 4; caudal forked, with numerous fulcra forward to adipose and anal fins; adipose well marked, merging forward into the back; dorsal short, the spine heavy, sharply striate on the sides; spine broad in front with graduated serrae, smooth behind, shorter than head; pectoral spine heavy, longer than head, with antrorse to straight hooks in front, and retrorse hooks behind; ventral with six rays reaching beyond the anus, not quite to the anal papilla; anal papilla fitting into the notch of the anal; anal base contracted.

Lower jaw projecting; jaws with narrow bands of firm teeth; maxillary barbel to tip of humeral process; mental barbels reaching beyond base of postmental, the latter not to base of pectoral; humeral process striate and a series of tubercles; frontal ovate, not open in front, about equal to the eye; eye about 3.3 in the head, 2.5 in the interorbital, 5 in snout; width of head slightly less than its length; spotted and streaked.

Near to $C$. intermedius, and differing in the greater depth, somewhat longer head, and larger eye; anal longer.

\section{Genus 28: TRACHYCORYSTES Bleeker}

Trachycorystes Bleeker, 1863, Nederl. Tỉjdsch. Dierk., I, 88;

Eigenmann and Eigenmann, 1890, Occ. Papers Cal. Acad. Sci., I, 272;

Eigenmann, 1910, Rept. Princeton Univ. Exped. Patagonia, III, 395.

\section{Type: Trachycorystes typus Bleeker}

Rio Magdalena and Peru to Rio de Janeiro

Separable from the preceding by the much longer anal, 19-41; caudal truncate or emarginate; mental barbels paired off; lower jaw slightly prolonged; teeth villi- 
form, none on vomer or palatine; eye small and lateral, covered; adipose very short; dorsal short; pectoral with stout, doubly serrate spine; anterior rays of anal enlarged as intromittent organ in male.

\title{
66. Trachycorystes galeatus (Limnaeus)
}

\author{
Plate $V$, fig. 1
}

Silum galeatus Limnaeus, 1766, Syst. Nat. ed. xii, 503, based on Seba, Locupl. Rer. Nat., III, pl. xxix, fig. 7 ;

Bloch, 1795, Ausl. Fische, VIII, 39, pl. 369, fig. 1;

Bloch and Schneider, 1801, Syst. Ichth., 384.

Pimclodus galcatus Lacépède, 1803, Hist. Nat. Poiss., V, 97, and 114.

Auchenipterus galeatus Günther, 1864, Cat. Fish. Brit. Mus., V, 196.

Trachycorystes galeatus Eigenmann and Eigenmann, 1888, Proc. Cal. Acad. Sci., (2), I, 155 ;

Eigenmann and Eigenmann, 1890, Oce. Papers Cal. Acad. Sci., I, 279;

Eigenmann, 1910, Rept. Princeton Univ. Exped. Patagonia, III, 396;

Eigenmann, 1912, Mem. Carnegie Mus., V, 198.

Auchenipterus striatulus Steindachner, 1876, Süsswf. sudöst. Brasil, III, 98

Trachycorystes striatulus Eigenmann and Eigenmann, 1888, Proc. Cal. Acad. Sci., (2), I, 155;

Von Ihring, 1937, Copeia, no. 4, 201.

\section{The Orinoco, Peru to Rio São Francisco}

15794, 8, 114-188 mm., Iquitos, Allen, September, 1920.

$15795,1,55 \mathrm{~mm}$., brook near Rio Itaya, Iquitos, Allen, September, 1920.

$15796,2,100$ and $113 \mathrm{~mm}$., creek, Yurimaguas, Allen, November, 1920.

$15975,1,157 \mathrm{~mm}$., Iquitos, Morris, 1922.

Von Ihring, 1937, eliminates the boundary between the species T. galeatus and striatulus, adhering to the latter name, created by Steindachner, in place of the older Linnean name. In this matter he appears to be guided by the opinion of Starks, 1906, who recognizes no distinction but the differences in the rugosity of the skin of the head, and finds all degrees of rugosity.

Other differences seem to exist, such as finray counts. Our specimens appear very close to the Linnean galeatus.

Our Iquitos specimens may be characterized as follows: stout, bulldog-like, all contours rounded and swollen except the fin insertions; jaws subequal, mandible slightly and roundly projected. Dorsal contour of head nearly straight, back rather straight and strongly notched at fin insertions; ventral contour moderately and uniformly convex; caudal peduncle short and elevated, at its lowest point 1.2 in the interorbital space.

Nares widely spaced, in a rectangle, their valves minute flaps; eye moderate, $5.3 \mathrm{in}$ head, 3.2 in the interorbital; bones of head thickened and finely granular, including the coalesced occipital processes and dorsal plate, to which the dorsal spine is broadly articulated by a ball-and-socket joint. First mental barbel short, half the interorbital space, reaching to base of second mental; the latter longer, reaching to end of pectoral base; maxillary barbel reaching past middle of pectoral spine, lying in a groove which subtends the orbit and opercle to near the extremity 
of the latter; opercular aperture small, low, and equal to interorbital space, margined by a broad flap; mouth moderate, its gape slightly less than half the greatest width of head; a bulbous tympanum arises lateral to dorsal plate on each side, its length equal to internarial space.

Paired fins short and horizontal; adipose very fleshy, short, elevated more than twice its length, its elevation 1.6 in the interorbital space, notched strongly into dorsal contour; D. I, 5, nearly 2 in the interorbital space, its longest ray equal to the interorbital plus the diameter of the orbit, its spine roughened along the anterior border; P. I, 6, spine broad and flat, 1.16 in length of head to end of opercle, about 32 low, antrorse hooks on forward border, about 24 longer retrorse hooks on posterior border; V. much smaller, broad, its longest rays about equal to interorbital space; A. long, low, fleshy, its length equal to that of the head; humeral process long, pointed, and equal to interorbital space; C. rounded, its upper rays the longest, giving the fin an oblique form.

Color light or medium brown, on back and sides, above; lower lateral aspect and belly with yellow ground-color, and diffuse, scattered spots; numerous brownish chromatophores more or less grouped in patches; caudal with a diffuse band of brown describing an obliquely vertical are midway of its rays.

A thick coating of mucus over the entire fish.

\section{Trachycorystes isacanthus (Cope)}

Auchenipterus isacanthus Cope, 1878, Proc. Amer. Phil. Soc., XVII, 677.

Trachycorystes isacanthus Eigenmann and Eigenmann, 1888, Proc. Cal. Acad. Sci., (2), I, 154;

Eigenmann and Eigenmann, 1890, Occ. Papers Cal. Acad. Sci. I, 275;

Eigenmann, 1910, Rept. Princeton Lniv. Exped. Patagonia, III, 396.

Known only from the Marañon.

\section{Trachycorystes Brevibarbus (Cope)}

Auchenipterus brevibarbus Cope, 1878, Proc. Amer. Phil. Soc., XVII, 676.

Trachycorystes brevibarbus Eigenmann and Eigenmann, 1888, Proc. Cal. Acad. Sci., (2), I, 155; Eigenmann and Eigenmann, 1890, Oce. Papers Cal. Acad. Sci., I, 279;

Eigenmann, 1910, Rept. Princeton Unir. Exped. Patagonia, III, 396.

Known only from Cope's material from the Marañon.

69. Trachycorystes coracoideus Eigenmann and Allen, sp. nov.

15794, 3, 128-136 mm., Iquitos, Morris, 1922.

Head broad, its width less than the length; snout broad, the jaws of equal length; eye large, longer than the snout, about 3 in the interorbital, 4 in the length of the head to end of opercle; pit of fontanel long, the fontanel much shorter, separated by a bridge from the anterior pit; head granular, the occipital process broad; the dorsal plate with a descending process behind; humeral process extending to below the downward process of the dorsal plate, nearly horizontal; maxillary barbel 
to the pectoral spine; mental barbel about reaching the postmental, the postmental not to the pectoral; coracoid process granular; dorsal spine reaching from snout to end of opercular membrane, with fine granules on anterior face, and fewer and a little larger spines behind; the pectoral spines reaching to origin or middle of the ventral, with serrae considerably longer than those of the dorsal, the anterior antrorse, the posterior retrorse; gill opening not extending below the dorsal margin of the pectoral spine; ventrals rounded, not extending to anal; anterior anal rays longer, but not falcate; caudal oblique, adipose small but well developed.

Greenish above, light below, shading from the middle of the back to the lateral line, free from chromatophores; upper part of sides with vertical series of pores in pigment-free areas; base of caudal rays pigmented.

Differing from its near ally $T$. galeatus in the granular coracoid process and head wide but narrower than its length.

\section{Genus 29: AUCHENIPTERUS Cuvier and Valenciennes}

Auchenipterus Cuvier and Valenciennes, 1840, Hist. Nat. Poiss., XV, 207, nuchalis;

Eigenmann and Eigenmann, 1890, Oce. Papers Cal. Acad. Sci., I, 294;

Eigenmann, 1910, Rept. Princeton Univ. Exped. Patagonia, III, 397;

Eigenmann, 1912, Mem. Carnegie Mus., V, 202.

Evancmus Müller and Troschel, 1819, Horae Ichth., III, 11, colymbetes.

\section{Type: Hypophthalmus muchalis Spix}

The Guianas and the Amazon

Of the six barbels the two pairs of mentals are disposed in a straight, transverse line near the symphysis; pectorals and ventrals rather long, the former with rays $I, 11$; the latter $12-15$ and posterior to the dorsal; the adipose short, the anal long; the zigzag lateral line with short branches; humeral process usually concealed.

\section{Auchenipterus nuchalis (Spix)}

Hypophthalmus nuchalis Spix, 1829, Sel. Gen. et Spec. Pise. Bras., 17, pl. xvii.

A uchenipterus nuchatis Cuvier and Valenciennes, 1840, Hist. Nat. Poiss., XV, 207;

Eigenmann and Eigenmann, 1888, Proc. Cal. Acad. Sci., (2), I, 151 ;

Eigenmann and Eigenmann, 1890, Occ. Papers Cal. Acad. Sci., I, 295;

Eigenmann, 1910, Rept. Princeton Univ. Exped. Patagonia, I, 397;

Fowler, 1939 (1940), Proc. Acad. Tat. Sci. Phila., XCI, 231, Contamana.

Euanemus muchalis Günther, 186t, Cat. Fish. Brit. Mus., I, 193;

Cope, 1878, Proc. Amer. Phil. Soc., XVII, 676, Peruvian Amazon.

The Amazons to Surinam

Mapara, Fowler, native name

15661, 2, 162 and $203 \mathrm{~mm}$., Rio Morona, Allen, October", 1920.

$15662,7,147-178 \mathrm{~mm}$., Iquitos, Allen, September, 1920.

$15776,1,205 \mathrm{~mm}$., Gosulimacocha, Rio Morona, Allen, October, 1920.

$15777,2,165$ and $253 \mathrm{~mm}$., Rio Huallaga, Yurimaguas, Allen, November, 1920.

$15778,3,197-233 \mathrm{~mm}$. . Manaos, Allen, December, 1920.

15978, 1, $163 \mathrm{~mm}$., Iquitos, Morris, 1922. 
As in the case of the nearby genera, a tough, leathery, insoluble coat of mucus invests these fishes; this remains undiminished after many years in alcohol. The flesh tends to soften.

\section{Auchenipterus brachyurus (Cope)}

Euanemus brachyurus Cope, 1878, Proc. Amer. Phil. Soc., XVII, 676, Peru. Auchenipterus brachyurus Eigenmann and Eigenmann, 1888, Proc. Cal. Acad. Sci., (2), I, 152;

Eigenmann and Eigenmann, 1890, Occ. Papers Cal. Acad. Sci., I, 298;

Eigenmann, 1910, Rept. Princeton Univ. Exped. Patagonia, III, 397.

Known from the types at Philadelphia.

\section{Genus 30: PSEUDAUCHENIPTERUS Bleeker}

Pseudauchenipterus Bleeker, 1863, Nederl. Tijdsch. Dierk., I, 88;

Eigenmann, 1910, Rept. Princeton Univ. Exped. Patagonia, III, 396.

Felichthys Swainson, 1839, Fish. Amph. Rept., II, 305;

Swain, 1882, Proc. Acad. Nat. Sci. Phila., 281;

Eigenmann and Eigenmann, 1890, Occ. Papers Cal. Acad. Sci., I, 285.

Type: Silurus nodosus Bloch

Lower courses of rivers Atlantic seaboard; Ucayali river

The genus is characterized by the emarginate anal fin and forked caudal; smooth outer margin of pectoral spine, sometimes granular; head longer than wide, but lower jaw shorter than upper; mental barbels in two pairs; eye large, lateral, covered with skin; palate and vomer edentulous; teeth villiform; bones of head thick, covered with skin.

\section{Pseudauchenipterus nodosus (Bloch)}

Silurus nodosus Bloch, 1794, Ausl. Fische, viii, 35, pl. 368, fig. 1;

Bloch and Schneider, 1801, Syst. Ichth., 383.

Arius nodosus Cuvier and Valenciennes, 18t0, Hist. Nat. Poiss., XV, 70.

Auchenipterus nodosus Müller and 'Troschel, 18t9, Horae Ichth., III, 11;

Günther, 186t, Cat. Fish. Brit. Mus., Y, 194.

Pseudauchenipterus nodosus Bleeker, 1863, Nederl. Tijdsch. Dierk., I, 88;

Eigenmann, 1910, Rept. Princeton Univ. Exped. Patagonia, III, 396;

Fowler, 1939 (1940), Proc. Acad. Nat. Sci. Phila., XCI, 231.

Felichthys nodosus Swain, 1882, Proc. Acad. Nat. Sci. Phila., 281;

Eigenmann and Eigenmann, 1888, Proc. Cal. Acad. Sci., (2), I, 154;

Eigenmann and Eigenmann, 1890, Occ. Papers Cal. Acad. Sci., I, 290.

Bahia and British Guiana to Peru

Fowler's record of a $145 \mathrm{~mm}$. specimen from Contamana seems to extend the known range of the species much farther inland.

Genus 31: EPAPTERUS Cope

Epapterus Cope, 1878, Proc. Amer. Phil. Soc., XVII, 677;

Eigenmann and Eigenmann, 1890, Oce. Papers Cal. Acad. Sci., I, 292. 


\section{Type: Epapterus dispilurus Cope}

Upper Amazonia

Like Auchenipterus in the transverse alignment of the mental barbels at the symphysis, but unlike in lacking the adipose fin and retaining only a rudimentary dorsal, I, 3; no teeth; ventrals have receded in a caudal direction and elongated to 14 rays; anal long; both postcoracoid and humeral processes present, the former sharply pointed.

\section{Epapterus dispilurus Cope}

Epapterus dispilurus Cope, 1878, Proc. Amer. Phil. Soc., XVII, 677;

Steindachner, 1882 (1883), Denksch. KK. Akad. Wiss. Wien, XLVI, 31, Peruvian Amazon;

Eigenmann and Eigenmann, 1888, Proc. Cal. Acad. Sci., (2), I, 152;

Eigenmann and Eigenmann, 1890, Occ. Papers Cal. Acad. Sci., I, 293;

Eigenmann, 1910, Rept. Princeton Univ. Exped. Patagonia, III, 397.

Fowler, 1939 (1940), Proc. Acad. Nat. Sci. Phila., XCI, 231, Contamana.

Upper Amazons.

Reported to Fowler under the vernacular name maparati.

\section{Family IV: Doradidae}

Due to the unusually high stages of water throughout the greater part of the Peruvian Amazon country during my visit in 1920 (W.R.A.) and the flooding of the smaller streams, our collections of Characins, Cichlids, and Poeciliids peculiar to smaller streams are not especially abundant. On the other hand, opportunity to collect such muddy-water forms as the Doradidae from larger streams, due to their taking refuge in the sloughs and estuaries, was good. With materials accumulated from other sources our Doradidae form part of the monograph of the family, Eigenmann, 1925, the last of the great groups of fishes to be undertaken by him with unimpaired strength and zeal. The Astroblepidae were to have followed.

Of the twenty-six genera and sixty-seven species recorded in the monograph, fifteen genera and twenty-two species belong to the range considered in this paper. Of these we have seventeen species and ten of the genera in the present collections. Seven of the genera and seven of the species are considered as new.

Throughout Tropical America; fishes with a series of lateral plates, diminishing in size caudally, each with a backward-directed curved, pointed spine, also diminishing correspondingly; fishes of moderate size; air-bladders with much specialized and variable Weberian apparatus, and themselves of extreme variability; dorsal usually short, and usually I, 6; dorsal spine variable; adipose usually present and short; pectoral spine long, doubly serrate (sometimes triply); head granular or striate; dorsal and pectoral spines with locking device; humeral process present, bordered above by a tympanum; six barbels, the narial lacking, barbels sometimes fimbriated, forming a dense, brush-like structure. 


\title{
Genus 32: MEGALODORAs Eigenmann
}

Megalodoras Eigenmann, 1925, Trans. Amer. Phil. Soe, XXII, 306.

Type: Megalodoras irwini Eigenmann

Rio Marañon, Middle Amazon and British Guiana

Mouth wide, head depressed; adipose longer than anal and extended forward as a keel; air-bladder two-chambered with both parts fringed with numerous diverticula, much depressed; dorsal spine with posterior serrae small or obsolete; lateral scutes few, less than 23.

\section{MEgalodoras IRWInI Eigenmann}

Megalodoras irwini Eigenmann, 1925, Trans. Amer. Phil. Soc., XXII, 307, pl. i, fig. 4; pl. iii, fig. 3; pl. vi, figs. 1-4; pl. xxv, fig. 2; text fig. 11, f.

15427, 5, 90-315 mm., type and paratypes, Iquitos, Allen, 1920 and Morris, 1922.

\author{
Iquitos to Santarem
}

Genus 33: CENTRODORAS Eigenmann

Centrodoras Eigenmann, 1925, Trans. Amer. Phil. Soc, XXII, 309.

\section{Type: Doras brachiatus Cope}

\section{Amazons}

Most characters those of Megalodoras; much more numerous lateral scutes, each side with $38-40$; dorsal spine with antrorse hooks on the anterior margin, the hooks behind varying from retrorse to straight; air bladder cardiform with numerous tufts of diverticula; a second bladder also with tufted diverticula. Three scutes in contact with the dorsal plate, about three rapidly decreasing in size, the remainder narrow.

\section{Centrodoras brachiatus (Cope)}

Doras brachiatus Cope, 1871, Proc. Acad. Nat. Sci. Phila., 270;

Eigenmann and Eigenmann, 1890, Occ. Papers Cal. Acad. Sci., I, 23t;

Eigenmann, 1910, Rept. Princeton Univ. Exped. Patagonia, III, 393.

Centrodoras brachiatus Eigenmann, 1925, Trans. Amer. Phil. Soc., XXII, 310, text fig. 16;

Fowler, 1939 (1940), Proc. Acad. Nat. Sci. Phila., XCI, 225, one, 163 mm., Contamana.

\section{The Amazons}

The origin of Cope's specimens is only known to have been the Robert Perkins collection made at various points between the Huallaga and the Rio Negro. It may belong to the area under present consideration; otherwise it is Brazilian. 


\section{Genus 34: PTERODORAS Bleeker}

Doras Valenciennes, in Humboldt, 1833, Rec. d'Obs. Zool. Anat., II, 181;

Eigenmann and Eigenmann, 1890, Occ. Papers Cal. Acad. Sci., I, 220;

Eigenmann, 1910, Rept. Princeton Univ. Exped. Patagonia, III, 392.

Pterodoras Bleeker, 1863, Nederl. Tijdsch. Dierk., I, 15, 16, and 86;

Eigenmann, 1925, Trans. Amer. Phil. Soc., XIII, 311.

\section{Type: Doras granulosus Valenciennes}

Peru to Buenos Aires and Uruguay

Similar to Megalodoras in the forward continuation of the adipose, and other characters, but differing in having many more and narrower scutes and a single air bladder, the latter with many diverticula along the side; head wide and depressed: caudal peduncle naked above and below; scutes 25-30, very narrow, and strongest over the anal; eye in anterior half of head; dorsal spine with about twenty hooks on the posterior border.

\section{Pterodoras granulosus (Valenciennes)}

Doras gramulosus Valenciennes, in Humboldt, 1833, Rec. d'Obs. Zool. Anat., II, 18t;

Eigenmann and Eigenmann, 1890, Occ. Papers Cal. Acad. Sci., I, 229;

Eigenmann, 1910, Rept. Princeton Univ. Exped. Patagonia, III, 392

Pterodoras granulosus Bleeker, 1863, Nederl. Tijdsch. Dierk., I, 15;

Eigenmann, 1925, Trans. Amer. Phil. Soc., XXII, 312, pl. i, figs. 1-3; pl. iii, fig. 6; pl. viii, figs. $1-5$; text fig. 17.

$15659,2,95$ and $117 \mathrm{~mm}$., Marañon below Pastaza, Allen, October, 1920.

$15846,2,203$ and $216 \mathrm{~mm}$., Contamana, Rio Ucayali. Allen, July, 1920.

$15847,14,87-182 \mathrm{~mm}$., Iquitos, Allen, September, 1920.

15818, 4, 150-200 mm., Rio Puinagua, mouth Rio Pacara, Allen, September, 1920.

\section{Genus 35: PLATYDORAS Bleeker}

Doras Lacépède, 1803, Hist. Nat. Poiss., V, 116, carinatus and costatus;

Curier and Valenciennes, 1810, Hist. Nat. Poiss., XV, 267;

Eigenmann and Eigenmann (part) 1890, Occ. Papers Cal. Acad. Sci., I, 220;

Eigenmann (part) 1910, Rept. Princeton Univ. Exped. Patagonia, III, 392.

Platydoras Bleeker, 1863, Nederl. Tijsch. Dierk., I, 16 and 86, costatus;

Eigenmann, 1925, Trans. Amer. Phil. Soc., XXII, 315.

\section{Type: Doras costatus (Linnaeus)}

The Doradid genus of widest distribution, from our territory to the Guianas, the Orinoco, São Francisco, and Paraguay.

Plated area extended to cover most of sides and leaving only a narrow naked zone across the back; first three scutes in contact with the dorsal plate; serrae of posterior surface of dorsal spine growing obsolete with age; mouth slightly inferior; air bladder double, of simple form, somewhat depressed anterior chamber, posterior chamber subconical. 


\section{Platydoras costatus (Linnaeus)}

Silurus costatus Linnaeus, 1766, Syst. Nat,, ed. xii, 506.

Cataphractus costatus Bloch, 1794, Ausl. Fische, VIII, 82, pl. 376.

Doras costatus Lacépède, 1803, Hist. Nat. Poiss., V, 116, part;

Cuvier and Valenciennes, 1840, Hist. Nat. Poiss., XV, 268;

Castelnau, 1855, Anim. Amér. Sud, Poiss., 48, Amazon;

Günther, 1864, Cat. Fish. Brit. Mus., V, 201;

Eigenmann and Eigenmann, 1890, Occ. Papers Cal. Acad. Sci., I, 231;

Eigenmann, 1910, Rept. Princeton Univ. Exped. Patagonia, III, 393.

Doras armatulus Müller and Troschel, in Schomburgk, 1848, Reisen, III, 629;

Steindachner, 1882 (1883), Denksch. KK. Akad. Wiss. Wien, XLVI, 5, one, $90 \mathrm{~mm}$. , Rio Huallaga.

Platydoras costatus Bleeker, 1863, Nederl. Tijdsch. Dierk., I, 16, 86;

Eigenmann, 1925, Trans. Amer. Phil. Soc., XXII, 316, pl. i, figs. 5 and 14; pl. iii, figs. 1 and 2; pl. ix, figs. 1-3.

Widely dispersed from the Guianas and Para to the Andes of Peru and Bolivia.

15874, 3, 59-81 mm., Yarinacocha, Yurimaguas, Allen, September, 1920.

$15875,5,77-81 \mathrm{~mm} .$, Rio Morona, Allen, October, 1920.

\section{Genus 36: AGAMYXIS Cope}

Doras Cope, 1870, Proc. Amer. Phil. Soc., XI, 568, Pebas;

Cope, 1871, Proc. Acad. Nat. Sci. Phila., XXIII, pl. iii;

Eigenmann and Eigenmann, 1890, Occ. Papers Cal. Acad. Sci., I, 241.

Doras (Agamyxis) Eigenmann, 1910, Rept. Princeton Univ. Exped. Patagonia, III, 393.

Agamyxis Cope, 1878, Proc. Amer. Phil. Soc, XVII, 101;

Eigenmann, 1925, Trans. Amer. Phil. Soc., XXII, 322.

\section{Type: Agamyxis pectinifrons Cope \\ Peruvian Amazon}

Distinguished from nearby genera Acanthodoras and Astrodoras by the covering of spiny plates over caudal peduncle above and below; alike in lack of serrae on rear of dorsal spine; nasal plate erect and pectinate; eye in anterior half of head; caudal rounded.

\section{Agamyxis pectinifrons (Cope)}

Doras pectinifrons Cope, 1870, Proc. Amer. Phil. Soc., XI, 568, Pebas;

Eigenmann and Eigenmann, 1890, Oce. Papers Cal. Acad. Sci., I, $2+1$.

Agamyxis pectinifrons Cope, 1878, Proc. Amer. Phil. Soc., XVII, 679;

Eigenmann, 1925, Trans. Amer. Phil. Soc., XXII, 322, pl. xvi, fig. 4; text fig. 19.

Known from the type in the Philadelphia museum.

\section{Agamyxis flavopictus (Steindachner)}

Doras flavopictus Steindachner, 1908, Sitzb. KK. Akad. Wiss. Wien, VII, 3, Iquitos.

Doras (Agamyxis) flavopictus Eigenmann, 1910, Rept. Princeton Univ. Exped. Patagonia, III, 393. Agamyxis flavopictus Eigenmann, 1925, Trans. Amer. Phil. Soc, XXII, 323. 
Known only from the two types, 90 and $110 \mathrm{~mm}$., in the Vienna Museum; from Iquitos.

Genus 37: LIOSOMADORAS Fowler

Liosomadoras Fowler, 1939 (1940), Proc. Acad. Nat. Sci. Phila., XCI, 226.

Type: Liosomadoras morrowi Fowler

Contamana, Rio Ueayali

Near Lithodoras and Agamyxis; robust; lacking lateral scutes on the trunk and tail.

\section{Liosomadoras morrowi Fowler}

Liosomadoras morrowi Fowler, 1939 (1940), Proc. Acad. Nat. Sci. Phila., XCI, 226, figs. 11-14.

Known from the type, $100 \mathrm{~mm}$. in length, from Contamana.

\section{Genus 38: AMBLYDORAS Bleeker}

Doras Cuvier and Valenciennes, 1840, Hist. Nat. Poiss., XV, 267;

Eigenmann and Eigenmann, 1890, Occ. Papers Cal. Acad. Sci., I, 220.

A mblydoras Bleeker, 1863, Nederl. Tijdsch. Dierk., I, 86, affinis;

Eigenmann, 1925, 'Trans. Amer. Phil. Soc., XXII, 325.

Zathorax Cope, 1872, Proc. Acad. Nat. Sci. Phila., 271.

\section{Type: Doras affinis Kner}

\section{Amazonia to the Guianas and Bolivia}

A large breastplate representing the coalesced granulations of coracoid and clavicle; coracoid process shorter than humeral; dorsal spine without lateral spinules, grooved and ridged; lateral scutes numerous and large, totalling more than half the sides; adipose fin not continued as a keel; eye midway of the head; mouth terminal.

\section{Amblydoras hancockin (Cuvier and Valenciennes)}

Doras costata Hancock, 1828, Zool. Jour., IV, 242, Demarara.

Doras hancockii Cuvier and Valenciennes, 1840, Hist. Nat. Poiss., XV, 279; Günther, 1864, Cat. Fish. Brit. Mus., V, 202;

Eigenmann and Eigenmann, 1890, Occ. Papers Cal. Acad. Sci., I, 23t;

Eigenmann, 1910, Rept. Princeton Univ. Exped. Patagonia, III, 393;

Eigenmann, 1912, Mem. Carnegie Mus., V, 187.

Amblydoras hancocki Eigenmann, 1925, Trans. Amer. Phil. Soc., XXII, 326, pl. iii, fig. 9; pl. xiii, figs. $1-4$.

Amblydoras hancockii Fowler, 1939 (1940), Proc. Acad. Nat. Sci. Phila., 228.

Doras affinis Kner, 1855, Sitzh. KK. Akad. Wiss. Wien, XVII, 121, pl. xi, fig. 1;

Günther, 1864, Cat. Fish. Brit. Mus., T, 202;

Eigenmann and Eigenmann, 1890, Occ. Papers Cal. Acad. Sci., I, 238.

Doras (Amblydoras) affinis, Eigenmann, 1910, Rept. Princeton Univ. Exped. Patagonia, III, 393. 


\section{Guiana to Guaporé and Peru}

15887, 1, 65 mm., Rio Itaya, Iquitos, Allen, September, 1920.

\section{Amblydoras monitor (Cope)}

Zathorax monitor Cope, 1871, Proc. Acad. Nat. Sci. Phila., XXIII, 272, pl. iv, fig. 1, Rio Ambyiacu. Doras monitor Eigenmann and Eigenmann, 1890, Occ. Papers Cal. Acad. Sci., I, 245.

Doras (Astrodoras) monitor Eigenmann, 1910, Rept. Princeton Univ. Exped. Patagonia, III, 393. Amblydoras monitor Eigenmann, 1925, Trans. Amer. Phil. Soc., XXII, 326, fig. 20.

Known only from the type specimen at the Philadelphia Academy of Sciences, Rio Ambyiacu.

\section{Genus 39: ANADORAS Eigenmann}

Doras Cope, 1871, Proc. Acad. Nat. Sci. Phila., 270.

Anadoras Eigenmann, 1925, Trans. Amer. Phil. Soc., XXII, 327.

\section{Type: Doras grypus Cope}

Amazon basin to Pilcomayo

Serrations lacking on the nasal; a space between granulations of right and left coracoids and clavicles covered only by skin; coracoid process shorter than humeral; adipose fin not continued as a keel; dorsal spine grooved and without serrations; caudal truncate; scutes numerous and covering less than one fourth of the sides; air bladder heart-shaped with a median groove and without marginal diverticula.

\section{Anadoras grypus (Cope)}

Doras grypus Cope, 1871, Proc. Acad. Nat. Sci. Phila., 270, pl. xv, figs. 1 and 1a, Rio Ambyiacu;

Eigenmann and Eigenmann, 1888, Proc. Cal. Acad. Sci., (2), I, 163;

Eigenmann and Eigenmann, 1890, Oce. Papers Cal. Acad. Sci., I, 239.

Doras weddellii Eigenmann, 1910, Rept. Princeton Univ. Exped. Patagonia, III, 393.

Anadoras grypus Eigenmann, 1925, Trans. Amer. Phil. Soc., XXII, 328, pl. iv, fig. 7; pl. xv, figs. 1-3.

\section{Marañon and Solimões drainage}

15849, 50-139 mm., Lago Cashiboya, Allen, August, 1920.

$15961,3,80-150 \mathrm{~mm}$. ., Iquitos, Morris, 1922.

\section{Anadoras nauticus (Cope)}

Zathorax nauticus Cope, 187t, Proc. Acad. Nat. Sci. Phila., XXVI, 133, Nauta;

Cope, 1878, Proc. Amer. Phil. Soc., XVII, 678.

Doras nauticus Eigenmann and Eigenmann, 1890, Occ. Papers Cal. Acad. Sci., I, 246.

Doras (Astrodoras) nauticus Eigenmann, 1910, Rept. Princeton Univ. Exped. Patagonia, III, 393. Anadoras nauticus Eigenmann, 1925, Trans. Amer. Phil. Soc., XXII, 329.

Nauta, former head of steamboat navigation of the Amazon, has furnished the only specimen, $82 \mathrm{~mm}$. in length, at the Philadelphia Museum of Natural Sciences. 


\section{Genus 40: HYPODORAS Eigenmann}

Hypodoras Eigenmann, 1925, Trans. Amer. Phil. Soc., XXII, 329.

\section{Type: Hypodoras forficulatus Eigenmann}

\section{Iquitos}

Readily distinguished by the large rhomboidal plate over the anterior two thirds of the adipose; air bladder reniform, without coeca, constricted longitudinally, the constriction prolonged into the posterior lobe, which is forked in its posterior three fifths; dorsal spine grooved and hookless; adipose little shorter than the anal and not keeled in an anterior direction; lateral scutes in contact with the plates above and below, and with a single hook; those forward of the peduncle with two to five hooks above and one or two below; humeral process very strong and spiniferous; eye just before middle point of head.

Known only from the type, one specimen.

\section{Hypodoras forficulatus Eigenmann}

Hypodoras forficulatus Eigenmann, 1925, Trans. Amer. Phil. Soc., XXII, 330, pl. iv, fig. 1; pl. xxv, fig. 3 ; text fig. 12 , I.

15876, 1, type, 123 mm., Iquitos, Allen, September, 1920.

Sole species and sole specimen of the genus.

\section{Genus 41: PHYSOPYXIS Cope}

Physopyxis Cope, 1871, Proc. Acad. Nat. Sci. Phila., XXIII, 112, 272;

Eigenmann and Eigenmann, 1890, Occ. Papers Cal. Acad. Sci., I, 220;

Eigenmann, 1910, Rept. Princeton Univ. Exped. Patagonia, III, 392;

Eigenmann, 1925, Trans. Amer. Phil. Soc., XXII, 330.

\section{Type: Physopyxis lyra Cope}

Known only from one specimen of the one species, from the Rio Ambyiacu collections.

Devoid of adipose; coracoid processes lyriform, much larger than humeral processes which do not reach to first lateral scute; caudal rounded; eye small and in forward half of head; serrae present on proximal half of anterior border of dorsal fin; pectoral spine overlapping origin of anal; extensive buckler consisting of coracoid and clavicles.

\section{Physopyxis lyra Cope}

Physopyxis lyra Cope, 1871, Proe. Acad. Nat. Sci. Phila., XXIII, 112, 272, figs. 1a-1e, Rio Ambyiacu; Eigenmann and Eigenmann, 1890, Oce. Papers Cal. Acad. Sci., I, 220;

Eigenmann, 1910, Rept. Princeton Univ. Exped. Patagonia, III, 392;

Eigenmann, 1925, Trans. Amer. Phil. Soc., XXII, pl. xvi, figs. 1 and 2 ; text fig. 22. 
A $35 \mathrm{~mm}$. specimen in the collections of the Philadelphia Academy of Sciences, collected from the Rio Ambyiacu by John Hauxwell.

\section{Genus 42: PSEUDODORAS Bleeker}

Pseudodoras Bleeker, 1858, Ichth. Arch. Indici., Siluri, 53, Doras niger Valenciennes;

Eigenmann, 1925, Trans. Amer. Phil. Soc., XXII, 331.

Oxydoras Bleeker, 1863, Nederl. Tijdsch. Dierk., I, 14, D. niger.

\section{Type: Doras niger Valenciennes}

Peru to the Guianas and Rio São Francisco

The genus Pseudodoras was abandoned by Bleeker on grounds shown by Eigenmann to be based on false assumptions of Kner. It therefore has priority over the Oxydoras of Kner with Doras niger Valenciennes as its type.

This and succeeding genera are characterized by less breadth than the preceding, the width at the clavicle less than the length of the head.

Adipose continued forward as a low ridge longer than the anal; eye laterally oriented, back of middle of the head; dorsal spine with serrae antrorse or vertical to it on the posterior margin; the serrae of the anterior margin stronger and more numerous; fontanel with a bridge; lateral plates not numerous, $3+18-23$; head not depressed, snout conical, mouth inferior; premaxillaries rhomboidal; anterior nares remote from lips; caudal emarginate.

Groups of tentacles on the roof of the mouth before the first gill arch and between the second and third pairs; air bladder double; first division cardiform with the beginnings of coeca; the second twice as long as wide, and less than two in the length of the anterior chamber.

\section{Pseudodoras niger (Valenciennes)}

Doras niger Valenciennes, in Humboldt, 1833, Ree. d'Obs. Zool. Anat., II, 184;

Cuvier and Valenciennes, 1840, Hist. Nat. Poiss., XV, 291;

Eigenmann, 1912, Mem. Carnegie Mus., V, 190, Rupununi.

Pseudodoras niger Bleeker, 1858, Ichth. Arch. Indici, Siluri, 53;

Eigenmann, 1925, Trans. Amer. Phil. Soc., XXII, 333, pl. i, fig. 16; pl. xvii, figs. 1-1; pl. xxiii, fig. 1; text figs. $2,6,7$, and 10 ;

Fowler, 1939 (1940), Proc. Acad. Nat. Sci. Phila., XCI, 228, Contamana.

Rhinodoras niger Günther, 186t, Cat. Fish. Brit. Mus., V, 209;

Cope, 1874, Proc. Acad. Nat. Sci. Phila., XXVI, 134, Nauta;

Cope, 1878, Proc. Amer. Phil. Soc., XVII, 678, Nauta.

Rhinodoras prionomus Cope, 1874, Proc. Acad. Nat. Sci. Phila., XXVI, 134, Nauta.

Oxydoras niger Eigenmann and Eigenmann, 1890, Occ. Papers Cal. Acad. Sci., I, 247;

Eigenmann, 1910, Rept. Princeton Univ. Exped. Patagonia, III, 393;

Fisher, 1917, Ann. Carnegie Mus., XI, 420.

Guianas to Rio São Francisco and Amazons to more than 3000 miles and 2500 feet above its mouth.

15651 and $15960,4,170-260 \mathrm{~mm}$., Iquitos, Allen, 1920 ; Morris, 1922.

15450, 1, 250 mm., Yarinacocha, Allen, September, 1920. 
$15845,1,200 \mathrm{~mm}$. Lago Cashiboya, Allen, August, 1920.

15850 , 1, skin, $650 \mathrm{~mm}$., La Merced (about 2500 feet), Señor Ecuador Praeli, 1918

16004, 1, $273 \mathrm{~mm}$, to end of scutes, Rio Pacaya, Allen, August, 1920.

The colloquial name toro is supplied by Fowler.

\section{Genus 43: TRACHYDORAS Eigenmann}

Trachydoras Eigenmann, 1925, 'Trans. Amer. Phil. Soc., XXII, 337.

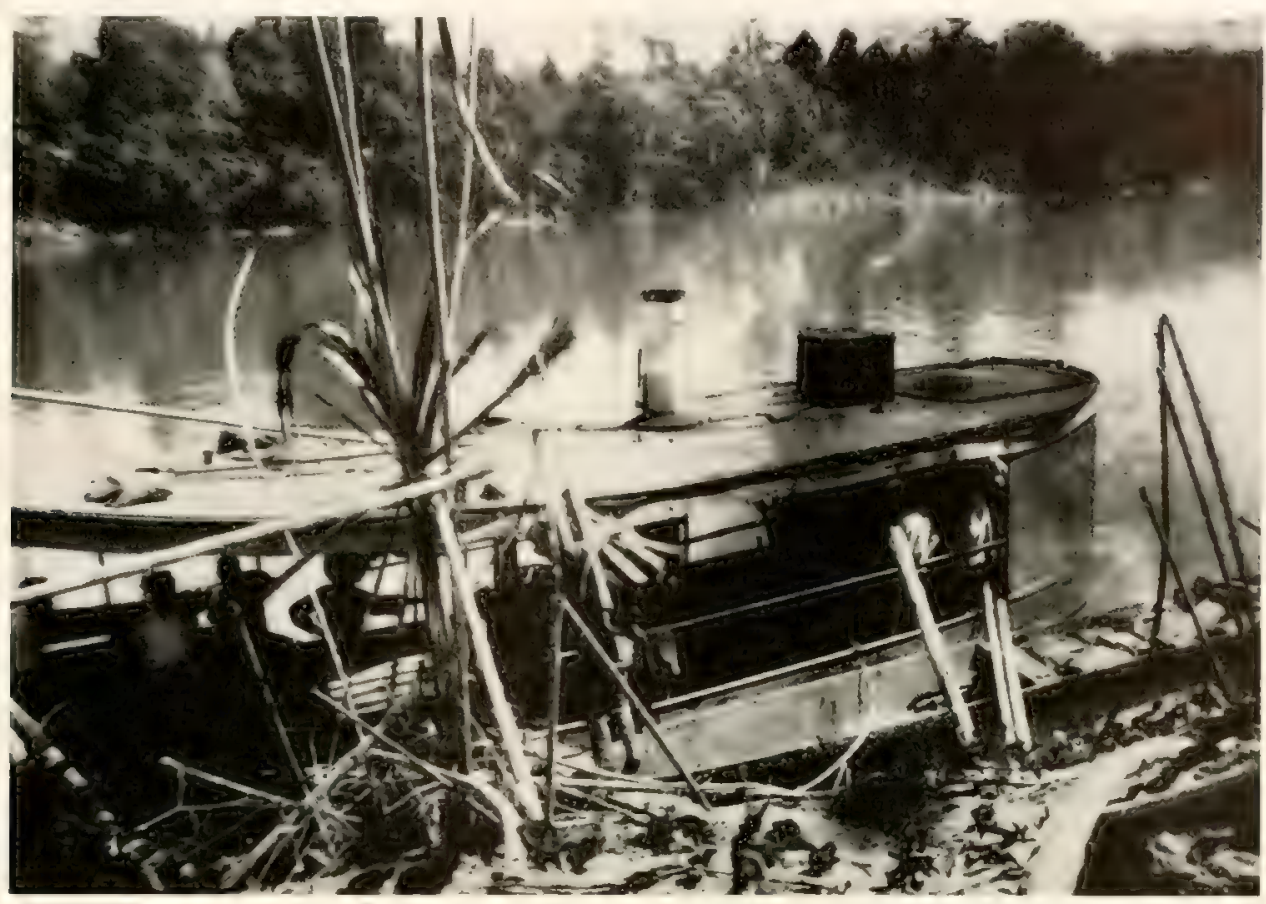

Fig. 18. The Cocamita, steam-launch with the least draft, and ascending streams the farthest, of the Iquitos fleet. Carries mail and passengers. Rio Pachitea.

\section{Type: Trachydoras atripes Eigenmann}

Amazonia to basin of Rio Paraguay

Maxillary barbels fringed and just reaching the gill opening or shorter; the bases of the mental barbels united by a membrane; eye beyond the middle of the head; the dorsal spine serrate on both margins; caudal forked; adipose short and sometimes continued as a ridge; second air bladder minute or wanting; opercle, preopercle and coracoid process granular; first lateral scute large, connecting with humeral process and dorsal plate; fontanel not continued backward as a groove; snout short, anterior nares nearer snout than to posterior, or equidistant; mouth narrow; teeth weak or wanting.

\section{Trachydoras NatTERERI (Steindachner)}

Oxydoras nattereri Steindachner, 1882 (1883), Sitab. KK. Akad. Wiss. Wien, XLII, 104, pl. i, fig. 2; pl. iv, figs. 1-1a, Teffé. 
Hemidoras nattereri Eigenmann and Eigenmann, 1888, Proc. Cal. Acad. Sci., (2), I, 158;

Eigenmann and Eigenmann, 1890, Occ. Papers Cal. Acad. Sci., I, 253;

Eigenmann, 1910, Rept. Princeton Univ. Exped. Patagonia, III, 394;

Fisher, 1917, Ann. Carnegie Mus., XI, 421.

Trachydoras nattereri Eigenmann, 1925, Trans. Amer. Phil. Soc., XXII, 338, pl. xviii, figs. 1 and 2; pl. xxvi, figs. 2 and 3 ;

Fowler, 1939 (1940), Proc. Acad. Nat. Sci. Phila., XCI, 228, two, Contamana.

Upper Amazon of Peru and Bolivia to Brazil

15967, 1, $130 \mathrm{~mm}$., Iquitos, Morris, 1922.

\section{Trachydoras atripes Eigenmann}

Trachydoras atripes Eigenmann, 1925, Trans. Amer. Phil. Soc., XXII, 339, pl. ii, fig. 5; pl. xviii, figs. $6-8$; pl. xxvi, fig. 4 .

\section{Marañon to basin of Rio Mamoré}

15877, 1, type, $72 \mathrm{~mm}$. over all, brook at Hacienda Iça, Rio Itaya, near Iquitos, Allen, September, 1920.

Specimens were collected by John Haseman in Bolivia.

\section{Genus 44: DORAS Lacépède}

Doras Lacépède, 1803, Hist. Nat. Poiss., V, 116, Silurus carinatus and costatus Linnaeus;

Bleeker, 1863, Nederl. Tijdsch. Dierk., I, 13, carinatus;

Jordan, 1917, The Genera of Fishes, 65;

Eigenmann, 1925, Trans. Amer. Phil. Soc., XXII, 340.

Oxydoras Kner, 1855, Sitzb. KK. Akad. Wiss. Wien, XVII, spp.

Hemidoras Bleeker, 1858, Ichth. Arch. Indici., Siluri, stenopeltis;

Eigenmann and Eigenmann, 1890, Oce. Papers Cal. Acad. Sci., I, 250.

non Doras Günther, Eigenmann and Eigenmann, etc.

Type: Silurus carinatus Linnaeus

Peru to Guianas and Bolivia

The Eigenmann monograph of the Doradidae regards Doras as a polyphyletic group, or the residuum of the family after the several specialized genera have been removed. If the air bladder is of as great taxonomic value as indicated throughout the monograph, we do have several possible genera still accepted as Doras. This is a question which may hinge upon embryological studies of numerous species. Here as in many like situations systematic ichthyology halts for the lack of detailed studies in the field upon the life histories and biology of living fishes.

Maxillary barbels fringed; bases of mental barbels united by a membrane; eye in posterior half of the head; adipose short and not continued as a low ridge; caudal forked; origin of the ventrals nearer the caudal than the snout; fontanel not prolonged into a groove; lateral scutes moderate, the first connecting the dorsal plate, the first rib, and the humeral process. Only one species recognized in our area. 


\section{Doras punctatus Kner}

Doras punctatus Kner, 1855, Sitzb. KK. Akad. Wiss. Wien, VII, 136, pl. vi, fig. 10, Matto Grosso and Rio Guaporé;

Eigenmann, 1925, Trans. Amer. Phil. Soc., XXII, 343, pl. iii, fig. 5; pl. xxi, figs. 1 and 2 ; texi fig. 12, E.

Hemidoras punctatus Eigenmann and Eigenmann, 1890, Oce. Papers Cal. Acad. Sci., I, 255;

Eigenmann, 1910, Rept. Princeton Univ. Exped. Patagonia, III, 394.

Peruvian Amazon to Matto Grosso and Guaporé

15882, 1, 118 mm., Rio Paranapura, Yurimaguas, Allen, November, 1920.

15883, many, largest $99 \mathrm{~mm}$. Lago Cashiboya, Allen, August, 1920.

Of the small-eyed group, the eye not exceeding the interorbital, but contained in it only 1.6 to 1.75 ; first lateral scute moderate, not reaching the coracoid process; dorsal spine shorter than the pectoral, not reaching the adipose; maxillary barbel not reaching beyond the base of the pectoral.

\section{Genus 45: HEMIDORAS Bleeker}

Hemidoras Bleeker, 1858, Ichth. Arch. Indici, Siluri, I, 53;

Eigenmann and Eigenmann, 1888, Proc.Cal. Acad. Sci., (2), I, 158;

Eigenmann and Eigenmann, 1890, Occ. Papers Cal. Acad. Sci., I, 250;

Eigenmann, 1925, Trans. Amer. Phil. Soc., XXII, 347.

Type: Hemidoras (Oxydoras) stenopeltis Kner

Upper Amazon, Madeira, and Rio Negro

Nuchal shields with a foramen on each side; maxillary barbel with a fringe of many barblets; a series of scutes between the dorsal and adipose, and sometimes between the ventral and anal; of the group with long, subconical snout; lateral plates well developed along the entire line; humeral process longer than deep; mouth small; mental barbels fringed and united by a membrane at the bases; fontanel continued as a groove.

\section{Hemidoras stenopeltis (Heckel)}

Corydoras stenopeltis Heckel, in Kner, 1855, Sitzb. IK. Akad. Wiss. Wien, XVII, 142, pl. iv, fig. 7 , Rio Negro.

Hemidoras stenopeltis Eigenmann and Eigenmann, 1888, Proc. Cal. Acad. Sci., (2), I, 158 ;

Eigenmann and Eigenmann, 1890, Occ. Papers Cal. Acad. Sci., I, 256;

Eigenmann, 1925, Trans. Amer. Phil. Soc., XXII, 347.

Peruvian Amazon to the Rios Madeira and Negro

$15907,1,80 \mathrm{~mm} .$, Pebas, J. B. Steere.

\section{Hemidoras Morrisi Eigenmann}

Hemidoras morrisi Eigenmann, 1925, 'Trans. Amer. Phil. Soc., XXII, 347, pl. xxvii, fig. "3. 
Known from the types taken at Iquitos.

15962, 2, 77 and $147 \mathrm{~mm}$., the latter the type, Iquitos, Morris, 1922.

Named for Percival Morris, the Barbado-Peruvian who assisted in making the collections in the vicinity of Iquitos, and continued collecting for more than a year thereafter, following my departure.

\section{Genus 46: OPSODORAS Eigenmann}

Opsodoras Eigenmann, 1925, Trans. Amer. Phil. Soc., XXII, 348.

\section{Type: Opsodoras orthacanthus Eigenmann}

Amazon basin to the Guianas

Back without scutes; origin of ventrals nearer caudal than snout; adipose not continued forward as a keel; mental barbels with a double series of barblets; a foramen on each side of the nuchal shield.

Air bladder single, usually with filamentous, branched diverticula.

\section{Opsodoras heMipeltis Eigenmann}

Opsodoras hemipeltis Eigenmann, 1925, Trans. Amer. Phil. Soc., XXII, 349, pl. xix, fig. 2; pl. xxiv, fig. 6.

Known only from the type at the California Academy Museum. 15879, 1, type, 143 mm., Rio Ucayali, Contamana, Allen, July, 1920.

Noteworthy for its spindle form among its extreme relatives.

\section{Opsodoras parallelus Eigenmann}

Opsodoras parallehus Eigenmann, 1925, Trans. Amer. Phil. Soc., XXII, 350, pl, xix, fig. 3; pl. xxiii, fig. 3.

Known only from the type from Iquitos in the Museum of the California Academy of Sciences.

15964, 1, type, $151 \mathrm{~mm}$., Iquitos, Morris, 1922.

Closely allied to $O$. hemipeltis, if distinct from it. Differing in the better development of the lateral scutes, $0+32$; top of head and nasals granular, opercle striate; maxillary barbel reaching beyond the eye; pectoral spines not reaching ventrals, with serrae on both surfaces of the spine.

\section{Opsodoras humeralis (Kner)}

Doras humeralis Íner, 1855, Sitzb. KK. Akad. Wiss. Wien, XVII, 140, pl. iv, fig. 6, Rio Negro. Oxydoras humeralis Günther, 1864, Cat. Fish. Brit. Mus., V, 206.

Hemidoras humeralis Eigenmann and Eigenmann, 1888, Proc. Cal. Acad. Sci., (2), I, 158;

Eigenmann and Eigenmann, 1890, Oce. Papers Cal. Acad. Sci., I, 258;

Eigenmam, 1910, Rept. Princeton Univ. Exped. Patagonia, III, 394. 
Opsodoras humeralis Eigenmann, 1925, Trans. Amer. Phil. Soc., XXII, 350, pl. i, fig. 6; pl. ii, fig. 4; pl. xriii, figs. 9 and $10 ;$ pl. xix, fig. 1.

Rio Negro to Bolivia and Rio Ucayali

$15880,1,15+\mathrm{mm}$. ., Rio Ueayali, Contamana, Allen, July, 1920.

15881, 22, largest $145 \mathrm{~mm}$., Iquitos, Allen, September, 1920.

\section{Opsodoras orthacanthus Eigenmann}

Opsodoras orthacanthus Eigenmann, 1925, Trans. Amer. Phil. Soc., XXII, 351, pl. xxii, fig. 3; pl. xxiii, fig. 2.

\section{Peruvian Amazons}

15884, 1, $133 \mathrm{~mm}$., type, Iquitos, Morris, 1922.

15885, 4, 69-82 mm., Lago Cashiboya, Allen, August 1920.

15886, 3, 77-98 mm., mouth Rio Pacaya, Allen, August, 1920.

\section{Opsodoras stübeliI (Steindachner)}

Oxydoras stübelii Steindachner, 1882 (1883), Denksch. KK. Akad. Wiss. Wien, XLVI, 5, pl. iii, figs. 1-1b, three, 80-120 mm., types, Rio Huallaga.

Hemidoras stübeli Eigenmann and Eigenmann, 1888, Proc. Cal. Acad. Sci., (2), I, 158;

Eigenmann and Eigenmann, 1890, Occ. Papers Cal. Acad. Sci., I, 257;

Eigenmann, 1910, Rept. Princeton Univ. Exped. Patagonia, III, 394.

Opsodoras stübeli Eigenmann, 1925, Trans. Amer. Phil. Soc., XXII, 354, pl. xxvii, figs. 6 and 7 .

Known only from the three types $80-120 \mathrm{~mm}$. in length, in the Vienna Museum.

The local name shitari is applied to this species by Steindachner.

\section{Genus 47: HASSAR Eigenmann and Eigenmann}

Hassar Eigenmann and Eigenmann, 1888, Proc. Cal. Acad. Sci., (2), I, 158;

Eigenmann, 1925, Trans. Amer. Phil. Soc., XXII, 355.

\section{Type: Oxydoras orestis Steindachner}

Upper Amazon to the Guianas and Paranahyba

Near Opsodoras and Leptodoras in the lack of scutes on the back; eye elongate, snout long and slender, humeral process large and rounded; maxillary barbel fringed with minute barblets; adipose not prolonged forward as a ridge.

Anterior lateral line scutes very small; pectoral spine not reaching, or barely reaching, ventrals; mouth large; small patch of minute teeth on the lower jaw; anterior nares at or behind middle point between snout and eye.

\section{Hassar ucayalensis Fowler}

Hassar ucayalensis Fowler, 1939 (1940), Proc. Acad. Nat. Sci. Phila., XCI, 228, figs. 15-17.

The Ueayali river at Contamana

Known from the type, $83 \mathrm{~mm}$. long, at the Philadelphia Academy. 


\section{Genus 48: LEPTODORAS Boulenger}

Leptodoras Boulenger, 1898, Ann. Mag. Nat. Hist., (7), II, 478;

Eigenmann, 1910, Rept. Princeton Univ. Exped. Patagonia, III, 395;

Eigenmann, 1925, Trans. Amer. Phil. Soc., XXII, 356.

Hemidoras Eigenmann and Eigenmann, 1888, Proc. Cal. Acad. Sci., (2), I, 158;

Eigenmann and Eigenmann, 1890, Occ. Papers Cal. Acad. Sci., I, 255.

\section{Type: Oxydoras acipenserinus Günther}

Peruvian Amazonia to the Guianas

Nuchal shields with a foramen on each side; maxillary barbel with portion beyond the bone divided into an unfringed and outer fringed part; back without scutes; slender form, depth 5-9; origin of ventrals forward of the middle point; adipose continued forward as a keel, to which the depressed dorsal spine nearly attains; mouth large and edentulous; barbels short, the width of the membrane uniting the bases of the mental barbels more than half their length, the outer mental barbel forked.

\section{Leptodoras Linnelli Eigenmann}

Leptodoras linnelli Eigenmann, 1910, Rept. Princeton Univ. Exped. Patagonia, III, 395 (name only);

Eigenmann, 1912, Mem. Carnegie Mus., V, 191, pl. xvii, fig. 1; pl. xviii, fig. 1;

Eigenmann, 1925, Trans. Amer. Phil. Soc., XXII, 357, pl. ii, fig. 2; pl.v, figs. 3 and 4; pl. xx, fig. 4; pl. xxiv, figs. $3-5$;

Fowler, 1939 (1940), Proc. Acad. Nat. Sci. Phila., XCI, 230.

Leptodoras acipenserinus (non Günther), Fisher, 1917, Ann. Carnegie Mus., XI, 422, Maciel and Rio Guaporé.

Hemidoras (Leptodoras) linnelli Steindachner, 1915 (1917), Denksch. KK. Akad. Wiss. Wien, XCIII, 79.

\section{British Guiana and Rio Ueayali}

Fowler's two specimens, 90 and 154, Contamana, are placed here.

\section{Leptodoras acipenserinus (Günther)}

Oxydoras acipenserinus Günther, 1868, Proc. Zool. Soc. London, 230, pl. xx, Xeberos;

Steindachner, 1880 (1882), Denksch. KK. Akad. Wiss. Wien, XLIII, 8, Xeberos.

Hemidoras acipenserinus Eigenmann and Eigenmann, 1888, Proc. Cal. Acad. Sci., (2), I, 158;

Eigenmann and Eigenmann, 1890, Occ. Papers Cal. Acad. Sci., I, 255.

Leptodoras acipenserinus Boulenger, 1898, Ann. Mag. Nat. Hist., (7), II, 478;

Eigenmann, 1910, Rept. Princeton Univ. Exped. Patagonia, III, 395;

Eigenmann, 1925, Trans. Amer. Phil. Soc., XXII, 358.

\section{Peruvian Amazon}

15878, 1, 110 mm., Rio Paranapura, Yurimaguas, Allen, November, 1920.

\section{Family V: Ageneiosidae}

Air bladder much reduced and well enclosed in the bony processes of the cervical vertebrae; maxillary barbels only. 
Genus 49: AGENEIOSUS Lacépède

Agenciosus Lacépède, 1805, Hist. Nat. Poiss., V, 132;

Eigenmann, and Eigenmann, 1890, Oce. Papers Cal. Acad. Sci., I, 299;

Eigenmann, 1910, Rept. Princeton Univ. Exped. Patagonia, III, 397;

Eigenmann, 1912, Mem. Carnegie Mus., V, 204.

Hypophthalmus Schomburgk, 1849, Fish. Brit. Guiana, 191.

Pseudageneiosus Bleeker, 1863, Nederl. 'Tijdsch. Dierk., I, 108.

Ageniosus Günther, 1864, Cat. Fish. Brit. Mus., V, 191.

Type: Ageneiosus armatus Lacépède

La Plata to Paranahyba, Guianas, and Peru

Teeth villiform; barbels at maxillaries only; eyes large, lateral, and snout much longer than eye; dorsal fin weak, with a weak spine and 6-7 rays; adipose very short; anal fin very long; ventrals behind the vertical from the dorsal, the inner rays adnate to sides for at least half their length; no humeral process; lateral line zigzag, with many branches given off at the angles; occipital process united to the dorsal plate.

\section{Ageneiosus ucayalensis Castelnau}

Ageneiosus ucayalensis Castelnau, 1855, Anim. Amér. Sud, Poiss., 49, pl. xvii, fig. 2, Ucayali;

Eigenmann and Eigenmann, 1888, Proc. Cal. Acad. Sci., (2), I, 150;

Eigenmann and Eigenmann, 1890, Occ. Papers Cal. Acad. Sci., I, 306;

Eigenmann, 1910, Rept. Princeton Univ. Exped. Patagonia, III, 397.

\section{Peruvian Amazon}

15781, 4, 110-260 mm., Lago Cashiboya, Allen, August 1920.

15785, 2, 168-200 mm., Iquitos, Allen, September, 1920.

15911, 1, $102 \mathrm{~mm}$., Pebas, Peru, Steere, specimen too juvenile for accurate determination, probably belongs here.

Our Cashiboya specimens may be described as follows:

Head 4 in the length to the end of the middle caudal rays; greatest width, at pectoral basis, 1.6 in the length of the head; greatest depth, at origin of anal, 1.4 in the head; eye 6.5 in the head, 3.4 in the interorbital space.

Head extremely flattened and spatulate toward anterior, its dorsal and ventral profiles straight, its greatest depth at occiput 2.4 in the length of the head; body becoming extremely compressed, narrowing from its greatest width at the midpectoral level, which is equal to the interorbital space, and 1.2 in the depth at the same point; width of caudal peduncle 2 in its elevation; both dorsal and ventral profiles moderately convex.

Mouth very wide and inferior, gape exceeding the inferior interorbital space and equalling that of the dorsal interorbital; eye lateral, moderate, slightly exserted on the rounded lateral angle of the head. Premaxillary broadly extended by a distance equal to the diameter of the eye, and, together with the mandible, thickly set with minute recurved teeth in a band; the mandibular band one fourth as wide as the length of the mandible. Inferior portion of gill membrane much 
greater than the superior, containing the latter 1.6 times; confluent with the isthmus; a series of fine, deep lamellae on the throat merging into the branchiostegals laterally; maxillary barbel minute, contained within the fold of the premaxillary, and reaching only half way to the extremity of the latter.

Dorsal fin far forward, the distance of its origin from the snout 3.6 in the length to the end of the middle caudal rays, its spine finely serrate on the anterior border; pectoral strongly exserted on the lateral angle of the head, not reaching the broad ventrals by one third of their length, the spine with small retrorse hooks on the posterior border; anal very long, having 40 rays, its basis equal to the distance of the origin of the dorsal from the snout; adipose remote and short, slightly forward of end of anal, and nearly twice as far from the dorsal basis as from the tip of the middle caudal rays; caudal broad and deeply forked.

Belly white; general ground color shades of saffron; black blotches across the narrow back merging into a black line at the adipose which extends along the bases of the rays of the upper caudal lobe; black blotches on occiput unite backward to form a black streamer below each side of the dorsal fin; forward a black line along each side of the fontanel, diverging along the bony crests to the snout, just within the nares.

\section{Ageneiosus Brevifilis Cuvier and Valenciennes}

Ageneiosus brevifilis Cuvier and Valenciennes, 1840, Hist. Nat. Poiss., XV, 242, Cayenne;

Günther, 1864, Cat. Fish. Brit. Mus., V, 192;

Günther, 1868, Proc. Zool. Soc. London, 229, Xeberos;

Cope, 1878, Proc. Amer. Phil. Soc., XVII, 676, Peruvian Amazon;

Eigenmann and Eigenmann, 1890, Occ. Papers Cal. Acad. Sci., I, 309.

Pseudageneiosus brevifitis Bleeker, 1864, Nat. Verh. Holl. Wetensch., (2), XX, 83, pl. xvi, fig. 1.

Ageneiosus (Pseudageneiosus) brevifilis Eigenmann, 1910, Rept. Princeton Univ. Exped. Patagonia, III, 397.

The Guianas to the Amazons and Rio Paraguay

$15655,3,197-294$ mm., Iquitos, Allen, September, 1920.

15786, 1, $26 \pm$ mm., Manaos, Allen, December, 1920.

15959, 3, 188-240 mm., Iquitos, Morris, 1922.

, 1, $193 \mathrm{~mm}$., Iquitos, J. C. Bradley, 1920.

Morris's specimens show the caudal obliquely truncate; back broader than usual.

Genus 50: TYMPANOPLEURA Eigenmann

Tympanopleura Eigenmann, 1912, Mem. Carnegie Mus., V, 203.

Type: Tympanopleura piperata Eigenmann

British Guiana and Peru

The genus Tympanopleura differs distinctly from Ageneiosus, with which it is closely related. The air bladder is large and fills the abdominal cavity from side to side, forming the large pseudo-tympanum laterally; snout short, profile concave; the dorsal and pectoral spines are pungent and serrate on the posterior face. 
103. Trmpanopleura nigricollis Eigenmann and Allen, sp. nov.

Plate V, figs. 2 and 3 ; plate VI, fig. 3

15788, 1, male, type, $106 \mathrm{~mm}$. to tip of upper caudal lobe, Iquitos, Allen, September, 1920.

15788, 3, females, paratypes, 65-117 mm., Iquitos, Allen, September, 1920.

15789, 1, female, paratype, $95 \mathrm{~mm}$., Rio Ucavali near Orellana, Allen, August, 1920.

Related to $T$. polystictus (Steindachner) and $T$. rondoni (Ribeiro), both of which are probably members of the genus Tympanopleura rather than Ageneiosus.

Head to end of bony opercle $3.2-3.5$ in the length; depth $5.0-5.5$; D. I. 6 ; A. 26-28; head wedge-shaped, slightly concave behind the eye; eye about 1.6 in the snout, about 4.5 in the head, about 3 in the width of the head, width of rictus about equal to snout and eye; length of gape about 3 in the width of the rictus; snout broad, semicircular; maxillary barbel of male osseous to beyond the rictus, equal to length of eye; the barbel fleshy in female; upper jaw slightly projecting all round; depth of premaxillary band of teeth about $\frac{1}{3}$ of eye; profile but slightly concave; occipital process at its base about equal to its length.

Pectoral not reaching to the ventral, the spine about equal to the snout and eye, the front of the spine roughened, with less than 20 serrae on the posterior face, largest at about the middle of the spine; dorsal spine similar, a little longer, the serrae not so high; caudal forked; anal low, not falcate; origin of anal about equidistant from base of middle caudal ray and pectoral spine; ventral reaching beyond origin of anal, less than pectoral spine.

Lower surface of head between rami of the jaws black; a dark area forward from pectoral, another forward from ventral; edge of lower jaw dark; side above anal dark; a light band from lower caudal lobe up and forward to the eye; upper part of head and back to caudal dark; a dark area along base of caudal; fins dusky, upper part of sides light, at times a dark streak along the lateral line.

Air bladder very large, nearly as long as snout and eye, with two coeca longer than pupil.

\section{Tympanopleura alta Eigenmann and Myers Plate VI, fig. 4}

Tympanopleura alta Eigenmann and Myers, in Myers, 1928, Ann. Mag. Nat. Hist., (10), II, 85.

$15790,1,132 \mathrm{~mm}$., type, Iquitos, Allen, September, 1920.

15977, 1, 128 mm., paratype, Iquitos, Morris, 1922.

Head $3.0-3.2$; depth $4-4.5$; D. I, 6 ; A. 32; eye $2.5-3$ in the snout, $5.5-7$ in the head, 3.5 in interorbital; barbel very small (female only) scarcely reaching to rictus; length of gape equals half the width between rictus and rictus; width of head less than width in front of pectorals; snout pointed, upper jaw projecting considerably beyond the lower jaw; depth of premaxillary band of teeth about 2 in eye; profile very concave (the concavity is a little greater than in drawing); fontanel reaching to near middle of eye; width of occipital process about equal to its length.

Pectoral reaching beyond origin of ventral; pectoral spine a little longer than snout and eye, the outer edge rugose, the inner edge with numerous (over 30) 
serrae; dorsal spine smooth anteriorly, similar to the pectoral spine, slightly shorter, its distance from snout 2.33 in standard length; caudal deeply forked; origin of the anal nearer base of middle caudal ray than to origin of pectoral spine; edge of anal not falcate; ventral reaching beyond origin of anal.

Lower side of head and belly white; sides and back dusky; anterior half of pectoral black; ventrals dark; tip and anterior half of dorsal dark; caudal unmarked; tympanum slightly shaded; dark area across frontal.

Air bladder nearly as long as snout; no coeca.

\section{Family VI: Hypophthalmidae}

Nematognath fishes with divided vestigial air bladder, a lobe on either side of the Weberian apparatus, and enclosed by a capsule of bone which is formed of (a) the lateral processes of the fused vertebrae, (b) the scapula, and (c) the processes connecting the scapula with the basioccipital. The external opening of the capsule is enclosed by the scapula and the lateral processes.

Dorsal fin on the anterior half of the body and over the very long anal, which has its origin near the origin of the second third of the body. The eye very low, the optic nerve descending to the eye beneath the skin. Gill membranes free.

\section{Genus 51: HYPOPHTHALMUS Spix}

Hypophthalmus Spix, 1829, Sel. Gen. et Spec. Pisc. Bras., 16, pl. ix, sp.;

Bleeker, 1863, Nederl. Tijdsch. Dierk., I, 109, edentatus;

Eigenmann and Eigenmann, 1890, Oce. Papers Cal. Acad. Sci., I, 313;

Eigenmann, 1910, Rept. Princeton Univ. Exped. Patagonia, III, 398;

Eigenmann, 1912, Mem. Carnegie Mus., V, 208.

\section{Type: Hypophthalmus edentatus Spix}

The Amazons and northward

Jaws and vomer edentulous; eye posterior to and lower than the rictus; adipose small; dorsal fin short, with a slightly spinous ray inserted posterior to the level of the ventrals; anal long; premaxillary very small; barbels six, conspicuous; gillopenings wide and nearly reaching the symphysis; ventrals with six rays; branchiostegals 13-14; gill-rakers long and slender; first two gill-arches with a single series of rakers and a broad membrane; fourth gill-arch free.

\section{Hypophthalmus edentatus Spix}

Hypophthalmus edentatus Spix, 1829, Sel. Gen. et Spec. Pisc. Bras., 16, pl. ix, equatorial Brazil; Günther, 1864, Cat. Fish. Brit. Mus., V, 67;

Cope, 1878, Proc. Amer. Phil. Soc., XVII, 673, Peruvian Amazon;

Eigenmann and Eigenmann, 1890, Occ. Papers Cal. Acad. Sci., I, 313;

Eigenmann, 1910, Rept. Princeton Univ. Exped. Patagonia, III, 398;

Eigenmann, 1912, Mem. Carnegie Mus., V, 209;

Fowler, 1939 (1940), Proc. Acad. Nat. Sci. Phila., XCI, 232, Contamana, two. 
Hypophthalmus perporosus Cope, 1878, Proc. Amer. Phil. Soc., XVII, 673, Nauta;

Steindachner, 1882, Denksch. KK. Akad. Wiss. Wien, XLVI, 4, Rio Huallaga.

Hypophthalmus edentulus Castelnau, 1855, Anim. Amẻr. Sud, Poiss., 47.

Rio Huallaga and Amazon northward

15653, 5, 230-324 mm., Iquitos, Allen, September, 1920.

$15779,8,220-302 \mathrm{~mm}$., Iquitos, Allen, September, 1920.

15780, 2, 248 and $287 \mathrm{~mm}$., Manaos, Brazil, Allen, December, 1920.

15787, 5, 215-300 mm., Manaos, Brazil, Allen, December, 1920.

$15976,1,245 \mathrm{~mm}$. ., Iquitos, Morris, 1922.

Known among the inhabitants of Eastern Peru as the maparaté. Conspicuous for the extreme width and flatness of the barbels, as well as their jet-black color. The barbels may be seen extended forward during locomotion, near the surface of the water. Usually found in muddy streams. Steindachner was supplied with a Quichua name of mapa-racui. The larger specimens have less black on fins and barbels. Those from Brazil have broader, blacker, more taeniiform barbels than the Peruvian specimens, especially the mental pair. Our Peruvian specimens, 15653 , have a larger head than the Manaos specimens, being contained more than four times in the total length in both cases.

Our specimens have the dorsal and ventral profiles moderately and uniformly convex, except for the elevated dorsal basis and slightly concave head; adipose short, elevated, thin; dorsal fin short, its origin well back, in the vertical from the tip of the pectoral, its distance from the tip of the snout 1.2 in its distance from the base of the middle caudal rays, the dorsal fin elevated, its spine long, smooth, slender, D. I, 6; pectoral fins well developed, a half longer than dorsal, with a similar spine only three fourths as long as the longest ray; ventral fins very small, the longest ray 2.6 in that of the pectoral, origin of fin at middle point of pectoral; anal very long, its basis nearly equal to distance of dorsal origin from tip of snout, anal rays about 64 ; caudal deeply forked, its upper lobe the narrower and somewhat longer, both lobes, especially the upper, sharply pointed.

Eye strongly inferior, 9.3 in the head, the interorbital space variable, due to the paper-thinness of the skull and elasticity of the opercular region and visceral skull; head widest behind posterior nares and behind eyes, narrower midway; snout obtusely pointed; jaws equal; gill-membranes cleft to within two eye-lengths of the symphysis. The six barbels of moderate length, the longest being the maxillary, reaching to near the tip of the pectoral fin. The conspicuous branches of the lateral line canal pitted at frequent and irregular intervals; numerous dichotomously branching or netted systems of canals on the head.

Barbels nearly black, all rayed fins tipped in black, extending over distal half of anal rays, and on one specimen nearly the entire caudal fin.

\section{Family VII: Pygidiidae}

Siluroidei trichomycteriformes Bleeker, 1863, Nederl. Tijdsch. Dierk., I, 112.

Trichomycteridae Gill, 1872, Families Fishes, 19.

Pygidiidae Eigenmann and Eigenmann, 1888, Amer. Nat., July, 619;

Eigenmann and Eigenmann, 1890, Oce. Papers Cal. Acad. Sci., I, 316;

Eigenmann, 1918, Mem. Carnegie Mus., VII, 259-398, pls. xxxvi-lvi, text figs. 1-39. 
Throughout most of South America, abounding in moderately high to extremely high elevations, contending with Orestias for the distinction of attaining the greatest altitudes among the fishes of the world.

Air bladder poorly developed; without adipose fin; median fins short to moderate; unarmored; skull enclosed by muscular coat and naked skin; teeth villiform; nares remote; dorsal fin not united to skull by a bony plate. Mostly given to burrowing and holding, the fins well back in response to this habit.

The names candimi and carnero, implying the habit of parasitism, are met with in regions of lower elevation and the more tropical portions of the continent of South America. These terms are as loosely applied to a variety of fishes as the words perch or trout in North America. In fact they are so universally known that few distinctive, colloquial names exist for any member of the family in those regions. It is true, however, that the inhabitants are rarely able to distinguish one from the other, even between distinct subfamilies.

Among the genera Acanthopoma, Vandellia, Stegophilus, Branchioica, Urinophilus, Cetopsis, Hemicetopsis and Tridens, representing three subfamilies, there are supposed to exist one or more species of minute, elongate fishes which exhibit the following type of behavior (or misbehavior):

1. A positive tropism toward urine in the water.

2. A tendency to enter the urethra or other natural opening of the body of man or other animal.

Dr. Eugene W. Gudger, with his genius for documentation and the pursuit of fish-lore to its ultimate hiding-place, has assembled an impressive volume of evidence in support of this popular belief. Some of his information is direct, leading back to supposedly original observation; elsewhere he is obliged to rely upon hearsay. As a summary of present day information on this subject Dr. Gudger has done a well-nigh perfect piece of work. He rightly approaches the subject from the generic angle, not definitely ascribing these attributes to a particular species, as, of course, there is little precise or experimental evidence as to the habits of the respective species.

The fearful appellation candiru was adopted by Spix (1829) as the specific name of the suspected form. "This fish belongs to Cetopsis, a genus which we have described, but I do not know whether these pests are the younger individuals of the species described $(C$. candiru and $C$. coecutiens) or whether they are individuals of a third species of smaller fishes endowed also by nature with this cruel instinct." (Martius, in Spix and Agassiz, 1829). Thus Martius in the preface of the same work leaves the matter of identity open; in spite of all the work done since it is still an open question as to whether Cetopsis candiru or other form is the candiri of tradition.

Eigenmann was greatly interested in establishing the truth as to the alleged tropism toward urine. $(1918$, c.) He was sufficiently convinced to attach the opprobrium of it to a new genus of Vandelliinae, Urinophilus. At his suggestion I made repeated efforts to collect these minute fishes by means of their attraction 
to urine. This was done by saturating cotton and cheesecloth with urine and using it as bait in a glass-jar type of lead-in trap, with a small fumnel opening. The experiment had only negative results.

Pearson (Gudger, 1930a, 180) collected Urinophitus erythrums on a bit of floating fresh meat, demonstrating a chemotropism for meat or blood on the part of that species. Marcoy described a similar episode in which a turtle shell with the meat cut away was both bait and trap for swarms of curnero.

My own efforts in the field warrant only the following conclusions which are briefly summarized without much discussion:

1. The occurrence of the several "carnero" species along beaches, among sand and rocks, and their possession of retrorse, opercular spines like those of the Pygidiidae in general, show these fishes well fitted for holding their places on the beds of rapid streams. The evolution of this intrusive manner of living into a parasitic one, with the use of the spines as holdfasts, is not difficult to imagine.

2. A single specimen, described by Myers as Urinophilus diabolicus (q.v.), was recovered from a Pseudoplatystoma, half inserted into the abdominal cavity. This seems an indubitable case of parasitism, but shows no special probability of a urinophilous tropism, as the point of entry was at some distance from the vent. A similar case was reported by Ternetz to Myers (Gudger, 1930a, 183).

3. Trapping experiments were wholly negative and inconclusive.

4. My host at the Rio Pacaya, Sr. Medina, showed me a scar at the groin which he attributed to the "carnero," but admitted that he did not have opportunity to make a satisfactory identification of his assailant.

5. There is a universal agreement on the part of the inhabitants as to the existence of urinophily, but no agreement as to the form or identity of the urinophile. In all the lowland regions visited the inhabitants were reluctant to enter the water at all, and did so only with some protection to the genitalia. Bathing was commonly engaged in as a daily, or twice daily, ritual. But it was nearly always done by dipping water over the person with a dipper or long-handled calabash, and on the stationary rafts at the water's edge. Some households afforded a riverside enclosure, or bath-house, built on the raft landings, for greater privacy. Among the better-class whites and mestizos the bathing-hours were apportioned. (This practise, as reported by Algot Lange, somewhat mistrusted by Gudger.)

6. No specimens were collected which were sufficiently small to effect an entrance to the urethra.

7. The mechanics of making the alleged entrance would seem impossibly difficult, and would meet with such prompt resistance, as to be but rarely successful, especially in the case of males.

8. It has been suggested that the odor, the salt, or the warmth of urine might be the attracting stimulus. At least in the case of the piranha blood is well shown to have such an attraction.

9. There is more reason to regard the behavior of the candiru, or candimis, as cases of parasite attacking a potential host, attempting to attach itself anywhere, at random. Of this there is no reason for entertaining doubt, in the light of 


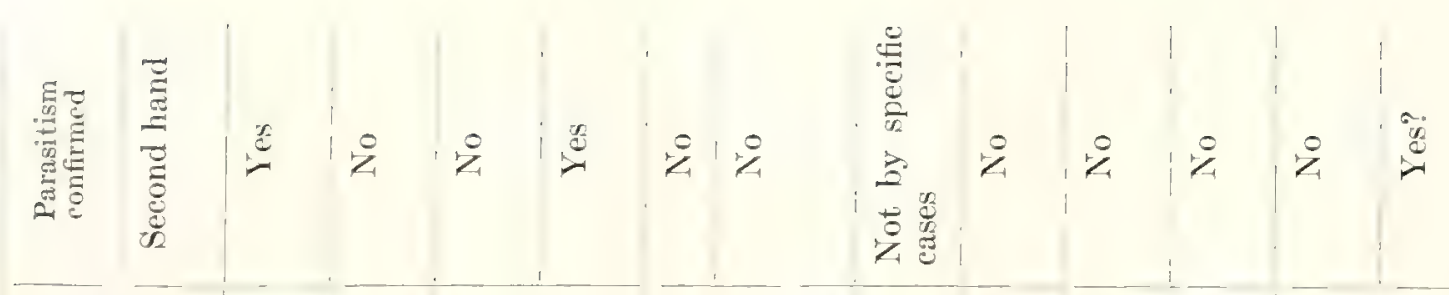

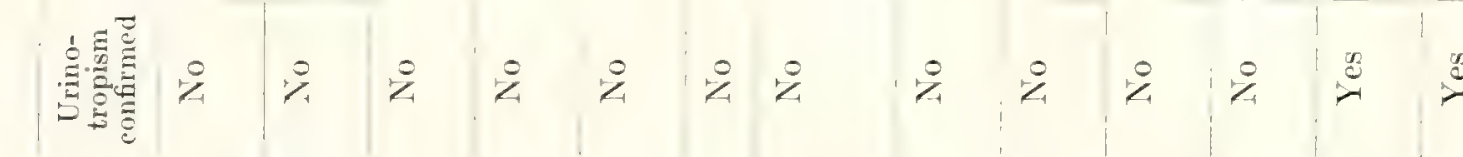

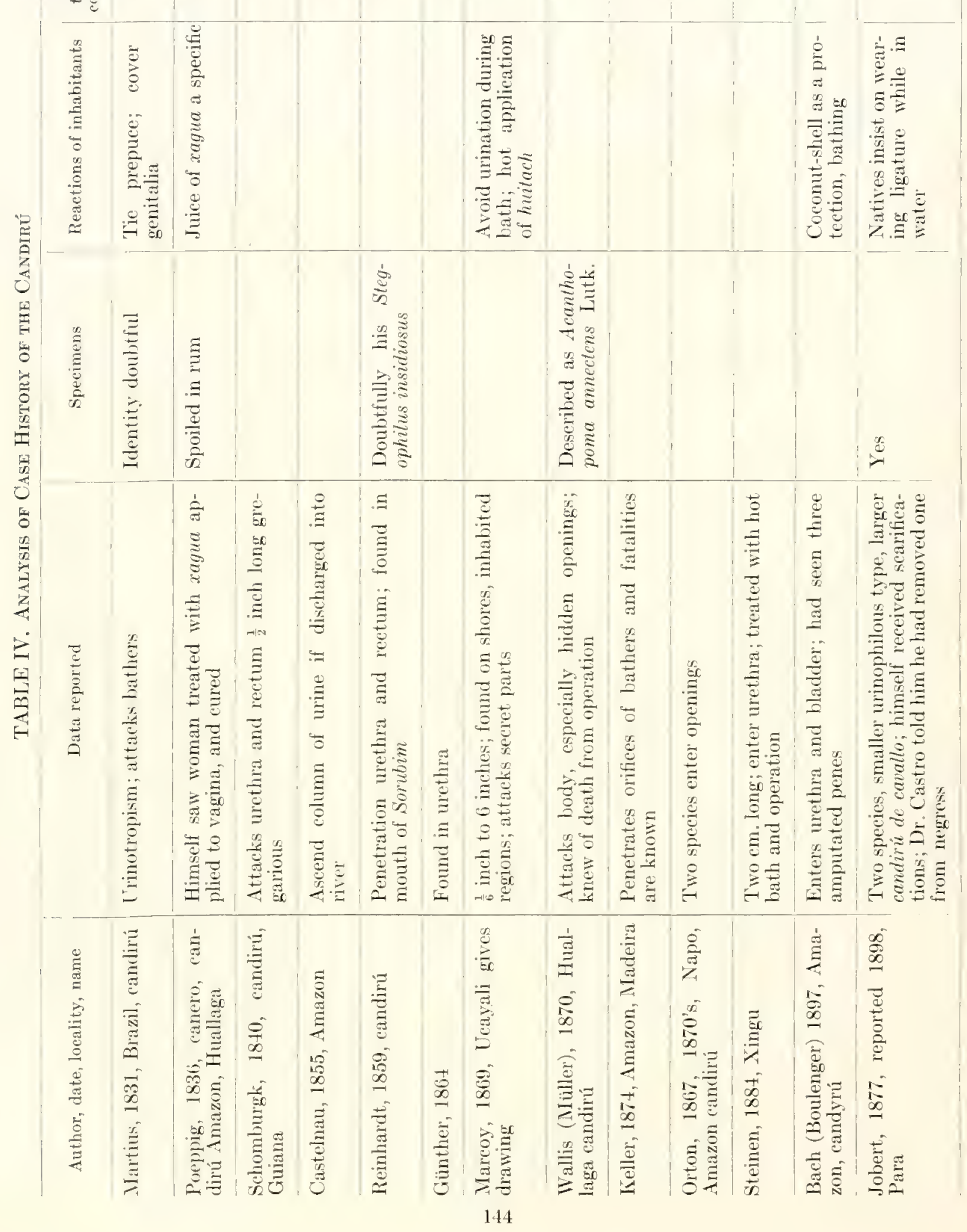




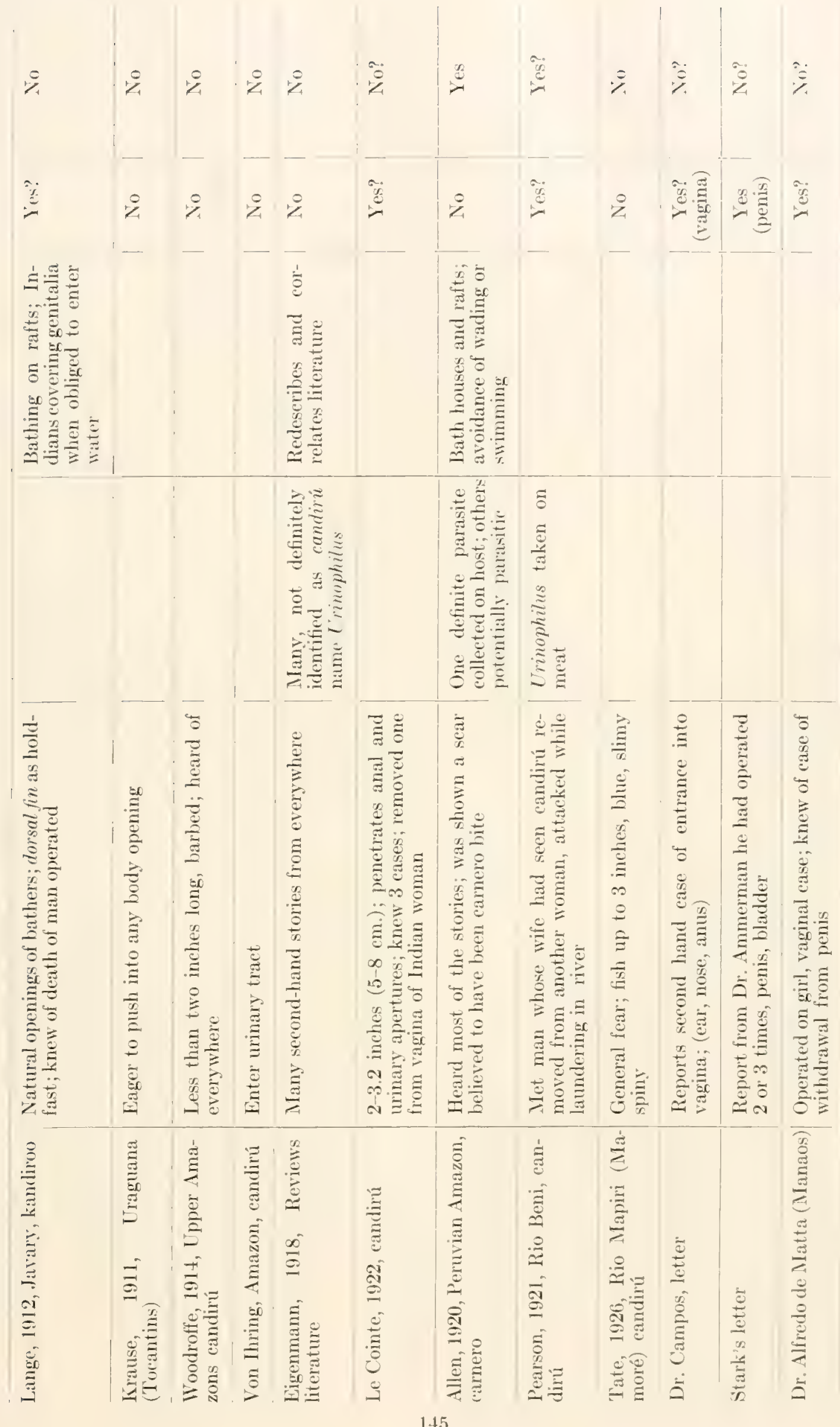


parasitism in general. It would seem to account for the lack of specific points of attack by the laws of chance.

10. The apparently genuine cases supporting the tradition would inevitably receive more attention than the random attacks of the fish upon other parts of the body. This may be partly due to the fact that the indigenous tribes of the region have a superstitious attitude, perhaps reverence, toward the organs of reproduction. Nor is the psyche of the white population without its rich erotic vein and consequent emphasis upon phallic matters.

If a study of the porpoises or manatees of the Amazon should yield abundant piscine parasites on or about the genitalia, a better interpretation of what Gudger calls "the only vertebrate parasite of man" could be made.

In the foregoing table I have attempted to bring into a bird's eye view the evidence pertaining to the candiru. Most of the cases given are taken direct from Gudger, or from sources cited by him.

A summarization of the table will warrant the following:

1. That the exact identity of the culprit is not clear, nor the limits of its depredations, whether it is the original Cetopsis candiru of Spix, or whether a number of species are involved, even whether some unknown species exists which is the guilty one. No specimen known to have attacked man has been preserved in a museum, so far as is known. Orton reported, and others have repeated, that two species exist. The Peruvians told me that there are two, a larger attacking females only. This may be the same form that Jobert calls candiru de cavallo, or "horse candirú."

2. The credibility of some of the witnesses may be impugned, when accepting such accounts as that of the fish ascending a jet of urine from the surface of the stream, or the dorsal fin being used as a holdfast, and the fish being a myxino (hagfish or lamprey).

3. A schooling habit is sometimes described, not easily reconciled with other habits described.

4. It cannot be questioned that members of this family sometimes attack other fishes or the raw flesh of fishes and other animals. They have been attracted and trapped by their taste for flesh. It would be an easy step, considering their intrusive habits, for them to attach themselves to the mouths or gills of larger catfishes, as witnesses report, or even to invade other parts of the host's body, or to be attracted to any opening which they find.

5. Persons have been attacked while bathing, and have received minor wounds not very clearly chargeable to these fishes.

6. Some of the cases of operations are doubtfully due to the candiru, others are rather directly reported and convincing, none quite first hand.

7. It will be noted that among the stories coming through popular sources, and also most of the older accounts, that the candiru is given to attacking males, while the more recent and more direct reports show that females risking themselves in the water are usually the objects of attack.

8. There is little clear-cut evidence by which we can definitely sort out cases 
of urinotropism from parasitism. Some of them could be as readily interpreted one way as the other. The case for urinotropism is very weak indeed, and few cases if any cannot be ascribed to parasitism. However, it is an incipient or facultative degree of parasitism at that, and not at all an obligate one. It lacks the ear-marks of true, obligate parasitism, for (a) there is no evidence that they cannot turn to predatism, or do not rely upon it nearly altogether; (b) there is no especial readaptation of the body for the inactivity of parasitism, unless, as in the case of Hemicetopsis, a very great capacity for soft, liquid food; and (c) there are no known modifications of life history for such a mode of life.

Haseman, 1911b, page 315, not quoted in the table above, agrees that some species of candiri are said to live in the branchial cavities of the larger siluroids. "In fact they attach themselves to any kind of fish or animal, including man. By means of suction for which their mouths are adapted, they fasten themselves to their victim, and then painlessly cut the skin, and gorge themselves upon its blood. The fishes brought into the market at Manaos often show many wounds inflicted by the Candirús. Below the first fall in the Madeira river it is difficult to take a catfish which has not been bitten several times by the Candiris:" This may be considered as much in the nature of predatism as parasitism.

Numerous popular authors give some brief space to the candin. Prodgers, Bolivia, page 115, calls them the kandiro, "a slimy leech, three to four inches long, which get up into the rectum," where they erect the dorsal fin and have to be cut out. In his Peru the same writer, page 210, calling them candero, $1 \frac{1}{2}$ to 3 inches long, "and a shark in mineature, with similar fins and teeth... when the fins fold down it looks like a worm ... its favorite point of attack is the fundament."

Orton found the name applied also to three species of Serrasalmo, by reason of the same dread inspired in bathers. "The natives accuse Vandellia of entering the nether openings of bathers" but he did not meet with any confirmatory cases. Guenther, 1931, alludes to it as a little, thread-like Silure ... an unpleasant acquaintance... forces its way into the urethra of bathers and owing to the spines on the gill-covers it cannot be extracted."

Marcoy, 1875, II, 184-188, provides us with a drawing which has more resemblance to Hemicetopsis than to other suspects, as you might also suppose from the stated length of 5-6 inches... "it wages relentless war on the calves of the natives who come within its reach; darts impetuously at the fleshy mass, and rends a portion away before the owner of the calf has time to realize his loss." Then he goes on to say that "the smaller of the species are 2-3 lines long and dangerous in quite another respect... introduce themselves into the secret parts of bathers, where their extended fins retain them captive... whispered warnings to avoid passing urine into the water ... one remedy alone the Ucayali doctors (sic) . . a tisane made with genipa or huitoch apple... hot ... dissolves (they pretend) the animal which obstructs." I (W.R.A.) found numerous natives using a fruit with the same name, rubbing it into the skin of hands, face, and feet, where it gave an intense, purplish black stain, said to be repellent to mosquitoes and sand-flies. 
Marcoy describes the procedure of fishing for the kandiroo with "turtle shells having a little flesh adhering ... the fish getting as fat as a goldfish in a globe . . the excess fish being fed to the poultry."

\section{Subfamily: CETOPSINAE}

Dorsal fin entirely forward of the ventrals; vomer with a single series of teeth; head compressed; anterior nares almost labial in position; eye almost entirely concealed under the skin; a single maxillary barbel; two pairs of mentals; opercle unarmed, and gill-membrane broadly united with the isthmus.

\section{Genus 52: HEMICETOPSIS Bleeker}

Cetopsis Agassiz, 1829, Sel. Gen. et Spec. Pisc. Bras., 11, sp.

Hemicetopsis Bleeker, 1862, Versl. Akad. Amst., XIV, 403;

Bleeker, 1863, Nederl. Tijdsch. Dierk., I, 111;

Eigenmann and Bean, 1907, Proc. U. S. Nat. Mus., XXXI, 664;

Eigenmann, 1910, Rept. Princeton Univ. Exped. Patagonia, III, 398;

Eigenmann, 1912, Mem. Carnegie Mus, V, 210.

Cetopsis (Hemicetopsis) Eigenmann and Eigenmann, 1890, Occ. Papers Cal. Acad. Sci., I, 318.

\section{Type: Silurus candiru Spix}

\section{Amazons and Guianas}

Dorsal fin forward of the vertical from the ventrals; teeth conical, vomerines in a single series.

\section{Hemicetopsis Candiru (Spix)}

Silurus candiru Spix, 1829, Sel. Gen. et Spec. Pisc. Bras., pl. x, fig. 1.

Cetopsis candiru Agassiz, 1829, Sel. Gen. et Spec. Pisc. Bras., 13;

Eigenmann and Eigenmann, 1890, Occ. Papers Cal. Acad. Sci., I, 319;

Pearson, 1924, Ind. Univ. Studies, XI, no. 64, 16, Rurrenabaque, Bolivia, a specimen of $242 \mathrm{~mm}$.

Cetopsis candira Cuvier and Valenciennes, 1839, Hist. Nat. Poiss., XIV, 386;

Günther, 1864, Cat. Fish. Brit. Mus., V, 199;

Cope, 1878, Proc. Amer. Phil. Soc., XVII, 678, Peruvian Amazon;

Steindachner, 1882 (1883), Denksch. KK. Akad. Wiss. Wien, XLVI, 5, Rio Huallaga, five specimens, $190-280 \mathrm{~mm}$;

Eigenmann and Eigenmann, 1888, Proc. Cal. Acad. Sci., (2), I, 157.

Hemicetopsis candiru Bleeker, 1862, Versl. Akad. Amst., XIV, 403;

Eigenmann and Bean, 1907, Proc. U. S. Nat. Mus., XXXI, 664;

Eigenmann, 1910, Rept. Princeton Univ. Exped. Patagonia, III, 398;

Fowler, 1939 (1940), Proc. Acad. Nat. Sci. Phila., XCI, 232, two, Contamana.

Rios Ucayali and Huallaga down the Amazon, to Bolivia

15801, 15, 118-174 mm., Rio Ucayali, Nueva Ytalia, near Cashiboya, Allen, August, 1920.

15814, 1, 137 mm., Bretaña, Rio Puinagua, Allen, September, 1920.

When taken, subcylindrical, and turgid with blood and offal. Specimens therefore much shrunken and wrinkled in alcohol. A favorite haunt of this species 
appears to be the shelter of the rafts used as farmstead canoe landings, or floating docks, where much of the life of the farm takes place. Among these activities are the butchering and fish-drying for the household, and the offal and fish blood are disposed of through the chinks. Sr. Julio Battistini showed me the method of taking these fishes with the greatest ease and rapidity. Without pole, line, hook, or sinker, a simple piece of fish-flesh was dangled between the logs of the raft. The carnero attacked the bait with such pertinacity that from one to three could be pulled up and shaken off into a basin at a time.

Among the natives they have the reputation of being tropic to urine, and are said to enter the body of female bathers only, due to their large size, while other species attack males.

My first collecting trip, which was confined to the coastal and cordilleran regions, did not penetrate into the tropical habitat of the candiru. But everywhere I met people familiar with the stories about it, and it is probably unknown to but very few of the inhabitants of Peru.

\section{Hemicetopsis plumbeus (Steindachner)}

Cetopsis plumbeus Steindachner, 1882 (1883), Denksch. KK. Akad. Wiss. Wien, XLVI, 31, pl. vi, fig. 3, Canelos, Ecuador, two, 60 and $70 \mathrm{~mm}$;

Boulenger, 1887, Proc. Zool. Soc. London, 276, Canclos;

Eigenmann and Eigenmann, 1890, Occ. Papers Cal. Acad. Sci., I, 320;

Pearson, 1924, Ind. Univ. Studies, XI, no. 6t, 16, Rio Bopi, Bolivia, ten, $7 t-140 \mathrm{~mm}$;

Pearson, 1937a, Proc. Cal. Acad. Sci., (4), XXIII, 94, Pusoc and Tingo de Pauca, upper Marañon.

Hemicetopsis plumbeus Eigenmann, 1910, Rept. Princeton Univ. Exped. Patagonia, III, 398.

Known only from Canelos and the two widely separated habitats listed by Pearsoll.

Differing from the preceding in that there are two or three series of premaxillary teeth, that the anterior nares are less widely spaced than the posterior; gillopenings higher, reaching above first pectoral ray; inner ventral ray adnate to belly wall; pectorals shorter, not reaching the ventral fins.

\section{Genus 53: PSEUDOCETOPSIS Bleeker}

Pseudocetopsis Bleeker, 1862, Versl. Akad. Amst., XIV, 403;

Eigenmann, 1910, Rept. Princeton Univ. Exped. Patagonia, III, 398.

Cetopsis (Pseudocetopsis) Eigenmann and Eigenmann, 1890, Occ. Papers Cal. Acad. Sci., I, 398.

Type: Cetopsis gobioides Kner

Both sides Ecuadorean Andes to Central Brazil

Without conical or incisor-like teeth, or at most a single band of conical teeth on vomer.

108. Pseudocetopsis ventralis (Gill)

Cetopsis ventralis Gill, 1870, Proc. Acad. Nat. Sci. Phila., AXII, 95, Napo or Marañon basin, Orton collection;

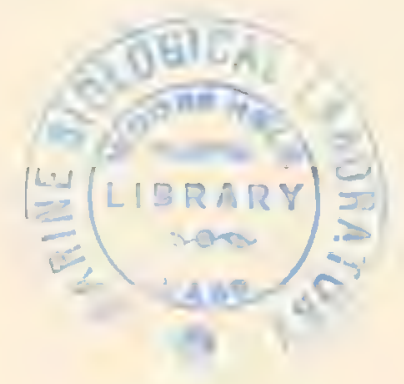


Eigenmann and Eigenmann, 1890, Occ. Papers Cal. Acad. Sci., I, 322.

Pseudocetopsis ventralis Eigenmann, Rept. Princeton Univ. Exped. Patagonia, III, 398.

Known only from Orton's specimens at the Philadelphia Academy Museum.

$$
\text { Subfamily: PYGIDIINAE }
$$

Mostly or altogether free-living South American Nematognaths, having the dorsal fin over or behind the ventrals; adipose fin wanting; opercle and interopercle spinous; barbels reduced to a pair at each angle of the mouth, and otherwise irregular; frequently of elongated, almost eel-like form, but very diverse in form and habit; generally intrusive, by virtue of the spines and hooks which anchor them to the sides of an opening, as they elbow themselves among the rocks of rapids and riffles or burrow in sand or mud, or insinuate themselves into the cavities and gillchambers of other fishes.

Fishes of the highlands and seantily dispersed into adjacent lowlands, rarely down to near sea-level. Next to Orestias the dominant fishes of the high Andes.

\section{Genus 54: PARIOLIUS Cope}

Pariolius Cope, 1871 (1872), Proc. Acad. Nat. Sci. Phila., XXIII, 289;

Eigenmann and Eigenmann, 1889, Proc. Cal. Acad. Sci., (2), II, 50;

Eigenmann and Eigenmann, 1890, Oce. Papers Cal. Acad. Sci., 1, 324;

Gosline, 1940, Copeia, no. 2, 78.

Type: Pariolius armillatus Cope

Range that of the species

Dorsal fin in front of the ventrals; no nasal barbels; opercle and preopercle without spines; a single barbel on each maxillary and two pairs of mentals. Near Pygidium, but not conforming to the boundaries of the subfamily; probably out of order here, and nearer the main trunk of the Stegophilines. Gosline considers it a nearer ally of the Pimelodidae.

\section{Pariolius armillatus Cope}

Pariolius armillatus Cope, 1871 (1872), Proc. Acad. Nat. Sci. Phila., XXIII, 289;

Eigenmann and Eigenmann, 1890, Oce. Papers Cal. Acad. Sci., I, 324;

Eigenmann, 1910, Rept. Princeton Univ. Exped. Patagonia, III, 398;

Gosline, 1940, Copeia, no. 2, 79.

Rio Ambyiacu

With new material from R. Ambyiacu Gosline has redescribed this fish.

\section{Genus 55: PYGIDIUM Meyen}

Trichomycterus Valenciennes, 1833, in Humboldt, Rec. d'Obs. Zool. Anat., II, 348, non Thrichomycterus Humboldt.

Pygidium Meyen, 1835, Reise in Peru, I, 47t, fuscum;

Eigenmann and Eigenmann, 1890, Oce. Papers Cal. Acad. Sci., I, 325; 
Eigenmann, 1910, Rept. Princeton Univ. Exped. Patagonia, III, 399;

Eigenmann, 1918c, Mem. Carnegie Mus., V, 288.

\section{Type: Pygidium fuscum Meyen}

Panama to Chile and Patagonia, inhabiting mountain lakes and streams, rarely lowland streams to near sea level, the species usually limited to a few closely connected drainage areas

Of elongate body form, cylindrical to terete, caudal peduncle compressed and elevated; without scales or plates, two barbels at each angle of mouth, no mental, generally short; eye small and at or before middle of head, without free orbital border; interopercle with several series of spines; gill-membrane narrowly united with isthmus, and usually a narrow, free margin across it; mouth terminal, moderate; jaws with two or more chisel-like teeth, sometimes conical; no labial or vomerine teeth; fins without spines, although sometimes filamentous; ventral fins at or beyond middle of body.

\section{Pygidium fuscum Meyen}

Pygidium fuscum Meyen, 1835, Reise in P'eru, I, 475;

Tschudi, 1845, Fauna Peru., 21;

Eigenmann, 1910, Rept. Princeton Univ. Exped. Patagonia, III, 399;

Eigenmann, 1918c, Mem. Carnegie Mus., VII, 298.

Peru, in the High Andes

Aside from Tschudi's assurance that P. fuscum is distinct from his own dispar, there is no corroboration of the existence of this species with its unsatisfactory description. Not even the locality is known, and may not be in that portion of Peru covered by this report. Or it may have originated in that portion of the larger viceregal Peru now known as Bolivia.

\section{Pygidium vittatum (Regan)}

Trichomycterus vittatus Regan, 1903, Ann. Mag. Nat. Hist., (7), XII, 623.

Pygidium vittatum Eigenmann, 1910, Rept. Princeton Univ. Exped. Patagonia, IL, 400;

Eigenmann, 1918c, Mem. Carnegie Mus., VII, 299.

\section{Marcapata valley, southeastern Peru}

Only the types are known. Origin of dorsal before vertical from anus, and its distance from the caudal one and one half the distance from the snout; anal wholly caudal of the vertical from the last dorsal ray; distance of the base of the last anal ray from the caudal four and one half times in the total length; caudal truncate; dark spots on head and body, and a dark lateral stripe.

\section{Pygidium dispar Tschudi}

Pygidium dispar 'T'schudi, in part, 1845, Fauna Peru., 22, pl. iii, upper figure, High Andes, eastern slope, 14,000 feet elevation; 
Eigenmann and Eigenmann, 1890, Occ. Papers Cal. Acad. Sci., I, 335;

Pellegrin, 1904, Bull. Soc. Zool. France, XXIX, 91;

Pellegrin, 1907, Poiss. Laes Hauts Plat. Amér. Sud, 17;

Eigenmann, 1910, Rept. Princeton Univ. Exped. Patagonia, III, 400;

Evermann and Radcliffe, 1917, Bull. U. S. Nat. Mus., no. 95, 35;

Eigenmann, 1918c, Mem. Carnegie Mus., VII, 299, pl. xlv, fig. 5.

Trichomycterus dispar Günther, 1864, Cat. Fish. Brit. Mus., V, 273;

Cope, 1877, Proc. Amer. Phil. Soc., XVII, 46;

Cope, 1878, Proc. Amer. Phil. Soc., XVII, 681, Urubamba, 10,000 feet elevation; Tinta, 11,400 feet.

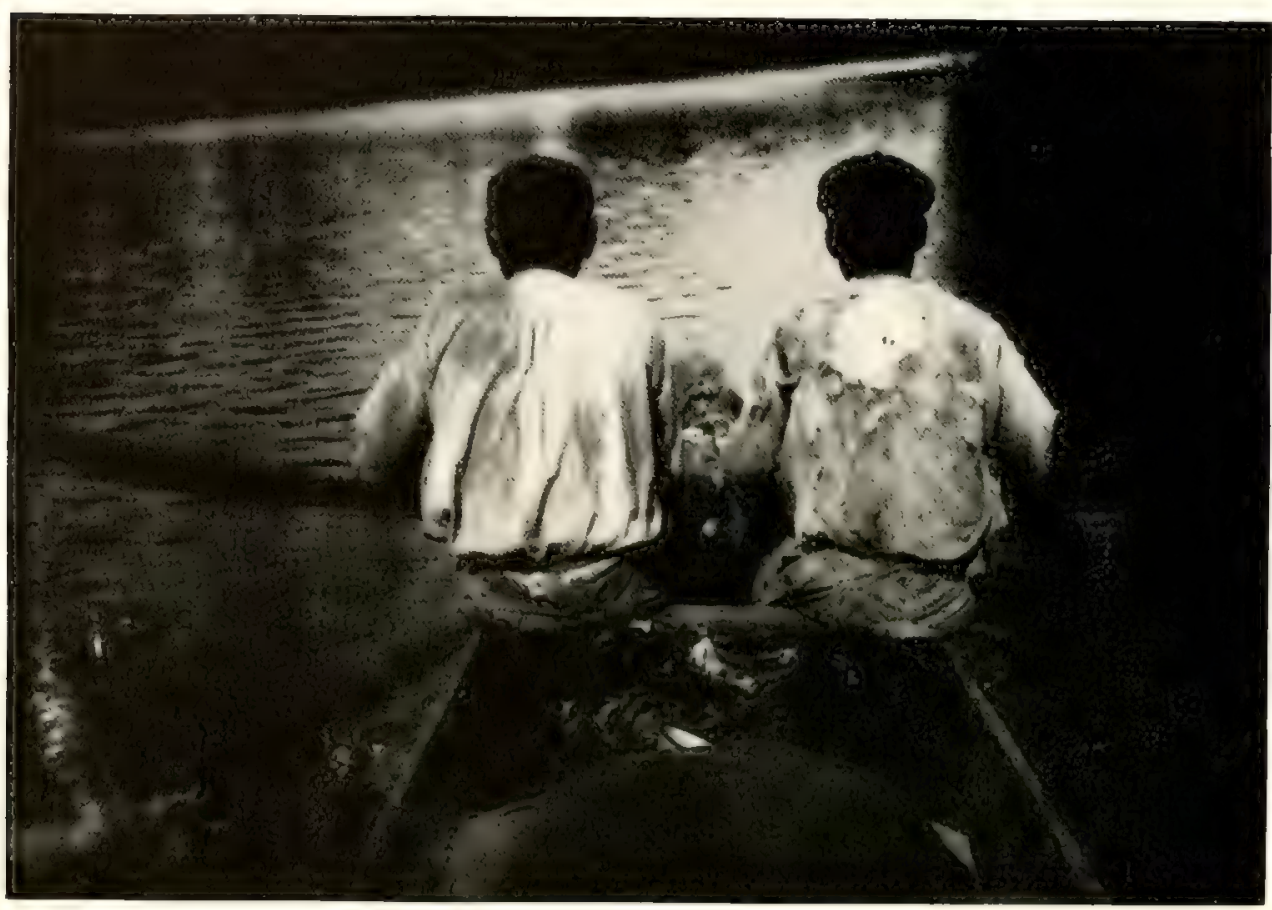

FIG. 19. The Rio Pacaya of the Ucarali basin. Twin-motored canoe of large size which was used on this stream. Its waters are brown, and infested with caymans.

Higher elevations both sides of the Andes and L. Titicaca

Cope's specimens may be $P$. rivulatum. Cope regards Günther's specimens as maculatum by reason of its smaller number of dorsal radii. With this we can agree except that Cope also appears to confuse dispar with rivulatum. Günther's characterization fits the latter species as well as dispar. He says also that it occurs in all parts of Lake Titicaca and its tributaries; eats small molluses, crustacea, and fishes; a 14-inch specimen contained one of six inches; brown, reticulated with many white lines, sometimes spotted like a trout; adult specimens of less than seven inches up to 16 ; the name maure given to the large ones, suche to the younger ones. Cope says the young have a more or less interrupted, lead-colored lateral band which breaks up with growth.

\section{Pygidium Rivulatum (Cuvier and Valenciennes)}

Trichomycterus riulatus Cuvier and Valenciennes, 1846, Hist. Nat. Poiss., XVIII, 495, Guasacona; Cope, 1877, Proc. Amer. Phil. Soc., XVII, 46, Lago Titicaca, one large specimen, too few dorsal rays to be dispar; 
Pellegrin, 1904, Bull. Soc. Zool. France, XXIX, 91;

Pellegrin, 1907, Poiss. Lacs Hauts Plat. Amér. Sud, 17, Lago Poopó, Pazña.

Pygidium rivulatum Eigenmann and Eigenmann, 1889, Proc. Cal. Acad. Sci., (2), II, 51, Cuzco, Moho, Puno, Lake 'Titicaca;

Eigenmann and Bean, 1907, Proc. U. S. Nat. Mus., XXXI, 771;

Eigenmann, 1918, Mem. Carnegie Mus., VII, 301;

Pearson, 1937a, Proc. Cal. Acad. Sci., (4), XXIII, 94, Cajamarca.

?Trichomycterus incae Cuvier and Valenciennes, 1846, Hist. Vat. Poiss., XVIII, 496, Cuzco, Rio Guatanai.

Trichomycterus gracilis Cuvier and Valenciennes, 1846, Hist. Nat. Poiss., XVIII, 497, Rio Azángaro near Guasacona; Rio Guatanai, Cuzco; Lago Compucila near Cuzco;

Cope, 1877, Proc. Amer. Phil. Soc., XVII, 681, Tinta.

Trichomycterus barbatula Cuvier and Valenciennes, 1816, Hist. Nat. Poiss., XVIII, 498, Guasacona; Pontezuela, near Coroico, Bol.

Trichomycterus pentlandi Castelnau, 1855, Anim. Amér. Sud, Poiss., 49, pl. xxiv, fig. 1, "lake communicating with the Ucayali."

Trichomycterus pictus Castelnau, 1855, Anim. Amér. Sud, Poiss., 59, pl. xxiv, fig. 2, Lago Titicaca. Trichomycterus dispar Garman (non 'Tschudi), 1875, Bull. MIs. Comp. Zool., III, 275, Lago Titicaca; Pellegrin, 1904, Bull. Soc. Zool. France, XXIX, 91;

Pellegrin, 1907, Poiss. Laes Hauts Plat. Amér. Sud, 7, Lago Titicaca.

Trichomycterus pardus Cope, 1874, Proc. Acad. Yat. Sci. Phila., XIVI, 132.

\section{Central plateaux of southern Peru and adjacent highlands}

13833, 1, 93 mm., Tirapata, 13000 feet, purchase from Rosenberg.

13750, 2, 123 and $140 \mathrm{~mm}$., Ollantavtambo, Rio Urubamba, E. Heller.

15063, many, 30-82 mm., Media Luna, Rio Urubamba, Eigenmann, November, 1918.

15061, many, Calacoto, Rio Desaguadero, Bolivia, Allen, 1919.

15065, 3, up to $300 \mathrm{~mm}$., Puno Market, L. Titicaca, Allen, December, 1918.

15066, 14, 42-150 mm., Ollantaytambo, R. Trubamba, Eigenmann, November, 1918.

15068, 7t, 106-156 mm., Saylla, Cuzco valley, Eigenmann, Tovember, 1918

15072, 7, 104-122 mm., Rio Urubamba, Eigenmann, November, 1918.

15073, many, 40-133 mm., Angostura, Cuzco valley, Eigenmann, November, 1918

15074, many, 30-125 mm., Saylla, Cuzco valley, Eigenmann, November, 1918.

16058, 2, about $400 \mathrm{~mm}$., Pto. Acosta, L. Titicaca, Allen, December, 1918.

16059, , Lago Titicaca, Puno, Allen, 1918.

17795, 3, 60-69 mm., Torontoy, R. Urubamba, Eigenmann, November, 1918.

17796, many, 36-178 mm., Lago Urcos, Eigenmann, November, 1918.

17797, many, 39-215 mm., Aguas Calientes, R. Vileanota, Allen, January 1919

17798, many, 41-90 mm., Lago Verde, R. Vileanota, Allen, January, 1919.

17809, many, 32-102 mm., lagoon, Huaypo, Eigenmann, November, 1918.

17810, many, 31-95 mm., Poroy, Ligenmann, November, 1918.

17811, , R. Huatanay, Eigenmann, Notember, 1918.

17812, 26, 39-73 mm., Iscuchaca, R. Huatanay, Eigenmann, November, 1918.

17813, many, 52-96 mm., Angostura, R. Huatanay, Eigenmann, November, 1918.

17814, many, 54-179 mm., Hermita, Oropesa, Eigenmann, November, 1918.

$17815,5,3 \overline{7}-58$ mm., R. de Langui, Eigenmann, Torember, 1918.

17816, 26, 24-86 mm., R. Occopata, Eigenmann, November, 1918.

Of the specimens numbered 17810 and 17816 none has the protracted ray of the pectoral well-developed, suggesting atochae. They are also mostly small and not robust.

Generally known as the suche (elsewhere locally called bagre, in a generic sense; also boga and mauri).

Our largest specimens were taken near Noho on Lake Titicaca, at Puerto Acosta, by means of a home-made wicker lead-in trap resembling the lobster-pot, 
with a funnel beneath, and suspended from a balsa by means of a native grass rope. In general the largest and best-conditioned specimens came from lakes.

Pearson (1924) collected $P$. rivulatum as far down into Bolivia as the fringe of the foothills at about 1500 feet elevation. His specimens show variations which are about constant within each locality. He finds none of the typical vermiculations of the upland specimens, but the spots are large or small, in horizontal lines, or irregular. His fluviatile specimens have larger barbels than those of lakes. His collections and those reported above show that diligent search has been made over a wide territory without bringing to light any specimens which we could identify as $P$. dispar, which may therefore fall within the wide range of variation of rivulatum, in case a few errors have been made in describing it.

While not a rival in numbers or amount marketed in the Titicaca valley, it outranks its competitor Orestias in size and quality. The flesh is soft and there are few bones. Suggesting Ameiurus of North America in form, the bottominhabiting habit is likewise similar.

\section{Pygidium oroyae Eigenmann and Eigenmann}

Pygidium oroyae Eigenmann and Eigenmann, 1889, Proc. Cal. Acad. Sci., (2), II, 51;

Eigenmann and Eigenmann, 1890, Occ. Papers Cal. Acad. Sci., I, 334, 8 specimens, R. Oroya, Pochachara;

Eigenmann, 1910, Rept. Princeton Univ. Exped. Patagonia, III, 399;

Evermann and Radeliffe, 1917, Bull. U. S. Nat. Mus., no. 95, 35, pl. iv, fig. 2, Oroya;

Eigenmann, 1918, Mem. Carnegie Mus., VII, 304, text fig. 10.

Rio Mantaro, central Peru, having a very restricted range, not extending far from the valley of the small river which gives it the name, except that it has invaded the upper Perené.

17799, many hundreds, 20-206 mm., Rio Oroya and Rio Mantaro, Oroya, Eigenmann and Allen, September, 1918.

17800, many hundreds, 20-102 mm., 'Tarma, R. de Tarma, Eigenmann, September, 1918.

-, many, , Tarma, R. de Tarma, and springs, Allen, June, 1920. , 18, 24-90 mm., Tarma, Lola E. Vance, about 1912.

17801, 11, 35-135 mm., Zigzag, branch R. Mantaro, Allen, October, 1918.

17802, 2, 137-184 mm., creek, L. Chinchaycocha, Allen, October, 1918.

17803, many, 36-110 mm., Tilarnioc, R. Mantaro, Eigenmann, September, 1918.

17804, 2, 94 and $115 \mathrm{~mm}$., Pachachaca, Eigenmann, September, 1918.

17805, many, 22-82 mm., Huancayo, Eigenmann, September, 1918.

17806, 26, 20-71 mm., Quebrada, Huancayo, Eigenmann, September, 1918.

$17807,1,115 \mathrm{~mm}$., Jauja, Ligenmann, September, 1918.

17808, 3, 30-77 mm., Palca, Peru, Eigenmann, September, 1918.

Originally described from eight specimens, the description amplified by Evermann and Radeliffe, 1917, from the examination of two. We have before us many hundreds reaching a maximum of $206 \mathrm{~mm}$. compared with former maxima of $140 \mathrm{~mm}$. and $130 \mathrm{~mm}$., and collected from a wide range of localities.

The dorsal fin overlaps the anal; ventrals much reduced; the caudal rounded in the younger, becoming subtruncate in the larger; pectoral short and rounded, first ray not prolonged; anal fin large; fins becoming thick and fleshy with age; lappet at angle of mouth triangular and bulbous. 
Markings obscure in older specimens, becoming more olivaceous with age, while in rivulatum the spots become more pronounced in the larger.

Higher up the Mantaro, in the slower, more sluggish streams and lakes of the pampas (13000 feet and above), such localities as Zigzag, Tilarnioc, and Junin, we find the specimens more elongate, the lappets not usually bulbous, and the color brown with no indication of an olivaceous tint.

Our first specimens were collected in the diminutive type stream, the Rio Oroya, where it rushes precipitously among rocks, boulders, and rubble for a halfmile to join the Rio Mantaro. The roots of the cubé plant were used here for the first time; the bruised pulp and milky extract were placed in the stream at the top of the canon, into water so turbulent that you would not expect to find any life. But in a short time the Pygidium began to boil out from among the rocks in enormous numbers, struggling for breath, and were easy victims to the dipnet. This was a surprise even to the bystanders.

\section{Pygidium taczanowski (Steindachner)}

Pygidium dispar Tschudi, part, 1845, Fauna Peru., 22, pl. iii, lower figure.

Trichomycterus taczanowskii Steindachner, 1882, Denksch. KK. Akad. IViss. Wien, XLVI, 22, pl. iv, figs. 1-1b, Rio de Huambo, Rio de 'Tortora.

Pygidium taczanowstii Eigenmann and Eigenmann, 1889, Proc. Cal. Acad. Sci., (2), II, 52;

Eigenmann and Eigenmann, 1890, Occ. Papers Cal. Acad. Sci., I, 338;

Eigenmann, 1910, Rept. Princeton Univ. Exped. Patagonia, III, 400;

Eigenmann, 1918, Mem. Carnegie Mus., VII, 301, pl. xlvi, figs. 5-8;

Pearson, 1937a, Proc. Cal. Acad. Sci., (4), XXIII, 93, Marañon.

Central Peru northward in moderate elevations

17817, 17, 130-226 mm., Rio Huallaga, Huánuco, Allen, October, 1918.

17818, 8, 45-69 mm., Rio Tingo, Huánuco, Allen, October, 1918.

The latter specimens all much smaller in this small tributary stream than in the nearby Huallaga into which it flows.

Steindachner was given the local name kutschin for this species. My informants usually applied the name bagre, meaning catfish, though others were calling it huascachallhua.

In many respects our Huánuco specimens show a close correspondence to the original descriptions: D. 9; A. 7; P. 9; width of head in its length 1.3 ; snout 2.1-2.3 ; interorbital 3.3-near 4, as compared with the broader $3.0-3.33$ of the original description; nasal barbels 1.3 ; lower barbels 1.6 ; width of mouth in head 2 ; eye in front of middle to middle of head. Our specimens unlike the types in that the origin of the dorsal is nearer the caudal than to the gill-opening in those of about $130 \mathrm{~mm}$., and in our largest 1.4 nearer the caudal as compared with 1.22 nearer in the types. The ratio of the first pectoral ray to the length of the head about the same. These measurements indicate greater variability in the young rather than a progressive advancement caudally of the dorsal fin with age. 


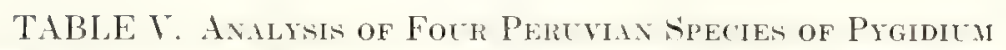

\begin{tabular}{|c|c|c|c|c|c|}
\hline Characters & Rivulatum & Oroyae & $\begin{array}{c}\text { Taczanowskii } \\
\text { type }\end{array}$ & $\begin{array}{l}\text { Taczanowskii } \\
\text { from Rio Tingo }\end{array}$ & Atochae \\
\hline Head in length & $4.5-5.5^{*}$ & $5.75-6.0$ & $4.75-5.5^{*}$ & $4.6-5.3^{*}$ & $4.7-6.3$ \\
\hline Dorsal & $13^{*}$ & $12^{*}$ & $9-10$ & $8-9$ & $8-9$ fleshy \\
\hline Anal & $11^{*}$ & $10-11^{*}$ & 7 & $7-8$ & $6-\gamma$ fleshy \\
\hline Pectoral & & $10^{*}$ & 9 & $8-9$ & $8-9$ \\
\hline $\begin{array}{l}\text { Nasal barbel in } \\
\text { head }\end{array}$ & to end of eye & \multirow{3}{*}{$\begin{array}{l}\text { none reaching } \\
\text { gill-opening }\end{array}$} & $1.25-1 . t$ & 1.3 & $2.2-2.6$ \\
\hline $\begin{array}{l}\text { Maxillary } \\
\text { barbel same }\end{array}$ & $\begin{array}{l}\text { edge pre- } \\
\text { opercle }\end{array}$ & & $1.21-1.25$ & 1.4 & $1.8-2.0$ \\
\hline $\begin{array}{l}\text { Mental barbel } \\
\text { same }\end{array}$ & & & $1.6-2.0$ & $1.6^{*}$ & $2.1-2.4$ \\
\hline C'atudal & l'ounded & rounded & 'matrinate & subtruncate & subtruncate \\
\hline Depth in length & $3.75-6.5^{*}$ & $5.75-8.0$ & $6.3-8.4$ & $6.0-7.0$ & $8.3-9.8$ \\
\hline Dorsal to anal & $\begin{array}{l}\text { overlaps half } \\
\text { way }\end{array}$ & $\begin{array}{l}\text { overlaps some- } \\
\text { what }\end{array}$ & barely reaches* & barely reaches* & $\begin{array}{l}\text { overlaps half } \\
\text { way }\end{array}$ \\
\hline Accessory rays & $\begin{array}{l}\text { distinct* } \\
\text { numerous }\end{array}$ & $\begin{array}{l}\text { few and in- } \\
\text { distinet }\end{array}$ & $\begin{array}{l}\text { few and in- } \\
\text { distinct }\end{array}$ & $\begin{array}{l}\text { few, not dis- } \\
\text { tinct }\end{array}$ & $\begin{array}{l}\text { Moderately } \\
\text { numerous }\end{array}$ \\
\hline
\end{tabular}

In the above brief tabular analysis, certain characters have attained their highest development in one or more species studied. P. rimulatum has or shares the extreme position in six cases, oroyae four times, the taczanowskit types three cases, the taczanowskii specimens from the Tingo four times, and atochae eight times. Intermediate positions are held by rivulatum three times, oroyae seven, taczanowskii types seven, taczanowskii from the Tingo eight times, and atochae only three times. Atochae shares no characters as listed with rivulatum, but does so once with oroyae and twice with taczanowskii. Thus the characters of the above species seem to arrange themselves in a series, following the order in which they are given, rivulatum the most extreme in robustness and in number of finrays, ete., with atochae its opposite. (One extreme shown by *; opposite extreme by italics).

116. Pygidium atochae Allen, sp. nov.

Plate XIII, figs. $3-5$

17819, many, type and paratypes, 38-105 mm., Rio de Atocha, Atocha, Bolivia, Allen, February, 1919.

Allied to Pygidium taczanowskii, oroyae, and rivulatum, in that order, differing most strikingly in its slender form and short barbels; middle of eye in advance of middle of head; body less compressed midway; caudal peduncle distinctly more elongate, about 3.7 in the total length; more distinct lateral band in fresh material.

Head in total length 6.2 ; width of head in length $6.4-6.7$; width of mouth in 
head 1.8; depth at origin of pectoral in length 9.7 ; distance from last anal ray to base of middle caudal rays (length of peduncle) in length 3.6-4.0 (mode about 3.7; in rimulatum of the same size mode about 4.4); depth of peduncle in length 10 (6.8-8.0 in rivulatum). Contours gradually verging from depressed to compressed narrowly.

Eye minute, slightly forward on head, nearly concealed; snout 2.5 in head; interorbital space 3.6 in head; barbels short; narial barbels $2.2-2.6$ in the head; maxillary barbels $1.8-2.0$ in head; inferior maxillaries $2.1-2.4$ in the head.

Longest pectoral rays $1.2-1.3$ in the head; first pectoral rays not prolonged, and short as last; origin of dorsal equidistant from end of opercle and base of middle caudal rays, directly above end of ventrals; end of dorsal basis above middle of anal; anal the larger with few accessory rays; ventrals very small; accessory rays of caudal not greatly pronounced; caudal truncate to subtruncate.

Color in alcohol generally a plumbeous gray, shading into yellowish on sides and about the pectoral fins; small, faint spots not uniform nor well localized, especially numerous in the young.

The small, braided type-stream drains an extremely rugged and desolate country where it flows through a narrow canyon, its various small rami often disappearing beneath the rocky bed. At first impression the fishes were taken to be emaciated specimens of a form like taczanowskii, due to the nature of the stream.

\section{Pygidium kneri (Steindachner)}

Trichomycterus knerii Steindachner, 1882, Denksch. KK Akad. Wiss. Wien, XLVI, 21, pl. v, figs. 1-1a, Canelos, Ecuador;

non Eigenmann and Eigenmann, 1889, Proc. Cal. Acad. Sci., (2), II, 52 :

non Eigenmann and Eigenmann, 1890, Occ. Papers Cal. Acad. Sci., I, 335.

Trichomycterus kneri Boulenger, 1887, Proc. Zool. Soc. London, 278.

Pygidium kneri Eigenmann, 1918, Mem. Camegie Mus., VII, 314, pl, xlvi, figs. 1 and 2.

Eastern Ecuador to Rio Meta

\section{Genus 56: PAREIODON Kner}

Pareiodon Kner, 1855, Sitzb. KK. Akad. Wiss. Wien, XVII, 160;

Eigenmann and Eigenmann, 1890, Occ. Papers Cal. Acad. Sci., 1, 346;

Eigenmann, 1910, Rept. Princeton Univ. Exped. Patagonia, III, 401;

Eigenmann, 1918, Mem. Carnegie Mus., VII, 343.

Centrophorus Kner, 1855, Denksch. KK. Akad. Wiss. Wien, XVII, 161.

Pariodon Günther, 1861, Cat. Fish. Brit. Mus., V, 275.

\section{Type: Pareiodon microps Kner \\ Amazon basin}

The gill-membranes confluent with the skin of the isthmus; the gill-opening a narrow slit; opercle and preopercle with numerous small spines; mouth nearly terminal; a single series of pointed incisors in each jaw; nasal and mental barbels wanting; double maxillary barbels at angles of mouth; anal short; caudal forked. 


\section{Pareiodon microps Kner}

Pareiodon microps Inner, 1855, Sitzb. KK. Akad. Wiss. Wien, XVII, 160;

Cope, 1871, Proc. Acad. Nat. Sci. Phila., XXIII, 290, Ambyiacu;

Eigenmann and Eigenmann, 1890, Occ. Papers Cal. Acad. Sci., I, 346;

Eigenmann, 1910, Rept. Princeton Univ. Exped. Patagonia, III, 401;

Eigenmann, 1918, Mem. Carnegie Mus, VII, 344.

Trichomycterus pusillus Castelnau, 1855, Anim. Amér. Sud, Poiss., 50, pl. xxiv, fig. 4, Amazon, Araguay.

Rio Ambyiacu to the Araguay

Subfamily: STEGOPHILINAE

A group of Pygidiidae lacking mental and nasal barbels and with two maxillary barbels, the lower pair very small; mouth inferior and wide, with numerous rows of regular teeth; opercle and interopercle spinous, but pectorals soft-rayed; anal short; many species capable of some degree of parasitism.

\section{Genus 57: HENONEMUS Eigenmann and Ward}

Henonemus Eigenmann and Ward, 1907, Ann. Carnegie Mus., IV, 118;

Eigenmann, 1918, Mem. Carnegie Mus., VII, 345.

\section{Type: Stegophilus intermedius Eigenmann and Eigenmann}

\section{Amazons and La Plata}

Originally separated on the basis of the lack of a second maxillary barbel, later discovered, but minute. The genus retained on the ground of the negligible size of this barbel and the presence of but two opercular spines.

Teeth numerous on jaws and lips; mandibulars transverse and united; separated from Stegophitus chiefly in having the caudal emarginate and in the reduced number of opercular spines; second maxillary barbel extremely small.

\section{Henonemus punctatus (Boulenger)}

Stegophilus punctatus Boulenger, 1887, Proc. Zool. Soc. London, 279, pl. xxi, fig. 4, Canelos. Henonemus punctatus Eigenmann, 1910, Rept. Princeton Univ. Exped. Patagonia, III, 401;

Eigenmann, 1918, Mem. Carnegie Mus., VII, 346, text figs. 23 and 24.

\section{Canelos, Ecuador; Santarem; Rio Madeira}

15499, 3, 70-88 mm., Rio Morona, Allen, October, 1920.

15707,1 , Rio Huallaga, Yurimaguas, Allen, November, 1920.

15708, 2, 65 and $70 \mathrm{~mm}$., Gosulimacocha, Rio Morona, Allen, October, 1920.

\section{Henonemus macrops (Steindachner)}

Stegophilus macrops Steindachner, 1882 (1883), Denksch. KK. Akad. Wiss. Wien, XLVI, pl. vi, figs. 2 and 2a, Lake Manacapurú;

Eigenmann and Eigenmann, 1889, Proc. Cal. Acad. Sci., (2), II, 55;

Eigenmann and Eigenmann, 1890, Occ. Papers Cal. Acad. Sci., I, 344;

Eigenmann and Eigenmann, 1891, Proc. U. S. Nat. Mus., XIV, 37. 
Henonemus macrops Eigenmann, 1910, Rept. Princeton Univ. Exped. Patagonia, III, 401;

Eigenmann, 1918, Mem. Carnegie Mus., VII, 346, text fig. 22.

Peru to Manacapurú

15705, 1, 34 mm., Yurimaguas, Allen, November, 1920.

Hitherto known only from the types, in the Vienna Museum.

Genus 58: PSEUDOSTEGOPHILUS Eigenmann and Eigenmann

Pscudostegophilus Eigenmann and Eigenmann, 1889, Proc. Cal. Acad. Sci., (2), II, 5t;

Eigenmann and Eigenmann, 1890, Occ. Papers Cal. Acad. Sci., I, 341;

Eigenmann, 1910, Rept. Princeton Univ. Exped. Patagonia, III, 400;

Eigenmann, 1918, Mem. Carnegie Mus., VII, 349.

\section{Type: Stegophitus nemurus Günther \\ Upper Amazon and Mamoré}

Differing from Henonemus in having the opercle provided with four or five spines directed caudodorsally; the interopercle with spines directed caudoventrally; eye 3.5-5.0 in the head; separated from Homodiaetus by the deeply forked caudal fin.

\section{Pseudostegophilus nemurus (Günther)}

Stegophilus nemurus Günther, 1869, Proc. Zool. Soc. London, 429, Peruvian Amazon.

Pseudostegophilus nemurus Eigenmann and Eigenmann, 1889, Proc. Cal. Acad. Sci., (2), II, 54, Marañon or Ucayali;

Eigenmann and Eigenmann, 1890, Occ. Papers Cal. Acad. Sci., I, 341;

Eigenmann, 1918, Mem. Carnegie Mus., VII, 350, pl. xliv, fig. 5.

\section{Upper Amazon to Rio Mamoré}

15716, 1, 53 mm., Inahuaya, Rio Ucayali, Allen, August, 1920.

$15969,2,57$ and $67 \mathrm{~mm}$., Iquitos, Morris, 1922.

\section{Genus 59: ACANTHOPOMA Lütken}

Acanthopoma Lütken, 1891 (1892), Vidensk. Meddel. Naturh. Foren. Ǐjöbenhavn, 53, fig., annectens; Eigenmann, 1910, Rept. Princeton Univ. Exped. Patagonia, III, 101;

Eigenmann, 1918, Mem. Carnegie Mus., VII, 354, pl. xxxvii.

Type: Acanthopoma annectens Lütken

Rio Huallaga, known only from the single type specimen

Gill membranes united across the isthmus in a free fold, as in Stegophilus. Unlike Stegophilus, Henonemus and Pseudostegophilus in not having the gillopening so greatly reduced.

\section{Acanthopoma annectens Lüitken}

Acanthopoma annectens Lütken, 1891 (1892), Vidensk. Meddel. Naturh. Foren. Kjöbenhavn, 53, fig., Huallaga; 
Eigenmann, 1910, Rept. Princeton Univ. Exped. Patagonia, III, 401;

Eigenmann, 1918, Mem. Carnegie MIus., VII, 355, fig. 28.

Rio Huallaga

Lütken considers this species as an intermediate between the Stegophilines and Pygidium.

\section{Genus 60: APOMATOCEROS Eigenmann}

A pomatoceros Eigenmann, 1922, Bijd. Tot de Dierk., XXII, 113, pls. iii and iv, figs. 1-9.

Type: Apomatoceros alleni Eigenmann

Peruvian Amazons

Near Acanthopoma, but lacking the opercular spines; caudal furcate; upper jaw widened so as to enclose the short, narrow, lower jaw; gill-membranes united with the isthmus, except for a broad, free membrane.

\section{Apomatoceros alleni Eigenmann}

Apomatoceros alleni Eigenmann, 1922, Bijdr. Tot de Dierk., XXII, 113, pls, iii and iv, figs. 1-9.

\section{Rio Morona and Marañon}

First taken on the extreme border of the Amazonian flood plain within view of the foothills of the Andes. Dr. G. S. Myers (letter) states that it has been rediscovered far down the Marañon at Pebas, by Mr. Wm. G. Scherer.

15500, 1, 146 mm., type, Rio Morona, Allen, October, 1920.

H. 8 ; depth 9 ; depth of head 16 ; eye 5.33 in head; interorbital equals snout plus half the eye diameter; P. 11 in the length; upper caudal lobe equals head, lower slightly longer. Depth of caudal peduncle $2.4 \mathrm{in}$ its length. D. 9; A. 8; base of anal nearly double that of dorsal; compressed behind pectorals, greatly compressed forward, pectorals nearly horizontal.

Mouth very large, subcircular, upper jaw flexible, curling inward, prolonged backward to near tips of interopercular spines; terminal barbel of the maxillary reaching tips of interopercular spines, lower barbel very small, scale-like in shape; lower jaw firm, not reaching forward to middle of eye; upper jaw evidently elastic and expansible into a disk for attachment. Seven very regularly arranged, concentric series of teeth in upper jaw; shorter rows interpolated between these near the symphysis to a total of eleven, the number of rows decreasing to four at the end of the premaxillary, only the outer four rows continued across the middle, the others interrupted in the middle by a naked area; four rows of similar teeth in the lower jaw, those of the two rami separated by a considerable space free of teeth. Gill-membranes united and joined to the isthmus, but with a wide, free membrane across the isthmus. Distance between the anterior nares more than twice the distance between the posterior. A median, dermal keel from the base of the last ventral ray to between the tips of the pectorals. Interopercle with a series of five straight spines; opercular spines wanting. 
A black spot on the nape, a narrow black band across the base of the caudal, a broad, silvery lateral band, otherwise translucent. The alimentary canal is a thin-walled tube, containing many fish-scales toward the end.

\section{Subfamily: VANDELLIINAE}

A group of Pygididae allied to the preceding subfamily in the lack of nasal and mental barbels, and differing in that the rows of lower teeth are in disconnected right and left rami, not transverse, and not strong; the mouth narrow; teeth few, slender, pointed.

Genus 61: VANDELLIA Cuvier and Valenciennes

Vandellia Cuvier and Valenciennes, 1846, Hist. Nat. Poiss., XVIII, 386, pl. 547;

Eigenmann and Eigenmann, 1890, Occ. Papers Cal. Acad. Sci., I, 344

Eigenmann, 1910, Rept. Princeton Univ. Exped. Patagonia, III, 401;

Eigenmann, 1918, Mem. Carnegie Mus., VII, 358.

Type: Vandellia cirrhosa Cuvier and Valenciennes Upper Amazonia to Orinoco, Mamoré, Apuré, L. Hyanuary

Characterized, with Urinophilus, by great elongation; small, inferior mouth; a few teeth in middle of upper jaw; often peculiar clawed teeth on the extremity of the maxillary; mandibular rami separated by a wide membrane; opercular spines directed caudo-dorsally, the interoperculars caudo-ventrally; gill-opening small; origin of ventrals nearer to caudal than to the snout; origin of anal back of dorsal; size of head and arrangement of spines would seem to adapt these fishes to a life of parasitism, or at least to intrusive habits; the intestine short, straight, and very distensible as in blood-sucking forms. The toothed maxillaries are almost unique in this subfamily, among all siluroids. The mandibles lack teeth in one substantial group of species, and these Eigenmann (1918 c) has retained as the genus $V$ andellia, at least provisionally, and until the types of $V$. cirrhosa can be examined; the name Urinophilus is provisionally applied to the toothed species until and unless cirrhosa is found to have the mandibular teeth. They are certainly wanting in $V$. plazai.

\section{Vandellia plazai Castelnau}

Tandellia plazaii Castelnau, 1855, Anim. Amér. Sud, P'oiss., 51, pl. xxriii, fig. 1, probably Rio Ucayali;

Eigenmann and Eigenmann, 1890, Occ. Papers Cal. Acad. Sci., I, 345;

Eigenmann, 1910, Rept. Princeton Univ. Exped. Patagonia, III, 401;

Eigenmann, 1918, Mem. Carnegie Mus., VII, 362, text fig. 30.

Peruvian and Middle Amazons

\section{Genus 62: URINOPHILUS Eigenmann}

Yandellia (in part) Cuvier and Valenciennes, 18t6, Hist. Nat. Poiss., XVIII, 386, pl. 547.

Urinophilus Eigenmann, 1918, Mem. Carnegie Mus., VII, 358;

Eigenmann, 1920, Science, LI, 441. 


\section{Type: Vandellia sanguinea Eigenmann}

The characters of the genus as indicated under the preceding.

\section{Urinophilus diabolicus Myers}

Urinophilus diabolicus Myers, 1927, Bull. Mus. Comp. Zool., LXVIII, 132.

\section{Upper Amazon}

17701, 1, type, 47 mm., Iquitos, Allen, September, 1920.

Called carnero by the inhabitants; taken from the belly of a doncella (Pseudoplatystoma), where it had penetrated half-way inside through the body wall, and not by a natural opening. Much distended with blood; color black, partly with the contents, while fresh.

Much less elongate than $U$. sanguineus and $U$. erythrurus; somewhat faded in alcohol to a brownish color, with finer, dark brown chromatophores on the back.

\section{Urinophilus ERythrurus Eigenmann}

Urinophilus erythrurus Eigenmann, 1922, Bijdr. Tot de Dierk. Amst., XXII, 114, pl. iv, figs. 10-16; Pearson, 1924, Ind. Univ. Studies, XI, no. 64, 17.

\section{Eastern Peru and northern Bolivia}

15584, 10, 120-145 mm., type and paratypes, Rio Morona, Allen, October, 1920.

15604, , Rio Morona, Allen, October, 1920.

15715, 3, 64-74 mm., Rio Paranapura, Yurimaguas, Allen, November, 1920.

15713, 3, 49-53 mm., Gosulimacocha, Rio Morona, Allen, October, 1920.

15714, 3, 45-51 mm., Rio. Morona, Allen, October, 1920.

15717, 1, 127 mm., Rio Ucayali near Orellana, Allen, August, 1920.

17104, 1, 75 mm., Rurrenabaque, Bolivia, Pearson, November, 1921.

It is of interest and possibly significant that both Pearson's specimen and those from Peru were all collected along the fringe of the piedmont, in the edge of the flood plains.

Body compressed; head depressed, flat below, arched above; depth of head equals distance between pupillary centers; eye about 5 in head; interorbital distance equal to snout; 5-9 teeth forming a crescentic row below the snout; a series of about four claw-like teeth on the maxillaries, concealed in a fleshy pocket; very few recurved teeth at the ends of the mandible, whose extremities are widely separated; outer barbel extending to the end of the interopercular spines; the latter numerous (about ten), their tips curved; opercular spines more numerous (about twenty-five), also curved at the tip; pectorals about equal to the head less half the snout; distance between the origin of the ventrals and base of caudal equal to about one-third the length; origin of dorsal forward of the vertical from the origin of the anal; depth of caudal peduncle 3 or more in its length; caudal emarginate.

Plumbeous above; white below, middle of caudal dark, the outer parts pink in life.

The maxillary is a two-part bone; the inner (mesial) division articulates in a 
movable joint with the wings of the ethmoid and is free of teeth; the ectal moiety of the maxillary with several overlapping, claw-like teeth in a single series. The barbels are continuous with the end of the maxillary.

A thin, blade-like bone covers the end of the maxillary, protecting the teeth; the inner, proximal end of this blade-like bone is narrowed and curved around the maxillary.

\section{Genus 63: TRIDENS Eigenmann and Eigenmann}

Tridens Eigenmann and Eigenmann, 1889, Proc. Cal. Acad. Sci., (2), I, 53;

Eigenmann and Eigenmann, 1890, Occ. Papers Cal. Acad. Sci., I, 339;

Eigenmann, 1910, Rept. Princeton Univ. Exped. Patagonia, III, 400;

Eigenmann, 1918, Mem. Carnegie Mus., V II, 369.

\section{Type: Tridens melanops Eigenmann and Eigenmann \\ The Brazilian-Peruvian frontiers}

Two species described from closely adjacent localities, and from few types, but so different as to suggest distinct genera.

Long body form, elongated anal (twenty or more rays), its origin before that of the dorsal; ventrals small and nearer the end of the snout than to the base of the caudal; head extremely depressed; eye lateral, extending upon both dorsal and ventral surfaces; labial teeth fine, followed by stronger teeth in the jaws; gill-membranes joined to form a broad, free fold across the isthmus; two maxillary barbels; opercle and interopercle spinous.

\section{Tridens melanops Eigenmann and Eigenmann}

Tridens melanops Eigenmann and Eigenmann, 1889, Proc. Cal. Acad. Sci., (2), II, 53, Iça;

Eigenmann and Eigenmann, 1890, Occ. Papers Cal. Acad. Sci., I, 339;

Eigenmann, 1910, Rept. Princeton Univ. Exped. Patagonia, III, 400;

Eigenmann, 1918, Mem. Carnegie Mus., VII, 369, pl. xliii, figs. 1 and 2.

The Amazon near the Peruvian-Brazilian frontier

Known only from the types, the largest $27 \mathrm{~mm}$. in length. Noteworthy for the three trident-shaped spines of the opercle, smaller preopercular spines of similar form and greatly reduced barbels; coterminous anal and dorsal fins, the rays of the former diminishing caudally; caudal fin rounded.

\section{Family VIII: Astroblepidae}

Siluroidei astroblepiformes Bleeker, 1863, Nederl. Tijdsch. Dierk., I, 110.

Siluridae proteropodes (in part) Günther, 186t, Cat. Fish. Brit. Mus., V, 4.

Argiidae Gill, 1872, Arrangement of Families of Fishes, 19;

Eigenmann and Eigenmann, 1888, Amer. Nat., XXII, 647;

Eigenmann and Eigenmann, 1890, Occ. Papers Cal. Acad. Sci., I, 347.

Argiinae Regan, 1904, Trans. Zool. Soc. London, XVII, 307;

Regan, 1905, Ann. Mag. Nat. Hist, (7), XV, 529-534.

Astroblepidae Eigenmann, 1922, Mem. Carnegie Mus., IX, 50. 
Naked catfishes with inferior mouth; lower lip much expanded and reverted; teeth bicuspid, in a narrow band in each jaw; gill-membranes broadly united with the isthmus; anterior and posterior nares closely approximated; maxillary barbels present, no mental or nasal barbels. Dorsal vertically placed above the ventrals; air bladder enclosed within Weberian apparatus forward, with a bony diaphragm. For reasons given below the genera Cyclopium, Arges, Brontes, and Styogenes, once considered members of a family Argiidae, are here synonyms of Astroblepus.

\section{Genus 64: ASTROBLEPUS Humboldt}

A stroblepus Humboldt, 1806, Rec. d'Obs. Zool. Anat., I, 19;

Eigenmann, 1910, Rept. Princeton Univ. Exped. Patagonia, III, 417;

Eigenmann, 1922, Mem. Carnegie Mus., IX, 51.

Cyclopium Swainson, 1839, Nat. Hist, Fish., II, 305.

Arges Cuvier and Valenciennes, 1840, Hist. Nat. Poiss., XV, 333, pl. 44;

Günther, 186t, Cat. Fish. Brit. Mus., V, 222;

Regan, 190t, Trans. Zool. Soc. London, XVII, 307.

Brontes Cuvier and Valenciennes, 1840, Hist. Nat. Poiss., XV, 3t1, pl. 445.

Styogenes Günther, 186t, Cat. Fish. Brit. Mus., V, 223, humboldtii.

Type: Astroblepus grixalvii Humboldt

The Andean highlands from Colombia to Peru

Cabezon, colloquial name in allusion to large head.

Adipose fin short, near caudal, with a short spine; teeth small, the mandibulars and inner intermaxillaries broadened and notched at the tips; eyes small and upturned.

One of the most successfully formed of all groups of fishes for climbing; lips flattened and suctorial; paired fins set so as to inch forward or backward in opposition to swift currents; gills so adapted as to valve water inward at the tops of the gill opening and to exhale at the bottom while using the mouth as a holdfast.

The Eigenmanns (1890) expressed doubt that the Humboldt genus Astroblepus should be placed with the genera Arges, Cyclopium, and Brontes in Gill's family Argiidae, on account of the supposed lack of ventral fins. Meanwhile the many years' collecting of the Carnegie Museum and Indiana University expeditions have brought to light no specimens without ventrals. This seems tojustify (Eigenmann, 1922 b) relegating the above genera to the synonomy of Astroblepus Humboldt.

\section{Astroblepus sabalo (Cuvier and Valenciennes)}

Arges sabalo Cuvier and Valenciennes, 1840, Hist. Nat. Poiss., XV, 335, pl. 441 , Santa Ana;

Günther, 1864, Cat. Fish. Brit. Mus., V, 222;

Steindachner, 1875, Sitzb. KK. Akad. Wiss. Wien, LXXII, 4S, Tulumayo;

Steindachner, 1876, Sitzb. KK. Akad. Wiss. Wien, LXXII, 598;

Cope, 1878, Proc. Amer. Phil. Soc., XVII, 681, seven, R. Urubamba;

Steindachner, 1879, Denksch. KK. Akad. Wiss. Wien, XLI, 23;

Steindachner, 1882 (1883), Denksch. KK. Akad. Wiss. Wien, IV, 17, pl. iv, fig. 2 and 2b, Rio Huambo; 
Eigenmann and Eigenmann, 1890, Oce. Papers Cal. Acad. Sci., I, 348;

Regan, 1904, 'Trans. Zool. Soc. London, XVII, 315.

Cyclopium sabalo Eigenmann, 1910, Rept. Princeton-Univ. Exped. Patagonia, IH, 117.

From the Urubamba to upper Huallaga tributaries

1. $135 \mathrm{~mm}$., Ollantaitambo, Rio Urubamba, 9000 feet eleration.

5, 58-80 mm., Puquiura, 9500 feet, E. Heller, E. C. Erdis. The latter specimens in bad condition, and identification uncertain.

15070, 9, 107-168 mm., Urubamba, Rio Urubamba, Eigenmann, November, 1918.

15071, , Ollantaitambo, Eigenmann, November, 1918.

15443, 1, 114 mm., Torontoy, Rio Urubamba, Eigenmann, November, 1918.

$15444,4,133-180 \mathrm{~mm}$., San Niguel, Unubamba, Eigenmann, November, 1918.

15445, 3, 180-220 mm., Mandor Pampa, Eigenmann, November, 1918.

15+46, 19, 62-91 mm., Culpani, Eigenmann, November, 1918.

15477 , many, 25-75 mm., Santa Ana, Rio Chupapa, Eigenmann, November, 1918.

17820, 13, 85-115 mm., Ollantaitambo, Eigenmann, November, 1918.

$17825,8,43-89$ mm., Huancayo, Mantaro valley, Eigenmann, September, 1918.

17826, 1, 102 mm., Huancachupa creek, Hu nuco, Allen, October, 1918.

17827, 1, 110 mm., mouth Rio Tingo, Huinuco, Allen, October, 1918.

The last a very emaciated specimen with thin, nearly membrancous adipose fin.

17828, 4, 72-118 mm., Rio Huallaga, Huánuco, Allen, October, 1918.

9971-9983, Field Mus., 13, 123-204 mm., Culcui, J. T. Zimmer, Dec. 1922.

Of the material collected at Culcui, and determined by N. E. Pearson, I examined numbers 9971, 9972, 9977, and 9982. (W.R.A.) They show certain consistent differences in comparison with the material collected on the Urubamba:

\begin{tabular}{|c|c|c|c|}
\hline & $\begin{array}{l}\text { Dorsal basis in } \\
\text { length without } \\
\text { caudal fin }\end{array}$ & $\begin{array}{l}\text { Hearl in } \\
\text { length }\end{array}$ & \\
\hline Astrablepus sabalo from Culcui. ............. & $7.1-7.6$ & $3.7-4.0$ & Much longer dorsal \\
\hline Astroblepus sabalo from the Urubamba........ & $10.1-10.8$ & $3.3-3.7$ & Larger head \\
\hline
\end{tabular}

Specimens of about equal length were used.

\section{Astroblepus prenadilla (Cuvier and Valenciennes)}

Brontes prenadilla Cuvier and Valenciennes, 1840, Hist. Nat. Poiss., XV, 313, pl. 445, Cotopaxi; Günther, 1864, Cat. Fish. Brit. Mus., V, 224.

Arges prenadilla Steindachner, 1882, Denksch. KK. Akad. Wiss. Wien, XLVI, 20, pl. vi, fig. 5, P'eru;

Eigenmann and Eigenmann, 1890, Oce. Papers Cal. Acad. Sci., II, 3t8;

Regan, 1904, Trans. Zool. Soc. London, XVII, 316.

Cyclopium prenadilla Eigenmann, 1910, Rept. Princeton Unir. Exped. Patagonia, III, 417.

\section{The Andes of Peru}

15069 , , Rio Yanahuana, Cerro de Pasco, Murdock, December, 1918.

\section{Astroblepus boulengeri (Regan)}

Styogenes humboldtii Günther (non Swainson), 1864, Cat. Fish. Brit. Mus., V, 223;

Boulenger, 1887, Proc. Zool. Soc. London, 276, pl. xxi, fig. 2.

Arges boulengeri Regan, 1904, Trans. Zool. Soc. London, XVII, 310.

Cyclopium cyclopum (in part) Eigenmann and Eigenmann, 1890, Occ. Papers Cal. Acad. Sci., I, 350.

Cyclopium boulengeri Eigenmann, 1910, Rept. Princeton Univ, Exped. Patagonia, III, 417. 
Canelos, Ecuador

Known only from three specimens of the Buckley collection; length $70 \mathrm{~mm}$.

\section{Astroblepus longifilis (Steindachner)}

Arges longifilis Steindachner, 1882, Denksch. KǨ. Akad. Wiss. Wien, XLVI, 19, pl. v, fig. 3 and 3b; Eigenmann and Eigenmann, 1890, Occ. Papers Cal. Acad. Sci., I, 349;

Regan, 1904, Trans. Zool. Soc. London, XVII, 314.

Cyclopium longifile Eigenmann, 1910, Rept. Princeton Univ. Exped. Patagonia, III, 417.

Astroblepus longifilis Pearson, 1937a, Proc. Cal. Acad. Sci., (4), XXIII, 94, one, 27 mm., Balsas, upper Marañon.

\section{North-central Peru, mountain streams}

Specimens from Rios Totora and Huambo reached $180 \mathrm{~mm}$.

\section{Astroblepus supramollis Pearson}

Astroblepus supramollis Pearson, 1937a, Proc. Cal. Acad. Sci., (4), XXIII, 94, many, 24-80 mm., Tingo de Pauca and Balsas, Upper Marañon.

\section{Upper Marañon}

Distinguished from $A$. sabalo chiefly on the basis of the lower adipose fin and spots of uniform brown rather than marbled effect. Known only from Pearson's collection.

\section{Astroblepus labialis Pearson}

Astroblepus labialis Pearson, 1937a, Proc. Cal. Acad. Sci., (4), XXIII, 95, pl. xiii, fig. 4, seven, Balsas, upper Marañon.

\section{Upper Marañon}

Known only from the Pearson collection; noteworthy for the extreme width of the lips, and their fleshy form.

\section{Astroblepus peruanus (Steindachner)}

Arges peruanus Steindachner, 1875, Sitzb. KK. Akad. Wiss. Wien, LXXII, 601, pl. ix, figs. 3-6; Steindachner, 1879, Denksch. KK. Akad. Wiss. Wien, XLI, 173, four, Amable Maria, Tambillo, Peru;

Eigenmann and Eigenmann, 1890, Oce. Papers Cal. Acad. Sci., I, 349;

Regan, 1904, Trans. Zool. Soc. London, XVII, 317.

Cyclopium peruanus Eigenmann, 1910, Rept. Princeton Univ. Exped. Patagonia, III, 417.

Astroblepus peruanus Pearson, 1937a, Proe. Cal. Acad. Sci., (4), XXIII, 94, many, Cajamarea, 24-62 $\mathrm{mm}$. in length.

Peruvian Andes

\section{Astroblepus simonsil (Regan)}

Arges simonsii Regan, 1904, Trans. Zool. Soc: London, XVII, 317, pl. xxi, fig. 9.

Cyclopium simonsii Eigenmann, 1910, Rept. Princeton Univ. Exped. Patagonia, III, 417. 


\section{Near Huaraz, Peru}

Five specimens up to $80 \mathrm{~mm}$. in length, collected by P. O. Simons at elevation 10,700 feet; it is doubtful whether this record belongs to the Atlantic drainage; if the elevation given is correct, the nearest point of such low altitude on the Atlantic side is far to the interior from Huaraz.

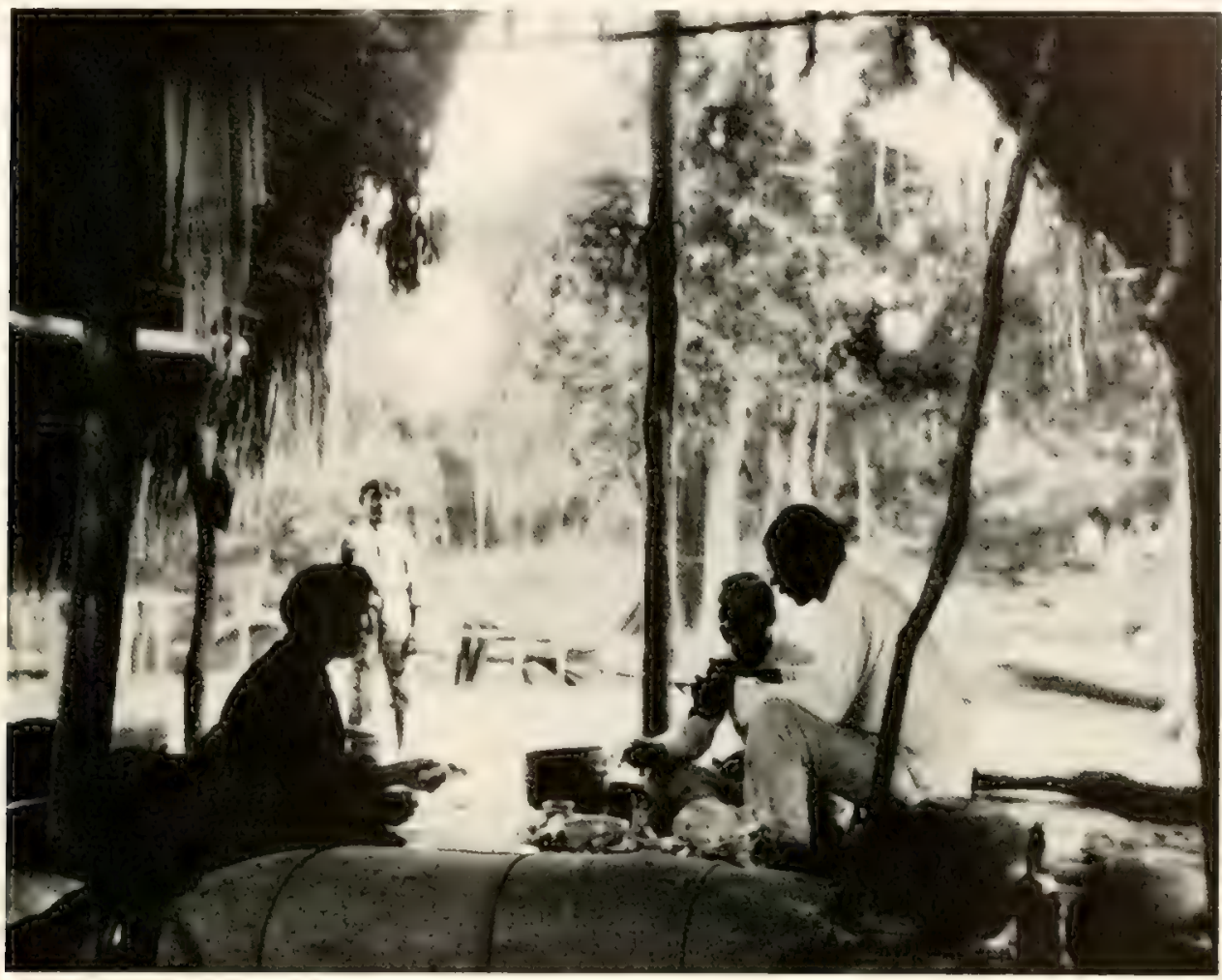

FIG. 20. Fishing-camp on the Rio Pacaya. My party, at its noontime bivouac, encounters Padre Augustino, whose parish would make an empire.

\section{Astroblepus taczanowskit (Boulenger)}

Arges sabalo (in part) Steindachner, 1876, Sitzb. KK. Akad. Wiss. Wien, LXXII, 598.

Arges taczanowskii Boulenger, 1890, Proc. Zool. Soc. London, 451, pl. xli, fig. 1;

Regan, 1904, Trans. Zool. Soc. London, XVII, 315.

Cyclopium taczanowskii Eigenmann, 1910, Rept. Princeton Univ. Exped. Patagonia, III, 417.

\section{Amable Maria, Peru}

137. Astroblepus MancoI Eigenmann (and Myers)

Plate XI, figs. 1-7

Astroblepus mancoi Eigenmann (in Myers), 1928, Ann. Mag. Nat. Hist., (10), II, 85.

Alto Urubamba river

, Rio Comberciato, Urubamba, Peru, elevation 1800 feet, Heller.

A species similar to A. trifasciatus and A. taczanowskii, named for the Inca Ayar Manco, colonizer of Cuzco, the "Moses of the Peruvian Indians," who, about $1100 \mathrm{~A}$. D. led the exodus from Tampu-tocco. 
Head 3.5 ; depth $5.33-6.0$; D. I, 6 ; A. I, 5 or I, 6.

Adipose fin high, arched, beginning at the tip of the depressed dorsal spine or farther forward, terminating at root of caudal in a minute spine, much more rarely continued without notch to the caudal.

Maxillary barbel ending about midway between posterior margin of lip and gill opening; teeth of anterior premaxillary series rather large, pointed or truncate, the median pair usually bicuspid; nasal flap pointed, not produced in a barblet; interorbital less than the distance between the eyes and the posterior nares; width of head very little less than its length; distance between snout and dorsal 2.25-2.4 in the length; dorsal spine prolonged, equal to head less space in front of anterior nares, the length of the rays diminishing from the first backward; adipose spine fleshy, bearing a few spinules, its tip usually continuous with the margin of the adipose ridge, a distinct notch behind it, a small membrane attaching the spine to the back, the spine rarely absent, the ridge with or without a posterior notch; caudal deeply emarginate, the lobes as long as the head or considerably longer; anal in male with second ray slightly shorter than those in front of or behind it; anal in female with the spine longest, the rays graduated; origin of the ventrals under or in front of the origin of the dorsal, reaching about three-fourths to the anus, about equal to the length of the head behind the nares; pectoral filament about as long as the head, reaching a little beyond the middle of the ventrals.

Color variable, rarely uniform dark brown, without spots on the fins, sometimes with a variable, light margin along posterior half of adipose ridge and a variable light band downward from the adipose spine. In addition there is a series of individuals with regular modifications from the smallest to the largest: in the smallest are three large, light areas, one in front of the dorsal, one behind it, and one across posterior portion of adipose, with a dark band across the caudal; these light areas become marbled and gradually fade with age, and the caudal becomes spotted.

138. Astroblepus ubidiai (Pellegrin)

Cyclopium ubidiai Pellegrin, 1931, Rev. Suisse Zool., XXXVIII, 113-115, fig. 1.

Eeuadorean highlands

139. Astroblepus longiceps Pearson

Astroblepus longiceps Pearson, 1924, Ind. Univ. Studies, XI, no. 64, 15, pl. ii, fig. 5, Rio Colorado, lower Bopi, Bolivia.

Eastern slopes of Peru and Bolivia

15069 and 17584, many, 20-58 mm. without caudal, Rio Yanahuana, Murdock, December, 1918.

A species near A. prenadilla, more attenuated, although the width of the head in the length is the same as in A. sabalo; no indication of marbling in our specimens. Appears to be confined to the Atlantic drainage. 
140. Astroblepus praeliorum Allen, sp. nov.

Plate XIII, figs. 6-7

17821, 31, 30-54 mm., Tarma, Ligenmann, September, 1918.

17822, many, 46-78 mm., without caudal, Palea, Eigenmann, September, 1918.

17823, 4, $47-54 \mathrm{~mm}$. . Huancayo, Eigenmann, September, 1918.

17824, 1, $55 \mathrm{~mm}$., Oroya, Eigenmann and Allen, September, 1918.

17829, 2, 38 and 58 mm., Huancachupa creck, Huánuco, Allen, October, 1918.

\section{Upper Mantaro and Huallaga basins}

Similar to A. sabalo and longiceps, less robust than the first, and more so than the latter; characterized by the truncate caudal fin, short, low adipose, small eye, and lack of filamentous prolongation of the pectoral, ventral, and caudal fins. except for the occasional slight growth of one or more of them.

Head 3.9-4.1; width of head about equal to the length; D. I, 4, short; distance from eye to first dorsal ray $3.5-3.8$ in the length (3.8-4.5 in an A. sabalo of the same length); adipose variable, but short and separated from dorsal by more or less the length of the folded dorsal, membrane of adipose not well developed, adipose never deep, spineless; P. I, 8-9, its spine slightly protracted, 1.25-1.3 in the head, and overlapping first third of the ventrals; V. I, 3-4, its spinous ray slightly protracted, or not at all, and well separated from the anus; A. 5-6, small; the first rays of the fins close set with curved spines directed posteriorly; ventral spine especially broad; caudal fin truncate.

Eye small, and nearly concealed; triangular nasal flap separating nares, not extending into a barbel at its tip; nares 1.25-1.33 times the interocular space from the eye; maxillary barbel not, or scarcely, reaching the edge of the opercle.

The Tarma specimens show faintly the marbled effect which characterizes our specimens of $A$. sabalo; Palca specimens have it in a scarcely perceptible degree; general color a light, chocolate brown.

Complimentary to the Hermanos Praeli, merchants of Tarma and La Merced, who were instrumental in procuring facilities and who aided the collecting in person.

\section{Family IX: Callichthyidae Gill}

Callichthyoidei Bleeker, 1863, Nederl. Tijdsch. Dierk., I, 82.

Siluridae proteropodes (in part) Günther, 186t, Cat. Fish. Brit. Mus., V, 4. (In part Hypostomatinae).

Callichthyidae Gill, 1872, Arrangement of the Families of Fishes, 19;

Eigenmann and Eigenmann, 1890, Oce. Papers Cal. Acad. Sci., I, 449;

Eigenmann, 1910, Rept. Princeton Univ. Exped. Patagonia, III, 401;

Eigenmann, 1912, Mem. Carnegie Mus., V, 214;

Gosline, 1940, Stanford Ichth. Bull., II, 1, 1-29.

South American Nematognathi, best characterized by the two series of lateral plates, one above the other, meeting along their length in a serrated line; mouth terminal, small, lower lip not reverted; teeth villiform; cavity of the air bladder communicating with the exterior by means of a long narrow slit in the temporal plate and by the last of a series of slits below the long one.

Panama to La Plata basin, foothills of the Andes to the Atlantic 


\section{Genus 65: CALLICHTHYS Linnaeus}

Callichthys Linnaeus, 1754, Amoen. Acad., I, 317;

Gronow, 1763, Zoophyl., 127;

Cuvier and Valenciennes, 1840, Hist. Nat. Poiss., XV, 294;

Bleeker, 1863, Nederl. 'Tijdsch. Dierk., I, 82;

Eigenmann and Eigenmann, 1890, Oce. Papers Cal. Acad. Sci., I, 451;

Eigenmann, 1910, Rept. Princeton Univ. Exped. Patagonia, III, 401;

Gosline, 1940, Stanford Ichth. Bull., II, 1, 6.

Cataphractus Bloch. 1794, Ausl. Fische, VIII, 80, preoccupied;

Lacépède, 1804, Hist. Nat. Poiss., V, 124;

Swainson, 1839, Fish. Amph. Rept., II, 304.

\section{Type: Silurus callichthys Linnaeus \\ Trinidad to La Plata basin}

Two pairs of nuchal plates between occiput and dorsal plate; suture between coracoid processes extending almost horizontally to the posterior margin of the pectoral armature; a large opening between coracoid and clavicle below and in front of the pectoral spine; coracoid covered with skin; sides of the head without bristles; mental barbels wanting; lower jaw with bands of teeth on the sides, small; a naked area along dorsal and ventral surfaces; suborbital bones concealed; dorsal spine rudimentary; caudal rounded.

\section{Callichthys Callichthys Limnaeus}

Callichthys tamoata Linnaeus, 1754, Mus. Adolphi Fred., 734;

Bleeker, 1864, Silures de Suriname, 22.

Silurus callichthys Linnaeus, 1758, Syst. Nat., ed. 10, 1, 307, America;

Linnaeus, 1766, Syst. Nat. ed. 12, I, 506;

Gmelin, 1788, Syst. Nat., I, 1361.

Cataphractus callichthis Bloch, 1794, Ausl. Fische, VIII, 86, 11. 377, fig. 1;

Bloch and Schneider, 1801, Syst. Ichth., 107;

Lacépède, 1803, Hist. Nat. Poiss., V, 124.

Cataphractus callichthys Eigenmann and Eigenmann, 1888, Proc. Cal. Acad. Sci., (2), I, 164.

Callichthys callichthys Eigenmann and Eigenmann, 1890, Occ. Papers Cal. Acad. Sci., I, 452;

Eigenmann, 1910, Rept. Princeton Univ. Exped. Patagonia, III, 402;

Eigenmann, 1912, Mem. Carnegie Mus., V, 215;

Gosline, 1940, Stanford Ichth. Bull., II, 1, 6.

Callichthys asper Günther, 1864, Cat. Fish. Brit. Mus., V, 226;

Castelnau, 1855, Anim. Amér. Sud, Poiss., 38;

Cope, 1871, Proc. Acad. Nat. Sci. Phila., XXIII, 275, Rio Ambyiacu;

Cope, 1878, Proc. Amer. Phil. Soc., XVII, 681, Nauta.

Patagonia to the Guianas and Peruvian Andes

15711, 6, 68-123 mm., creek, Yurimaguas, Allen, November, 1920.

16133, 1, 136 mm., Lago Cashiboya, Allen, August, 1920.

\section{Genus 66: HOPLOSTERNUM Gill}

Callichthys (part) Cuvier and Valenciennes, 1810, Hist. Nat. Poiss., XV, 294.

Hoplosternum Gill, 1858, Ann. Lyc. Nat. Hist. N. Y., VI, 395; 
Eigenmann, 1858, Proc. Cal. Acad. Sci., (2), I, 164;

Eigenmann and Eigenmann, 1890, Oce. Papers Cal. Acad. Sci., I, 456;

Eigenmann, 1910, Rept. Princeton Univ. Exped. Patagonia, III, 102;

Ligenmann, 1912, Mem. Carnegie Mus., V, 216;

Gosline, 1940, Stanford Ichth. Bull.. II. 1. 6.

\section{Type: Callichthys laevigatus Cuvier and Valenciennes \\ Trinidad to Rio Plata and Peruvian Andes}

Coracoid process naked, the bone united to clavicle for the entire length; mandibular symphysis and lower lip without barbels; two at each rictus; a long naked area on venter; dorsal spine low and flat; pectoral spine in young serrate on inner margin.

\section{Hoplosternum littorale (Hancock)}

Callichthys littoratis Hancock, 1828, Zool. Jour., IV, 24t, Demarara;

Günther, 186t, Cat. Fish. Brit. \Ius., V, 227, British Guiana:

Steindachner, 1882, Denksch. IK Akad. Wiss. Wien, XLVI, 6, one, 105 mm., Rio Huallaga.

Hoplosternum littorale Eigenmann and Eigenmann, 1888, Proc. Cal. Acad. Sci., (2), I, 164, Surinam to Tabatinga;

Eigenmann and Eigenmann, 1890, Oce. Papers Cal. Acad. Sci., I, 456;

Eigenmann, 1910, Rept. Princeton Univ. Exped. Patagonia, III, 402;

Eigenmann, 1912, Mem. Carnegie \us., $V$, 217, pl. xxiv, fig. 1;

Gosline, 1940, Stanford Ichth. Bull., 11, 1, 8.

\section{Trinidad to Rio Plata and Peruvian Andes}

16136, 1, $213 \mathrm{~mm}$., Iquitos, Allen, September, 1920.

The single specimen of good size appears to belong here. The occipital plate reaches to the fontanel; the azygous plates, ten in number, reach the dorsal.

\section{Hoplosternum thoracatum (Cuvier and Valenciemes)}

Callichthys thoracatus Cuvier and Valenciennes, 18t0, Hist. Nat. Poiss., XV, 309, pl. 443;

Günther, 1864, Cat. Fish. Brit. Mus., I, 228;

Regan, 1913, Ann. Mag. Nat. Hist., (8), XII, 281, Rio Ueayali.

Hoplosternum thoracatum Gill, 1858, Ann. Lye. Nat. Hist. N. Y., VI, 396;

Eigenmann and Eigenmann, 1888, Proc. Cal. Acad. Sci., (2), I, 164;

Eigenmann and Eigenmann, 1890, Occ. Papers. Cal. Acad. Sci., I, 458;

Eigenmann, 1910, Rept. Princeton Lniv. Exped. Patagonia, III, 402;

Eigenmann, 1912, Mem. Carnegie Mus., V, 218, pl. xxiv, fig. 2.

Hoplosternum thoracatum thoracatum Gosline, 1940, Stanford Ichth. Bull., II, 1, 7 .

Hoplosternum longifilis Gill, 1858, Ann. Lye. Nat. Hist. I. Y., VI, 396;

Cope, 1878, Proc. Amer. Phil. Soc., XVII, 681, Nauta.

\section{Amazon northward}

15710, 2, 63-69 mm., creek, Yurimaguas, Allen, Norember, 1920.

$16135,3,143-168 \mathrm{~mm}$., creek, Yurimaguas, Allen, November, 1920.

16134, 4, 77-93 mm., brook near Rio Itaya, Iquitos, Allen, September, 1920.

Considerable variation in form and color. 
Caudal with three bands; pectoral reaching ventrals or far beyond origin of the latter; occipital reaching the elongate fontanel; caudal rounded or slightly emarginate.

In 16135, the occipital is truncate behind, with a narrow naked stretch between the occipital and the pair of bones behind it.

15712, 1, 141 mm., Iquitos, Allen, September, 1920.

15793, 1, 163 mm., Iquitos, Morris, 1922.

16130, 2, 142 and $144 \mathrm{~mm}$, brook near Rio Itaya, Iquitos, Allen, Sept. 1920.

16131, 15, 46-141 mm., creek, Yurimaguas, Allen, November, 1920.

Caudal without a band; fontanel circular in 16130, 15712, and 15973 ; the occipital pointed in front, not reaching the fontanel; in 16131 the occipital reaching the fontanel or not.

Caudal bands in all cases faint at base and extremity of fin; in middle of fin broad, deep, irregular, as though formed by the coalescence of many minute spots.

The younger specimens (16134) have three faint bands on ventral; in older specimens either more diffuse, or two fainter bands.

One specimen alone has pectoral extended to middle of ventral (16135). This one also has a cirrus caudal of the anus; coracoid plates broader than in other specimens, nearly meeting in middle line (sexual characters?). The Amsterdam specimens from Guiana have coracoids meeting for whole length.

\section{Hoplosternum melampterum (Cope)}

Callichthys melampterus Cope, 1871, Proc. Acad. Nat. Sci. Phila., 275, pl. xiv, fig. 4, Ambyiacu river. Hoplosternum melampterus Eigenmann and Eigenmann, 1888, Proc. Cal. Acad. Sci., (2), I, 165.

Hoplosternum melampterum Eigenmann and Eigenmann, 1890, Oce. Papers Cal. Acad. Sci., I, 461. Cataphractops melampterus Gosline, 1940, Stanford Ichth. Bull., II, 1, 9. Rio Ambyiacu.

Known only from the types at the Philadelphia Academy of Sciences.

\section{Hoplosternum shirui Fowler}

Hoplosternum shirui Fowler, 1939 (1940), Proc. Acad. Nat. Sci. Phila., 232, figs. 18-20, two, type and paratype, 122 and $125 \mathrm{~mm}$., Contamana, Peru.

Hoplosternum littorale Gosline, 1940, Stanford Ichth. Bull., II, 1, 8.

Near Hoplosternum melampterum Cope.

Known only from the types.

\section{Genus 67: DECAPOGON Eigenmann and Eigenmann}

Decapogon Eigenmann and Eigenmann, 1888, Proc. Cal. Acad. Sci., (2), I, 165 ;

Eigenmann and Eigenmann, 1890, Occ. Papers Cal. Acad. Sci., I, 461.

Type: Callichthys adspersus Steindachner

Porto do Moz and Rio Huallaga

Separable from Hoplosternum on the basis of its 4-6 barbels on the lower lip; plates extended ventrally to cover belly; dorsal spine high and pointed, subterete; pectoral spine serrate on inner margin, more finely toothed on outer margin. 


\section{Decapogon adspersum (Steindachner)}

Callichthys adspersus Steindachner, 1876, Sitzb. KK. Akad. Wiss. Wien, LXXIV, 87, pl. xi, figs. 2 and $2 \mathrm{~b}$, Tabatinga to Porto do $\mathrm{Moz}$.

Decapogon adspersus Eigenmann and Eigenmann, 1888, Proc. Cal. Acad. Sci., (2), I, 165.

Decapogon adspersum Eigenmann and Eigenmann, 1890, Occ. Papers Cal. Acad. Sci., I, 461.

Dianema longibarbis Gosline, 1940, Stanford Ichth. Bull., II, 1, 9.

\section{Rio Huallaga to Santarem and Porto do $\mathrm{Moz}$}

15709, , Iquitos, Allen, 1920.

15706, 4, 93-110 mm., Yurimaguas, Allen, November, 1920.

16129, 1, $120 \mathrm{~mm}$., brook near Rio Itaya, Iquitos, Allen, September, 1920.

\section{Genus 68: CORYDORAS Lacépède}

Corydoras Lacépède, 1803, Hist. Nat. Poiss., V, 145, geoffroyi = punctatus;

Eigenmann and Eigenmann, 1890, Occ. Papers Cal. Acad. Sci., I, 465 ;

Eigenmann, 1910, Rept. Princeton Univ. Exped. Patagonia, III, 402;

Eigenmann, 1912, Mem. Camegie Mus., V, 219;

Myers (Gosline), 1940, Stanford Ichth. Bull., II, 1, 10, 11.

Hoplisoma Swainson, 1839, Fish. Amph. Rept., II, 301, punctata.

Hoplosoma Gill, 1858, Ann. Lyc. Nat. Hist. N. Y., VI, 402, punctata.

Gasterodermus Cope, 1878, Proc. Amer. Phil. Soc., XVII, 681.

\section{Type: Corydoras geoffroyi Lacépède}

The Guianas to the Argentine

Resembling Brochis in the narrow occipital process which extends to the dorsal plate, but having only $6-8$ rays in the dorsal compared with $10-11$ found in that genus.

Suture between coracoid and humeral processes extending from the large pectoral pore obliquely downward and backward to the ventral margin of the pectoral armature; dorsal and pectoral spines long, pungent, their outer surfaces smooth.

\section{Cormdoras aeneus (Gill)}

Hoplosoma aeneum Gill, 1858, Ann. Lyc. Nat. Hist. N. Y., VI, 43, Trinidad.

Callichthys aeneus Günther, 186t, Cat. Fish. Brit. Mus., V, 230.

Corydoras aeneus Jordan, 1886, Proc. U. S. Nat. Mus., IX, 560;

Eigenmann and Eigenmann, 1890, Oce. Papers Cal. Acad. Sci., I, 471;

Eigenmann, 1910, Rept. Princeton Univ. Exped. Patagonia, III, 403;

Regan, 1912, Ann. Mag. Nat. Hist., (8), X, 218;

Ellis, 1913, Mem. Carnegie Mus., VIII, 404;

Marherr, 1937, Bl. Aquar.-Terrar. Stuttgart, XLVIII, 240;

Gosline, 1940, Stanford Ichth. Bull., II, 1, 19.

Trinidad to Rio Pichis, Peru, Matto Grosso and Bolivia

16165, 18, 38-57 mm., Puerto Bermudez, R. P'ichis, Allen, July, 1920.

Apparently identical with Gill's specimens from Trinidad, and although unreported from intermediate points, have been reported from Bolivia and Matto Grosso. Mrs. Ellis, however, found that her three specimens of aeneus from Trini- 
dad were nearer $C$. venezuelanus von Ihring than to his description of $C$. aeneus. "The specimens from which aeneus was described were 63.5 to $101.6 \mathrm{~mm}$., those from which venezuelanus was described were $35-45 \mathrm{~mm}$., which may account for the variation in proportion of height to length found by the two authors." Mrs. Ellis's three specimens were $60-80 \mathrm{~mm}$.

Gill's aeneus had the greatest height less than one fifth the total length, venezuelamus is described as having the height 2.66 in the length to the base of the caudal fin; the interorbital space in the former is less than the snout, in the latter greater than the length of the snout.

My material from the foothills of the Peruvian Andes is as follows:

D. I, 8; A. I, 7 ; interorbital 2 or more in the head; depth $3.0-3.3$ in the length; barbel to or not to gill-opening; eye $2.25-2.5$ in the interorbital, $4-5$ in the head; 5-6 azygous plates in front of the adipose; humeral plate and streak from it backward dark, fading out before reaching caudal;streak along middle of back dark, with a lighter line separating it from the previously-named dark areas. Plates: $22-25$

\section{Corydoras armatus (Günther)}

Callichthys armatus Günther, 1868, Proc. Zool. Soc. London, 230, fig. 1, three, types, $160 \mathrm{~mm}$., Yeberos; seven, $55 \mathrm{~mm}$., R. Huallaga.

Corydoras armatus Cope, 1871, Proc. Acad. Nat. Sci. Phila., XXIII, 282, Rio Huallaga, Xeberos; Cope, 1874, Proc. Acad. Nat. Sci. Phila., XXVI, 135, Nauta;

Eigenmann and Eigenmann, 1888, Proc. Cal. Acad. Sci., (2), I, 166;

Eigenmann and Eigenmann, 1890, Oce. Papers Cal. Acad, Sci., I, 471;

Eigenmann, 1910, Rept. Princeton Univ. Exped. Patagonia, III, 403;

Regan, 1912, Ann. Mag. Nat. Hist., (8), X, 215;

Gosline, 1940, Stanford Ichth. Bull., II, 1, 19.

Gasterodermus armalus Cope, 1878, Proc. Amer. Phil. Soc., XVII, 681, Nauta.

Peruvian Amazon and tributaries; Rio Juruá

\section{Corydoras Elegans Steindachner}

Corydoras elegans Steindachner, 1876, Sitzb. KK. Akad. Wiss. Wien, LXXIV, 93, Cudajas, Teffé; Eigenmann and Eigenmann, 1890, Occ. Papers Cal. Acad. Sci., I, 469;

Regan, 1913, Ann. Mag. Nat. Hist., (8), XII, 281, Rio Ucayali;

Gosline, 1940, Stanford Ichth. Bull., II, 1, 19.

Ucayali and Solimões rivers

\section{Corydoras ambiacus Cope}

Corydoras ambiacus Cope, 1872 (1871), Proc. Acad. Nat. Sci. Phila., XXIV, 280, Rio Ambyiacu;

Fowler, 1915, Proc. Acad. Nat. Sci. Phila., LXVII, 232, types of both ambiacus and trilineatus Cope;

Gosline, 1940, Stanford Ichth. Bull., II, 1, 19.

Corydoras trilineatus Cope, 1871 (1872), Proc. Acad. Nat. Sci. Phila., XXIV, 281, pl. vi, fig. 2, Rio Ambyiacu; 
Eigenmann and Eigenmann, 1890, Oce. Papers Cal. Acad. Sci., I, 473;

Eigenmann, 1910, Rept. P'rinceton Univ. Exped. Patagonia, III, 103 ;

Regan, 1912, Ann. Mag. Kat. Hist., (8), X, 215.

\section{Basin of Rio Marañon}

\section{Corydoras acutus Cope}

Corydoras acutus Cope, 1871 (1872), Proc. Acad. Nat. Sci. Phila., XXIV, 281, Rio Ambyiacu;

Eigenmann and Eigenmann, 1890, Oce. Papers Cal. Acad. Sci., I, 47t;

Eigenmann, 1910, Rept. Princeton Univ. Exped. Patagonia, III, 403;

Ellis, 1913, Ann. Carnegie Mus., VIII, 407;

Gosline, 1940, Stanford Ichth. Bull., II, 1, 16.

\section{Rio Ambyiacu}

\section{Corydoras amphibelus Cope}

Corydoras amphibelus Cope, 1871 (1872), Proc. Acad. Tat. Sci. Phila., XXIT, 282, Rio Ambyiacu;

Eigenmann and Eigenmann, 1890, Oce. Papers Cal. Acad. Sci., I, 474;

Eigenmann, 1910, Rept. Princeton Univ. Exped. Patagonia, III, 403;

Ellis, 1913, Ann. Carnegie Mus., VIII, 408.

?Corydoras armatus Gosline, 19t0, Stanford Ichth. Bull., II, 1, 19.

\section{Rio Ambyiacu}

\section{Corydoras paleatus (Jenyns)}

Callichthys punctatus Cuvier and Valenciennes, 18t0, Hist. Nat. Poiss., XV, 318;

Valenciennes, 1847, Voy. Amer. Merid., IX, Atlas ii, pl. v, fig. 1.

Callichthys paleatus Jenyns, 18 42 , Voy. Beagle, IV, 113;

Günther, 186t, Cat. Fish. Brit. Mus., V, 230.

Corydoras palcatus Cope, 1871, Proe. Acad. Nat. Sci. Phila., XXIII, 280;

Eigenmann and Eigenmann, 1890, Occ. Papers Cal. Acad. Sci., I, 471;

Eigenmann, 1910, Rept. Princeton Univ, Exped. Patagonia, III, 403;

Stoye, 1934, Aquarium, 12-14, source unknown.

Rio de la Plata basin and Rio Ambyiacu

The aquarium habits and spawning are deseribed by $\mathrm{Mr}$. Stoye, and his article is illustrated by an excellent photograph from life.

154. Corydoras zygatus Eigenmann and Allen, sp. nov. Plate XII, fig. 1

15704, 8, 55-77 mm., the largest the type, creek, Yurimaguas, Allen, Norember, 1920.

Allied to C. macrosteus and C. eques, with lateral plates more numerous and with less vertical profile.

Humeral plates in contact, at least in front. Preorbital not equal to its distance from the lips.

Head 3.25 ; depth 2.66 ; D. I, 7 or I, 8 ; A. 6; plates 24 above, 21 below; one 
specimen with 3 , four with 4 , two with 5 , and one with 6 plates in front of the adipose; snout longer than the rest of the head; interorbital 2.0 to 2.3 in the head; eye 4.0-4.5 in the head; preorbital about two in its distance from the edge of the

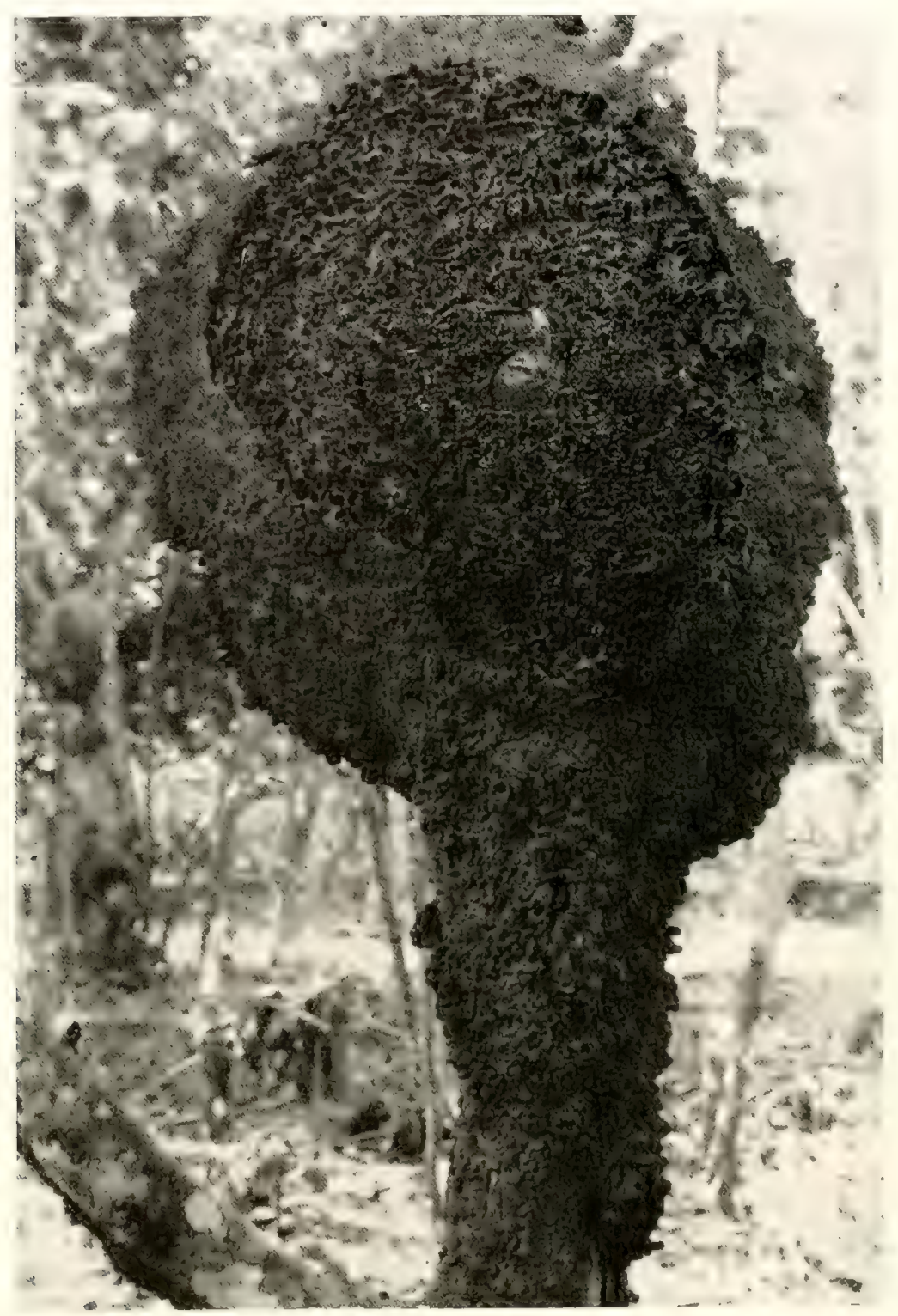

FIG. 21. A natural bait. A termites' nest cut open with machete. Such nests, found in most sections of the tropical lowlands above the level of inundation, afford a convenient means of learning whether a pool contains fish. Pieces of the nest, crumbled into the water with their temite larvae, are a great attraction to them. The inhabitants of Loreto often feed their chickens the same convenient protein food.

lip; occipital process tapering, its margin concave; humeral plates in contact for most of their length in the largest, a less distance in the smaller; barbels reaching gill-openings; dorsal spine about 1.5 in the head; pectoral spine longer, equal to 
snout and eye or a little more, reaching ventrals or farther; humeral plates separated from ventrals by one plate; caudal deeply forked, the upper lobe longer. Adipose spine conical, sharp, more than 2 in dorsal spine. Somewhat longer behind dorsal spine than before; caudal peduncle equal to snout.

Mouth moderate, lobes of lower lip somewhat prolonged, acute, suggesting a barbel.

A black band across the nape and back along the sides, following the middle of the upper series of plates, to the scales at the base of the upper lobe of the caudal, and continued faintly along middle caudal rays. No other markings except a cloudy line along the spines of fins and a faint dark area on the middle of the sides, even with the distal half of the pectoral.

155. Corydoras stenocephalus Eigenmann and Allen, sp. nov.

Plate XII, fig. 2

15817, 1, 59 mm., type, Yarinacocha, Allen, September, 1920.

Near C. armatus; differs in its greater depth; dorsal basis longer than its distance from origin of adipose; snout greatly prolonged.

Head 3, depth 2.66 ; D. I, 8; A. I, 7; plates 23 above, 20 below; interorbital 3 in the head; snout three times as long as the postorbital part of the head; eye 4.3 in the head; fontanel broad and deep, its groove to the base of the occipital process, which is as broad as long and concave laterally; barbels reaching the vertical from the front margin of the eye; snout pointed, the suborbital reaching about one fourth of the space to the upper lip; dorsal spine nearly equals length of snout; base of dorsal equals its distance from the adipose plus half the adipose; three azygous plates; pectoral spine about equal to dorsal spine or longer; adipose spine elongated, 1.5 in the dorsal spine.

Somewhat longer behind dorsal spine than before; dorsal contour of head very convex, the apex a distinct transverse ridge between the fontanel and nares; mouth very narrow, width slightly less than orbit, about 5 in the length of the head.

Anal notched into the ventral contour; caudal peduncle contracted in its depth to a measurement contained in the fontanel 1.25 times; humeral plates widely separated except at cephalic extremity.

In this specimen the lower lips prolonged into barbels, the right one shrunken, abnormal, and forked, forming a letter-Y.

\section{Corydoras episcopi Eigenmann and Allen, sp. nov.}

Plate XII, fig. 3

15605, 1, $33 \mathrm{~mm}$., type, Rio Morona, Allen, October, 1920.

15816,3 , 40-45 mm., paratypes, Yarinacocha, September, 1920.

Similar to Corydoras acutus, differing in having about one more lateral plate of each series, dark area of dorsal covering distal ends of five rays, dark zigzag pencilling along contiguous margins of the lateral plates.

Length to base of caudal $123 \mathrm{~mm}$., head $8 \mathrm{~mm}$., depth $10 \mathrm{~mm}$., interorbital 
$4 \mathrm{~mm}$., eye $3 \mathrm{~mm}$., height of dorsal $7 \mathrm{~mm}$., dorsal spine $6 \mathrm{~mm}$., pectoral spine $7 \mathrm{~mm}$., pectoral ray $8 \mathrm{~mm}$., ventral $6 \mathrm{~mm}$., upper caudal lobe $10 \mathrm{~mm}$.; plates 23 above, 20 below, fontanel short, not reaching base of occipital process.

D. I, 7.5; A. I, 6.5; base of dorsal equal to its distance from the tip of the adipose; barbel not reaching gill opening; lower lip only slightly prolonged into an acute barbel-like tip; length before and behind dorsal spine the same; depth 2.4; adipose spine short and conical, equal to eye; caudal peduncle equal to length of snout; snout short, less than double the postorbital space, tending to be vertical, frontal elevated and convex; eye 1.7 in snout; anal slightly notched into ventral contour; pectoral reaching to last third or fourth of ventral; humeral plates narrow and widely separated entire length.

A dark spot on tip of dorsal, a line along the spine, a line along the margin of the fin, and the penultimate dorsal ray dark; adipose fin dusky behind the spine and in a submarginal band; six narrow dark lines across the caudal fin and its lobes; one or two similar lines across the anal; in the type a conspicuous black band (hooked in front) along the middle of the sides in a much wider colorless band; each scale above and below the band with a black vertical line; a black line along the base of dorsal fin; head with asymmetric vermiculating lines. In the paratypes the dark median line fades anteriorly, the vertical lines tending to break up into spots.

157. Corydoras leucomelas Eigenmann and Allen, sp. nov.

Plate XII, fig. 4

15818, 1, 39 mm., type, Yarinacocha, Allen, September, 1920.

Head 3 ; depth 2.5 ; D. I, 7.5; A. I, 6.5; plates 23 above, 20 below; interorbital 2.25 in the head; snout twice as long as the postorbital part of the head; dorsal contour of the head only moderately convex; eye 3.3 in the head; fontanel not reaching the base of the occipital process, which is oval and as long as broad; barbels just reaching the vertical from the anterior margin of the eye; mental barbels but slightly bifid; suborbital reaching about one fourth to the upper lip; dorsal spine greater than snout and eye; length before and behind dorsal spine the same; base of dorsal greater than its distance from the adipose; an azygous plate in front of the adipose; adipose spine conical, decurved, sharp-pointed, slightly exceeding the eye in length; pectoral reaching past the middle of ventral fin; pectoral spine a little longer than the dorsal spine; anal spine 2.5 in the longest anal rays; caudal peduncle narrow and elevated, only slightly exceeding snout; humeral plates widely separated, short, and subacute behind.

Dorsal mostly black, only the antepenultimate ray with its membranes and the tip of the preceding ray hyaline; caudal with two vertical bars and vertical series of spots, the first through the level of the tips of the middle rays; anal with a bar through its middle; sides with many spots, decreasing in size downward.

Similar to $C$. punctatus in many respects; dorsal all dark except for the two penultimate rays and the tips of the two preceding; single azygous plate. 


\section{Supplement to CoRYdoras}

158. Corydoras bertoni Eigenmann, sp. nov.

154t1, 1, type, $32 \mathrm{~mm}$. to end of middle caudal rays, Puerto Bertoni, Alto Paraná, Paraguay.

Unusually slender with large fins.

Depth and head about 3.25 in the length; plates 23 ; ; D. I, 7 ; A. I, 5; dorsal reaching the adipose, the spine slightly shorter than the pectoral spine, which is equal in length to the head; pectoral to within the width of a lateral plate from the tip of the ventrals; barbels to below the anterior edge of the eye; interorbital 2.5 in the head; eye 1.5 in the snout, 3.3 in the head, 1.3 in the interorbital space; preorbital very narrow, its width about 3 in its distance from the lip. Three azygous plates in front of the adipose.

Sides light, with numerous, irregular, dark, vertical spots; dorsal with two oblique bands; caudal with three cross bands; anal with a vertical band across anterior third; upper surfaces of pectoral and ventral faintly marked.

For A. de W. Bertoni, the collector of the specimen.

\section{Genus 69: DIANEMA Cope}

Dianema Cope, 1871, Proc. Acad. Nat. Sci. Phila., 276;

Eigenmann and Eigenmann, 1890, Occ. Papers Cal. Acad. Sci., I, 462;

Gosline, 1940, Stanford Ichth. Bull., II, 1, 9.

\section{Type: Dianema longibarbis Cope}

\section{Rio Ambyiacu}

Separable from Hoplosternum and Decapogon in having one barbel at each rictus, and a pair of long barbels at the symphysis; the exposed coracoid joined to clavicle its entire length, and coracoid processes entirely covering breast and belly; lateral plates meeting and covering back and belly. Unlike Callichthys in not having coracoid enclosed by skin; differing from Brochis and Corydoras in the two pairs of nuchal plates, where those genera have a narrow process reaching dorsal plate. Adipose dorsal with a spine.

\section{Dianema longibarbis Cope}

Dianema longibarbis Cope, 1871, Proc. Acad. Nat. Sci. Phila., XXIII, 276, pl. vii, figs. 1a, 1b, and 1c, Rio Ambyiacu;

Eigenmann and Eigenmann, 1890, Oce. Papers Cal. Acad. Sci., I, 463 ;

Eigenmann, 1910, Rept. Princeton Univ. Exped. Patagonia, III, 402;

Ellis, 1913, Ann. Carnegie Mus., VIII, 392;

Gosline, 1940, Stanford Ichth. Bull., II, 1, 9.

Known only from a Rio Ambyiacu specimen of $90 \mathrm{~mm}$. in the Museum of the

Philadelphia Academy of Sciences

\section{Genus 70: BROCHIS Cope}

Brochis Cope, 1871, Proc. Acad. Nat. Sci. Phila., 277;

Eigenmann and Eigenmann, 1890, Occ. Papers Cal. Acad. Sci., I, 463 ;

Gosline, 1940, Stanford Ichth. Bull., II, 1, 24. 


\section{Type: Brochis coeruleus Cope \\ Peruvian Amazon}

The ten to twelve dorsal rays separate the genus from the next, compared with its $6-8$; they are allied in having the narrow occipital process reaching the dorsal plate.

\section{Brochis coeruleus Cope}

Brochis coeruleus Cope, 1871, Proc. Acad. Nat. Sci. Phila., XXIII, 277, pl. vii, figs. 2a and 2b; pl. ix, fig. 3, R. Ambyiacu;

Eigenmann and Eigenmann, 1890, Occ. Papers Cal. Acad. Sci., I, 464;

Eigenmann, 1910, Rept. Princeton Univ. Exped. Patagonia, III, 402;

Gosline, 1940, Stanford. Ichth. Bull., II, 1, 24.

Brochis dipterus Cope, 1871, Proc. Acad. Nat. Sci. Phila., XXIII, 278, Rio Ambyiacu;

Ellis, 1913, Ann. Carnegie Mus., VIII, 394.

\section{Rio Ambyiacu, Peru}

\section{Genus 71: CHAENOTHORAX Cope}

Chaenothorax Cope, 1878, Proc. Amer. Phil. Soc., XVII, 679, Peruvian Amazon;

Eigenmann, 1910, Rept. Princeton Univ. Exped. Patagonia, III, 402;

Ellis, 1913, Ann. Carnegie Mus., VIII, 392.

Brochis Eigenmann and Eigenmann, 1890, Occ. Papers Cal. Acad. Sci., I, 463, (in part);

Gosline, 1940, Stanford Ichth. Bull., II, 1, 24.

\section{Type: Chaenothorax bicarinatus Cope \\ Peruvian Amazonia}

Similar to Brochis in the character of the occipital process; differing in the short dorsal fin, having only $6-8$ rays; exposed coracoid processes variable, but not enclosing the breast and belly entirely.

\section{Chaenothorax bicarinatus Cope}

Chaenothorax bicarinatus Cope, 1878, Proc. Amer. Phil. Soc., XVII, 679, Peruvian Amazon;

Eigenmann, 1910, Rept. Princeton Univ. Exped. Patagonia, III, 402;

Ellis, 1913, Ann. Carnegie Mus., VIII, 392.

Brochis (Chaenothorax) bicarinatus Eigenmann and Eigenmann, 1890, Occ. Papers Cal. Acad. Sci., I, 464 .

Brochis coeruleus Gosline, 1940, Stanford Ichth. Bull,, II, 1, 24.

\section{Peruvian Amazon}

\section{Chamothorax semiscutatus (Cope)}

Corydoras semiscutatus Cope, 1871, Proc. Acad. Nat. Sci. Phila., XXIII, 280, pl. vi, figs. 1a and 1b, Rio Ambyiacu.

Brochis semiscutatus Eigenmann and Eigenmann, 1888, Proe. Cal. Acad. Sei., (2), I, 165.

Brochis (Chaenothorax) semiscutatus Eigenmann and Eigenmann, 1890, Occ. Papers Cal. Acad. Sci., I, 464 . 
Chacnothorax semiscutatus Eigenmann, 1910, Rept. Princeton Univ. Exped. Patagonia, III, 402; Ellis, 1913, Ann. Carnegie XIus., VIII, 393.

Brochis coeruleus Gosline, 1940, Stanford Ichth. Bull., II, 1, 24.

Known only from the Ambyiacu

\section{Genus 72: OSTEOGASTER Cope}

Corydoras (in part) Eigenmann and Eigenmann, 1890, Oce. Papers Cal. Acad. Sci., I, 468;

Regan, 1912, Ann. Mag. Nat. Hist., (8), X, 209.

Osteogaster Cope, 1894, Proc. Amer. Phil. Soc, XXXIII, 102;

Eigenmann, 1910, Rept. Princeton Univ. Exped. Patagonia, III, 403.

Brochis (in part) Regan, 1912, Ann. Mag. Nat. Hist., (8), X, 209;

Gosline, 1940, Stanford Ichth. Bull., II, 1, 24.

Type: Corydoras eques Steindachner

Throughout the Amazon

Separable from the nearby Corydoras on the basis of the meeting of the coracoid processes in the middle line of the belly, a doubtful point, however, which has been solved in the Gosline monograph by making it a synonym of Brochis.

\section{Osteogaster splendens (Castelnau)}

Callichthys splendens Castelnau, 1855, Anim. Amér. Sud, Poiss., 39, pl. xviii, fig. 3, Rio Tocantins. Corydoras splendens Cope, 1871, Proc. Acad. Nat. Sci., Phila., XXIII, 283, Rio Ambyiacu;

Eigenmann and Eigenmann, 1890, Occ. Papers Cal. Acad. Sci., I, 468.

Osteogaster splendens Eigenmann, 1910, Rept. Princeton Univ. Exped. Patagonia, III, 403;

Ellis, 1913, Ann. Carnegie Mus., VIII, 412.

Brochis coeruleus Gosline, 1940, Stanford Ichth. Bull., II, 1, 24.

Rio Tocantins and Rio Ambyiacu

\section{Family X: Loricariidae}

Siluroides (in part) Cuvier, 1817, Règne Anim., ed. i, II, 199.

Goniodontes Agassiz, 1829, Sel. Gen. et Spee. Pisc. Bras., 1.

Loricata Kner, 1853, Denksch. KK. Akad. Wiss. Wien, VI, 75.

Loricaroidei Bleeker, 1863, Nederl. Tijdsch. Dierk., I, 77.

Hypostomatina (in part) Günther, 1864, Cat. Fish. Brit. Mus., V, 11.

Loricaridae Gill, 1872, Arr. Fam. Fish., 19;

Eigenmann and Eigenmann, 1888, Amer. Nat., XXII, 649;

Eigenmann and Eigenmann, 1890, Occ. Papers Cal. Acad. Sci., 1, 351;

Regan, 1904, Trans. Zool. Soc. London, XVII, 191;

Eigenmann, 1912, Mem. Carnegie Mus., Y, 221.

\section{Most of South America}

A family of Nematognath fishes extending throughout the lowlands and moderate elevations. Invested on sides and back, sometimes on the venter, with an armor of bony plates; the plates sometimes with few or many denticles. Mouth inferior, bordered with a broad lip; maxillaries thin, terminating in a barbel, and 
partly united with the labial apparatus, forming an oral sucker; mental and nasal barbels not present; teeth absent, or hooked and lobed at the distal extremity; active teeth in a single series; premaxillaries disjoined, box-like, and filled with numerous relay teeth; dentaries similarly disunited and similar in structure; palate edentulous; fontanels wanting in frontal and occipital.

Dorsal fin abdominal, and not connected with the occipital; adipose usually present, consisting of a spine with a thin membrane; gill-membranes united to the isthmus, openings wholly lateral; intestine very long and greatly recoiled.

$$
\text { Subfamily: HYPOSTOMATINAE }
$$

Tail short; caudal peduncle compressed, cylindrical, or moderately depressiform; haemal spines all simple; lower, and fourth upper, pharyngeals without teeth; belly naked, or at most with minute, granular plates; intestinal canal of extravagant length.

The fishes of this subfamily are rather generally known under the colloquial name carachama. Despite their forbidding exteriors they are surprisingly found to be favorite food fishes on the part of the inhabitants of the lowlands. This I learned is due not to any superiority in flavor, but rather to the ease with which the meat may be scooped out of the armor when boiled and served entire, together with boiled rice or plantains. This convenience is regarded as more than fair compensation for the strong, rancid flavor, for which a toleration must be acquired.

These fishes were taken in unbelieveable numbers in the quieter backwater bayoux, in water often shaded by the forest and brown with fallen vegetation. Their vitality is remarkable. Many of them, taken in seines and thrown into the dugout canoes, were found alive and vigorous many hours later. Although the skin would be entirely dry, the gills were at least moist. They invariably found the wettest place on the bottom of the boat and assembled there. While the canoe was under way, the puddles of water would sometimes run from side to side or end to end, and all the carachamas turned and followed it back and forth. With the flat, inferior mouth and wide lips closely applied to the timbers, they could suck up a few drops of water, enough to keep the gills from drying out altogether.

The vocal powers of the Hypostomatinae are not inconsiderable. While on the bottom of the boat they emit grunting sounds which enhance the pig-like behavior described above.

Señor Medina said to me, "Son Inglés. Hablan muy abajo en la garga." "They are English. They speak very far down in the throat."

Before leaving for South America, Miss Siebenthal, the artist, had said, "Dr. Eigenmann has brought us a lot of good fish stories. He found fishes walking, others climbing. You will have to find them talking." And so it came about.

\section{Genus 73: CANTHOPOMUS Eigenmann and Allen, gen. nov.}

Plecostomus Gronow, 1754, Mus. Ichth., I, 24, (in part);

Gronow, 1763, Zoophyl., 127;

Bleeker, 1863, Nederl. Tijdsch. Dierk., I, 77, brasiliensis. 
Rhinelepis Spix, 1829, Sel. Gen. et Spee. Pise. Bras., 2;

Steindachner, 1878, Sitzb. KK. Akad. Wiss. Wien, LXXVI, 228.

Pogonopoma Regan, 1904, Trans. Zool. Soc. London, XVII, 205.

Canthopomus Eigenmann, 1910, Rept. Princeton Univ. Exped. Patagonia, III, 407, nomen nudum.

\section{Type: Rhinelepis agassizii Steindachner}

\section{Throughout Amazonia}

Regan used the subgeneric name Pogonopoma for Plecostomus wertheimeri Steindachner, Plecostomus pellegrini Regan, and Rhinelepis genibarbis Cuvier and Valenciennes, of which he considers Rhinelepis agassizii a synonym.

Plecostomus wertheimeri seems from our material generically distinct from Plecostomus pellegrini and Rhinelepis genibarbis, and if we restrict the name Pogonopoma to wertheimeri, the term Canthopomus may be applied to agassizii.

Plecostomus wertheimeri Steind.

Plecostomus pellegrini Regan

Rhinelepis genibarbis C. \& V.

Rhinelepis agassizii Steind.
REGAN

\begin{tabular}{l}
\multicolumn{3}{c}{ REGaN } \\
Subg. Pogonopoma \\
"6 \\
" \\
Synonym
\end{tabular}

EIGENMANN

Pogonopoma

Plecostomus

Rhinelepis

Canthopomus

No trace of an adipose fin; scutes 24 or 25 ; occipital bordered by three plates; lower surface with minute granular plates and a series of large plates on the sides between pectorals and ventrals; scutes of sides carinate; opercle hirsute.

\section{Canthopomus agassizil (Steindachner)}

\section{Plate VII, figs. 1-2}

Rhinelepis agassizii Steindachner, 1878, Sitzb. KK. Akad. Wiss. Wien, LXXVI, 228;

Steindachner, 1882, Denksch, KK. Akad. Wiss. Wien, XLVI, 7;

Eigenmann and Eigenmann, 1889, Proc. Cal. Acad. Sci., (2), II, 42;

Eigenmann and Eigenmann, 1890, Occ. Papers Cal. Acad. Sci., I, 416.

Acanthicus genibarbis Eigenmann and Eigenmann, 1890, Occ. Papers Cal. Acad. Sci., I, 441.

Plecostomus genibarbis (in part) Regan, 1904, Trans. Zool. Soc. London, XVII, 219.

Canthopomus genibarbis (in part), Eigenmann, 1910, Rept. Princeton Univ. Exped. Patagonia, III, 407.

\section{Lake Manacapurú to Rio Huallaga}

$15970,1,154 \mathrm{~mm}$. to end of plates at base of caudal, Iquitos, Morris, 1922.

\section{Genus 74: HYPOSTOMUS (Lacépède)}

Plecostomus Gronow, after Artedi, 1751, Mus. Ichth., I, 24;

Gronow, 1763, Zoophyl., 127, sp., not binomial;

Bleeker, 1863, Nederl. Tijdsch. Dierk., I, 77, brasitiensis;

Eigenmann and Eigenmann, 1890, Occ. Papers Cal. Acad. Sci., I, 396;

Eigenmann, 1910, Rept. Princeton Univ. Exped. Patagonia, III, 403 ;

Regan, 1904, Trans. Zool. Soc. London, XVII, 202;

Authors generally. 
Hypostomus Lacépède, 1803, Hist. Nat. Poiss, V, 144, guacari = plecostomus; Cuvier and Valenciennes, 1840, Hist. Nat. Poiss., XV, 489, plecostomus; Jordan, Evermann, and Clark, 1928 (1930), Rept. U. S. Comm. Fish., Part II, 130.

Type: Hypostomus guacari Lacépède = Loricaria plecostomus Linnaeus Throughout the Atlantic drainage to the foothills of the Andes of Peru, Magdalena basin, Guayaquil

Snout granular; no spines or bristles about the head; adipose fin present; sides and back completely enclosed within plates; first scute of lateral series posterior to clavicle and temporal plate, separating the second entirely from the temporal; snout with granular plates to the margin; venter naked or with small granular scales.

\section{Hypostomus emarginatus Cuvier and Valenciennes}

Hypostomus emarginatus Cuvier and Valenciennes, 1840, Hist. Nat. Poiss., XV, 500, Brazil;

Kner, 185+, Denksch. KK. Akad. Wiss. Wien, VII, 260.

Plecostomus emarginatus Günther, 1864, Cat. Fish. Brit. Mus., V, 233;

Steindachner, 1882, Denksch. KK. Akad. Wiss. Wien, XLIII, 112;

Eigenmann and Eigenmann, 1888, Proc. Cal. Acad. Sci., (2), I, 167;

Eigenmann and Eigenmann, 1890, Occ. Papers Cal. Acad. Sci., I, 400;

Regan, 1904, Trans. Zool. Soc. London, XVII, 210;

Eigenmann, 1910, Rept. Princeton Univ. Exped. Patagonia, III, 406;

Fowler, 1939 (1940), Proc. Acad. Nat. Sci. Phila., XCI, 233, Contamana.

Plecostomus scopularius Cope, 1871, Proc. Acad. Nat. Sci. Phila., 55 and 286, pl. xvi, figs. 1 and 2,

Ambyiacu R.

Plecostomus biseriatus Cope, 1871, Proc. Acad. Nat. Sci. Phila., 285, Ambyiacu.

Plecostomus virescens Cope, 1874, Proc. Acad. Nat. Sci. Phila., XXVI, 137, Nauta;

Cope, 1878, Proc. Amer. Phil. Soc., XVII, 681, Peruvian Amazon;

Eigenmann and Eigenmann, 1890, Occ. Papers Cal. Acad. Sci., I, 408.

Amazons, Para to Peruvian Andes, Guianas, R. Magdalena

15360, 3, 170-245 mm., Iquitos, Amazon, Allen, September, 1920.

15362, 1, 159 mm., Gosulimacocha, Rio Morona, Allen, October, 1920.

15363, 5, 23-242 mm., Rio Morona, Allen, October, 1920.

1536t, many, largest $231 \mathrm{~mm}$., Yurimaguas, Rio Paranapura, Allen, November, 1920.

15365, 3, 122-193 mm., Contamana, Rio Ucayali, Allen, August, 1920.

15361 and 15366, many, 25-310 mm., Yurimaguas, Allen, November, 1920.

\section{Hypostomus plecostomus (Linnaeus)}

Acipenser plecostomus Linnaeus, 1758, Syst. Nat., ed. x, 238.

Loricaria plecostomus Linnaeus, 1766, Syst. Nat., ed xii, 508, America.

Hypostomus plecostomus Cuvier and Valenciennes, 1810, Hist. Nat. Poiss., XV, 489, Guiana;

Kner, 1854, Denksch. KK. Akad. Wiss. Wien, VII, 263.

Plecostomus plecostomus Eigenmann and Eigenmann, 1888, Proc. Cal. Acad. Sci., (2), I, 168, 169, Brazil;

Eigenmann and Eigenmann, 1890, Occ. Papers Cal. Acad. Sci., I, 406;

Eigenmann, 1910, Rept. Princeton Univ. Exped. Patagonia, III, 403;

Pearson, 1937a, Proc. Cal. Acad. Sci., (4), XXIII, 96, Pusoc, upper Marañon.

Plecostomus bicirrhosus Gronow, 175t, Cat. Fish., 158;

Günther, 186t, Cat. Fish. Brit. Mus., V, 231, Guianas, Para;

Steindachner, 1881, Denksch. KK. Akad. Wiss. Wien, XLIII, 109;

Boulenger, 1887, Proc. Zool. Soc. London, 277. 
Hypostomus guacari Lacépède, 1803, Hist. Nat. Poiss., 145.

Plecostomus guacari Regan, 1904, Trans. Zool. Soc. London, XVII, 205.

Both slopes of Panama and southward to Uruguay

167. Hypostomus phrixosoma (Fowler)

Plecostomus phrixosoma Fowler, 1939 (1910), Proc. Acad. Nat. Sci. Phila., XCI, 233, figs. 21-23, one, type, $150 \mathrm{~mm}$., Contamana.

Known from the type taken at Contamana

Near H. commersonii and punctatus Cuvier and Valenciennes. The common name Carocha de brada was supplied to the collectors.

\section{Genus 75: HEMIIANCISTRUS Bleeker}

Hypostomus (in part) Cuvier and Talenciennes, 1840, Hist. Nat. Poiss., XV, 489, sp.

Ancistrus Kner, 1853 (1854), Denksch. KK. Akad. Wiss. Wien, VII, 272;

Regan (in part), 1904, 'Trans. Zool. Soc. London, XVII, 221.

Hemiancistrus Bleeker, 1863, Nederl. Tijdsch. Dierk., I, 78;

Eigenmann and Eigenmann, 1890, Occ. Papers Cal. Acad. Sci., I, 417;

Eigenmann, 1910, Rept. Princeton Univ. Exped. Patagonia, III, 408.

Chactostomus (in part) Güther, 186t, Cat. Fish. Brit. Mus., V, 240.

Type: Ancistrus medians Kner

\section{La Plata and Amazon systems, Guianas to Panama}

The enclosure of the ventral surface by small plates led to its designation by Kner as medians, intermediate between Ancistrus and Plecostomus (Hypostomus); Bleeker held this character as sufficient justification for the present genus. Separated from the preceding by the erectile spines borne on a movable plate; dorsal and adipose fins not approximated; margin of snout granular, sometimes with a naked spot near the tip; body deep, plates keeled, occipital keeled; teeth small; D. I, 7 , the last ray connected with the succeeding scute by a small membrane. "All species seem to be rare."

\section{Hemincistrus ucatalensis Fowler}

Hemiancistrus ucayalensis Fowler, 1939 (1940), Proc. Acad. Nat. Sci. Phila., XCI, 235, figs. 2t-25, three, type and paratypes, $117-124 \mathrm{~mm}$., Contamana.

The Ucayali basin, Contamana

169. Hemiancistrus arenarius Eigenmann and Allen, sp, nor.

Plate VI, fig. 2

15356, 2, 94 and $106 \mathrm{~mm}$., the latter the type, Yurimaguas, Allen, Norember, 1920.

15357, 1, $123 \mathrm{~mm}$., Alto Marañon, below Pastaza, Allen, October, 1920.

15358, 1, 129 mm., Amazon, Iquitos, Allen, September, 1920.

Head 2.66-2.9; depth 4.0-4.33; D. I, 7; A. I, 4; scutes $24+1$; width of head 1.2 in its length; interorbital 2 ; eye $6,3.5$ in the snout; longest interopercular spine 
as long as eye; mandibular ramus about as long as the premaxillary, about 4 in the interorbital, with about 23 teeth; snout rounded; no carinae on head or scutes; depth of caudal peduncle 2 in its length; dorsal spine less than the length of the head; caudal very deeply emarginate, the upper lobe narrow, long, and pointed, equal to the length of the head in the smaller, lower lobe but little longer than the snout and eye in the smaller, equal to the head in the larger. In the largest, 15358, the caudal is very obliquely emarginate, the upper lobe 1.5 in the head, the lower very little shorter than the head. Dorsal spotted as in the others, the caudal with cross bands, five of them especially prominent on the lower lobe.

Ventrals reaching anal or a little farther; pectorals beyond middle of ventrals; last dorsal ray not connected with the back by a membrane.

Sandy colored; faint cross shades or spots on head and sides; fins with alternate series of light and dark spots or crossbands.

Near Ancistrus bachi (Boulenger); differing in somewhat narrower head, shorter interopercular spine, rounded snout, greater depth of body and caudal peduncle.

\section{Genus 76: PANAQUE Eigenmann and Eigenmann}

Panaque Eigenmann and Eigenmann, 1889, Proc. Cal. Acad. Sci., (2), II, 44, nigrolineatus;

Eigenmann and Eigenmann, 1890, Occ. Papers Cal. Acad. Sci., I, 425;

Regan, 1904, Trans. Zool. Soc. London, XVII, 242;

Eigenmann, 1910, Rept. Princeton Univ. Exped. Patagonia, III, 410.

\section{Type: Chaetostomus nigrolineatus Peters}

Peru, most of Brazil, to the Magdalena

Teeth few and spatulate, large; interopercular spines in a large bundle, erectile.

\section{Panaque dentex (Günther)}

Chaetostomus dentex Günther, 1868, Proc. Zool. Soc. London, 233, Xeberos.

Panaque dentex Eigenmann and Eigenmann, 1889, Proc. Cal. Acad. Sci., (2), II, 44;

Eigenmann and Eigenmann, 1890, Occ. Papers Cal. Acad. Sci., I, 427;

Regan, 1904, Trans. Zool. Soc. London, XVII, 243;

Eigenmann, 1910, Rept. Princeton Univ. Exped. Patagonia, III, 410.

Known from a specimen of $85 \mathrm{~mm}$. length, collected by Bartlett at Xeberos, Peruvian Amazon

\section{Genus 77: MONISTIANCISTRUS Fowler}

Monistiancistrus Fowler, 1939 (1940), Proc. Acad. Nat. Sci. Phila., XCI, 236.

Type: Monistiancistrus carachama Fowler

Range that of the one species known

Differing from Ancistrus chiefly in the lack of the adipose fin, reduced teeth, and small jaws. 
171. Monistiancistrus carachama Fowler

Monistiancistrus carachama Fowler, 1939 (1940), Proc. Acad. Nat. Sci. Phila., XCI, 238, figs. 26 and 27.

\section{Contamana, Rio Ucayali}

One specimen, the type, $95 \mathrm{~mm}$. in length, at the Philadelphia Academy, is known.

\section{Genus 78: PTERYGOPLICHTHYS Gill}

Pterygoplichthys Gill, 1858, Ann. Lye. Nat. Hist. N. Y., VI, 408;

Eigenmann and Eigenmann, 1890, Occ. Papers Cal. Acad. Sci., I, 427;

Eigenmann, 1910, Rept. Princeton Univ. Exped. Patagonia, III, 408;

Eigenmann, 1912, Mem. Carnegie Mus., V, 227.

Liposarcus Günther, 1864, Cat. Fish. Brit. Mus., V, 238, sp.

Ancistrus (in part) Regan, 1904, Trans. Zool. Soc. London, XVII, 221.

Type: Hypostomus duodecimalis Cuvier and Valenciennes

Rio Cauca, the Guianas to the São Francisco and Huallaga

The granular snout and ten or more dorsal rays are diagnostic of the genus; the interopercle of form similar to that of Hypostomus, but often bearing more spines. On the whole they appear more robust and more erect than nearby genera.

\section{Pterygoplichthys gibBiceps (Kner)}

Ancistrus gibbiceps KKner, 1854, Denksch. KK. Akad. Wiss. Wien, VII, 28t, pl.v, fig. 2;

Regan, 1904, Trans. Zool. Soc. London, XVII, 227.

Liposarcus altipinnis Günther, 1864, Cat. Fish. Brit. Mus., V, 239.

Pterygoplichthys gibbiceps Günther, 1864, Cat. Fish. Brit. Mus., V, 252;

Eigenmann and Eigenmann, 1889, Proc. Cal. Acad. Sci., (2), II, 44;

Eigenmann and Eigenmann, 1890, Occ. Papers Cal. Acad. Sci., I, 429;

Eigenmann, 1910, Rept. Princeton Univ. Exped. Patagonia, III, 407.

Liposarcus scrophus Cope, 1874, Proc. Acad. Nat. Sci. Phila., XXVI, 136;

Cope, 1878, Proc. Amer. Phil. Soc., XVII, 681, Nauta.

Chaetostomus gibbiceps Steindachner, 1882, Denksch. KK. Akad. Wiss. Wien, XLIII, 114, pl. iv, fig. 1.

Hemiancistrus gibbiceps Fowler, 1939 (1940), Proc. Acad. Nat. Sci. Phila., XCI, 235, five, 117-270 mm., Contamana.

The Amazons, Gurupá to the Ucayali

15349, 2, 293 and 343 mm., Iquitos, bayou, Allen, September, 1920.

15350, 4, 159-280 mm., Yarinacocha, Rio Pacaya, Allen, August, 1920.

The Iquitos specimens from muddy water much paler in color than those from the Pacaya. In the bulk, handling this species is like handling chestnuts in the bur.

\section{Pterygoplichthys punctatus Günther}

Ancistrus duodecimalis Kner (non Cuvier and Valenciennes), 1853 (185t), Denksch. KK. Akad. Wiss. Wien, VII, 281. 
Loricaria punctata Natterer, in Kiner, 1853 (1851), Denksch. KK. Akad. Wiss. Wien, VII, 281.

Pterygoplichthys punctatus Günther, 1864, Cat. Fish. Brit. Mus., V, 251;

Eigenmann and Eigenmann, 1889, Proc. Cal. Acad. Sci., (2), II, 45;

Eigenmann and Eigenmann, 1890, Occ. Papers Cal. Acad. Sci., I, 431;

Eigenmann, 1910, Rept. Princeton Univ. Exped. Patagonia, III, 409.

Chaetostomus punctatus Steindachner, 1880 (1882), Denksch. KK. Akad. Wiss. Wien, XLIII, 113, Cudajas to Tabatinga.

Ancistrus punctatus Regan, 190t, Trans. Zool. Soc. London, XVII, 229.

\section{Upper Amazonia of Brazil and Peru}

15355, 6, 55-187 mm., creeks, Yurimaguas, Allen, November, 1920.

\section{Pterygoplichthys multiradiatus (Hancock)}

Hypostomus multiradiatus Hancock, 1828, Zool. Jour., IV, 246, Demarara.

Hypostomus pardalis Castelnau, 1855, Anim. Amér. Sud, Poiss., 42, pl. xx, fig. 3, Amazon.

Liposarcus multiradiatus Günther, 1864, Cat. Fish. Brit. Mus., V, 238.

Liposarcus pardalis Günther, 1864, Cat. Fish. Brit. Mus., V, 239.

Liposarcus varius Cope, 1871, Proc. Acad. Nat. Sci. Phila., XXIII, 284, Rio Ambyiacu.

Liposarcus jeanesianus Cope, 1874, Proc. Acad. Nat. Sci. Phila., 135;

Cope, 1878, Proc. Amer. Phil. Soc., XVII, 681, Nauta.

Plccostomus (Liposarcus) pardalis Peters, 1877, MB. Akad. Berlin, 477;

Steindachner, 1882 (1883), Denksch. KK. Akad. Wiss. Wien, XLVI, 6, Rio Huallaga.

Pterygoplichthys multiradiatus Eigenmann and Eigenmann, 1890, Oec. Papers Cal. Acad. Sci,, I, 433, Demarara;

Eigenmann, 1910, Rept. Princeton Univ. Exped. Patagonia, III, 408;

Eigenmann, 1912, Mem. Carnegie Mus., V, 228.

Pterygoplichthys pardalis Eigenmann and Eigenmann, 1889, Proc. Cal. Acad. Sei., (2), II, 45;

Eigenmann and Eigenmann, 1890, Oce. Papers Cal. Acad. Sci., I, 431.

Pterygoplichthys jeanesianus Eigenmann and Eigenmann, 1889, Proc. Cal. Acad. Sci., (2), II, 45;

Eigenmann and Eigenmann, 1890, Occ. Papers Cal. Acad. Sci., I, 433.

Ancistrus multiradiatus Regan, 1904, Trans. Zool. Soc. London, XVII, 228.

Demarara to the Paraguay and upper Amazons

15351, 7, 100-157 mm., creek, Rio Morona, Allen, October, 1920.

15352, 1, $187 \mathrm{~mm}$., Contamana, Rio Ucayali, Allen, August, 1920.

$15353,13,115-320 \mathrm{~mm}$., Cashiboya, Rio Ueayali, Allen, August, 1920.

15354, 1, about $340 \mathrm{~mm}$., Lago Sanango, Allen, November, 1920.

$17831,1,94 \mathrm{~mm}$. without caudal, Iquitos, Morris, 1922.

The Cashiboya specimens have three distinct areas on supraoccipital and interorbital where radiating lines run into vermiculations. In this respect Pearson, 1924, finds that his two specimens from Lago Rogoagua, Bolivia, differ from them, and that the dorsal vermiculations do not radiate from a center. The ventral surfaces of his specimens are vermiculated, sometimes breaking up into spots.

\section{Genus 79: PARANCISTRUS Bleeker}

Hypostomus (in part) Castelnau, 1855, Anim. Amér. Sud, Poiss., 43.

Parancistrus Bleeker, 1863, Nederl. Tijdsch. Dierk., I, 79;

Eigenmann and Eigenmann, 1890, Occ. Papers Cal. Acad. Sci, I, 422;

Eigenmann, 1910, Rept. Princeton Univ. Exped. Patagonia, III, 409; Ancistrus (in part) Regan, 1904, Trans. Zool. Soc. London, XVII, 221. 


\section{Type: Hypostomus aurantiacus Castelnau}

The Amazon valley

Hemiancistrus and the present genus are scarcely separable except that the latter is marked by a greater or less continuity between the dorsal and adipose fins.

\section{Parancistrus aurantiacus (Castelnau)}

Hypostomus aurantiacus Castelnau, 1855, Anim. Amér. Sud, Poiss., 43, pl. xxi, fig. 2, Rio Ĺcayali. Hypostomus nigricans Castelnau, 1855, Anim. Amér. Sud, Poiss., 4t, pl. xxii, fig. 1. Hypostomus vicinus Castelnau, 1855, Anim. Amér. Sud, Poiss., 45, pl. xxiii, fig. 1. Parancistrus aurantiacus Bleeker, 1863, Nederl. 'Tijdsch. Dierk., 1, 79;

Eigenmann and Eigenmann, 1889, Proc. Cal. Acad. Sci., (2), II, 44;

Eigenmann and Eigenmann, 1890, Occ. Papers Cal. Acad. Sci., I, 424;

Eigenmann, 1910, Rept. Princeton Univ. Exped. Patagonia, III, 409.

Parancistrus nigricans Eigenmann and Eigenmann, 1889, Proc. Cal. Acad. Sci., (2), II, 44.

Chaetostomus aurantiacus Günther, 1864, Cat. Fish. Brit. MIs., V, 246.

Chactostomus nigricans Günther, 1864, Cat. Fish. Brit. Mus., V, 246.

Ancistrus aurantiacus Regan, 1904, 'Trans. Zool. Soc. London, XVII, 236.

\section{Peruvian Amazon}

Three specimens in British Museum. Imperfectly known through Castelnau's figures and description.

\section{Genus 80: ACANTHICUS Spix}

Acanthicus Spix, 1829, Sel. Gen. et Spec. Pisc. Bras., 2;

Eigenmann and Eigenmann, 1890, Oce. Papers Cal. Acad. Sci., I, 439;

Regan, 1904, Trans. Zool. Soc. London, XVII, 261;

Eigenmann, 1910, Rept. Princeton Univ. Exped. Patagonia, III, 412.

\section{Type: Acanthicus hystrix Spix}

\section{The Amazon and tributaries}

Lacking adipose fin; postdorsal area with rather large plates; predorsal plates small and numerous, and isolated like those of the sides; entire margin of snout wellbristled.

\section{ACanthicus Hystrix Spix}

Acanthicus hystrix Spix, 1829, Sel. Gen. et Spec. Pise. Bras., 3, pl. i;

Günther, 1864, Cat. Fish. Brit. Mus., V, 253;

Günther, 1868, Proc. Zool. Soc. London, 233, Xeberos;

Eigenmann and Eigenmann, 1889, Proc. Cal. Acad. Sci., (2), II, 46;

Eigenmann and Eigenmann, 1890, Occ. Papers Cal. Acad. Sci., I, 440;

Regan, 1904, Trans. Zool. Soc. London, XVII, 262;

Eigenmann, 1910, Rept. Princeton Univ. Exped. Patagonia, III, 412.

\section{Amazon}

Three specimens known, collected by Bartlett, probably from Xeberos, possibly enroute down the Amazon. 


\section{Genus 81: LASIANCISTRUS Regan}

Ancistrus (Lasiancistrus) Regan, 1904, Trans. Zool. Soc. London, XVII, 224, 237.

Lasiancistrus Eigenmann, 1910, Rept. Princeton Univ. Exped. Patagonia, III, 409.

\section{Type: Chaetostomus heteracanthus Günther}

\section{Peruvian Amazon to Panama}

Separated from Ancistrus, Parancistrus, and Pseudancistrus as follows (after Regan): with stoutish bristles on the interopercle where they have slender ones; sides of snout with or without short bristles, where the other genera are provided

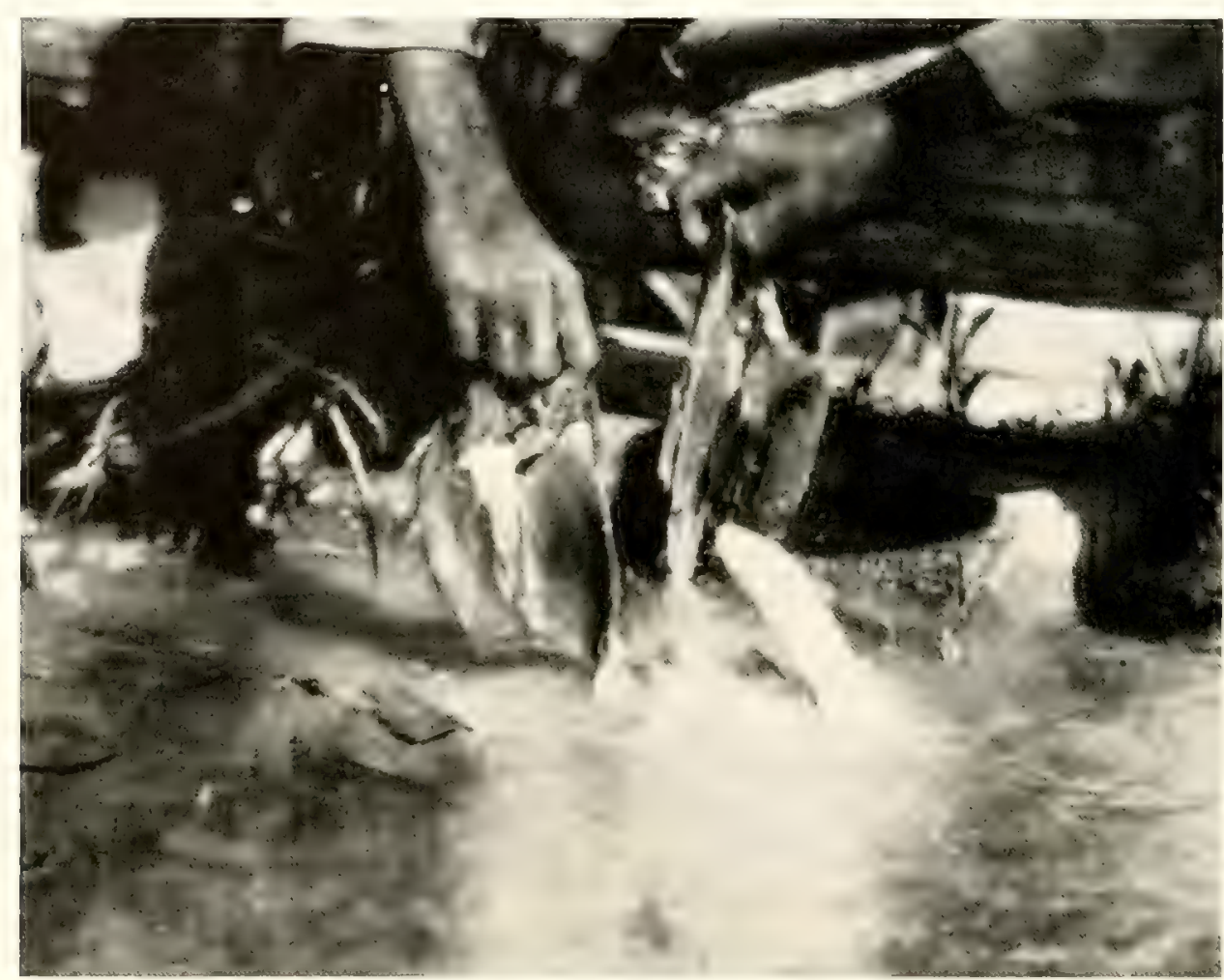

Fig. 22. Catching the candiru on split fish without the aid of tackle.

with them; a few slender bristles outside the stouter ones. Resembling the other genera except Pseudancistrus in the retractile nature of the spines, withdrawing beneath the opercle.

\section{Lasiancistrus heteracanthus (Günther)}

Chaetostomus heteracanthus Günther, 1869, Proc. Zool. Soc. London, 425, figs. 3 and 4, one, $7 \frac{1}{2}$ inches, Bartlett, Peruvian Amazon.

Hemiancistrus heteracanthus Eigenmann and Eigenmann, 1889, Proc. Cal. Acad. Sci., (2), II, 44; Eigenmann and Eigenmann, 1890, Occ. Papers Cal. Acad. Sci., I, 420.

Ancistrus (Lasiancistrus) heteracanthus Regan, 1904, Trans. Zool. Soc. London, XVII, $224,237$. Lasiancistrus heteracanthus Eigenmann, 1910, Rept. Princeton Univ. Exped. Patagonia, III, 409. 


\section{Peruvian Amazon}

\section{Lasiancistrus pictus (Castelnau)}

Hypostomus pictus Castelnau, 1855, Anim. Amér. Sud, Poiss., 44, pl. xxii, fig. 2.

Ancistrus (Lasiancistrus) pictus Regan, 1904, Trans. Zool. Soc. London, XVII, 237.

Lasiancistrus pictus Eigenmann, 1910, Rept. Princeton Univ. Exped. Patagonia, III, 409.

\section{Rio Ucayali}

One poor specimen known.

\section{Genus 82: CHAETOSTOMA Heckel}

Hypostomus (in part) Cuvier and Valenciennes, 1840, Hist. Nat. Poiss., XV, 489.

Ancistrus (in part) Kner, 185t, Denksch. KK. Akad. Wiss. Wien, VII, i, 272.

Chactostoma Heckel, in T'sehudi, 18t6, Fauna Peru., 25, loborhynchus;

Jordan, 1919, Genera of Fishes, II, 230.

Chaetostomus Kner, 1854, Denksch. KK. Akad. Wiss. Wien, VII, i, 271 with an unjustified change of spelling;

Bleeker, 1863, Nederl. Tijdsch. Dierk., I, 78, loborhynchus;

Günther, 186t, Cat. Fish. Brit. Mus., V, 240;

Eigenmann and Eigenmann, 1889, Proc. Cal. Acad. Sci., (2), II, 46;

Eigenmann and Eigenmann, 1890, Occ. Papers Cal. Acad. Sci., I, 413 ;

Regan, 1904, Trans. Zool. Soc. London, XVII, 24t;

Eigenmann, 1910, Rept. Princeton Univ. Exped. Patagonia, III, 410, and of authors generally.

Type: Chactostoma loborhyncha Tschudi

Mountain regions northwestern South America, from the Chagres basin to that of the Beni in Bolivia

Hypostomatinae having a narrow, naked area about the snout, and free from tentacles; mouth wide, mandible about equal to the interorbital; lower surfaces generally naked.

The species restricted usually to limited areas in the interandine valleys due to effective barriers. In this they show a similar distribution pattern to that found in plants, molluses, and even in such winged forms as the butterflies.

\section{Chaetostona furcata Fowler}

Chactostomus furcatus Fowler, 1939 (1940), Proc. Acad. Nat. Sci. Phila., XCI, 238, figs. 28 and 29.

\section{The Ucayali, Contamana}

Known from the unique specimen at the Philadelphia Academy, the type, $127 \mathrm{~mm}$., named for the very long, forked caudal fin.

\section{Chaetostoma taczanowski Steindachner}

Chaetostomus taczanowskii Steindachner, 1882, Denksch. KK. Akad. Wiss. Wien, XLVI, 23, pl. v, figs. 2 and $2 \mathrm{a}$, R. Huambo; 
Eigenmann and Eigenmann, 1889, Proc. Cal. Acad. Sci., (2), II, 46;

Eigenmann and Eigenmann, 1890, Occ. Papers Cal. Acad. Sci., I, 442;

Regan, 1904, Trans. Zool. Soc. London, XVII, 247;

Eigenmann, 1910, Rept. Princeton Univ. Exped. Patagonia, III, 410.

Oriental Peru to elevations of 6000 feet

$15+17,6$, 86-153 mm., Rio Tingo, Huánuco, over 6000 feet, Allen, October, 1918.

15418, many, 42-137 mm., Huancachupa creek, Huánuco, Allen, October, 1918.

17832, 2, 75 and $82 \mathrm{~mm}$., Rio Huallaga, Huánuco, Allen, October, 1918.

17833, 2, 55 and 65 mm., Rio Urubamba, Pueblo Urubamba, Eigenmann, November, 1918.

1783t, 6, 3t-60 mm., Rio Urubamba, Santa Ana, Eigenmann, November, 1918.

Naked part of snout tumid, densely covered with papillae, somewhat larger than the largest ones on the lips, snout projecting much beyond mouth by reason of the underlying cushion of connective and serous tissues; mouth wide, equals snout, and nearly equals the pectoral spine.

Base of dorsal longer than its distance from the tip of the adipose fin.

Mandibular ramus equals interorbital; eye 3 in interorbital, the latter 3 in the head.

Scutes armed with spinules directed backward, those of the edge of each scute forming rows which outline the scutes in a bright, golden-amber light; spinules of the fins longer than those of the scutes except for the anal fin.

Uniformly dark, or with shadow spots on the trunk. Caudal in young with 3 series of spots forming cross bands; 5 or 7 less regular series in the adult; dorsal with 6-12 alternating light and dark areas on the rays, the number increasing with age; lower fins uniform or but slightly spotted.

The Rio Tingo specimens, 15417 , exhibit the following scutation: D. 18 scutes

$25+124+1$

$2 \quad 1$

The Santa Ana specimens, 17834, are of more depressed form, depth at pectoral girdle being only $\frac{3}{4}$ that of the specimens from Pueblo Urubamba of the same river, and of those from the Huallaga.

181. Chaetostoma lineopunctata Eigenmann and Allen, sp. nov. Plate VI, fig. 1

15373, 2, 52 and $143 \mathrm{~mm}$, the larger the type, Rio Azupizú, Allen, July, 1920.

D. I, 8; A. I, 5. head $40 \mathrm{~mm}$; depth $20 \mathrm{~mm}$; ; length to base of caudal plates $13 \mathrm{~mm}$; snout $26 \mathrm{~mm}$., eye $5 \mathrm{~mm}$., postorbital part of head $10 \mathrm{~mm}$., interorbital $10.5 \mathrm{~mm}$., width of head $41 \mathrm{~mm}$., mandibular ramus $13 \mathrm{~mm}$.; width at origin of ventrals $33 \mathrm{~mm}$.; depth of caudal peduncle $15 \mathrm{~mm}$., its length $32 \mathrm{~mm}$.; pectoral spine $36 \mathrm{~mm}$.; outer ventral ray $31 \mathrm{~mm}$.; upper caudal ray $34 \mathrm{~mm}$., dorsal spine $29 \mathrm{~mm}$., base of dorsal fin $31 \mathrm{~mm}$., distance of the snout to the origin of the dorsal fin 46 mm.; scutes $25+1$.

Broad, flat below, but little elevated at any point; naked part of snout rather narrow; interopercle with $3-4$ short spines; last dorsal ray not adnate, just reaching 
the adipose spine; caudal fin obliquely truncate; ventrals reaching the middle of the anal or farther; pectorals to or beyond the origin of the second third of the ventrals, base of dorsal equal to its distance from a point halfway between the caudal and the tip of the adipose spine.

Head and sides everywhere with many obscure black spots, smallest of the head, those of the caudal peduncle about the size of the pupil; lower surface of caudal peduncle similarly spotted, the belly unspotted; a series of spots between the dorsal spine and the first ray; two series of spots between the rays, the spots conspicuous, of the size of those on the center of the caudal peduncle; each membrane of the caudal, anal, pectoral, and ventral fins with a dark longitudinal line bordered by hyaline; tips of the upper and lower caudal lobes rusty.

In the smaller specimen the peculiar markings of body and fins have not developed; the caudal is obliquely truncate, blackish, margined with rusty, the rusty widest on the tips of the lobes.

Near to $C$. anomalus in the size of the eye, length of mandibular ramus, form of the caudal peduncle, depth (2.14 in length), the number of the dorsal rays, and the narrow interorbital; differing in the number of anal rays, more slender form (head in the length about 3.6 compared with 3 ), and in the coloration, especially that of the fins.

182. Chaetostoma marmorescens Eigenmann and Allen, sp. nov.

15403, many, 52-135 mm., the largest the type, Huancachupa creek, near Huánuco, elevation 6000 feet, Allen, October, 1918.

15402, 3, 86-107 mm., Rio Tingo, Huánuco, Allen, October, 1918.

Evidently allied to loborhynchus, anomalus, and taczanowskii, resembling the last-named in respect to the form of the dorsal fin, the second-named in the proportions of the eye and interorbital space and slender caudal peduncle; differing from anomalus in the longer, lower form of the dorsal fin, and from all in the warty growths of the head.

Head 3.0-3.9; depth 5.25-5.75; D. I, 7 in two, I, 8 in 68, and I, 9 in 18; A. I, 3 or I, 4; scutes $25+1,5$ or 6 scutes between the dorsals, one or two of them unpaired, 9 or 10 between anal and caudal; base of dorsal nearly equal to its distance from the caudal; naked part of snout densely covered with warts a little larger than those on the lip; interopercle with 8-16 nearly or quite straight spines.

Eye 8 in snout, 2.5 in the postorbital part of the head, 3.4 in interorbital; interorbital $3.25-3.56$ in the length of the head; loreal region with the naked portion wider than the armored part; mandibular ramus equals interorbital; head but little longer than wide.

Dorsal much longer than high, the last ray sometimes reaching adipose; adipose well developed; caudal very slightly emarginate in the young, oblique and slightly rounded in the adult; ventrals rounded or angulated, the fourth ray forming the angle, reaching the middle of the anal; pectoral spine reaching a little beyond origin of ventral, the first ray reaching beyond the spine; depth of caudal peduncle 2.25 2.5 in its length. 
Uniform dark brown or indications of marbling, dorsal membranes translucent, the rays alternately light and dark; caudal in the young with three dark bars, the bars more numerous and less regular in the old, the membranes always translucent, the angles of the fins sometimes very narrowly rusty; anal, ventrals and pectorals uniform or the ventral rays alone with faint spots.

\section{Chaetostoma sericea Cope}

Chaetostomus sericeus Cope, 1871, Proc. Acad. Nat. Sci. Phila., 288;

Eigenmann and Eigenmann, 1889, Proc. Cal. Acad. Sci., (2), II, 46;

Eigenmann and Eigenmann, 1890, Occ. Papers Cal. Acad. Sci., I, 443.

Xenocara sericea Regan, 1904, Trans. Zool. Soe. London, XVII, 252.

Rio Ambyiacu

\section{Chaetostoma variola Cope}

Chaetostomus variolus Cope, 1871, Proc. Acad. Nat. Sci. Phila., 288;

Eigenmann and Eigenmann, 1889, Proc. Cal. Acad. Sci., (2), II, 46;

Eigenmann and Eigenmann, 1890, Occ. Papers Cal. Acad. Sci., I, $4+2$.

Xenocara cirrhosa (in part) Regan, 1904, Trans. Zool. Soc. London, XVII, 256.

Ancistrus cirrhosus Eigenmann, 1910, Rept. Princeton Univ. Exped. Patagonia, III, 411.

Rio Ambyiacu

\section{Chaetostoma BRanicki Steindachner}

Chaetostomus branickii Steindachner, 1881, Denksch. KK. Akad. Wiss. Wien, XLIII, 118, pl. vi, fig. 1, one, $110 \mathrm{~mm}$., R. Huambo;

Eigenmann and Eigenmann, 1889, Proc. Cal. Acad. Sci., (2), II, 46;

Eigenmann and Eigenmann, 1890, Occ. Papers Cal. Acad. Sci., I, 443;

Regan, 1904, Trans. Zool. Soc. London, XVII, 250;

Eigenmann, 1910, Rept. Princeton Univ. Exped. Patagonia, III, 410.

Rio de Huambo; Callacate, Peru, specimens reaching $135 \mathrm{~mm}$.

\section{Chaetostoma dermorhyncha Boulenger}

Chaetostomus dermorhynchus Boulenger, 1887, Proc. Zool. Soc. London, 277, pl. xxii, Canelos;

Eigenmann and Eigenmann, 1889, Proc. Cal. Acad. Sci., (2), II, 46;

Eigenmann and Eigenmann, 1890, Occ. Papers Cal. Acad. Sci., I, 443;

Regan, 1904, Trans. Zool. Soc. London, XVII, 248;

Eigenmann, 1910, Rept. Princeton Univ. Exped. Patagonia, III, 410.

Canelos, Ecuador, the types alone being known

\section{Chaetostoma loborhyncha Tschudi}

Chaetostomus loborhynchus Tschudi, 1845, Fauna Peru., 26, pl. iv;

Günther, 1864, Cat. Fish. Brit. Mus., V, 250;

Eigenmann and Eigenmann, 1889, Proc. Cal. Acad. Sci., (2), II, 46; 
Eigenmann and Eigenmann, 1890, Oce. Papers Cal. Acad. Sci., I, 443;

Regan, 1904, Trans. Zool. Soc. London, XVII, 246;

Eigenmann, 1910, Rept. Princeton Univ. Exped. Patagonia, III, 410.

The Andean streams of eastern Peru (Marcapata valley)

\section{8. Сhaetostoma microps Günther}

Hypostomus erinaceus Günther, 1859, Proc. Zool. Soc. London, 420.

Chaetostomus microps Günther, 1864, Cat. Fish. Brit. Mus., V, 250;

Steindachner, 1882 (1883), Denksch. KK. Akad. Wiss. Wien, XLVI, 23, Rio de Huambo;

Boulenger, 1887, P'roc. Zool. Soc. London, 277, Canelos;

Eigenmann and Eigenmann, 1889, Proc. Cal. Acad. Sci., (2), II, 46;

Eigenmann and Eigenmann, 1890, Occ. Papers Cal. Acad. Sci., I, 443;

Regan, 1904, Trans. Zool. Soc. London, XVII, 251, pl. xiv, fig. 3;

Eigenmann, 1910, Rept. Princeton Univ. Exped. Patagonia, III, 410.

\section{Eastern Andes of Peru and Ecuador}

\section{Chaetostoma maculata Regan}

Chaetostomus maculatus Regan, 1904, Trans. Zool. Soc. London, XVII, 246, pl. xiv, fig. 4.

Two specimens of $65 \mathrm{~mm}$. length from "Rozmaiu", "Upper Peru."

\section{Chaetostoma marcapatae Regan}

Chaetostomus marcapatae Regan, 1904, Trans. Zool. Soc. London, XVII, 246, pl. xiv, fig. 1;

Eigenmann, 1910, Rept. Princeton Univ. Exped. Patagonia, III, 410.

Marcapata valley, southeastern Peru

Known from the 100-mm. type collected by Ockenden.

\section{Chaetostoma Brevis Regan}

Chaetostomus brevis Regan, 1904, Trans. Zool. Soc. London, XVII, 217, pl. xiii, fig. 3;

Eigenmann, 1910, Rept. Princeton Univ. Exped. Patagonia, III, 410;

Pearson, 1937a, Proc. Cal. Acad. Sci., (4), XXIII, 96, Balsas, Tingo de Pauca, upper Marañon, possibly two species.

Eastern fringe of Andes of Ecuador and Peru

\section{Chatetostoma mollinasa Pearson}

Chaetostomus mollinasus Pearson, 1937a, Proc. Cal. Acad. Sci., (4), XXIII, 96, pl. xiii, figs. 1 and 2, Balsas and Cajamarca.

Both sides Central Cordillera, northern Peru

Notable for the subcutaneous cushion of the snout, like that of a tugboat, extending and increasing forward from the interopercles. 


\section{Genus 83: XENOCARA Regan}

Chaetostoma (in part) Heckel (Tschudi), 1846, Fauna Peru., 25.

Xenocara Regan, 1904, Trans. Zool. Soc. London, XVII, 251;

Eigenmann, 1905, Science, n.s. XXI, 794;

Eigenmann, 1910, Rept. Princeton Univ. Exped. Patagonia, III, 410;

Eigenmann, 1912, Mem. Carnegie Mus., V, 235.

\section{Type: Chaetostoma latifrons Günther \\ Rivers of much of South America}

Interopercle movable, usually spinous; mouth narrow, mandible much less in width than interorbital; teeth of respective jaws subequal; snout with naked margin; skull characterized by stays separating superficial bones from the brain case, the outer shell consisting of portions of the frontals, postfrontals, supraoccipitals, and squamosals.

\section{Xenocara latifrons (Günther)}

Chaetostomus latifrons Günther, 1869, Proc. Zool. Soc. London, 426;

Eigenmann and Eigenmann, 1889, Proc. Cal. Acad. Sci., (2), II, 46;

Eigenmann and Eigenmann, 1890, Occ. Papers Cal. Acad. Sci., I, 142.

Xenocara latifrons Regan, 1904, Trans. Zool. Soc. London, XVII, 253, pl. xv, fig. 1;

Eigenmann, 1910, Rept. Princeton Univ. Exped. Patagonia, III, 410.

\section{Peruvian Amazon}

Represented by the type, $160 \mathrm{~mm}$, in the British Museum.

\section{Genus 84: ANCISTRUS Kner}

Ancistrus Kiner, 1853, Denksch. KK. Akad. Wiss. Wien, VII, 272, sp.;

Bleeker, 1863, Nederl. Tijdsch. Dierk., I, 77, cirrhosus;

Eigenmann and Eigenmann, 1890, Occ. Papers Cal. Acad. Sci, I, 444;

Regan, 1904, Trans. Zool. Soc. London, XVII, 221;

Eigenmann, 1910, Rept. Princeton Univ. Exped. Patagonia, III, 411.

Xenocara (in part) Regan, 1904, Trans. Zool. Soc. London, IVII, 251.

\section{Type: Hypostomus cirrhosus Cuvier and Valenciennes}

Panama to the Guianas and La Plata basin

Plecostominae having snout granular to margin (sometimes naked in females), tentaculate, the tentacles more numerous in the males; the interopercle a movable plate, spinous or bristly; teeth of premaxillaries and dentaries subequal and in about the same number.

\section{Ancistrus hoplogenys (Günther)}

Chaetostomus hoplogenys Günther, 186t, Cat. Fish. Brit. Mus., V, 247.

Ancistrus hoplogenys Eigenmann and Eigenmann, 1889, Proc. Cal. Acad. Sci., (2), II, 48;

Eigenmann and Eigenmann, 1890, Occ. Papers Cal. Acad. Sci., I, 4t8;

Eigenmann and Eigenmann, 1891, Proc. U. S. Nat. Mus., XIV, 43; 
Eigenmann, 1910, Rept. Princeton Univ. Exped. Patagonia, III, 411;

Eigenmann, 1912, Mem. Carnegie Mus., V, 239.

Tenocara hoplogenys Regan, 1904, Trans. Zool. Soc. London, XVII, 255.

Chactostomus alga Cope, 1871, Proc. Acad. Nat. Sci. Phila., XXIII, 287, Rio Ambyiacu.

Chactostomus malacops Cope, 1871, Proc. Acad. Nat. Sci. Phila., XXII, 287, pl. v, fig. 2 Rio Ambyiacu;

Eigenmann and Eigenmann, 1889, Proc. Cal. Acad. Sci., (2), II, 46;

Eigenmann and Eigenmann, 1890, Oce. Papers Cal. Acad. Sci., I, 443.

Chactostomus tectirostris Cope, 1871, Proc. Acad. Nat. Sci. Phila., XXIII, 288, pl. xт, fig. 2, Rio Ambyiacu;

Eigenmann and Eigenmann, 1889, Proc. Cal. Acad. Sci., (2), II, 46;

Eigenmann and Eigenmann, 1890, Oce. Papers Cal. Acad. Sci., I, 442.

Chactostomus leucostictus Steindachner, doubtful, 1882 (1883), Denksch. KK. Akad. Wiss. Wien, XLVI, 7, Rio Huallaga, 1 specimen.

15370, 1, 110 mm., Iquitos, Amazon, Allen, November, 1920.

15371, 1, $97 \mathrm{~mm}$., creek, Rio Morona, Allen, October, 1920.

\section{Ancistrus Bufonius (Cuvier and Valenciennes)}

Hypostomus bufonius Cuvier and Valenciennes, 1810, Hist. Nat. Poiss., XV, 511, Rio Apurimac, elevation 2000 meters.

Chaetostomus bufonius Eigenmann and Eigenmann, 1889, Proc. Cal. Acad. Sci., (2), II, 46;

Eigenmann and Eigenmann, 1890, Occ. Papers Cal. Acad. Sci., I, 444.

Xenocara bufonia Regan, 1904, Trans. Zool. Soc. London, XVII, 258.

Ancistrus bufonius Eigenmann, 1910, Rept. Princeton Univ. Exped. Patagonia, III, 111.

Andes of Peru and Bolivia, moderate elevations

15367, 17, 37-106 mm., La Mereed to Puerto Bermudez, Allen, July, 1920.

15368, 1, 68 mm., La Merced, Allen, July, 1920.

\section{Ancistrus occloi Eigenmann (and Myers)}

Plate $\mathrm{X}$, figs. 1 and 2

Ancistrus occloi Eigenmann (in Myers), 1928, Ann. Mag. Nat. Hist., (10), II, 86.

\section{Upper Urubamba river}

15067,2 , the larger the type, $115 \mathrm{~mm}$., Ollantaitambo, Heller.

Similar to A. bufonius. Taken at 9000 feet elevation on the Urubamba. Named for the wife of the Inca Manco, Occlo.

The type measures $89 \mathrm{~mm}$. to the base of the plates at the origin of the caudal fin; head $36 \mathrm{~mm}$., width of head $33 \mathrm{~mm}$., depth of head at occipital process $15 \mathrm{~mm}$., interorbital $14 \mathrm{~mm}$., ramus of mandible $9 \mathrm{~mm}$., snout $22 \mathrm{~mm}$., orbit $3.5 \mathrm{~mm}$.; lower caudal lobe $27 \mathrm{~mm}$., upper lobe $24 \mathrm{~mm}$.; base of dorsal $18 \mathrm{~mm}$., distance between dorsal and adipose 14, length of dorsal spine $20 \mathrm{~mm}$; length of pectoral spine 23 mm. length of ventral spine $22 \mathrm{~mm}$. lateral plates 25 ; D. I, 7; A. I, 3; length of caudal peduncle 25 , its depth 9 ; interopercular spines $13-14$, longest interopercular spine 9.

Eleven or twelve plates between anal and caudal fins, six or seven between 
dorsal and adipose spine; spiniferous portion of pectoral not quite reaching spiniferous part of the ventrals; ventrals reaching to near tip of anal; mouth with a double row of tentacles, in the middle a few tentacles between the two rows.

Sides and top of head with obscure light spots about as large as the eye; dorsal rays alternately light and dark; caudal with two irregular cross-bands lighter in color; ventral and pectoral fins like the dorsal in color.

A specimen of $54 \mathrm{~mm}$. from the Rio Comberciato probably belongs here. It had only two small tentacles just before each interopercle, one belonging to the upper, the other to the lower series. General coloration of head and trunk uniform dark.

\section{Ancistrus temmincki (Cuvier and Valenciennes)}

Hypostomus temminckii Cuvier and Valenciennes, 1840, Hist. Nat. Poiss., XV, 514, Cayenne. Ancistrus temminckii Bleeker, 1864, Silures de Suriname, 11, pl. i, fig. 3; pl. ii, fig. 2, Surinam;

Eigenmann and Eigenmann, 1889, Proc. Cal. Acad. Sci., (2), I, 48;

Eigenmann and Eigenmann, 1890, Oce. Papers Cal. Acad. Sci., I, 448;

Eigenmann and Eigenmann, 1891, Proc. U. S. Nat. Mus., XIV, 43;

Eigenmann, 1910, Rept. Princeton Univ. Exped. Patagonia, III, 411. Ancistrus temmincki Eigenmann, 1912, Mem. Carnegie Mus., V, 237.

Xenocara temminckii Regan, 1904, Trans. Zool. Soc. London, XVII, 254.

\section{Guiana and Peruvian Amazonia}

15369, 2, 127 and $162 \mathrm{~mm}$., creek, Yurimaguas, Allen, November, 1920. 15372, 1, 92 mm., Puerto Bermudez, Allen, July, 1920.

Largest nearly twice the size of the specimens from Guianas.

Mandibular ramus 3.3 in the interorbital (Guiana specimens 2.33 to 3.0 ); D. 8 (Guiana specimens 6 ); eye 6.3 (Guiana specimens 5.5 ); 14 interopercular spines (Guiana specimens about 10); 3d pair of dorsal plates divided by dorsal fin (in Guiana specimens $3 \mathrm{~d}$ pair lies between occiput and dorsal); in the Yurimaguas specimens 13 plates between anal and caudal (Guiana specimens 10); 5 between dorsals in both; lateral plates in Yurimaguas specimens 25 (Guiana 23).

In our material the opercular spines clothed to near their extremities; dorsal spine equals length of head; spots on the fins form a wavy line.

In other respects the Peruvian specimens conform very well to the descriptions of temminckii. Many of the above variations may be accounted for largely by the greater size and age of the material, and the juvenile character of the types.

\section{Ancistrus occidentalis (Regan)}

Xenocara occidentalis Regan, 1904, Trans. Zool. Soc. London, XVII, 257, pl. xiv, fig. 5. Ancistrus occidentalis Eigenmann, 1910, Rept. Princeton Univ. Exped. Patagonia, III, 411.

\section{Canelos, Ecuador}

Seven specimens of the Buckley collection, up to $115 \mathrm{~mm}$., referred by Boulenger to Ancistrus cirrhosus. 


\section{Ancistrus CIRrhosus (Valenciennes)}

Hypostomus cirrhosus Cuvier and Valenciennes, 18t0, Hist. Nat. Poiss., XV, 511, Rio de Janeiro,

Buenos Aires:

Valenciennes, in d'Orbigny, 1847, Voy. Amer. Merid., IX, atlas ii, pl. vii, fig. 3.

Ancistrus cirrhosus Kiner, 1853, Denksch. KK. Akad. Wiss. Wien, VII, 272, Rio Guaporé;

Eigenmann and Eigenmann, 1889, Proc. Cal. Acad. Sci., (2), II, 48;

Eigenmann and Eigenmann, 1890, Occ. Papers Cal. Acad. Sci., I, 146 ;

Eigenmann and Eigenmann, 1891, Proe. U. S. Nat. Mus., XIV, 43;

Eigenmann, 1910, Rept. Princeton Univ. Exped. Patagonia, III, 411;

Eigenmann, 1912, Mem. Carnegie Mus., V, 239.

Chactostomus cirhosus Günther, 186t, Cat. Fish. Brit. Mus., V, 247;

Steindachner, 1882, Denksch. KK. Akad. Wiss. Wien, XLVI, 7, Huallaga;

Boulenger, 1887, Proc. Zool. Soc. London, 277, Canelos.

Jenocara cirhosa Regan, 1904, 'Trans. Zool. Soc. London, XVII, 256;

Regan, 1913, Ann. Mag. Nat. Hist., (8), XII, 281, Rio Ucayali.

Amazons to Huallaga and Guaporé rivers

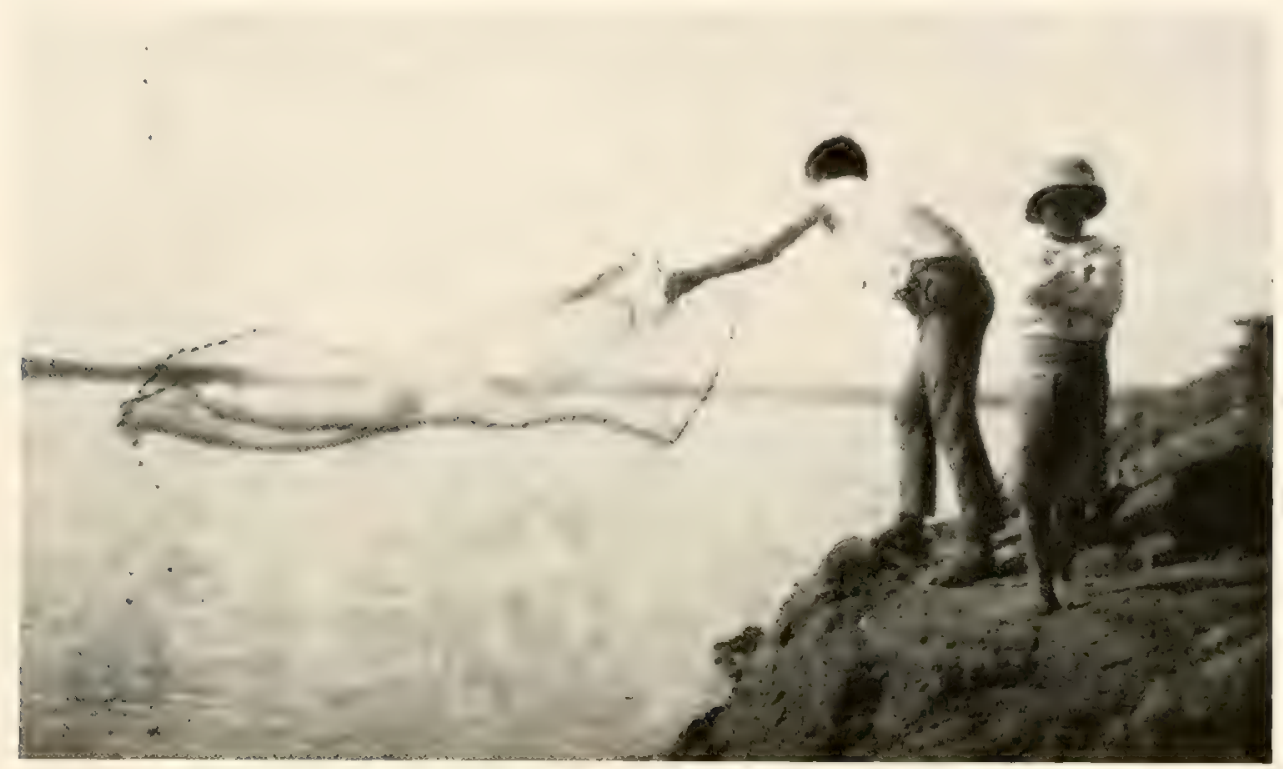

FIG. 23. Fishing with tarafa, or throw net, along the banks of the Ucayali during the upstream migration of the fishes.

\section{Subfamily: HYPOPTOPOMATINAE}

With no more than moderate elongation of the caudal peduncle, but differing from the nearer Hypostomatinae in the exposure of the lower transverse part of the clavicles and coracoids as two pairs of plates between the bases of the pectoral fins.

Margin of snout more or less well plated; preopercle without spines; pharyngeals edentulous; teeth in single series; upper part of body enclosed in bony scutes forming five longitudinal series anteriorly on each side of caudal peduncle, 3 posteriorly. 


\section{Genus 85: HYPOP'TOPOMA Günther}

Hypoptopoma Günther, 1868, Proc. Zool. Soc. London, 234;

Eigenmann and Eigenmann, 1890, Occ. Papers Cal. Acad. Sci., I, 388;

Regan, 1904, Trans. Zool. Soc. London, XVII, 263;

Eigenmann, 1910, Rept. Princeton Univ. Exped. Patagonia, III, 412.

Type: Hypoptopoma thoracatum Günther

Upper Amazons

Snout low, spatulate, somewhat movable; eyes lateral, as visible from below as above; teeth slender, bifid; adipose reduced to a vestigial spine; a dermal ossification of the clavicle and coracoid bones forming two pairs of granular plates.

\section{Hypoptopoma gulare Cope}

Hypoptopoma gulare Cope, 1878, Proe. Amer. Phil. Soc., XVII, 679;

Eigenmann and Eigenmann, 1889, Proc. Cal. Acad. Sci., (2), II, 40;

Eigenmann and Eigenmann, 1890, Occ. Papers Cal. Acad. Sci., I, 390;

Regan, 1904, Trans. Zool. Soc. London, XVII, 265;

Eigenmann, 1910, Rept. Princeton Univ. Exped. Patagonia, III, 412.

The Marañon

\section{Hypoptopoma thoracatum Günther}

Hypoptopoma thoracatum Günther, 1868, Proc. Zool. Soc. London, 234, fig. 2, one specimen, Xeberos;

Eigenmann and Eigenmann, 1889, Proc. Cal. Acad. Sci., (2), II, 40;

Eigenmann and Eigenmann, 1890, Occ. Papers Cal. Acad. Sci., I, 388;

Regan, 1904, Trans. Zool. Soc. London, XVII, 263, upper Amazon;

Eigenmann, 1910, Rept. Princeton Univ. Exped. Patagonia, III, 412.

Hypoptopoma bilobatum Cope, 1870, Proc. Amer. Phil. Soc., XI, 566, two text figs., Pebas;

Cope, 1878, Proc. Amer. Phil. Soc., XVII, 679, Pebas;

Steindachner, 1882 (1883), Denksch. KK. Akad. Wiss. Wien, XLVI, 7, Rio Huallaga, one specimen.

\section{Upper Amazon northward}

$15737,3,51-59$ mm., to end of middle caudal rays, mouth of Rio Pacaya, Allen, August, 1920.

\section{HYPoptopoma JoBerti (Vaillant)}

Otocinclus joberti Vaillant, 1880, Bull. Soc. Philom., (7), IV, 147;

Eigenmann, 1910, Rept. Princeton Univ. Exped. Patagonia, III, 412.

Hypoptopoma joberti Regan, 1904, Trans. Zool. Soc. London, XVII, 265.

Hypoptopoma thoracatum (in part), Eigenmann and Eigenmann, 1890, Occ. Papers Cal. Acad. Sci., I, 389 .

\section{Rio Juruá and Solimões to the Ucayali}

$15738,1,65 \mathrm{~mm}$. to end of middle caudal rays, mouth of Rio Pacaya, Allen, August, 1920.

15401, 1, 88 mm., Lago Cashiboya, Allen, August, 1920. 


\section{Hypoptopoma carinatum Steindachmer}

Hypoptopoma carinatus Steindachner, 1879, Denksch. KK. Akad. Wiss. Wien, XLI, 49, pl. vi, Amazon near Peruvian boundary;

Eigenmann and Eigenmann, 1890, Occ. Papers Cal. Acad. Sci., I, 390.

Hypoptopoma carinatum Regan, 1913, Mnn. Mag. Nat. Hist., (8), X1I, 281, Rio Ucayali.

Solimões and Ucayali rivers

\section{Genus 86: OTOCINCLUS Cope}

Otocinclus Cope, 1871, Proc. Acad. Nat. Sci. Phila., 283;

Eigenmann and Eigenmann, 1889, Proc. Cal. Acad. Sci., (2), II, 4 ;

Eigenmann and Eigenmann, 1890, Occ. Papers Cal. Acad. Sci., I, 390;

Regan, 1904, Trans. Zool. Soe. London, XVII, 265;

Eigenmann, 1910, Rept. Princeton Univ. Exped. Patagonia, III, 412.

Type: Otocinclus vestitus Cope

Rio Ambyiacu, southeastern Brazil and La Plata

Distinguishable by the extreme size of the ventral plate and the unique perforations of the temporal plate.

\section{Otocinclus vestitus Cope}

Otocinclus vestitus Cope, 1871 (1872), Proc. Acad. Nat. Sci. Phila., 283, pl. iv, figs. 2a, 2b, and 2c, tributaries of R. Ambyiacu;

Eigenmann and Eigenmann, 1889, Proc. Cal. Acad. Sci., (2), II, 41 ;

Eigenmann and Eigenmann, 1890, Occ. Papers Cal. Acad. Sci., I, 393;

Regan, 1904, Trans. Zool. Soc. London, XVII, 267;

Eigenmann, 1910, Rept. Princeton Univ. Exped. Patagonia, III, 412.

\section{Rio Ambyiacu}

Known only from the types in the Philadelphia Academy.

205. Otocinclus macrospilus Eigenmann and Allen, sp. nov.

$$
\text { Plate XIII, fig. } 1
$$

15606, 12, 27-45 mm., the largest the type, Rio Morona, Allen, October, 1920.

Head 2.8; depth 4; D. I, 7; A. I, 5; scales 25, eye 2 in snout, 4.5 in the head, 2.25 in the interorbital; depth of caudal peduncle about equal to the length of the snout; dorsal spine a little shorter than the head; pectoral reaching to the middle of the ventral fins, the length of its spine about equal to the length of the head less half the snout.

Back with dark cross-shades; top of head punctate; a black band from tip of snout along the middle of the sides to above the tip of the anal, tending to break up into spots toward the end; a very large, isolated spot across the entire end of caudal peduncle and base of the caudal; a curved dark bar across the caudal near the tip of the middle rays, another across the middle of the caudal lobes, more or less complete bars across the dorsal, and sometimes across the anal rays where they 
fork; outer pectoral and ventral rays more or less punctate, the remaining parts of the fins hyaline. In the type the bars across the lobes are continuous with a submarginal bar across the middle caudal rays; there are also faint spots on the dorsal rays in a series below the series at the forks.

Similar to affinis, with a larger eye, broader head, less pointed contours, more robust form; markings more numerous.

\section{Subfamily: LORICARIINAE}

Tail region much elongated, becoming depressed posteriorly, with a single series of plates on the sides; intestine usually of much less length than that of the preceding subfamilies, and not greatly exceeding the body length; haemal spines of the vertebrae bifid in the region of the anal fin; fourth upper pharyngeals and the lowers dentate; jaw teeth in one series; adipose fin wanting; first finrays rather usually adorned with filaments of extreme length.

In Oriental Peru the general name shitari is applied to any member of the subfamily.

\section{Genus 87: LORICARIA Linnaeus}

Loricaria Limnaeus, 1758, Syst. Nat., ed. x, I, 307;

Cuvier and Valenciennes, 1840, Hist. Nat. Poiss., XV, 453;

Kner, 1853, Denksch. KK. Akad. Wiss. Wien, VI, 77;

Bleeker, 1863, Nederl. Tijdsch. Dierk., I, 80;

Gủnther, 186t, Cat. Fish. Brit. Nus., V, 25t;

Eigenmann and Eigenmann, 1889, Proc. Cal. Acad. Sci., (2), II, 34;

Eigenmann and Eigenmann, 1890, Occ. Papers Cal. Acad. Sci., I, 360;

Regan, 1904, Trans. Zool. Soc. London, XVII, 270;

Eigenmann, 1910, Rept. Princeton Univ. Exped. Patagonia, III, 113;

Eigenmann, 1912, Mem. Carnegie Mus., V, 243.

Type: Loricaria dura Linnaeus = Loricaria cataphracta Linnaeus

Both slopes of Panama to Rio de la Plata, Guiana to Peru

A genus of Loricariidae lacking a series of spines bordering the snout, which is only moderately produced; the lips terminating in tentacles; anal plate wanting; an orbital notch present, of greater or less extent; jaw teeth few or moderate in number and not setiform; tail with lateral keel and snout not expanded at the end.

\section{Loricaria puganensis Pearson}

Loricaria puganensis Pearson, 1937a, Proc. Cal. Acad. Sci., (4), XXIII, 96, Pusoc and Tingo de Pauca, upper Marañon.

The upper Marañon

\section{Loricaria Filamentosa Steindachner}

Loricaria filamentosa Steindachner, 1878, Denksch. KK. Akad. Wiss. Wien, XXXIX, 29, pl. ix, Magdalena; 
Boulenger, 1887, Proc. Zool. Soc. London, 277, Canelos;

Eigenmann and Eigenmann, 1889, Proc. Cal. Acad. Sci., (2), II, 36;

Eigenmann and Eigenmann, 1890, Oce. Papers Cal. Acad. Sci., I, 370;

Regan, 1904, Trans. Zool. Soc. London, XVII, 274;

Eigenmann, 1910, Rept. Princeton Univ. Exped. Patagonia, III, 113.

Eastern Ecuador and the Magdalena

208. LORICARIA WOLfei (Fowler)

Rhineloricaria wolfei Fowler, 1939 (1940), Proc. Acad. Nat. Sci. Phila, XCI, 241, figs, 33-35.

\section{Contamana}

Known from the unique type, $149 \mathrm{~mm}$. in length, in the Museum of the Academy of Natural Sciences at Philadelphia.

Described as having the first pair of scutes adjoining the supraoccipital well separated by truncate end of the supraoccipital; length of third (last) predorsal scute subequal with the first.

\section{Loricaria lanceolata Gïnther}

Loricaria lanceolata Günther, 1868, Proc. Zool. Soc. London, 235, fig. 3, Xeberos;

Boulenger, 18s7, Proc. Zool. Soc. London, 277, Canelos, two;

Eigenmann and Eigenmann, 1889, Proc. Cal. Acad. Sci., (2), I1, 39;

Eigenmann and Eigenmann, 1890, Oce. Papers Cal. Acad. Sci., I, 378;

Regan, 1904, 'Trans. Zool. Soc. London, NVII, 277, Canelos;

Eigenmann, 1910, Rept. Princeton Univ. Exped. Patagonia, III, 413.

\section{Oriental Peru and Ecuador}

\section{LORICARIA ACUTA Cuvier and Valenciennes}

Loricaria acuta Cuvier and Valenciennes, 1810, Hist. Nat. Poiss., XV, 472;

Günther, 1864, Cat. Fish. Brit. MIus., V, 258;

Cope, 1871, Proc. Acad. Nat. Sci. Phila., XXIII, 289, R. Ambyiacu;

Eigenmann and Eigenmann, 1890, Occ. Papers Cal. Acad. Sci., I, 375;

Regan, 1904, Trans. Zool. Soc. London, XVII, 287;

Eigenmann, 1910, Rept. Princeton Univ. Exped. Patagonia, III, 414.

\section{From the Amazon basin northward}

\section{LORICARIA BRUNneA Hancock}

Loricaria brunnea Hancock, 1828, Zool. Jour., IV, 217;

Cuvier and Valenciennes, 1840, Hist. Nat. Poiss., XV. 479 ;

Eigenmann and Eigenmann, 1890, Oce. Papers Cal. Acad. Sci., I, 370;

Eigenmann, 1910, Rept. Princeton Univ. Exped. Patagonia, III, 415.

Loricariichthys brunneus Eigenmann, 1912, Mem. Carnegie Mus., V, 247, pl. xxx, fig. 3, and pl. xxxi, fig. 4, British Guiana.

\section{Guianas and Peru}

15398, 2, 105 and $109 \mathrm{~mm}$. to tip of middle caudal rays, Yarinacocha, Allen, September, 1920. 
The Peruvian specimens differ from the types taken in British Guiana (Loricariichthys brunneus) in having a distinct bar across the back, on the first two scutes opposite the dorsal, in addition to the five behind the dorsal; one of the specimens with the margin of the lower surface of the caudal plates dark, caudal with a basal dark spot; margin dark in one, the entire caudal fin behind the basal spot spotted in the other.

The lateral keels not completely coalescent.

15397, 2, 82-97 mm. to tip of middle caudal rays, Rio Pacaya, Allen, August, 1920.

15982, 1, $123 \mathrm{~mm}$., Iquitos, Allen, September, 1920.

Color of 15982 from Iquitos much lighter, markings indistinct, apparently accounted for by the greater amount of silt prevalent in most waters about Iquitos, although in this respect the Pacaya specimens are intermediate, and the river only moderately opaque at the time when I was there, brown in color, not turbid. The Rio Pacaya specimens lack the ocellus in front of the dorsal; the basal caudal spot present.

\section{LORICARIA KONOPICKYI Steindachner}

Loricaria konopickyi Steindachner, 1879, Denksch. KK. Akad. Wiss. Wien, XLI, 45, pl. vi, Amazon;

Eigenmann and Eigenmann, 1889, Proc. Cal. Acad. Sei., (2), II, 39;

Eigenmann and Eigenmann, 1890, Occ. Papers Cal. Acad. Sci., I, 378;

Regan, 1904, Trans. Zool. Soc. London, XVII, 281;

Eigenmann, 1910, Rept. Princeton Univ. Exped. Patagonia, III, 413.

Rhineloricaria konopickyi Regan, 1913, Ann. Mag. Nat. Hist., (8), XII, 282.

Amazon; Calderon; Iquitos

15985, 2, 172 and $184 \mathrm{~mm}$. to end of middle caudal rays, Iquitos, Morris, 1922.

\section{LORICARIA TYPUS (Bleeker)}

Parahemiodon typus Bleeker, 186t, Nat. Verh. Holl. Maats., XX, 20, pl. vi, fig. 1; pl, xiii, fig. 1. Loricaria typus Regan, 1904, Trans. Zool. Soc. London, XVII, 286.

Loricaria stübelii Steindachner, 1882 (1883), Denksch. KK. Akad. Wiss. Wien, XLVI, 7, pl. iii, figs. 2 and $2 \mathrm{~b}$, three, R. Huallaga;

Eigenmann and Eigenmann, 1889, Proc. Cal. Acad. Sci., (2), II, 37;

Eigenmann and Eigenmann, 1890, Oce. Papers Cal. Acad. Sei., I, 370.

Lower Amazons to the Huallaga

Near L. maculata Bloch, L. spixii and L. acuta Cuvier and Valenciennes, but more rounded snout and extreme spotting of the fins separate it.

\section{Loricaria CHANJoo (Fowler)}

Parahemiodon chanjoo Fowler, 1939 (1940), Proc. Acad. Nat. Sci. Phila., XCI, 240, figs. 30-32.

\section{Contamana}

Four specimens, type and paratypes, $170-225 \mathrm{~mm}$., in the Philadelphia Museum. 
Not clearly separable from other subgenera of Loricaria. Described mostly on the basis of markings and broader, more depressed head than the nearby Parahemiodon spixii. Buceal disk without dark border and without fringed anterior margin.

\section{Loricaria MaCUlata Bloch}

Loricaria maculata Bloch, 1794, Ausl. Fische, VIII, 73, pl. 375, fig. 1;

Lacépède, 1803, Hist. Nat. Poiss., V, 140, South America;

Cuvier and Valenciennes, 1810, Hist. Nat. Poiss., XV, 473;

Eigenmann and Eigenmann, 1889, Proc. Cal. Acad. Sci., (2), II, 38;

Eigenmann and Eigenmann, 1890, Occ. Papers Cal. Acad. Sci., I, 377;

Regan, 1904, 'Trans. Zool. Soc. London, XVII, 286, lower Amazon;

Eigenmann, 1910, Rept. Princeton Univ. Exped. Patagonia, III, 414.

Plecostomus maculatus Swainson, 1839, Fish. Amph. Rept., II, 304.

Loricaria amazonica Castelnau, 1855, Anim. Amér. Sud, Poiss., 46, pl. xxiii, fig. 2.

Loricariichthys maculatus Bleeker, 1864, Nat. Verh. Holl. Maats., XX, 16.

\section{The Guianas to the Amazons and Paraguay}

15388, 5, 59-257 mm., Lago Cashiboya, Allen, August, 1920.

15389, 3, 202-240 mm., Contamana, Rio Ucayali, Allen, August, 1920.

15393, 9, 43-98 mm., Gosulimacocha, Rio Morona, Allen, October, 1920.

15652, 7, 68-230 mm., Iquitos, Norris, 1922.

\section{LORICARIA UCAYAlENSIS Regan}

Loricariichthys ucayalensis Regan, 1913, Ann. IIag. Nat. Hist., (8), XII, 281, Rio Ueayali.

Described from two males, 185 and $220 \mathrm{~mm}$., from an unnamed locality on the Ucayali, collected by Mounsey. Near to L. typus in the form of the lower lip, and to L. maculata in other respects, differing in the larger head, shorter tail, and less elevated dorsal and anal fins.

\section{Loricaria CASHibo Eigenmann and Allen, sp. nov.}

15416, 1, $131 \mathrm{~mm}$. to end of middle caudal rays, type, Lago Cashiboya, Allen, August, 1920.

Among the specimens from Lake Cashiboya, one, $131 \mathrm{~mm}$., differs from the remainder notably in the length of the snout, and the width of the head, representing a new species evidently allied to $L$. maculata, with which, indeed, it was collected.

The following comparison is made with a specimen of L. maculata, $188 \mathrm{~mm}$. in length to the end of the middle caudal rays:

\begin{tabular}{|c|c|c|}
\hline & Loricaria maculata & Loricaria cashibo \\
\hline 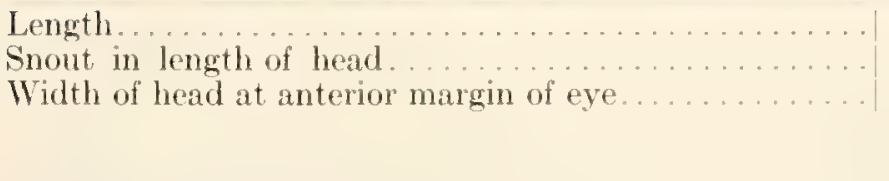 & $\begin{array}{l}188 \mathrm{~mm} \text {. } \\
\quad 2 \\
=\text { snout and eye } \\
\text { with noteh }\end{array}$ & $\begin{array}{l}131, \mathrm{~mm} \text {. } \\
1.4 \\
\text { not quite equal to } \\
\text { the length of snout } \\
\text { alone }\end{array}$ \\
\hline $\begin{array}{l}\text { Interorbital in the length of the snout............. } \\
\text { Width of the head in its own length.... }\end{array}$ & $\begin{array}{l}2.5 \\
1.3\end{array}$ & $\begin{array}{l}3.5 \\
1.8\end{array}$ \\
\hline
\end{tabular}


Where in maculata the granular border on the lower surface of the snout is of nearly uniform width, in cashibo it is twice as wide in front as it is along the sides. In maculata the supraoccipital and the plates behind it are smooth; in cashibo there is a double ridge on the supraoccipital, and the plates behind it are bicarinate. In many characters the specimen is not clearly differentiated from $L$. maculata.

For the indigenous tribe of the region, the Cashibos, who have given their name also to the lake, Cashiboya, the type locality, an oxbow lake formed in an old channel of the Ucayali.

\section{Loricaria EVANSII Boulenger}

Loricaria eransii Boulenger, 1892, Ann. Mag. Nat. Hist., (6), X, 10, pl. i;

Regan, 1904, Trans. Zool. Soc. London, XVII, 290;

Eigenmann, 1910, Rept. Princeton Univ. Exped. Patagonia, III, 414.

\section{Matto Grosso and Marañon}

15983, 1, $243 \mathrm{~mm}$. (208 to end of middle caudal ray), Iquitos, Morris, 1922.

\section{LORICARIA NUdiRostris Kner}

Loricaria nudirostris Ǩner, 1854, Denksch. KK. Akad. Wiss. Wien, 86, pl. iv; Günther, 1864, Cat. Fish. Brit. Mus., V, 259;

Regan, 1904, Trans. Zool. Soc. London, XVII, 288;

Eigenmann, 1910, Rept. Princeton Univ. Exped. Patagonia, III, 414.

\section{Rio Negro and Iquitos}

1598t, 1, $200 \mathrm{~mm}$. to end of middle caudal rays, Iquitos, Morris, 1922.

The lips of this specimen interrupted; width of head 1.5 in its own length; scutes $17+14+11$; anal plate, ventral armature present.

\section{LoRicaria PUNCTATA Regan}

Loricaria punctata Regan, 190t, Trans. Zool. Soc. London, XVII, 285, Manaos and lower Amazon; Eigenmann, 1910, Rept. Princeton Univ. Exped. Patagonia, III, 414.

\section{Amazons}

15394, many, 42-170 mm. to end of middle caudal rays, Rio Paranapura, Yurimaguas, Allen, November, 1920 .

15395, 9, 105-168 mm., Rio Huallaga, Yurimaguas, Allen, November, 1920.

15396, 1, 138 mm., Iquitos, Allen, September, 1920.

15399, 1, 138 mm., Rio Itaya, Iquitos, Allen, September, 1920.

15981, 10, 112-167 mm., Iquitos, Morris, 1922.

Edge of armored area of ventral surface concave in front, except in 15399, in which it is straight; ventrals truncate, opposite origin of anal, or the fifth ray the longest, the fourth, third, second, and first successively shorter. The spots on the dorsal at the anterior edges of the rays; pectoral with spots on rays and membranes; ventrals with only a few spots. 


\section{Ioricaria lamina Günther}

Loricaria lamina Günther, 1S68, Proc. Zool. Soe. London, 239, figs. 6 and 7 , three, $7-8$ in.;

Eigenmann and Eigenmann, 1889, Proc. Cal. Acad. Sci., (2), II, 37 ;

Eigenmann and Eigenmann, 1890, Oce. Papers Cal. Acad. Sci., I, 385;

Regan, 1904, Trans. Zool. Soc. London, XVII, 291;

Eigenmann, 1910, Rept. Princeton Univ. Exped. Patagonia, III, $\$ 15$;

Eigenmann, 1912, Mem. Camegie Mus., V, 415.

\section{Xeberos, Peru}

Known from the three types.

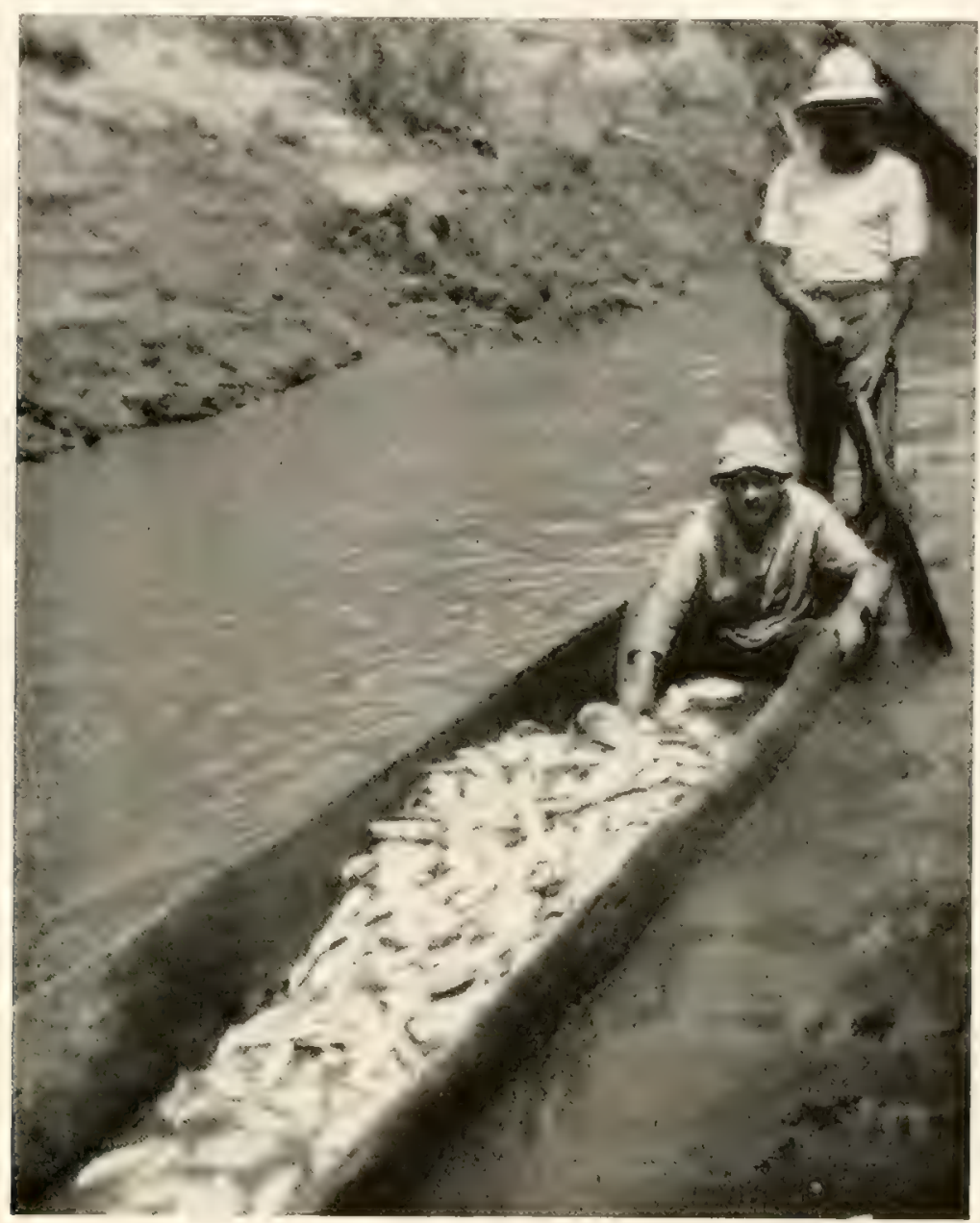

Fig. 24. An hour's catch with tarafa, or throw-net. Taken along the shore of the Rio Ueayali during the rising stages, when such fishes as the lisa, bocachica, and palometo are ascending the streams in great schools.

\section{LORICARIA sIMLLIMA Regan}

Loricaria simillima Regan, 1901, Trans. Zool. Soc. London, XVII, 292, pl. xrii, fig. 2, Canelos, Ecuador;

(misspelled similima) Eigenmann, 1910, Rept. Princeton Univ. Exped. Patagonia, III, 415. 
Canelos

Three specimens which had been referred to L. filamentosa by Boulenger.

\section{Loricaria macromystax Günther}

Loricaria macromystax Günther, 1869, Proc. Zool. Soc. London, 426, figs. 5 and 6, Peruvian Amazon;

Eigenmann and Eigenmann, 1889, Proc. Cal. Acad. Sci., (2), II, 37;

Eigenmann and Eigenmann, 1890, Occ. Papers Cal. Acad. Sci, I, 385;

Regan, 1904, Trans. Zool. Soc. London, XVII, 294;

Eigenmann, 1910, Rept. Princeton Univ. Exped. Patagonia, III, 415.

\section{Peruvian Amazon}

Known from the type, $155 \mathrm{~mm}$. in length.

\section{Loricaria petleyi (Fowler)}

Rhineloricaria petleyi Fowler, 1939 (1940), Proc. Acad. Nat. Sci. Phila., XCI, 243, figs. 36-38.

\section{Contamana}

Two specimens, type and paratype, 152 and $172 \mathrm{~mm}$. long, described as having the first pair of scutes adjoining the supraoccipital contiguous with one another; third predorsal scute much exceeding the first and second in length.

\section{LORICARIA MoRrowi (Fowler)}

Rhineloricaria morrowi Fowler, 1939 (1940), Proc. Acad. Nat. Sci. Phila., XCI, 244, figs. 39-11.

\section{Contamana, Peru}

One specimen, the type, $165 \mathrm{~mm}$. in length, with five spines bordering the basis of the dorsal fin.

\section{Loricaria Carinata Castelnau}

Loricaria carinata Castelnau, 1855, Anim. Amér. Sud, Poiss., 46, pl. xxiii, fig. 3, Amazon;

Regan, 1913, Ann. Mag. Nat. Hist., (8), XII, 282.

Loricaria cataphracta (in part), Eigenmann and Eigenmann, 1890, Occ. Papers Cal. Acad. Sci., I, 382.

Loricaria (Loricaria) carinata Fowler, 1939 (1940), Proc. Acad. Nat. Sci. Phila., XCI, 246, figs. 42 and 43.

\section{Contamana, Peru, on the Ucayali}

One specimen in the Philadelphia Academy Museum, $305 \mathrm{~mm}$. long.

\section{LORICARIA CATAPHRACTA Linnaeus}

Loricaria dura Linnaeus, 175t, Mus. Adolphi Fred., 79, pl. xxix, figs. 1 and 2;

Bleeker, 1864, Nat. Verh. Holl. Maats., (2), XX, 18, Surinam.

Loricaria cataphracta Linnaeus, 1758, Syst. Nat., ed. x, 307;

Linnaeus, 1766, Syst. Nat. ed. xii, 508, America;

Bloch, 1794, Ausl. Fische, VIII, 76, pl. lxxv, figs. 3 and 4; 
Cuvier and Valenciennes, 1840, Hist. Nat. Poiss., XV, 459:

Günther, 1864, Cat. Fish. Brit. Mus., V, 255;

Cope, 1878, Proc. Amer. Phil. Soc., XVII, 681, Rio Marañon;

Eigenmann and Eigenmann, 1889, Proc. Cal. Acad. Sci., (2), II, 36;

Eigenmann and Eigenmann, 1890, Occ. Papers Cal. Acad. Sci., I, 382;

Regan, 1904, Trans. Zool. Soc. London, XVII, 292;

Eigenmann, 1910, Rept. Princeton Univ. Exped. Patagonia, III, 415;

Eigenmann, 1912, Mem. Carnegie Mus., V, 243.

The Amazons and Guianas

$15390,1,186 \mathrm{~mm}$. to end of middle caudal rays, Rio Huallaga, Yurimaguas, Allen, November, 1920.

Head 5 to end of plate on side of caudal; depth 11; D. I, 7; A. 6; scutes $21+14$; the keels approximated, not united from the $22 \mathrm{~d}$ on; width of head 1.33 in its length, its depth 2.6, eye 6.5, interorbital 5.33; about 7 spoon-shaped teeth in the upper jaw, about 9 similar but shorter ones in the mandibular ramus; lips with numerous papillae over and covering their entire surface, those along the margin of the lower lip bifid, those along the lateral edge, on the margin of the barbel, each with from one to four lateral papillae; barbel reaching to base of pectoral spine; interorbital smooth, slightly convex, without keels; snout near nares tumid; occipital with a single low crest, the two plates behind it bicarinate, the predorsal plate with a single keel; a feeble keel from opposite the middle of the base of the dorsal forward; head naked below, covered with the lips except the marginal granular area which is extended inward in front of the gill-opening; ventral surface covered with small plates from the anus to the lips, anterior margin of the armored part convex, extending forward of the angle of the gill-opening; no preanal plate; about three series of granular plates between the lateral scutes in front of the ventrals, about 7 near the pectorals; pectoral spines very heavy, reaching ventrals, outer ventral rays to end of anal basis; anal rounded, shorter than head; dorsal slightly emarginate, the first ray extending the width of a scute beyond the last when the fin is depressed; upper caudal ray produced. Pectoral and inner part of ventrals blue black; dorsal with a streak of the same color along the posterior half of the membranes, interrupted on the first half of the fin; caudal with a blue black bar across the middle of the upper lobe and continued along the margin of the middle rays and of lower lobe; anal without markings.

15391, 1, 212 mm., Rio Itaya, Iquitos, Allen, September, 1920.

Barbels much shorter, not covering the surface of the lips; plates of the ventral surface forming a straight line between gill-openings; width of head $1.25 \mathrm{in}$ its length; occipital with a pair of closely approximated crests; anal and dorsal truncate, the first dorsal ray slightly prolonged, outer pectoral ray extending beyond base of ventrals, outer ventral ray beyond base of anal; dorsal, pectorals and ventrals dark, with lighter spots, anal with a few dark spots, caudal spotted, 4 dark cross-shades behind the dorsal.

15980, 9, 146-215 mm., Iquitos, Morris, 1922.

15393, 1, 58 mm., Gosulimacocha, Allen, October, 1920.

15100, 1, $66 \mathrm{~mm}$., Rio Paranapura, Allen, October, 1920. 
Of this group, the smallest, 15393, is more like 15391 from Iquitos, and the Paranapura specimen from the Yurimaguas region, with its long, falcate ventrals, is more like 15390 from the nearby Huallaga.

Three teeth in the upper jaw, 5 in the lower; in both the occipital bicarinate.

In 15393 the dorsal has a broad, oblique bar, the caudal black, its outer rays light; in 15400 the dorsal punctate, the caudal dusky.

Ranging from the Huallaga to Surinam, we have a species of considerable variability, if not indeed a distinct species in this portion of its range, or species in the making.

\section{Loricaria Clavipinna Fowler}

Loricaria (Fusiloricaria) clavipinna Fowler, 1939 (1940), Proc. Acad. Nat. Sci. Phila., XCI, 247, figs. $45-47$.

\section{Contamana, Peru}

The type known, a specimen $161 \mathrm{~mm}$. to the tip of the lower caudal lobe, in the collections of the Philadelphia Academy. Noteworthy for the hypertrophied pectoral spine, expanded into a club distally.

\section{Genus 88: HEMIODONTICHTHYS Bleeker}

Hemiodon (non Swainson) Kner, 185t, Denksch. KL. Akad. Wiss. Wien, VI, 89. Hemiodontichthys Bleeker, 1863, Nederl. Tijdsch. Dierk., I, 81;

Eigenmann and Eigenmann, 1890, Occ. Papers Cal. Acad. Sci., I, 358;

Regan, 1904, Trans. Zool. Soc. London, XVII, 296;

Eigenmann, 1910, Rept. Princeton Univ. Exped. Patagonia, III, 415;

Eigenmann, 1912, Mem. Carnegie Mus., V, 250.

Type: Hemiodon acipenserinus Kner

Peruvian Amazonia to Matto Grosso and British Guiana

A genus distinguished by the long rostrum, expanded at the extremity, and bearing recurved hooks at the tip; the hooks of the lateral keels more pronounced than in other genera; teeth wanting in the upper jaw, never numerous, nor setiform; orbital notch more or less distinct.

\section{Hemodontichthys acipenserinus (Kner)}

Hemiodon acipenserinus Kner, 1853, Denksch. KK. Akad. Wiss. Wien, VI, 92, pl. vii, fig. 2, Rio Guaporé; Matto Grosso.

Loricaria acipenserinus Günther, 1864, Cat. Fish. Brit. Mus., V, 260.

Hemiodontichthys acipenserinus Bleeker, 1863, Nederl. Tijdsch. Dierk., I, 81;

Eigenmann and Eigenmann, 1889, Proc. Cal. Acad. Sci., (2), II, 34;

Eigenmann and Eigenmann, 1890, Occ. Papers Cal. Acad. Sci., I, 359;

Regan, 1904, Trans. Zool. Soc. London, XVII, 296;

Eigenmann, 1907, Ann. Carnegie Mus., IV, 120, pl. xxxv, fig. 1;

Eigenmann, 1910, Rept. Princeton Univ. Exped. Patagonia, III, 115;

Eigenmann, 1912, Mem. Carnegie Mus., V, 250.

Iquitos to British Guiana, Matto Grosso

15972, 8, 119-140 mm. to end of middle caudal rays, Iquitos, Morris, 1922. 
Genus 89: HART'TIA Steindachner

Sturisoma (in part) Swainson, 1838, Fish. Amph. Rept., I, 337.

Hartia Steindachner, 1876, Sitzb. KK. Akad. Wiss. Wien, LXXIV, 668;

Eigenmann and Eigenmann, 1890, Occ. Papers Cal. Acad. Sci., I, 385;

Eigenmann, 1910, Rept. Princeton Univ. Exped. Patagonia, III, 415.

Oxyloricaria (in part) Regan, 1904, Trans. Zool. Soc. London, XVII, 297.

Type: Harttia loricariformis Steindachner

Peruvian Amazon to Guiana and southeastern Brazil

That group of Loricarinae with broad, depressed body and great length of tail, whose lateral plates are without keels; belly naked; adipose wanting; teeth numerous and well developed; a series of broad, paired plates behind the dorsal.

230. Hartita filamentissima Eigenmann and Allen, sp. nov.

Plate VIII, figs. 1 and 2

15378, 1, $170 \mathrm{~mm}$. to end of middle caudal rays, type, Rio Huallaga, Allen, November, 1920. $15379,1,120 \mathrm{~mm}$., Lago Cashiboya, Allen, August, 1920.

Head 5.7; depth 8, equal to snout and eye; D. I, 7; A. I, 5; scutes $15-16$, the lateral keels completely united from the 16th on; head as broad as long, its depth equal to half its length; eye 7 in head, interorbital 3 ; snout 1.75 , rounded, a low ridge along its middle; supraorbital ridges not raised; none of the scutes carinate; lower surface of the head covered with small plates, except where covered with narrow, papillose lips; no free barbel; abdomen completely covered with 5-10 series of small plates between the lateral scutes; a single median plate in front of the anus, a pair of plates covering the sides and area behind it; width at the 15 th scute equals snout and half the eye.

Fins all large, the dorsal, the pectorals, and caudal lobes with the first ray greatly prolonged; the dorsal filament $182 \mathrm{~mm}$. long, longer than the fish exclusive of the caudal lobes; lower caudal lobe with its filament $192 \mathrm{~mm}$., the upper filament broken; the pectoral filaments reaching the antepenultimate scute; ventrals reaching a little beyond the base of the anal; uniform sand color.

This species is evidently closely related to $H$. platystoma. The eye is smaller, the depth at the dorsal greater, the profile consequently much steeper; the fins much as in platystoma except for the great prolongation of the outer rays of the dorsal, pectoral, and caudal fins.

The second specimen differs somewhat in proportions (15379); there is a dusky stripe along the middle of the back, behind the dorsal, and a dusky stripe along the sides; similarly colored stripes on the dorsal, and within the outer rays of the caudal; barbel slightly free; eye 6 in the head, interorbital 3.5 .

231. HartTia microps Eigenmann and Allen, sp. nov. Plate VIII, figs. 3 and 4 ; plate IX, fig. 1

15380, 5, type and paratypes, 150-17+ mm. to end of middle caudal rays, Iquitos, Allen, September, 1920. 
Head 5.0-5.33; depth 8.0-8.5, about equal to preorbital; D. I, 7; A. I, 5; scutes 17 or $18-17$ or 18 , the keels entirely coalesced on the 17 th or 18 th scute; width of head 1.2 in its length; eye minute, about 12 in the head, 3 in interorbital; interorbital 4 in the head, snout 1.75; snout parabolic, with scarcely perceptible median ridge; the orbital margins not raised; scutes not carinate; lower surface of the head covered with small scales except where covered by the papillose lips; barbel short; belly entirely covered with 5-10 small plates between the lateral series; a single plate in front of the anus, a pair of them on the sides and behind; width at the 17 th scute equal to snout and eye or a little wider.

Fins medium to large, the dorsal spine not equal to its distance from the snout, not prolonged in a filament; the outer caudal rays prolonged, the upper much longer $(310 \mathrm{~mm}$.) than the lower $(85 \mathrm{~mm}$.) in the specimen $150 \mathrm{~mm}$. long; one or the other of the filaments is broken in the remaining specimens. First pectoral rays extending to or beyond the origin of the caudal; ventrals reaching to the middle or the end of the base of the anal.

Dusky; outer rays and ends of middle caudal rays light, the lobes of the caudal black; a pair of light spots at the bases continuous or not with the light margin of the middle rays; other fins uniform dark, the outer rays lighter.

\section{Harttia brevirostris (Eigenmann and Eigenmann)}

Loricaria brevirostris Eigenmann and Eigenmann, 1889, Proc. Cal. Acad. Sci., (2), II, 35 ;

Eigenmann and Eigenmann, 1890, Occ. Papers Cal. Acad. Sci., I, 367.

Oxyloricaria brevirostris Regan, 1904, Trans. Zool. Soc. London, XVII, 299.

Hartia brevirostris Eigenmann, 1910, Rept. Princeton Univ. Exped. Patagonia, III, 415.

$$
\text { "Iça", Peru, probably a finca }
$$

The type alone known, $210 \mathrm{~mm}$. to end of caudal, collector W. James.

\section{Genus 90: STURISOMA Swainson}

Sturisoma Swainson, 1838, Fish. Amph. Rept., I, 337; II, 30t;

Eigenmann, 1910, Rept. Princeton Univ. Exped. Patagonia, III, 416.

Oxyloricaria Bleeker, 1863, Nederi. Tijdsch. Dierk., I, 80;

Regan (in part), 1904, Trans. Zool. Soc. London, XVII, 297.

Loricaria (in part) Eigenmann and Eigenmann, 1890, Occ. Papers Cal Acad. Sci., I, 366.

\section{Type: Loricaria rostrata Spix}

\section{Panama to Paraguay}

Separable from other genera of Loricariinae by the strong development of teeth in both jaws; prolonged snout whose lower surface is granular; lateral keels coalescent; orbit without a notch; ventral aspect of the head with small plates; head without keels; anterior profile concave.

\section{Sturisoma rostratum Spix}

Loricaria rostrata Spix, 1829, Sel. Gen. et Spec. Pisc. Bras., 5, pl. iii, figs. 1 and 2, Brazil;

Cuvier and Valenciennes, 1840, Hist. Nat. Poiss., XV, 478;

Günther, 1864, Cat. Fish. Brit. Mus., V, 256; 
Günther, 1869, Proc. Zool. Soc. Iondon, 235, Xeberos;

Cope, 1874, Proc. Acad. Nat. Sci. Phila., XXVI, 135;

Cope, 1878, Proc. Amer. Phil. Soe, XVII, 681, Peruvian Amazon;

Eigenmann and Eigenmann, 1890, Oce. Papers Cal. Acad. Sci., I, 360.

Sturisoma rostrata Swainson, 1839, Fish. Amph. Rept., II, 304;

Eigenmann, 1910, Rept. Princeton Univ. Exped. Patagonia, III, 416.

Oxyloricaria rostrala Regan, 1904, Trans. Zool. Soc. London, XVII, 300.

Panama, Rio Marañon, to upper Paraguay valley

15382, 4, 104-233 mm. to end of middle caudal rays, Amazon, Iquitos, Allen, Mlorris, 1920-1922. 15383, 5, 91-232 mm., Rio Morona, Allen, October, 1920.

15384, 2, female, $192 \mathrm{~mm}$; male, $250 \mathrm{~mm}$., Rio Huallaga, Yurimaguas, Allen, November, 1920.

15385, 4, 143-201 mm., Rio Ucayali, near Orellana, Allen, August, 1920.

15386, 1, $225 \mathrm{~mm}$., Lago Cashiboya, Allen, August, 1920.

15387, 1, $211 \mathrm{~mm}$., Rio Ucayali, Contamana, Allen, July, 1920.

\section{Sturisoma güntheri (Regan)}

Loricaria rostrata (non Spix) Günther, 1868, Proc. Zool. Soc. London, 235;

Eigenmann and Eigenmann, 1889, Proc. Cal. Acad. Sei., (2), II, 35;

Eigenmann and Eigenmann, 1890, Oce. Papers Cal. Acad. Sci., I, 366.

Oxyloricaria guentheri Regan, 1904, Trans. Zool. Soc. London, XVII, 299, pl. xviii, fig. 1.

Sturisoma güntheri Eigenmann, 1910, Rept. P'rinceton Univ. Exped. Patagonia, III, 416.

Xeberos, Peruvian Amazon; middle Amazon

235. Sturisoma nigrorostrum Fowler

Sturiosoma nigrorostrum Fowler, 1939 (1940), Proc. Acad. Nat. Sci. Phila., XCI, 249, figs. 48-50.

\section{Rio Ucayali, Contamana}

Represented by three specimens at the Philadelphia Academy of Sciences, type and paratypes, $179-220 \mathrm{~mm}$. in length to end of broken caudal filament. Distinguishable by the black snout.

\section{Genus 91: FARLOWELLA Eigenmann and Eigenmann}

Acestra (non Dallas) Ḱner, 1853, Denksch. KK. Akad. Wiss. Wien, VI, 93;

Gïnther, 186t, Cat. Fish. Brit. Mus., V, 260.

Farlowella Eigenmann and Eigenmann, 1889, Proc. Cal. Acad. Sci., (2), II, 32;

Eigenmann and Eigenmann, 1890, Occ. Papers Cal. Acad. Sci., I, 355;

Regan, 1904, Trans. Zool. Soc. London, XVII, 302;

Eigenmann and Eigenmann, 1910, Rept. Princeton Univ. Exped. Patagonia, III, 16 ;

Eigenmann, 1912, Mem. Carnegie Мus., I, 252.

\section{Type: Acestra acus Kner \\ Amazons to the Guianas}

Delicate, slender, long-snouted, loricariiform fishes; dorsal opposite the anal, in part over the ventrals; $6-8$ plates separate the occipital plate from the dorsal fin; ventral plates large and in two or three series. 


\section{Farlowella hnerit (Steindachner)}

Acestra knerii Steindachner, 1882, Denksch. KK. Akad. Wiss. Wien, XLVI, 26, pl. vii, figs. 1 and 1a, Canelos;

Boulenger, 1887, Proc. Zool. Soc. London, 278, Canelos, Sarayacu.

Farlowella knerii Eigenmann and Eigenmann, 1889, Proc. Cal. Acad. Sci., (2), 34;

Eigenmann and Eigenmann, 1890, Occ. Papers Cal. Acad. Sci., I, 358;

Eigenmann, 1910, Rept. Princeton Univ. Exped. Patagonia, III, 416.

Farlowella kneri Regan, 1904, Trans. Zool. Soc. London, XVII, 304.

\section{Eastern slopes of Andes of Ecuador and Peru}

\section{Farlowella amazona (Günther)}

Acestra amazonum Günther, 1864, Cat. Fish. Brit. Mus., V, 271, Santarem.

Farlowella carinata Eigenmann and Eigenmann, 1889, Proc. Cal. Acad. Sci., (2), II, 33;

Eigenmann and Eigenmann, 1890, Occ. Papers Cal. Acad. Sci., I, 356.

Farlowella amazonum Regan, 1904, Trans. Zool. Soc. London, XVII, 305;

Eigenmann, 1910, Rept. Princeton Univ. Exped. Patagonia, III, 416.

\section{Peruvian Amazon to Santarem}

15377, 1, 130 mm., $128 \mathrm{~mm}$. to end of middle caudal rays, Rio Pacaya, Allen, August, 1920.

Length of produced part of snout $20 \mathrm{~mm}$.; distance between tip of snout and anus $55 \mathrm{~mm}$.

\section{Farlowella smithi Fowler}

Fartowella smithi Fowler, 1914, Proc. Acad. Nat. Sci. Phila., LXVI, 574, fig. 24.

15375, 3, 156-159 mm. to end of middle caudal rays, Rio Huallaga, Yurimaguas, Allen, November, 1920.

$15376,3,15+-220 \mathrm{~mm}$. to end of middle caudal ravs, Iquitos, Allen, September, 1920.

$15380,1,84 \mathrm{~mm}$. to end of middle caudal rays, Rio Morona, Allen, October, 1920.

Of 15375 , two have a snout length of $22 \mathrm{~mm}$., produced part, and distance between anus and tip of snout $62 \mathrm{~mm}$. (third broken).

For 15376 the respective measurements are as follows:

$$
\begin{aligned}
& \text { a. snout length } 22 \mathrm{~mm} \text {.; snout to anus } 65 \mathrm{~mm} \text {. } \\
& \text { b. " " " } 23 \mathrm{~mm} \text {; " " " " } 66 \mathrm{~mm} \text {. } \\
& \text { c. " " } 30 \mathrm{~mm} \text {; " " " " } 88 \mathrm{~mm} \text {. }
\end{aligned}
$$

\section{Order HETEROGNATHI}

An order allied to the Nematognathi in the possession of the Weberian apparatus, differing in the possession of scales.

\section{Family XI: Characidae}

Characini Müller, 1843, Archiv Naturg., IX, 323.

Characinidae Richardson, 1856, Encycl. Brit., ed. viii, XII, 245;

Jordan, Evermann and Clark, 1928 (1930), Rept. U. S. Comm. Fish., Part II, 95;

Gregory and Conrad, 1938, Zoologica, XXIII, 319. 
Characidae Gill, 1893, Mem. Acad. Nat. Sci., VI, 131;

Eigenmann, 1917-1929, Mem. Mus. Comp. Zool., XLIII, 17.

An extensive family, mainly tropical, through the freshwaters of South America and Africa. Scaly fishes with adipose dorsal usually; short dorsal, single, without spines; barbels and plated areas lacking. Extremely variable in body form, possibly polyphyletic, the respective subfamilies having resemblance to other fishes in similar habitats.

\section{First Division-Cheirodontine group of Subfamilies Subfamily: CHEIRODONTINAE}

Moderately deep-bodied; anal fin long, its origin beneath the last dorsal ray and extending almost to the caudal, which is deeply forked; mouth terminal and relatively small; cycloid scales of unspecialized type; dentition rariable, allied to that of various subfamilies. Gregory and Conrad assign this subfamily the place nearest the stem of the more specialized forms.

\section{Genus 92: OTHONOCHEIRODUS Myers}

Othonocheirodus Myers, 1927, Bull. Mus. Comp. Zool., LXVIII, iii, 113.

\section{Type: Othonocheirodus eigenmanni Myers}

The middle Huallaga

Like Monotocheirodon differing from Holosthenes, Odontostilbe and Cheirodon in the horizontal gape and the naked teeth of the upper jaw; unlike the first-named in the great horizontal extent of the maxillary; teeth $6-7$; vertical ramus slight, scarcely intersecting the line of the mandibular tooth-bases, its end not rounded or free; body more compressed.

\section{Othonocheirodus eigenmanni Myers}

Othonocheirodus eigenmanni Mvers, 1927, Bull. MIus. Comp. Zool., LXVIII, ii, 114.

Rio Huallaga at Cayumba rapids

1767 4, 17675 (original number 16125), 4, type and paratypes, 38-t7 mm., Cayumba rapids, Rio Huallaga, Allen, October, 1918.

\section{Second Division - Tetragonopterine group of Subfamilies \\ Subfamily: TETRAGONOPTERINAE}

Characins of oblong form, often elevated considerably; scales of moderate size; dentition complete in both jaws; gill-openings wide, the membranes not attached to the isthmus; nasal openings closely approximated; teeth compressed, notched.

\section{Genus 93: HEMIIBRYCON Gïnther}

Hemibrycon Günther, 186t, Cat. Fish. Brit. Mus., V, 318;

Eigenmann, 1910, Rept. Princeton Univ. Exped. Patagonia, III, 432 ;

Eigenmann, 1927, Mem. Mus. Comp). Zool., XLIII, iv, 401. 


\section{Type: Hemibrycon polyodon Günther}

\section{Trinidad and Colombia to southeastern Peru and Bolivia}

Maxillary teeth (at least in adults) in greater number than in Bryconamericus; maxillary slender and reaching to near middle of pupil; head short and body elongated; gill rakers of first arch long and setiform.

Reaching to higher elevations than any other Characin genus, and descending to sea level in the North. It is quite possible that the respective species have been evolved independently from different species of Bryconamericus or Astyanax. Four species have been recorded heretofore from Peru: Hemibrycon ipanquianus by E. D. Cope "dedicated to the memory of the Inca Ypanqui, who in the city of Cuzco on the Urubamba, the first of his line, devoted himself to monotheism" was taken on the Urubamba at 11500 feet; Hemibrycon jelskii (Steindachner) was recorded from Monterico, eastern central Peru, and from the Rio Huambo; Hemibrycon huambonicus Steindachner has been recorded from Callacate and the Rio Huambo; and Hemibrycon tridens from Uruhuasi in southern Peru.

\section{Hemibricon tridens Eigenmann}

Hemibrycon tridens Eigenmann, 1922, Mem. Carnegie Mus., IX, 152;

Eigenmann, 1927, Mem. Mus. Comp. Zool., XLIII, iv, 403, pl, xevi, fig. 3.

13723, 1, 65 mm., Rosenberg, Uruhuasi, southern Peru.

\section{Hemibrycon helleri Eigenmann}

Hemibrycon helleri Eigenmann, 1927, Mem. Mus. Comp. Zool., XLIII, iv, 406, pl. xeri, fig. 2; Pearson, 1937a, Proc. Cal. Acad. Sci., (4), XXIII, 91.

-, 18, 45-100 mm., the largest the type, Rio Comberciato, Heller, 1915.

17611 , 1, 65 mm., Paipay, Rio Crisnejas, Pearson, 1922.

16047, Santa Ana creek, Eigenmann, November, 1918.

\section{Southern Peru and upper Marañon}

Near $H$. huambonicus, but pectorals shorter, not reaching ventrals; anal shorter; middle caudal rays black; a large, obscure, vertical humeral spot; margin of anal dusky; anterior rays of anal with hooks to near the tips in the males.

\section{Hemibrycon huambonicus (Steindachner)}

Tetragonopterus huambonicus Steindachner, 1882 (1883), Denksch. KK. Akad. Wiss. Wien, XLVI, 28 , pl. v, fig. 1.

Hemibrycon polyodon Eigenmann, 1910, Rept. Princeton Univ. Exped. Patagonia, III, 432.

Hemibrycon huambonicus Pearson, 1924, Ind. Univ. Studies, no. 64, 42;

Eigenmann, 1927, Mem. Mus. Comp. Zool., XLIII, iv, 410, pl. xxxix, fig. 5;

Pearson, 1937a, Proc. Cal. Acad. Sei., (4), XXIII, 91.

\section{Mountain slopes on Atlantic side of Peru and Bolivia}

and 13753 , 5 females, $63-100 \mathrm{~mm}$., Rio Comberciato, 1800 feet above sea level, E. Heller, September $15,1915$.

16195, many, 48-119 mm., Huancachupa ereek, Huánuco, Allen, October, 1918. 
16196, many, 36-108 mm., Rio 'Tingo, Huánuco, Allen, October, 1918.

16198, many, 51-110 mm., Rio Huallaga, Huánuco, Allen, October, 1918.

16199, many, 4t-112 mm., Rio Chinchao, Piedra Blanca, Allen, October, 1918.

16120, , below Cayumba rapids, Allen, October, 1918.

16121, 9, 61-117 mm., Rio Huallaga, Ambo, Allen, Oetober, 1918.

16122, 14, 19-91 mm., Chumatagua creek, above Cayumba rapids, Rio Huallaga, Allen, September, 1918.

The above specimens taken from Chumatagua creek at about 2000 feet, Rio Chinchao nearer 2500 feet, the Huanuco district at about 6000 feet, and from Ambo near 7500 feet, all records from above the barrier, or pongo, of the Huallaga, the rapids of Cayumba.

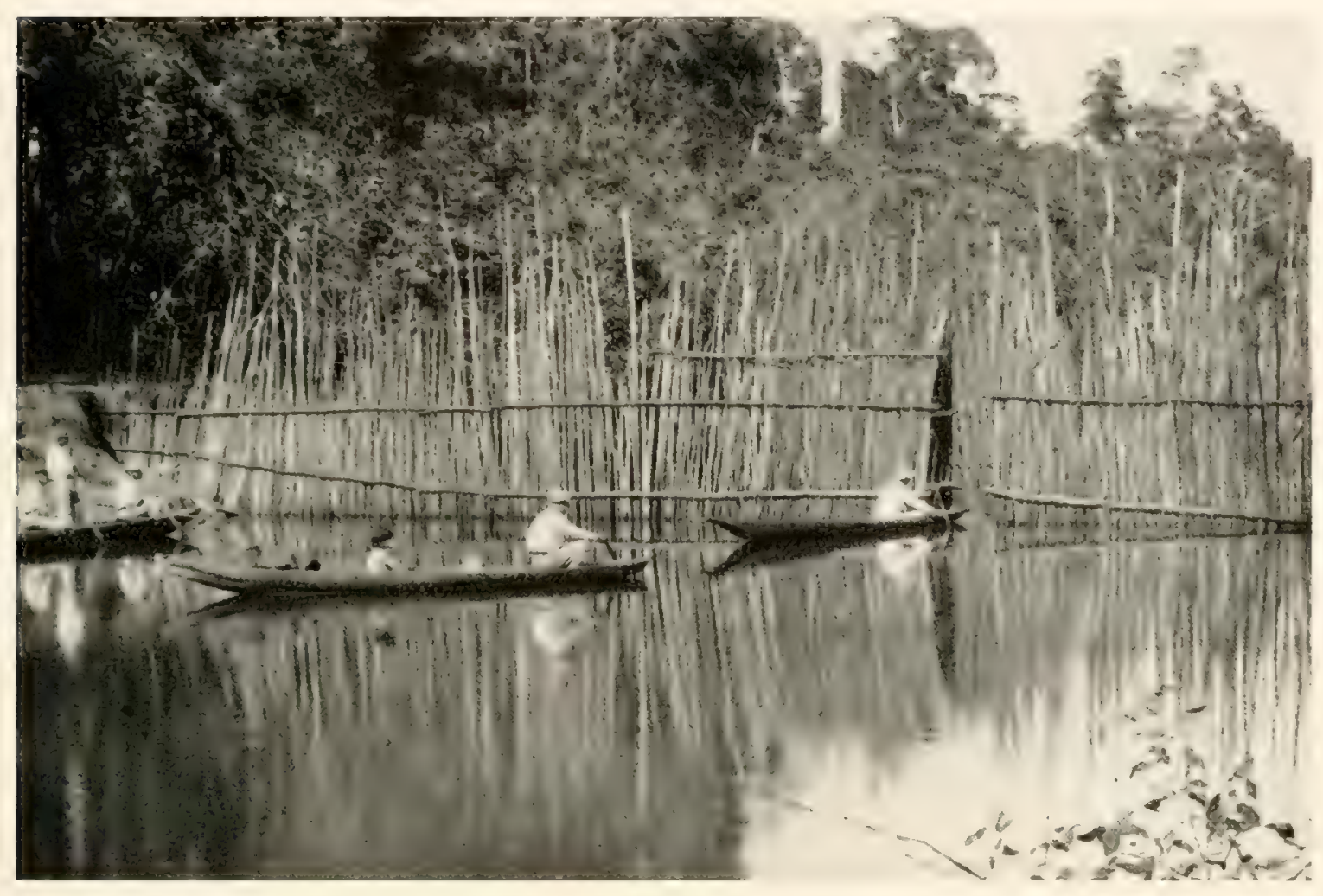

FIG. 25. Fish weir of Oriental Peru. This trap is placed across the mouth of a bayou or channel. Fishes of large size press open the door suspended in the pound at the center, and are unable to open it the other way.

Fishes of rapid mountain streams, with rock ledges, pools, and riffles, in and about the upper rain forest zone. It is a region in which a true dry season is wanting, and in which almost daily rains occur. The streams tumbling down the mountain sides have almost daily freshets, and subside again as rapidly, in the section about the Cayumba rapids, although about Huánuco and Ambo the species has entered the fringe of a more distinct wet and dry season area.

Osgood obtained a specimen at Moyobamba and Pearson a number of them in the upper Marañon. Pearson also found the species common at elevations near 1500 feet on the Rio Beni, Bolivia.

Head 4.5 ; depth 3.0 ; D. 10 ; A. 30, twenty-nine and thirty-one in a few cases; 
lateral line 40-42, in some areas 46-47; pectorals reaching ventrals; origin of ventrals equidistant between tip of snout and base of the last third or fourth of the anal; caudal lobes more pointed than in $H$. helleri, a little longer than the head; ventrals reaching the anal in the smaller specimens. Humeral spot fainter, margin of anal darker than in $H$. helleri, numerous chromatophores between middle of anal and lateral line; middle caudal rays black; frontals entirely separated by the fontanel and ethmoid even in the largest. In other respects like $H$. helleri.

These specimens, differing more or less from Steindachner's figure of $H$. huambonicus, may represent a distinct species, although his area is embraced within the extremes of our range.

\section{Hemibrycon JelskiI (Steindachner)}

Tetragonopterus jelskii Steindachner, 1875, Sitzb. KK. Akad. Wiss. Wien, LXXII, 40, Monterico; Steindachner, 1882 (1883), Denksch. KK. Akad. Wiss. Wien, XLVI, 25, Rio de Huambo, one, $115 \mathrm{~mm}$.

Hemibrycon jelskii Eigenmann, 1910, Rept. Princeton Univ. Exped. Patagonia, III, 432;

Eigenmann, 1927, Mem. Mus. Comp. Zool., XLIII, iv, 412;

Pearson, 1937a, Proc. Cal. Acad. Sci., (4), XXIII, 92.

Eastern slopes of central Peru

17640, 51, 30-40 mm., Rio Pusoc, upper Marañon, Pearson, 1922.

A species not well characterized except in mathematical terms, and resembling H. dariensis.

\section{Genus 94: ACROBR YCON Eigenmann and Pearson}

Tetragonopterus (in part) Cope, 1878, Proe. Amer. Phil. Soc., XVII, 44, Rio Urubamba.

Hemibrycon (in part) Eigenmann, 1910, Rept. Princeton Univ. Exped. Patagonia, III, 432.

Astyanax Fowler, 1906, Proc. Acad. Nat. Sci. Phila., LVIII, 337.

Acrobrycon Eigenmann and Pearson, 192t, Ind. Univ. Studies, no. 64, 44.

\section{Type: Tetragonopterus ipanquianus Cope}

Atlantic slopes of the Andes of Peru and Bolivia

Intimately allied to Hemibrycon, from which it differs in that the male bears a large caudal pouch; scales extend much farther back on the middle of the caudal than above or below, and along the ventral side only half as far as midway; the scales of the lower portion of the caudal not attached to rays, but to skin which is pouched away from the rays.

\section{Acrobrycon ipanguianus (Cope)}

Tetragonopterus ipanquianus Cope, 1878, Proc. Amer. Phil. Soc., XVII, 14, collected by Orton on the Urubamba;

Cope, 1878, Proc. Amer. Phil. Soc., XVII, 691, the Marañon;

Eigenmann and Eigenmann, 1891, Proc. U. S. Nat. Mus., XIV, 53.

Astyanax ipanquianus Fowler, 1907, Proc. Acad. Nat. Sci. Phila., LVIII, 337, fig. 25. 
Acrobrycon ipanquiamus Eigenmann and Pearson, 1924, Ind. Univ. Studies, no. 64, 44, Espia, Bolivia;

Eigenmann, 1927, Mem. Mus. Comp. Zool., XLIII, iv, 416, pl. Ixix. figs. i and 2; pl. Ixxxy, fig. 1 .

Rio Urubamba to northern Bolivia

15076, many, 57-103 mm., Ollantaitambo, Eigenmann, November, 1918.

16052, , San Miguel, Eigenmann, November, 1918.

16053, 2, 105 and $117 \mathrm{~mm}$., Lake Huatana, Eigenmann, November, 1918.

$1605 t, 2,87$ and $118 \mathrm{~mm}$., Urcos, Rio Urubamba, Eigenmann, November, 1918.

16055, many, 28-125 mm., Torontoi, Rio Urubamba, Eigenmann, November, 1918.

16056, 1, 70 mm., Pueblo Urubamba, Eigenmann, November, 1918.

16193, many, 56-116 mm., San Miguel, Eigenmann, November, 1918.

Like Hemibrycon pectinatus and polyodon, etc., in the reduced anal radii and maxillary teeth; differing in smaller and more numerous scales.

\section{Genus 95: PHENACOGASTER Eigenmann}

T'etragonopterus (in part) Cope, 1870, Proc. Amer. Phil. Soc., XI, 560.

Astyanax (in part) Fowler, 1906, Proc. Acad. Nat. Sci. Phila., LVIII, 341.

Phenacogaster Eigenmann, 1907, Amer. Nat., XLI, 492, 769;

Eigenmann, 1912, Mem. Carnegie Mus., V, 366;

Eigenmann and Myers, 1929, Mem. Mus. Comp. Zool., XLIII, v, 442.

\section{Type: Tetragonopterus pectinatus Cope}

The Guianas to the Amazons

Anal origin beneath that of the dorsal fin; lateral line complete; scales in front of the ventral fins in two series, overlapping in the center; compressiform; fishes of small size.

\section{Phenacogaster pectinatus (Cope)}

Tetragonopterus pectinatus Cope, 1870, Proc. Amer. Phil. Soc., XI, 560;

Eigenmann and Eigenmann, 1891, Proc. U. S. Nat. Mus., XIV, 54.

Astyanax pectinatus Fowler, 1906 (1907), Proc. Acad. Nat. Sci. Phila., LVIII, 341, fig. 30 (figure mislabeled longior).

Phenacogaster pectinatus Eigenmann, 1907, Amer. Nat., XLI, 769;

Eigenmann, 1910, Rept. Princeton Univ. Exped. Patagonia, III, 431;

Eigenmann and Myers, 1929, Mem. Mus. Comp. Zool., XLIII, v, 443, pl. lxviii, figs. 2-5.

Tetragonopterus tabatingae Steindachner, 1876, Sitzb. KK. Akad. Wiss. Wien, XLVI, 35, 'Tabatinga;

Eigenmann and Eigenmann, 1891, Proc. U. S. Nat. Mus., XIV, 53.

Tetragonopterus bairdii Steindachner, 1882 (1883), Denksch. KK. Akad. Wiss. Wien, XLVI, 35, Peruvian Amazon to Tabatinga; Cudajas.

Phenacogaster bairdi Eigenmann, 1910, Rept. Princeton Univ. Exped. Patagonia, III, 431.

\section{Marañon and Solimões rivers}

\section{Genus 96: ASTYANAX Baird and Girard}

Astyanax Baird and Girard, 185t, Proc. Acad. Nat. Sci. Phila., VII, 26;

Eigenmann, 1907, Ann. Carnegie Mus., IV, 127; 
Eigenmann, 1910, Rept. Princeton Univ. Exped. Patagonia, III, 432;

Eigenmann, 1912, Mem. Carnegie Mus., V, 350;

Eigenmann, 1921, Mem. Mus. Comp. Zool., XLIII, iii, 227.

\section{Type: Astyanax argentatus Baird and Girard}

\section{Most of tropical America from Mexico to Patagonia}

Small, usually very small, tetragonopteroid, compressed, more or less elongated; premaxillary with two series of teeth, the first series with several teeth; mandible with strong teeth in front and very small or minute teeth laterally, and no teeth of conical form in the second series; maxillary with few teeth or none.

Anal fin short and moderate; caudal naked; lateral line complete; gill-rakers setiform; no predorsal spine, predorsal line sealed.

\section{Astyanax asymmetricus Eigenmann}

Astyanax asymmetricus Eigenmann, 1908, Bull. Mus. Comp. Zool., LII, 94;

Eigenmann, 1910, Rept. Princeton Univ. Exped. Patagonia, III, 432;

Eigenmann, 1921, \em. \Ius. Comp. Zool., XLIII, iii, 238, pl. xli, fig. 2.

\section{Tabatinga and Peruvian Amazon}

15885, 1, 52 mm., Rio Morona, Allen, October, 1920.

A. 26; scales 11-51-9. Except for this specimen, known from the three types collected by Bourget of the Agassiz expedition. Identifiable by the triangular, or spindle-shaped caudal spot, dividing the lobes.

\section{Astranax bimaculatus (Limaeus)}

Albula maculata Linnaeus, 175t, Mus. Adolphi Fred., 78, tab. xxxiii, fig. 2.

Charax no. 54 Gronow, 175t, Mus. Ichth., 19, tab. i, fig. 5.

Salmo bimaculatus Linnaeus, 1758, Syst. Nat., ed. x, I, 311;

Linnaeus, 1766, Syst. Nat., ed. xii, 513;

Bloch, 1794, Ausl. Fische, VIII, 110, taf. 382, fig. 2;

Bloch and Schneider, 1801, Syst. Ichth., 413.

Charax bimaculatus Gronow, ed. Gray, 185t, Syst. Ichth., $15 t$.

Tetragonopterus maculatus. Iüller and Troschel, 1845, Horae Ichth., I, 14, tab. iii, fig. 4.

Astyanax bimaculatus Fowler, 1906, Proc. Acad. Nat. Sci. Phila., LVIII, 432, Peruvian Amazon, etc.;

Eigenmann, 1910, Rept. Princeton Univ. Exped. Patagonia, III, 132;

Eigenmann, 1912, Mem. Carnegie Mus., V, 359;

Eigenmann, 1921, Mem. Mus. Comp. Zool., XLIII, iii, 249;

Pearson, 1924 (1925), Ind. Univ. Studies, no. 64, 40, Rio Beni;

Pearson, 1937a, Proc. Cal. Acad. Sci., (4), XXIII, 91, Puisoc and Paipay, upper Marañon;

Fowler, 1939 (1940), Proc. Acad. Nat. Sci. Phila., XCI, 263, one, 87 mm., Contamana.

Tetragonopterus bartlettii Günther, 1866, Ann. Mag. Nat. Hist., (3), XVIII, 30, upper Amazon;

Cope, 1871, Proe. Acad. Nat. Sci. Phila., XXIII, 260, Rio Ambyiacu.

Astyanax bartletti Fowler, 1906, Proc. Acad. Nat. Sci. Phila., LVIII, 343, fig. 31, Rio Ambyiacu.

Astyanax lacustris Fowler. 1906, Proc. Acad. Nat. Sci. Phila., LVIII, 433, Peruvian Amazon. 
Eastern ranges and piedmont of Peru and Bolivia, to the Magdalena and Argentina

13760, 60, largest about $95 \mathrm{~mm}$., Santa Ana, 3400 feet, Rio Urubamba, Edmund Heller.

A. 27-30; lateral line $35-37$.

, 90, up to $117 \mathrm{~mm}$., Perené valley, Lola E. Vance, clevation 2000.

Scales $6-8 ; 31-41 ; 5-7$; humeral spot somewhat elongated on three scales in the series along the lateral line and the next above that series, dark area surrounded by a pale one; caudal spot on peduncle and variably continued to end of middle caudal rays; variation considerable in respect to sex, age, environment, food-supply, but geographic rarieties independent of these factors.

15869, 33, 53-143 mm., Rio Chanchomayo, La Merced, Allen, June, 1920.

$15870,30,57-85 \mathrm{~mm}$, creek, Puerto Bermudez, Allen, July, 1920.

15871, 6, largest $110 \mathrm{~mm}$., Contamana, Allen, Alugust, 1920.

15872 , 3, 92-132 mm., mouth Rio Pacaya, Allen, August, 1920.

15873, 36, 40-112 mm., Puerto Melendez, Alto Marañon, Allen, October, 1920.

16046, 16057, many, 33-110 mm., Santa Ana, Rio Urubamba, Eigenmann, November, 1918.

16123, 1, 86 mm., Chumatagua creek, above Cayumba rapids, Allen, September, 1918.

Pearson has extended the known range to many localities in the basin of the Beni in Bolivia. The altitudinal range is considerable, and rather unusual, extending from the tropical flood plains such as the mouth of the Pacaya up to mountainous situations of at least 3000 feet.

\section{Astyanax longior (Cope)}

Tetragonopterus tongior Cope, 1878, Proc. Amer. Phil. Soe., XVII, 691, Moyobamba;

Eigenmann and Eigenmann, 1891, Proc. U. S. Nat. Mus., XIV, 53.

Astyanax longior Fowler, 1907, Proc. Acad. Nat. Sci. Phila., LVIII, 341, fig. 29, Moyobamba;

Eigenmann, 1910, Rept. Princeton Univ. Exped. Patagonia, III, 433;

Eigenmann, 1921, Mem. Mus. Comp. Zool., XLIII. iii. 282, pl, lxix, figs. 3 and 4; pl. lxxxv, fig. 2 .

\section{Huallaga and Marañon basins}

\section{Astyanax maximus (Steindachner)}

Tetragonopterus maximus Steindachner, 1875, Sitzb. KK. Akad. Wiss. Wien, LXXII, 43, pl. vii, Tullumayo; Monterico;

Steindachner, 1878, Sitzb. KK. Akad. Wiss. Wien, LXXVII, 384.

Astyanax maximus Fowler, 1906 (1907), Proc. Acad. Nat. Sci. Phila., LVIII, 3ł2, the Orton collection, Peruvian Amazon;

Eigenmann, 1910, Rept. Princeton Univ. Exped. Patagonia, III, 432;

Eigenmann, 1921, Mem. Mus. Comp. Zool., XLIII, iii, 289, pl. lxxxvii, figs. 1-3;

Pearson, 1937a, Proc. Cal. Acad. Sci., (4), XXIII, 91, upper Marañon.

Tetragonopterus alosa Günther, 1876, Ann. Mag. Nat. Hist., (4), XVII, 399, Monterico.

Tetragonopterus rutilus Starks (non Jenyns), 1906, Proe. U. S. Nat. Mis., XXX, 777, Rio Perené. 


\section{Mountain streams of eastern Peru}

13672, 1, 116 mm., Yahuarmayo, Peru, purchase.

16018, , Rio Azupizú, Allen, July, 1920.

16045, 14, 41-114 mm., Rio Urubamba, Santa Ana, Eigenmann, November, 1918.

16194, 2, 181 and $220 \mathrm{~mm}$., Rio Huallaga, below Cayumba rapids, Allen, October, 1918.

$17707,1,107 \mathrm{~mm}$., same data.

, 12, 97-133 mm., Moyobamba, Osgood and Anderson.

Humeral spot faint or undiscernible altogether; caudal spot large on peduncle, narrowing to end of middle rays; head 4.5 ; depth 2.5 ; D. 11 ; A. $\frac{28}{4}$, $\frac{30}{3}$; scales $7-8$; $38-40 ; 6$; eye 3.3 in the head, 1.5 in the interorbital; rakers $10+16$, lanceolate, slender, but little shorter than filaments which are $\frac{2}{3}$ the diameter of the eye.

\section{Astyanax fasciatus (Cuvier)}

Chalceus fasciatus Cuvier, 1819, Mém. Mus. Hist. Nat, V, 352, Brazil.

Tetragonopterus fasciatus Cuvier and Valenciennes, 18t8, Hist. Nat. Poiss., XXII, 149.

Astyanax fasciatus Fowler, 1906 (1907), Proc. Acad. Nat. Sci. Phila., LVIII, 346;

Eigenmann, 1907, Ann. Carnegie Mus., IV, 131;

Eigenmann, 1910, Rept. Princeton Univ. Exped. Patagonia, III, 433;

Eigenmann, 1921, Mem. Mus. Comp. Zool., XLIII, iii, 292, pl. xlv, figs. 1-7; pl. xlix, figs. 2 and 3 ; pl. i, fig. 2 ; pl. xev, fig. 1 .

Astyanax carolinae Gill, 1870, Proc. Acad. Nat. Sci. Phila., XXII, 92, Napo or Marañon basin, Orton collection.

Tetragonopterus rutilus Boulenger, 1887, Proc. Zool. Soc. London, 281, Canelos, Ecuador.

\section{Mexico to Patagonia}

\section{Astyanax abramis (Jenyns)}

Tetragonopterus abramis Jenyns, 1842, Zool. Beagle, Fishes, 123, pl. xxiii, fig. 1, Rio Paraná.

Tetragonopterus sp. (?) Cope, 1878, Proc. Amer. Phil. Soc., XVII, 691, Peruvian Amazon.

Astyanax abramis Fowler, 1906 (1907), Proc. Acad. Nat. Sci. Phila., LVIII, 439, Peruvian Amazon;

Eigenmann, 1910, Rept. Princeton Univ. Exped. Patagonia, III, 132;

Eigenmann, 1921, Mem. Mus. Comp. Zool., XLIII, iii, 248;

Pearson, 1924 (1925), Ind. Univ. Studies, no. 6t, 40, Rio Beni.

Orinoco basin to that of La Plata

Similar to $A$. bimaculatus, differing in scale number, having a count of $7-8$; $38-49$; 6-7; a silvery lateral band, a caudal spot, tapering to the ends of about four middle rays.

\section{Genus 97: CERATOBRANCHIA Eigenmann}

Ceratobranchia Eigenmann, 1914, Ind. Univ. Studies, no. 19, 3;

Eigenmann, 1927, Mem. Mus. Comp. Zool., XLIII, iv, 356.

\section{Type: Ceratobranchia obtusirostris Eigenmann \\ Central and southern Peru}

Premaxillary teeth in two parallel series, four in each; the tetragonopteroid outer series dominant; mandibular teeth graduated; caudal with basal third scaled; 
adipose prominent; origin of dorsal fin near middle of the body; second suborbital in contact with the preopercle beneath.

\section{Ceratobranchia obtusirostris Eigenmann}

Ceratobranchia obtusirostris Eigenmann, 1914, Ind. Univ. Studies, no. 19, t;

Eigenmann, 1927, Mem. Mus. Comp. Zool., XLIII, iii, 356, pl. Kxxyiii, figs. 2 and 3.

The Chanchomayo valley of Peru

13154, 1, $65 \mathrm{~mm}$., type, Chanchomayo valley, Rosenberg (purchased).

Elongate (depth 4.66 in the length); antler-like type of gill-rakers at the angle; humeral spot vertical, crossing the third and fourth scales of the lateral line; a dusky lateral band reaching to the ends of the middle rays of the caudal fin.

\section{Ceratobranchia binghami Eigenmann}

Ceratobranchia binghami Eigenmann, 1927, Mem. Mus. Comp. Zool., XLIII, iv, 357, pl. xevi, fig. 1.

$$
\text { Urubamba valley of southern Peru }
$$

13561, 13758, 27, Urubamba at Santa Ana and Rio Comberciato, Heller.

16049, many, 27-64 mm., Santa Ana, Rio Urubamba, Eigenmann, November, 1918.

Lacking the antlered character of the gill-rakers in obtusirostris, and teeth distinctly unlike.

\section{Genus 98: BRYCONAMERICUS Eigenmann}

Bryconamericus Eigenmann, 1907, Ann. Camegie Mus., IV, 139;

Eigenmann, 1927, Mem. Mus. Comp. Zool., XLIII, iv, 358.

\section{Type: Bryconamericus exodon Eigenmann Costa Rica to Argentina}

I am unable to separate this genus widely enough from its near allies such as Astyanax or Hemibrycon to warrant its removal to the subfamily Characinae in agreement with Gregory and Conrad. Small species not exceeding $132 \mathrm{~mm}$., most prevalent toward the northern extremity of the range. Lateral line complete; caudal naked; second suborbital in contact with lower limb of the preopercle, not leaving a naked triangle below the suture between the first and second suborbitals.

\section{Bryconamericus grosvenori Eigenmann}

Bryconamericus grosvenori Eigenmann, 1927, Mem. Mus. Comp. Zool., XLIII, iv, 365, pl. xcix, fig. 2.

The basin of the Rio Urubamba, southern Peru

$31562 \mathrm{MCZ}, 1,58 \mathrm{~mm}$., type, Rio Comberciato, Heller.

$7055 \mathrm{CM}, 13757 \mathrm{IU}, 16$, the largest $60 \mathrm{~mm}$., Rio Comberciato, Heller.

$7050 \mathrm{CM}, 13761 \mathrm{IU}, 9$, the largest $40 \mathrm{~mm}$., Santa Ana, Heller.

16048, 4, about 35-68 mm., creek, Rio Urubamba, Santa Ana, Eigenmann, November, 1918. 
There is confusion as to the origin of the type and as to the locality in which the Eigenmann specimens were collected: in the former case the text says the material was collected by Heller on the Comberciato while the legend with the figure gives Santa Ana as the type locality; in the case of 16048, the description, page 365 , assigns the specimens to Santa Clara, while the label in the bottle credits the specimens to Santa Ana.

\section{Bryconamericus diaphanus (Cope)}

Tetragonopterus diaphanus Cope (in part), 1878, Proc. Amer. Phil. Soc., XVII, 691, Orton collection from the Marañon;

Eigenmann and Eigenmann, 1891, Proc. U. S. Nat. Mus., XIV, 53.

Astyanax diaphanus Fowler, 1906 (1907), Proc. Acad. Nat. Sei. Phila., LVIII, 339, fig. 27.

Bryconamericus diaphanus Eigenmann, 1910, Rept. Princeton Univ. Exped. Patagonia, III, 434;

Eigenmann, 1927, Mem. Mus. Comp. Zool., XLIII, iv, 367.

The basin of the Marañon

The type, $40 \mathrm{~mm}$. long, is the only specimen known; part of the Orton collections at the Philadelphia Academy.

\section{Bryconamericus phoenicopterus (Cope)}

Tetragonopterus phoenicopterus Cope, 1871, Proc. Acad. Nat. Sci. Phila., XXII, 261, Rio Ambyiacu Hauxwell collection;

Eigenmann and Eigenmann, 1891, Proc. U. S. Nat. Mus., XIV, 54.

Astyanax phoenicopterus Fowler, 1907, Proc. Acad. Nat. Sci. Phila., LVIII, 338, fig. 26.

Bryconamericus phocnicopterus Eigenmann, 1910, Rept. Princeton Univ. Exped. Patagonia, III, 434;

Eigenmann, 1927, Mem. Mus. Comp. Zool., XLIII, iv, 373, pl. lxix, figs. 5 and 9; pl. lxxxv, fig. 3.

\section{Rio Ambyiacu}

The unique type specimen is at the Philadelphia Academy.

\section{Bryconamericus PACHACUTi Eigenmann}

Bryconamericus pachacuti Eigenmann, 1927, Mem. Mus. Comp. Zool., XLIII, iv, 376, pl. xcix, fig. 3.

\section{Urubamba basin of southern Peru}

31563 MCZ, 1, 74 mm., type, Santa Ana, Rio Urubamba, Heller. $7053 \mathrm{CM}, 13756 \mathrm{IU}, 70$, largest $75 \mathrm{~mm}$., paratypes, Santa Ana, Heller. $705+$ CM, 2, 46 and $52 \mathrm{~mm}$., Rio Comberciato, Heller.

16051, many, 38-81 mm., Urubamba, Santa Ana, Eigenmann, November, 1918.

\section{Bryconamericus caucanus Eigenmann}

Bryconamericus caucanus Eigenmann, 1913, Ind. Univ. Studies, no. 18, 17;

Eigenmann, 1922, Mem. Carnegie Mus., IX, 151;

Eigenmann, 1927, Mem. Mus. Comp. Zool., XLIII, iv, 387, pl. xxxviii, fig. 1; pl. lxxv, figs. 2,9 , and 11 ;

Pearson, 1937a, Proc. Cal. Acad. Sci., (4), XXIII, 91. 
Atlantic and Pacific drainage of Colombia to Marañon

Many specimens taken at Tingo de Pauca (upper Marañon) and the tributary Rio Crisnejas, down to Balsas. Close to B. peruanus of the western slopes of Peru and Ecuador, separated in space by the lowest passes of the middle Andes.

259. Bryconamericus osgood Eigenmann and Allen, sp. nov. Plate XIV, fig. 6

$15915,1,61 \mathrm{~mm}$. to end of middle caudal rays, Moyobamba, W. H. Osgood, July, 1912.

Near $B$. alpha, beta, and caucamus, having seven scales where they have six.

Head 4.33 ; depth 2.5 ; D. 10 ; A. 28-29; eye more than 3 ; interorbital 3 ; scales $7 ; 39 ; 5.5$ or 6.5 ; erect, depth 2.7 in length without the caudal; compressed; dorsal and ventral contours convex, the ventral the deeper; slight depression above the occipital; elongate caudally, depth of peduncle $1.3 \mathrm{in}$ its length.

Maxillary teeth 4 ; premaxillary $4-4$; maxillary bone nearly equal to eye.

Anal fin broad, its rays short, its base 3.4 in length of fish; origin of dorsal equidistant from snout and base of caudal, in front of anal, its first ray equal to head; pectoral triangular, its first ray nearly equal to first dorsal ray, and reaching to end of first third of ventral; ventrals small, only slightly longer than their distance from the origin of the anal; caudal forked deeply, the ventral lobe slightly longer.

Lateral line slightly decurved; scales cycloid and very regular, even over the rounded preventral and predorsal ridges; sheath over base of cephalic half of anal fin.

Colors obscured and not well preserved; a small dusky area across nape, another four scale-rows wide obliquely upward from distal end of pectoral; a third about four rows wide from base of dorsal to base of anal; and a fourth band from middle of anal upward. A dusky spot at upper ends of first 3 dorsal rays; pectoral and ventrals apparently uniformly dark; anterior half of anal with longer rays and darker; middle caudal rays and nodes dark.

To W. H. Osgood, who collected the type.

\section{Bryconamericus alfredae Eigenmann}

Bryconamericus alfredae Pearson, 1924, Ind. Univ. Studies, no. 64, 43 (nom. nud.);

Eigenmann, 1927, Mem. Mus. Comp. Zool., XLIII, iv, 394, pl. xcix, fig. 1;

Pearson, 1937a, Proc. Cal. Acad. Sci., (1), XXIII, 91, Rio Crisnejas.

Upper Maranon to Urubamba and Beni basins

"It is possible that this is the young of Acrobrycon ipanquianus, which is known from specimens twice as long as the largest of these." Larger specimens have about 12 weak teeth, conical or tricuspid, along the greater part of the maxillary border; in the young the more distal teeth are wanting. A. ipanquianus has 8-9 maxillaries.

Genus 99: BRYCONACIDNUS Myers

Bryconacidnus Myers, in Eigenmann and Myers, 1929, Mem. Mus. Comp. Zool., XLIII, v, suppl., 545 . 
Type: Hyphessobrycon ellisi Pearson

Beni basin, Bolivia, and the Chanchomayo, central Peru

"This genus is Bryconamericus with incomplete lateral line."

\section{Bryconacidnus ellisi (Pearson)}

Hyphessobrycon ellisi Pearson, 1924 (1925), Ind. Univ. Studies, no. 64, 39.

Bryconacidnus ellisi Myers, in Eigenmann and Myers, 1929, Mem. Mus. Comp. Zool., XLIII, v, 545.

Rios Beni and Chanchomayo

2, 25 and 26 mm., Rio Chanchomayo, La Merced, Allen, June, 1920.

The material on which this species is founded was collected from several localities in the Beni by Dr. Pearson, on the Mulford Expedition, and two specimens were taken by Allen at La Merced. The absence of collections from intermediate points may be due to the lack of thorough exploration in the upper tributaries of the Madre de Dios, Alto Ucayali, and adjacent territory.

Genus 100: CREAGRUTUS Günther

Creagrutus Günther, 1864, Cat. Fish. Brit. Mus, V, 339;

Eigenmann, 1910, Rept. Princeton Univ. Exped. Patagonia, III, 435;

Eigenmann, 1912, Mem. Carnegie Mus., V, 347;

Eigenmann, 1927, Mem. Mus. Comp. Zool., XLIII, iv, 417.

\section{Type: Creagrutus mülleri Günther}

\section{Colombia to Guiana, Rio Tocantins, and Bolivia}

Small fishes similar to Astyanax and Bryconamericus, with mouth and anal fin unlike; mandibulars in a single series and the premaxillaries in three series; anal short, having not more than 14 rays; lateral line complete and caudal fin naked.

\section{Creagrutus peruanus (Steindachner)}

Piabina peruana Steindachner, 1875, Sitab. KK. Akad. Wiss. Wien, LXXII, 46, Monterico. Creagrutus peruanus Steindachner, 1878, Sitzb. KK. Akad. Wiss. Wien, LXXVII, 6;

Steindachner, 1882 (1883), Denksch. KK. Akad. Wiss. Wien, XLVI, 25, Rio Huambo;

Eigenmann and Eigenmann, 1891, Proc. U. S. Nat. Mus., XIV, 56;

Eigenmann, 1910, Rept. Princeton Univ. Exped. Patagonia, III, 435;

Eigenmann, 1927, Mem. Mus. Comp. Zool., XLIII, iv, 420, pl.xxxv, figs. 4 and 5.

Creagrutus nasutus Günther, 1876, Ann. Mag. Nat. Hist., (4), XVII, 400.

\section{Atlantic streams of Peru}

16050 , Rio Urubamba, Eigenmann, 1918.

16050, 2, 45 and $53 \mathrm{~mm}$., Santa Ana, Heller.

$13759,27,45-85 \mathrm{~mm}$., Rio Comberciato, Heller.

ㄴ, 19, 57-93 mm., Rio Chanchomayo, La Merced, Allen, June, 1920. 
263. Creagrutus iüLleri (Gïnther)

Leporinus mülleri Günther, 1859, Proe. Zool. Soc. London, 92.

Creagrutus mülleri Günther, 186t, Cat. Fish. Brit. Mus., V, 339;

Boulenger, 1887, Proc. Zool. Soc. London, 281;

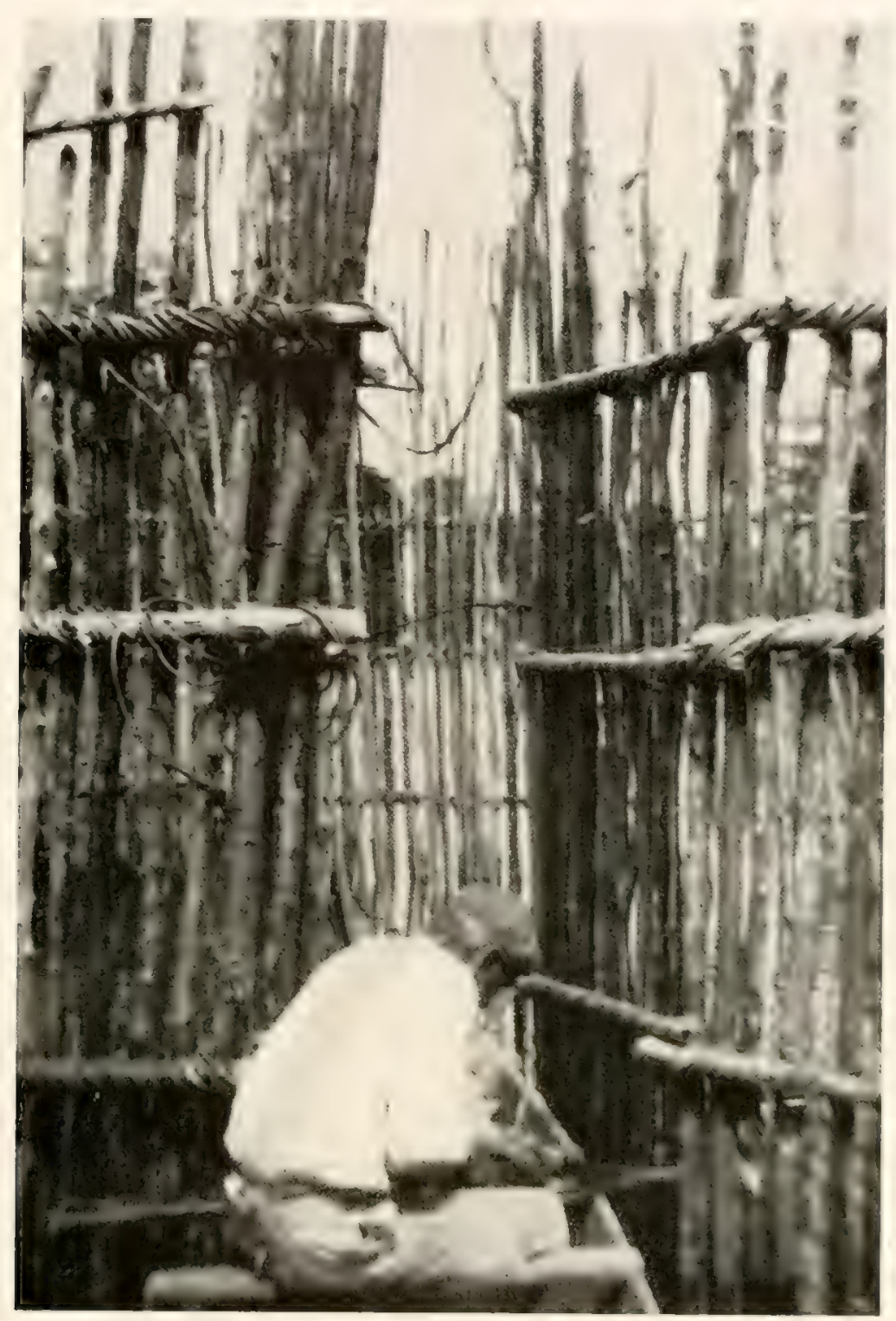

FIG. 26. Entrance to the pound. The one-way door is suspended by lianas so as to close the vestibule within. Fishes trapped in the pound are removed by gigging.

Eigenmann and Eigenmann, 1891, Proc. U. S. Nat. Mus., XIV, 56;

Eigenmann, 1910, Rept. Princeton Univ. Exped. Patagonia, III, 435;

Eigenmann, 1927, Mem. Mus. Comp. Zool., XLIII, iv, 420, pl. xxxy, figs. 6 and 7 .

Canelos to the Cauca basin 


\section{Creagrutus beni Eigenmann}

Creagrutus beni Eigenmann, 1912, Ann. Carnegie MIus., VIII, 172;

Eigenmann, 1927, Mem. Mus. Comp. Zool., XLIII, iv, 421, pl. Iviii, fig. 3; pl. xciii, figs. 4, 5 and 7 ;

Pearson, 1924, Ind. Lniv. Studies, no. 64, 45, Rio Beni;

Pearson, 1937 a, Proc. Cal. Acad. Sci., (4), XXIII, 92.

Rio Beni to Colombia, Venezuela, and Rio Tocantins

17600, 29, 43-74 mm., Balsas, upper Marañon, Pearson, 1922.

17601, 12, 31-70 mm., Tingo de Pauca, upper Marañon, Pearson, 1922.

17602, 83, 28-56 mm., Paipay, Rio Crisnejas, Pearson, 1922.

\section{Genus 101: MICROGENYS Eigenmann}

Microgenys Eigenmann, 1913, Ind. Lniv. Studies, no. 18, 22;

Eigenmann, 1927, Mem. Mus. Comp. Zool., XLHI, iv, 353.

\section{Type: Microgenys minutus Eigenmann \\ Upper Cauca and upper Marañon}

"Allied to Creagrutus and Bryconamericus, having the anal like the former, and the teeth like the latter."

\section{Microgenys lativirgatus Pearson}

Microgenys lativirgatus Pearson, in Eigenmann, 1927, Mem. Mus. Comp. Zool., XLIII, iv, 355;

Pearson, 1937a, Proc. Cal. Acad. Sci., (t), XXIII, 91.

Rio Pusoc, Upper Marañon, northern Peru

17642, 4, cotypes, 56-71 mm., Rio Pusoc, Balsas, Pearson, 1922.

\section{Genus 102: CTENOBRYCON Eigemmann}

Ctenobrycon Eigenmann, 1908, Bull. Mus. Comp. Zool., LII, 94;

Eigenmann, 1910, Rept. Princeton Unir. Exped. Patagonia, III, 435;

Eigenmann, 1912, Mem. Carnegie Nus,, V, 362;

Eigenmann, 1927, \Iem. MIus. Comp. Zool., XLIII, iv, 330.

\section{Type: Tetragonopterus hauxwellianus Cope}

\section{Rio Paranahyba and Amazons northward}

Separable from other tetragonopterines by its ctenoid scales, the cycloid scales on the sides of the young becoming ctenoid with age; compressiform; anal long, margin nearly straight; mouth very small, maxillary not reaching the eye; lateral line complete, a long tubular structure extended along the membrane of the midcaudal; the latter naked. Maxillary teeth $2-9$; a series of tricuspids on the premaxillary, and an inner series of 5-pointed ones, whose denticles are arranged in a $\mathrm{U}$-shape, the premaxillaries in parallel series. 


\section{Ctenobrycon hauxwellianus (Cope)}

Tetragonopterus hauxucllianus Cope, 1870, Proc. Amer. Phil. Soc., XI, 560, Pebas, collected by Hauxwell:

Cope, 1878, Proc. Amer. Phil. Soc., XVII, 691, Peruvian Amazon, Orton collection. Astyanax hauxucllianus Fowler, 1906 (1907), Proc. Acad. Nat. Sci. Phila., LVIII, 340, fig. 28.

Ctenobrycon hauxwellianus Eigenmann, 1910, Rept. Princeton Univ. Exped. Patagonia, III, 435;

Eigenmann, 1927, Mem. Mus. Comp. Zool., XLIII, iv, 331, pl. xxxii, fig. 2; pl. xcviii, fig. 7;

Fowler, 1939 (1940), Proc. Acad. Xat. Sci. Phila., XCI, 264, one, $80 \mathrm{~mm}$. long, lower Ueayali, at Boca Chica.

\section{The Amazons to Paraguay and Bolivia}

15874, 5, 47-63 mm., Rio Ucayali, Contamana, Allen, August, 1920.

$15875,34,33-63 \mathrm{~mm}$., same data.

$15876,1,56 \mathrm{~mm}$., Yarinacocha, Allen, August, 1920.

15882, 1, $65 \mathrm{~mm}$., mouth Rio Pacaya, Allen, September, 1920.

15883, 4, 37-60 mm., Gosulimacocha, Allen, October, 1920

15884, 10, 36-59 mm., creek, Yurimaguas, Allen, November, 1920.

Occurring in great abundance in certain localities; more than fifty taken by Bourget at Tabatinga, fifty-nine by Orton, numerous specimens by Pearson in the Beni.

Compressed extremely; dorsal profile with "a distinct hump"; ventral profile arched extremely and regularly, deepest point at the origin of the anal; the anal basis straight. Silvery lateral band interrupted by a faint vertical humeral spot about the 4 th or 5 th lateral line scale. Preventral scales serrate. Rakers on lower part of first arch appear to be ten in number and of less length than the corresponding gill-filaments.

\section{Genus 103: HEMIGRAMNUS Gill}

Hemigrammus Gill, 1858, Ann. Lye. Nat. Hist. N. Y., VI, 416;

Eigenmann, 1910, Rept. P'rinceton Unir. Exped. Patagonia, III, 435;

Eigenmann, 1912, Mem. Carnegie Mus., I , 331;

Eigenmann, 1918, Mem. Mus. Ccmp. Zool, XLIII, ii, 135.

Type: Poecilurichthys unilineatus Gill

Orinoco, Trinidad, Guiana southward to Paraguay

Fishes small to minute in size; premaxillary teeth in two rows; maxillary teeth wanting, or at least reduced in number and restricted to the upper part of its free margin; lateral line incomplete; caudal scaled; a genus of uncertain boundaries and rapid evolution at the present time.

\section{Hemigramus schmardae (Steindachner)}

Tetraganopterus schmardae Steindachner, 1882 (1883), Denksch. KK. Akad. Wiss. Wien, XLVI, 37 , pl. vii, fig. 6, 'Tabatinga;

Eigenmann and Eigenmann, 1891, Proc. U. S. Nat. Mus., XIV, 54.

Hemigrammus schmardae Fowler, 1906 (1907), Proc. Acad. Nat. Sci. Phila., LVIII, 335, Peruvian Amazon; 
Eigenmann, 1910, Rept. Princeton Unir. Exped. Patagonia, III, 436;

Eigenmann, 1918, Mem. Mus. Comp. Zool., XLIII, ii, 163, pl. xx, fig. 2; pl. 1xxviii, fig. 1.

Amazons

\section{Hemigramuus paipayensis Pearson}

Hemigrammus paipayensis Pearson, in Eigenmann and Myers, 1929, Mem. Mus. Comp. Zool., XLIII, suppl., 533, upper Marañon;

Pearson, 1937a, Proc. Cal. Aead. Sci., (t), XXIII, 91.

Upper Marañon basin

A border species lying between Hemigrammus or Bryconamericus on the one hand and Knodus on the other, having characters pertaining to all three, in some individuals irregular. Nyers in a footnote, page 534, throws doubt upon its being a Hemigrammus species. Dr. Pearson points out that the scales are larger than usual in the above group of genera; the second suborbital in contact with the preopercle below; the lateral line may be considered complete, and if so, and the caudal scaled, it is a Hemigrammus.

269. Hemgramus pulcher Ladiges

Hemigrammus pulcher Ladiges, 1938, Zool. Anz., CXXIV, 49.

\section{Peruvian Amazon}

\section{Genus 104: HYPHESSOBRYCON Durbin}

Hyphessobrycon Durbin, 1908, Bull. Mus. Comp. Zool., LII, 100;

Eigenmann, 1910, Rept. Princeton Univ. Exped. Patagonia, III, 436;

Eigenmann, 1912, \em. Carnegie \us., V, 338;

Eigenmann, 1918, \Iem. Mus. Comp. Zool., XLIII, ii, 172.

Type: Hemigrammus compressus Meek

Mexico to Paraguay and Rio São Francisco

Separated from Hemigrammus on the lack of caudal seales.

270. Hyphessobricon SP.

1591., 9, 34-4t mm., Noyobamba, W. H. Osgood, July, 1912.

\section{Hyphessobrycon Robustulus (Cope)}

Hemigrammus robustulus Cope, 1870, Proc. Amer. Phil. Soc., XI, 561, Pebas, Hauxwell collection;

Cope, 1878, Proc. Amer. Phil. Soc., XVII, 690, Peruvian Amazon, the Orton Collection;

Fowler, 1906 (1907), Proc. Acad. Nat. Sci. Phila., LVIII, 335, fig. 24, Pebas and Rio Marañon.

Tetragonopterus robustulus Eigenmann and Eigenmann, 1891, Proc. U. S. Nat. Mus., XIV, 54.

Hyphessobrycon robustulus Eigenmann, 1910, Rept. Princeton Univ. Exped. Patagonia, III, 437;

Eigenmann, 1918, Mem. Mus. Comp. Zool., XLIII, ii, 195.

\section{Peruvian Amazonia}




\section{Hyphessobrycon INNESI Myers}

Hyphessobrycon innesi Myers, 1936, 1'roc. Biol. Soc. Wash., XLLIX, 97

A single specimen, adult female, $22 \mathrm{~mm}$., from a shipment of live fishes via Paris to Mr. W. T. Innes, of Philadelphia. Supposedly from near Iquitos.

273. Hyphessobrycon LORETOENSIS Ladiges

Iyphessobrycon loretoensis Ladiges, 1938, Zool. Anz, CXXIT, 51.

Peruvian Amazon, locality not stated

274. Hrphessobricon PERUVianus Ladiges

Hyphessobrycon peruianus Ladiges, 1938, Zool. Anz., CXXIV, 50.

Peruvian Amazon, locality unknown

Genus 105: MOENKHAUSIA Eigenmann

Moenkhausia Eigenmann, 1903, Smithsonian Misc. Coll., XLV, 145;

Eigenmann, 1910, Rept. Princeton Univ. Exped. Patagonia, III, 437;

Eigenmann, 1912, Mem. Camegie Mus., V, 320;

Eigenmann, 1917, \em. Mus. Comp. Zool., XLIII, i, 65.

Type: Tetragonopterus xinguensis Steindachner

Amazonia to the Guianas, Paraná, Paraguay and Doce

Tetragonopterines of small size with lateral line only slightly decurved or not at all; separable from Hemigrammus by the complete lateral line and from Astyanax on the finely scaled caudal; two series of notched scales on the premaxillary; the maxillary with few teeth.

\section{Moenkhausia oligolepis (Günther)}

Tetragonopterus taeniatus (non Jenyns) Müller and Troschel, 1848, in Schomburgk, Reisen, III, 635. Tetragonopterus oligolepis Günther, 1864, Cat. Fish Brit. Mus., V, 327;

Eigenmann and Eigenmann, 1891, Proc. U. S. Nat. Mus., XIV, 53.

Astyanax oligolepis Fowler, 1906, Proc. Acad. Nat. Sci. Phila., LXVIII, 438, fig. 37, Peruvian Amazon, Orton collection.

Moenkhausia oligolepis Eigenmann, 1910, Rept. Princeton Univ. Exped. Patagonia, III, 437;

Eigenmann, 1912, Mem. Carnegie Mus., V, 321, pl. xlvi, fig. 3;

Eigenmann, 1917, Mem. Mus. Comp. Zool., XLIII, i, 79, pl. vii, fig. 4; pl. xer, fig. 4; pl. c, fig. 5 .

Tetragonopterus agassizii Steindachner, 1876, Sitzb. KK. Akad. Wiss. Wien, LXXIV, 41, pl. viii, fig. 2, Tabatinga and Brazil;

Cope, 1878, Proc. Amer. Phil. Soc, XVII, 691, Marañon;

Eigenmann and Eigenmann, 1891, Proc. U. S. Nat. MIus., XIV, 53.

The basin of the Marañon to the Guianas

Separable from nearby species by its greater length, 29-32 lateral line scales, five between lateral line and dorsal, $3 \frac{1}{2}-4$ rows ventral to lateral line; a broad, black band across the entire width of the caudal fin. 


\section{Moenkhausia atahualpiana (Fowler)}

Astyanax atahualpianus Fowler, 1906 (1907), Proc. Acad. Nat. Sci. Phila., LVIIT, 436, fig. 36, Pebas, Orton collection of 1877.

Moenkhausia atahualpiana Eigenmann, 1910, Rept. Princeton Univ. Exped. Patagonia, III, 437. Moenkhausia oligolepis (in part) Eigenmann, 1917, Mem. Mus. Comp. Zool., XLIII, i, 79, Pebas.

\section{Rio Marañon}

\section{Moenkhausia bondi (Fowler)}

Phenacogaster bondi Fowler, 1911, Proc. Acad. Nat. Sci. Phila., 419.

Moenkhausia prof unda Eigenmann, 1912, Mem. Carnegie Mus., V, 322.

Moenkhausia bondi Eigenmann, 1917, Mem. Mus. Comp. Zool., XLIII, i, 69, pl. xiv, fig. 3; pl. c, fig. 7 .

\section{Caribbean coast to Para and Peru}

15878, 28, 32-75 mm., brook, Rio Itaya, Iquitos, Allen, September, 1920.

15881, about 70, 30-75 mm., ponds, brooks, Iquitos, Allen, September, 1920.

15885, 9, 48-53 mm., creek, Yurimaguas, Allen, November, 1920.

Much compressed; depth considerably more than half the length; ventral profile an almost perfect arc; a humeral band followed by a faint band of lighter color, and that by a faint band of dark color. Close to Ephippicharax except for the absence of a movable predorsal spine. Our records extend the known distribution some two thousand miles.

\section{Moenkhausia simulata Eigenmann and Pearson}

Astyanax simulatus Eigenmann, in Pearson, 1924 (1925), Ind. Univ. Studies, no. 64, 41.

Mocnkhausia simulata Eigenmann and Pearson, in Eigenmann and Myers, 1929, Mem. Mus. Comp. Zool., XLIII, v, suppl., 523, pl. lvii, fig. 3.

\section{Basin of Rio Pichis}

15860, 10, type and paratypes, 35-72 mm., creek, Puerto Bermudez, Rio Pichis, Allen, July, 1920.

Known only from this clear stream entering the Pichis, which is usually muddy, at the head of launch navigation and the end of the "Pichis trail" and the foot of the "Cadena de la Sal".

Alluded to under the name Astyanax simulatus by Pearson, 1924; finally described by Eigenmann and Pearson in Myers' supplement to Eigenmann and Myers, Part V of The American Characidae.

Near Moenkhausia latissima, differing most strikingly in the almost complete suppression of the humeral spot, which is vertical, and in the much more pronounced longitudinal stripes in the middle of the scale rows, while in latissima they are much broken and follow the boundaries of the scale rows. The caudal is but slightly scaled.

Suggests Bario steindachneri in coloration, but is readily separable by the small size of the nuchal scale, absence of crenulations on the scales, and the unbroken character of the stripes. No caudal spot, or at most an indistinct one. 
Head $3.5-3.8$; depth 2.2 ; D. 10-11; A. 30-32; scalation 4.5-5, 32-35, 4.5-5.5; eye $2.3-2.7$; interorbital $2.3-2.5$.

Deep, very compressed, dorsal and ventral profiles about equal, concave over eye, ventral with very uniform curvature. Predorsal region sharply ridged and covered with a median series of scales, 10-12, bent saddlewise. Occipital process rather erect, with sides curved inward, about equal to eye; a median series of scales, about 9 , not so sharply ridged, separating dorsal and adipose fins, and over the short caudal peduncle a more rounded series of about $4-6$; preventral well rounded; postventral trenchant, keeled, with few or no median scales.

Dorsal fin but slightly notched into profile, about equal to head; its origin two scales in front of vertical from anus and about equidistant from snout and base of upper caudal rays; pectoral smaller by about a pupillary diameter, reaching to end of the first fourth of the ventral fins; ventrals smaller by about the diameter of the eye, but reaching to within less than two scales the origin of the anal; anal exceeds the head length by about the diameter of the eye, its rays moderate in length, the first about double the last, its origin on the vertical from the last dorsal ray; caudal moderately furcate.

Premaxillary teeth four, the third weak, near the second, and out of line; six teeth in the second series; four mandibular teeth, larger, and several smaller.

Scale rows even and rather uniform in size; scales entire, faintly rayed, with scattered chromatophores. Ground color in alcohol a rusty brass, brighter and more uniform than in Bario steindachneri, and less dusky dorsally; nine or ten longitudinal, mahogany-colored stripes, strongest near lateral line, more interrupted and shorter both dorsally and ventrally; stripes follow the middle of the scale-rows, that of the lateral line broken into a series of equality-signs; base of membrane between anal rays strongly pigmented and somewhat concealed by a sheath of scales; elsewhere the fins only slightly pigmented, especially along rays, and on the middle of the caudal fin; faint trace on some specimens of humeral and caudal spots.

\section{Moenkhausia coma Eigenmann}

Moenkhausia comma Eigenmann, 1908, Bull. MIus. Comp. Zool., LII, 102, two, Cudajas;

Eigenmann, 1910, Rept. Princeton Univ. Exped. Patagonia, III, 437;

Eigenmann, 1917, Mem. Mus. Comp. Zool., XLIII, i, 77, pl. vi, fig. 2.

Marañon basin and Cudajas, Brazil

15879 and 15880, 2, 67 and 49 mm., brook, Iquitos, Allen, September, 1920.

Known from the above four specimens and two localities.

\section{Moenkhausia crisnejas Pearson}

Moenkhausia crisnejas Pearson, in Eigenmann and Myers, 1929, Mem. Mus. Comp. Zool., XLIII, v, suppl., 524, Paipay, Rio Crisnejas;

Pearson, 1937a, Proc. Cal. Acad. Sci., (4), XXIII, 91. 
The upper, or intercordilleran, Marañon

"A Knodus but for the nature of the second suborbital."

Base of caudal scaled, scales rather large and extending back along the middle of the caudal lobes; lateral line complete; second suborbital not in contact with the preopercle below, leaving a wide naked area.

\section{Moenkhausia ovalis (Günther)}

Tctragonopterus ovatis Günther, 1868, Proc. Zool. Soc. London, 245, one foul-inch specimen from the Bartlett collection, Xeberos;

Eigenmann and Eigenmann, 1891, Proc. U. S. Nat. Mus., XIV, 53;

Fowler, 1906, Proc. Acad. Nat. Sci. Phila., 441, fig. 38, Marañon;

Regan, 1913, Ann. Mag. Nat. Hist, (8), VIII, 281, Rio Ucayali.

Tetragonopterus chalceus in part, Cope, 1878, Proc. Amer. Phil. Soc, XVII, 691, Rio Marañon.

Moenkhausia ovalis Eigenmann, 1910, Rept. Princeton Univ. Exped. Patagonia, III, 437;

Eigenmann, 1917, Mem. Mus. Comp. Zool., XLIII, i, 87, pl. vii, fig. 3.

\section{Marañon basin}

Depth 2; maxillary with two teeth and extending beyond anterior margin of eye; dorsal contour slightly convex and only slightly depressed at the head; a faint humeral spot; a caudal spot not reaching end of middle caudal rays, diffuse; iris reddish brown.

\section{Genus 106: KNODUS Eigenmann}

Knodus Eigenmann, 1911, Ann. Mag. Nat. Hist., (8), VII, 216;

Eigenmann, 1918, Mem. Mus. Comp. Zool., XLIII, ii, 114.

\section{Type: Knodus meridae Eigenmann}

Rios Tapajos, Tocantins and Paraguay to Venezuela

Near Moenkhausia; second suborbital reaching preopercle below; four teeth in the second row of the premaxillary; caudal scaled at the base; lateral line slightly decurved.

\section{Knodus moenkhausi (Eigenmann and Kennedy)}

Poecilurichthys moenhhausii Eigenmann and Kennedy, 1903, Proc. Acad. Nat. Sci. Phila., 522, Arroyo Trementina.

Bryconamericus moenkhausii Eigenmann, 1910, Rept. Princeton Univ. Exped. Patagonia, III, 434. Knodus moenkhausii Pearson, 1937a, Proc. Cal. Acad. Sci., (4), XXIII, 91, Rio Pusoc, upper Marañon.

\section{Upper Amazon to Middle}

\section{KNODUS BREVICEPS (Eigenmann)}

Bryconamericus breviceps Eigenmann, 1908, Bull. Mus. Comp. Zool., LII, 105, Goyaz;

Eigenmann, 1910, Rept. Princeton Univ. Exped. Patagonia, III, 434.

Knodus breviceps Eigenmann, 1918, Mem. Mus. Comp. Zool., XLIII, ii, 118, pl. x, fig. 2;

Pearson, 1937a, Proc. Cal. Acad. Sci., (4), XXIII, 91, Tingo de Pauca and Rio Pusoc, upper Marañon. 


\section{KNodus Megalop's Myer's}

Knodus megalops Myers, in Eigenmann and Myers, 1929, Mem. Mus. Comp. Zool., XLIII, v, suppl., 527.

Rio Pichis, Oriental Peru

17668, 1, type, 59 mm., Puerto Bermudez, Rio Pichis, Allen, July, 1920.

\section{Genus 107: BARIO Myers}

Tetragonopterus (in part) Cuvier, 1817, Règne Anim., II, 166, argenteus.

Entomolepis Eigenmann, 1917, Mem. Mus. Comp. Zool., XLIII, i, 63, preoccupied.

Bario Myers, 1940, Stanford Ichth. Bull., II, 1, suppl., 35.

\section{Type: Tetragonopterus steindachneri Eigenmann \\ Peruvian and Middle Amazons}

Caudal scaly; lateral line complete and but little curved; scales crenate; one scale enlarged on either side of occipital process; maxillary with few teeth; second suborbital withdrawn so as to leave a narrow naked area on the cheek.

Differing from Moenkhausia chiefly in the crenate scales.

\section{Bario steindachneri (Eigenmann)}

Tetragonopterus lincatus Steindachner (non Perugia), 1891, Sitzb. KK. Akad. Wiss. Wien, C, 368 pl. ii, fig. 1, Iquitos, four, $110 \mathrm{~mm}$.

T'etragonopterus steindachneri Eigenmann, 1893, Proc. U. S. Nat. MIus., XVI, 53.

Moenkhausia steindachneri Eigenmann, 1910, Rept. Princeton Univ. Exped. Patagonia, III, 437.

Entomolepis steindachneri Eigenmann, 1917, Mem. Mus. Comp. Zool., XLIII, i, 64, pl. v, fig. 1, Peruvian Amazon.

Bario steindachneri Myers, 1940, Stanford Ichth. Bull., II, 1, 35.

\section{Middle and Alto Amazonas}

15750, 35, 63-110 mm., brook, Rio Itaya, near Iquitos, Allen, September, 1920.

Distinguished by the crenulations of the scales, compressed line of the preventral, and peculiar coloration.

A general silvery body color tinged with saffron, becoming brownish above; a faint humeral spot above the fourth scale of the lateral line; a series of dark longitudinal lines between the series of scales; a large caudal blotch not reaching the ends of the middle caudal rays.

The illustration of the species mentioned above is erroneously labeled (1917, Mem. Mus. Comp. Zool., XLIII, i, pl. v). The figure which belongs with Bario steindachneri is no. 1, and should be so indicated; plate v, fig. 3 should be Moenkhausia jamesi.

\section{Genus 108: TETRAGONOPTERUS Cuvier}

Tetragonopterus Artedi, Seba, 1758, Locupl. Rerum, III, pl. xxxiv, fig. 3, argenteus; Cuvier, 1817, Règne Anim., II, 166, argenteus;

Eigenmann, 1910, Rept. Princeton Univ. Exped. Patagonia, III, 438;

Eigenmann, 1912, Mem. Carnegie Mus., V, 319;

Eigenmann, 1917, Mem. Mus. Comp. Kool., XLIII, i, 54. 


\section{Type: Tetragonopterus argenteus Cuvier \\ Guianas to Orinoco, Rio de Janeiro, and La Plata basin}

Depth half the length or greater; occipital region elevated, with profile depressed at eye; premaxillary teeth in two rows, the outer series small, regular, inner series longer, multicuspid, graduated, the cusps of each tooth forming a curved figure, the middle cusp much the most elevated; several large, graduated, pointed teeth in the mandible at the middle, becoming abruptly minute at the sides; maxillary toothed or not at its upper, anterior edge. Preventral area flat, bounded by sharp angles; breast with a median series of scales.

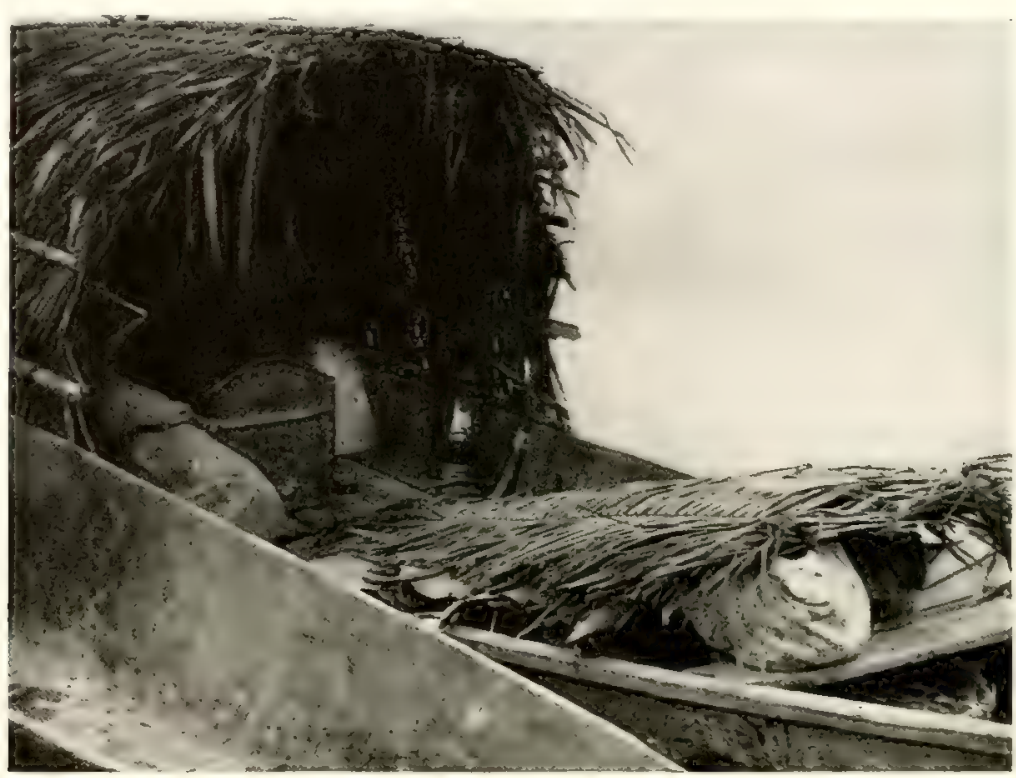

FIG. 27. An equipage suitable for a somewhat nomadic bachelor. He had named it the "Thime Is Money." The boat and its owner were helpful in assembling the collections made about the Rio Pacaya.

\section{Tetragonopterus argenteus Cuvier}

Tetragonopterus argenteus Cuvier, 1818, Mém. Mus. Hist. Nat., IV, 455;

Cuvier and Valenciennes, 1818, Hist. Nat. Poiss., XXII, 132;

Günther, 1864, Cat. Fish. Brit. Mus., V, 318;

Steindachner, 1882 (1883), Denksch. KK. Akad. Wiss. Wien, XLVI, 13, Amazon, Iquitos, two specimens;

Eigenmann and Eigenmann, 1891, Proc. U. S. Nat. Mus., XIV, 52;

Eigenmann, 1910, Rept. Princeton Univ. Exped. Patagonia, III, 438;

Eigenmann, 1912, Mem. Carnegie Mus., V, 319;

Eigenmann, 1917, Mem. Mus. Comp. Zool., XLIII, i, 55, pl. ii, fig. 1; pl. iv, fig. 2;

Fowler, 1939 (1940), Proc. Acad. Nat. Sci. Phila., XCI, 263, five.

Orinoco basin to that of the Plata

15615, 1, 97 mm., Lago Sanango, Allen, November, 1920.

15616, 5, 47-88 mm., Rio Morona, Allen, October, 1920.

15617, 2, 103 and $116 \mathrm{~mm}$., Alto Marañon, Allen; Oetober, 1920. 
15732, 4, 88-136 mm., Rio Huallaga, Yurimaguas, Allen, Yovember, 1920.

$15801,10,79-112 \mathrm{~mm}$., mouth Rio P'acaya, Allen, August, 1920.

$15861,5,47-120 \mathrm{~mm}$., Rio Ucayali, Contamana, Allen, August, 1920.

15862, 1, 114 mm., Puerto Bermudez, Rio Pichis, Allen, July, 1920.

15863, 4, 100-118 mm., Iquitos, Allen, September, 1920.

15864, 2, 86 and $105 \mathrm{~mm}$., brook, Rio Itaya, Allen, September, 1920.

15865, 5, 6t-77 mm., Lago Cashiboya, Allen, August, 1920.

15866, 7, 85-142 mm., Rio Pachitea, Allen, July, 1920.

15867, 3, 106-142 mm., Rio Ucayali, Orellana, Allen, August, 1920.

15868, 11, 65-11t mm., Yarinacocha, Allen, August, 1920.

, 3, $12-110 \mathrm{~mm}$., Iquitos, Morris, 1922.

Of extreme depth, 1.6-1.8 in the length; two humeral bars usually distinct, and at least faintly seen. Rare in the Guianas and wanting in coastal streams.

\section{Tetragonopterus chalceus Agassiz}

Coregonus amboinensis Artedi, 1738, Spec. Pisc., 44.

Tetragonoplerus chalceus Agassiz, 1829, Sel. Gen. et Spec. Pise. Bras., 70, tab. xxxiii, fig. 1;

Cuvier and Valenciennes, 18 18, Hist. Nat. Poiss., XXII, 140;

Günther, 1861, Cat. Fish. Brit. Mus., V, 320;

Cope, 1871, Proc. Acad. Nat. Sci. Phila., XXIII, 260, R. Ambyiacu;

Cope, 1878, Proc. Amer. Phil. Soc., XVII, 691, Peruvian Amazon:

Fowler, 1906, Proc. Acad. Nat. Sci. Phila., LVIII, 440, Rio Ambyiacu, Pebas, the Hauxwell, Perkins, Orton collections;

Eigenmann, 1910, Rept. Princeton Univ. Exped. Patagonia, III, 438;

Ligenmann, 1912, Mem. Carnegie Mus., V, 320;

Eigenmann, 1917, Mem. Mus. Comp. Zool., XLIII, i, 59, pl. iv, fig. 1; pl. cxviii, fig. 4.

Tetragonopterus ortonii Gill, 1870, Proc. Acad. Nat. Sci. Phila., XXII, 92, Napo or Marañon;

Cope, 1870, Proc. Amer. Phil. Soc., XI, 566, Pebas;

Cope, 1878, Proc. Amer. Phil. Soc., XVII, 691, Marañon.

\section{Upper Amazons to the Guianas}

Head $3.0-3.66$; depth $1.66-2.0$; D. III, 9 ; A. IV, 30 or I-IV, 36, usually 33 , sometimes 34 , developed rays; scales $8,30+3,5$ ( 6 to anal); dusky blotch at the base of the caudal.

\section{Subfamily: STETHAPRIONINAE}

Differing from the Tetragonopterinae in the procumbent, predorsal spine; like them very deep and very compressiform; dorsal and ventral contours similar and very convex; premaxillary teeth in two series, the mandibulars in one; maxillaries in one series or wanting; caudal scaled; lateral line complete; ventral margin compressed to an edge; dorsal fin variously falcate; an adipose fin present; pectorals short; anal long.

\section{Genus 109: STETHAPRION Cope}

Stethaprion Cope, 1870, Proc. Amer. Phil. Soc., XI, 562;

Steindachner, 1882 (1883), Denksch. KK. Akad. Wiss. Wien, ILVI, 13;

Eigenmann, 1910, Rept. Princeton Univ. Exped. Patagonia, III, 441;

Eigenmann and Myers, 1929, Mem. Mus. Comp. Zool., XLIII, v, 500. 
Type: Stethaprion erythrops Cope

Madeira basin of Bolivia to Peruvian and Ecuadorean Amazon

A long, slender predorsal, equal to eye diameter, with a pair of lateral retrorse hooks at its middle, fitting into a groove before the dorsal fin; scales small, the ventral scales but slightly serrate; dorsal profile greatly arched, highest at the origin of the dorsal fin, where it forms an angle of about 120 degrees; ventral profile more convex, lowest at the origin of the anal fin; head broad above and compressed ventrally; mouth large; ventral fins very small; lateral line but slightly decurved.

\section{Stethaprion erythrops Cope}

Stethaprion erythrops Cope, 1870, Proc. Amer. Phil. Soc., XI, 562, fig. c, Pebas;

Steindachner, 1882 (1883), Denksch. KK. Akad. Wiss. Wien, XLVI, 13, two, Rio Huallaga; Fowler, 1906 (1907), Proc. Acad. Nat. Sci. Phila., LVIII, 481, fig. 59, Pebas:

Eigenmann, 1910, Rept. Princeton Univ. Exped. Patagonia, III, 441;

Eigenmann and Myers, 1929, Mem. Mus. Comp. Zool., XLIII, v, 501, pl. lxx, fig. 1; pl. xeviii, fig. 6, Iquitos, Yarinacocha.

\section{Amazons}

15803, 31, 60-100 mm., Yarinacocha, Allen, August, 1920.

15877, 4, 64-92 mm. Rio Itaya, Iquitos, Allen, September, 1920.

15886, 1, 66 mm., Iquitos, Allen, September, 1920.

\section{Stethaprion chryseum Cope}

Stethaprion chryseum Cope, 1871, Proc. Acad. Nat. Sci. Phila., 261;

Cope, 1878, Proc. Amer. Phil. Soc., XVII, 692;

Fowler, 1906 (1907), Proc. Acad. Nat. Sci. Phila., LVIII, 482, fig. 60;

Eigenmann, 1910, Rept. Princeton Univ. Exped. Patagonia, III, 441;

Eigenmann and Myers, 1929, Mem. Mus. Comp. Zool., XLIII, v, 502.

\section{Lower Marañon}

May be identical with S. erythrops; not known except through the one 71-mm. specimen of the Hauxwell collection of Cope.

\section{Genus 110: EPHIPPICHARAX Fowler}

Fowlerina Eigenmann, 1907, Ann. Carnegie Mus., IV, 153;

Eigenmann, 1907, Amer. Nat., XLI, 771 (preoceupied).

Ephippicharax Fowler, 1913, Science, XXXVIII, 51;

Fowler, 1914, Proc. Acad. Nat. Sci. Phila., LXVI, 250;

Eigenmann and Myers, 1929, Mem. Mus. Comp. Zool., XLIII, v, 503.

Type: Tetragonopterus compressus Günther

Peruvian Amazon, Guianas, to Paraguay and Rio São Francisco

Predorsal spine simple with hollow below, and fitting scale-like into a notch in the predorsal line; preanal spine wanting; caudal scaled; anal with one row of scales and long, scales 34-36; preventral a single series of smooth, median scales. 


\section{Ephippicharax orbicularis (Cuvier and Valenciennes)}

Tetragonopterus orbicularis Cuvier and Valenciennes, 1848, Hist. Nat. Poiss., XXII, 138, Essequibo to Amazon;

Günther, 1868, Proc. Zool. Soc. London, 229;

Eigenmann and Eigenmann, 1891, Proc. U. S. Nat. Mus., XIV, 52.

Fowlerina orbicularis Eigenmann, 1910, Rept. Princeton Univ. Exped. Patagonia, III, 441;

Eigenmann, 1912, Mem. Carnegie Mus., V, 37t, pl. xlvi, fig. 2

Ephippicharax orbicularis Fowler, 1914, Proc. Acad. Nat. Sci. Phila., LXVI, 250;

Pearson, 1925, Ind. Univ. Studies, no. 64, 48;

Eigenmann and Myers, 1929, Mem. Mus. Comp. Zool., XLIII, v, 503, pl. lxx, fig. 2; pl. xeviii, fig. 5.

Peruvian Amazon to Guianas and doubtfully R. Parahyba

\section{Third division-Serrasalmonine subfamilies \\ Subfamily: SERRASALMONINAE}

Fishes collectively known as the paña, piranha, piraya, or perai, caribe, etc., in various countries. Abdomen trenchantly keeled and serrated, with a median series of scales or bony plates; compressed, elevated; dorsal fin long, anal long and with oblique basis; ventrals minute; scales small; predorsal naked; premaxillary and mandible with a single series of notched or lobate teeth; palate sometimes toothed.

\section{Genus 111: SERRASALMUS Lacépède}

Serrasalmus Lacépède, 1803, Hist. Nat. Poiss., V, 283;

Norman, 1928, Proc. Zool. Soc. London, 784.

Serrasalmo Cuvier, 1819, Mém. Mus. Hist. Nat., V, 367;

Eigenmann, 1910, Rept. Princeton Univ. Exped. Patagonia, III, 4t1;

Eigenmann, 1912, Mem. Carnegie Mus., V, 380;

Eigenmann, 1915, Ann. Carnegie Mus., IX, 248; and authors generally.

\section{Type: Salmo rhombeus Linnaeus}

Orinoco and Guianas southward to Rio Paraguay and Bolivia

Belly trenchant, serrate, serrae extending from the level of the pectorals to that of the anus; premaxillary with a single series of teeth; a series of triangular teeth on each side of the palatine; second suborbital covering about all of cheek; anal partially enclosed by scales.

\section{Serrasalmus spilopleura Kner}

Serrasalmo spilopleura Kner, 1859, Denksch. KK. Akad. Wiss. Wien, XVIII, 35, taf. v, fig. 2, Matto Grosso, Guaporé;

Günther, 186t, Cat. Fish. Brit. Mus., V, 370, Rio Capim;

Eigenmann, 1910, Rept. Princeton Univ. Exped. Patagonia, III, 442 ;

Eigenmann, 1915, Ann. Carnegie Mus., IX, 252. 
Serrasalmus spilopleura Norman, 1928, Proc. Zool. Soc. London, 798, fig. 13.

Serrasalmo oesopus Cope, 1871, Proc. Acad. Nat. Sci. Phila., XXIII, 269, Amazons between Rio Huallaga and Rio Negro;

Eigenmann, 1910, Rept. Princeton Univ. Exped. Patagonia, III, 442;

Eigenmann, 1915, Ann. Carnegie Mus., IX, 252, doubtfully separable from the preceding. Serrasalmus oesopus Fowler, 1906 (1907), Proc. Acad. Nat. Sei. Phila., LVIII, 469, fig. 53.

The oesopus material is limited to a single specimen in the museum of the Philadelphia Academy.

\section{Serrasalmus elongatus Kner}

Scrrasalmo elongatus Kner, 1860, Denksch. KKK. Akad. Wiss. Wien, XVIII, 44, pl. v, fig. 12;

Günther, 1864, Cat. Fish. Brit. Mus., V, 371;

Steindachner, 1882 (1883), Denksch. KK. Akad. Wiss. Wien, XLVI, 16, Rio Huallaga, one specimen, $140 \mathrm{~mm}$;

Eigenmann, 1910, Rept. Princeton Univ. Exped. Patagonia, III, 442;

Eigenmann, 1915, Ann. Carnegie Mus., IX, 250.

Serrasalmus elongatus Norman, 1928, Proc. Zool. Soc. London, 806, fig. 18, one, 180 mm., Solimões.

Huallaga basin to that of the Guaporé

15696, 2, 110 and $200 \mathrm{~mm}$., Yarinacocha, Allen, August, 1920.

\section{Serrasalmus rhombeus (Linnaeus)}

Salmo rhombeus Linnaeus, 1766, Syst. Nat., ed. 12, I, 514, Surinam;

Gmelin, 1788, Syst. Nat., I, 686, no. 28;

Bloch, 1794, Ausl. Fische, VIII, 112, pl. 383;

Bloch and Schneider, 1801, Syst. Ichth., 404.

Serrasalmo rhombeus Lacépède, 1804, Hist. Nat. Poiss., V, 284;

Cuvier, 1919, Mém. Mus. Hist. Nat, V, 367;

Cuvier and Valenciennes, 1848, Hist. Nat. Poiss., XXII, 272;

Castelnau, 1855, Anim. Amér. Sud, Poiss., pl. xxxvii, fig. 3;

Günther, 1864, Cat. Fish. Brit. Mus., V, 369, Guianas;

Eigenmann and Eigenmann, 1891, Proe. U. S. Nat. Mus, XIV, 60;

Eigenmann, 1910, Rept. Princeton Univ. Exped. Patagonia, III, 442 ;

Eigenmann, 1912, \Iem. Carnegie MIus., V, 382;

Eigenmann, 1915, Ann. Carnegie Mus., IX, 254, pl. Iviii.

Serrasalmo (misspelled Serrasalimo) immaculatus Cope, 1878, Proc. Amer. Phil. Soc., XVII, 692, Rio Marañon;

Fowler, 1906 (1907), Proc. Acad. Nat. Sci. Phila., LVIII, 471, fig. 54, with notes on the types;

Eigenmann, 1910, Rept. Princeton Univ. Exped. Patagonia, III, 442.

Serrasalmus rhombeus (in part), Norman, 1928, Proc. Zool. Soc. London, 800, fig. 1t, one, collected by Higgins, Neberos;

Fowler, 1939 (1910), Proc. Acad. Nat. Sci. Phila., XCI, 271, pirana.

\section{Amazonia to the Guianas}

Cope's Marañon material supposedly distinguished from his oesopus by smaller scales and elongate snout; Haseman reports a jet-black phase from Santarem. 


\section{Serrasalmus maculatus Kner}

Serrasalmo maculatus Kner, 1859, Denksch. KK. Akad. Wiss. Wien, XVIII, 41, pl. iv, fig. 10, Rio Guaporé;

Günther, 186t, Cat. Fish. Brit. Mus., V, 371;

Cope, 1870, Proc. Amer. Phil. Soc., XI, 566;

Steindachner, 1882 (1883), Denksch. KK. Akad. Wiss. Wien, XLVI, 15, Rio Huallaga, four specimens;

Eigenmann, 1910, Rept. P'rinceton Univ. Exped. Patagonia, III, 442;

Eigenmann, 1915, Ann. Carnegie Mus., IX, 253.

Serrasalmus maculatus Fowler, 1906 (1907), Proc. Acad. Nat. Sei. Phila., LVIII, 469.

Serrasalmus spiloplewa Norman (in part), 1928, Proc. Zool. Soc. London, 798, fig. 13.

\section{Peruvian Amazon to Bolivia}

\section{Serrasalmus humeralis Cuvier and Valenciennes}

Serrasalmo humeralis Cuvier and Valenciennes, 18t8, Hist. Nat. Poiss., XXII, 279;

Castelnau, 1855, Anim. Amér. Sud, Poiss., 71, pl. xxxvii, fig. 2;

Kner (in part), 1859, Denksch. KK. Akad. Wiss. Wien, XVIII, 30, pl. iv, fig. 9;

Günther, 1868, Proc. Zool. Soc. London, 229;

Cope, (1871), 1872, Proc. Acad. Nat. Sci. Phila., XXIII, 292, Amazon, below Ueayali?;

Steindachner, 1882 (1883), Denksch. KK. Akad. Wiss. Wien, XLVI, 15, three specimens, Rio Huallaga;

Eigenmann, 1910, Rept. Princeton Univ. Exped. Patagonia, III, 442;

Eigenmann, 1915, Ann. Carnegie Mus., IX, 256, pl. i.

Serrasalmus humeralis Fowler, 1906 (1907), Proc. Acad. Nat. Sci. Phila., LVIII, 469, with notes on Cope's specimens.

Serrasalmus rhombeus Norman (part), 1928, Proc. Zool. Soc. London, 800, fig. 14.

Serrasalmo marğinatus Norman (part), 1928, Proc. Zool. Soc. London, 802, fig. 15.

Serrasalmo iridopsis Cope, 1871 (1872), Proc. Acad. Nat. Sci. Phila., XXIII, 268, pl. ix, fig. 2, Rio Ambyiacu;

Eigenmann and Eigenmann, 1891, Proc. U. S. Nat. Mus., XIV, 60;

Fowler, 1906 (1907), Proc. Acad. Nat. Sci. Phila., LVIII, 471, with notes on the type;

Eigenmann, 1910, Rept. Princeton Univ. Exped. Patagonia, III, $4+2$.

\section{Basins of Amazons and Paraguay rivers}

15613, 11, 90-230 mm., Lago Sanango, Allen, November, 1920.

$15689,2,150$ and $178 \mathrm{~mm}$., Manaos, Allen, December, 1920.

15690, 1, 143 mm., Rio Pichis, P'uerto Bermudez, Allen, July, 1920.

15691, 1, 118 mm., Iquitos, Allen, September, 1920.

15692, 2, 93 and $212 \mathrm{~mm}$., mouth Rio Pacaya, Allen, August, 1920.

15694, 16, 67-132 mm., Lago Cashiboya, Allen, August, 1920.

15695, 4, 78-109 mm., Rio Pacaya, Yarinacocha, Allen, August, 1920.

$15699,2,92$ and $126 \mathrm{~mm}$., Rio Huallaga, Yurimaguas, Allen, November, 1920.

15909 , , Pebas, Steere.

17727, 1, 74 mm., Iquitos, Morris, 1922.

\section{Genus 112: ROOSEVELTIELLA Eigenmann}

Serrasalmus (in part) Lacépède, 1803, Hist. Nat. Poiss., V, 283;

Norman, 1928, Proc. Zool. Soc. London, 787.

Roosevelticlla Eigenmann, 1915, Ann. Carnegie Mus., IX, 240. 


\section{Type: Serrasalmo nattereri Kner}

Amazons and La Plata basin

Adipose fin without rays; palate without teeth; cheek of adult more or less fully armed; profile of head very slightly depressed; eye rather small, interorbital correspondingly wide; upper jaw short and very oblique; mandible powerful, its teeth very long, cutting edges nearly symmetrical, and much larger than those of the upper jaw.

\section{Rooseveltiella nattereri (Kner)}

Pygocentrus nattereri Kner, 1859, Denksch. KK. Akad. Wiss. Wien, XVII, 28, taf. iii, fig. 8;

Eigenmann and Eigenmann, 1891, Proc. U. S. Nat. Mus., XIV, 60;

Fowler, 1906 (1907), Proc. Acad. Nat. Sei. Phila., LVIII, 468, Pebas;

Eigenmann, 1910, Rept. Princeton Univ. Exped. Patagonia, III, 442

Serrasalmo nattereri Cope, (1871), 1872, Proc. Acad. Nat. Sci. Phila., XXIII, 292, Perkins and Orton collections.

Serrasalmus nattereri Norman, 1928, Proc. Zool. Soc. London, 787, text figs. 4 and 5;

Fowler, 1939 (1940), Proc. Acad. Nat. Sci. Phila., XCI, 271, seven, 98-158 mm., Contamana.

Rooscreltiella nattereri Eigenmann, 1915, Ann. Carnegie Mus., IX, 242.

\section{La Plata and Amazon systems}

\section{Rooseveltiella alta (Gill)}

Pygocentrus altus Gill, 1870, Proc. Acad. Nat. Sci. Phila., XXII, 93, the Orton collection from the Napo or Marañon;

Eigenmann and Ogle, 1907, Proc. U. S. Xat. Mus., XXXIII, 35, one, $155 \mathrm{~mm}$. from the Orton collections;

Eigenmann, 1910, Rept. Princeton Univ. Exped. Patagonia, III, 472.

Rooseveltiella altus Eigenmann, 1915, Ann. Carnegie Mus., IX, 244, pl. xlvi.

Serrasalmus nattereri Norman, 1928, Proc. Zool. Soc. London, 787.

\section{Marañon basin}

15614, 1, 155 mm., Lago Sanango, Allen, November, 1920.

15684, 14, 83-170 mm., Rio Pacaya, Allen, August, 1920.

15685, 2, 122 and $132 \mathrm{~mm}$., Yarinacocha, Allen, August, 1920.

15686, 4, 133-162 mm., Lago Cashiboya, Allen, August, 1920.

15687, 1, 142 mm., Iquitos, Allen, September, 1920.

15688, 3, 102-170 mm., Rio Ueayali, Contamana, Allen, August, 1920.

15700, 1, 123 mm., Rio Huallaga, Yurimaguas, Allen, November, 1920.

15910, 1, $108 \mathrm{~mm}$. ., Pebas, probably Steere coll.

The members of this subfamily constitute the infamous tribe of "man-eaters" known in the Guianas as the perai, piraya, and caribe, in Brazil as the piranha (pronounced peer-ahn'-yah), and in the Oriente of Peru as paña (pronounced pahn'yah). They are most frequently taken in the clearer waters of the quieter, backwater bayous and their inlets or outlets, and less abundantly in the swifter and muddier waters. They, together with the caymans and such fishes as Roeboides, make set-net fishing impossible. Some of my gill-nets were destroyed the very first time that they were placed in the water. 
On pulling seines, it was necessary to take the pañas out as quickly as possible before other fishes, to prevent their eating their way out of the seine in the direction of the water, and even then it was impossible to prevent their damaging the fabric. Hook and line fishing was almost as difficult because of their voracious appetite for bait, so that they generally strike before other desired species have a chance, or devour the others before they can be pulled out. Furthermore it is necessary to fish with large hooks, for otherwise the paña will either bite your line, your leader, or your hook in two as a part of the day's work. Hooks lost and leaders bitten off were the rule rather than the exception. The numbers of specimens reported above is a very inadequate expression of the abundance of specimens taken and shared with helpers for gastronomic purposes.

According to Humboldt (Obs. Zool. II, 174) the earliest account of these fishes is that of Fray Pedro Simon, who describes among the loot taken from an Indian village garments made in the form of trousers of a coarse net tied in knots as a safeguard against caribes while fishing. Humboldt also relates that a young Indian, inspecting a drawing of the caribe, pointed out that the constellation of the Southern Cross was called by the name of the fish. Schomburgk tells of seeing three young capybara with toes amputated by the fish, and waterfowl walking about on stumps of feet.

Accounts like the above run through both the scientific and the popular literature. Domville-Fife calls them river shark, and Dyott the vultures of the river. But the imagination of a Duguid paints it in colors most vividly of all writers:

The alligator was..."dangled overboard with the tail cut off. The dark water kindled, a troubled cloud grew to immense proportions, and a silver terror shone beneath the surface. Occasionally there was a bright flash of scales and a flourish of fins.... An air of concealed energy, horrible and intense, kept our eyes on the jerking rope ... if ever a liquid may be said to heave, the river Paraguay did that afternoon.... At last we could bear it no longer. We hauled with all our strength, and as the body slithered over the side, a gout of water shot into the engine. Queer, flapping noises came from the interior, and a deep-bellied fish fluttered on the floor-boards."

Contrast with this the reaction of Haseman, who simply recorded on his label of a Pygocentrus and put it in alcohol with the specimen "bit my thumb", and on another, "nearly severed finger."

The biting powers and destruction of fish-hooks are widely commented upon (Dyott, 158; Beebe, 359; Woodroffe, 95; Paez, 420). Whitney describes the mouthful of "canine" teeth. Lange $(1912,208)$ tells of one biting a piece out of a steering paddle. The dangers of entering streams are discussed by many writers (DomvilleFife, 237; Koebel, 1915, 233; im Thurn, 137; Guenther, 175). Grubb (page 9) says towing a canoe is dangerous work on their account. Cherrie (page 71) alludes to their threat to wounded cattle. Many writers relay to us the story of the attraction of blood of wounded animals, misleading Whitney to say the piranha "eats blood, not flesh". That blood does serve as an attraction is well shown by the great numbers in which I found them in a drainage ditch leading from the slaughter-house at Manaos. 
The dangers to man are not greatly exaggerated, for we do have numbers of well-authenticated stories of their attack: im Thurn tells of one of his rowers having his toes stripped of flesh. The well-known Colonel Rondon lost a toe to one of them. Many Indians are seen with the extremities of fingers and toes missing. Miller (page 164) relates the loss of a piece of finger while washing the blood of a specimen from his hands at the water's edge. Cherrie (page 265) repeats the Miller story and that of the loss of a finger by Mrs. S. The latter while idly dangling her hand overboard in a canoe, thought one of her oarsmen had struck her with his paddle. She began to rebuke him for his awkwardness when she discovered that the finger was gone. Mr. Cherrie himself while baiting piranha from a limb overhanging the water, fell into the stream beside them. Although he thrashed the water furiously, he was unable to escape without numerous lacerations.

Conversely, Miller tells of a native who, in fishing for piranha, dropped his purse overboard among them. By wading out cautiously from shore without agitating the water, he recovered the purse with his feet, and was not molested. Other observers report that the tribesmen of the forest know where, and under what circumstances, it is safe to enter streams without fear of lurking piranha, although known to be near at hand.

McGovern relates an observation: (page 42) a sheep carcass was completely consumed in two and one-half minutes. Im Thurn knew personally several cases of drownings in which only the bones of the victim were discovered after more or less immediate search. Hartt tells of a half-wit who, sitting on a river-bank, was frightened by the discharge of a cannon, fell into the water, and parts of whom were recovered in the stomachs of piranha taken next day. He also tells of a young woman, who, venturing to bathe in a stream, was devoured. Lange (1914, 213) relates that he killed a wild-pig in a river, and that its flesh had all been removed before the carcass could be hauled ashore.

I was frequently cautioned by my associates to keep specimens which we had caught, and which were floundering about on the bottom of our dugout, at a safe distance from my feet. In fact I had to guard my specimens from mutilation, so great was their fear of them. When handled, they did in fact always attempt to snap at us, even though out of water. Beebe mentions this necessity of constant vigilance, but one author spoils all other accounts by saying that he was snapped at by a bodyless head.

That such capable raptores should have a special place in relation to their biological environment goes almost without saying. Their great numbers and complete dominance might indicate a one-sided balance of nature, except that we find such numbers of species and individuals of many kinds. Castelnau, im Thurn, and others relate the observation of birds, iguanas, turtles, and alligators with feet and tails trimmed. White (Beebe) comments on the general attractiveness of tails, and tells of finding fragments of ducks, kingfishers, and kiskadees in the stomachs of fishes. Bird collectors report shooting specimens which they are unable to recover in time to save them. Duguid (page 37 ) says that cattle drovers of the "Green Hell" were accustomed to reckoning the loss of a steer at every ford from the attacks of piranha. 
Incredible numbers are found in small space, sometimes. Duguid (page 93) describes the taking of piranha on lines with numerous unbaited hooks. This is probably the weighted throwline described elsewhere. The Guiana Indians prefer to first concentrate their quarry by baiting, then to shoot arrows into the crowded waters. Paez asserts that they have a preference for red objects, even human victims clad in red.

It appears from some accounts that at least not all the species of this subfamily are totally camivorous. White from long years' observation reports that they are fond of the seeds of citrus fruits; that they congregated about a citrate manufactory to devour the seed and pulp of limes thrown into the river.

That such predators, whose extreme vigor and rapacity are expressed even in line and color, should be useful to man does not seem credible. But as a matter of fact they are rather favorite food fishes in many sections (Roosevelt, 300), and their provocative temperaments make them especially easy to take. Aside from food, there is another use to which primitive man has put them from time immemorial, and from Guiana to Peru, that is, the lower jaw is removed and used as standard equipment on every blowgun, being lashed to the weapon by a chambira-fiber cord. The hunter, at the last moment before dipping his dart into the poison, rings the point deeply between the piranha teeth so that it will break off in the wound and complete its mission. (Im Thurn, 137; White, 359; up de Graff; Waterton, 134, ete.)

The Guarani of southwestern Brazil and Bolivia are said by Tolten (page 257), to employ the jaws of piranha as trimmers for keeping the hair evened on the forehead. It is reported further that when the first white-man's scissors were shown these people, they gave them the name of the fish as the nearest synonym.

A still more astonishing use of this fish subfamily is one reported by Paez (page 156). He says that among the inundated savannas about the mouth of the Orinoco, where for months inhumation of the dead is impossible, the caribe solves the problem. They quickly deflesh the corpse, the skeleton then is dyed, decorated, and placed in mortuary places of honor in the platform villages.

The Carib term caribe is the source of the tribal name, and signifies cannibal, that is man-eating. But considerable contradictory information comes to us as to whether the fishes camnibalize upon their own kind. It has been my observation that they will turn as readily upon their own wounded as upon any other form, fish or otherwise. Lange reports feeding them fragments of the meat of their own kind as a form of sport.

Little is known of the life-histories or of the younger stages of any species. Waterton (page 454) found their eggs among the roots of lianas which he definitely assigned to piraya. Hartt, a reliable observer, deseribes the nests of Pygocentrus as depressions fanned out in sand during flood stages, where the eggs were laid in a ball of two or three inches diameter.

An excellent general account of the Serrasalmoninae comes from the pen of Beebe, 1917, Chapter XXIII; more recently we have a chapter on piranha in Cutright's "Great Naturalists Explore South America." 


\section{Subfamily: MYLINAE}

Resembling the Serrasalmoninae closely in the great depth, the compressed form, and serrated ventral line.

Mandible with a single series of teeth, and in some cases a pair of subconical teeth behind those of the symphysis and in contact with them; palate and maxillary edentulous; dorsal fin rather long, ventrals very small; anal long, oblique; adipose variable; gill-rakers well developed.

\section{Genus 113: METYNNIS Cope}

ILetynnis Cope, 1878, Proc. Amer. Phil. Soc., XVII, 693;

Eigenmamn, 1910, Rept. Princeton Univ. Exped. Patagonia, III, 443;

Eigenmann, 1912, Mem. Carnegie Mus., V, 389;

Eigenmann, 1915, Ann. Carnegie Mus., IX, 261, 267 ;

Ahl, 1923, Mitt. Zool. MIus. Berlin, XI, 15;

Norman, 1928, Proc. Zool. Soc. London, 815.

Sealeina Fowler, 1906 (1907), Proc. Acad. Nat. Sci. Phila., LVIII, 478.

Type: Metynnis luna Cope

Guianas to Peru and Paraguay basin

Belly trenchant and with a serrate median series of scales; premaxillary with two series of teeth; mandible with a pair of teeth behind the front series; a procumbent, predorsal spine present; adipose exceeding half the length of the dorsal; free margin of anal slightly convex, lobate anteriorly, or sinuate; dorsal falcate, with fewer than 20 rays.

\section{Metynnis Luna Cope}

Metynnis luna Cope, 1878, Proc. Amer. Phil. Soc., XVII, 692, Peruvian Amazon;

Fowler, 1906 (1907), Proc. Acad. Nat. Sci. Phila., LVIII, 479, fig. 58, Orton collection of Cope; Eigenmann, 1910, Rept. Princeton Univ. Exped. Patagonia, III, 443;

Ahl, 1923, Mitt. Zool. Mus. Berlin, XI, 20;

Norman, 1928, Proc. Zool. Soc. London, 816, one, Amazon.

Myletes hypsauchen Ulrey, 1895, Ann. N. Y. Acad. Sci, VIII, 299.

\section{Marañon basin}

15610, 6, 68-98 mm., Lago Sanango, Allen, November, 1920.

15698, 1, 33 mm., Lago Cashiboya, Allen, August, 1920.

15802, 4, 62-68 mm., Yarinacocha, Allen, August, 1920.

\section{Metynnis hypsauchen (Müller and Troschel)}

Myletes hypsauchen Müller and Troschel, 1845, Horae Ichth., I, 38, pl. x, fig. 1; Cuvier and Valenciennes, 1848, Hist. Nat. Poiss., XXII, 219; Günther, 1864, Cat. Fish. Brit. Mus., V, 376; Steindachner, 1882 (1883), Denksch. KK. Akad. Wiss. Wien, XLVI, 16, Rio Huallaga, one specimen.

Metynnis hypsauchen Cope, 1878, Proc. Amer. Phil. Soc., XVII, 691; Eigenmann and Eigenmann, 1891, Proc. U. S. Nat. Mus., XIV, 61;

Eigenmann, 1910, Rept. Princeton Univ. Exped. Patagonia, III, 443; 
Eigenmann, 1912, Mem. Carnegie Mus., V, 389;

Eigenmann, 1915, Ann. Carnegie Mus., IX, 269

Ahl, 1923, Mitt. Zool. Mus. Berlin, XI, 21;

Jorman, 1928, Proc. Zool. Soc. London, 819.

Guianas to Rios Huallaga, Guaporé, and Paraguay

Genus 114: MYLEUS Müller and Troschel

Myleus Müller and 'Trosehel, 1845, Horae Iehth., I, 24;

Eigenmann, 1912, Mem. Camegie Mus., V, 393.

Type: Myleus setiger Müller and Troschel

Orinoco and Guianas to Rios São Francisco and Paraguay

Belly trenchant, like the preceding, the serrae obsolescent with age; the two series of premaxillary teeth closely approximated, the outer protruding and incisorlike; mandible with a pair of conical teeth in front; anal falcate in female, bilobed in male; dorsal rays filamentous in male.

\section{Myleus setiger Mïller and Troschel}

Myleus setiger Müller and Troschel, 18t5, Horae Ichth., I and II, 21 and 39, pl. xi, fig, 1;

Norman, 1928, Proc. Zool. Soc. London, 821, Guianas to Matto Grosso;

Fowler, 1939 (1940), Proc. Acad. Nat. Sci. Phila., XCI, 272, one, Contamana. .Myleus pacu Eigenmann, 1912, Mem. Carnegie Mus., V, 394.

\section{Guianas to Matto Grosso and Peru}

\section{Genus 115: PIARCTUS Eigenmann}

Piarctus Eigenmann, 1903, Smithson. Misc. Coll., XLV, 148;

Eigenmann, 1910, Rept. Princeton Univ. Exped. Patagonia, III, 443.

Colosoma Eigenmann, 1915, Ann. Carnegie Mus., IX, 261.

Colossoma (in part) Xorman, 1928, Proc. Zool. Soc. London, 808.

\section{Type: Myletes brachypomus Cuvier \\ Orinoco basin to that of La Plata}

Predorsal spine wanting; anal not scaled, and as long as the head or shorter, first rays highest, fin without lobes. Separated from the nearby Colossoma on the rayed adipose and broad membrane bordering the operculum; gill rakers fine and numerous.

\section{Piarctus nigripinnis (Cope)}

Myletes nigripinnis Cope, 1878, Proc. Amer. Phil. Soc., XVII, 693, Nauta and R. Ambyiacu; Steindachner, 1881, Denksch. KK. Akad. Wiss. Wien, XLII, 25, pl. rii, fig. 1;

Eigenmann and Eigenmann, 1891, Proc. U. S. Nat. Mus., XIV, 61. Colossoma nigripinnis Eigenmann, 1903, Smithson. Misc. Coll., XLV, 1+8; Eigenmann, 1910, Rept. Princeton Univ. Exped. Patagonia, III, 44t; Norman, 1928, Proc. Zool. Soc. London, 811. 
Colosoma (Waiteina) nigripinnis Fowler, 1906 (1907), Proc. Acad. Nat. Sci. Phila., LVIII. 473, fig. 55, Peruvian Amazon.

Piarctus nigripinnis Eigenmann, 1915, Ann. Carnegie Mus., IX, 262, pl. liii;

Ahl, 1922, Blaett. Aquar-Terrarienkunde, no. 12, 1, fig.

The Amazons

15668, 4, 158-227 mm., Iquitos, Allen, September, 1920.

15669, 1, $150 \mathrm{~mm}$. , Yarinacocha, Allen, August, 1920.

Anterior part of adipose with jointed rays; "inferior part" scaly; scales 26, $65+6,21$.

\section{Genus 116: COLOSSOMA Eigenmann}

Colossoma Eigenmann, 1903, Smithson. Misc. Coll., XLV, 148;

Eigenmann and Kennedy, 1903, Proc. Acad. Nat. Sci. Phila., LV, 530;

Eigenmann, 1910, Rept. Princeton Univ. Exped. Patagonia, III, 444.

Colosoma Eigenmann, 1915, Ann. Carnegie Mus., IX, 261, 262.

Waiteina Fowler, 1906 (1907), Proc. Acad. Nat. Sci. Phila., LVIII, 473, for Myletes nigripinnis Cope.

Reganina Fowler, 1906 (1907), Proc. Acad. Nat. Sci. Phila., LVIII, 475, for Myletes bidens Agassiz.

Type: Myletes oculus Cope

The Amazons and La Plata

Predorsal spine wanting; mandibular teeth conical; teeth close-set and incisorlike, molar-like, or with oblique cutting edge; premaxillary with each ramus bearing an outer series of five and an inner series of two teeth; abdomen serrated both before and behind ventral fins.

\section{Colossoma oculus (Cope)}

Myletes oculus Cope, 1871 (1872), Proc. Acad. Nat. Sci. Phila., XXIII, 268, pl. xii, fig. 2, Rio Am. byiacu, Hauxwell collection.

Colossoma oculus Eigenmann, 1903, Smithson. Nisc. Coll., XLV, 148;

Fowler, 1906 (1907), Proc. Acad. Nat. Sci. Phila, LVIII, 472;

Eigenmann, 1910, Rept. Princeton Univ. Exped. Patagonia, III, 444;

Norman, 1928, Proc. Zool. Soc. London, 811.

\section{Peruvian Amazon}

Norman differentiates this species from his C. nigripinnis on larger head, fewer gill-rakers, unrayed adipose, and coloration, and considers it possibly the young of that species.

\section{Colossoma bidens (Agassiz)}

Myletes bidens Agassiz, 1829, Sel. Gen. et Spec. P'isc. Bras., 75, pl. xxxii;

Günther, 1864, Cat. Fish. Brit. Mus., V, 375;

Cope, 1871 (1872), Proc. Acad. Nat. Sci. Phila., 291, Perkins coll.;

Cope, 1878, Proc. Amer. Phil. Soc., XVII, 694, Marañon, Orton coll.;

Steindachner, 1881 (1882), Denksch. KK. Akad. Wiss. Wien, XLIV, 13.

Reganina bidens Fowler, 1906 (1907), Proc. Acad. Nat. Sci. Phila., LVIII, 175. 
Colossoma bidens Eigenmann, 1910, Rept. Princeton Univ. Exped. Patagonia, III, 44t;

Norman, 1928, Proc. Zool. Soc. London, 810.

Colosoma bidens Eigenmann, 1915, Ann. Carnegie Mus., IX, 262.

\section{The Amazons}

$15670,2,118$ and $154 \mathrm{~mm}$., Contamana, Allen, August, 1920.

$15671,2,14 t$ and $147 \mathrm{~mm}$., Manaos, Allen, December, 1920.

15672, 3, 130-166 mm., Yarinacocha, Allen, August, 1920.

15701, 3, 126-130 mm., Lago Cashibora, Allen, August, 1920.

\section{Colossoma herniarium (Cope)}

Myletes herniarius Cope, (1871), 1872, Proc. Acad. Nat. Sci. Phila., XXIII, 268, pl. xii, fig. 3, R. Ambyiacu, Hauxwell collection;

Cope, 1878, Proc. Amer. Phil. Soc., XVIII, 693, Peruvian Amazon, Orton collection. Colossoma herniarium Eigenmann, 1910, Rept. Princeton Univ. Exped. Patagonia, III, 144. Starksina herniarius Fowler, 1906 (1907), Proc. Acad. Nat. Sci. Phila., LVIII, 476.

Mylossoma aureum Norman, 1928, Proc. Zool. Soc. London, 812;

Fowler, 1939 (1940), Proc. Acad. Nat. Sei. Phila., XCI, 271.

\section{Peruvian Amazon}

\section{Genus 117: MYLOSSOMA Eigenmann}

Mylossoma Eigenmann, 1903, Smithson. Mise. Coll. XLV, 148;

Eigenmann and Kennedy, 1903, Proc. Acad. Nat. Sci. Phila., 350;

Eigenmann, 1910, Rept. Princeton Univ. Exped. Patagonia, III, 444;

Ahl, 1922, Wochen Aquar.-Terrarienkunde, no. 11.

Lylosoma Eigenmann, 1915, Ann. Carnegie Mus., IX, 261, 265.

Starksina Fowler, 1906 (1907), Proc. Acad. Nat. Sci. Phila., LVIII, 476.

\section{Type: Myletes albiscopus Cope}

\section{Orinoco to La Plata}

Differing from Colossoma in the numerous supplementary scales which may obscure the primary scales; anal scaled at least its proximal half, and its rays increasing toward the last; length of anal base equals or surpasses half the length of the fish without the caudal; operculum with a narrow lobe; gill-rakers of moderate length.

\section{Mrlossoma aureum (Spix)}

Myletes aureus Spix, 1829, Sel. Gen. et Spec. Pisc. Bras., 74, pl. xxxi.

Mylossoma aureum Eigenmann, 1910, Rept. Princeton Univ. Exped. Patagonia, III, 141;

Fowler, 1939 (1940), Proc. Acad. Nat. Sei. Phila., XCI, 271, seven, 83-173 mm., Contamana.

Mylosoma aureum Eigenmann, 1915, Ann. Carnegie Mus., IX, 265.

\section{Orinoco to Ucayali and La Plata}

\section{Mylossoma duriventre (Cuvier)}

Myletes duriventris Cuvier, 1818, Mém. Mus. Hist. Nat., IV, 151, pl. xxii, fig. 2;

Cuvier and Valenciennes, 1848, Hist. Nat. Poiss., XXII, 206;

Günther, 186t, Cat. Fish. Brit. Mus., V, 375; 
Günther, 1868, Proc. Zool. Soc. London, 229, 247, Xeberos;

Cope, 1870, Proc. Amer. Phil. Soc., XI, 566, Pebas;

Steindachner, 1882 (1883), Denksch. KK. Akad. Wiss. Wien, XLVI, 16, Rio Huallaga, four specimens.

Mylossoma duriventris Norman, 1928, Proc. Zool. Soc. London, 813;

Fowler, 1939 (1940), Proc. Acad. Nat. Sci. Phila., XCI, 272, nine, 65-125 mm., Contamana.

\section{Orinoco, upper Amazons, La Plata systems}

Both Steindachner and Fowler report the local name Palometa for the species; I found the name used for all the thinner members of the subfamily, to which the name Pacu could not be applied.

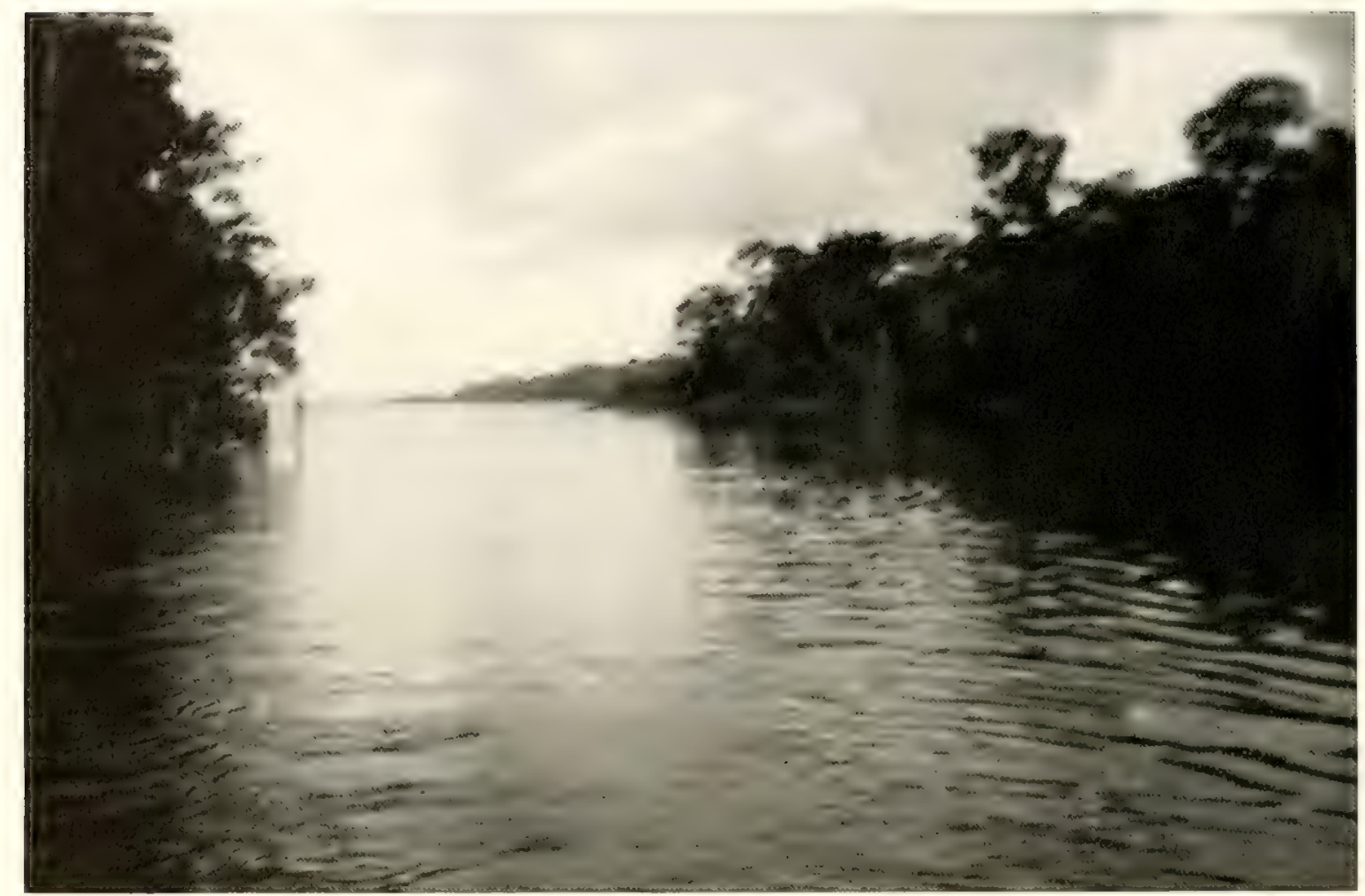

FIG. 28. The mouth of the Rio Itaya, at Iquitos, looking out into the Amazon.

\section{Mylossona albiscopum (Cope)}

Myletes albiscopus Cope, 1871 (1872), Proc. Acad. Nat. Sci. Phila., XXIII, 267, pl. xii, fig. 1, many

Rio Ambyiacu, Hauxwell coll.

Mylossoma albiscopus Eigenmann, 1903, Smithson. Misc. Coll., XLV, 148.

Mylosoma albiscopus Eigenmann, 1910, Rept. Princeton Univ. Exped. Patagonia, III, 44.

Mylossoma duriventris Norman (in part), 1928, Proc. Zool. Soc. London, 813;

Fowler (in part), 1939 (1940), Proc. Acad. Nat. Sci. Phila., XCI, 272.

\section{Peruvian Amazon}

15601, 15611, 1567t, 15679, 29, 103-23t mm., Lago Sanango, Allen, November, 1920.

15612, 1, 118 mm., Rio Marañon, below Pastaza, Allen, October, 1920. 
15673, 1, 238 mm., Rio Pachiten, Allen, July, 1920.

$15675,12,108-195 \mathrm{~mm}$., Iquitos, Allen, September, 1920.

$15676,1,134 \mathrm{~mm}$., Manaos, Allen, December, 1920.

$15677,6,70-186 \mathrm{~mm}$., Contamana, Allen, August, 1920.

$15678,3,102-160 \mathrm{~mm}$. R. Ucayali, Orellana, Allen, August, 1920.

15680, 15681, 21, 63-90 mm., Lago Cashiboya, Allen, August, 1920.

15682, 15, 65-104 mm., Lago Cashiboya, Allen, August, 1920.

15913, Pebas, Steere.

$17726,4,76-91 \mathrm{~mm}$., Iquitos, Morris, 1922.

15674,2 , about $225 \mathrm{~mm}$., locality unknown.

The specimens under 15611, eight in number, have the caudal naked, two of the largest, about $185 \mathrm{~mm}$., are female. The two specimens under 15674 , about $225 \mathrm{~mm}$., have naked caudal and orange anal fin. Numbers $15673,15675,15676$ have the caudal scaled. Numbers $15677,15678,15680,15681$ have caudal both scaled and naked; 15674 has the anal orange.

The younger specimens of this form are darker dorsally, with a faint indication of four or five dark, vertical bands down to or beyond the lateral line. The lighter colored members of the species have originated more frequently in the more turbid waters. The palometas in general are among the migratory species, found among those traveling upstream during rising waters, and spreading over the inundated bottom lands.

\section{Genus 118: MYLOPLUS Gill}

Myletes (non Cuvier) Müller and Troschel, 18t5, Horae Ichth., I, 22;

Günther, 1864, Cat. Fish. Brit. Mus., V, 372 (part).

IIyloplus Gill, 1895, Proc. U. S. Nat. Mus., XVIII, 214;

Eigenmann, 1912, Mem. Carnegie Mus., V, 390;

Eigenmann, 1915, Ann. Carnegie Mus., IX, 262.

Iyleus (in part) Eigenmann, 1910, Rept. Princeton Univ. Exped. Patagonia, III, 443.

Type: Myletes asterias Müller and Troschel

Orinoco and Guianas to Amazons and Paraguay

Belly trenchant and serrate; teeth variable; premaxillaries with two series of teeth, not meeting; mandible with a pair of conical teeth; a procumbent predorsal spine present; gill-rakers short, lanceolate; adipose short, finrays not prolonged individually; dorsal rays 21-31; cheeks mostly naked; anal fin bilobed in male, falcate in female.

\section{Mrloplus Rhomboidalis (Cuvier)}

Myletes rhomboidalis Cuvier, 1818, Mém. Mus. Hist. Nat., IV, 449, pl. xxii, fig. 3.

Myletes parma Günther, 1864, Cat. Fish. Brit. Mus., V, 374.

Myleus parma Eigenmann, 1910, Rept. Princeton Univ. Exped. Patagonia, III, 143.

Myloplus rhomboidalis (in part) Norman, 1928, Proc. Zool. Soc. London, 827. 


\section{Amazon basin}

Norman has redescribed the species from eight specimens, $60-180 \mathrm{~mm}$, including the types of $M$. parma.

15751, 5, 125-158 mm., Manaos, Allen, December, 1920.

\section{Mrloplus Levis (Eigenmann and McAtee)}

Myleus levis Eigenmann, McAtee, and Ward, 1907, Ann. Carnegie MIus., IV, 142, pl. xlii, fig. 2;

Eigenmann, 1910, Rept. Princeton Univ. Exped. Patagonia, III, 443.

Myloplus levis Eigenmann, 1915, Ann. Carnegie Mus., IX, 271;

Norman, 1928, Proc. Zool. Soc. London, 825.

The Paraguay and Ucayali rivers

15752, 1, $100 \mathrm{~mm}$., Iago ('ashiboya, Allen, August, 1920.

15805, 24, 75-115 mm., Yarinarocha, Allen, August, 1920.

\section{Myloplus Rubripinnis (Müller and Troschel)}

Myletes rubripinnis Müller and Troschel, 1845, Horae Ichth., I, 38, pl. ix, fig. 3;

Güther, 186t, Cat. Fish. Brit. MIus., V, 373;

Eigenmann and Eigenmann, 1891, Proc. U. S. Nat. Mus., XIV, 60.

Myleus rubripinnis Eigenmann, 1910, Rept. Princeton Univ. Exped. Patagonia, III, 443.

Myloplus mubripinnis Eigenmann, 1912, Mem. Carnegie Mus., V, 391, pl. lvii, fig. 3, British Guiana;

Fowler, 1939 (1940), Proc. Acad. Nat. Sci. Phila., XCI, 273, two, 100 and 103 mm., Contamana.

\section{Guianas and Peruvian Amazon}

The Mylinae are known to the Peruvians of the Oriental provinces under the names palometa or palometo and paco (pacu of Guiana). The pacos are the wider, more robust, and larger Myleus-type, while the thinner, more silvery, less colorful Metynnis or Mylosoma are the palometo. I found the latter group migrating in enormous numbers with the Prochilodus and Leporinus types, during the rising stages of the rivers. They were so abundant and so readily available in quantity with the throw-net, that they were the prime favorites for drying during the late dry season, despite the limited flesh. In this form they are a staple food for the rainy season when fishing becomes more difficult. The wrist-watch thinness and bony character of such fishes is cheerfully accepted by the Loretans by reason of abundance and the sweet flesh. With but little dressing they are thrown into stew pan or kettle entire, including heads and many scales, and cooked with rice or green plantains. They form a part of the luggage of many a traveler, together with the rice, beans, salt, etc., and a bunch of the plantains thrown on top the cargo.

The thin and hatchet-like contours of the Chalcinus forms, carried further in the shorter Gasteropelecus, is emphasized still further in the Mylinae. Like the others named, they do a great deal of leaping from the water, especially at nightfall, describing a peculiar are through the air, and cleaving the water again with hardly a ripple, hatchet-edge-foremost. This activity is as much a part of the palometo as its body, and they may readily be identified by it, even at some distance. 


\title{
Fourth Division-The Characinine Group of Subfamilies
}

\author{
Subfamily: BRYCONINAE
}

\section{Genus 119: BRYCON Müller and Troschel}

Brycon Müller and Troschel, 1844, Arch. Naturg., 90;

Müller and Troschel, 1845, Horae Ichth., I, 15;

Eigenmann, 1910, Rept. Princeton Univ. Exped. Patagonia, III, 430;

Eigenmann, 1912, Mem. Carnegie Mus., V, 370.

Type: Brycon falcatus Müller and Troschel Guatemala to Argentina

Lower jaw with two series of teeth, the outer lobed, the inner conical; inner series consisting of a pair of conical teeth near the symphysis and a row of much smaller teeth along the posterior part of the mandibular ramus; upper jaw with three or more series; skull with two large fontanels.

\section{Brycon cephalus (Günther)}

Megalobrycon cephalus Günther, 1869, Proc. Zool. Soc. London, 123, fig. 1, one, 13 inches Brycon cephalus Eigenmann, 1910, Rept. Princeton Univ. Exped. Patagonia, III, 430.

Peruvian Amazon

\section{Brycon stübeLII Steindachner}

Brycon stübelii Steindachner, 1882 (1883), Denksch. KK. Akad. Wiss. Wien, XLVI, 13, pl. i, fig. 1, Peruvian Amazon, one, $130 \mathrm{~mm}$;

(misspelled stubelli) Eigenmann, 1910, Rept. Princeton Univ. Exped. Patagonia, III, 130.

\section{Peruvian Amazon}

\section{Brycon capito Cope}

Brycon capito Cope, 1871 (1872), Proc. Acad. Nat. Sci. Phila., XXIII, 261, Rio Ambyiacu;

Fowler, 1906 (1907), Proc. Acad. Nat. Sci. Phila., LVIII, 446, fig. 42, Rio Ambyiacu, Hauxwell collection;

Eigenmann, 1910, Rept. Princeton Univ. Exped. Patagonia, III, 431.

\section{Rio Ambyiacu}

\section{Brycon melampterum (Cope)}

Megalobrycon melampterum Cope, 1871, Proc. Acad. Nat. Sci. Phila., XXIII, 262, pl. xiii, fig. 1, Rio Ambyiacu.

Brycon melampterum Fowler, 1906 (1907), Proc. Acad. Nat. Sci. Phila., LVIII, 447, Rio Ambyiacu, Hauxwell and Orton collections.

Brycon melampterus Eigenmann, 1910, Rept. Princeton Univ. Exped. Patagonia, III, 430. 


\section{Rio Ambyiacu to the Pichis}

16021, 2, 165 and 167 mm., Yarinacocha, Allen, August, 1920.

16022 ,

16027 , , Orellana, Rio Ueayali, Allen, August, 1920.

16028 , , Rio Pachitea, Allen, July, 1920.

16029,16030 , ,

, Pto. Bermudez, Rio Pichis, Allen, July, 1920. , Mouth Rio Pacaya, Allen, August, 1920.

\section{Brycon erythropterum (Cope)}

Megalobrycon erythropterum Cope, 1871 (1872), Proc. Acad. Nat. Sci. Phila., XXIII, 263, Rio Ambyiacu.

Brycon erythropterus Eigenmann, 1910, Rept. Princeton Univ. Exped. Patagonia, III, 430.

Brycon erythropterum Fowler, 1939 (1940), Proc. Acad. Nat. Sci. Phila., XCI, 263, one, 145, Contamana.

\section{Rio Ambyiacu to the Pachitea}

16023, 3, 165-212 mm., Rio Ucayali, Orellana, Allen, August, 1920.

16025, 2, 188 and 192 mm., Lago Cashiboya, Allen, August, 1920.

16026, 1, 220 mm., Rio Pachitea, Allen, July, 1920.

$17844,1,210$ mm., Iquitos, Allen, September, 1920.

17031, 17032, , , Iquitos, Allen, September, 1920.

Rumi-uma (red-tail) is a colloquial name of this species.

\section{5a. BRYCON SP.}

Brycon siebenthali iquitensis Nakashima, 1941, Bol. Mus. Hist. Nat. Lima, V, 69.

\section{Brycon stolzmanni Steindachner}

Brycon stolzmanni Steindachner, 1879, Denksch. KK. Akad. Wiss. Wien, XLI, 22, pl. ii, fig. 6;

Eigenmann, 1910, Rept. Princeton Univ. Exped. Patagonia, III, 431;

Pearson, 1937a, Proc. Cal. Acad. Sci., (4), XXIII, 90, Paipay, Tingo de Pauca, Pusoc, upper Marañon.

\section{Intercordilleran Marañon}

The type specimens of Steindachner were taken on a tributary of the upper Marañon at Chota, a point near the Pearson localities.

\section{Subfamily: IGUANODECTINAE}

Gregory and Conrad's paper (1938, p. 335) would encourage the view that the Iguanodectinae belong nearer to this point than to the Tetragonopterinae.

\section{Genus 120: IGUANODECTES Cope}

Iguanodectes Cope, 1871 (1872), Proc. Acad. Nat. Sci. Phila., 260;

Eigenmann, 1910, Rept. Princeton Univ. Exped. Patagonia, III, 430;

Eigenmann, 1912, Mem. Carnegie Mus., V, 314;

Eigenmann and Myers, 1929, Mem. Mus. Comp. Zool., XLIII, v, 494. 
Type: Iguanodectes tenuis Cope

Range that of the unique species

Upper jaw with two series of pluricuspid incisor-like teeth, the outer series having a single tooth on each side; origin of the long anal beneath the dorsal; pectorals low, with a nearly horizontal base; preventral area rounded with breast broad between the pectorals, and with a perceptible median ridge; gill-membranes united, free from the isthmus; lateral line complete.

\section{Iguanodectes tenuis Cope}

Iguanodectes tenuis Cope, 1871 (1872), Proe. Acad. Nat. Sci. Phila., XXIII, 260, pl. viii, figs. 1 and la, Rio Ambyiacu;

Eigenmann and Eigenmann, 1891, Proc. U. S. Nat. Mus., XIV, 5t;

Eigenmann, 1910, Rept. P'rinceton Univ. Exped. Patagonia, III, 430;

Eigenmann, 1912, Mem. Carnegie Mus., V, 314;

Eigenmann and Myers, 1929, Mem. Mus. Comp. Zool., XLIII, r, 49t, pl. lxxi, figs. 3 and 6; pl. xevii, fig. 14 .

\section{Rio Ambyiacu and British Guiana \\ Genus 121: PIABUCUS Oken}

Les Piabuques Cuvier, 1817, Règne Anim., II, 166, Salmo argentinus.

Piabucus Oken, 1817, Isis, 1183;

Eigenmann, 1910, Rept. Princeton Univ. Exped. Patagonia, III, 440;

Eigenmann, 1912, Mem. Carnegie Mus., V, 316.

Type: Salmo argentinus Linnaeus

Guiana to basin of La Plata

Slender, smelt-like; mouth minute; teeth incisors with numerous cusps, in single series, except that the premaxillary may bear an anterior series of two teeth; gill-membranes united across, but free from the isthmus; preventral contour sharply compressed and little expanded; pectorals large, low, with oblique bases; origin of anal forward of the vertical from the dorsal fin.

\section{Piabucus dentatus (Koelreuter)}

Piabuca (native name) Marcgrave, 1648, Hist. Rerum Nat. Bras., IV, 170.

Trutta dentata Koelreuter, 1761, Nov. Comm. Petropoli, VIII, 413, tab. 14, fig. 4.

Piabucus dentatus Eigenmann, 1910, Rept. Princeton Univ. Exped. Patagonia, III, 140;

Eigenmann, 1912, Mem. Carnegie Mus., V, 316;

Eigenmann and Myers, 1929, Mem. Mus. Comp. Zool., XLIII, v, 497, pl. lxxi, figs. 2 and 4; pl. xevii, fig. 15.

Salmo argentinus Linnaeus (in part), 1766, Syst. Nat, ed. xii, 511.

Piabuca argentina Cuvier, 1817, Règne Anim., II, 310;

Cuvier and Valenciennes, 1848, Hist. Nat. Poiss., XXII, 108;

Günther, 1864, Cat. Fish. Brit. Mus., V, 34t;

Steindachner, 1891, Sitzb. KK. Akad. Wiss. Wien, C, 36t, Iquitos;

Eigenmann and Eigenmann, 1891, Proc. U. S. Nat. Mus., XIV, 57.

Iquitos to Para and the Guianas 


\section{Genus 122: CHARAX Scopoli}

Charax Gronow, 175t, Mus. Ichth., I, 10;

Gronow, 1763, Zoophyl., 123;

Scopoli, 1777, Hist. Nat., 455 ;

Eigenmann, 1910, Rept. Princeton Univ. Exped. Patagonia, III, 444 ;

Eigenmann, 1912, Mem. Carnegie Mus., V, 400.

Characinus Lacépède, 1803, Hist. Nat. Poiss., V, 269;

Swainson, 1829, Fish. Amph. Rept., II, 289;

Gill, 1895, Proc. U. S. Nat. MIus., XVIII, 213.

Epicyrtus AIüller and Troschel, 184t, Arch. Naturg., 92, preoccupied.

Anacyrtus Günther, 186t, Cat. Fish. Brit. Mus., V, 345.

\section{Type: Salmo gibbosus Linnaeus}

Guianas to the Paraguay system

Premaxillary with a small canine at each end and a double row of teeth between; lower jaw with two feeble canines and a series of conical teeth; anal very long; lateral line complete; fins naked; preventral line flattened and bordered by lower edges of the clavicles which take a blade-like shape and end both forward and backward with spines.

\section{Charax pauciradiata (Günther)}

Anacyrtus pauciradiaius Günther, 1864, Cat. Fish. Brit. Mus., V, 345;

Steindachner, 1882 (1883), Denksch. KK. Akad. Wiss. Wien, XLVI, 14, Iquitos, one specimen; Boulenger, 1887, Proc. Zool. Soc. London, 282, Canelos.

Charax pauciradiata Eigenmann, 1910, Rept. Princeton Univ. Exped. Patagonia, III, 444.

\section{Peruvian Amazon}

\section{Charax limaesquamis (Cope)}

Anacyrtus (misspelled Anacrytus) limaesquamis Cope, 1878, Proc. Amer. Phil. Soc., XVII, 686, R. Marañon, Orton collection.

Cyrtocharax limaesquamis Fowler, 1906 (1907), Proc. Acad. Nat. Sci. Phila., LVIII, 454, fig. 44; Fowler, 1939 (1940), Proc. Acad. Nat. Sci. Phila., XCI, 270, one, 183 mm., Contamana.

Charax limaesquamis Eigenmann and Ogle, 1907, Proc. U. S. Nat. Mus., XXXIII, 32;

Eigenmann, 1910, Rept. Princeton Univ. Exped. Patagonia, III, 44.

\section{The Marañon}

\section{Charax tectifer (Cope)}

Anacyrtus tectifer Cope, 1870, Proc. Amer. Phil. Soc., XI, 565, Pebas, Hauxwell collection.

Anacyrtus sanguineus Cope, 1872, Proc. Acad. Nat. Sci. Phila., XXIII, 266, pl. ix, fig. 1, Rio Ambyiacu, Hauxwell collection;

Cope, 1878, Proc. Amer. Phil. Soc., XVII, 686, Marañon, Orton coll.;

Eigenmann and Ogle, 1907, Proc. U. S. Nat. Mus., XXXIII, 32. 
Charax tectifer Fowler, 1906 (1907), Proc. Acad. Nat. Sci. Phila., LXVIII, 453;

Eigenmann, 1910, Rept. Princeton Univ. Exped. Patagonia, II I, 44.

\section{Rio Ambyiacu}

H. 3.5; depth 3 ; D. II, 9 ; A. III, 42 ; width of head in its length 2.6 ; depth of head 1.6 ; snout 4 ; eye 3.5 ; maxillary 1.42 ; interorbital 3.5 ; mandible 1.66 ; caudal peduncle 3.4. (Fowler).

In other respects Cope's types of sanguineus correspond to the description of the species, except that Cope's figure erroneously indicates the origin of the anal fin opposite the origin of the dorsal.

\section{Charax amazonum (Gïnther)}

Anacyrtus (Cynopotamus) amazonum Günther, 1868, Proc. Zool. Soc. London, 246, two, 10 inches. Bartlett coll., Xeberos.

Charax amazonum Eigenmann, 1910, Rept. Princeton Lnir. Exped. Patagonia, III, 445.

Xeberos

Known only from the above types

\section{Charax gibbosus (Limnaeus)}

"Charax 53" Gronow, 1754, Mus. Ichth., I, 19, pl. i, fig. 4;

Gronow, 1763, Zoophyl, 12t, no. 380.

Salmo gibbosus Linnaeus, 1758, Syst. Nat., ed. x, I, 311, no. 19;

Linnaeus, 1766, Syst. Nat., ed. xii, I, 513, Surinam;

Bloch and Schneider, 1801, Syst. Ichth., 419.

Epicyrtus gibbosus Müller and Troschel, 1845, Horae Ichth., I, 17, pl. ii, fig. 1;

Müller and 'Troschel, 1848, in Schomburgk's Reisen, III, 635.

Cynopotamus gibbosus Cuvier and Valenciennes, 1818, Hist. Tat. Poiss., XXII, 321, pl. 645, Essequibo and Amazon;

Castelnau, 1855, Anim. Amér. Sud, Poiss., 75, Amazon to Ucayali;

Garman, 1890, Bull. Essex Inst., XXII, 11, Tabatinga.

Anacyrtus gibbosus Günther, 186t, Cat. Fish. Brit. Mus., V, 346, Guianas;

Eigenmann and Eigenmann, 1891, Proc. U. S. Nat. Mus., XIV, 57 ;

Perugia, 1897, Ann. Mus. Genova, (2), XVIII, 26, Rio Beni.

Charax gibbosus Fowler, 1906 (1907), Proc. Acad. Nat. Sei. Phila., LVIII, 453, Surinam;

Eigenmann, 1910, Rept. Princeton Univ. Exped. Patagonia, III, 444;

Eigenmann, 1912, Mem. Carnegie Mus., V, 400;

Fowler, 1939 (1940), Proc. Acad. Nat. Sci. Phila., XCI, 270, two, 98 and 103 mm., Contamana.

\section{Peruvian Amazon to the Guianas}

\section{Genus 123: ROEBOIDES Günther}

Roeboides Günther, 186t, Cat. Fish. Brit. Mus., V, 345;

Eigenmann, 1910, Rept. Princeton Univ. Exped. Patagonia, II I, 445 ;

Eigenmann, 1912, Mem. Carnegie Mus., V, 398.

Cynocharax Fowler, 1907, Proc. Aead. Nat. Sci. Phila., LVIII, 157. 


\section{Type: Anacyrtus guatemalensis Günther}

Mexico to Argentina, in lowlands, but reaching several thousand feet elevation.

Teeth small and conical or tricuspid, in a single series on the maxillary and sides of the mandibles, in two imperfect series on the premaxillary, and sometimes on the front of the mandible; middle premaxillaries slightly larger; maxillary with or without teeth along its entire length; anterior mandibular teeth and one on each corner slightly enlarged; several larger tooth-like prongs extending forward from the upper jaw at the margin of the lip; maxillary sometimes the same; lower jaw with 2-4 prongs directed forward.

Cheeks almost entirely overspread by the suborbitals; gill-membrane free from the isthmus; gill-rakers similar on the two limbs, strong, long, few in number; pharyngeals with short, stiff rakers; scales small, cycloid; dorsal over origin of anal fin, which is very long ( $42-57$ rays); pectorals overlapping ventrals; preventral area flattened; tongue free; lateral line complete; alimentary canal short.

\section{Roeboides myersit Gill}

Roeboides myersii Gill, 1870, Proc. Acad. Nat. Sci. Phila., XXII, 92;

Cope, 1871 (1872), Proc. Acad. Nat. Sci. Phila., XXIII, 265;

Cope, 1878, Proc. Amer. Phil. Soc, XVII, 686, Orton and Hauxwell collections, Peruvian Amazon;

Fowler, 1906 (1907), Proc. Acad. Nat. Sci. Phila., LVIII, 455, fig. 45;

Eigenmann and Ogle, 1907, Proc. U. S. Nat. Mus., XXXIII, 32;

Eigenmann, 1910, Rept. Princeton Univ. Exped. Patagonia, III, 455;

Fowler, 1939 (1940), Proc. Acad. Nat. Sci. Phila., XCI, 270, one, 101 mm., Contamana.

Anacyrtus myersii Steindachner, 1882 (1883), Denksch. KK. Akad. Wiss. Wien, XLVI, 14, Rios

Huallaga and Marañon, two.

\section{Peruvian Amazons}

\section{Roeboides AfFinis (Günther).}

Anacyrtus affinis Günther, 1868, Proc. Zool. Soc. London, 246, two, four inches, Rio Huallaga;

Günther, 1868, Ann. Mag. Nat. Hist., 481.

Roiboides rubrivertex Cope, 1871 (1872), Proc. Acad. Nat. Sci. Phila., XXIII, 265, Peruvian Amazon or Ueayali, Perkins collection.

Roeboides (Cynocharax) affinis Fowler, 1906 (1907), Proc. Acad. Nat. Sci. Phila., LVIII, 457, fig. 46. Roeboides affinis Eigenmann, 1910, Rept. Princeton Univ. Exped. Patagonia, III, 445;

Fowler, 1939 (1940), Proc. Acad. Nat. Sci. Phila., XCI, 269, seven, 114-164 mm., lower Ucayali.

Amazon and Orinoco basins

\section{Roeboides bicornis Cope}

Roeboides bicornis Cope, 1870, Proc. Amer. Phil. Soc., XI, 564, fig., Pebas, Hauxwell collection; Eigenmann, 1910, Rept. Princeton Univ. Exped. Patagonia, III, 445;

Fowler, 1939 (1940), Proc. Acad. Nat. Sci. Phila., XCI, 268, three, 78-102 mm., lower Ueayali. Roeboides (Cynocharax) bicornis Fowler, 1906 (1907), Proc. Acad. Nat. Sci. Phila., LVIII, 458, fig. 47 .

\section{Rios Marañon and Ucayali}


326a. ROEBOIDES SP.

15806,15807 , Lago Sanango, Allen, November, 1920.

Genus 124: Crnopotamus Cuvier and Valenciennes

Cynopotamus Cuvier and Valenciennes, 1848, Hist. Nat. Poiss, XXII, 317;

Fowler, 1939 (1940), Proc. Acad. Nat. Sci. Phila., XCI, 268.

Eucynopotamus Fowler, 1904, Proc. Acad. Nat. Sci. Phila., LIII, 119;

Eigenmann, 1910, Rept. Princeton Univ. Exped. Patagonia, III, 445.

Type: Hydrocyon argenteus Valenciennes

Rio Magdalena to Peruvian Amazon and La Plata

Placed by Fowler with Hydrolicus in the subfamily Cynodontinae.

Teeth of lower jaw in a single series, having four canines in front (the third the largest) and numerous small teeth along the sides; premaxillary teeth in two series, a canine at each end; maxillary without canines; lateral line complete; scales very small (90 or more on the lateral line series); no opercular spine; clavicle slightly notched, lower edge not blade-like, without spines.

\section{Cinopotamus gulo Cope}

Cynopotamus gulo Cope, 1870, Proc. Amer. Phil. Soc., XI, 565, Pebas, Hauxwell collection;

Fowler, 1939 (1940), Proc. Acad. Nat. Sci. Phila., XCI, 268, four, 128-164 mm., Contamana. Cynopotamus (Eucynopotamus) gulo Fowler, 1904, Proc. Acad. Nat. Sci. Phila., LIII, 119;

Fowler, 1906 (1907), Proc. Acad. Yat. Sci. Phila., LVIII, 459, fig. 48.

Eucynopotamus gulo Eigenmann, 1910, Rept. Princeton Univ. Exped. Patagonia, III, 445;

Pearson, 1937a, Proc. Cal. Acad. Sci., (t), XXIll, 92, 'Tingo de Pauca and Pusoc, upper \\arañon.

Marañon basin

\section{Cynopotamus kneriI (Steindachner)}

Anacyrtus knerii Steindachner, 1879, Denksch. KK. Akad. Wiss. Wien, XXXIX, 65, Canelos;

Boulenger, 1887, Proc. Zool. Soc. London, 282.

Eucynopotamus knerii Fowler, 190t, Proc. Acad. Nat. Sci. Phila., LIII, 119;

Eigenmann, 1910, Rept. Princeton Univ. Exped. Patagonia, III, 445.

Peruvian Amazon to La Plata

, 1, $167 \mathrm{~mm}$., Rio Itaya, Iquitos, Allen, September, 1920.

The members of the present subfamily and the preceding are known to the inhabitants of eastern Peru in a general sense as the peje perro, or "dog fish". They have the reputation of being very rapacious, and destructive to fishing gear.

$$
\text { Subfamily: SALMININAE }
$$

\section{Genus 125: SALMIINUS Agassiz}

Salminus Agassiz, 1829, Sel. Gen. et Spec. Pisc. Bras., 18;

Eigenmann, 1910, Rept. Princeton Univ. Exped. Patagonia, III, 146 ;

Eigenmann, 1922, Mem. Carnegie Mus., IX, 158. 
Type: Hydrocyon brevidens Valenciennes (non Hydrocyon brevidens Cuvier) = Salminus maxillosus Cuvier and Valenciennes

Cauca to Rio Grande do Sul and La Plata basins

Palate edentulous; salmonoid, abdomen long, separating the pectorals more widely from the remote ventrals than in nearby characinine genera; teeth of outer series larger than the inner both above and below; scales conspicuously large.

\section{Salminus affinis Steindachner}

Salminus affinis Steindachner, 1880, Denksch. KK. Akad. Wiss. Wien, XLII, 80, pl. vii, figs. 2 and 2a, Cauca;

Boulenger, 1898, Boll. Mus. Zool. Torino, XIII, 4, R. Santiago;

Eigenmann, 1910, Rept. Princeton Univ. Exped. Patagonia, III, 446;

Eigenmann, 1916, Ann. Carnegie Mus., X, 92, Honda;

Eigenmann, 1922, Mem. Carnegie Mus., IX, 158.

Rios Cauca, Santiago, Ucayali and Chanchomayo

16024, 2, 228 and $240 \mathrm{~mm}$, Rio Ueayali, Orellana, Allen, August, 1920.

The occurrence of the species in the Ucayali seems to add plausibility to the Rio Santiago record in southeastern Ecuador, considered a doubtful identification. The Salminus collected by Eigenmann and daughter in the Chanchomayo were lost in transit, and were doubtless S. affinis.*

The name corvina is misapplied to this genus.

\section{Subfamily: CHALCININAE}

The well-known Chalcinus and Chalcininae are hopefully retained despite Myers' (1940) replacement by Triportheus Cope in order to vacate the name for a possible occupancy in the Chalcididae, as of Rafinesque, 1815.

\section{Genus 126: CHALCINUS Cuvier and Valenciennes}

Chalceus Müller and Troschel (non Cuvier and Valenciennes), 1845, Horae Ichth., I, 15, angulatus. Chalcimus Cuvier and Valenciennes, 1849, Hist. Nat. Poiss., XXII, 258;

Eigenmann, 1910, Rept. Princeton Úniv. Exped. Patagonia, III, 410;

Eigenmann, 1912, Mem. Carnegie Mus., V, 376.

Triportheus Cope, 1871 (1872), Proc. Acad. Nat. Sci. Phila., XXIII, 263;

Myers, 1940, Stanford Ichth. Bull., I, v, 170.

Type: Chalcinus brachypomus Cuvier and Valenciennes = Chalceus angulatus Agassiz

Rio Magdalena to Guianas, Peru, and La Plata

Compressiform, herring-like; lateral line decurved; preventral line trenchantly compressed; pectoral large; mouth small; a pair of conical teeth in mandible behind a series of lobed teeth; upper jaw with two series of teeth; caudal fin emarginate, the middle rays prolonged.

*Specimens of Salminus collected by Nakashima at Iquitos were published by him (1941) as a new species, Holobrycon iquitensis. Dr. G. S. Myers has seen the paper, and unhesitatingly places the species in the synonymy of Salminus hilarii, already known from the Amazons further down. 


\section{Chalcinus angulatus (Agassiz)}

Chalceus angulatus Agassiz, 1829, Sel. Gen. et Spec. Pisc. Bras., 67.

Chalcinus angulatus Steindachner, 1882 (1883), Denksch. KK. Akad. Wiss. Wien, XLVI, 14, Huallaga, two, $130 \mathrm{~mm}$;

Eigenmann, 1910, Rept. Princeton Univ. Exped. Patagonia, III, 440;

Fowler, 1939 (1940), Proc. Acad. Nat. Sci. Phila., XCI, 265, eight, 156-178 mm., Bajo Ucayali.

Chalcinus brachypomus Cuvier and Valenciennes, 1848, Hist. Nat. Poiss., XXII, 258;

Günther, 1868, Proc. Zool. Soc. London, 229;

Cope, 1870, Proc. Amer. Phil. Soc., XI, 566, Pebas.

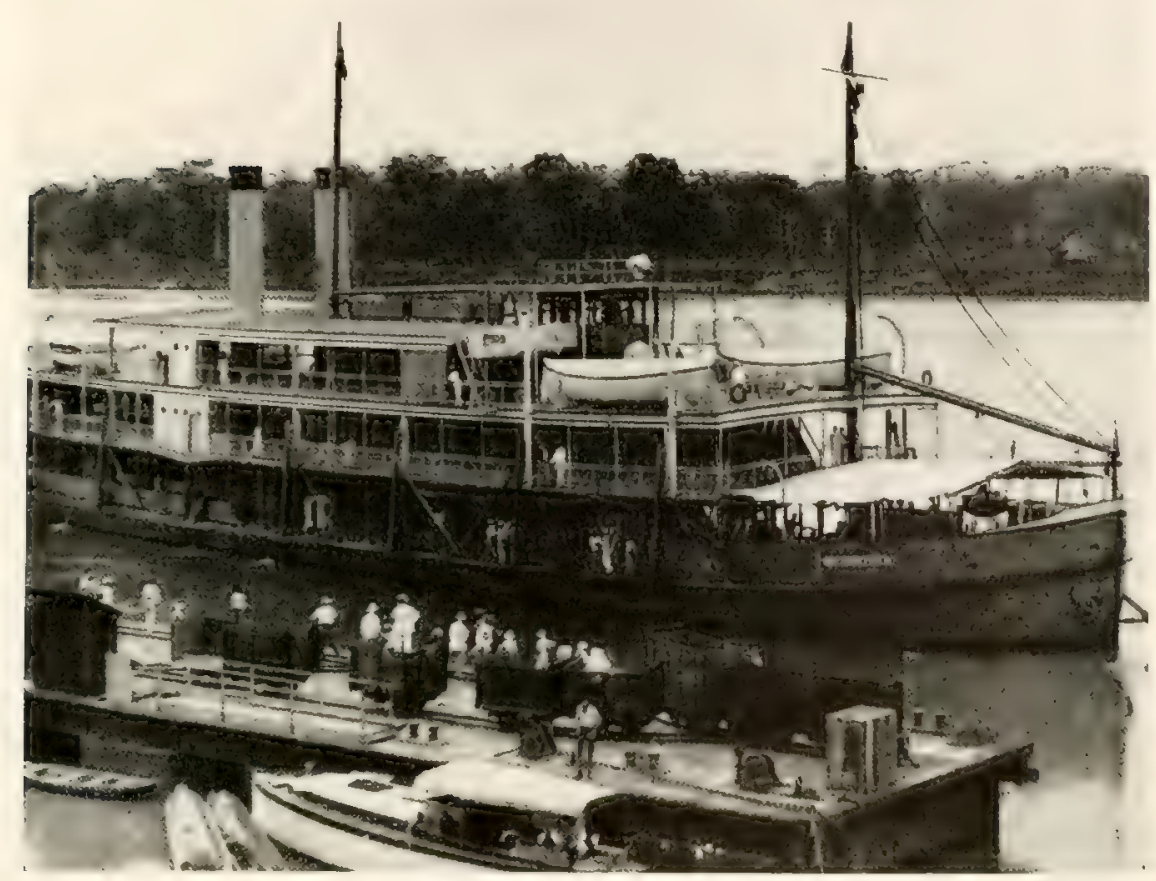

FIG. 29. The Amazon at Iquitos, Peru. The greater half of the river lies beyond the island seen in the background.

Chalcimus nematurus Gill, 1870, Proe. Acad. Nat. Sci. Phila., XXII, 92, Marañon or Napo, Orton collection:

Cope, 1878, Proc. Amer. Phil. Soc., XVII, 692, Marañon.

Triporthcus flavus Cope, 1871 (1872), Proc. Acad. Nat. Sci. Phila., XXIII, 264, pl. xiv, fig. 1, Rio Ambriacu.

Orinoco basin to Amazons and the Paraguay

Colloquially known as sapo mama and anchoeta (Steindachner). I learned from the people a rariant of the latter name, anchoveta.

$15741,1,172 \mathrm{~mm}$., Iquitos, Allen, September, 1920.

$157+3,1,156 \mathrm{~mm}$., Rio Morona, Allen, October, 1920.

$15744,1,157 \mathrm{~mm}$. Alto Marañon, below Pastaza, Allen, October, 1920

$15745,2,194 \mathrm{~mm}$., Rio Huallaga, Yurimaguas, Allen, Norember, 1920.

15746, 7, 150-187 mm., Lago Sanango, Allen, November, 1920. 


\section{0a. Chalcinus angulatus vittatus Garman}

Chalcinus angulatus vittatus Garman, 1890, Bull. Essex Inst., XXII, 1-7;

Eigenmann, 1910, Rept. Princeton Univ. Exped. Patagonia, III, 440.

The Amazons

15749, 7, 172-226 mm., Lago Sanango, Allen, November, 1920.

\section{Chalcinus albus (Cope)}

Triportheus albus Cope, 1871 (1872), Proc. Acad. Nat. Sci. Phila., XXIII, 264, pl. viii, fig. 3; pl. xiv, fig. 2, Rio Ambyiacu, Hauxwell.

Chalcinus albus Fowler, 1906 (1907), Proc. Acad. Nat, Sci. Phila., LVIII, 447, Ambyiacu, Hauxwell collection;

Eigenmann, 1910, Rept. Princeton Cnir. Exped. Patagonia, III, 440.

\section{The Amazons}

15747, 1, 112 mm., Rio Huallaga, Yurimaguas, Allen, November, 1920.

\section{Chalcinus rotundatus (Schomburgk)}

Chalceus rotundatus Schomburgk, 1840, Fish. Brit. Guiana, I, 209.

Chalcinus brachypomus Cuvier and Valenciennes, 1848, Hist. Nat. Poiss., XXII, 259;

Günther, 1864, Cat. Fish. Brit. Мus., I, 339.

Chalcinus rotundatus Eigenmann, 1912, MIem. Carnegie Mus, V, 377, pl. lv, fig. 1.

Chalcinus rotundatus iquitensis Nakashima, 1941, Bol. Nus. Hist. Nat. Lima, V, 64 (fide G. S. Myers.)

\section{Chalcinus elongatus Gïnther}

Chalcinus elongatus Günther, 186t, Cat. Fish. Brit. Mus, V, 342;

Steindachner, 1876, Sitzb. KK. Akad. Wiss. Wien, LXXIY, 54, 'Teffé and Peruvian Amazon; Garman, 1890, Bull. Essex Inst., XXII, 6, Tabatinga;

Eigenmann, 1910, Rept. Princeton Univ. Exped. Patagonia, III, 440;

Eigenmann, 1912, \em. Carnegie \Ius, V, 377;

Fowler, 1939 (1940), Proc. Acad. Yat. Sei. Phila., XCI, 265, fig. 60, two, 108 and 123 mm., Contamana.

Chalcimus elongatus iquitensis Nakashima, 1941, Bol. MIus. Hist. Nat. Lima, V, 63.

Orinoco and Guianas, to Amazons

15742,2 , about $220 \mathrm{~mm}$., Iquitos, Allen, September, 1920 .

$15748,10,210-235 \mathrm{~mm}$., Lago Sanango, Allen, November, 1920.

\section{Genus 127: COSCINOXYRON Fowler}

Coscinoxyron Fowler, 1906 (1907), Proc. Acad. Nat. Sci. Phila., LVIII, 450;

Eigenmann, 1910, Rept. Princeton Univ. Exped. Patagonia, III, 440.

Chatcinus (part) Eigenmann, 1912, Mem. Carnegie Mus., V, 376.

\section{Type: Chalcinus culter Cope}

Range that of the species

Gill-rakers, finer, longer, and more numerous on the first arch than in Chalcinus, totaling about one hundred; dorsal fin in a posterior position, at about the two-thirds point in the length of the head and trunk. 
334. Coscinoxyron culter (Cope)

Chalcinus culler Cope, 1871 (1872), Proc. Acad. Nat. Sci. Phila., XIIII, 265, pl. xiv, fig. 3, Rio Ambyiacu, Hauxwell collection;

Cope, 1878, Proc. Amer. Phil. Soc., XVII, 692, Marañon, Orton coll.

Coscinoxyron culter Fowler, 1906 (1907), Proc. Acad. Nat. Sci. Phila., LVIII, 450, Nauta and R. Ambriacu;

Eigenmann, 1910, Rept. Princeton Univ. Exped. Patagonia, II, 440;

Fowler, 1939 (1940), Proc. Acad. Nat. Sci. Phila., XCI, 265, two, 202 and 216 mm., Contamana.

Peruvian Amazon to São Paulo on the Brazilian Amazon

\section{Genus 128: CLUPEACHARAX Pearson}

Chepacharax Pearson, 1924, Ind. Univ. Studies, no. 64, 46.

Type: Chupeacharax anchoveoides Pearson

Range that of the only known species

Having much the form of an anchovy; greatly elongate, compressed, with upper profile straight, and breast with a median keel; premaxillary with two series of teeth, two teeth in the outer series, five in the inner; maxillary edentulous, long, slender, widened in front; mandible with three 5- or 6-pointed teeth; gill-membranes free from isthmus and from one another; origin of anal in advance of origin of dorsal; ventrals small; pectorals large and falcate; adipose present; anal long; lateral line complete.

\section{Clupeacharax anchoveoides Pearson}

Clupeacharax anchoreoides Pearson, 1921, Ind. Univ. Studies, no. 64, 47, pl. vii, fig. 3; pl. xi, fig. 2.

\section{Oriental Peru and Bolivia}

Described from a specimen taken by its author at Cachuela Esperanza, Bolivia. Dr. Myers kindly permits me to mention its having been taken by Mr. Scherer at Pebas on the Marañon, for the Stanford University collections.

\section{Subfamily: PYRRHULININAE \\ Genus 129: COPEINA Fowler}

Copeina Fowler, 1906 (1907), Proc. Acad. Nat. Sci. Phila., LVIII, 294;

Eigenmann, 1910, Rept. Princeton Univ. Exped. Patagonia, III, 428;

Regan, 1912, Ann. Mag. Nat. Hist., (8), X, 392.

Type: Pyrrhulina argyrops Cope

Most of Amazonia

The premaxillaries in a single series; mandibulars in two series, of which the outer row are conical; fontanels and adipose fin wanting; air bladder with walls not broken up into cells. 
336. Copeina argyrops (Cope)

Pyrrhulina argyrops Cope, 1878, Proc. Amer. Phil. Soc., XVII, 69t, Rio Maranon, Orton collection. Copeina argyrops Fowler, 1906 (1907), Proc. Acad. Nat. Sci. Phila., LVIII, 295, fig. 2;

Eigenmann, 1910, Rept. Princeton Univ. Exped. Patagonia, III, 428;

Regan, 1912, Ann. Mag. Nat. Hist., (8), X, 395.

The Amazons

\section{Genus 130: PYRRHULINA Cuvier and Valenciennes}

Pyrrhulina Cuvier and Valenciennes, 1846, Hist. Nat. Poiss., XIX, 534;

Eigenmann, 1910, Rept. Princeton Univ. Exped. Patagonia, III, 428;

Eigenmann, 1912, Mem. Carnegie Mus., V, 278.

Holotaxis Cope, 1870, Proc. Amer. Phil. Soc., XI, 563.

\section{Type: Pyrrhulina filamentosa Cuvier and Valenciennes}

Rios Paraguay and Amazon to the Guianas

Small, elongate characin fishes having premaxillary and dentary provided with two or more series of conical teeth; palatines without teeth; mouth opening extremely oblique; nares closely approximated; dorsal and anal fins short; no adipose fin and no lateral line.

\section{Pyrrhulina melanostoma (Cope)}

Holotaxis melanostomus Cope, 1870, Proc. Amer. Phil. Soc., XI, 563.

Pyrrhutina melanostoma Eigenmann, 1910, Rept. Princeton Univ. Exped. Patagonia, III, 428. Pyrhulina nattereri Regan, 1912, Ann. Mag. Nat. Hist., (8), \, 390, one specimen, 40 mm., Amazon.

Pebas on the Peruvian Amazon

\section{Pyrrhulina laeta (Cope)}

Holotaxis laetus Cope, 1871 (1872), Proc. Acad. Nat. Sci. Phila., XXIII, 257, Ambyiacu, Hauxwell collection.

Pyrrhulina lacta Fowler, 1906 (1907), Proc. Acad. Nat. Sci. Phila., LVIII, 294, fig. 1;

Eigenmann, 1910, Rept. Princeton Univ. Exped. Patagonia, III, 428.

Pyrrhulina semifasciata Regan, 1912, Ann. Nag. Nat. Hist., (8), X, 390.

Rio Ambyiacu

Known from the types in the Philadelphia Museum.

339. Pyrrhulina eleanorae Fowler

Pyrrhulina eleanorae Fowler, 1939 (1940), Proc. Acad. Nat. Sci. Phila., XCI, 262, fig. 59.

\section{Contamana, Bajo Ucayali}

Known from the type, $52 \mathrm{~mm}$. long. Near P. brevis Steindachner, with dark horizontal line through mandible, eye, opercle, and two scale rows beyond. 
340. Pyrrhulina lugubris Eigenmann

Pyrrhulina lugubris Eigenmann, 1922, Mem. Carnegie Mus., IX, 231, pl. xxi, fig. 1, Rio Meta; Myers, 1927, Bull. Mus. Comp. Zool., LXVIII, 111.

Pyrrhulina obermülleri Myers, 1926, Copeia, no. 156, 150, Iquitos.

Rios Meta and Marañon

—, several, largest 55 mm., Iquitos, Allen, September, 1920.

Subfamily: APHIOCHARACINAE

Possibly, as indicated by Gregory and Conrad (1938, 335) these fishes are entitled to a place nearer the stem of the characinine group of subfamilies, uniting them with the cheirodonts.

\section{Genus 131: ODONTOSTILBE Cope}

Odontostilbe Cope, 1870, Proc. Amer. Phil. Soc, XI, 566;

Eigenmann, 1910, Rept. Princeton Univ. Exped. Patagonia, III, 429 ;

Eigenmann, 1912, Mem. Carnegie Mus., V, 311.

Type: Odontostilbe fugitiva Cope

Trinidad to the valley of the Marañon

Minute fishes; teeth incisor-like, in a single series above and below, teeth having numerous cusps; lateral line complete.

\section{Odontostmbe fugitiva Cope}

Odontostilbe fugitiza Cope, 1870, Proc. Amer. Phil. Soc., XI, 566;

Eigenmann, 1910, Rept. Princeton Univ. Exped. Patagonia, III, 429.

Pebas region, lower Marañon

\section{Genus 132: APHYOCHARAX Günther}

Aphyocharax Günther, 1868, Proc. Zool. Soc. London, 245, 254;

Eigenmann, 1910, Rept. Princeton Univ. Exped. Patagonia, III, 429;

Eigenmann, 1912, Mem. Carnegie Mus., V, 312.

\section{Type: Aphyocharax pusillus Günther \\ Amazonia to Paraguay basin}

Separable from the cheirodonts in having a few teeth on the maxillary; dorsal fin long, situated midway of the length, behind the ventrals; anal long; lateral line not evident on all the scales; abdomen rounded before the ventrals; cleft of mouth narrow, maxillary short; premaxillary, maxillary, and mandible with a single series of pointed teeth; those of the premaxillary with three lateral cusps on one or both sides, others pointed; gill-membranes not adnate to the isthmus; frontal and parietal fontanels present. 


\section{Aphyocharax pusillus Günther}

Aphyocharax pusillus Günther, 1868, Proc. Zool. Soc. London, 245, three specimens, $2 \frac{1}{2}$ inches, Bartlett collection, Xeberos, Huallaga;

Cope, 1872, Proc. Acad. Nat. Sci. Phila., XXIII, 260, Hauxwell collection, Rio Ambyiacu;

Cope, 1878, Proc. Amer. Phil. Soc., XVII, 689, Orton collection, Rio Marañon;

Fowler, 1906 (1907), Proc. Acad. Nat. Sci. Phila., LVIII, 333, fig. 22;

Eigenmann, 1910, Rept. Princeton Univ. Exped. Patagonia, III, 429.

The Maranon and its tributaries

\section{Aphyocharax filigerus Cope}

Aphyocharax filigerus Cope, 1870, Proc. Amer. Phil. Soc., XI, 564, Pebas, Hauxwell collection;

Fowler, 1906 (1907), Proc. Acad. Nat. Sci. Phila., LVIII, 33t, fig. 23;

Eigenmann, 1910, Rept. Princeton Univ. Exped. Patagonia, III, 429.

The Peruvian Amazon

\section{Aphyocharax alburnus (Günther)}

Chirodon alburnus Günther, 1869, Proc. Zool. Soc. London, 424, fig. 2, Rio Marañon, one specimen, $2 \frac{1}{2}$ inches.

A phyocharax alburnus Eigenmann, 1910, Rept. Princeton Univ. Exped. Patagonia, III, 429.

Peruvian Amazon and La Plata basins

Subfamily GASTEROPELECINAE

Gasteropelecidae Jordan, Evermann, and Clark, 1928 (1930), Rept. U. S. Comm. Fish., Part II, 99.

The flying powers of these fishes are the subject of a study by Ridewood (1913), in which he found the flying mechanism to surpass by far in its development and specialization that of Exocoetus, a flying-fish. He seems to have demonstrated that there is an actual flight and that they maintain a much longer trajectory through the air than would be possible by planing. He shows further that the pectoral girdle is greatly expanded and the pectoral muscles enlarged in Thoracocharax to onefourth the body weight, while in a nearby form they constitute only one-one-hundred-fortieth the total weight.

\section{Genus 133: GASTHROPELECUS Gronow}

Gasteropelecus Gronow, 1756, Mus. Ichth., II, 7;

Gronow, 1763, Zoophyl., 135;

Günther, 1864, Cat. Fish. Brit. Mus., V, 342;

Garman, 1890, Bull. Essex Inst., XXII, 8;

Eigenmann, 1910, Rept. Princeton Univ. Exped. Patagonia, III, 439.

Type: Clupea sternicla Linnaeus = Salmo gasteropelecus Pallas

\section{The Amazons}

Short, extravagantly compressed, and belly line deflected downward to near the origin of the anal; adipose fin present; premaxillary teeth in a single series; $1-3$ large, conical teeth along the margin of the maxillary. 


\section{Gasteropelecus sternicla (Linnaeus)}

Gasteropelecus Gronow, 1756, \Ius. Ichth., II, 7, no. 255, pl. vii, fig. 5.

Clupea sternicla Linnaeus, 1758, Syst. Yat., ed. $x, 319$, Surinam.

Gasteropelecus stemicla Cuvier and Valenciennes, 1848, Hist. Nat. Poiss., XXII, 169, pl. 640, Surinam:

Eigenmann and Eigenmann, 1891, Proc. U. S. Nat. Mus., XIV, 56;

Eigenmann, 1910, Rept. Princeton Univ. Exped. Patagonia, III, 439;

Regan, 1913, Ann. Mag. Nat. Hist., (8), XII, 281, Rio Ucayali.

Salmo gasteropelecus Pallas, 1769, Spic. Zool., VIII, 80, pl. iii, fig. 4;

Bloch, 1785, Ausl. Fische, III, 66, pl. xevii, fig. 3;

Bloch and Schneider, 1801, Syst. Ichth., 418.

The Amazons

5, 24-33 mm., pond, Iquitos, Allen, September, 1920.

346. Gasteropelecus coronatus Allen, sp. nov.

Plate XIV, fig. 4

, 1, t7 mm., from mandibular symphysis to end of middle caudal rays, type, brook, Rio
Itaya, near Iquitos, September, 1920 .
, 5, 31-38 mm., same measurement, Yurimaguas creek, Allen, November, 1920 .

Like Gasteropelecus in the adipose fin, curvature of the dorsal contour, but near Carnegiella in dentition and general body form. Readily distinguished from known species of either by the teeth and the black line along each side. At first taken to be Pterodiscus levis, but found to fall within the generic boundaries of Gasteropelecus; also differing apparently in the lesser extent of the black outline of the venter. When taken in the dipnet swimming beneath the surface, this black line acted as a ruptive marking, giving the fish the appearance of a long, slender, minnow-like form. It was a matter of surprise when it was brought up and the rest of the fish below the line came into view.

Head 3.3 ; depth 1.75; eye equals snout to end of chin, 4 in the head, 1.4 in the interorbital space, nearly equals gape; mouth superior, directed obliquely backward at premaxillaries, thence deflected vertically downward; mandible moderately long and deeply convex along the outside.

Premaxillary teeth uniform, a series of seven or eight on each side, each tooth of moderate size, and each with a pointed central, and two pointed lateral, cusps; a single external maxillary tooth at the level of the pupil, hooked and conical in shape; a series of about five similar tricuspid teeth on each ramus of the mandible adjacent to symphysis. Premaxillary pointed and jutting to form a thin, obtusely angulate snout; head flattened dorsally from level of nares to end of occipital; crown bordered on each side by a slightly elevated ridge tangent to the orbit; a median third ridge ascends and broadens from the level of the nares to a nodular apex at the level of the posterior margin of the eye, thence descending and narrowing to the simuously truncate occipital border'; anterior naris partly encircled by the posterior.

Dorsal fin low and short, 11-12 rays, and directed strongly backward, notched into the dorsal contour of the body; adipose present, weak and feebly rayed, more in the nature of a second dorsal; caudal strongly lobed, the ventral lobe slightly 
longer and wider; anal low, with elongated basis, 2.3 in standard length, and rays about 30; ventral fins wanting; pectorals for flying, long, sickle-like, tapering, curved both in horizontal and vertical planes, rays about 9 , the first the longest, 2.2-2.3 in body length.

Flat, three-ridged contours of the head continue brokenly in three scale-series along the back, tapering caudally for five scale-rows; thence a single series of eleven median, saddle-like scales continue to the origin of the dorsal, uniformly narrowing to a sharper edge. Caudal peduncle low and compressed, delicate, slightly higher in its four scale-rows than the diameter of the orbit; four scales separate dorsal and adipose fins; fins not scaled except for a few on the base of the caudal, and two series on the base of the anal rays; scales cycloid, having one or two conspicuous radials. Lateral line pores about twelve, in a very direct line, deflected ventrally to a point four scales above the origin of the anal. More than thirty scales like ridge-tiles form the median series along the very sharp pre-ventral line.

Anus notched into ventral contour three-tenths nearer caudal basis than to chin; post-anal trunk an acute angle, with its apex on the caudal peduncle, the angle approximately trisected by two lines, the first line being the widest part of the trunk along the middle of the vertebrae, the second line seen translucently along the border between haemal processes and the radials of the anal fin. Viscera seen darkly opaque, descending obliquely from opercle to vent; just above and behind this the broad, translucent line of the air-bladder, bulbous anteriorly; ribs seen radiating through translucent breast.

Iris and opercle yellow and iridescent; a black, longitudinal line, 33 scales long, half a scale wide, in the fourth series from the dorsal fin, from third or fourth row to the base of the middle caudal rays; a narrow, dark line parallels the edge of the venter to the end of the anal, brokenly on the anal basis; upper scales and proximal portion of caudal fin finely sprinkled with chromatophores; anal rays outlined finely in dark; pectorals with rows of chromatophores diminishing toward the last; first ray with rings of dots, segment-like in appearance; body color yellowish silvery.

The allusion of the name is to the encirclement of the back by the pair of dark lines mentioned above.

\section{Genus 134: THORACOCHARAX Fowler}

Thoracocharax Fowler, 1906 (1907), Proc. Acad. Nat. Sci. Phila., LVIII, 452;

Eigenmann, 1910, Rept. Princeton Univ. Exped. Patagonia, III, 439.

Type: Gasteropelecus stellatus Kner

Pacific slope of Panama and Orinoco to the Paraguay

Anterior profile of the back convex.

\section{Thoracocharax stellatus (Kner)}

Gasteropelecus stellatus Tiner, 1860, Denksch. KiK. Akad. Wiss. Wien, XVIII, 17;

Gill, 1870, Proc. Acad. Nat. Sci. Phila., XXII, 92, Marañon or Napo, Orton collection; Cope, 1870, Proc. Amer. Phil. Soc., XI, 566, Pebas, Hauxwell coll.; 
Cope, 1872, Proc. Acad. Nat. Sei. Phila, XXII, 265, Rio Ambyiacu, Hauxwell collection;

Steindachner, 1882 (1883), Denksch. KK. Akad. Wiss. Wien, XLVI, 13, one, Amazon at Iquitos.

Thoracocharax stellatus Fowler, 1906 (1907), Proc. Acad. Nat. Sci. Phila., LVIII, 452;

Eigenmann, 1910, Rept. Princeton Univ. Exped. Patagonia, III, 439.

Orinoco, Amazons, and Paraguay basins

15619, 2, 76 and $80 \mathrm{~mm}$., Lago Sanango, Yurimaguas, Allen, October, 1920.

15620, 2, 62 and $72 \mathrm{~mm}$., Gosulimacocha, Rio Morona, Allen, October, 1920.

15621, 27, 40-58 mm., creek, Rio Morona, Allen, October, 1920.

Head $3.33-3.8$; depth $1.6-1.87$; D. II, 12 to II, 15, usually II, 13; A. III, 35 to III, 39; lateral line 18-20; pectoral 1.8-2.0 in the combined length of head and trunk; eye 3.0 ; interorbital 2.0-2.66.

\section{Thoracocharax pectorosus (Garman)}

Gasteropelecus pectorosus Garman, 1890, Bull. Essex Inst., XXII, 9.

Thoracocharax pectorosus Eigenmann, 1910, Rept. Princeton Univ. Exped. Patagonia, III, 440;

Fowler, 1939 (1940), Proe. Acad. Nat. Sci. Phila., XCI, 264, fig. 3, one, 94 mm., Contamana.

Gasteropelecus securis Filippi, 1853, Rev. Mag. Zool, 165, Rio Xapo.

Gasteropelecus stcllatus (non Kiner) Fowler, 1906 (1907), Proc. Acad. Nat. Sci. Phila., 452, Pebas.

Peruvian Amazon

\section{Genus 135: CARNEGIELLA Eigenmann}

Carnegiella Eigenmann, 1909, Ann. Carnegie MIus., VI, 13;

Eigenmann, 1910, Rept. Princeton Univ. Exped. Patagonia, III, 439;

Eigenmann, 1912, Nem. Carnegie MIus., V, 378.

Type: Gasteropelecus strigatus Günther

Guianas and Peruvian Amazon

Unlike Gasteropelecus in the lack of adipose fin; premaxillary with about nine tricuspid teeth in a series; maxillary with a single large, conical tooth at its upper anterior angle.

\section{Carnegiella strigata (Günther) \\ Plate XIV, fig. 5}

Gasteropelccus strigatus Günther, 1864, Cat. Fish. Brit. MIus., V, 343;

Eigenmann and Eigenmann, 1891, Proc. U. S. Nat. Mus., XIV, 57.

Carnegiella strigata Eigenmann, 1909, Ann. Carnegie MIs., VI, 13;

Eigenmann, 1910, Rept. Princeton Univ. Exped. Patagonia, III, 439;

Eigenmann, 1912, Mem. Carnegie Mus., V, 378, pl. Iv, figs. 2 and 3.

Gasteropelecus fasciatus Garman, 1890, Bull. Essex Inst., XXI, 10;

Eigenmann and Eigenmann, 1891, Proc. U. S. Nat. Mus., XIV, 57.

Peruvian Amazon and Guianas 
This delightful miniature sailing fish, according to Stoye, was first introduced in to aquaria by Fritz Mayer, in 1910, the source of the specimens unknown.

___ , 5, 22-30 mm., woodland brook near Iquitos, Allen, September, 1920.

\section{Subfamily: AGONIATINAE}

Genus 136: PARAGONIATES Steindachner

Paragoniates Steindachner, 1876, Sitzb. KK. Akad. Wiss. Wien, LXXIV, 117;

Eigenmann, 1910, Rept. Princeton Univ. Exped. Patagonia, III, 441.

Type: Paragoniates alburnus Steindachner

Marañon to southeastern Brazil

Dorsal fin in a posterior position, short; body narrow, much compressed; anal fin very long; jaw-teeth in single series, larger incisors with 1-2 lateral cusps; gape long; scales large; lateral line poorly developed except on forward part of trunk.

\section{Paragoniates alburnus Steindachner}

Paragoniates alburnus Steindachner, 1876, Sitzb. KK. Akad. Wiss. Wien, LXXIV, 117, pl. viii, fig. 3, Canelos;

Boulenger, 1887, Proc. Zool. Soc. London, 281;

Eigenmann, 1910, Rept. Princeton Univ. Exped. Patagonia, III, 441.

Solimões and Marañon valley 5, 48-61 mm., Rio Morona, Allen, October, 1920.

Determination by G. S. Myers; Boulenger points out the considerable width of the mouth, the interruption of the lateral line, and slight precedence of the anal with respect to the backward dorsal.

\section{Genus 137: LEPTAGONIATES Boulenger}

Leptagoniates Boulenger, 1887, Proc. Zool. Soc. London, 281; Eigenmann, 1910, Rept. Princeton Univ. Exped. Patagonia, III, 441.

Type: Leptagoniates steindachneri Boulenger Range that of the one species

Body very elongate and compressed; gape of mouth narrow; premaxillary, maxillary, and mandible with single series of tricuspid teeth; dorsal fin short, posterior to middle of body, and remotely beyond ventrals; anal very long, nearly two-thirds total length of the fish; lateral line complete.

\section{Leptagoniates steindachner Boulenger}

Leptagoniates steindachneri Boulenger, 1887, Proc. Zool. Soc. London, 282, pl. xxiii, fig. 3; Eigenmann, 1910, Rept. Princeton Univ. Exped. Patagonia, III, 441.

$$
\text { Sarayacu, Peru }
$$

Known from the unique type $95 \mathrm{~mm}$. in length. 


\section{Fifth Division-Hepsetine Group of Subfamilies}

Sarcodacinae Gregory and Conrad, 1938, Zoologica, XXIII, 321, 338.

Hepsetinae Hubbs, 1939, Copeia, 168, by replacement of Sarcodaces Günther with Hepsetus Swainson.

\section{Subfamily: CYNODONTINAE}

\section{Genus 138: RHAPHIODON Agassiz}

Rhaphiodon Agassiz, 1829, Sel. Gen. et Spee. Pise. Bras., 59;

Eigenmann, 1910, Rept. Princeton Univ. Exped. Patagonia, III, 444.

Cynodon Steindachner, 1882 (1883), Denksch. KK. Akad. Wiss. Wien, XLVI, 15.

\section{Type: Rhaphiodon vulpinus Spix}

\section{Range that of the one species}

Little compressed, large oblique mouth; teeth sharp both jaws; maxillaries long, narrow set with smaller teeth; tongue large, free; branchiostegals four, slender; body long, compressed, carinate; pectorals large, ventrals small, anal the broadest.

\section{Rhaphiodon vulpinum Spix}

Rhaphiodon vulpinus Spix, 1829, Sel. Gen. et Spec. Pisc. Bras., 59;

Fowler, 1906 (1907), Proc. Acad. Nat. Sci. Phila., LVIII, 467, two, Orton collection;

Eigenmann, 1910, Rept. Princeton Univ. Exped. Patagonia, III, 444.

Raphiodon vulpinus Cope, 1878, Proc. Amer. Phil. Soc., XVII, 688.

Cynodon vulpinus Steindachner, 1882 (1883), Denksch. KK. Akad. Wiss. Wien, XLVI, 15, Rio Huallaga, three specimens, $310-390 \mathrm{~mm}$.

\section{Orinoco basin to that of La Plata}

15726, 4, 240-328 mm., circa, mouth Rio Pacaya, Allen, September, 1920.

15727, 1, $305 \mathrm{~mm}$. , Rio Huallaga, Yurimaguas, Allen, November, 1920.

, 1, 180 mm., Lago Cashiboya, Allen, August, 1920.

Chambira-challhua is a name reported by Steindachner, its significance not clear, the first part of the name applying to a species of palm used for fiber, the suffix challhua being Quichua for fish. Numbers of specimens believed to belong here were taken in gill-nets, but more or less completely mutilated by caymans and piranhas.

\section{Genus 139: CYNODON Spix}

Cynodon Spix, 1829, Sel. Gen. et Spec. Pisc. Bras., 59, 76; Steindachner, 1882 (1883), Denksch. KK. Akad. Wiss. Wien, XLVI, 15; Eigenmann, 1910, Rept. Princeton Univ. Exped. Patagonia, III, 444;

Eigenmann, 1912, Mem. Carnegie Mus., I, 395.

Type: Cynodon gibbus Spix

Range that of the type species

Separable on the great elongation of the anal fin, about 80 rays, much longer than the preventral area; pectorals reaching anal, dorsal fin above it; seales cycloid. 


\section{Cynodon grbbum Spix}

Cynodon gibbus Spix, 1829, Sel. Gen. et Spec. Pisc. Bras., 76;

Cuvier and Valenciennes, 1848, Hist. Nat. Poiss., XXII, 333, Amazon;

Castelnau, 1855, Anim. Amér. Sud, Poiss., 75, Amazon;

Günther, 1864, Cat. Fish. Brit. Mus., V, 359;

Steindachner, 1882 (1883), Denksch. KK. Akad. Wiss. Wien, XLVI, 15, Rio Huallaga, three specimens;

Eigenmann and Eigenmann, 1891, Proc. U. S. Nat. Mus., XIV, 59;

Fowler, 1906 (1907), Proc. Acad. Nat. Sci. Phila., LVIII, 467, pl. xxvii;

Eigenmann, 1910, Rept. Princeton Univ. Exped. Patagonia, III, 444;

Eigenmann, 1912, Mem. Carnegie Mus., V, 395.

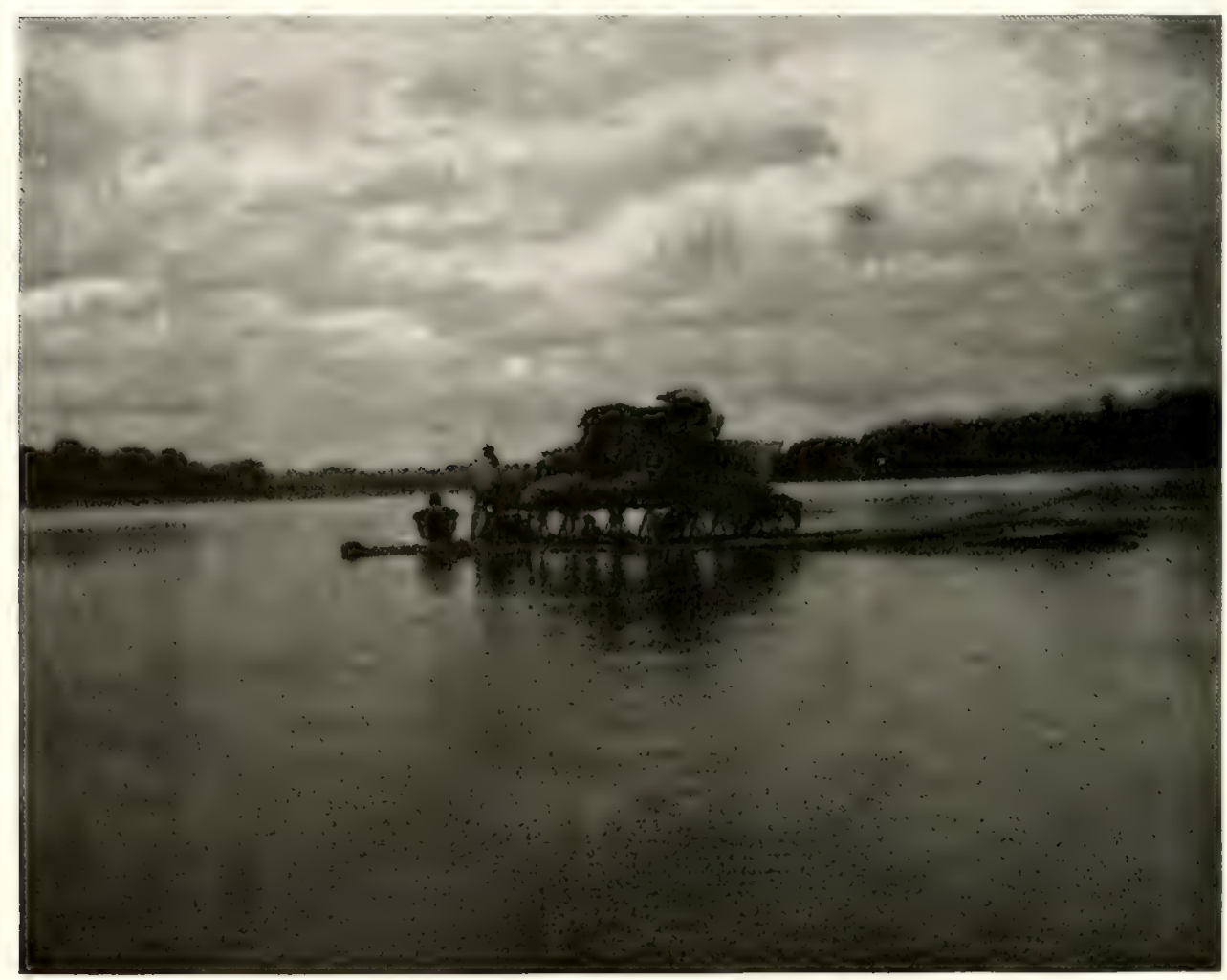

FIG. 30. The lower' Huallaga river and navigation by raft constructed of balsa-wood.

Raphiodon gibbus Cope, 1878, Proc. Amer. Phil. Soc., XVII, 688, Peruvian Amazon, two, Orton collection.

\section{Amazon to Rio Mamoré}

15734, 6, 152-230 mm., Lago Sanango, Yurimaguas, Allen, November, 1920.

The popular name dentón (long-tooth) is reported by Steindachner. I found the name peje-perro (dog-fish) commonly current.

\section{Genus 140: HYDROLICUS Müller and Troschel}

Hydrolicus Müller and Troschel, 1844, Arch. Naturg., 93;

Müller and Troschel, 1845, Horae Ichth., I, 18; 
Eigenmann, 1910, Rept, Princeton Univ. Exped. Patagonia, III, 444;

Eigenmann, 1912, Mem. Carnegie Mus., V, 396.

Cynodon (part) Steindachner, 1882 (1883), Denksch. KK. Akad. Wiss. Wien, XLVI, 15.

Type: Hydrocyon scomberoides Cuvier

Rio Orinoco and Guianas to Rio Araguay and Peru

Caudal fin rounded and anal fin short; dorsal in advance of the anal; anal and caudal fins scaled, the scales ctenoid, with pectinate or serrate margins; anal rays about thirty-five.

\section{Hydrolicus scomberoides (Cuvier)}

Hydrocynus scomberoides Cuvier, 1817, Règne Anim., II, 168.

Hydrocyon scomberoides Cuvier, 1819, Mém. Mus. Hist. Nat., V, 357, pl. xxrii, fig. 2.

Hydrolicus scomberoides Müller and Troschel, 1845, Horae Ichth., I, 19, pl. v, fig. 2;

Cope, 1872, Proc. Acad. Nat. Sci. Phila., LVIII, 292, between Rios Ucayali and Negro, Perkins collection:

Eigenmann and Eigenmann, 1891, Proc. U. S. Nat. MIus., XIV, 59;

Fowler, 1906 (1907), Proc. Acad. Nat. Sci. Phila., LVIII, 466 ;

Eigenmann, 1910, Rept. Princeton Univ. Exped. Patagonia, III, 444;

Eigenmann, 1912, Mem. Carnegie Mus., V, 396;

Fowler, 1939 (1940), Proc. Acad. Nat. Sci. Phila., XCI, 267, three, 143-180 mm., Contamana.

Cynodon scomberoides Cuvier and Valenciennes, 1848, Hist. Nat. Poiss., XXII, 324;

Castelnau, 1855, Anim. Amér. Sud, Poiss., 75, pl, xxxix, fig. 2;

Günther, 186t, Cat. Fish. Brit. IIus., V, 358:

Steindachner, 1882 (1883), Denksch. KK. Akad. Wiss. Wien, XLVI, 15, Iquitos, two, 230 and $260 \mathrm{~mm}$.

\section{Caribbean countries to Amazon and Araguay}

15733, 1, 210 mm., circa, Lago Sanango, Allen, November, 1920.

, 1, $260 \mathrm{~mm}$., circa, Manaos, Allen, December, 1920.

$15728,1,253 \mathrm{~mm}$. . Lago Cashiboya, Allen, August, 1920.

15729, 1, 295 mm., Gosulimacocha, Allen, October, 1920.

\section{Hydrolicus pectoralis (Günther)}

Cynodon pectoralis Günther, 1866, Ann. MIag. Nat. Hist., (3), XVIII, 30; Günther, 1868, Proc. Zool. Soc. London, 247, Xeberos.

Hydrolicus pectoralis Cope, 1878, Proc. Amer. Phil. Soc., XVII, 688, Nauta, six, Orton collection; Fowler, 1907, Proc. Acad. Nat. Sci. Phila., LVIII, 466, Marañon;

Eigenmann, 1910, Rept. Princeton Univ. Exped. Patagonia, III, 444.

Marañon basin

\section{Hydrolicus copei Gill}

Hydrolicus copei Gill, 1870, Proc. Acad. Nat. Sci. Phila., XXII, 93;

Eigenmann, 1910, Rept. Princeton Univ. Exped. Patagonia, III, 44.

Marañon basin

Known from the four types collected by Orton. 


\section{Subfamily: XIPHOSTOMINAE}

Hydrocyninae Eigenmann, 1910, Rept. Princeton Univ. Exped. Patagonia, III, 446, (here restricted to African genera).

Yiphostomidae Regan, 1911, Ann. Mag. Nat. Hist., (8), VIII, 13;

Jordan, Evermann and Clark, 1928 (1930), Rept. U. S. Comm. Fish., Part II, 100.

Sarcodacinae (in part) Gregory and Conrad, 1938, Zoologica, XXIII, 338.

\section{Genus 141: XIPHOSTOMA (Agassiz)}

Hydrocynus and Hydrocyon Cuvier (in part), 1817, Règne Anim., II, 167.

Xiphostoma Agassiz, 1829, Sel. Gen. et Spee. Pisc. Bras., 60, 78;

Eigenmann, 1910, Rept. Princeton Univ. Exped. Patagonia, III, 446;

Eigenmann, 1912, Mem. Carnegie Mus., V, 411;

Jordan, 1917, The Genera of Fishes, 132 (Restricting Hydrocynus to the African forskali Cuvier).

\section{Type: Xiphostoma cuvieri Agassiz}

\section{Guiana to the Peruvian Amazon}

Body long and cylindrical; snout and mandible much prolonged, forming a beak; both jaws with a series of minute conical teeth; dorsal fin in a posterior position, but nearer the level of the ventrals than to that of the anal; anal short; scales with denticulate margins; lateral line complete.

\section{Xiphostoma maculatum (Cuvier and Valenciennes)}

Hydrocynus maculatus Cuvier and Valenciennes, 1848, Hist. Nat. Poiss., XXII, 509;

Eigenmann, 1910, Rept. Princeton Univ. Exped. Patagonia, III, 446.

Xiphostoma maculatum Steindachner, 1882 (1883), Denksch. KK. Akad. Wiss. Wien, XLVI, 15, Rio Huallaga, three specimens;

Fowler, 1906 (1907), Proc. Acad. Nat. Sci. Phila., LVIII, 463.

Xiphostoma taedo Cope, 1871 (1872), Proc. Acad. Nat. Sci. Phila., XXIII, 267, pl. xiii, fig. 2, two,

R. Ambyiacu, Hauxwell;

Cope, 1878, Proc. Amer. Phil. Soc, XVII, 688, Marañon, Orton.

\section{Upper Amazons}

The garza-challua (challhua) or añas-challua of Steindachner, the former name aptly meaning heron-fish in allusion to the beak.

\section{Subfamily: ACESTRORHYNCHINAE}

Acestrorhamphinae Eigenmann, 1910, Rept. Princeton Univ. Exped. Patagonia, III, 447;

Eigenmann, 1922, Mem. Carnegie Mus., V, 165.

Acestrorhynchinae Eigenmann, 1912, Nem. Carnegie Mus., V, 406.

\section{Genus 142: ACESTRORHYNCHUS Eigenmann}

Xiphorhynchus Agassiz, 1829, Sel. Gen. et Spec. Pisc. Bras., 76, preoccupied in birds, 1827. Xiphorhamphus Müller and Troschel, 1845, Horae. Ichth., I, 17, preoceupied in birds, 1843. Acestrorhynchus Eigenmann, 1903, Smithson. Mise. Coll., XLV, 146;

Eigenmann, 1910, Rept. Princeton Univ. Exped. Patagonia, III, $44 \mathbf{7}$;

Eigenmann, 1912, Mem. Carnegie Mus., V, 106. 
Acestrorhamphus Eigenmann, 1903, Smithson. Misc. Coll, XLV, 146.

Sphyraenocharax Fowler, 1906 (1907), Proc. Acad. Nat. Sci. Phila., LVIII, 460 , Iiphorhamphus abbreviatus Cope.

\section{Type: Salmo falcatus Bloch \\ Guiana and Peru to Rio São Francisco and Paraguay}

Premaxillary horizontal, its teeth conical, in a single series; the second tooth (or first) and penultimate are exaggerated, sharp, canine; anterior, upper part of maxillary but little oblique, its teeth similar to those of the premaxillary, the first and fourth or fifth being canine; posterior part of the maxillary abruptly very oblique, and, with the exception of the teeth, entirely concealed by the first suborbital when the mouth is closed; posterior part of the mandible with minute, recurved teeth, preceded by three widely spaced canines, the middle one the largest.

Pectorals not reaching the remote ventrals, at any rate not overlapping them; scales cycloid; lateral line complete; tongue long, free.

\section{Acestrorhynchus abbreviatus (Cope)}

Tiphorhamphus abbreviatus Cope, 1878, Proc. Amer. Phil. Soc., XVII, 687, Peruvian Amazon, Orton collection.

Acestrorhamphus abbreviatus Eigenmann, 1903, Smithson. Misc. Coll., XLY, 146;

Eigenmann, 1910, Rept. Princeton Univ. Exped. Patagonia, III, 447.

Acestrorhynchus abbreviatus Fowler, 1906 (1907), Proc. Acad. Nat. Sci. Phila., LVIII, 461, fig. 49 ;

Fowler, 1939 (1940), Proc. Acad. Nat. Sei. Phila., XCI, 274, two, 175 and $180 \mathrm{~mm}$., Bajo Ucavali.

\section{Peruvian Amazon and tributaries}

\section{Acestrorhynchus falcirostris (Cuvier)}

Hydrocyon falcirostris Cuvier, 1819, Mém. Mus. Hist. Nat., V, 361, pl. xxvii, fig. 3.

Tiphorhynchus falcirostris Agassiz, 1829, Sel. Gen, et Spec. Pisc. Bras., 76.

Xiphorhamphus falcirostris Müller and Troschel, 18t5, Horae Ichth., I, 18;

Gunther, 186t, Cat. Fish. Brit. Mus., V, 35t;

Günther, 1868, Proc. Zool. Soc. London, 247, Xeberos, Pebas;

Cope, 1878, Proc. Amer. Phil. Soc., XVII, 688, Peruvian Amazon;

Steindachner, 1882 (1883), Denksch. KK. Akad. Wiss. Wien, XLVI, 15, Rio Huallaga, one specimen;

Eigenmann and Eigenmann, 1891, Proc. U. S. Nat. Mus., XIV, 58.

Acestrorhynchus falcirostris Fowler, 1906 (1907), Proc. Acad. Nat. Sci. Phila., LVIII, 462;

Eigenmann, 1910, Rept. Princeton Univ. Exped. Patagonia, III, 447 ;

Fowler, 1939 (1940), Proc. Acad. Nat. Sci. Phila., XCI, 273, five, 195-26 1 mm., Bajo Ucayali.

\section{Peruvian Amazon to Guiana and Matto Grosso}

The vernacular name canero was reported to Steindachner, doubtless meaning camero. This name is well-earned, but evidently is not in common currency today for these fishes, but is employed only for Hemicetopsis and certain other Pygidiids. 
360. Acestrorhynchus heterolepis (Cope)

Xiphorhamphus heterolepis Cope, 1878, Proc. Amer. Phil. Soc., XVII, 687, Rio Marañon, Orton collection.

Acestrorhynchus heterolepis Eigenmann, 1903, Smithson. Misc. Coll., XLV, 146;

Fowler, 1906 (1907), Proc. Acad. Nat. Sci. Phila., LVIII, 462, fig. 50;

Eigenmann, 1910, Rept. Princeton Univ. Exped. Patagonia, III, 447.

Peruvian Amazonia

\section{Acestrorhynchus falcatus (Bloch)}

Salmo falcatus Bloch, 1794, Ausl. Fische, VIII, 120, pl. 385.

Xiphorhynchus falcatus Cuvier and Valenciennes, 1818, Hist. Nat. Poiss., XXII, 337, part, Surinam; Castelnau, 1855, Anim. Amér. Sud, Poiss., 75, Amazon.

Xiphorhamphus falcatus Müller and Troschel, 1845, Horae Ichth., I, 17;

Günther, 1864, Cat. Fish. Brit. Mus., V, 354.

Acestrorhynchus falcatus Eigenmann, 1903, Smithson. Misc. Coll., XLV, 146;

Eigenmann, 1910, Rept. Princeton Univ. Exped. Patagonia, III, 447;

Eigenmann, 1912, Mem. Carnegie Mus., V, 407, pl. Ixi, fig. 3.

Xiphorhamphus ferox Günther, 1863, Ann. Mag. Nat. Hist., (3), XII, 443;

Günther, 1864, Cat. Fish. Brit. Mus., V, 355;

Günther, 1868, Proc. Zool. Soc. London, 229, R. Huallaga, Bartlett.

\section{Guianas to Rio Paraguay}

\section{Acestrorhynchus microlepis (Schomburgk)}

Hydrocyon microlepis Schomburgk, 1841, Fish. Brit. Guiana, I, 247.

Xiphorhamphus microlepis Müller and Troschel, 1845, Horae. Ichth., I, 18;

Müller and Troschel, 18t8, in Schomburgk, Reisen, III, 636;

Günther, 1864, Cat. Fish. Brit. Mus., V, 355;

Steindachner, 1882 (1883), Denksch. KK. Akad. Wiss. Wien, XLVI, 14, Rio Huallaga and Iqquitos, two;

Eigenmann and Eigenmann, 1891, Proc. U. S. Nat. MIus, XIV, 58.

Acestrorhynchus microlepis Eigenmann, 1910, Rept. Princeton Univ. Exped. Patagonia, III, 447;

Eigenmann, 1912, Mem. Carnegie Mus., V, 408.

\section{Guianas to Rio Huallaga}

\section{Acestrorhynchus cachorro Fowler}

Acestrorhynchus cachorro Fowler, 1939 (1940), Proc. Acad. Nat. Sci. Phila., XCI, 27t, fig. 61, Bajo Ucayali.

Known from the types at Philadelphia.

Near A. microlepis (Schomburgk). Cachorro a local name.

\section{Sixth Division-Erythrinine Group of Subfamilies \\ Subfamily: LEBIASININAE}

By reason of the close affinity shown by Gregory and Conrad to exist between the Erythrininae and the more primitive Characinae, such as Brycon, Piabucina, 
etc. the former are introduced here. Chalcous, with its affiliation to Piabucina is assigned to this subfamily, although by the authors mentioned (page 347, fig. 27 ) it is placed under the Characinae. A relationship deduced from the study of the teeth would place the genus nearer Brycon, while skeletal characters would show closer allegiance with the Erythrinine group. The true relationship is not remote from either.

\section{Genus 143: CHALCEUS Cuvier}

Chalceus Cuvier, 1817, Mém. Mus. Hist. Nat., IV, 454, pl. xxi;

Cuvier, 1819, Mém. Mus. Hist. Nat., V, 351;

Eigenmann, 1910, Rept. Princeton Univ. Exped. Patagonia, III, 439;

Eigenmann, 1912, Mem. Carnegie Mus., V, 372.

Pellegrinina Fowler, 1906 (1907), Proc. Acad. Nat. Sci. Phila., LVIII, 442.

\section{Type: Chalceus macrolepidotus Cuvier}

Range that of the one species

Teeth similar to those of Brycon, but with an outer series of multicuspid and an inner series of conical teeth on the mandible; premaxillary with teeth in three series; scales above the lateral line very large; greatly decurved lateral line, with much smaller scales beneath it; gill-membranes free; venter rounded.

\section{Chalceus macrolepidotus Cuvier}

Chalceus macrolepidotus Cuvier, 1817, Mém. Mus. Hist. Nat., IV, 454, pl. xxi, fig. 1;

Cuvier and Valenciennes, 1848, Hist. Nat. Poiss., XXII, 240;

Günther, 1864, Cat. Fish. Brit. Mus., V, 333;

Cope, 1871, Proc. Acad. Nat. Sci. Phila., XXIII, 262, R. Ambyiacu;

Eigenmann, 1910, Rept. Princeton Univ. Exped. Patagonia, III, 439;

Eigenmann, 1912, Mem. Carnegie Mus., V, 372;

Regan, 1912, Ann. Mag. Nat. Hist., (8), X, 388.

Chalceus macrolepidotus iquitensis Nakashima, 1941, Bol. Nus. Hist. Nat. Lima, V, 76.

Pellegrinina heterolepis Fowler, 1906 (1907), Proc. Acad. Nat. Sci. Phila., LVIII, 442, fig. 39.

\section{Guianas and upper Amazons}

15971, 4, 171-199 mm., Iquitos, Morris, 1922.

17865, 12, 98-135 mm., Yarinacocha, Allen, August, 1920.

$17866,3,188-208$ mm., Manaos, Allen, December, 1920.

Much bright red remains in the caudal fins of the larger specimens even after twenty years in alcohol.

\section{Genus 144: PLETHODECTES Cope}

Plethodectes Cope, 1870, Proc. Amer. Phil. Soc., XI, 563;

Fowler, 1906 (1907), Proc, Acad. Nat. Sci. Phila., LVIII, 4t1;

Eigenmann, 1910, Rept. Prineeton Univ. Exped. Patagonia, III, 439.

Chalceus Cope, 1872, Proc. Acad. Nat. Sci. Phila., XXIII, 262. 
Type: Plethodectes erythrurus Cope

Range that of the one species

Regan, 1912, justifies the abandonment of the genus on the ground that the teeth of the outer premaxillary series, while less expanded, are provided with a pair of cusps resembling C. macrolepidotus, but less expanded and somewhat more conical. Fowler still regards the genus as valid, in spite of Cope's change of opinion. Jordan (1919) holds Plethodectes to be a synonym of Chalceus.

\section{Plethodectes ertthrurus Cope}

Plethodectes erythrurus Cope, 1870, Proc. Amel. Phil. Soc., XI, 563, fig. 6, Pebas, Hauxwell collection;

Fowler, 1906 (1907), Proc. Acad. Nat. Sci. Phila., LVIII, 4t1;

Eigenmann, 1910, Rept. Princeton Univ. Exped. Patagonia, III, 439.

Chalceus erythrurus Cope, 1871 (1872), Proc. Acad. Nat. Sci. Phila., XXIII, 262, Rio Ambyiacu;

Regan, 1912, Ann. Mag. Nat. Hist., (8), X, 385.

Pebas, Peruvian Amazon, and Rio Cupai

Genus 145: PIABUCINA Cuvier and Valenciennes

Piabucina Cuvier and Valenciennes, 1848, Hist. Nat. Poiss., XXII, 161;

Eigenmann, 1910, Rept. Princeton Univ. Exped. Patagonia, III, 439;

Eigenmann, 1922, Mem. Carnegie Mus., IX, 125.

Type: Piabucina erythrinoides Cuvier and Valenciennes

Panama to Ecuador and Guiana

Similar to Lebiasina in the lack of fontanels, mandibular teeth in two series anteriorly, cellular anterior walls of air bladder; differing in that adipose fin is never wanting.

\section{Piabucina unitaeniata Günther}

Piabncina unitaeniata Günther, 1864, Cat. Fish. Brit. Mus., V, 311;

Eigenmann, 1910, Rept. Princeton Unir. Exped. Patagonia, III, 439.

Canelos, Ecuador, to British Guiana

\section{Piabucina elongata Boulenger}

Piabucina elongata Boulenger, 1887, Proc. Zool. Soc. London, 280, pl. xxiii, fig. 2, eastern Ecuador; Eigenmann, 1910, Rept. Princeton Univ. Exped. Patagonia, III, 439.

Piabucina unitaeniata Steindachner (non Günther), 1882 (1883), Denksch. KK. Akad. Wiss. Wien,

XLVI, 41, Canelos, two specimens.

\section{Oriente of Ecuador}

Known from two specimens from Canelos and three from the Buckley collection taken at Sarayacu. 
Genus 146: LEBIASINA Cuvier and Valenciennes

Lebiasina Curier and Valenciennes, 1846, Hist. Nat. Poiss., XIX, 531;

Eigenmann, 1910, Rept. Princeton Univ. Exped. Patagonia, III, 439;

Eigenmann, 1922, Mem. Carnegie Mus., IX, 123.

Type: Lebiasina bimaculata Cuvier and Valenciennes

Western slopes of Ecuador and Peru

Insufficiently separable from Piabucina on the usual lack of an adipose fin; air bladder with cellular anterior wall: fontanels absent.

\section{Lebiasina bimaculata Cuvier and Valenciennes}

Lediasina bimaculata Cuvier and Valenciennes, 1846, Hist. Nat. Poiss., XIX, 531, pl. 587, Rio Rimac; Eigenmann, 1910, Rept. Princeton Univ. Exped. Patagonia, III, 439;

Eigenmann, 1922, Mem. Carnegie MIus., IX, 123;

Eigenmann, 1923, Sci., LVIII, no. 1513, 532;

Pearson, 1937a, Proc. Cal. Acad. Sci., (4), XXIII, 89.

Distribution that of the genus

Fishes primarily of the Pacific slopes of Ecuador and Peru. Pearson collected sixty-six specimens in the Rio Crisnejas, tributary of the upper Marañon, at Paipay. Very plausibly he accounts for this unique occurrence on the Atlantic slope as a case of transportation by human agency, possibly in recent times. In support of this explanation Pearson calls attention to the hardy nature of the species, and to the existence of pools of the pre-Conquest period in the region of Cajamarca which suggest fish-culture to him rather than irrigation or water-supply.

Recently $L$. bimaculata has been introduced into other new localities as one of the species most readily adapted to the haunts of the yellow-fever mosquito. It is fitted to act as sanitary police by its ready acceptance of mosquito larvae, and its hardihood under exacting conditions. Since it is so hardy, and was so convenient to Lima, it has been used as an aquarium-fish in that city for an unknown length of time.

\section{Subfamily: ERYTHRININAE}

At times regarded as among the most advanced of the Characins, by Gregory (1933) assigned to a rank among the more primitive derivatives of the Cheirodontinae, due to its superficial amioid characters; again advanced to a more exalted position intermediate on the phyletic scale as the result of the studies of Gregory and Conrad (1938, p. 343), who have shown that the external Amia-like structures are underlain by more specialized, deep-seated ones.

\section{Genus 147: HOPIIAS Gill}

Macrodon Müller, 18 $\$ 3$, Arch. Naturg., 163, preoceupied;

Günther, 1864, Cat. Fish. Brit. Mus., V, 282. 
Hoplias Gill, 1903, Proc. U. S. Nat. Mus., XXVI, 1016;

Eigenmann, 1910, Rept. Princeton Univ. Exped. Patagonia, III, 4t7;

Eigenmann, 1912, Mem. Carnegie Mus., V, 412.

Type: Esox malabaricus Bloch

Atlantic slope La Plata northward; Pacific slope Ecuador northward

Mouth large; cheeks well occupied by the suborbitals; teeth conical; premaxillary with a large canine near the symphysis, a smaller one laterally, and many small teeth; maxillary with a large canine and many small teeth; palatine with patches of teeth, the outer patch the largest; a series in front of the palatine; maxillary reaching beyond the orbit; occipital process, fontanels, and adipose fin wanting; caudal fin rounded; air-bladder with walls normal. General configuration of Amia.

\section{Hoplias malabaricus (Bloch)}

Tareira Maregrave, 1648, Hist. Rer. Nat. Bras., IV, 157.

Esox malabaricus Bloch, 1794, Ausl. Fische, VIII, 149, pl. 392.

Synodus malabaricus Bloch and Schneider, 1801, Syst. Ichth., 397.

Macrodon malabaricus Eigenmann and Eigenmann, 1889, Proc. Cal. Acad. Sci., (2), II, 102.

Hoplias malabaricus Gill, 1903, Proc. U. S. Nat. Mus, XXVI, 1015;

Fowler, 1906 (1907), Proc. Acad. Nat. Sci. Phila., LVIII, 293, Rios Amazon and Ambyiacu, Orton and Hauxwell collections;

Eigenmann, 1910, Rept. Princeton Lniv. Exped. Patagonia, III, 447;

Eigenmann, 1912, Mem. Carnegie Mus., V, 115 ;

Fowler, 1939 (1940), Proc. Acad. Nat. Sci. Phila., XCI, 275, nine, 115-248 mm., Contamana. Erythrinus trahira and macrodon Spix, 1829, Sel. Gen. et Spec. Pisc. Bras., 43, pl. xviii.

Macrodon trahira Günther, 1864, Cat. Fish. Brit. Mus., V, 281;

Günther, 1868, Proc. Zool. Soc. London, 239, Huallaga;

Cope, 1870, Proc. Amer. Phil. Soc., XI, 566, Pebas;

Cope, 1871, Proc. Acad. Nat. Sei. Phila., XXIII, 257, R. Ambyiacu;

Cope, 1878, Proc. Amer. Phil. Soc., XVII, 69t;

Steindachner, 1882 (1883), Denksch. KK. Akad. Wiss. Wien, XLVI, 11, one, Rio Huallaga.

Rio Magdalena to Rios Huallaga and La Plata; Trinidad

15891, 1, 402 mm., Gosulimacocha, Rio Morona, Allen, October, 1920.

15892, 14, 135-215 mm. Lago Cashiboya, Allen, August, 1920.

15893, 4, 145-348 mm., Yarinacocha, Allen, August, 1920.

15894, 10, 38-300 mm., Yurimaguas, creek, Allen, November, 1920.

15895, 1, 135 mm., Contamana, Rio Ucayali, Allen, August, 1920.

$15896,4,90-115 \mathrm{~mm}$., creek, Rio Morona, Allen, October, 1920.

15897, 1, 129 mm., Iquitos, Allen, September, 1920.

15898, 4, 165-214 mm., Rio Huallaga, Yurimaguas, Allen, November, 1920.

15899, 3, 145-184 mm., Iça, Rio Itaya, Iquitos, Allen, September, 1920.

The dorme-dorme of Fowler.

\section{Genus 148: HOPLERYTHRINUS Gill}

Hoplerythrinus Gill, 1895, Proc. U. S. Nat. Mus., XVIII, 208;

Eigenmann, 1910, Rept. Princeton Univ. Exped. Patagonia, III, 448;

Eigenmann, 1912, Mem. Carnegie Mus., V, 418.

Ophiocephalops Fowler, 1906 (1907), Proc. Acad. Nat. Sci. Phila, LVIII, 293. 
Type: Erythrinus unitaeniatus Spix

Guianas via Peru to La Plata

Unlike Hoplias in having teeth on the pterygoids as well as on the palatine bones; dorsal rounded; walls of air-bladder cellular.

\section{Hoplerythrinus unitaeniatus (Spix)}

Iaturaque of Maregrave, 1648, Hist. Rer. Nat. Bras., IV, 169.

Erythrimus unitaeniatus Spix, 1829, Sel. Gen. et Spec. Pise. Bras., t2, pl. xix;

Mü̈ller and Troschel, 18+5, Horae Ichth., I, 5, pl. iii, fig. 1;

Cuvier and Valenciennes, 1846, Hist. Nat. Poiss., XIX, 486;

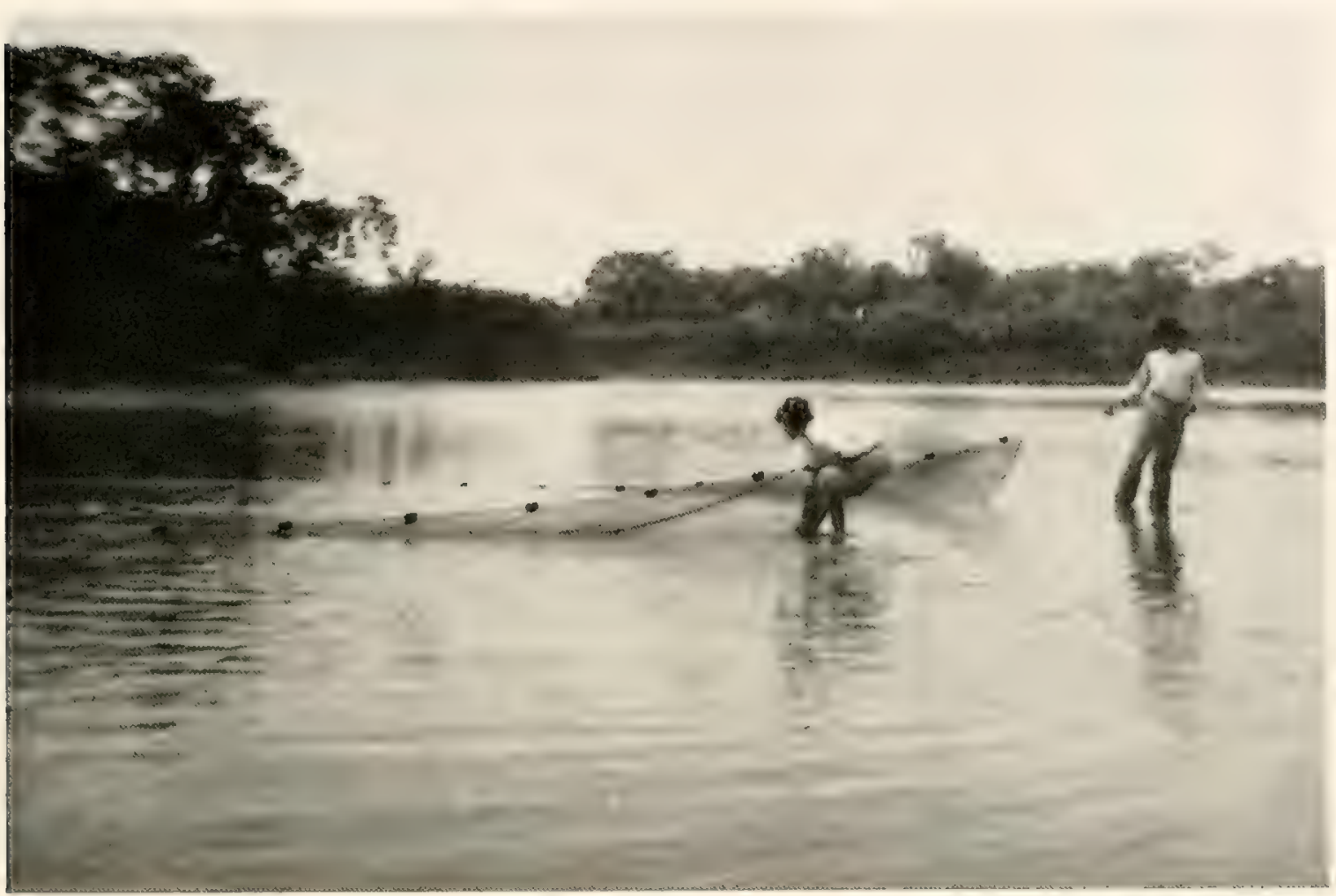

Fic. 31. Seining the sand-bars of a group of islands of the Rio Huallaga, above Yurimaguas.

Günther, 1864, Cat. Fish. Brit. Mus., V, 283;

Günther, 1868, Proc. Zool. Soc. London, 289;

Steindachner, 1882 (1883), Denksch. KK. Akad. Wiss. Wien, XLVI, 11;

Regan, 1906, Proc. Zool. Soc. London, 382.

Erythrinus (Ophiocephalops) unitacniatus Fowler, 1906 (1907), Proc. Acad. Nat. Sci. Phila., LVIII,

294, MIarañon, Orton coll.

Hoplerythrinus unitacniatus Gill, 1895, Proc. U. S. Nat. Mus., XVIII, 208;

Eigenmann, 1910, Rept. Princeton Univ. Exped. Patagonia, III, 448;

Eigenmann, 1912, Mem. Carnegie Mus., V, 418 ;

Fowler, 1939 (1940), Proc. Acad. Nat. Sci. Phila., XCI, 275, one, 148 mm., Contamana.

Peruvian Amazon to Bahia, La Plata, and Trinidad

, 1, $146 \mathrm{~mm}$. , brook at Iça, Rio Itaya, Allen, September, 1920. 
In other respects than those mentioned in the descriptions, the species differs from either Hoptias or Erythrimus and often occupies an intermediate position.

The body form is more robust than in the former, and less so than the latter; scales intermediate in size, but less sculptured than in either; eye larger than in either; dorsal fin, caudal, and anal shaped more as in Hoplias, not as in Erythrinus; markings much more clearly defined than in either; paired fins less spotted than in either of the others; body color with less marbled effect than in the specimens from the Guianas.

\section{Genus 149: ERYTHRINUS Gronow}

Erythrinus Gronow, 175t, Mus. Ichth., II, 6, no. 15t, pl. vii, fig. 6;

Gronow, 1763, Zoophyl., 114;

Scopoli, 1777, Hist. Nat., $4+9$;

Müiller and Troschel, 1845, Horae Ichth., I, 5;

Eigenmann, 1910, Rept. Princeton Univ. Exped. Patagonia, III, 448;

Eigenmann, 1912, Mem. Carnegie Mus., V, 420.

Synodus Bloch and Schneider, 1801, Syst. Ichth., 397.

Hetererythrinus Günther, 1864, Cat. Fish. Brit. Mus., 283, salmoneus.

Type: Salmo erythrinus Bloch and Schneider = Erythrinus erythrinus Bloch and Schneider = Cyprinus cylindricus Linnaeus

Guianas and Peru to Rio de Janeiro

No occipital crest, fontanel or adipose fin; caudal well rounded; anterior nares marginal, tubular; gill-membranes free, gill-opening wide; walls of anterior portion of air-bladder cellular; palatine teeth villiform, in a single patch on the side; maxillary teeth pectinate, no canines; dentary with short, conical teeth; two canines near symphysis, the outer larger; all teeth blunt; snout decurved; pterygoids without teeth.

\section{Erythrinus ERYthrinus (Bloch and Schneider)}

Cyprinus cylindricus Linnaeus, 175t, Mus. Adolphi Fred., 77, pl. xxx.

Cyprinus cephalus Linnaeus, 1758, Syst. Nat., ed. x, I, 322;

Linnaeus, 1766, Syst. Nat., ed. xii, I, 527.

Synodus erythrinus Bloch and Schneider, 1801, Syst. Ichth., 397.

Erythrinus erythrinus Eigenmann and Eigenmann, 1889, Proc. Cal. Acad. Sci., (2), II, 107, Tabatinga;

Fowler, 1906 (1907), Proc. Acad. Nat. Sci. Phila., LVIII, 294;

Eigenmann, 1910, Rept. Princeton Univ. Exped. Patagonia, III, 448;

Eigenmann, 1912, Mem. Carnegie Mus., V, 420.

Erythrinus brevicauda Günther, 1864, Cat. Fish. Brit. Mus., V, 285;

(Misspelled) Cope, 1870, Proc. Amer. Phil. Soc., XI, 566, Pebas, Hauxwell collection;

Cope, 1878, Proc. Amer. Phil. Soc., XVII, 694.

Erythrinus salmoneus Gronow, 175t, Mus. Ichth., 170, Surinam;

Günther, 1864, Cat. Fish. Brit. Mus., V, 28t;

Cope, 1878, Proc. Amer. Phil. Soc., XVII, 694, Peruvian Amazon. 
Surinam to Rio de Janeiro and Peruvian Amazon

6, 63-93 mm., creek, Yurimaguas, Allen, November, 1920.

2, 161-163 mm., brook, Iça, R. Itaya, Iquitos, Allen, September, 1920.

Neoceratodus-like, short, broad-tailed, peduncle erect and compressed, basis of caudal and anal well built up and encased in a sealy armor, the former 5-6 irregular rows. These specimens are lightest in color on the lower trunk region and caudal peduncle, from the base of the ventral fins caudally.

The Erythrininae are given credit by the people of Oriental Peru for considerable powers of travel overland. They assert that these fishes, when trapped in a pool of water which is drying up after the close of the rainy season, set out by night in search of some new body of water, and find it with some degree of assurance by a keen moisture sense. Meanwhile the operculum is kept closed over a mouthful of water to keep the gills moist. Such a method of conserving a scant water supply is not without parallel (see remarks under Hypostomatinae).

An unusual assemblage of this subfamily was taken from a single small, woodland brook at Iça, flowing into the Rio Itaya above Iquitos. It is probably correct to say that they are usually found apart, but here Hoplias, Hoplerythrinus, and Erythrinus were taken together.

Table Vi. Comparison of Three Erxthrinid Genera

\begin{tabular}{|c|c|c|c|}
\hline Character & Hoplias & Hoplerythrinus & Erythrinus \\
\hline $\begin{array}{l}\text { Head and } \\
\text { body form }\end{array}$ & $\begin{array}{l}\text { Head } 3.15 \text { in length; eso- } \\
\text { ciform }\end{array}$ & Head 3.2 in the length & $\begin{array}{l}\text { Head } 3.8 \text { in the length; } \\
\text { amiaform }\end{array}$ \\
\hline Mouth & $\begin{array}{l}\text { Large, extending beyond } \\
\text { eye; } 6.6 \text { in the length }\end{array}$ & $\begin{array}{l}\text { Large, extending beyond } \\
\text { eye; } 8.2 \text { in the length }\end{array}$ & $\begin{array}{l}\text { Moderate, reaching pupil; } \\
9.3 \text { in the length }\end{array}$ \\
\hline Eye & 6.2 in the head & $\begin{array}{l}5.8 \text { in the head; actually } \\
\text { the largest (head longer) }\end{array}$ & $\begin{array}{l}5.8 \text { in head, the smallest } \\
\text { (but head smallest) }\end{array}$ \\
\hline Depth & $\begin{array}{l}5 \text { in length; somewhat } \\
\text { slender }\end{array}$ & 4.5 in length; more robust & 4.5 in length; more robust \\
\hline $\begin{array}{l}\text { Caudal } \\
\text { peduncle }\end{array}$ & $\begin{array}{l}\text { Height } 7.7 \text { in the total } \\
\text { length; moderate }\end{array}$ & $\begin{array}{l}7.5 \text { in the length; moder- } \\
\text { ate }\end{array}$ & 5.6 in the length; robust \\
\hline Seale count & $5-42-7 ;$ small smooth & $\begin{array}{l}3-37-4 ; \text { smooth large, } \\
\text { thin, close }\end{array}$ & $\begin{array}{l}3-36-3 \frac{1}{2} ; \text { large, rough- } \\
\text { ish, conspicuous }\end{array}$ \\
\hline Fins: & $\begin{array}{l}\text { Dorsal a straight crest } \\
\text { Pectorals ventrals anals } \\
\text { rounded }\end{array}$ & $\begin{array}{l}\text { Dorsal rounded } \\
\text { Pectorals, ventrals anals } \\
\text { rounded }\end{array}$ & $\begin{array}{l}\text { Triangular, antepenulti- } \\
\text { mate ray the longest } \\
\text { Pectorals moderately, } \\
\text { anals, ventrals sharply } \\
\text { pointed }\end{array}$ \\
\hline Colors & $\begin{array}{l}\text { Many, smaller, clouded, } \\
\text { reddish spots }\end{array}$ & $\begin{array}{l}\text { Uniform, darker red } \\
\text { above, black lateral } \\
\text { band, uniform lighter be- } \\
\text { low }\end{array}$ & $\begin{array}{l}\text { Larger, deeper red spots, } \\
\text { cloudier and more confluent }\end{array}$ \\
\hline Fin colors & $\begin{array}{l}\text { All fins spotted, forming } \\
\text { broken cross bars }\end{array}$ & $\begin{array}{l}\text { Pectorals reddest, anal } \\
\text { spotted, ientrals light }\end{array}$ & $\begin{array}{l}\text { Darker on all distal borders, } \\
\text { shading to lighter proxi- } \\
\text { mally }\end{array}$ \\
\hline
\end{tabular}


It is not without interest to make a comparison of the three genera superficially and to discover the extent to which Hoplerythrimus is actually intermediate to the other two. Table VI is taken from a study of the specimens referred to above. Similarity in form is shown by ordinary type, dissimilarity to the other genera in a given character shown by boldface, intermediates shown by italics.

If this analysis is correct it seems to show that Hoplerythrinus is decidedly intermediate to the other two genera.

In four of the characters named the intermediate nature of Hoplerythrinus is measurable; in none of them does it seem to occupy an extreme position; in four characters it resembles Hoplias more; in three the resemblance to Erythrinus is greater

Hoplias is in the extreme position three times, in the intermediate position not at all. Erythrinus is an extreme five times, an intermediate only once.

\section{Seventh Division - Hemiodontine Group of Subfamilies}

Subfamily: HEMIODONTINAE

Family Hemiodontidae Regan, 1911, Ann. Mag. Nat. Hist., (8), VIII, 13.

\section{Genus 150: HEMIODUS Müller}

Hemiodus Müller, 1842, Monatsch. Akad. Wiss. Berlin, 324;

Eigenmann, 1910, Rept. Princeton Univ. Exped. Patagonia, III, 423;

Eigenmann, 1912, Mem. Carnegie Mus., V, 275.

Type: Hemiodus crenidens Müller = Salmo unimaculatus Bloch

Rio Orinoco to Peruvian Amazon and Rio São Francisco

Gill-membranes free from each other and from the isthmus; scales below the lateral line of similar size to those above, and mostly small; dorsal fin shorter than the head; teeth in the upper jaw only, pluricuspid, in a horseshoe-shaped series; fontanels large.

\section{Hemiodus Microlepis Kner}

Hemiodus microlepis Kiner, 1859, Denksch. KK. Akad. Wiss. Wien, XVII, 155, pl. iv, fig. 8, Matto Grosso and Rio Negro;

Cope, 1871 (1872), Proc. Acad. Nat. Sci. Phila., XXIII, 291, upper or mid-Amazon, Perkins collection, Philadelphia Academy Museum;

Cope, 1878, Proc. Amer. Phil. Soc., 686, Marañon, Orton collection;

Fowler, 1939 (1940), Proc. Acad. Nat. Sci. Phila., XCI, 257, two, 220 and 228 mm., Contamana.

Hemiodus (Hemiodopsis) microlepis Fowler, 1906 (1907), Proc. Acad. Nat. Sci. Phila., LVIII, 318.

Upper and middle Amazons to Matto Grosso

Genus 151: PTEROHEMIODUS Fowler

Pterohemiodus Fowler, 1939 (1940), Proc. Acad. Nat. Sci. Phila., XCI, 257. 
Type: Pterohemiodus atranalis Fowler

Contamana, Bajo Ucayali

Scales below lateral line similar to those above it; scales of larger size than in Hemiodus; dorsal fin much longer than the head, which is moderate in size, snout short, pointed; eye large, little forward of center of head; mouth small, terminal; upper jaw with a row of weak, flat, crenate teeth; mandible edentulous; nares small, approximated, advanced on snout; gill-rakers fine, weak, short; caudal peduncle moderate; caudal fin deeply forked, much exceeding the head in length.

\section{Pterohemiodus atranalis Fowler}

Pterohemiodus atranalis Fowler, 1939 (1940), Proc. Acad. Nat. Sci. Phila., XCI, 258, fig. 57.

Range identical with that of genus

Known from the three types in the museum of the Philadelphia Academy of Sciences, $80-120 \mathrm{~mm}$.

\section{Genus 152: ANISITSIA Eigenmann}

Anisitsia Eigenmann, 1903, Smithson. Misc. Coll., XLV, 144;

Eigenmann, 1910, Rept. Princeton Univ. Exped. Patagonia, III, 423;

Eigenmann, 1912, Mem. Carnegie Mus., V, 277.

Type: Anodus notatus Schomburgk

Guianas to Peru and Rio Paraguay

Similar in form to Anodus, with scales increasing in size and decreasing in number from the lateral line downward; fontanels large, Hemiodus-like; mandible edentulous; teeth of upper jaw in a crescent series.

\section{Anisitsia amazonum (Humboldt)}

Curimatus amazonum Humboldt, 1821, Obs. Zool., II, 165.

Hemiodus amazonum Eigenmann and Eigenmann, 1891, Proc. U. S. Xat. Mus., XIV, 49. Anisitsia amazonum Eigenmann, 1910, Rept. Princeton Univ. Exped. Patagonia, III, 423.

The Amazons

15725, , Gosulimacocha, Allen, October, 1920.

$$
\text { Subfamily: PARODONTINAE }
$$

Genus 153: PARODON Cuvier and Valenciennes

Parodon Cuvier and Valenciennes, 18t8, Hist. Nat. Poiss., XXII, 50;

Eigenmann, 1910, Rept. Princeton Univ. Exped. Patagonia, III, 422;

Eigenmann, 1912, Mem. Carnegie Mus., V, 274.

Type: Parodon suborbitalis Cuvier and Valenciennes

Colombia to Rios São Francisco and La Plata 
Mouth inferior, cutting edge of pluricuspid teeth of the upper jaw forming a straight transverse line; lower teeth consisting at most of 1-3 truncate incisors, curved outward, on the inner side of an ampulla; gill-membranes united and free from the isthmus.

\section{Parodon Buckleyt Boulenger}

Parodon buckleyi Boulenger, 1887, Proc. Zool. Soc. London, 279, pl. xxiii, fig. 1;

Eigenmann, 1910, Rept. Princeton Univ. Exped. Patagonia, III, 423.

\section{Eastern Ecuador}

Known from the type, a single specimen taken at Canelos, as a part of the Buckley collection.

\section{Genus 154: APAREIODON Eigenmann}

A pareiodon Eigenmann, 1916, Ann. Carnegie Mus., X, 71;

Eigenmann, 1922, Mem. Carnegie Mus., IX, 109.

\section{Type: Parodon piracicabae Eigenmann}

Panama to northern Peru, chiefly on Pacific slopes

Differing from Parodon chiefly in the consistent freedom of the sides of the mandible from teeth, ampulla small; alike in the rod-shaped proximal portion, and double-bladed distal portion of the mandible, and in the transverse cutting edge of the upper teeth, which are small at the base, horizontal, and tapering to a pectinate distal end.

376. Apareiodon pongoense Allen, sp. nov.

\section{Plate XIV, fig. 7}

4, 49-70 mm., type $67 \mathrm{~mm}$., and three paratypes, forest brook, foothills at Pongo de
Manseriche, Allen, October, 1920 .

Near A. itapicuruensis Eigenmann, differing in the greater number of premaxillary teeth and slight differences in scales and finrays; subacute caudal lobes. Of similar general form to $A$. ecuadorensis and terminalis, more like the former in the inferior mouth; differing from both in the size and position of fins, in the similarity of the maxillary to the premaxillary teeth, in the shorter head and greater depth, and greater number of scale rows below the lateral line.

Head 4.4-4.8; depth $4.5-4.6$; D. 12 ; A. 8; P. 13 ; scales $4-49-4$ or 5 ; eye 1.3 in the snout, 3.4 in the head, 1.3 in the interorbital.

Subcylindrical, elongate; dorsal profile moderately convex, ventral profile nearly straight to slightly curved; spindle-shaped forward to snout; regularly more and more compressed toward the caudal fin; preventral area more or less flattened, having a median series of 19-20 scales; rounded predorsal with a median series of $12-13$ seales.

Mouth small and decidedly inferior; premaxillary with eight incisor teeth, narrowly rooted, broad at cusps, turned back nearly horizontally at apices, exposed 
externally, and forming a straight line closely fitting the straight, untoothed edge of the mandible; each maxillary tooth with about 10-11 minute, dark-colored, digitlike denticles, forming the cutting edge; maxillary teeth about two each side, curved too far medially to be in line with the premaxillary teeth, smaller, with fewer denticles. Mandible with anterior margin narrow, straight, its ramus constricted midway, spatulate, edentulous, weak; gill-rakers fine, close-set, curved, short, 19 on lower arch.

Origin of dorsal fin equidistant from end of snout and distal end of adipose fin, or nearer to snout; dorsal fin short and low, its height 5.4 in the standard length; adipose feebly developed; caudal fin moderate, 5.3 in the length; anal low, broad, sub-triangular, 7 in the length; ventrals directly beneath the dorsal, tips not quite reaching the vertical from the tip of dorsal; pectorals broad, tips separated from the origin of the ventrals by four scale-rows; paired fins low and horizontal as in benthic types generally.

Lateral line straight; scales with three or more radials; edges turned sharply outward, outlining each scale with a pronounced epidermal eminence; axillary scales well developed; fins naked except caudal, whose lobes have 4-5 rows each of scales, diminishing in number and increasing in size to a single large scale (or two) midway on the lobes.

A dark band originates on the snout, encloses the nares and the eye, becomes fainter on the opercle, continues darkly along the lateral line $1 \frac{1}{2}$ scale-rows in width, to the end of the middle caudal rays, expanding in older specimens to the proximal half of the first half-dozen rays of the lower lobe; diffuses in the lower lobe to numerous, minute, irregular chromatophores. A second band arises above the eye and passes about one scale's width at a scale's distance below the dorsal fin, uniting with the corresponding band of the opposite side at the adipose, along the median scales to the caudal fin, there diffusing downward a little way into the dorsal lobe. A third band runs medially from the occiput to embrace the dorsal basis. A faint patch on the base of the lowest caudal rays; areas between the bands a dull, brassy yellow (alcohol), without markings on the lower sides, but upward from the lateral line sprinkled with scattered chromatophores, finely dotted along the radials of the scales.

The name is in reference to the only known locality, a small woodland stream opposite Puerto Melendez, just below the Pongo de Manseriche, where the Peruvian Amazon bursts through its last mountain barrier into the lowlands, at about 1500 feet elevation. (Pronounced mahn-say-reé-chay.)

\section{Subfamily: NANNOSTOMATINAE}

Minute fishes having broad teeth with equal points and equal jaws; skull truncate; occipital process wanting; no fontanel, lateral line, or adipose fin.

\section{Genus 155: POECILOBRYCON Eigenmann}

Poccilobrycon Eigenmann, 1909, Ann. Carnegie MIs., VI, 43;

Eigenmann, 1910, Rept. Princeton Univ. Exped. Patagonia, III, 427;

Eigenmann, 1912, Mem. Carnegie Mus., V, 283. 


\section{Type: Poecilobrycon harrisoni Eigenmann}

British Guiana and Amazons

Skull truncate, without either crest or fontanel; lateral line wanting; teeth broadly tipped and five-pointed.

\section{Poecilobrycon Eques (Steindachner)}

Nannostomus eques Steindachner, 1876, Sitzb. KK. Akad. Wiss. Wien, LXXIV, 78, fig. 3. Poecilobrycon eques Eigenmann, 1910, Rept. Princeton Univ. Exped. Patagonia, III, 427.

\section{Peruvian Amazon}

\section{Genus 156: CHARACIDIUMI Reinhardt}

Characidium Reinhardt, 1866, Overs. Dansk. Forh. Kjöbenhavn, 56, pl. ii, figs. 1 and 2;

Eigenmann, 1910, Rept. Princeton Univ. Exped. Patagonia, III, 427;

Eigenmann, 1912, Mem. Carnegie Mus., V, 288.

Chorimycterus Cope, 1894, Amer. Nat., XLVIII, 67, tenuis.

Nanognathus Boulenger, 1895, Boll. Mus. Zool. 'Torino, X, 196, 3, borelli.

Poecilusomatops Fowler, 1906 (1907), Proe. Acad. Nat. Sci. Phila., LXVIII, 323, Characidium etheostoma.

Type: Characidium fasciatum Reinhardt

Orinoco and Guianas southward to São Francisco and La Plata

Premaxillary and dentary each bearing a single series of conical or trituberculate teeth; no frontal fontanel, a small, circular occipital fontanel; triangular occipital process; adipose fin present; complete lateral line.

\section{Characidium fasciatum Reinhardt}

Characidium fasciatum Reinhardt, 1866, Overs. Dansk. Forh. Kjöbenhavn, 56, pl. ii, figs. 1 and 2; Steindachner, 1882, Sitzb. KK., Akad. Wiss. Wien, LXXXII, 19, Canelos;

Boulenger, 1887, Proc. Zool. Soc. London, 280, Sarayacu, four;

Eigenmann, 1910, Rept. Princeton Univ. Exped. Patagonia, III, 427.

Orinoco basin southward to La Plata

\section{Characidium etheostoma Cope}

Characidium etheostoma Cope, 1871 (1872), Proc. Acad. Nat. Sci. Phila., XXIII, 259, pl. xiii, fig. 3, R. Ambyiacu, Hauxwell;

Eigenmann, 1910, Rept. Princeton Univ. Exped. Patagonia, III, 427.

Characidium (Poecilosomatops) etheostoma Fowler, 1906 (1907), Proc. Acad. Nat. Sci. Phila., LXVIII, 323 , fig. 17 .

\section{Rio Ambyiacu}

\section{Characidium steindachneri Cope}

Characidium steindachneri Cope, 1878, Proc. Amer. Phil. Soc., XVII, 688, Peruvian Amazon, Orton collection; 
Fowler, 1906 (1907), Proc. Acad. Nat. Sci Phila., LVIII, 325;

Eigenmann, 1910, Rept. Princeton Unir. Exped. Patagonia, III, $42 \overline{7}$.

Peruvian Amazon

Eighth Division-Anostomatine Group of Subfamilies

Subfamily: CURIMATINAE

Genus 157: POTAMORHINA Cope

Potamorhina Cope, 1878, Proc. Amer. Phil. Soc., XVII, 685, Maranon;

Eigenmann and Eigenmann, 1889, Ann. Y. Y. Acad. Sci., IV, 411 ;

Eigenmann, 1910, Rept. Princeton Univ. Exped. Patagonia, III, 120.

Type: Curimatus pristigaster Steindachner

Amazons from the Andes to Rio Negro

A Curimatus with clupeoid form of belly, breast strongly flattened, predorsal area without scales, scales small.

\section{Potamorhina Pristigaster (Steindachner)}

Curimatus pristigaster Steindachner, 1876, Sitzb. KK. Akad. Wiss. Wien, LXXIV, 25, pl. vi.

Potamorhina pristigaster Cope, 1878, Proc. Amer. Phil. Soc., XVII, 685, Rio Marañon, Orton collection;

Eigenmann and Eigenmann, 1889, Ann. N. Y. Acad. Sci., IV, 411;

Fowler, 1906 (1907), Proc. Acad. Nat. Sci. Phila., LVIII, 306;

Eigenmann, 1910, Rept. Princeton Univ. Exped. Patagonia, III, 420.

Rios Negro, Solimões, Marañon

15665, 1, 195 mm., Iquitos, Allen, September, 1920.

Genus 158: PSECTROGASTER Eigenmann and Eigenmann

Psectrogaster Eigenmann and Eigenmann, 1889, West. Amer. Sci., VI, 7;

Eigenmann and Eigenmann, 1889, Ann. N. I. Acad. Sci., IV, 412 ;

Eigenmann and Eigenmann, 1891, Proc. U. S. Nat. Mus., XIV, 46 ;

Eigenmann, 1910, Rept. Princeton Univ. Exped. Patagonia, III, 120.

Type: Psectrogaster rhomboides Eigenmann and Eigenmann

\section{Rio Paraguay northward}

Edentulous; postrentral area trenchant, the scales of each side with a flange enclosing the ventral line, and terminating in a median spinous process; preventral area rounded; predorsal scaled; scales large, 50-60 on the lateral line.

\section{Psectrogaster amazonicus Eigenmann and Eigenmann}

Psectrogaster amazonica Eigenmann and Eigenmann, 1889, Ann. I. I. Acard. Sci., IV, 413;

Eigenmann and Eigenmann, 1891, Proc. U. S. Nat. Mus., XIV, 46.

Psectrogaster amazonicus Eigenmann, 1910, Rept. Princeton Lniv. Exped. Patagonia, III, 420.

Psectrogaster ciliatus Fowler, 1906 (1907), Proc. Acad. Nat. Sci. Phila., LVIII, 305. 


\section{The Amazons}

15824, 17, 105-172 mm., Lago Sanango, Allen, November, 1920.

15834, , Rio Paranapura, Allen, November, 1920.

15838, 15, 112-140 mm., Rio Nanay, Allen, September, 1920.

17846, 65, 66-140 mm., Lago Cashiboya, Allen, August, 1920.

$17847,2,120$ and 127 mm., Rio Ucayali, Orellana, Allen, August, 1920.

17849, 5, 67-108 mm., Rio Ucayali, Contamana, Allen, August, 1920.

17852, 1, 113 mm., Iquitos, Allen, September, 1920.

The ripe females are of much deeper form than the males. The depth contained in the length of two individuals which were about equal in length: $\sigma^{7} 3$ o 2.15 ; in number 15838 , depth 2.36-3.40.

Some individuals have a dark area near the extremity of each caudal lobe, others not. Dorsal truncate, the longest ray of the depressed fin extending beyond the tip of the last; anal truncate; preventral area rounded; air bladder extending to the posterior end of the anal fin; origin of the dorsal midway between end of snout and tip of adipose fin; origin of ventrals nearer end of snout than to the origin of the caudal fin.

\section{Psectrogaster cisandinus Allen, sp. nov.}

\section{Plate XIV, fig. 3}

15834, 1, 135 mm., Rio Paranapura, Allen, November, 1920.

15837, 2, 102 and $106 \mathrm{~mm}$., Rio Nanay, Iquitos, Allen, September, 1920.

$17850,3,67-146 \mathrm{~mm}$., the largest the type, Iquitos, Morris, 1922.

17851, 2, 102 and 103 mm., Lago Cashiboya, Allen, August, 1920.

15842, , Rio Paranapura, Yurimaguas, Allen, November, 1920.

Readily separated from the nearby $P$. amazonicus by the greater fin length, the strong lateral keels of the preventral region, the greater general angularity, strongly inferior mouth, low lateral line.

Head 3.0-3.3; depth $2.5-2.7$; D. 2.6-2.8 in the length, rays $10-11 ;$ A. 13-14; scales $10-14,53-55,6$; eye $3.0-3.3$; interorbital 2.3 .

Dorsal curvature greater, and not nearly so regular as the ventral; depressed above the eye; fontanel furrow long, narrow, less than pupillary diameter; occipital process sub-triangular, equal in length to fontanel; predorsal region slightly acute, partly with median scales, moderately compressed; dorsal fin slightly interrupting the dorsal line. Venter broad, laterally keeled; postventral moderately trenchant, with 8-9 median scales, scales ridged in median line, not spinous; anal slightly set into ventral contour.

Dorsal fin erect, triangular, its last rays one-fourth to one-third the length of the first; pectoral variable, sometimes overlapping first fifth of the ventral fin, sometimes failing somewhat to reach it; ventrals variable, but usually more than reaching anus; anal emarginate, its first rays the longest, graduated down; caudal forked about half its entire length.

Snout prolonged, mouth inferior, its width not exceeding snout measured from the orbit; without teeth; gill-rakers soft, widely spaced, about ten in each series, becoming elongate ventrally. 
Scales smallest on nape, progressively larger ventrally, finely crenulate along their entire margins.

Color rich, golden, iridescent yellow, darkened toward the mid-dorsal line; markings limited to a few ashen or dusky areas on the dorsal line and extremities of the fins.

\section{Genus 159: CURIMATELLA Eigenmann and Eigenmann}

Curimatella Eigenmann and Eigenmann, 1889, Ann. N. Y. Acad. Sci., IV, 415 ;

Eigenmann, 1910, Rept. Princeton Univ. Exped. Patagonia, III, 420;

Eigenmann, 1912, Mem. Carnegie Mus., V, 262.

\section{Type: Curimatella lepidurus Eigenmann and Eigenmann}

Peru and Guiana to Rios Paraguay and São Francisco

A Curimatus having caudal lobes covered with scales to their extremities; tongue with free margins; lateral line complete; teeth lacking.

\section{Curmatella meyeri (Steindachner)}

Curimatus meyeri Steindachner, 1882 (1883), Denksch. KK. Akad. Wiss. Wien, XLVI, 11, pl. i, fig. 4, Rio Huallaga, one, $130 \mathrm{~mm}$.

Curimatus (Curimatella) meyeri Eigenmann and Eigenmann, 1889, Ann. $\mathrm{Y}$. Y. Acad. Sci., IV, 418. Curimatella meyeri Fowler, 1906 (1907), Proc. Acad. Nat. Sci. Phila., LVIII, 296, Peruvian Amazon, Orton collection:

Eigenmann, 1910, Rept. Princeton Univ. Exped. Patagonia, III, 420;

Fowler, 1939 (1940), Proc. Acad. Nat. Sci. Phila., XCI, 252, six, 125-175 mm., Contamana.

\section{Peruvian Amazons}

\section{Curmatella alburna (Müller and Troschel)}

Anodus alburnus Müller and Troschel, 1845, Horae Ichth., I and II, 26, pl. iv, fig. 3, British Guiana. Curimatus alburnus Kner, 1859, Denksch. KK. Akad. Wiss. Wien, XVII, 14t, Rio Guaporé and IIatto Grosso;

Steindachner, 1876, Sitzb. KK. Akad. Wiss. Wien, LXXIV, 33, Teffé;

Steindachner, 1881, Denksch. KK. Akad. Wiss. Wien, XLIII, 36;

Eigenmann and Eigenmann, 1889, Ann. N. Y. Acad. Sci., IV, 418;

Eigenmann and Eigenmann, 1891, Proc. U. S. Nat. Mus., XIV, 46;

Pellegrin, 1899, Bull. Mus. Hist. Nat., V, 157;

Eigenmann, 1910, Rept. Princeton Univ. Exped. Patagonia, III, 420;

Eigenmann, 1912, Mem. Carnegie Mus., V, 262.

Curimatella alburnus Fowler, 1906 (1907), Proc. Acad. Nat. Sci. Phila., LVIII, 297, Surinam;

Fowler, 1939 (1940), Proc. Acad. Nat. Sci. Phila., XCI, 251, fig. 52, two, 84 and $87 \mathrm{~mm}$. , Contamana.

The Guianas to Peru, Rio Guaporé, and Rio Paraguay

17848, 8, 95-108 mm., pond, Iquitos, Allen, September, 1920.

Fowler's informants have collected the name Gordillo, which is the equivalent of "Fatty", for the species. 
Very similar to the Guiana specimens of $C$. alburna; lacks about one in all scale and finray counts; faint indication of black on base of the caudal fin, which may indicate identity with Pellegrin's subspecies caudimaculata. Fowler says in his Contamana specimens the ventrals do reach and pass the vent.

\section{Genus 160: CURIMATA Walbaum}

Curimata Walbaum, 1792, Artedi Pisc., 80;

Jordan, Evermann, and Clark, 1928 (1930), Rept. L. S. Comm. Fish., Part II, 100.

Les Curimates Cuvier, 1815, Mém. Mus. Hist. Nat., I, 109, French name without types or deseription;

Cuvier, 1817, Règne Anim., 165, as above.

Curimatus Oken, 1817, Isis, 1182, supplying the deficiencies of Curier;

Cuvier and Valenciennes, 1848, Hist. Nat. Poiss., XXII, 4;

Eigenmann and Eigenmann, 1889, Ann. X. Y. Acad. Sci., IV, 15;

Eigenmann and Eigenmann, 1891, Proc. L. S. Nat. XIus, XIV, 47;

Eigenmann, 1910, Rept. Princeton Univ. Exped. Patagonia, III, 421;

Eigenmann, 1912, \em. Carnegie \us., V, 263;

Eigenmann, 1922, Mem. Carnegie Mus., LX, 100.

Type: Salmo marcgravii Walbaum = Salmo cyprinoides Linnaeus

Panama throughout the Atlantic drainage to Argentina, and West Coast to Peru

Without teeth; caudal not scaled; lateral line complete; scales moderate to large; gill-rakers short; belly rounded or flat, and without spines; tongue short, thick, adnate; mouth horizontal, or but little oblique.

\section{Curimata spilura Gïnther}

Curimatus spilurus Günther, 1804, Cat. Fish. Brit. Mus., T, 288, Essequibo;

Cope, 1878, Proc. Amer. Phil. Soc., XVII, 68t, Peruvian Amazon;

Eigenmann and Eigenmann, 1889, Ann. N. Y. Acad. Sci., IV, 419;

Eigenmann and Eigenmann, 1891, Proc. L. S. Nat. Mus., XIT, 47;

Eigenmann, 1910, Rept. Princeton Univ. Exped. Patagonia, III, 121 ;

Eigenmann, 1912, Mem. Carnegie Mus., V, 263.

Curimata (Cyphocharax) spilura Fowler, 1906 (1907), Proc. Acad. Xat. Sci. Phila., LVIII, 297, fig. 4, Peruvian Amazon.

\section{Orinoco and Guianas to Paraguay system}

387. Curimata nasa Steindachner

Curimatus nasus Steindachner, 1882 (1883), Denksch. KK. Akad. Wiss. Wien, XLVI, 20, pl. v, fig. 2, Canelos;

Eigenmann and Eigenmann, 1889, Ann. N. Y. Acad. Sci., IV, 421.

Canelos, Ecuador

\section{Curimata bimaculata Steindachner}

Curimatus bimaculatus Steindachner, 1876, Sitzb. KK. Akad. Wiss. Wien, LXXTY, 28, Hvararr.

Eigenmann and Eigenmann, 1889, Ann. N. Y. Acad. Sci., IV, 422;

Eigenmann, 1910, Rept. Princeton Unir. Exped. Patagonia, III, 421. 
Rio Huallaga to Paraguay basin

15828, 6, 49-89 mm., creck, Rio Morona, Allen, October, 1920.

15831, 2, 38 and $75 \mathrm{~mm}$., creek, Yurimaguas, Allen, November, 1920.

\section{Curimata trachystetha Cope}

Curimatus trachystethus Cope, 1878, Proc. Amer. Phil. Soc., XVII, 68t, Peruvian Amazon, Orton collection.

Curimatus bimaculatus trachystethus Eigenmann and Eigenmann, 1889, Ann. X. Y. Acad. Sci., IV, 422 ;

Eigenmann and Eigenmann, 1891, Proc, U. S. Nat. Mus., XIV, 47;

Eigenmann, 1910, Rept. Princeton Univ. Exped. Patagonia, III, 421.

Curimata (Stcindachnerina) trachystethus Fowler, 1906 (1907), Proc. Acad. Nat. Sci. Phila., LVIII, 299, fig. 5.

\section{Peruvian Amazon and Serpa}

According to Fowler differing from $C$. bimaculata in the greater arching of the ventral line, the lack of a caudal spot, a blackish spot behind the tip of the occipital process, and scales of smaller size, $8-48$ to $52-6$ to 7 .

\section{Curimata dobula Günther}

Curimatus dobula Günther, 1868, Proc. Zool. Soc. London, 243, Rio Huallaga, three, $4 \frac{1}{2}$ inches, Bartlett collection;

Boulenger, 1887, Proc. Zool. Soc. London, 279, Canelos;

Eigenmann and Eigenmann, 1889, Ann. N. Y. Acad. Sci., IV, 423;

Eigenmann and Eigenmann, 1891, Proc. U. S. Nat. Mus., XIV, 17 ;

Eigenmann, 1910, Rept. Princeton Univ. Exped. Patagonia, II I, 421.

\section{Eastern slopes of Peru and Ecuador}

Without a black spot on the middle caudal rays or sides; a black spot on base of dorsal fin; lateral line count 43.

\section{Curimata aspera Günther}

Curimatus asper Günther, 1868, Proc. Zool. Soc. London, 243, text fig. 8, four specimens, 7 inches, Huallaga and Xeberos;

Eigenmann and Eigenmann, 1889, Ann. N. Y. Acad. Sci., IV, 426;

Eigenmann and Eigenmann, 1891, Proc. U. S. Nat. Mus., XIV, 47;

Eigenmann, 1910, Rept. Princeton Univ. Exped. Patagonia, III, 422.

\section{Peruvian Amazon}

15819, 2, 180 and $20+\mathrm{mm}$., Gosulimacocha, Allen, October, 1920.

D. $10-11$; A. 12-13; scale counts respectively: $13-51-7$ and $14-54-7$.

Like $C$. dobula in the lack of spots on the middle caudal rays or sides, but unlike it in also lacking the black spot on the dorsal fin; differing from C. leucisca in the greater number of scales; near C. rutiloides in the scale formula, and differing in the slightly inferior mouth. 


\section{Curimata Rutiloides Kner}

Curimatus mutiloides Iñner, 1859, Denksch. IK. Akad. Wiss. Wien, XVII, 141;

Günther, 1864, Cat. Fish. Brit. Mus., V, 290;

Steindachner, 1882 (1883), Denksch. KK. Akad. Wiss. Wien, XLVI, 11, Rio Huallaga, five specimens;

Eigenmann and Eigenmann, 1889, Ann. N. Y. Acad. Sci., IV, 426 ;

Eigermann and Eigenmann, 1891, Proc. U. S. Nat. Mus., XIV, 47;

Eigenmann, 1910, Rejt. Princeton Univ. Exped. Patagonia, III, 122.

Rio Huallaga to the basin of the Paraguay

Huimba-shitari is a colloquial name reported to Steindachner, with the earmarks of improvisation, since the latter part of the name appears generally applied to certain Loricariinae.

The smaller scales of the lateral line differentiate it from asper; mouth terminal.

\section{Curimata leucisca Günther}

Curimatus leuciscus Günther, 1868, Proc. Zool. Soc. London, 239, two specimens, $5 \frac{1}{2}$ inches, Rio Huallaga, Bartlett collection;

Eigenmann and Eigenmann, 1889, Ann. N. Y. Acad. Sei., IV, 426;

Eigenmann and Eigenmann, 1891, Proc. U. S. Nat. Mus., XIV, t7;

Eigenmann, 1910, Rept. Princeton Univ. Exped. Patagonia, III, 422.

\section{The Amazons}

15820, 1, $164 \mathrm{~mm}$., Gosulimacocha, Rio Morona, Allen, October, 1920.

15826, 1, 117 mm., Rio Huallaga, Yurimaguas, Allen, November, 1920.

15833, 1, 85 mm., Rio Paranapura, Yurimaguas, Allen, November, 1920.

15835, 3, 66-120 mm., Gosulimacocha, Rio Morona, Allen, October, 1920

15839, many, 60-125 mm., Gosulimacocha and Lago Sanango mixed, Allen, October-November, 1920.

1785t, 1, 117 mm., Rio Ucayali, Orellana, Allen, August, 1920.

17855, 3, 75-133 mm., Lago Cashiboya, Allen, August, 1920.

15832, 1, 107 mm., Lago Sanango, Allen, November, 1920.

15832 was determined by Eigenmann as C. bimaculatus, and 15833 as near bimaculatus. To me they are clearly the present species.

At least locally known as the yavarachi or llavarachi.

Belonging to the small-scaled division, having a scale count of $10-60$ to $69-8$.

Back of uniform color, dorsal and median caudal rays unspotted, separating it from the remotely-distributed mivartii; elongate like spilura.

Ventral profile straight, and dorsal contour arched, especially toward the forward end; preventral area flattened, postventral rounded; predorsal line keeled, postdorsal rounded; not depressed at the eye level; mouth inferior; eye diameter little exceeding the snout, 3.0-3.33 in the head, $1.5-1.6$ in the interorbital.

Scales serrate, somewhat deciduous; caudal not scaled; longest dorsal ray about equal to the head; anal short, emarginate, longest ray reaching caudal fin; ventrals reaching about to the vent, the pectorals not reaching the ventrals.

Silvery below, light brown above; a blackish spot in front of the dorsal fin, a second behind the occipital process; a white lateral band.

H. $4.0-4.25$; depth $3.66-3.75$; D. $12-13$; A. $10-11$. 
394. Curimata ciliata (Müller and Troschel)

Anodus ciliatus Müller and 'Troschel, 1845, Horae Ichth., 25, pl. iv, fig. 4.

Curimatus ciliatus Castelnau, 1855, Anim. Amér. Sud, Poiss., 58, Amazon:

Guinther, 1864, Cat. Hish. Brit. Mus., V, 292;

Eigenmanu, 1912, Mem. Carnegie Mus., V, 268.

Curimata (Curimata) ciliata Fowler, 1939 (1940), Proc. Acad. Nat. Sci. Phila., XCI, 253, fig. 53, six, 99-148 mm., Contamana.

Psectrogaster ciliata Eigenmann and Ligenmann, 1889, Ann. Y. Y. Acad. Sci., IV, 5;

Eigenmann and Eigenmann, 1891, Proc. U. S. Nat. Mus., XIV, 46;

Fowler, 1906 (1907), Proc. Acad. Nat. Sci. Phila., LYIII, 305;

Eigenmann, 1910, Rept. Princeton Univ. Exped. Patagonia, III, 120.

Curimatus rutitoides Cope (non Iner), 1871, Proc. Acad. Nat. Sci. Phila., XXIII, 258, Rio Ambyiacu.

Curimatus cyprinoides Cope (non Linnaeus), 1871, Proc. Acad. Nat. Sei. Phila., XXIII, 258, Rio Ambyiacu.

Rios Ambyiacu and Solimões; Ueayali

395. Curimata cyprinoides (Limaeus)

Salmo cyprinoides Linnaeus, 1766, Syst. Nat., ed. xii, 514.

Salmo edentulus Bloch, 1785, Ausl. Fische, 380;

Bloch and Schneider, 1801, Syst. Ichth., 472.

Characinus cyprinoides Lacépède, 1801, Hist. Nat. Poiss., nos. 272, $27 t$.

Curimatus cyprinoides Cuvier and Valenciennes, 1848, Hist. Nat. Poiss., XXII, 7;

Günther, 186t, Cat. Fish. Brit. Mus., V, 290;

Cope, 1871, Proc. Acad. Nat. Sci. Phila., XXIII, 258, Rio Ambyiacu, Hauxwell collection;

Eigenmann and Eigenmann, 1889, Ann. T. Y. Acad. Sci., IV, 429;

Eigenmann, 1910, Rept. Princeton Univ. Exped. Patagonia, III, 122.

Curimata cyprinoides Fowler, 1906 (1907), Proc. Acad. Nat. Sci. Phila., LVIII, 300, fig. 6;

Fowler, 1939 (1940), Proc. Acad. Nat. Sci. Phila., XCI, 253, fifteen, 83-157 mm., Contamana.

Amazons northward

Belonging to the group of Curimata having a trenchant postventral area, with angular preventral; some dorsal rays protracted into a filament; in all these respects resembling $C$. knerii of the middle and lower Amazon and Surinam, but differing consistently in the lower number of all scales.

Fowler's Contamana specimens measure 2.25-2.8 in the ratio of length to depth; pectorals barely reach the ventrals; scales 14 or $15-50$ to $60-8$ or 9 .

The name Chilio has been reported to Fowler.

396. Curimata reticulata Allen, sp. nov.

Plate XIV, fig. 2

17856, 1, $132 \mathrm{~mm}$., Rio Ueayali, near Orellana, Allen, August, 1920.

17857, 12, 75-113 mm., the type $105 \mathrm{~mm}$., Lago Cashiboya, Allen, August, 1920.

Similar to $C$. gilberti in the unaugmented median series of scales, obtuse keels, but of less robust form, lacking the dark line of the tail, which is scaled; scales few, in regular rows above the lateral line, whose formula is $5-40-5$ or 6 , and which is straight; eye unlike in size. 
D. 11; length of dorsal 3.8-4.7 in the length of the fish; A. 9; eye greater than snout by half the width of the iris, 3 in the head, 1.6 in the interorbital width; depth in length 2.8-3.3. All fins small, ventrals in length 4.8, moderate, not reaching to the anus by a considerable space; pectorals still shorter, 6.7 in the length and far short of reaching the ventrals; dorsal origin slightly nearer the tip of the snout than to that of the adipose, its tip separated by four scale rows from the adipose fin, which is considerably elevated; the anal reaching the caudal origin; the caudal moderately forked, with a few diminishing series of scales on the base.

Cypriniform; dorsal contour strongly arched from the nape to the extremity of the dorsal basis; wide and flat on the top of the head and first series of predorsal scales; preventral contour more regular, but somewhat arched both ways in the preventral region; only moderately compressed; lateral keels of preventral area rounded.

Mouth distinctly inferior, nearly equals the interorbital space; scales increasing in size ventrally, but only moderately; crenulations moderate and inconspicuous. A slightly pigmented epidermis about the margin of each scale, each of which is darker than its border, forms a lighter network with a lace-like, regular pattern on the dorsal half of the sides. Iridescent, bluish silver ground color, becoming golden or brassy on the opercle and iris.

The name alludes to the light network about the upper scales of the sides.

\section{Curimata hypostoma Boulenger}

Curimatus hypostomus Boulenger, 1887, Ann. Mag. Nat. Hist., XIX, 172, Rio Ucayali;

Eigenmann and Eigenmann, 1889, Ann. N. Y. Acad. Sci., IV, 426;

Eigenmann, 1910, Rept. Princeton Univ. Exped. Patagonia, III, 422.

\section{Peruvian Amazonia}

15825, 13, 99-107 mm., Rio Huallaga, Yurimaguas, Allen, November, 1920.

15827, 10, 67-84 mm., Rio Huallaga, Yurimaguas, Allen, November, 1920.

15829, 1, 105 mm., Rio Morona, Allen, October, 1920.

17858, 13, 58-103 mm., Rio Paranapura, Yurimaguas, Allen, November, 1920.

The apparently juvenile specimens under number 15827 are separable from 15825 from the same source by several characters:

\begin{tabular}{|c|c|c|}
\hline & 15825 & 15827 \\
\hline Lateral line scales. . . . . . . . . . . . . . . . . & $50-5 t$ & $46-48$ \\
\hline Mouth. & More inferior & Less inferior \\
\hline Depth in length.............. & $3.9-4 . t$ & $3.4-4.0$ \\
\hline Ventral fin. . & Not reaching anus & Reaching anu \\
\hline
\end{tabular}

With respect to other characters these specimens are hypostoma.

Curimata hypostoma should be the ideal baitfish in several ways: with its perfection of minnow form, its brilliant silver iridescence, and its broad snout for 
the attachment of a hook, a snout perhaps all the tougher for the lack of teeth; they seem unusually able to withstand handling out of water.

397a. Curimata hypostoma hastata Allen, subsp. nov.

17859, 1, 133 mm., Rio Pichis, Puerto Bermudez, Allen, July, 1920.

Although separated from the preceding (or united to the preceding, as you may prefer) by some 600 to 800 miles of water, it is very close to C. hypostoma, somewhat stouter. More specimens would have warranted making it a new species. In all respects except the greater robustness and differences in color it

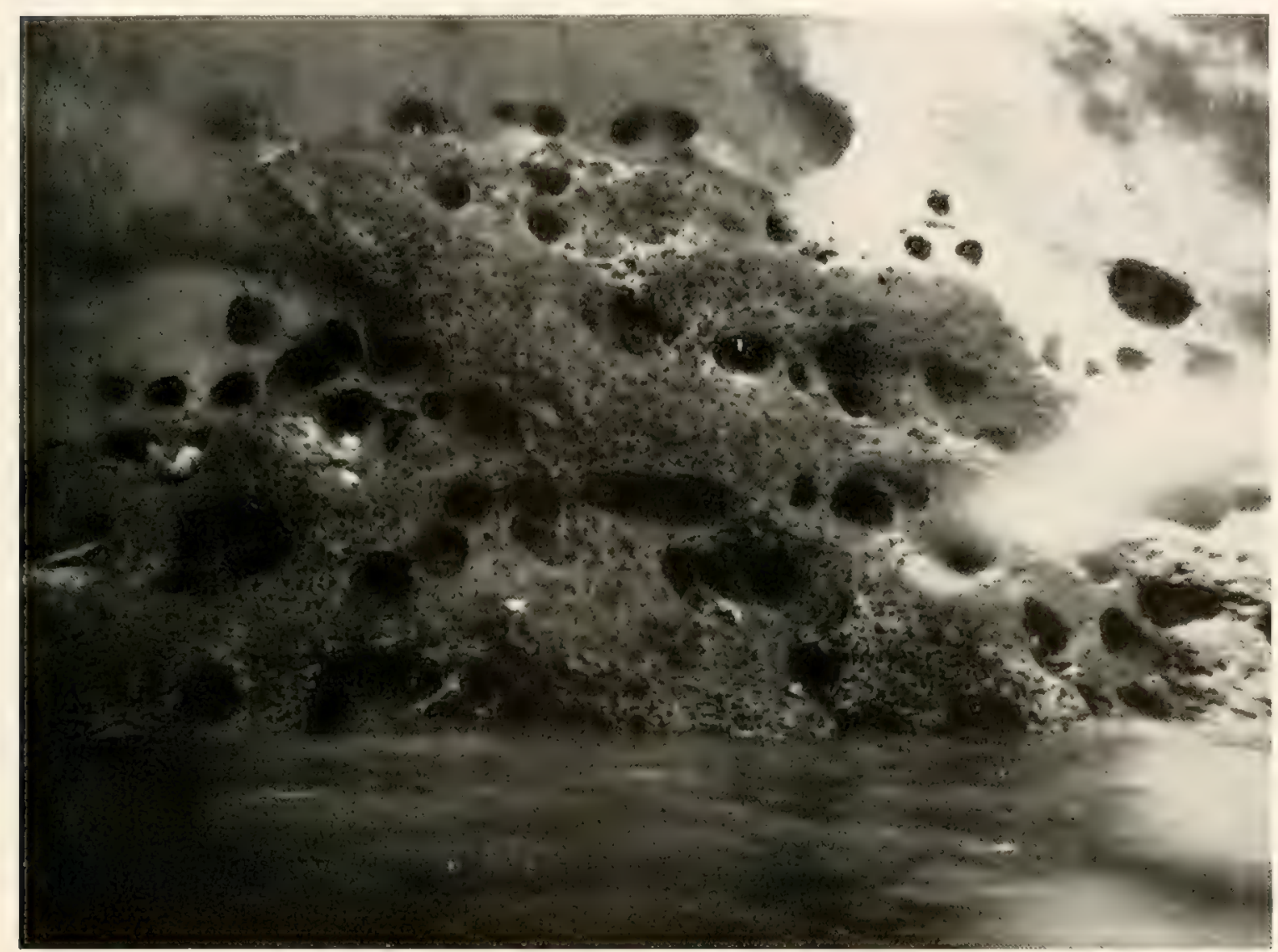

FIG. 32. Nests of Loricariid fishes in the clay banks of the Rio Huallaga near Yurimaguas.

exactly resembles our specimens of $C$. hypostoma; leucisca-like in form, color, and striae of the scales; hypostoma-like in the position of the mouth; and suggesting C. elegans and gilberti of southeastern Brazil in the javelin of black along the sides, the head of the javelin black on the caudal peduncle, its point bearing on the middle caudal rays, the handle of the javelin a fainter black, mostly above the lateral line.

Scales 7-49-6, regular, nearly uniform, naked, rayed, crenulate, firmly embedded. Dorsal and ventral curvature slight and about equal; fishes elongate in form, the outline slightly interrupted by the bases of the fins; length of the caudal peduncle 1.5 in its own depth; moderately compressed; only faintly keeled.

Head 4; depth 3.4 in the length; eye equals snout, 3.6 in the head. 
398. Curimata robustula Allen, sp. nov.

15830, 8, 57-8+ mm., creek, Yurimaguas, Allen, November, 1920.

A form from near the foothills of the Andes nearly resembling $C$. elegans of the Atlantic seaboard streams, but unlike in markings and scalation, as seen below; form more robust.

Head 3.6; depth in the length 2.9-3.2; eye in head 2.6, exceeding snout by width of iris or more, nearly equals interorbital; D. 11, equals head; A. 10; scale count $5-34$ to $36-5$.

Rather erect and short in form, dorsal and ventral contours subequal, dorsal nearly straight, ventral moderately convex; slightly concave over the eye; compressed; tends to form a double keel on each side of preventral region; mouth only slightly inferior, its width equal to eye. Dorsal fin equal to head, truncate; pectoral fin rather long, nearly reaching ventral; ventral fin moderately long, reaching within two scales or less to the anus; anal rather long, sometimes reaching the caudal; caudal shallowly furcate. Scales few, large, uniform in size, slightly crenate, slightly rayed, naked, deciduous.

Black area on lower part of middle dorsal rays, 5th to 8th; faint dark streak along lateral line, especially persistent on the caudal peduncle, and continuing to the end of the middle caudal rays.

\section{Curimata simulata Eigenmann and Eigenmann}

Curimatus simulatus Eigenmann and Eigenmann, 1889, Ann. N. Y. Acad. Sci., IV, 430;

Eigenmann 1910, Rept. Princeton Univ. Exped. Patagonia, III, 422.

\section{Solimões and Peruvian Andes}

15821, 2, 142 and 175 mm., Lago Sanango, Allen, November, 1920.

Back greatly arched with steep anterior profile; preventral area flattened; postventral region prominently keeled; predorsal trenchant; scales more or less "ciliate"; caudal naked.

Profile somewhat depressed at the occiput; mouth inferior, snout pointed; eye equal to snout, $3.33-3.5$ in the head, 1.66 in the interorbital space; head 3.2-3.4; depth $2.33-2.6$; D. $12-13$; A. $12-14$; scale formula $14-51$ to $53-6$ or 7 .

400. Curimata murieli Allen, sp. nov.

Plate XIV, fig. 1

17853, 1, 80 mm., Contamana, Rio Ucayali, August, 1920.

Near Curimata simulata Eigenmann and Eigenmann, and in other respects similar to C. aspera Günther; differs most conspicuously in the faint band of brown along the lateral line (suggesting $C$. hastata) and in the eight more or less distinct bands across the back, none but the first reaching the lateral line. Much elongated; head narrow; lateral line curved; fins shorter than above.

Head 3 in the length; depth 3.2; eye 3 in the head and exceeding snout by the 
width of the yellow iris, nearly equal to the interorbital space; mouth slightly inferior; dorsal profile slightly depressed on the head; D. 11; A. 11; scales 13-55-7; lateral line depressed slightly at its anterior end; fins moderate; longest dorsal rays $4.3 \mathrm{in}$ the length of the fish; pectoral fin not reaching to the ventral, nor the ventrals to the anus.

Caudal peduncle elongated, its depth 1.4 in its length; base of the anal fin 1.3 in the base of the dorsal or interorbital space; preventral area distinctly keeled, postventral only perceptibly. scales.

Scales mostly cycloid, the exposed margins only sinuate at most; fins without

For Capitan Muriel of the frontier military district with headquarters at Contamana, who gave much assistance during a month's work in that area.

\section{Curimata brevipes Eigenmann and Ogle}

Curimatus breripes Eigenmann and Ogle, 1907, Proc. U. S. Nat. Mus., XXXIII, 3, fig. 1, one, probably Peru, Orton collection;

Eigenmann, 1910, Rept. Princeton Lniv. Exped. Patagonia, III, 122.

The type, probably Perurian, unique.

\section{Curimata melaniris Fowler}

Curimata (Steindachnerina) melaniris Fowler, 1939 (1940), Proc. Acad. Nat. Sci. Phila., XCI, 253, fig. $5 t$.

\section{Lower Rio Ucayali, Peru}

Known from the unique type in the collections of the Philadelphia Museum, $150 \mathrm{~mm}$. long, Boca Chica, Morrow collection.

Genus 161: CURIMATOIDES Fowler

Curimatoides Forler, 1939 (1940), Proc. Acad. Nat. Sci. Phila., XCI, 255.

Type: Curimatoides ucayalensis Fowler

Contamana, Rio Ucayali

"Resembling Curimata in the scaleless caudal fin (?), complete lateral line, and general appearance, and differing in the absence of an adipose fin.

"Elongate, compressed, predorsal becoming flattened anteriorly; belly broad before and after the vent; edentulous, without gill-rakers, gill-filaments long; gill-membranes united and joined to the isthmus; scales large, and more or less uniform; mouth broad, obtuse."

\section{Curmatoides ucaralensis Fowler}

Curimatoides ucayalensis Fowler, 1939 (1940), Proc. Acad. Nat. Sci. Phila., XCI, 255, fig. 55.

Known from the $80-\mathrm{mm}$. type from Contamana, at Philadelphia. 


\section{Subfamily: $A N O D I N A E$}

\section{Genus 162: ANODUS Spix}

Anodus Spix, 1829, Sel. Gen. et Spec. Pisc. Bras., 57;

Cope, 1878, Proc. Amer. Phil. Soc., XVIII, 682;

Eigenmann and Eigenmann, 1889, Ann. N. Y. Acad. Sci., IV, 410;

Eigenmann, 1910, Rept. Princeton Univ. Exped. Patagonia, III, 420.

Elopomorphus Gill, 1878, Ann. Mag. Nat. Hist., (5), III, 112, jordani.

\section{Type: Anodus elongatus Spix}

Rios Orinoco and Amazon

Gill-arches with long, slender rakers.

\section{Anodus laticeps (Cuvier and Valenciennes)}

Curimatus laticeps Cuvier and Valenciennes, 1848, Hist. Nat. Poiss., XXII, 21, pl. 634;

Steindachner, 1880 (1882), Denksch. KK. Akad. Wiss. Wien, XLIII, 37.

Semitipicis laticeps Eigenmann and Eigenmann, 1889, Ann. N. Y. Acad. Sci., IV, 417, 432;

Fowler, 1906 (1907), Proc. Acad. Nat. Sci. Phila., LVIII, 305, Peruvian Amazon, Orton collection:

Eigenmann, 1910, Rept. Princeton Univ. Exped. Patagonia, III, 422;

Fowler, 1939 (1940), Proc. Acad. Nat. Sci. Phila., XCI, 256, fig. 56, twelve, 73-153 mm., Contamana, Norrow collection.

Curimatus altamazonicus Cope, 1878, Proc. Amer. Phil. Soc., XVII, 684, Peruvian Amazon.

\section{Lake Maracaibo to Rio Paraguay via Peru}

15663, 15823, 5, 175-213 mm., Lago Sanango, Allen, November, 1920.

15836, 3, 148-170 mm., Rio Nanay, Iquitos, Allen, September, 1920.

17860, 1, 207 mm., Rio Ucayali, Orellana, Allen, August, 1920.

17861, 12, 70-141 mm., Rio Ucayali, Contamana, Allen, August, 1920.

17862, 35, 71-170 mm., Lago Cashiboya, Allen, August, 1920.

Fowler was given the local name Yahnarache (yanarache?). At least in some localities it is known as rumiuma, or "red-tail." This name is also applied to one or more quite different fishes.

The generic appellation Semitipicis has been justified on the very numerous, small scales, 85-110 in the lateral line; median predorsal scales growing deciduous with age, thin, crenate; postdorsal and preventral areas rounded, the latter trenchant, but without carina; head wider and flatter than in latior, upper profile more elevated and convex; origin of dorsal fin nearer snout than to tip of the adipose fin; dorsal fin truncate, or with some of the anterior rays produced as long as the head.

\section{Anodus latior Spix}

Anodus latior Spix, 1829, Sel. Gen. et Spec. Pise. Bras., 62, pl. xli.

Curimatus latior Cuvier and Valenciennes, 1848, Hist. Nat. Poiss., XXII, 19;

Günther, 1864, Cat. Fish. Brit. Mus., V, 293;

Günther, 1868, Proc. Zool. Soc. London, 229;

Steindachner, 1880 (1881), Denksch. KK. Akad. Wiss. Wien, XLIII, 36, Teffé, Rio Negro; 
Steindachner, 1882 (1883), Denksch. KK. Akad. Wiss. Wien, XLVI, 12, Rio Huallaga, one specimen, $135 \mathrm{~mm}$;

Eigenmann and Eigenmann, 1889, Ann. N. Y. Acad. Sci., IV, 432.

Gasterotomus latior Eigenmann, 1910, Rept. Princeton Univ. Exped. Patagonia, III, 422;

Fowler, 1939 (1940), Proc. Acad. Nat. Sci. Phila., XCI, 257, three, 101-212 mm., Contamana.

Peruvian Amazon to Argentina, not coastal rivers, and to Surinam

15666, 3, 163-181 mm., Lago Sanango, Allen, November, 1920.

15822, 3, 170-179 mm., Lago Sanango, Allen, November, 1920.

17863, 3, 181-205 mm., Rio Ucayali, Contamana, Allen, August, 1920.

1786t, 2, 100 and $121 \mathrm{~mm}$., Lago Cashiboya, Allen, August, 1920.

The species may most readily be separated from laticeps by the fact that in the latter the venter is keeled from the origin of the ventral to the base of the anal, in lation from the pectoral region to the anal. I question the constancy of the scaled line of the predorsal area used in the keys. In most of the specimens of A. laticeps the predorsal is naked, but in some of them crowded closely with scales. In latior there are areas on the predorsal line in which the scales are rubbed off entirely, and in none is there complete scalation there.

Elongate, compressiform, entire venter trenchant and non-carinate; dorsal contours less rounded than in A. laticeps; scales small, thin, ctenoid; anterior profile not depressed; air bladder extending beyond the origin of the anal fin.

The name Yulilla was collected for Steindachner.

\section{Anodus Elongatus Spix}

Anodus elongatus Spix, 1829, Sel. Gen. et Spec. Pisc. Bras., 57, pl. xl;

Eigenmann and Eigenmann, 1889, Ann. N. Y. Acad. Sci., IV, 411;

Fowler, 1906 (1907), Proc. Acad. Nat. Sci. Phila., LVIII, 306, fig. 9;

Eigenmann, 1910, Rept. Princeton Univ. Exped. Patagonia, III, 420;

Fowler, 1939 (1940), Proc. Acad. Nat. Sci. Phila., XCI, 251, fig. 51, six specimens, 234-264 mm., Bajo Ueayali river.

Curimatus elongatus Cuvier and Valenciennes, 1848, Hist. Nat. Poiss., XXII, 20.

Elopomorphus elongatus Steindachner, 1880 (1881), Denksch. KK. Akad. Wiss. Wien, XLIII, 38.

Elopomorphus jordani Gill, 1878, Ann. Mag. Nat. Hist., (5), III, 112.

Anodus steatops Cope, 1878, Proc. Amer. Phil. Soc, XVII, 683, Rio Marañon, Orton collection;

Eigenmann and Eigenmann, 1889, Ann. X. Y. Acad. Sci., IV, 411.

The Amazons

\section{Genus 163: EIGENMANNINA Fowler}

Eigenmannina Fowler, 1906 (1907), Proc. Acad. Nat. Sci. Phila., LVIII, 307;

Eigenmann, 1910, Rept. Princeton Univ. Exped. Patagonia, III, 420.

\section{Type: Anodus melanopogon Cope}

Orinoco and Peruvian Amazon

May be known for the extremely large head and opercle; dorsal profile decidedly concave; mandible strongly produced, mouth superior; eye dorsal to the center of the head; body heavy at the shoulder, tapering caudally. 


\section{Eigenmannina melanopogon (Cope)}

Anodus melanopogon Cope, 1878, Proc. Amer. Phil. Soc., XVII, 682, Peruvian Amazon, Orton collection;

Eigenmann and Eigenmann, 1889, Ann. N. Y. Acad. Sci., IV, 411.

Eigenmannina melanopogon Fowler, 1906 (1907), Proc. Acad. Nat. Sci. Phila., LVIII, 308, fig. 10;

Eigenmann, 1910, Rept. Princeton Univ. Exped. Patagonia, III, 420.

\section{Peruvian Amazon}

Known from the types in the Philadelphia Academy Museum.

\section{Subfamily: ANOSTOMATINAE}

Anostomatidae Jordan, Evermann and Clark, 1928 (1930), Rept. U. S. Comm. Fish., Part II, 100.

\section{Genus 164: LAEMIOLYTA Cope}

Lacmolyta Cope, 1872, Proc. Acad. Nat. Sci. Phila., XXIII, 258;

Eigenmann, 1910, Rept. Princeton Uniy, Exped. Patagonia, III, 425.

Schizodontopsis Garman, 1890, Bull. Essex Inst., XXII, 19;

Eigenmann, 1912, Mem. Carnegie Mus., V, 298.

\section{Type: Schizodon taeniatus Kner}

\section{Orinoco and Amazon basins}

Teeth truncate in adult, mouth oblique.

\section{Laemolyta taeniata (Kner)}

Schizodon taeniatus Tiner, 1859, Denksch. KK. Akad. Wiss. Wien, XVII, 150;

Günther, 186t, Cat. Fish. Brit. Mus., V, 304.

Laemolyta taeniata Cope, 1872, Proc. Acad. Nat. Sci. Phila., XXIII, 259, Rio Ambyiacu, Hauxwell collection:

Fowler, 1906 (1907), Proc. Acad. Nat. Sci. Phila., LVIII, 322;

Eigenmann, 1910, Rept. Princeton Univ. Exped. Patagonia, III, 425.

Anostomus taeniatus Steindachner, 1882 (1883), Denksch. KK. Akad. Wiss. Wien, XLVI, 12, Rio Huallaga, three, $115-120 \mathrm{~mm}$.

\section{The Amazons}

The comprehensive name Lisa was reported to Steindachner.

\section{Genus 165: ANOSTOMUS Gronow}

Anostomus Gronow, 175t, Mus. Ichth., II, 13, pl. vii, fig. 2;

Gronow, 1763, Zoophyl., 112;

Scopoli, 1777, Hist. Nat., 451;

Eigenmann and Eigenmann, 1891, Proc. U. S. Nat. Mus., XIV, 49 ;

Eigenmann, 1910, Rept. Princeton Univ. Exped. Patagonia, III, 425;

Eigenmann, 1912, Mem. Carnegie \us., V, 294;

Borodin, 1931, Bull. Mus. Comp. Zool., LXXII, 37-52. 
Pithecocharax Fowler, 1906 (1907), Proc. Acad. Nat. Sci. Phila., LVIII, 319;

Eigenmann, 1910, Rept. Princeton Unir. Exped. Patagonia, III, 425.

\section{Type: Salmo anostomus Limnaeus}

\section{Amazon basin northward}

Small to medium-sized fishes; snout elliptical to nearly circular in cross-section; mouth minute, rertical; lips thick and plicate; about eight teeth above and below, respectively, bilobed to multilobed; gill-membrane united with the isthmus.

\section{Anostomus trimaculatus (Kner)}

Schizodon trimaculatus Kner, 1859, Denksch. KK. Akad. Wiss. Wien, XVII, 25, pl. vi, fig. 12;

Cope, 1878, Proc. Amer. Phil. Soc., XVII, 690, Marañon, Orton coll.

Anostomus trimaculatus Günther, 1864, Cat. Fish. Brit. Mus., V, 304;

Eigenmann and Eigenmann, 1891, Proc. U. S. Nat. Mus., XIV, 50;

Pellegrin, 1899, Bull. Mus. Iist. Nat., V, 406;

Eigenmann, 1910, Rept. Princeton Univ. Exped. Patagonia, III, 125;

Eigenmann, 1912, Mcm. Carnegie Mus., V, 295, pl. xli, fig. 2.

Amazon basin and British Guiana

410. Anostomus ucayalensis (Fowler)

Pithecocharax ucayalensis Fowler, 1906 (1907), Proc. Acad. Nat. Sei. Phila., LVIII, 320;

Eigenmann, 1910, Rept. Princeton Univ. Exped. Patagonia, III, 425.

Peruvian Amazon or Ueayali

\section{Genus 166: SCHIZODON Agassiz}

Anostomus (in part) Gronow, 1754, Mus. Ichth., II, 13.

Schizodon Agassiz, 1829, Sel. Gen. et Spec. Pise. Bras., 66, pl. xxxvi;

Eigenmann, 1910, Rept. Princeton Univ. Exped. Patagonia, II I, 425;

Eigenmann, 1912, Mem. Carnegie Mus., V, 297.

\section{Type: Curimatus fasciatus Spix}

The Guianas to La Plata basin

Anostomus-like, but with cross-section of snout region more decidedly elliptical; mouth terminal; mandibular teeth short and broad.

\section{Schizodon Fasciatum (Spix)}

Curimatus fasciatus Spix, 1829, Sel. Gen. et Spee. Pise. Bras., pl. xxxvi.

Schizodon fascialus Agassiz, 1829, Sel. Gen. et Spec. Pisc. Bras., 66;

Cope, 1870, Proc. Amer. Phil. Soc., XI, 566, Para;

Cope, 1878, Proc. Amer. Phil. Soc., XVII, 689, Marañon, Orton coll.;

Fowler, 1906 (1907), Proc. Acad. Nat. Sci. Phila., LYIII, 322, Ambyiacu river, Hauxwell collection:

Eigenmann, 1910, Rept. Prinecton Univ. Exped. Patagonia, II I, 425;

Ligenmann, 1912, Mem. Carnegie \us, I, 297; 
Fowler, 1939 (1940), Proc. Acad. Nat. Sci. Phila., XCI, 261, six, 109-220 mm., Contamana, Rio Ucayali.

Anostomus fasciatus Günther, 1864, Cat. Fish. Brit. Mus., V, 304;

Cope, 1871 (1872), Proe. Acad. Nat. Sci. Phila., XXIII, 258, Rio Ambyiacu, Hauxwell collection;

Steindachner, 1882 (1883), Denksch. KK. Akad. Wiss. Wien, XLVI, 12, Rio Huallaga, six, $125-230 \mathrm{~mm}$.;

Eigenmann and Eigenmann, 1891, Proc. U. S. Nat. Mus., XIV, 50.

Venezuela and the Amazons to the Rio Paraguay

The vernacular name Huito-challua is assigned to this species by Steindachner; nulilla is Fowler's name for it. The recurrence of the suffix challhua (fish) in so many of Steindachner's names indicates the possibility that many of them may have been named by one person, possibly at one sitting. I did not find such usage common in the lowland country, although more prevalent in the mountain sections.

\section{Genus 167: RHYTIODUS Kner}

Rhytiodus Kner, 1859, Denksch. KK. Akad. Wiss. Wien, XVII, 165;

Eigenmann, 1910, Rept. Princeton Univ. Exped. Patagonia, III, 425.

Garmanina Fowler, 1906 (1907), Proc. Acad. Nat. Sci., Phila., LVIII, 326, argenteofuscus

Type: Rhytiodus microlepis Kner

Upper Amazon, Peru to Rio Negro

Mouth small, terminal; teeth laminate; premaxillary convex before; maxillary teeth flexuose, bicuspid; head slightly depressed, body elongate, subterete; anal short; near Schizodon, separated by form of teeth, elongation of body, and broad depressed head.

\section{Rhytiodus microlepis Kner}

Rhytiodus microlepis Kner, 1859, Denksch. KK. Akad. Wiss. Wien, XVII, 165, pl. ii, fig. 15, Rio Negro;

Fowler, 1906 (1907), Proc. Acad. Nat. Sci. Phila., LVIII, 326, Pebas;

Eigenmann, 1910, Rept. Princeton Univ. Exped. Patagonia, III, 425;

Fowler, 1939 (1940), Proc. Acad. Nat. Sci. Phila., XCI, 261.

\section{Rio Negro and Peruvian Amazon}

Within our area represented by three specimens in the Philadelphia Academy Museum, from Contamana, $153-212 \mathrm{~mm}$. in length.

\section{Rhytiodus ARgenteofuscus Kner}

Rhytiodus argenteofuscus Kner, 1859, Denksch. KK. Akad. Wiss. Wien, XVII, 166, Rio Negro;

Fowler, 1906 (1907), Proc. Acad. Nat. Sci. Phila., LVIII, 326;

Eigenmann, 1910, Rept. Princeton Univ. Exped. Patagonia, III, 425.

Schizodon sagittarius Cope, 1878, Proc. Amer. Phil. Soc., XVII, 689, Peruvian Amazon, Orton collection. 


\section{Genus 168: LEPORINUS Spix}

Leporimus Spix, 1829, Sel. Gen. et Spec. Pisc. Bras., 58;

Eigenmann and Eigenmann, 1891, Proc. U. S. Nat. Mus., XIV, 52;

Eigenmann, 1910, Rept. Princeton Unir. Exped. Patagonia, III, 426;

Eigenmann, 1912, Mem. Carnegie Mus., V, 299.

Abramites Fowler, 1906 (1907), Proc. Acad. Nat. Sci. Phila., LVIII, 331.

\section{Type: Leporinus novemfasciatus Agassiz}

All eastern slope streams Rio Magdalena to La Plata

Separable by the moderately to greatly reduced dimensions of the head, which is cone-shaped; mouth minute with teeth reduced to not more than six in each jaw, and directed obliquely forward toward the middle; teeth lobed or truncate; nares widely separated.

These and related fishes known as lisa.

\section{Leporinus FRIDERICI (Bloch)}

Salmo friderici Bloch, 1795, Ausl. Fische, VIII, 78, pl. 378;

Bloch and Schneider, 1801, Syst. Ichth., 401.

Leporinus friderici Iüller and Troschel, 1845, Horae Ichth., I, 11;

Cuvier and Valenciennes, 1849, Hist. Nat. Poiss., XXII, 25;

Eigenmann, 1910, Rept. Princeton Univ. Exped. Patagonia, III, 126;

Eigenmann, 1912, Iem. Carnegie دIus., V, 302, pl. xliii, fig. 4;

Borodin, 1929, Mem. Mus. Comp. Zool., L, 275, Brazilian waters;

Fowler, 1939 (1940), Proc. Acad. Nat. Sci. Phila., XCI, 261, one, 178 mm., Contamana,

Norrow collection.

Leporinus frederici Cope, 1870, Proc. Amer. Phil. Soc., XI, 566, Pebas, Hauxwell collection;

Cope, 1878, Proc. Amer. Phil. Soc., XVII, 690, Marañon, Orton coll.;

Pellegrin, 1899, Bull. Mus. Hist. Nat., V, 406;

Fowler, 1906 (1907), Proc. Acad. Nat. Sci. Phila., LVIII, 328.

Leporinus megalepis (in part) Günther, 1868, Proc. Zool. Soc. London, 244, one, 6 inches, Xeberos, Bartlett collection.

Curimatus acutidens Valenciennes, 18.7, in D'Orb. Voy. Amér. Merid., Poiss., 9, pl. viii, fig. 1.

Guianas and Venezuela to Peru and La Plata basin

\section{Leporinus bimaculatus Castelnau}

Leporinus bimaculatus Castelnau, 1855, Anim. Amér. Sud, Poiss., 58;

Eigenmann, 1910, Rept. Princeton Univ. Exped. Patagonia, III, 426.

Leporinus frederici (in part) Cope, 1878, Proc. Amer. Phil. Soc., XVII, 690, Rio MIarañon;

Steindachner, (in part), 1875, Sitzb. KK. Akad. Wiss. Wien, LXXI, 223, Tabatinga.

\section{Peruvian and Brazilian Amazons}

\section{Leporinus striatus Kner}

Leporinus striatus Kner, 1859, Denksch. KK. Akad. Wiss. Wien, XVII, 171;

Boulenger, 1887, Proc. Zool. Soc. London, 280;

Eigenmann, 1910, Rept. Princeton Univ. Exped. Patagonia, III, 426.

Magdalena to Peruvian Amazon and Rio Paraguay 


\section{Leporinus WOLFEI Fowler}

Leporinus wolfei Fowler, 1939 (1940), Proc. Acad. Nat. Sei. Phila., XCI, 261, fig. 58.

Bajo Ucayali at Boca Chica

Two specimens, type and paratype, 110 and $148 \mathrm{~mm}$., in the Norrow collection at the Philadelphia Academy. Near L. alternans, but lacking the indistinct lighter bands which characterize that species.

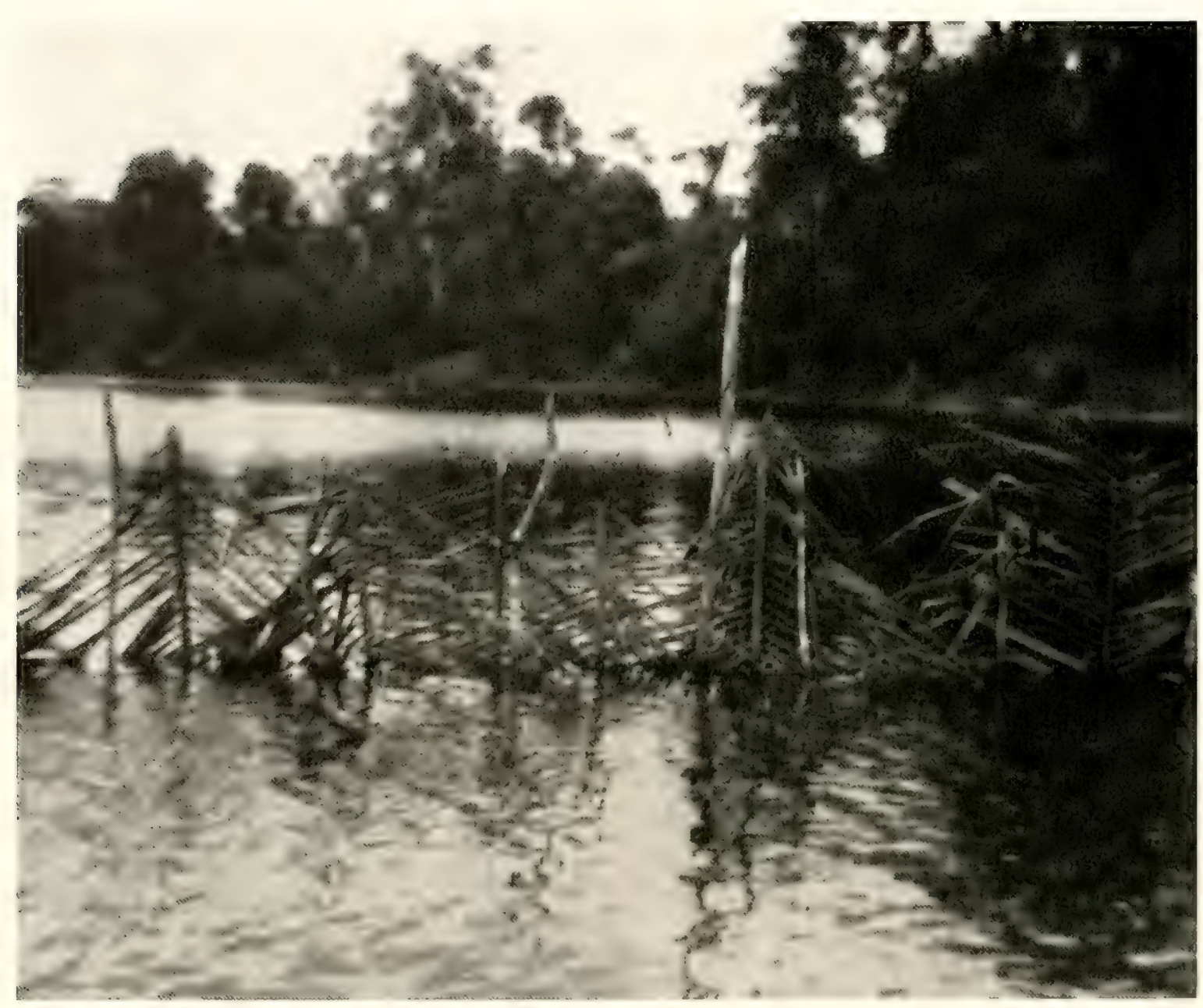

Ficr. 33. Barrien for migrating fishes. The fish while nuzzling its way through the fence agitates the brush and thus directs the aim of the fisherman's harpoon.

418. LEPORINUs MüLLERI Steindachner

Leporinus mülleri Steindachner, 1876, Sitzb. KK. Akad. Wiss. Wien, LXXIV, 105, pl. ix, fig. 5;

Eigenmann, 1910, Rept. Princeton Univ. Exped. Patagonia, III, 426;

Borodin, 1929, Mem. Mus. Comp. Zool., L, 281.

Rios Orinoco, Solimões, Marañon

419. Leporinus megalepis Günther

Leporinus megalepis Günther, 1863, Amn. MIag. Nat. Hist., (3), XII, 443; Günther, 186t, Cat. Fish. Brit. Mus., V, 307; 
Günther, 1868, Proc. Zool. Soc. London, 24t, Xeberos, Bartlett coll., young with upper incisors distinctly notehed;

Eigenmann, 1910, Rept. Princeton Univ. Exped. Patagonia, III, +26.

Leporinus maculatus Eigenmann, 1912, Mem. Carnegie Mus., V, 305 (part).

The Guianas, Peruvian Amazon, Rio de Janeiro

420. Leporinus maculatus Müller and Troschel

Leporinus maculatus Mïller and Troschel, 1845, Horae Ichth., 1, 11, Guiana;

Cope, 1871, Proc. Acad. Nat. Sei. Phila., XXIII, 259, R. Ambyiacu;

Eigenmann, 1910, Rept. Princeton Univ. Exped. Patagonia, III, 427;

Eigenmann, 1912, Mem. Carnegie Mus., V, 305, pl. xliii, fig. 2.

Rio Ambyiacu to Guianas and Goyaz

\section{Leporinus trifasciatus Steindachner}

Leporinus trifasciatus Steindachner, 1882 (1883), Denksch. IK Akad. Wiss. Wien, NLVI, 13, Rio Huallaga, two, $130 \mathrm{~mm}$;

Eigenmann and Eigenmann, 1891, Proc. U. S. Nat. Mus., XIV, 51;

Eigenmann, 1910, Rept. Princeton Univ. Exped. Patagonia, III, 126.

Rio Huallaga to the basin of Rio Paraguay

\section{Leporinus holostictus Cope}

Leporinus holostictus Cope, 1878, Proc. Amer. Phil. Soc., XVII, 690, Marañon, Orton collection;

Fowler, 1906 (1907), Proc. Acad. Nat. Sci. Phila., LVIII, 330, fig. 20;

Eigenmann, 1910, Rept. Princeton Univ. Exped. Patagonia, III, 427.

\section{Peruvian Amazon}

\section{Leporinus mulitifasciatus Cope}

Leporinus multifasciatus Cope, 1878, Proc. Amer. Phil. Soc., XVII, 690, Peruvian Amazon, Orton collection:

Fowler, 1906 (1907), Proc. Acad. Nat. Sci. Phila., LVIII, 329;

Eigenmann, 1910, Rept. Princeton Univ. Exped. Patagonia, III, 427.

Peruvian Amazon and tributaries

\section{Leporinus sp.}

, 4, 85-116 mm., Lago Cashiboya, Allen, August, 1920.

, 147 mm., mouth Rio Pacaya, Allen, August, 1920.

Many specimens of Leporinus were taken, especially on the Ucayali, and especially with Prochilodus and the Mylinae while fishing with the tarafa, or thrownet. However most of them have been lost, or at least I was unable to find them while working over the collections in the summer of 1928.

$$
\text { Subgenus: Abramites Fowler }
$$




\section{Leporinus hypselonotus Günther}

Leporinus hypselonotus Günther, 1868, Proc. Zool. Soc. London, 244, pl. xxii, several, 6 inches, Xeberos, Bartlett collection;

Cope, 1878, Proc. Amer. Phil. Soc., XVII, 690, Peruvian Amazon, Orton collection;

Eigenmann and Eigenmann, 1891, Proc. U. S. Nat. Mus., XIV, 51;

Eigenmann, 1910, Rept. Princeton Univ. Exped. Patagonia, III, 426;

Borodin, 1929, Mem. Mus. Comp. Zool., L, 287, pl, xvii, figs. 1-7.

Abramites hypselonotus Fowler, 1906 (1907), Proc. Acad. Nat. Sci. Phila., LVIII, 331.

\section{Orinoco, Marañon, to Rio Paraguay}

, 3, 102-153 mm., Iquitos, Allen, August, 1920.

Separated by Fowler from the remaining Leporinus species on the longer basis of the anal fin. Borodin points out the additional characters: weak attachment of the gill-membranes; very deep and hump-backed body, which he regards as a step in the direction of the Tetragonopterines. He accepts Abramites logically as a probable future subgenus.

On the Marañon above Iquitos I encountered a young man who took from his pocket and showed me a mummified specimen of hypselonotus, known to him under the name San Pedro, which he informed me was his "lucky piece." The good fortune it was supposed to bring was not at all evident about his person.

All of Mr. Bartlett's specimens were found by Günther to have the gill-chamber of one side occupied by parasitic Crustacea.

\section{Subfamily: LEPORELLINAE}

\section{Genus 169: LEPORELLUS Lütken}

Leporellus Lütken, 1874, Overs. Dansk. Vid. Forh. Ǩjöbenhavn, 129;

Eigenmann and Eigenmann, 1891, Proc. U. S. Nat. Mus., XIV, 50;

Eigenmann, 1910, Rept. Princeton Univ. Exped. Patagonia, III, 427.

\section{Type: Leporinus pictus Kner = Leporinus vittatus \\ Cuvier and Valenciennes \\ Range that of the unique species}

Nares approximated; branchial aperture deeply cleft, branchiostegal membrane free, scarcely adnate to isthmus, by which character it is near the Tetragonopterines.

\section{Leporellus vittatus (Cuvier and Valenciennes)}

Leporinus vittatus Cuvier and Valenciennes, 1840, Hist. Nat. Poiss., XXII, 33, Rio Magdalena and Rio das Velhas;

Cope, 1878, Proc. Amer. Phil. Soc., XVII, 690, Peruvian Amazon, Orton collection.

Leporellus vittatus Lütken, 1874 (1875), Overs. Dansk. Vid. Forh. Kjöbenhavn, 129;

Fowler, 1906 (1907), Proc. Acad. Nat. Sci. Phila., LVIII, 327;

Eigenmann, 1910, Rept. Princeton Univ. Exped. Patagonia, III, 427.

Magdalena drainage to Peru and Rio das Velhas 


\section{Subfamily: PROCHILODINAE}

\section{Genus 170: PROCHILODUS Agassiz}

Prochilodus Agassiz, 1829, Sel. Gen. et Spec. Pise. Bras., 57;

Eigenmann and Eigenmann, 1891, Proc. U. S. Nat. MIus., XIV, 48;

Eigenmann, 1910, Rept. Princeton Univ. Exped. Patagonia, III, 424;

Eigenmann, 1912, Mem. Camegie Mus., V, 270.

Type: Prochilodus argenteus Spix

Western Ecuador to Rio Magdalena and La Plata

Both jaws very weak, but with teeth, which are inserted on the lips, movable, with a single series on the sides and two in the middle; mouth sucker-like when opened, ventral, non-protractile; a procumbent dorsal spine; scales ctenoid, rough.

\section{Prochilodus nigricans Agassiz}

Prochilodus nigricans Agassiz, 1829, Sel. Gen. et Spec. Pisc. Bras., 64;

Günther, 1866, Ann. Mag. Nat. Hist., (3), XVIII, 30;

Günther, 1868, Proc. Zool. Soc. London, 229;

non Günther, 1864, Cat. Fish. Brit, Mus., V, 295;

Steindachner, 1882 (1883), Denksch. KKK. Akad. Wiss. Wien, XLVI, 12, Rio Huallaga, one poorly preserved, $245 \mathrm{~mm}$;

Eigenmann, 1910, Rept. Princeton Univ. Exped. Patagonia, III, 424;

Pearson, 1937a, Proc. Cal. Acad. Sci., (4), XXIII, 90, R. Crisnejas.

\section{Amazon and La Plata valleys}

15664, 5, 153-216 mm., Alto Marañon, Allen, October, 1920.

$15667,1,17 \pm \mathrm{mm}$., Rio Norona, Allen, Oetober, 1920.

$17835,1,210 \mathrm{~mm}$., Rio Pachitea, Allen, July, 1920.

17836, 8, 126-220 mm., Rio Ucayali, Contamana, Allen, August, 1920.

$17837,2,215$ and $220 \mathrm{~mm}$., Iquitos, Allen, September, 1920.

17838, 2, 1 t2 and 149 mm., Pto. Melendez, Alto Marañon, Allen, October, 1920.

17839, 1, 228 mm., Rio Pichis, Pto. Bermudez, Allen, July, 1920.

17840, 6, 142-180 mm., mouth Rio Pacaya, Allen, August, 1920.

178+1, 8, 110-192 mm., Lago Cashiboya, Allen, August, 1920.

17842, 1, 315 mm., Lago Sanango, Turimaguas, Allen, November, 1920.

Günther, in comparing Bartlett's material from the Peruvian Amazon with that which he had catalogued as $P$. nigricans from the Essequibo, identified the former as nigricans and the Guiana material as mbrotacniatus of Schomburgk. The Amazon form has somewhat smaller scales, $10-48-9$; depth 3 in standard length.

In our collections the following notes are applicable:

Margins of scales form a series of longitudinal, dark, wary lines; general color dark blue to blue-black; patch of blue-black on the operculum; about 11 faint vertical blue bands in the younger; iris yellow; dorsal and caudal fins with narrow. irregular, blue-black bands; rhombic scale-pattern above the lateral line.

The flesh of this species softens in preservative, regardless of care, and assumes a bad odor, with a shriveling of the entire specimen. It is one of the three types of fishes found in greatest numbers running upstream during the creciente, or floodstages of the rivers (the other two being various Mylinae and Leporinus). These 
three forms are the favorites for drying during the dry-season for consumption in the period of inundation.

Widely known as boca chica for the small, suctorial mouth; the name chupadora was also somewhat current (in allusion to the carp-like chewing of mud and debris). 17843, 3, 157-172 mm., Iquitos, Allen, September, 1920.

These specimens assigned to $P$. nigricans show considerable departure from other known types. They are identical in color, in the bands of color (unless there are more), and in the irregular bands on fins and spot on the opercle.

\begin{tabular}{|c|c|c|}
\hline & nigricans & 17843 \\
\hline Interorbital space ................. & 6.7 & 5.7 \\
\hline Depth at base of dorsal fin......... & 3.7 & $2.5-2.8$ \\
\hline First anal rays prolonged ........... & $\begin{array}{l}\text { little or none, except in cne } \\
\text { or two specimens }\end{array}$ & $\begin{array}{l}\text { considerably, at least equal } \\
\text { to half the last ray }\end{array}$ \\
\hline Rhombic outline of scales...... & only above the lateral line & $\begin{array}{l}\text { continued below the lateral } \\
\text { line }\end{array}$ \\
\hline
\end{tabular}

This would ordinarily be considered sufficient ground for the creation of at least a subspecies, except for the fact that the Puerto Melendez specimens, 17838 , appear to fit in midway between these aberrant Iquitos specimens and the rest.

\section{Prochilodus ortonianus Cope}

Prochilodus ortonianus Cope, 1878, Proc. Amer. Phil. Soc., XVII, 685, Peruvian Amazon, Orton collection;

Fowler, 1906 (1907), Proc. Acad. Nat. Sci. Phila., LVIII, 311, fig. 12;

Eigenmann, 1910, Rept. Princeton Univ. Exped. Patagonia, III, 42t;

Fowler, 1939 (1940), Proc. Acad. Nat. Sci. Phila., XCI, 253.

\section{Peruvian Amazon}

Known from the types and from nine specimens from the Bajo Ucayali, part of the Morrow collection of the Philadelphia Academy.

\section{Prochilodus cephalotes Cope}

Prochilodus cephalotes Cope, 1878, Proc. Amer. Phil. Soc., XVII, 686, Peruvian Amazon, Orton collection;

Fowler, 1906 (1907), Proc. Acad. Nat. Sci. Phila., LVIII, 312, fig. 13;

Eigenmann, 1910, Rept. Princeton Univ. Exped. Patagonia, III, 424.

\section{Eastern Peru}

\section{Prochilodus theraponeura Fowler}

Prochilodus insignis Cope, 1872, Proc. Acad. Nat. Sci. Phila,, XXIII, 258, Rio Ambyiacu, Hauxwell collection.

Prochilodus theraponeura Fowler, 1906 (1907), Proc. Acad. Nat. Sci. Phila., LVIII, 313, fig. 14;

Fowler, 1939 (1910), Proc. Acad. Nat. Sci. Phila., XCI, 260. 


\section{Peruvian Amazonia}

Known from the type, a Hauxwell specimen from the prolific Ambyiacu river, $2 \frac{1}{4}$ inches long; an additional specimen $118 \mathrm{~mm}$. long from the Ucayali at Contamana, both in the Museum of the Philadelphia Academy. One of the species with an ornate tail fin, of the mbrotacniatus group.

\section{Prochllodus amazonensis Fowler}

Prochitolus amazonensis Fowler, 1906 (1907), Proc. Acad. Nat. Sci. Phila., LVIII, 316, fig. 15, lower Amazons:

Fowler, 1939 (1940), Proc. Acad. Nat. Sci. Phila, XCI, 260.

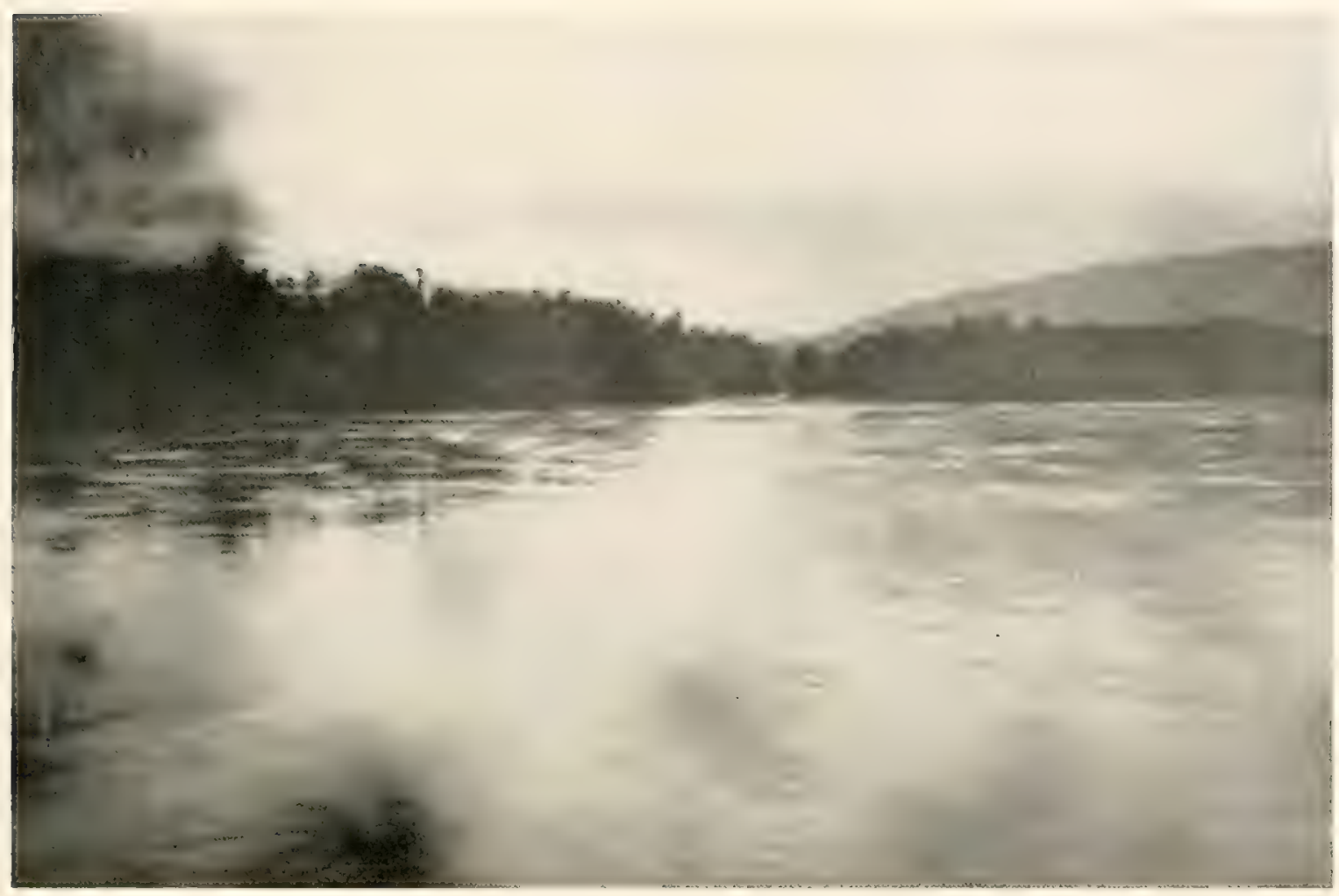

FIG. 34. Sunset in the Pongo de Manseriche. The Peruvian Amazon just below the water gap of the Andean foothills, where the great river bursts its last bonds and escapes to the alluvial plains.

\section{Upper and lower Amazons}

Represented in Peruvian waters by Fowler's three specimens of the Morrow collection, 98-130 mm., from Boca Chica, Bajo Ucayali. Near P. insignis Schomburgk, and, like theraponeura, differs in having a dorsal fin longer than the head.

\section{Prochilodus insignis Schomburgk}

Prochilodus insignis Schomburgk, 1841, Fish. Brit. Guiana, 261;

Kner, 1859, Denksch. KK. Akad. Wiss. Wien, XVII, 147;

Günther, 1861, Cat. Fish. Brit. Mus., V, 296; 
Cope, 1871 (1872), Proe. Acad. Nat. Sci. Phila., XXIII, 258, Rio Ambyiacu;

Eigenmann and Eigenmann, 1891, Proc. U. S. Nat. Mus., XIV, 48;

Eigenmann, 1910, Rept. Princeton Univ. Exped. Patagonia, III, 424.

\section{Guianas and Amazonia}

A species belonging to the lower Amazon, and, fide Cope, to the upper stream. Innes, the Aquarium, May, 1932, has an excellent photograph of a $3 \frac{1}{2}$-inch specimen from life.

\section{Prochilodus Rubrotaeniatus Schomburgk}

Prochilodus rubrotaeniatus Schomburgk, 18+1, Fish. Brit. Guiana, I, 258, pl. xxviii;

Eigenmann and Eigenmann, 1891, Proc. U. S. Nat: Mus., XIV, 48;

Eigenmann, 1910, Rept. Princeton Univ. Exped. Patagonia, III, 424;

Eigenmann, 1912, Mem. Carnegie Mus., V, 270.

Guianas, Rio Negro, upper Amazons

1, $204 \mathrm{~mm}$., Iquitos, Allen, December, 1920.

434. Prochilodus Caudofasciatus Starks

Prochilodus caudofasciatus Starks, 1906, Proc. U. S. Nat. Mus., XXX, 773;

Eigenmann, 1910, Rept. Princeton Univ. Exped. Patagonia, III, 124.

Rio Perené

\section{Order GLANENCHELI}

Gymnonoti Jordan, Evermann, and Clark, 1923 (1930), Rept. U. S. Comm. Fish., Part II, 101.

\section{Family XII: Gymnotidae}

Gymnotidae Eigenmann and Ward, 1905, Proc. Wash. Acad. Sci., VII, 159-188;

Ellis, 1913, Mem. Carnegie Mus., VI, 109-195, pls. xv-xxiii.

KEY TO THE SUBFAMILIES OF THE GYMNOTIDAE

(A revision of the keys in Eigenmann, 1912, and Ellis, 1913)

a. Large frontal and parietal fontanels; mandible not prolonged; head not depressed (except Rhabdolichops)

b. No caudal fin; tail extending beyond anal fin, slender, pointed; no dorsal filament c. Snout short, not tubular. . . . . . . . . . . . . . . sternopyginae

ce. Snout tubular, very much compressed and elongate fishes. RHAMPHICHTHYINAE

bb. With caudal fin; tail short; dorsal filament present.............. APTERoNotivaE aa. No frontal fontanel; mandible projecting; head more or less depressed

d. Anal basis extending around end of tail, forming a false caudal fin; electric organs present; body not scaled...................... ELECTROPHORINAE

dd. Anal basis not extending around slender, cylindrical tail; no electric organs; body scaled.

GYMNOTINAE

\section{Subfamily: STERNOPYGINAE}

KEY TO 'THE GENERA OF' THE SUBFAMILY STERNOPYGINAE

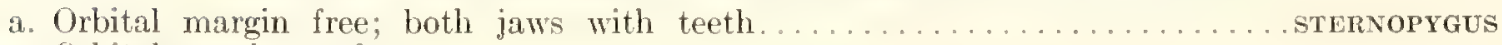
aa. Orbital margin not free 
b. 'Teeth in both jaws; body much compressed

c. Tail normally prolonged.

"r. Extremo probongation of tail

EIGENMANNIA

RHIBDOLICHOPS

bb. 'Teeth wanting; body subeylindrical

d. A groove on each side of the chin containing a short, wiry filament. steatogenYs dd. No groove in mental region; head rather pointed.

HYPOPONUS

\section{Genus 171: STERNOPYGUS Müller and Troschel}

Gymnotus Cuvier, 1817, Règne Anim., II, 235;

Gill, 1864, Proc. Acad. Nat. Sci. Phila., 152

Sternopygus Mïller and Troschel, 1819, Horae Ichth., III, 13;

Eigenmann, 1910, Rept. Princeton Unir. Exped. Patagonia, II , 450;

Eigenmann, 1912, Mem. Carnegie Mus., V, 427 ;

Ellis, 1913, Mem. Carnegie Mus., VI, 121.

\section{Type: Gymnotus macrurus Bloch and Schneider}

Western Ecuador via Magdalena to Rios Paraguay and São Francisco

Differing from the nearby Eigenmannia and all other Gymnotids most strikingly in the possession of a free orbital margin; caudal fin wanting; teeth in patches in both jaws; snout short, stout.

\section{Sternopygus macrurus (Bloch and Schneider)}

Gymnotus macrurus Bloch and Schneider, 1801, Syst. Ichth., 522;

Cuvier, 1817, Règne Anim., II, 237.

Sternopygus macrurus Müller and Troschel, 1849, Horae Ichth., III, 14;

Steindachner, 1868, Sitzh). KK. Akad. Wiss. Wien, LVIII, 11;

Cope, 1871 (1872), Proc. Acad. Nat. Sci. Phila., XXIII, 257, Rio Ambyiacu;

Cope, 1878, Proc. Amer. Phil. Soc., XVII, 57;

Eigenmann, 1910, Rept. Princeton Univ. Exped. Patagonia, III, 450;

Eigenmann, 1912, Mem. Carnegie Mus., T, 427 ;

Ellis, 1913, Mem. Carnegie Mus., VI, 121, fig. 3;

Pearson, 1937a, Proc. Cal. Acad. Sei., (4), XXIH, 92, Pusoc and Tingo de Pauca, upper Marañon.

Sternopygus carapus Günther, 1870, Cat. Fish. Brit. \Ius, VIII, 7;

Boulenger, 1887, Proc. Zool. Soc. London, 282, Canelos.

Carapus sanguinolentus Castelnau, 1855, Anim. Amér. Sud, Poiss., 85, pl, xxxii, fig. 1, Urubamba or Alto Ueayali.

\section{Rio Orinoco to Peru and Paraguay}

15417, 5, 115-127 mm., Rio Pichis, Pto. Bermudez, Allen, July, 1920.

15424, 1, $93 \mathrm{~mm}$., Rio Morona, Allen, Uctober, 1920.

\section{Genus 172: STEATOGENYS Boulenger}

Steatogenys Boulenger, 1898, Trans. Zool. Soc. London, XIT, 428;

Eigenmann, 1910, Rept. Prinecton Univ. Exped. Patagonia, III, 449;

Eigenmann, 1912, Mem. Carnegic Mus., I, 432.

Steatogenes Eigenmann and Ward, 1905, Proc. Wash. Acad. Sei., VI, 171;

Ellis, 1913, Mem. Carnegie Mus., VI; 132. 
Type: Rhamphichthys elegans Steindachner

Range that of the one species

Hypopomus-like, but with a groove on either side of mental region, within which is a small filament; fontanels present; no caudal fin; snout bluntly rounded; body broad forward, tapering rapidly; gape short; without teeth; eyes small, within membrane.

\section{Steatogenys elegans (Steindachner)}

Rhamphichthys elegans Steindachner, 1880, Denksch. KK. Akad. Wiss. Wien, XLII, 37. Brachyrhamphichthys elegans Eigenmann and Eigenmann, 1891, Proe. U. S. Nat. Mus., XIV, 62. Steatogenys elegans Boulenger, 1898, Trans. Zool. Soc. London, XIV, 428, Rio Juruá;

Eigenmann, 1910, Rept. Princeton Univ. Exped. Patagonia, III, 449;

Eigenmann,'1912, Mem. Carnegie Mus., V, 432.

Steatogenes elegans Eigenmann and Ward, 1905, Proc. Wash. Acad. Sci, VII, 171;

Ellis, 1913, Mem. Carnegie Mus., VI, 132.

Solimões and tributaries, Guianas

15717, 4, about 130-210 mm., Iquitos, Allen, September, 1920.

\section{Genus 173: HYPOPOMUS Gill}

Hypopomus Gill, 186t, Proc. Acad. Nat. Sci. Phila., XVI, 152, mülleri;

Eigenmann and Ward, 1905, Proc. Wash. Acad. Sci., VII, 169;

Eigenmann, 1910, Rept. Princeton Univ. Exped. Patagonia, III, 449 ;

Eigenmann, 1912, \em. Carnegie Mus., V, 433;

Ellis, 1913, Mem. Carnegie Mrus., VI, 133.

Type: Rhamphichthys mülleri Kaup

Cauca, Guianas, southward to Peru and Rio Paraguay

Belonging to the short-snouted, edentulous category, without caudal fin, and eyes without free orbital margin; body slender, tapering; mouth and gape small; eyes moderate and enclosed by a membranous fold of the skin; scales small, cycloid, lateral line complete; anal fin originating about the length of the pectoral behind a vertical line through the gill-opening.

\section{Hypopomus Brevirostris (Steindachner)}

Rhamphichthys trevirostris Steindachner, 1868, Sitzb. KK. Akad. Wiss. Wien, LVIII, 25t, pl. ii, fig. 2.

Brachyrhamphichthys brevirostris Eigenmann and Eigenmann, 1891, Proc. U. S. Nat. Mus., XIV, 62.

Hypopomus brevirostris Eigenmann and Kennedy, 1903, Proc. Acad. Nat. Sci. Phila., 530;

Eigenmann and Ward, 1905, Proc. Wash. Acad. Sci., VII, 170;

Eigenmann, 1910, Rept. Princeton Univ. Exped. Patagonia, III, 449 ;

Eigenmann, 1912, Mem. Carnegie Mus., V, 433;

Ellis, 1913, Mem. Carnegie Mus., VI, 13t;

Schindler, 1937, Zool. Anz., CXIX, 19-25, 11 figs. 
Of extremely wide distribution, from the Chagres of Panama to the Guianas, the Paraguay, Peru

15993, 5, 55-214 mm., brooks, ponds near Iquitos, Allen, September, 1920.

15+18, 4, 86-126 mm., creek, Yurimaguas, Allen, November, 1920.

\section{Genus 174: EIGENMANNIA Jordan and Evermann}

Sternopygus (in part) Müller and Troschel, 18t9, Horae Ichth., III, 13.

Cryptops Eigenmann, 1894, Ann. N. Y. Acad. Sci., VII, 626, preoccupied.

Eigenmannia Jordan and Evermann, 1896, Bull. U. S. Nat. Mus., I, 341;

Eigenmann and Ward, 1905, Proc. Wash. Acad. Sci., VII, 171;

Eigenmann, 1910, Rept. Princeton Univ. Exped. Patagonia, III, 449;

Eigenmann, 1912, Mem. Carnegie Mus., V, 429;

Ellis, 1913, Mem. Carnegie Mus., VT, 125.

Type: Sternopygus humboldtii Steindachner

Pacific slopes of Panama to La Plata

Both jaws bearing patches of teeth; snout short; caudal fin not present and tail extending beyond the anal fin, slender, cylindrical, pointed; eye without free orbital margin; scales cycloid; lateral line not broken or discontinued.

\section{KEY TO THE SPECIES OF THE GENUS EIGENMANNIA}

a. Caudal filament less than half the length of anal fin

b. Head of moderate length, 7.0-10.5 in the length; anal fin 185-22t

c. Eye large, $3.33-5.0$ in the head; maxillary equal to diameter of eye..... virescens

cc. Eye small, 8.0-9.0 in the head; maxillary twice the eye diameter.......troscheli

bb. Head short, $12.0-12.25$ in the length; anal fin $239-259 \ldots \ldots \ldots \ldots \ldots$. . . . . . . . . . . .

aa. Caudal filament equal to half the total length without the head; eye larger than the maxillary;

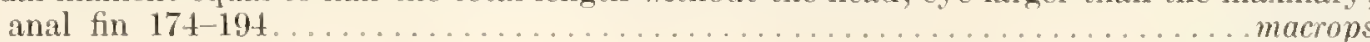

(extralimital)

\section{Eigenmannia virescens (Valenciennes)}

Sternarchus virescens Valenciennes, 1847, in d'Orb. Voy. Amér. Merid., V, 11, pl. xiii, fig. 2.

Sternopygus virescens Müller and 'Troschel, in Schomburgk, 1848, Reisen, III, 640;

Kaup, 1856, Cat. Apod., 137;

Günther, 1868, Proc. Zool. Soc. London, 229, Xeberos;

Günther, 1870, Cat. Fish. Brit. Mus., VIII, 7 ;

Cope, 1870, Proc. Amer. Phil. Soc., XI, 570, Pebas;

Cope, 1871, Proc. Acad. Nat. Sci. Phila., XXIII, 257, R. Ambyiacu;

Cope, 1878, Proc. Amer. Phil. Soc., XVII, 682, Peruvian Amazon;

Eigenmann and Eigenmann, 1891, Proc. U. S. Nat. Mus., XIV, 62.

Eigenmannia virescens Jordan and Evermann, 1896, Bull. U. S. Nat. Mus., I, 341;

Eigenmann and Norris, 1901, Rev. Mus. Paulista, IV, 549;

Eigenmann and Ward, 1905, Proc. Wash. Acad. Sci., VII, 172;

Eigenmann, 1910, Rept. Princeton Univ. Exped. Patagonia, III, 419;

Eigenmann, 1912, Mem. Carnegie Mus., V, 430 ;

Ellis, 1913, Mem. Carnegie Mus., VI, 127 ;

Fowler, 1939 (1940), Proc. Acad. Nat. Sci. Phila., XCI, 276, one, 335 mm., Contamana.

Rio Magdalena to Amazons, Rios São Francisco, La Plata

15123, 2, 146 and $170 \mathrm{~mm}$., creek, Yurimaguas, Allen, November, 1920. 


\section{Eigenmannia troscheli (Kaup)}

Sternopygus troscheli Kaup, 1856, Cat. Apod., 139;

Steindachner, 1868, Sitzb. KK. Akad. Wiss. Wien, LVIII, 12;

Günther, 1870, Cat. Fish. Brit. Mus., VIII, 8.

Sternopygus troschelii Cope, 1878, Proe. Amer. Phil. Soc., XVII, 682, Peruvian Amazon.

Eigenmannia troscheli Eigenmann and Ward, 1905, Proc. Wash. Acad. Sei., VII, 174:

Eigenmann, 1910, Rept. Princeton Univ. Exped. Patagonia, III, 449 ;

Ellis, 1913, Mem. Carnegie Mus., VI, 131, pl. xxii, fig. 2;

Fowler, 1915, Copeia, no. 15, Peruvian Amazon;

Fowler, 1939 (1940), Proc. Acad. Nat. Sci. Phila., XCI, 270, one, 185 mm., Contamana.

\section{Upper Amazonia of Peru and Brazil}

15995, 3, 255-275 mm., Iquitos, Morris, 1922.

15609, 11, 234-275 mm., Iquitos, Allen, September, 1920.

15422, 4, 105-210 mm., Lago Cashiboya, Allen, August, 1920

440. Eigeniannia conirostris Eigenmann and Allen, sp. nov. Plate XVI, figs. 2 and 5

15739, 5, type and paratypes, 270-346 mm., Iquitos, Allen, September and November, 1920.

Head 12.0-12.25; depth 7.8-8.2 in the length; eye 9 or more in the head, 3.2 in the snout, 2.6 in the interorbital width; maxillary 5 ; interorbital space 3.7 ; dorsal and ventral contours of the head nearly rectilinear, wide at occipital, and narrowing uniformly toward the snout; head slightly, and body greatly, compressed; width of head at opercle in the $300-\mathrm{mm}$. specimen $12 \mathrm{~mm}$.; depth at occipital 18-19 mm., or two in the greatest depth of the body, or near 1.33 in the length of the head; snout conical, 3 in the head; mouth small, its width 1.33 in the interorbital space; jaws nearly equal, the lower fitting into the upper; eyes small.

Anus nearer the vertical from the eye than to the end of the operculum; depth at the origin of the caudal filament $5 \mathrm{~mm}$.; length to the end of the anal fin $220 \mathrm{~mm}$., the head to the eye $9.0-9.5 \mathrm{~mm}$.; eye $2.5 \mathrm{~mm}$.; maxillary $5.0 \mathrm{~mm}$.; interorbital $6.5 \mathrm{~mm}$; ; anus situated $20 \mathrm{~mm}$. from the tip of the snout; anal fin 192-197 $\mathrm{mm}$., its origin beneath that of the pectoral; anal rays $242-259$; pectoral equal to head without snout, $17 \mathrm{~mm}$. long. (Measurements from type; counts taken also from paratypes.)

Scales cycloid and largely deciduous; back partly naked; caudal filament flat and ribbon-like, moderate length, 3.7 in the total length of the fish.

Color in alcohol pale buff, little changed from life; very slightly darker along the dorsal line; no markings along the lateral line; anal hyaline, fringed with dusky, resembling some of the specimens of $E$. virescens.

A paratype $346 \mathrm{~mm}$. in length, head $28 \mathrm{~mm}$., is a gravid female as of November.

The species is near $E$. virescens and troscheli, but unlike in the shorter, conical head, small eye, short, compressed caudal filament and color.

Genus 175: RHABDOLICHOPS Eigenmann and Allen, gen. nor.

Five of our specimens resembling those of Eigenmannia closely in many respects, are different in the following characters: 
Dorsal scalation lacking; mouth large while that of Eigenmannia is minute; unlike in that the jaws are more nearly equal; dorsal profile of the head concave (Eigenmannia convex).

No caudal fin or dorsal filament; snout not projecting; eye without a free margin; back naked to a point over the last third of the anal fin; mouth terminal, large, the maxillary very oblique; mandible rounded or pointed; mandibular teeth in four regular rows across the front, none on the lateral rami; teeth of the upper jaw in about five less regular series.

\section{Rhabdolichops longicaudatus Eigenmann and Allen, sp. nov. Plate XVI, figs. 3 and 4}

$15436,1,497 \mathrm{~mm}$., total length, type, Iquitos, Morris, 1922.

$15810,1,840 \mathrm{~mm}$., total length, paratype, Iquitos, Allen, September, 1920.

$15996,3,400-415 \mathrm{~mm}$. to end of anal fin, paratypes, Iquitos, Morris, 1922.

Of the five specimens one appears to be more nearly normally proportioned. and it is designated as the type. The others all have enormously exaggerated tails, which are tumid and greatly prolonged. It would seem impossible for such a species, even in a streamline-conscious era, to exist, carrying a tail of the dimensions of no. 15810 , for instance; impossible for it to survive in waters teeming with rapacious fishes among which even conservative Gymnotids so frequently suffer mutilations.

Description of the type:

Head 14; depth 12 ; A. 254; length to the end of the anal fin $317 \mathrm{~mm}$., tail 180 $\mathrm{mm}$.; snout 3.5 in the head; eye 6.36 ; interorbital 6 ; depth of head equal to half its length; anus under the vertical from the eye; origin of anal fin behind the vertical from the base of the pectoral fin; pectoral 0.7 in the length of the head; upper profile of the head depressed, the lower strongly convex; mouth large, terminal; gape slightly oblique when the mouth is closed, the maxillary nearly vertical when the mouth is open; free edge of the maxillary nearly equal to the snout.

Scales of the lateral line large, those above and below it smaller; back naked, the naked area extending down to the lateral line at its origin, becoming more constricted caudally; about 130 scales in the lateral line forward from the end of the anal fin.

Back dusky, sides light, no definite markings.

As stated above, only the type seems to have a normal tail, unless we may consider the hypertrophy of the majority as a normal. Of the other four specimens the tail is unusual, if not indeed abnormal. In two of these the tail has been broken in life, and the ends are lost, either in the digestive tracts of fishes, or incidentally to the collecting procedure. Of the two remaining, one has a pointed tail $432 \mathrm{~mm}$. long, of the usual shape. Without the appendage the specimen, 15810 , is $408 \mathrm{~mm}$. in length, that is, the tail exceeds the owner in length; the anal has 237 rays. In the fourth specimen the tail appears broken at a point about $210 \mathrm{~mm}$. beyond the anal, and is continued as a bag about $40 \mathrm{~mm}$. long, covered with thin seales. The end of the bag is blunt, suggesting a second injury. Total length of this specimen is $670 \mathrm{~mm} .420$ to the end of the anal fin, tail $250 \mathrm{~mm}$. 
Similar to Eigenmannia troscheli, differing in the characters mentioned in the description of the genus, and the tumid tail.

\section{Subfamily: APTERONOTINAE}

Sternarchinae Eigenmann, 1912, Mem. Carnegie Mus., V, 437.

Gymnotids with caudal fin, tail short; orbital margin not free; a dorsal filament present; teeth in patches on one or both jaws.

\section{KEY TO THE GENERA OF THE SUBFAMILY APTERONOTINAE}

a. Snout produced, the eye behind the middle of the head; mouth small; teeth in both jaws

b. Snout decurved; mouth minute...................... STERNARCHORHYNCHUS

bb. Snout straight

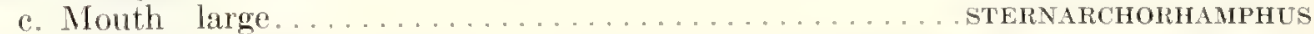

ce. Nouth minute, as in $\mathrm{b} \ldots \ldots \ldots \ldots \ldots$ (extralimital) ORTHOSTERNARCHus aa. Snout produced or not; mouth large; eye in anterior part of the head, or the rictus under the eye

d. Lower jaw normal, included

e. Teeth in both jaws normal

f. Back scaled

g. Mouth variable, its angle little if any in front of the eye. APTERoNotus

gg. Nouth small, its angle under posterior nostril...sternarchelLa

ff. Back naked, mouth small; seales above lateral line subcircular. . POROTERGus ee. No teeth, or teeth confined to mandible; back naked; scales above the lateral line

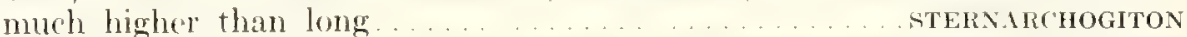

eee. Teeth strong, fixed, many on tumid, everted jaws; back naked; scales above the

lateral line much higher than long............... OEDEMOGNATHus

dd. Lower jaw heavy, projecting beyond the upper, both on the sides and in front; no teeth;

back with scales ADONTOSTERNARCHUS

\section{Genus 176: STERNARCHORHYNCHUS Castelnau}

Sternarchorhynchus Castelnau, 1855, Anim. Amér. Sud, Poiss., 91, 95;

Eigenmann and Eigenmann, 1891, Proc. U. S. Nat. Mus., XIV, 62;

Eigenmann, 1910, Rept. Princeton Univ. Exped. Patagonia, III, 449;

Eigenmann, 1912, Мem. Carnegie Mus., V, 437;

Ellis, 1913, Mem. Carnegie Mus., VI, 140.

Rhamphosternarehus Günther, 1870, Cat. Fish. Brit. Mus., VI, 140.

Type: Sternarchorhynchus mülleri Castelnau =

Sternarchus oxyrhynchus Müller and Troschel

\section{Guianas to Peruvian Amazon}

With caudal fin; gape very small; patches of teeth on both jaws; head medium, conical; snout long, tubular, and somewhat decurved; no free orbital margin; fontanels present; caudal fin small, terminal, fan-shaped, slightly scaled at base; body compressed and slightly elongate, becoming very slender in caudal region; scales cycloid; lateral line complete; anal long, widest in the middle, narrowing toward both extremities.

\section{Sternarchorhynchus oxyrhynchus (Müller and Troschel)}

Sternarchus oxyrhynchus Müller and Troschel, 1818, in Schomburgk, Reisen, III, 640;

Müller and Troschel, 1849, Horae Ichth., III, 16, pl. ii, figs. 1 and 2;

Kaup, 1856, Cat. Apod., 127; 
Günther, 1870, Cat. Fish. Brit. MIus., VIII, 4;

Boulenger, 1898, Trans. Zool. Soc. London, XIV, 427, Juruá.

Sternarchorhynchus oxyrhynchus Eigenmann and Eigenmann, 1891, Proc. U. S. Nat. Mus., XIV, 62;

Eigenmann and Ward, 1905, Proc. Wash. Acad. Sci., VII, 167;

Eigenmann, 1910, Rept. Princeton Univ. Exped. Patagonia, III, 449;

Eigenmann, 1912, Mem. Carnegie Mus., $V, 437$;

Ellis, 1913, Mem. Carnegie Mus., VI, 140.

Sternarchorhynchus mülleri Castelnau, 1855, Anim. Amér. Sud, Poiss, 95.

Sternarchus mormyrus Steindachner, 1868, Sitzb. KK. Akad. Wiss. Wien, 5, pl. i, fig. 3 ;

Günther, 1870, Cat. Fïsh. Brit. Mus., VIII, 4, Peruvian Amazon;

Eigenmann and Ligenmann, 1891, Proc. U. S. Nat. Mus, XIY, 62.

Sternarchorhynchus mormyrus Eigenmanm and Ward, 1905, Proc. Wash. Acad. Sci., VII, 167, Peruvian Amazon;

Eigenmann, 1910, Rept. Princeton Univ, Exped. Patagonia, III, 449.

Sternarchus (Rhamphosternarchus) curvirostris Boulenger, 1887, Proc. Zool. Soc. London, 282, pl. xxiv, two specimens, Canelos.

Sternarchorhynchus curvirostris Eigenmann and Eigenmann, 1891, Proc. U. S. Nat. Mus., XIV, 62;

Eigenmann and Ward, 1905, Proc. Wash. Acad. Sci., VII, 167;

Eigenmann, 1910, Rept. Prineeton Univ. Exped. Patagonia, III, 449.

\section{Guianas and Upper Amazon}

15991, 1, about $310 \mathrm{~mm}$., Iquitos, MIorris, 1922.

\section{Genus 177: STERNARCHORHAMPHUS Eigenmann and Ward}

Sternarchorhamphus Eigenmann and Ward, 1905, Proc. Wash. Acad. Sci., VII, 165;

Eigenmann, 1910, Rept. P'rinceton Unir. Exped. Patagonia, III, 449;

Ellis, 1913, IIem. Camegie Mus., VI, 142.

\section{Type: Sternarchus mülleri Steindachner \\ Peruvian Amazons to Para}

Fontanels present; caudal fin; snout produced, straight; mouth large; body very elongate and compressed; maximum depth at or just behind the pectoral fins; head medium to moderately large, pointed, produced; gape rather straight; small conical teeth above and below; eyes small and covered; scales cycloid; lateral line straight and complete; anal long, widest forward, tapering caudally; caudal fin very small.

\section{Sternarchorhamphus macrostomus (Günther)}

Sternarchus macrostoma Günther, 1870, Cat. Fish. Brit. Mus., VIII, 4.

Rhamphosternarchus macrostomus Cope, 1878, Proc. Amer. Phil. Soc., XVII, 682, Yeberos and Peruvian Amazon.

Sternarchorhynchus macrostoma Eigenmann and Eigenmann, 1891, Proc. U. S. Nat. Mus., XIV, 62. Sternarchorhamphus macrostomus Eigenmann and Ward, 1905, Proc. Wash. Acad. Sci., VII, 166, Peruvian Amazon:

Eigenmann, 1910, Rept. Princeton Univ. Exped. Patagonia, III, 449;

Ellis, 1913, Mem. Camegie Mus., VI, 144.

\section{Peruvian Amazon}




\section{Sternarchorhamphus mëLleri (Steindachner)}

Stemarchus (Rhamphostcmarchus) mülleri Steindachner, 1881 (1882), Denksch. KK. Akad. Wiss.

Wien, XLIV, 18, pl. xviii, fig. 4.

Sternarchorhynchus mülleri Eigenmann and Eigenmann, 1891, Proc. U. S. Nat. Mus., XIV, 62.

Sternarchorhamphus mülleri Eigenmann and Ward, 1905, Proc. Wash. Acad. Sci., VII, 166;

Eigenmann, 1910, Rept. Princeton Univ. Exped. Patagonia, III, 449;

Ellis, 1913, Mem. Carnegie Mus., VI, 142, fig. 10;

Fowler, 1939 (1940), Proc. Acad. Nat. Sci. Phila., XCI, 276, two, 358 and 400 mm., Contamana.

\section{From the Lower Amazon to the Ucayali}

\section{Genus 178: APTERONOTUS Lacépède}

Apteronotus Lacépède, 1800, Hist. Nat. Poiss., II, 208, passan = albifrons;

Jordan, 1917, The Genera of Fishes, Stanford Univ. Publ., Part I, 56.

Sternarchus Bloch and Schneider, 1801, Syst. Ichth., 497, albifrons;

Cuvier, 1817, Règne Anim., II, 237;

Eigenmann and Eigenmann, 1891, Proc. L. S. Nat. Mus, XIV. 61:

Eigenmann and Ward, 1905, Proc. Wash. Aead. Sei., VII, 161;

Eigenmann, 1910, Rept. Princeton Univ. Exped. Patagonia, III, 448:

Eigenmann, 1912, Mem. Carnegie Mus., V, 438;

Ellis, 1913, Mem. Carnegie Mus., VI, 145.

\section{Type: Gymnotus albifrons Linnaeus}

\section{Amazons, British Guiana to Paraguay and Rio Paraná}

Fontanels present; caudal present, and small; both jaws with patches of teeth; mouth large, gape long and horizontal, lower jaw included within the upper, two or more rows of teeth in the upper, two rows on lower; snout short and not tubular; eyes without a free orbital margin; back scaled, head naked, scales cycloid; pectorals not equal to more than half the depth; origin of anal at or before vertical from gill. opening, of uniform depth, not reaching caudal.

\section{KEY TO THE SPECIES OF THE GENUS APTERONOTUS}

a. Scales small, 11 to 16 rows above the lateral line

b. Snout more or less pointed, interorbital width more than 5 in the head

c. Distance of eye to snout twice the distance from eye to upper angle of gill-opening

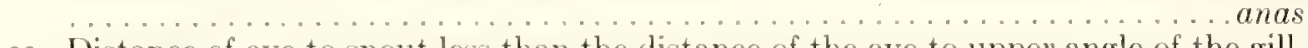

cc. Distance of eye to snout less than the distance of the eye to upper angle of the gill-

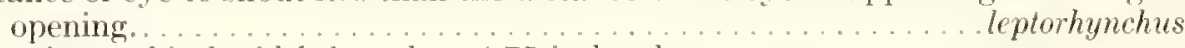

bb. Snout blunt, interorbital width less than 4.75 in head

d. Rather slim; flesh color to light grey, entirely covered with fine chromatophores hasemani

dd. Robust; ground-color dead black; 2 white bands encircling body, one at base of caudal, the other near end of anal; frontal area more or less white... albifrons

aa. Scales above lateral line large, not to exceed eight rows bonapartii

\section{Apteronotus albifrons (Linnaeus)}

Gymnotus albifrons Linnaeus, 1766, Syst. Nat., ed. xii, 428.

Sternarchus albifrons Bloch and Schneider, 1801, Syst. Ichth., 497, pl. xeiv; Castelnau, 1855, Anim. Amér. Sud, Poiss., 91, pl. xlv, fig. 1;

Cope, 1878, Proc. Amer. Phil. Soe., XVII, 682, Peruvian Amazon; 
Boulenger, 1887, Proc. Zool. Soc. London, 282, Canelos;

Eigenmann and Eigenmann, 1891, Proc. U. S. Nat. Mus., XIV, 61;

Eigenmann and Ward, 1905, Proc. Wash. Acad. Sci., VII, 162;

Eigenmann, 1910, Rept. Princeton Univ. Exped. Patagonia, III, 448;

Eigenmann, 1912, Mem. Carnegie Mus., V, 439;

Ellis, 1913, Mem. Carnegie Mus., VI, 148.

Sternarchus maximilliani Castelnau, 1855, Anim. Amér. Sud, Poiss, 93, pl. xlv, fig. 4, Urubamba river:

Orinoco, Guianas, Amazons, Rios Paraguay and Paraná

15432, 1, $300 \mathrm{~mm} .$, Iquitos, Morris, 1922.

\section{Apteronotus leptorhynchus Ellis}

Sternarchus leptorhynchus Ellis, 1912, in Eigenmann, Mem. Carnegie Mus, V, 139;

Ellis, 1913, Mem. Carnegie Mus., VI, 147, pl. xxii, fig. 4;

Eigenmann, 1922, Mem. Carnegie Mus., IX, 175, pl. xxxy, fig. 1.

Colombia to Peru and British Guiana

15434, 1, over $340 \mathrm{~mm}$. (probably $100 \mathrm{~mm}$. lost), Iquitos, Morris, 1922.

Snout much elongated; gape also very long; anus beneath vertical limb of preopercle.

Depth 1.16 in the head length; eye equidistant between snout and third fifth of the pectoral; distance between the eye and the upper angle of the gill-opening about 1.22 in the snout.

It is a question whether this specimen may not be identical specifically with A. anas rather than with the more remote Guiana types. In the type of $A$. leptorhynchus $260 \mathrm{~mm}$. in length the eye is nearer the tip of the snout than to the gillopening, but in other characters such as depth it resembles the present species. There is a reasonable expectation of finding it here.

447. Apteronotus anas Eigenmann and Allen, sp. nov.

$$
\text { Plate XV, fig. } 1
$$

15433, 1, 365 mm., type, Iquitos, Morris, 1922.

Head 3.7; depth 2 in the head; eye nearer tip of pectoral than to tip of snout by one-seventh the length of the snout; distance between the eye and the upper angle of the gill-opening less than one-half the length of the snout; about 11 scales above the lateral line; origin of anal under the middle of the gill-opening; caudal peduncle short (normal?), blackish; a light, median dorsal line; caudal light in the middle, dark above and below.

Near A. leptorhynchus Ellis, and differing most strikingly in the shape and proportions of the head, the eye being conspicuously farther back than in the type of leptorhynchus.

448. Apteronotus bonaparti Castelnau

Sternarchus bonapartii Castelnau, 1855, Anim. Amér. Sud, Poiss., 92, pl. xlv, fig. 2, Ucayali;

Günther, 1870, Cat. Fish. Brit. Mus., VIII, 3;

Cope, 1878, Proc. Amer. Phil. Soc, XVI1, 682, Peruvian Amazon; 
Eigenmann and Eigenmann, 1891, Proc. U. S. Nat. Mus., XIV, 62;

Eigenmann and Ward, 1905, Proc. Wash. Acad. Sci., VII, 163;

Eigenmann, 1910, Rept. Princeton Univ. Exped. Patagonia, III, 448;

Ellis, 1913, Mem. Carnegie Mus., VI, 149, fig. 13;

Fowler, 1915, Copeia, no. 15, Peruvian Amazon;

Fowler, 1939 (1940), Proc. Acad. Nat. Sci. Phila., XCI, 277, one specimen, 308 mm., Contamana.

\section{Lower and middle Amazons, Rio Ucayali}

\section{Apteronotus hasemani Ellis}

Sternarchus hasemani Ellis, 1913, Mem. Carnegie Mus, VI, 147, pl. xxiii, fig. 1;

Pearson, 1937a, Proc. Cal. Acad. Sci., (4), XXIII, 92, Tingo de Pauca and Paipay, upper Marañon.

Known from Santarem and from upper Marañon; Iquitos.

15425, 2, 294 and $318 \mathrm{~mm}$., Iquitos, Morris, 1922.

\section{Genus 179: STERNARCHELLA Eigenmann and Ward}

Sternarchella Eigenmann and Ward, 1905, Proc. Wash. Acad. Sci., VII, 163;

Eigenmann, 1910, Rept. Princeton Univ. Exped. Patagonia, III, 448;

Ellis, 1913, Mem. Carnegie Mus., VI, 150.

\section{Type: Sternarchus schotti Steindachner}

Barro do Rio Negro to Peru

Short-snouted; gape short, not reaching beyond posterior naris; eyes small, covered, nearer tip of snout than to end of the opercle; small teeth in both jaws; scales moderately large and eycloid.

\section{Sternarchella schotti (Steindachner)}

Sternarchus schotti Steindachner, 1868, Sitzb. KK. Akad. Wiss. Wien, LVIII, 4, pl. i, figs. 1 and 2; Günther, 1870, Cat. Fish. Brit. MIus., VIII, 3;

Cope, 1878, Proc. Amer. Phil. Soc., XVII, 682, Peruvian Amazon;

Eigenmann and Eigenmann, 1891, Proc. U. S. Nat. Mus., XIV, 61.

Sternarchella schotti Eigenmann and Ward, 1905, Proe. Wash. Acad. Sci., VII, 164;

Eigenmann, 1910, Rept. Princeton Univ. Exped. Patagonia, III, 448;

Ellis, 1913, Mem. Carnegie Mus., VI, 151, fig. 14;

Fowler, 1939 (1940), Proc. Acad. Nat. Sci. Phila., XCI, 277, one, 190 mm., Contamana.

Solimões and Marañon systems, and Ucayali river

\section{Genus 180: POROTERGUS Ellis}

Porotergus Ellis, 1912, in Eigenmann, Mem. Carnegie Mus., V, 440;

Ellis, 1913, Mem. Carnegie Mus., VI, 152.

Type: Porotergus gymnotus Ellis

Peruvian Amazon, Santarem, Rio Essequibo

May be known for the want of scales along the back to a point more or less beyond the origin of the dorsal filament; scales along the lateral line of large size; 
gape long, nearly reaching the vertical from the eye; teeth in both jaws; in other respects much as Apteronotus and other members of the subfamily.

KEY TO TIE SPECIES OF THE GENUS POROTERGUS

a. Mouth inferior, minute; rictus between the nostrils; snout very blunt, about 4 in the head a. Mouth terminal

b. Mouth minute, similar to that of Sternopygus macrurus; rictus under anterior nostril;

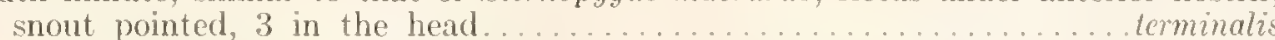

bb. Mouth larger, the rictus behind the posterior nostril; snout 2.75 in the head...gymnotus (extralimital)

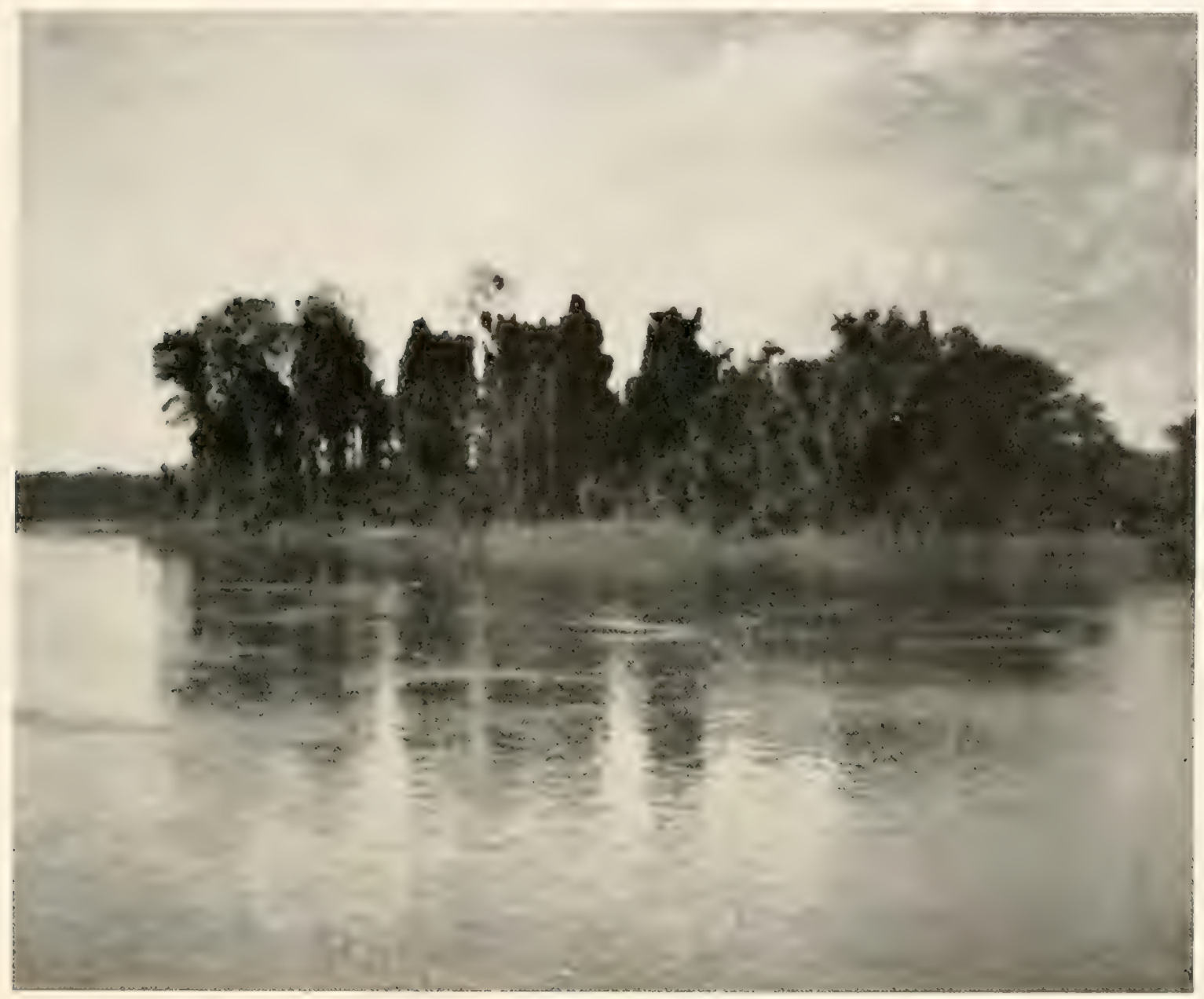

FIG. 35. The Upper Amazon flows so swiftly below the Pongo de Manseriche that launches make way upstream with some difficulty. Numerous islands such as this occur.

\section{Porotergus gimbeli Ellis}

Porotergus gimbeli Ellis (in Eigenmann), 1912, Nem. Carnegie Mus., V, 411 ;

Ellis, 1913, Mem. Carnegie Mus., VI, 15.

Guiana, Amazons Peru to Para

15435, 1, 95 mm., Iquitos, Allen, September, 1920.

Very similar to Stemarchogiton nattereni, but with strong teeth in both jaws. Hitherto known only from the types, four specimens from Para and British Guiana, collected by Haseman and Ellis respectively. 
452. Porotergus terminalis Eigenmann and Allen, sp. nov.

15994, 1, $240 \mathrm{~mm}$., type, Iquitos, Morris, 1922

15720, 2, 225 and $299 \mathrm{~mm}$., paratypes, Iquitos, Allen, September, 1920.

Similar in form to the type species $P$. gymnotus, and in many characters not unlike $P$. gimbeli; differs from the short-snouted gimbeli in the terminal position of the mouth, much longer head and greater depth; more resembles gimbeli in the number of anal rays, having many more than gymnotus; teeth much stronger than in either.

Head 5.5-5.8; depth 5.33-5.66; A. 179-184; lateral line about 70 ; origin of anal under emarginate part of the opercle; anus a little behind the vertical from the eye; profile straight, eye placed high; depth of head equals its length less the opercle; interorbital width $4.5-5.5$ in the length of the head to the end of the opercular spine; snout $3.2-3.3$; mouth small, terminal; maxillary nearly vertical; teeth strong; in two series in each jaw; gill-opening not equal to the snout; scales on the sides, from the lateral line to the anal muscles, large, and from the lateral line upward much smaller, circular toward the naked back; naked part of the back extending down to the lateral line in front, much more narrowly restricted farther back; the pectoral fin equal to the length of the head less the opercle; back dusky, other parts colorless.

Named for the distal position of the mouth.

\section{Genus 181: STERNARCHOGITON Eigenmann and Ward}

Sternarchogiton Eigenmann and Ward, 1905, Proc. Wash. Aead. Sci., VII, 164;

Eigenmann, 1910, Rept. Princeton Univ. Exped. Patagonia, III, 448;

Ellis, 1913, Mem. Carnegie Mus., VI, 155.

Type: Sternarchus nattereri Steindachner

Middle Amazon to Peru

Sometimes a few teeth appear in a single series in the lower jaw, sometimes on the sides only, sometimes none; no teeth on the upper jaw; the head much compressed, the lower jaw grooved into the upper; back naked; scales above the lateral line much higher than long.

\section{KEY TO THE SPECIES OF THE GENUS STERNARCHOGITON}

a. Head smaller, about 12 in the length, eye larger, snout smaller, about 3.5

nattereri

aa. Head larger, about 9 , eye 7 in snout.

porcinum

\section{Sternarchogiton NATTERERI (Steindachner)}

Sternarchus nattereri Steindachner, 1868, Sitzb. KKL. Akad. Wiss. Wien, LVIII, 3, pl. ii, fig. 1, Barro do Rio Negro;

Gïnther, 1870, Cat. Fish. Brit. Mus, VIII, 3;

Eigenmann and Eigenmann, 1891, Proe. U. S. Yat. Mus, XIV, 62.

Sternarchogiton nattereri Eigenmann and Ward, 1905, Proc. Wash. Acad. Sci., VII, 165;

Eigenmann, 1910, Rept. Princeton Univ. Exped. Patagonia, III, 448;

Ellis, 1913, \Iem. Carnegie MIus., VI, 155. 
Rio Negro to Rio Juruá and Peruvian Amazon

15721, 1, 202 mm., Iquitos, Allen, September, 1920.

454. Sternarchogiton porcinum Eigenmann and Allen, sp. nov.

Plate XVI, fig. 1

$15740,1,300$ mm., type, Rio Huallaga, Yurimaguas, Allen, November, 1920.

15722, 1, paratype, $186 \mathrm{~mm}$., Iquitos, Allen, September, 1920.

Not unlike its congener, S. nattereri, differing, however, in several dimensions, in the extent of the anal fin; colors also differing considerably.

Head about 9 in the length; depth 8.5; anal rays about 200; origin of the anal fin beneath the middle of the opercle.

Snout 3.5 in the length of the head; interorbital width 5 in the head length; eye about 7 in the snout, and smaller than usual among a small-eyed family; scales large, about $4-5$ series above the lateral line, pores between the scales toward the back, the scales much higher than long; pectoral fin not as long as the head.

Sides straw-colored, the back dark; posterior half of the pectoral fins and the distal half of the anal rays very dark, their basal halves without dark pigmentation.

The name in allusion to the strong inclusion of the lower jaw within the upper.

\section{Genus 182: OEDEMOGNATHUS Myers}

Oedemognathus Myers, 1936, Proe. Biol. Soc. Wash., XLIX, 115.

Type: Oedemognathus exodon Myers

Iquitos and lower Peruvian Amazon

A single specimen, $92 \mathrm{~mm}$. in length, collected by Morris at Iquitos, was described as a new genus and species by Eigenmann and Allen (the present paper). In 1936 a similar fish, $202 \mathrm{~mm}$. long, was found and described by Dr. G. S. Myers from collections made by Mr. William G. Scherer in 1935 for the U. S. National Museum, under the present name.

Caudal fin and dorsal filament present; snout very short; teeth in both jaws strong, all those of the upper jaw fixed on the everted lip; those of the lower jaw in part antrorse, in part located in the mouth and retrorse; area in front of the dorsal filament naked. Similar to Porotergus and Sternarchogiton, but with everted teeth.

Maxillary oblique, gape short, not quite reaching the vertical from the eye. ticulars:

Our specimen differs from the type apparently only in the following par-

The eye, while minute, is not covered; that the mandibular teeth are contained within the mouth.

\section{Oedemognathus exodon Myers}

Plate XV, figs. 2 and 3

Oedemognathus exodon Myers, 1936, Proc. Biol. Soc. Wash., XLIX, 115, one, Pebas, Scherer collection.

15421, 1, $92 \mathrm{~mm}$., to base of caudal, Iquitos, Morris, 1922. 
The complete identity of our specimen with the type of Oe. exodon is not certain in the absence of scale counts and measurements, and considerable doubt may be entertained from the fact that the type has 193 or more anal rays, while our specimen has but 163; the anal is conspicuously elevated in our specimen (to about three-fifths the greatest body depth) and even more so in the type (two-thirds). The dimensions of the former are much as we might expect in a juvenile of the latter.

Head 7.5; depth at the pectoral fin equal to the length of the head; A. 163, its origin under the angle of the preopercle, much in advance of the pectoral fin; anus under the eye; width of the head about 3 in its length; interorbital greatly arched; eye without free orbital margin, 3.5 in the snout, 9.33 in the head; scales on sides above the anal fin-musculature larger, about 70 in a longitudinal series; the back in front of the dorsal filament naked, with minute pits; scales covering the anal musculature minute.

Naked portion of the back dusky; sides light, no distinct markings.

In general appearance this is a Porotergus, and so closely resembles Sternarchogiton nattereri (Steindachner) that it would be easy to mistake it for an abnormal specimen of that species. The head, however, is decidedly different, the eyes are less elevated, the mouth different, and the teeth unique.

Known only from Iquitos and the nearby Rio Ambyiacu region.

\section{Genus 183: ADONTOSTERNARCHUS Ellis}

Adontosternarchus Ellis, 1913, Mem. Carnegie Mus., VI, 155.

\section{Type: Sternarchus sachsi Peters}

Throughout Amazons, the Madeira, and the Orinoco

Characterized by the heavy lower jaw into which the pointed upper jaw fits by a $\mathrm{V}$-shaped groove, somewhat as in the case of the whalebone whale; edentulous.

KEY TO THE SPECIES OF THE GENUS ADONTOSTERNARCHUS

a. Without longitudinal stripes; colors rariegated, at least while in fresh condition........ sachsi

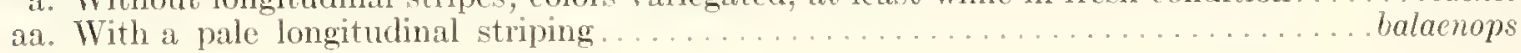

\section{Adontosternarchus sachsi (Peters)}

Sternarchus sachsi Peters, 1877, Monatsb. Akad. Wiss. Berlin, 473, fig. 4, Venezuela;

Eigenmann and Eigenmann, 1891, Proc. U. S. Nat. Mus., XIV, 62.

Sternarchogiton sachsi Eigenmann and Ward, 1905, Proc. Wash. Acad. Sci., VII, 165;

Eigenmann, 1910, Rept. Princeton Univ. Exped. Patagonia, III, 148.

Adontosternarchus sachsi Ellis, 1913, Mem. Carnegie Mus., VI, 156, lower Amazons;

Fowler, 1939 (1940), Proc. Acad. Nat. Sci. Phila., XCI, 278, one, 154 mm., Contamana.

Rivers Orinoco, upper and lower Amazon, Madeira

15719, 4, the largest about $195 \mathrm{~mm}$., Iquitos, Allen, September, 1920.

These specimens while fresh show considerable variegation in pattern, no trace of a longitudinal striation; distal half of the pectoral fin, and the distal portion of 
the anterior half of the anal, together with its entire posterior part, dark; a dark spot above the gill-opening.

\section{Adontosternarchus balaenops (Cope)}

Sternarchus balaenops Cope, 1878, Proc. Amer. Phil. Soc., XVII, 682, Peruvian Amazon;

Eigenmann and Eigenmann, 1891, Proc. U. S. Nat. IIus., XIV, 62.

Sternarchella balaenops Eigenmann and Ward, 1905, Proc. Wash. Acad. Sci., VII, 164;

Eigenmann, 1910, Rept. Princeton Univ. Exped. Patagonia, III, 4t8;

Ellis, 1913, Mem. Carnegie Mus., VI, 152.

\section{Peruvian Amazon}

Described by Cope, and not collected since his time. Differing from S. sachsi in the color, having "a pale dorsal band which reaches the dorsal thong, and a pale narrow band on each side near the dorsal band."

\section{Subfamily: RHAMPHICHTHYINAE}

\section{Genus 184: RHAMPHICHTHYS Müller and Troschel}

Gymnotus (in part) Linnaeus, 1766, Syst. Nat., ed. xii, 427.

Rhamphichthys Nüller and Troschel, 1849, Horae Ichth., III, 15;

Eigenmann and Eigenmann, 1891, Proc. U. S. Tat. Mus., XIV, 62;

Eigenmann, 1910, Rept. Princeton Univ. Exped. Patagonia, III, 449;

Eigenmann, 1912, Mem. Carnegie Mus., V, 435;

Ellis, 1913, Mem. Carnegie Mus., VI, 137.

Type: Gymnotus rostratus Linnaeus

The Guianas to Peru and La Plata

Snout long and tubular; without teeth; body greatly elongate and compressed; no caudal fin; anus in front of the vertical from the eye; origin of anal fin forward of the vertical from the gill-opening; body entirely scaled, scales minute and cycloid; caudal appendage large and scaled; eyes small and overgrown by the skin; mouth small.

\section{KEY TO THE SPECIES OF THE GENUS RHAMPHICHTHYS}

a. Snout longer, the postorbital part of the head $3 \mathrm{in}$ the total length of the head; the eye much farther from the base of the pectoral than from the snout.............. rostratus

aa. Postorbital part of head 2.4 in head length; eye equidistant from snout and pectoral basis

\section{Rhamphichthys rostratus (Linnaeus)}

Gymnotus Gronow, 1754, Mus. Ichth., no. 73.

Gymnotus rostratus Linnaeus, 1766, Syst. Nat., ed. xii, I, 428.

Carapus rostratus Cuvier, 1817, Règne Anim., II, 237.

Rhamphichthys rostratus Müller and Troschel, 18 19 , Horae Ichth., III, 15;

Günther, 1870, Cat. Fish. Brit. Mus., VIII, 5;

Eigenmann and Ward, 1905, Proc. Wash. Acad. Sci., VII, 168;

Eigenmann, 1910, Rept. Princeton Univ. Exped. Patagonia, III, 449;

Ellis, 1913, Mem. Carnegie Mus., VI, 137. 


\section{The Guianas and the Amazons}

15608, 2, the longer $561 \mathrm{~mm}$., Iquitos, Allen, September, 1920.

15809, 1, $405 \mathrm{~mm}$. (tail broken), Iquitos, Allen, September, 1920.

\section{Rhamphichthys marmoratus Castelnau}

Rhamphichthys marmoratus Castelnau, 1855, Anim. Amér. Sud, Poiss., 86, pl. xlvi, fig. 2, Uruguay; Eigenmann and Eigenmann, 1891, Proc. U. S. Nat. Mus., XIV, 62;

Eigenmann and Ward, 1905, Proc. Wash. Acad. Sci., VII, 168;

Eigenmann, 1910, Rept. Princeton Univ. Exped. Patagonia, III, 449.

Rhamphichthys pantherinus Castelnau, 1855, Anim. Amér. Sud, Poiss., 86, pl. xlvi, fig. 3, lake near Rio Ucayali;

Günther, 1870, Cat. Fish. Brit. Mus., VIII, 5;

Cope, 1878, Proc. Amer. Phil. Soc., XVII, 682, Peruvian Amazon;

Steindachner, 1880, Denksch. KK. Akad. Wiss. Wien, XLII, 38, Ucayali.

Rhamphichthys lineatus Castelnau, 1855, Anim. Amér. Sud., Poiss., 87, pl. xlvii, fig. 1, tributary of Rio Ueayali;

Kaup, 1856, Cat. Apod., 130, fig. 5.

Gymnotus rostratus Steindachner, 1868, Sitzb. KK. Akad. Wiss. Wien, LVIII, 8, in part.

Rhamphichthys rostratus (in part) Ellis, 1913, Mem. Carnegie Mus., VI, 137.

\section{Rio Orinoco and the Guianas southward to La Plata}

15423, 1, broken, the piece $330 \mathrm{~mm}$., Iquitos (?), Allen, 1920.

Much resembles $R$. rostratus, the postorbital part of the head greater, however, 2.4 in the length of the head, the eye bisecting the distance between the snout and pectoral basis. In size the specimen evidently lies between the extreme lengths of the three specimens of $R$. rostratus, in all of which the postorbital part of the head is one-third the total length of the head. The elongation of the snout places it here rather than with rostratus.

\section{Subfamily: GYMNOTINAE}

\section{Genus 185: GYMNOTUS Linnaeus}

Gymnotus Linnaeus, 1758, Syst. Nat., ed. x, 246;

Cuvier, 1817, Règne Anim., II, 235;

Günther, 1870, Cat. Fish. Brit. Mus., VIII, 10;

Eigenmann and Ward, 1905, Proc. Wash. Acad. Sci., VII, 174;

Eigenmann, 1910, Rept. Princeton Univ. Exped. Patagonia, III, 450;

Ellis (in Eigenmann), 1912, Mem. Carnegie MIus., V, 425;

Ellis, 1913, Mem. Carnegie Mus., VI, 116 (contains a very comprehensive bibliography of the genus);

Eigenmann, 1922, Mem. Carnegie Mus., IX, 171.

\section{Type: Gymnotus carapo Linnaeus \\ Range that of the one species}

No frontal fontanel; anal basis not continuing as a false caudal fin around the end of the tail, which is terminal and cylindrical; body scaled, teeth conical, a single row in each jaw; not electric. 


\section{Grmnotus carapo Linnaeus}

Carapo Marcgrave, 1648, Hist. Rer. Nat. Bras., 170.

Gymnotus carapo Linnaeus, 1758, Syst. Nat., ed. x; I, 246;

Eigenmann, 1910, Rept. Princeton Univ. Exped. Patagonia, III, 450;

Eigenmann, 1912, Mem. Carnegie Mus., V, 425;

Ellis, 1913, Mem. Carnegie Mus., VI, 117, fig. 2.

Gymnotus carapus Eigenmann and VTard, 1905, Proc. Wash. Acad. Sci., VII, 175.

Gymnotus fasciatus Pallas, 1769, Spic, Zool., VII, 35.

Carapus fasciatus Cuvier, 1817, Règne Anim., II, 237;

Steindachner, 1868, Sitzb. KK. Akad. Wiss. Wien, LVIII, 13;

Günther, 1870, Cat. Fish. Brit. Mus., VIII, 9;

Cope, 1871, Proc. Acad. Nat. Sci. Phila., XXIII, 257, R. Ambyiacu;

Cope, 1878, Proc. Amer. Phil. Soc., XVII, 682;

Boulenger, 1887, Proc. Zool. Soc. London, 282.

Gymnotus brachiurus Bloch, 1786, Ausl. Fische, II, 61, pl. 157, fig. 1.

Carapus brachyurus Cuvier, 1817, Règne Anim., II, 237.

Sternopygus carapo Eigenmann and Eigenmann, 1891, Proc. U. S. Nat. Mus., XIV, 62.

Giton fasciatus Eigenmann and Ward, 1905, Proc. Wash. Acad. Sci., VII, 177.

Guatemala southward to La Plata. Andes eastward

15420, 1, about $390 \mathrm{~mm}$., Iquitos, Allen, November, 1920.

$15718,3,25,185$, and $205 \mathrm{~mm}$., Iquitos, Allen, November, 1920.

15724, many, 190-295 mm., creek, Yurimaguas, Allen, November, 1920.

15992, 7, 142-247 mm., brooks, Rio Itaya, Allen, September, 1920.

In the smallest the crossbands are fully developed on the body muscles, but do not extend over the muscles of the anal fin. In the middle-sized ones the bands extend to the anal, and in the largest they are broken into irregular double rows of spots on the back, remaining most completely outlined on the musculature of the anal fin. The lateral bands are most conspicuous in the smaller specimens from Yurimaguas, and remain the brightest on the tail. The occurrence of the brightest coloration in the swift, rocky streams of the piedmont and mountain sections is consistent with other cases previously mentioned. The coloration and markings of this species are much the brightest of all the members of the family, and quite naturally was the first to attract the attention of European naturalists among the five Linnaean species.

Subfamily: ELECTROPHORINAE

\section{Genus 186: ELECTROPHORUS Gill}

Gymnotus (in part) Linnaeus, 1766, Syst. Nat., ed. xii, 427 .

Electrophorus Gill, 1864, Proc. Acad. Nat. Sci. Phila., XVI, 151;

Eigenmann, 1910, Rept. Princeton Univ. Exped. Patagonia, III, 450;

Eigenmann, 1912, Mem. Carnegie Mus., V, 42t;

Ellis, 1913, Mem. Carnegie Mus., VI, 114.

(Excellent bibliography of older references). 


\section{Type: Gymnotus electricus Linnaeus \\ Most of Brazil and Peruvian Amazon northward}

Cylindrical in form; scaleless; frontal fontanel wanting; the basis of the anal fin continued around the tail, constituting a pseudo-caudal; much of the hypaxial musculature of the tail modified into an electric organ on each side.

\section{Electrophorus electricus (Limnaeus)}

Gymnotus electricus Linnaeus, 1766, Syst. Nat., ed. xii, I, 427;

Müller and Troschel, in Schomburgk, Reisen, 1818, HII, 639;

Steindachner, 1868, Sitzb. KK. Akad. Wiss. Wien, LVIII, 14;

Günther, 1870, Cat. Fish. Brit. Mus., VIII, 10, and many authors.

Electrophoms electricus Gill, 1864, Proc. Acad. Nat. Sci. Phila., XVI, 151;

Eigenmann, 1910, Rept. Princeton Univ. Exped. Patagonia, III, 450;

Eigenmann, 1912, Mem. Carnegie Mus., V, 424;

Ellis, 1913, Mem. Carnegie Mus., VI, 114, fig. 1.

All of Amazonia northward to Venezuela, Guianas

15419, 4, 76-130 mm., Pto. Bermudez, R. Pichis, Allen, July, 1920.

This is the most western and most elevated record for the species. Not especially prevalent in most of our area. Not nearly so greatly feared by the inhabitants as the urinophilous Pygidiids or the piranha.

Known to the inhabitants of eastern Peru as the anguila electrica, at least among the educated class. The name puraqué is given by Cox, and poraqué by Guenther (p. 175). Haseman's spelling is purakee.

This is the electric eel of fame, and the subject of numerous researches from the time of Faraday to the present, with numerous articles from the pens of zoologists and physicists alike. Many papers are summarized in Ellis's monograph of 1913 (p. 162). Witnesses have had all sorts of experiences with the fish, and conflicting reports are found in the literature as to the effects of the shock, and as to the place in Nature which the species occupies.

Im Thurn (p. 137) says that the fish is numerous in the region of the penal colony of French Guiana, where he experienced a very painful shock from one which the Indians had poisoned. Herndon (p. 344) characterizes the discharge as being unpleasant, but not painful. He says that persons differ in their susceptibility, and that Captain Lee was unable to feel it at all, while a certain lady was entirely overcome by it. He relates further that a Mr. Norris saw a horse drinking from a tub in which a live Electrophorus was kept, and that such a shock was given that the horse was jerked quite off its feet. Up de Graff (p. 245) relates the incredible experience of being unable to cut the head off the fish - the shock would only knock the machete out of his hand, and paralyze his arm!

Señor Paez (p. 117) can always be depended upon for a good story. He tells that an electric eel was found among the catch in a seine. A boy was dragging it along by a rope, and unintentionally drew it across the carcass of a cayman recently killed. An electric discharge happened to take place at that moment, and the cayman "opened his huge jaws and closed them with a loud erash."

Eubank (p. 138) like others tells of the "gymnotus" being kept in captivity, 
among them one of two feet in length which had been a pet or a curiosity in a cistern of a monastery cloister for fifteen years.

In the spirit of Faraday's experiment in which he used the discharge to ignite gumpowder or to charge Leyden jars, Coates and Cox have resumed physical studies of the fish with the more refined methods of modem apparatus. Cox (1938) has shown from his field and laboratory studies that the minor electroplax of the fish differs from the major electric organ in that it delivers a low, constant discharge while swimming, which may be either a warning or a protection. He finds also that the fish not only discharges electricity, but is sensitive to it as well. He was able to use a hand-generator, with the positive and negative plates in the water, as a lure, the fishes being attracted to the positive pole. These workers have made studies of the character of the electric discharge, its control, its volume, duration, and like matters. They have been able to register voltages up to nearly 600 , and wattages up to 1000 , but over such brief periods of time that the filaments of lamps could not reach incandescence.

Haseman's experiences may help to explain the degrees of potency of the electric discharge (1911b). An Indian had shot a purakee five feet long, with bow and arrow, the same length as the one which Herndon discusses. Haseman swam after the specimen and pulled it ashore. While the fish yet had the tail in water, he was able to pass his hand over it repeatedly. The shock was acute, but not overpowering. Then while removing it with a copper dipnet from the water, "I received all its voltage, and fell helpless in the moist sand. A series of terrible shocks continued as long as the eel remained on my bare legs, and I could not let go the dipnet. The Indian relieved me by pulling the eel away by means of the arrow." Haseman is convinced that the electric organ is nothing more than a protection, for he has seen no evidence of its ever being used offensively for taking prey.

Ellis's studies of the Gymnotid family led him to regard the lower Amazon as the center of its dispersal. The present report, in which we list about the same number of species for Perurian waters as Ellis lists for all South America, would encourage the view that the center of dispersal is farther up the Amazon than he had reason to believe (1913).

\section{Order SYMBRANCHIA \\ Family XIII: Symbranchidae}

Genus 187: SYMBRANCHUS Bloch

Synbranchus Bloch, 1795, Ausl. Fische., IX, 86;

Eigenmann, 1910, Rept. Princeton Univ. Exped. Patagonia, III, 450.

Symbranchus (corrected spelling) most authors;

Eigenmann, 1912, Mem. Carnegie Mus, V, $4+2$;

Eigenmann, 1922, Mem. C'amegie Mus., IX, $17 \%$.

Type: Synbranchus marmoratus Bloch

Range that of the one species

Anguilliform, scaleless; tail shorter than trunk; right and left gill-membranes joined in midventral line, forming a single, small, median ventral gill-aperture. 


\section{Symbranchus marmoratus Bloch}

Synbranchus marmoratus Bloch, 1795, Ausl. Fische, IX, 87, pl. 418;

Müller and Troschel, 1848, in Schomburgk, Reisen, III, 640;

Günther, 1870, Cat. Fish. Brit. Mus., VIII, 15;

Jordan and Evermann, 1898, Bull. U. S. Nat. MIus., XLVII, 342;

Eigenmann, 1910, Rept. Princeton Univ. Exped. Patagonia, III, 450.

Symbranchus marmoratus Cope, 1871, Proc. Acad. Nat. Sci. Phila., XXIII, 290, Rio Ambyiacu;

Cope, 1878, Proc. Amer. Phil. Soc., XVII, 673, near Pebas;

Eigenmann, 1912, Mem. Carnegie Mus., V, 443;

Eigenmann, 1922, Mem. Carnegie Mus., IX, 177.

\section{Cuba and Mexico to Peru and Rio de la Plata}

16162, 14 (1, 193 mm., 13 juvenile, about 45 mm.) creek, Yurimaguas, Allen, November, 1920.

A species with wider distribution than any other South American freshwater form.

\section{Order ISOSPONDYLI \\ Family XIV: Engraulidae}

\section{Genus 188: LYCENGRAULIS Günther}

Lycengraulis Günther, 1868, Cat. Fish. Brit. Mus., VII, 385;

Eigenmann and Eigenmann, 1891, Proc. U. S. Nat. Mus., XIV, 63;

Eigenmann, 1910, Rept. Princeton Univ. Exped. Patagonia, III, 452.

Type: Engraulis grossidens Cuvier

Marine, Guiana to Rio de Janeiro, entering rivers; the Amazons

Differing from other anchovies in the possession of unequal teeth, partly canine.

\section{Lycengraulis Batesi Günther}

Lycengraulis batesii Günther, 1868, Cat. Fish. Brit. Mus., VII, 399;

Eigenmann, 1910, Rept. Princeton Univ. Exped. Patagonia, III, 452.

Engraulis iquitensis Nakashima, 1941, Bol. Mus. Hist. Nat. Lima, V, 62.

\section{Rio de Para to cis-Andean Peru}

16151, 2, 145 and $215 \mathrm{~mm}$., Yurimaguas, Allen, November, 1920.

16152, 2, 143 and 198 mm., Gosulimacocha, R. Morona, Allen, October, 1920.

16153, 1, $162 \mathrm{~mm}$. R. Paranapura, Yurimaguas, Allen, November, 1920.

The species appears to be completely adjusted to fresh waters, although its nearest relatives are partly marine.

Nakashima's specimens, fide G. S. Myers, are undoubtedly this species.

Genus 189: AMPLOVA Jordan and Seale

Amplova Jordan and Seale, 1925, Copeia, no. 141, 31, balboae;

Myers, 1940, Proc. Cal. Acad. Sci., (4), XXIII, 438. 
Type: Amplova balboae Jordan and Seale

Pacific coast of Panama to coastal streams of the Guianas and Brazil; Amazons

"Venter keeled, compressed, without scutes; gill-membranes not united; lower" ramus of first gill-arch with fewer than 30 rakers; fewer than 46 vertebrae; mouth small, snout short; maxillary short, curved, broad and rounded at the end." (Myers).

A letter from Dr. S. F. Hildebrand, now engaged in revising the anchovies of the Americas, informs me concerning the boundaries of the genus Anchoviella:

"maxillary of moderate length, but reaching well beyond the eye and nearly to the joint of the mandible; no enlarged teeth in the jaws; the gill-membranes separate; gill-rakers in small or moderate number and not increasing with age."

The following species was described under Amplova, but it appears that Hildebrand may show in his fortheoming monograph that the Amplova of Jordan and Seale is not distinct from Anchoviella Fowler. He says that the principal character on which Amplova was created is the short mandible, supposed not to reach the posterior margin of the eye, an observation which he has been unable to verify.

The geographical boundaries of the genus or genera will be better known after his paper appears (an event which may precede the publication of these lines).

\section{Amplova Alieni Myers \\ Plate XXII, fig. 3}

Amplora alleni Iyers, 1940, Proc. Cal. Acad. Sci., (4), XXIII, 438.

Peruvian Amazonia, in and about the piedmont

- 1, 84 mm., Gosulimacocha, R. Morona, Allen, October, 1920.

12, 68-88 mm., Contamana, Allen, August, 1920.

, 6, 81-87 mm., Lago Cashiboya, Allen, August, 1920.

6421 Mus. Cal. Aead. Sci., 1, type, $68 \mathrm{~mm}$. standard length, Lago Cashiboya, Allen, August, 1920. , 1, $76 \mathrm{~mm}$., Rio Morona, Allen, October, 1920.

\section{Family XV: Clupeidae}

\section{Genus 190: PRISTIGASTER Cuvier}

Pristigaster Cuvier, 1817, Règne Anim., II, 176;

Eigenmann, 1910, Rept. Princeton Univ. Exped. Patagonia, III, 452.

\section{Type: Pristigaster cayanus Cuvier}

Range marine and fresh waters, both coasts; Amazons

Without ventral fin; body much compressed and deep, belly protracted; strongly toothed, jaws similar to herring.

\section{Pristigaster cayanus Cuvier}

Pristigaster cayanus Cuvier, 1817, Règne Anim., II, 176 (nom. nud.);

Cuvier, 1829, Règne Anim., 321;

Eigenmann, 1910, Rept. Princeton Univ. Exped. Patagonia, III, 452. 
Pristigaster martii Agassiz, 1829, Sel. Gen. et Spec. Pise. Bras., 55, pl. xxiv, a;

Fowler, 1939 (1940), Proc. Acad. Nat. Sci. Phila., XCI, 221, fig. 2, one, 80 mm., Contamana.

Coastal Guiana and Brazil; R. Juruá, Marañon, Huallaga

15618, 1, 97 mm., Lago Sanango, Yurimaguas, Allen, November, 1920.

16145, , mm., Iquitos, Morris, 1922.

A marine anchovy, one of the relict fish fauna of a former inland sea, now surviving here at some 2800 miles from the mouth of the Amazon and at the fringe of the Andes.

\section{Genus 191: ILISHA Richardson}

Platygaster Swainson, 1839, Fish. Amph. Rept., II, 29t, preoccupied.

Ilisha (Gray) Richardson, 1845, Rept. Brit. Assoc. Adv. Sci., 306;

Bleeker, 1866, Nederl. Tijilsch. Dierk., III, 300, abnormis;

Eigenmann, 1910, Rept. Princeton Univ. Exped. Patagonia, III, 452;

Eigenmann, 1912, \em. Carnegie Mus., V, 445.

Pellona Cuvier and Valenciennes, 1847, Hist. Nat. Poiss., XX, 300, flavipinnis;

Eigenmann and Eigenmann, 1891, Proc. U. S. Nat. Mus., XIV, 63.

\section{Type: Ilisha abnormis Gray}

Marine and coastal fresh waters, Amazons

With long anal fin, 39 rays; dorsal fin in posterior position; mandible with four or five strong, conical, recurved teeth on each side, anteriorly; premaxillary teeth about 14 in a graduated series; maxillary bordered with minute but strong teeth; vomer edentulous, tongue with a broad patch of granular teeth; anal fin posterior to end of dorsal, caudal forked; adipose lid strongly developed, leaving only a narrow, vertical slit.

\section{Ilisha altamazonica (Cope)}

Pellona altamazonica Cope, 1871 (1872), Proc. Acarl. Nat. Sci. Phila., XXIII, 256, Rio Ambyiacu; Eigenmann and Eigenmann, 1891, Proc. U. S. Nat. Nus, XIV, 63.

Ilisha altamazonica Eigenmann, 1910, Rept. Princeton Univ. Exped. Patagonia, III, 452.

\section{Rio Ambyiacu, Rio Tocantins}

467. Ilisha iQuitensis Nakashima

Ilisha iquitensis Nakashima, 1941, Bol. Mus. Hist. Nat. Lima, V, 66.

\section{Iquitos}

Dr. G. S. Myers, who has seen the paper, accepts $I$. iquitensis as a good species on the basis of a dorsal fimray count of $15 ; \mathrm{A} .52$; scutes 30 .

\section{Ilisha deaurata Nakashima}

Ilisha deauratus Nakashima, 1941, Bol. Mus. Hist. Nat. Lima, V, 67. 


\section{Iquitos}

As in the preceding regarded as a good species by Dr. G. S. Myers, who has seen the paper. D. 18 ; A. 38 ; scutes 28 ; rakers $9+13$.

\section{Family XVI: Osteoglossidae}

\section{Genus 192: OSTEOGLOSSUM Vandelli}

Ostcoglossum (Vandelli) Cuvier, 1829, Règne Anim., ed. ii, II, 328;

Agassiz, 1829, Sel. Gen. et Spec. Pisc. Bras., 47;

Eigenmann and Eigenmann, 1891, Proc. U. S. Nat. Mus., XIV, 63;

Eigenmann, 1910, Rept. Princeton Lniv. Exped. Patagonia, III, 453;

Eigenmann, 1912, Mem. Camegie Mus., $\mathrm{T}, 4+9$.

\section{Type: Osteoglossum bicirhosum Vandelli}

The Amazons northward

Elongate, body compressed roundly above and drawn to a knife edge ventrally, tapering toward the tail; mandible extremely long and narrow, the gape nearly vertical, bearing a pair of mental barbels which extend forward while swimming; eye large, scales large and conspicuous.

\section{Osteoglossum bicirrhosum Vandelli}

Osteoglossum bicimhosum Vandelli, 1829, Sel. Gen. et Spec. Pisc. Bras., 45; Günther, 1868, Cat. Fish. Brit. MIus., VII, 378;

Cope, 1871, Proc. Acad. Nat. Sei. Phila., XYIII, 257, Ambyiacu;

Cope, 1878, Proc. Amer. Phil. Soc., XIII, 695;

Steindachner, 1882 (1883), Denksch. KK. Akad. Wiss. Wien, XLVI, 16, Rio Huallaga;

Eigenmann, 1910, Rept. Princeton Unir. Exped. Patagonia, III, 453;

Eigenmann, 1912, Mem. Carnegie Mus., V, 450;

Fowler, 1939 (1940), Proc. Acad. Nat. Sci. Phila., XCI, 221, fig. 1, two, 305 and $350 \mathrm{~mm}$. Contamana, Norrow collection.

\section{Range that of the genus}

15730, 1, 305 mm., mouth Rio Pacara, Allen, September, 1920.

15731, 1, $230 \mathrm{~mm}$., Lago Cashiboya, Allen, August, 1920, specimen sent to L. S. National Museum. $15953,1,325 \mathrm{~mm}$., Iquitos, Morris, 1922.

This species is known throughout eastern Peru under the name which may be rendered in the Spanish as arahuana (arowana of the Guiana Indians, as reported by Eigenmann, 1912). This appears to be a name given by the aborigines of Guiana rather than Peru, first borrowed by the white inhabitants of that country, and transmitted to other remote regions by them since the Conquest.

Characterized by the vivid colors, large scales, compressed body, and two short, but prominent barbels. The use of the barbel is debated, but I have seen them extended forward while in motion.

They inhabit the clearer waters of the backwater lakes and bayoux, and seek the surface, at least a considerable part of the time. 


\section{Family XVII: Arapaimidae}

Formerly united with the Osteoglossidae by reason of superficial similarities, large scales, colors, etc., now separated on the basis of the rounded venter, want of barbels, dentition, scaled ventral fins, etc.

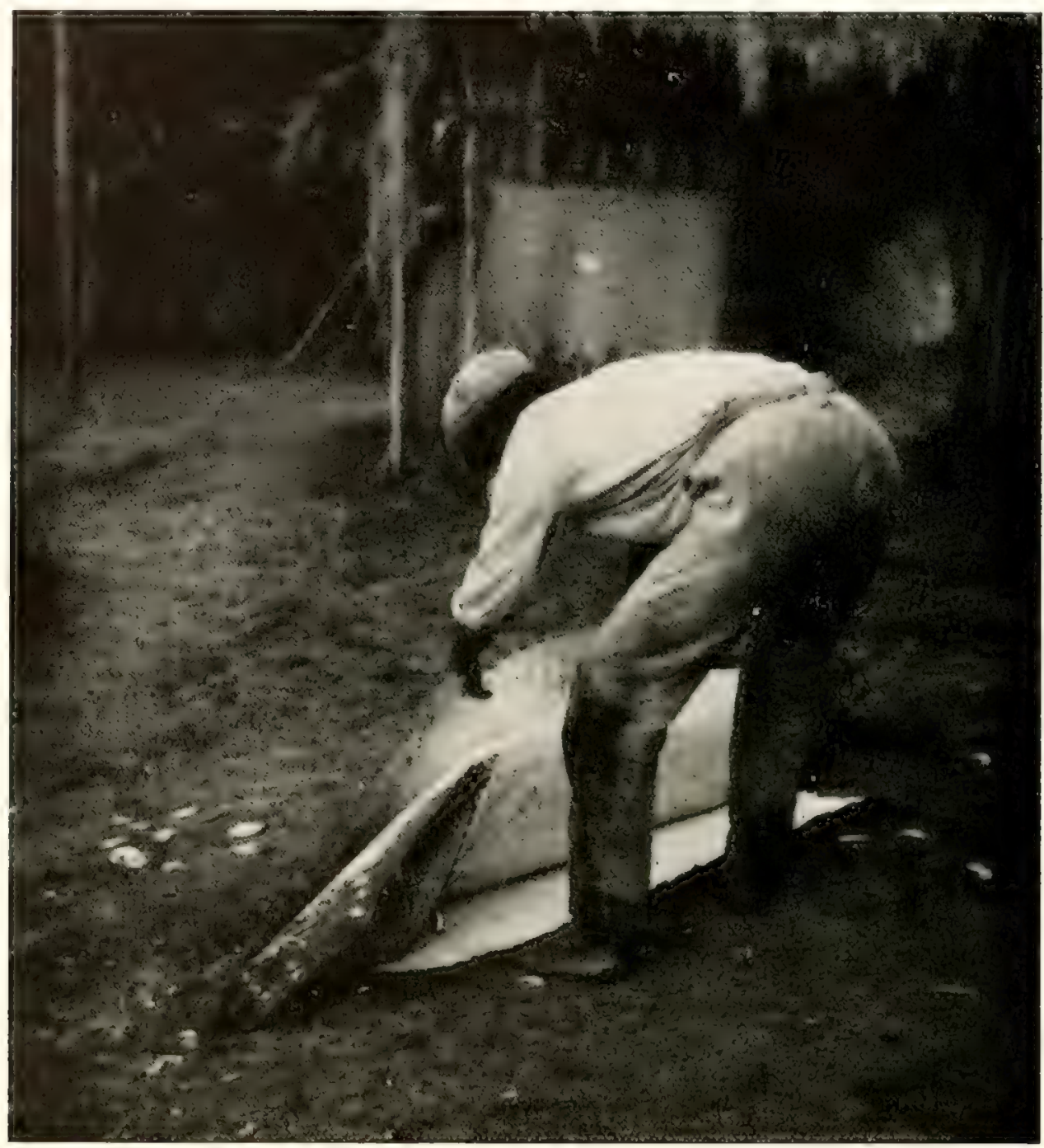

FIG. 36. Preparation of the paiche for drying; skinning. The fish lies belly-downward, the head to the right.

Genus 193: ARAPAIMA Müller

Sudis Cuvier, 1817, Règne Anim., II, 180, preoccupied by Rafinesque.

Arapaima Müller, 1843, Arch. Naturg., 191;

Nü̈ller, 1846, Abh. Akad. Wiss. Berlin, 191;

Günther, 1868, Cat. Fish. Brit, Mus., VII, 379;

Eigenmann and Eigenmann, 1891, Proc. U. S. Nat. Mus., XIV, 64;

Eigenmann, 1910, Rept. Princeton Univ. Exped. Patagonia, III, 453;

Eigenmann, 1912, Mem. Carnegie Mus., V, 450.

Vastres Cuvier and Valenciennes, 1846, Hist. Nat. Poiss, XIX, 433. 
Type: Sudis gigas Cuvier

Atlantic coast streams, Guianas to Bahia: Amazons

"Elongate, compressed moderately, head depressed, belly rounded; mouth wide, mandible prominent; without barbels; jaws with an outer series of small, conical teeth; broad bands of rasp-like teeth on vomer, palatines, pterygoids, sphenoid, hyoid, and tongue; pectorals moderate; ventrals scaled; gill-membranes not united." (Günther).

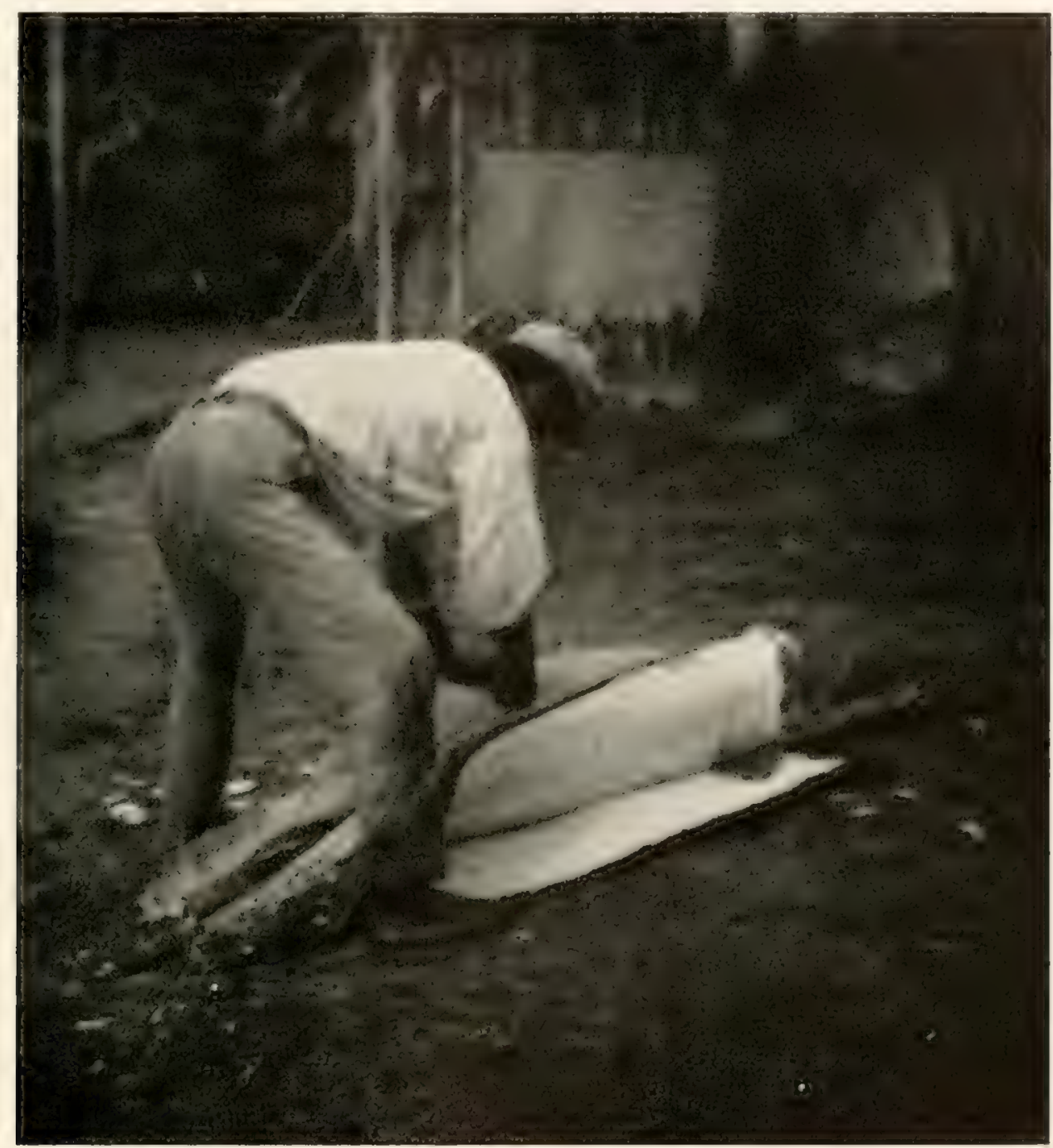

FIG. 37. Continuation of Fig. 36. The flesh teing cut into strips, the backbone and viscern removed.

\section{Arapaima gigas (Cuvier)}

Sudis gigas Cuvier, 1817, Règne Anim., II, 180;

Agassiz, 1829, Sel. Gen. et Spec. Pisc. Bras., 31, pl. B;

Schomburgk, 1811, Fish. Brit. Guiana, 1, 198, pl. xi.

Sudis pirarucu Spix, 1829, Sel. Gen. et Epec. Pisc. Bras., pl. xvi. 
Arapaima gigas Nüller, 1843, Arch. Naturg., 191;

Müller, 1816, Abh. Akad. Wiss. Berlin, 191;

Müller and Troschel, 1848, in Schomburgk, Reisen, III, 638;

Guinther, 1868, Cat. Fish. Brit. Mus., VII, 379;

Eigenmann and Eigenmann, 1891, Proc. U. S. Nat. Mus., XIV, 64;

Eigenmann, 1910, Rept. Princeton Univ. Exped. Patagonia, III, 453;

Eigenmann, 1912, Mem. Carnegie Mus., V, 451.

Arapaema gigas Cope, 1878, Proc. Amer. Phil. Soc., XVII, 695, Nauta.

Vastres gigas Cuvier and Valenciennes, 18t6, Hist. Nat. Poiss., XIX, 433.

Range that of the genus

, 72 mm. x 78 mm., scales only, Rio Pacaya, Allen, August, 1920.

Known throughout Amazonia and to Bahia and British Guiana, it is the pirarucu of Brazil, the paiche (pié-chay) of Peru, and the arapaima of the Guianas.

No specimens were collected for the unexcusable reason that, except for scales, the preservation of specimens was too long postponed until those small enough for ready handling and transportation could be taken. Such an opportunity did not arise, and meanwhile numbers of fine, large specimens were passed by until too late. The paiche is in many respects the most intriguing and most interesting fish of all South America. They are everywhere within their range the most valuable and most sought-after species, mainly on account of the large size and economic value, their comparative freedom from bones, and complete freedom from small bones, and the ease with which they can be dried for marketing and for domestic use during the rainy season. The species is therefore becoming extinct in the more inhabited regions, and scarce in more remote ones. I found it still common, but not abundant, in such remote districts as the Rio Pacaya.

Something of the former abundance may be guessed at from older writings. For example, Bates, during the 1850 's, found it diminishing along the main course of the Brazilian Amazon, predicting its early extinction, together with that of the turtles, which were also being used up at an enormous rate. Statistics of annual catches are not available, nor would they be reliable, but Marcoy (II, p. 427) says authoritatively during the 1870 's: "In the early days a fortnight's fishing of a single village produced 10,000 pirarocou and 4000 lamentin (manatee)."

In spite of the great importance of the pirarucu commercially, no writer exhibits much knowledge of it, and many false accounts of it have wide currency.

I find allusions in the scientific and travel literature under names as widely diversified as the following:

Maius osteoglossum (Marcoy)

Primodontos gigas (Lange)

Vastres gigas (various writers following Cuvier and Valenciennes)

Arapaima gigans (Beebe)

Sudis gigas (Orton, etc.)

The first two generic names have not found their way into Jordan's Genera of Fishes. Of course the currently accepted name is used by some authors.

Among the popular names are the following:

Pirarucu, often used, and correctly so

Piraracú (Fleming) 
Piraracu (Woodroffe)

Piracuru (Koebel)

Pirarocou and Pira-rocou (Marcoy)

Lou-lou (Whitney)

Paiche (Beals, Woodroffe, and others, correctly)

Payshi (Orton, Herndon, probably the original Indian name)

Anatto (Orton and others)

Warapaima (Beebe gives this as the original Guiana form)

Authors vary greatly in their reports as to the size and weight attained by the species:

$\begin{array}{lcc}\text { Author } & \text { Length attained } & \text { Weight attained } \\ \text { Martin } & 5 \text {-6 feet } & \\ \text { Koebel } & 6 \text { feet } & 200 \text { pounds } \\ \text { Miller } & 6 \text { feet } & 200 \text { pounds } \\ \text { Domville-Fife } & 6 \text { feet } & 300 \text { pounds } \\ \text { Woodroffe } & 7 \text { feet } & 300 \text { pounds } \\ \text { Gibbon } & 6-8 \text { feet } & \\ \text { Dyott } & 6-8 \text { feet } & \\ \text { Spruce } & 6-8 \text { feet } & 60-100 \text { pounds } \\ \text { Lange } & 9-10 \text { feet } & 250 \text { pounds } \\ \text { Toebel, ibidem } & 8 \text { feet } & 150 \text { pounds } \\ \text { Franck } & 10 \text { feet } & \\ \text { Orton } & 10 \text { feet } & 300 \text { pounds } \\ \text { Beebe } & & 100 \text { pounds } \\ \text { MeGovern } & & 300 \text { pounds } \\ \text { Eigenmann } & 15 \text { feet } & 400 \text { pounds }\end{array}$

Examination of the above table would show conclusively that the scientific traveler has information no more definite than that of the most casual rambling reporter. It is true that scales suitable for weighing so large a fish are found but rarely. In my own experience none was weighed, and only one measured carefully. This one specimen taken at Yarinacocha measured seven feet one inch. By the estimates of the people present it was regarded as having attained more than half the maximum length of twelve feet, and about half the maximum weight. Weight is always estimated in Loreto in terms of strips, rather than pounds or kilos. The maximum number of strips, they say, is twelve, while this specimen cut six strips. My principal witness regarding the specimen was Señor Medina, planter and merchant, who was accustomed to dealing in the dried product for shipment to Iquitos downriver. After discussion of the matter with numerous people, I am forced to regard the Eigenmann estimates as too high, and would place the probable maximum size of the paiche, at least in the upper Amazon, at about 12 feet, and the maximum weight nearer 300 pounds.

A number of authors agree in saying that the paiche is the largest of the world's freshwater fishes, (Fleming, glossary; even Guenther, p. 175). Of course they are forgetting momentarily the sturgeon.

Other false conceptions have reached the printed page:

Franck, that great traveler and observer, doubtless hearing the pirarucu compared with the cod as I did many times, misunderstood the allusion, and calls it the "freshwater cod ... which dies if it gets into salt water." Some native of the Amazon with tongue in cheek must have told him "expert fishermen ... make the 
pirarucu tow his canoe home", although it is more authentically related that the fish has been known to drag a canoe for some distance in its struggles. He says the pirarucu is an article of export from Pará, but actually this city, Manaos, and Iquitos are the consumers for a vast hinterland.

Most American and European writers in their brief accounts report that they themselves are indifferent to the dried paiche, McGovern (p. 54) for instance, com-

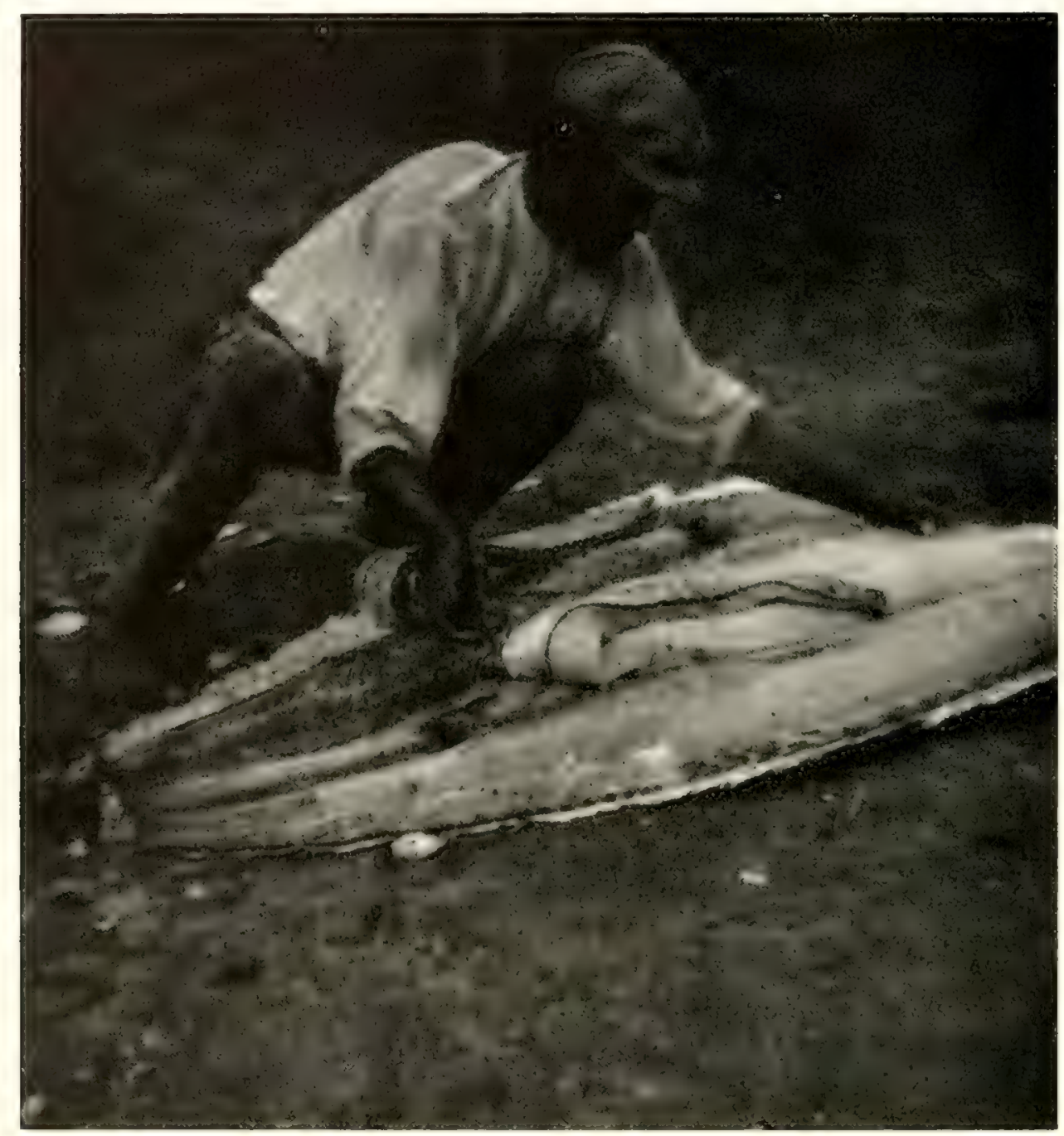

FIG. 38. Continued. The strips of flesh removed from the eviscerated body.

paring its flavor to rancid soap, or Lange (1912, pp. 261, 266) commenting upon the total lack of savor of the two principal Amazonian dishes, pirarucu and farinha. Others, however, find that in the fresh condition the flesh, or parts of it, are very acceptable. Spruce, for example, says "the lower belly, or ventrexa roasted on a spit, is a choice morsel." Woodroffe testified (p. 256) as to the nutritious soup which could be made of the bones. I visited a rubber camp where a barbecued paiche head was the pièce-de-resistance, and would recommend it highly to a hungry man.

The use of dried paiche as a dependable food is acknowledged by all writers 
regardless of their liking, that is when alluding to the entire Amazon country. Beebe, however, (p. 481) reports that native Indian tribes (Guiana) do not like it; Whitney (p. 25) says that the Brazilians "look upon scaleless fishes such as it is with aversion, claiming that the flesh conduces to a fever," (untrue in each of the three clauses). Gibbon states that pirarucu was, at the time of his risit in the 1850 's,

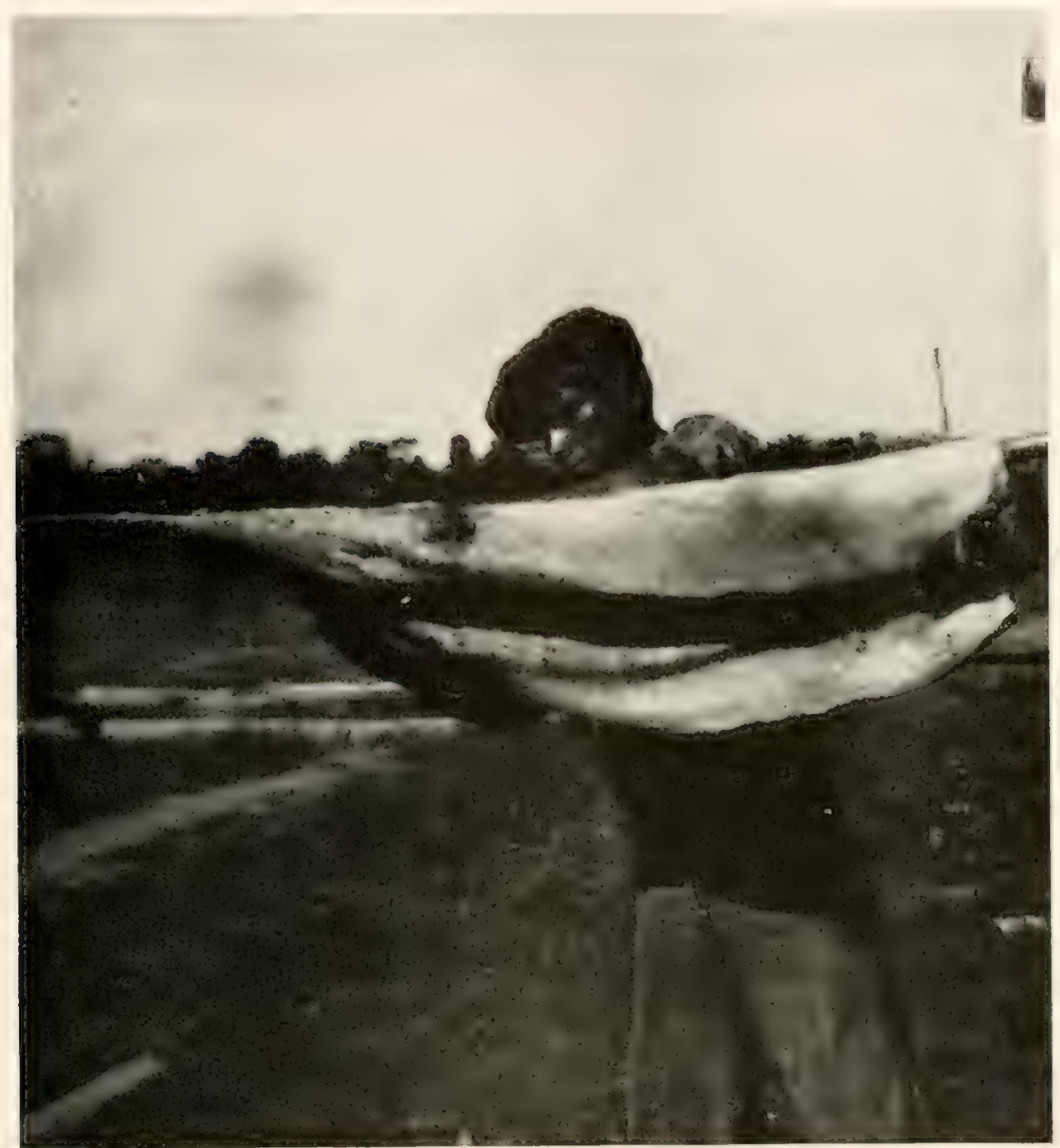

Frg. 39. Continued. The veneering process. Each strip taken out in the preceding figure is skillfully cut into a thin sheet for drying.

entirely new to the Cuyabás of the Madeira. Nash rightly says (p. 80) "its flesh is to the inhabitants of the Amazon what beef is to central and southern Brazil." I have many times seen the inhabitants of the Peruvian Amazons making preparations for a journey, or stopped for a chat with them while on a journey. Without exception somewhere about the canoe a roll of paiche was to be seen, together with a stewpan for cooking it, and either a bunch of green plantains, a bag of rice, or a bag of beans. 
Authors frequently allude to encounters with fishermen. I do not believe that I ever met a fisherman in the interior of South America, that is in a professional sense, although many persons take time from other occupations to do some fishing for home consumption, and even, of course, taking time for rather extensive trips to better fishing grounds. In fact, it is only when in need of meat that the urge overtakes the average individual, or when the rainy season begins to draw near. At other times it is difficult to persuade most men to forsake their usual pursuits, even for wages. The same remark may be made concerning the profession of shepherd in the mountain section. Sheep and llamas are kept and are herded, but the business of herding sheep is a family matter, except upon large sheep ranches.

The inhabitants of Amazonia as one man are sensitive to the criticism of foreigners bestowed upon the pirarucui; many times they ask a foreigner to say whether he regards it as the equal of the cod, in the dried state. In this I could well reassure them. The more forward-looking inhabitants are discussing the practicability of restoring the species to something like its pristine abundance by legislation and by the introduction of hatcheries or nurseries. In this they are thinking not only of a diminishing food supply, but they look forward to such increase that they will be able to export a dried or tinned product in competition with the fisheries of other parts of the world. The Loretan has much ground for criticism of the Government at Lima, he believes, and the matter of the neglected fisheries is one of them.

The most important Amazonian fish is one of the least known. Its life history, habits, food, migrations are not only unknown, but misinformation about them prevails, and a fertile subject for future study awaits someone. Now limited almost altogether to the more hidden and least inhabited backwater lakes, the inhabitants of the more populous navigable streams engage in seasonal fishing trips, sometimes of several weeks duration. On the shores of the bayoux they set up semipermanent camps, known in Brazil as feitorias (factories). These consist usually only of poles set in the ground in lieu of walls, and a substantial thatch. Hammocks swing from pole to pole, and the cooking fire is lighted in the center. Perishables hang from the pole rafters. The rising waters of the creciente, when the rainy season has begun at the headwaters, is the best time to work. At that time the paiche and various other species are traveling upstream into the bayoux and backwaters. (Fig. 20.)

A favorite method of locating the prey consists in mounting guard over a barricade placed across the shallower passages in the cochas (lakes) or cañas (channels). The barricade is made of brush, palm fronds, and the like, thrust into the mud of the bottom. When the fish on its way upstream reaches the fence (see Fig. 33) it becomes a victim of the man poised in his canoe, harpoon in hand. I have elsewhere described the more elaborate weirs of more permanent form. (Figs. 25, 26.)

While traveling up and down the rivers with the inhabitants, I noted that there is always much excitement when a paiche leaps, even at a distance. The paddlers forget to paddle, and every voice is heard together, "Paich', paich'!" It is like the view-halloo at the fox-chase, or still more the cry of "whale" from the masthead and decks of the whaler. The natives taught me how to recognize the paiche leaping, even though it was half a mile distant, distinguishing it from several of the 
larger Pimelodinae which are also leapers. This species launches itself straight upward clear of the water, then drops tail-foremost where it arose; and as it leaves the water, a spiral spray is thrown aloft by the tail in characteristic pattern.

Near the home of many of the settlers, and near the fishing camps, drying platforms with poles for support, and with palm thatch, are erected. Here the paiche is prepared and spread out on sunny days to dry. In the preparation for drying, a rigid, standardized procedure is followed. First the fish is laid on the ground belly-downward. The operator then starts skinning on each side of the backbone,

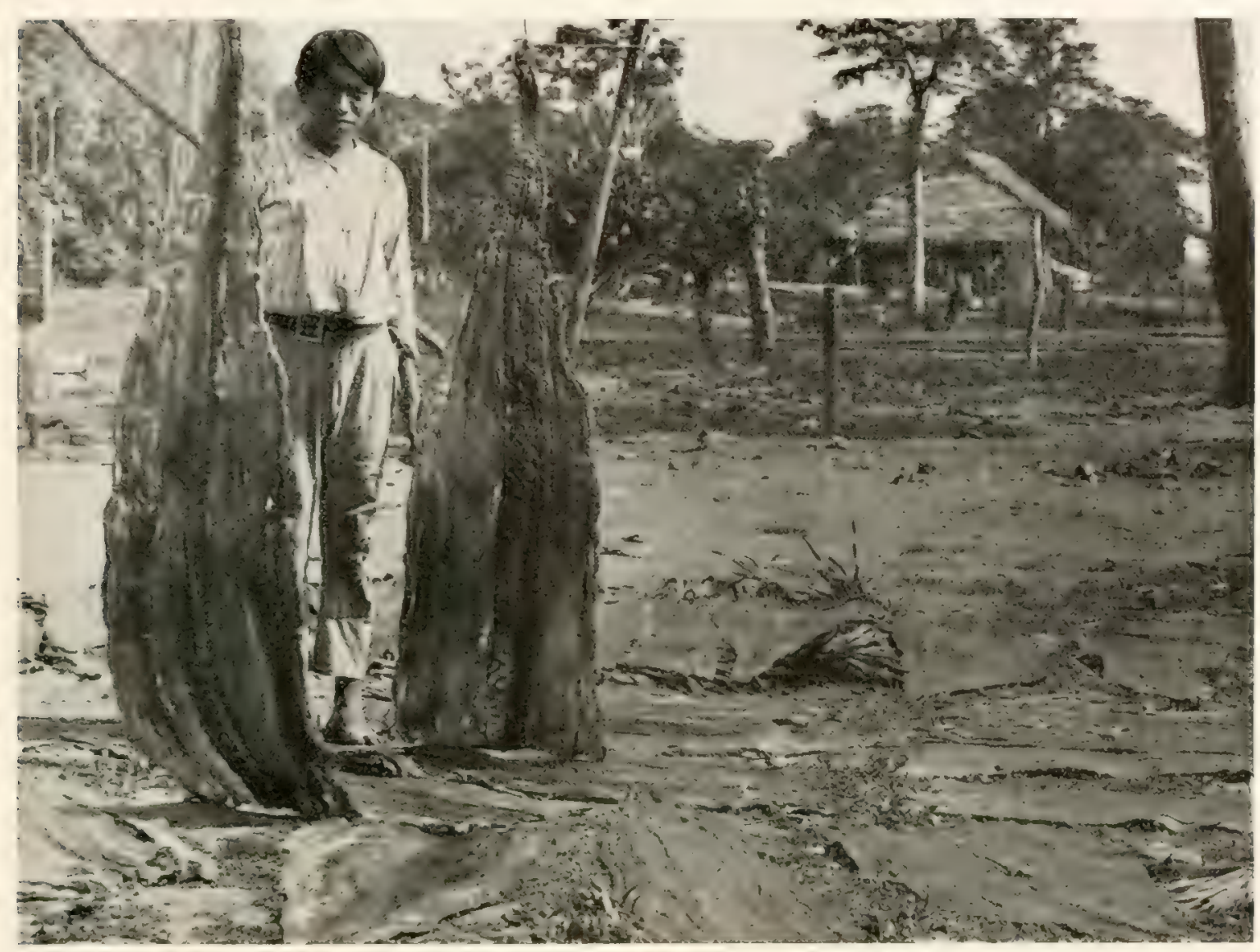

Fig. 40. Drying paiche. Veneer-like slabs of paiche-meat spread out on palm-branches for drying in the sun; two strips suspended from the clothes-line for photographing. The banks of the Leayali river at the right.

laying the skin back on each side, and performing the remaining steps on the skin. The backbone is next removed, then the viscera, and the head. The meat is then divided into strips, not transversely as you would expect, but lengthwise of the entire fish. The epaxial and hypaxial muscle bundles are then split lengthwise into as many strips as the size warrants, six, eight, ten, or rarely twelve.

The muscle bundles five to eight or nine feet long, several inches in diameter, are then laid lengthwise on a pole, shoulder high. Starting at one end, the operator with a sharp knife begins cutting the strip into a thin veneer, rotating it on the pole, and skilfully holding his blade so as to maintain a uniform thickness of a quarter- 
inch or so. When he has finished, the bundle has become a wide sheet of flesh, ready to be spread out on the drying racks. Much as in a wood-veneer the sheet is criss-crossed with odd grain-patterns where the myotomes and myocommata are cut across. (Text fig. 39.)

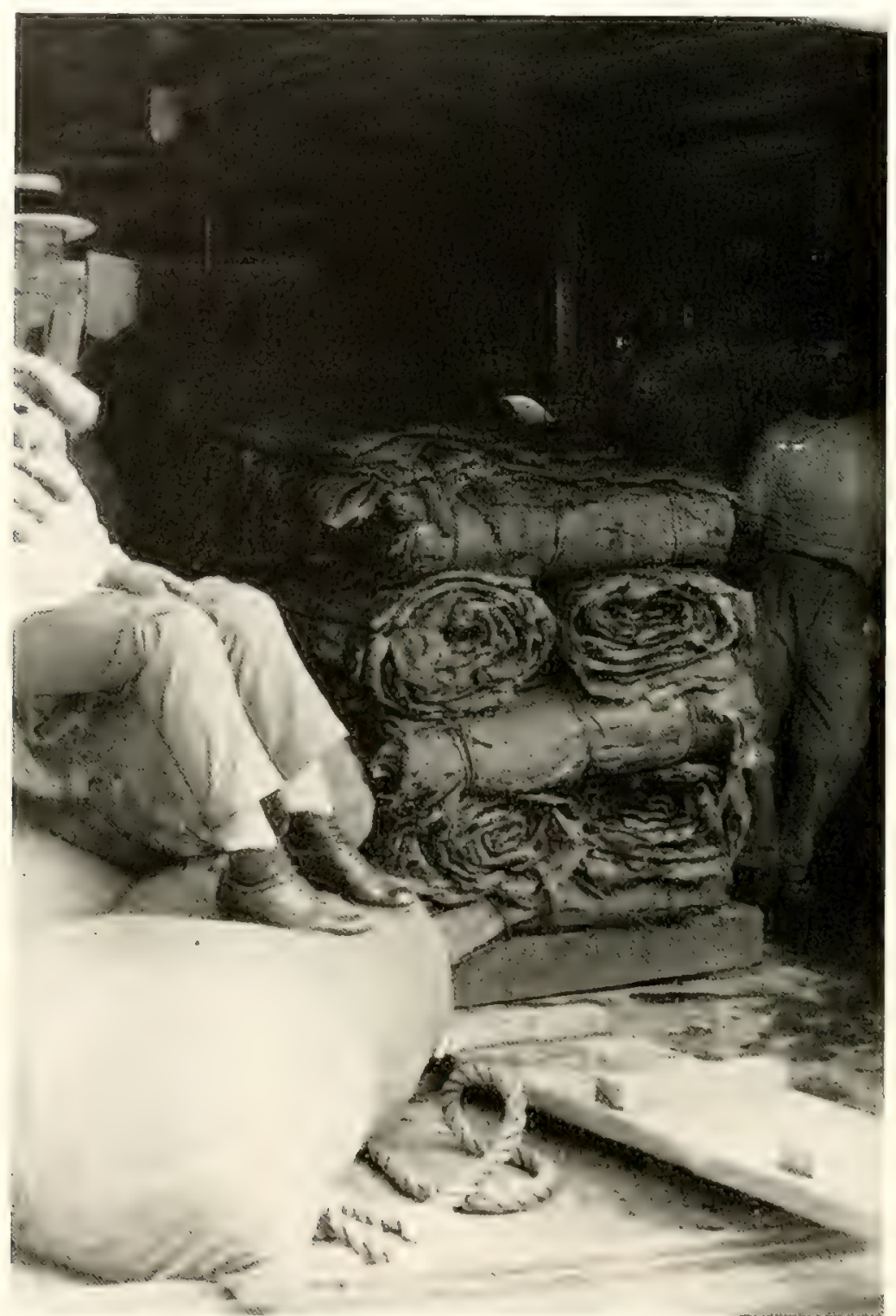

Fig. 41. Deck cargo of paiche meat. The dried strips are tied in rolls for shipment to market.

The dried strips of flesh are rolled into bundles and stored in the farmhouse ware-room until needed for domestic use or until sold. Huckstering merchants, mostly from Iquitos, make more or less regular trips up and down all the main streams by steam-"launch", bartering trade-goods for cotton, rubber, ivory-nuts, dried paiche, etc., and thus the surplus supply of the fish finds its way to the city market. At the time of my visit, no sanitary service existed in Loreto, and no 
regulations concerning the marketing of dried fish. The bales of paiche-veneer, tied with lianas or strips of bark, were piled on the ground, or on the decks of the launches, with no more care than so many hides. The Brazilians, however, were obliged by law or custom to wrap their bundles in banana leaf or some such cover enroute to market. (Fig. 41.)

Beebe, through Mr. White, his principal informant, and an excellent observer, asserts that the "warapaima" prefers the deeper holes of a stream-bed for its hidingplace.

I was shown nipple-like outgrow ths about the head which the people believed to be found on the female alone, and which were supposed to be in the nature of mammary glands. It is more probable that they belong to the male than the female and might be a holdfast.

The species has certain other points of usefulness than as an article of food. In the early day, before the advent of kerosene in its five-gallon tin, and in the heyday of the fish, its oil was employed as an illuminant, along with that of the turtle egg. Here in this broad land of alluvial character, a land without mineral resources, the aboriginal tribes exhibit to this day certain cultural aspects older than the stone age, as, for example, the expedients by which they make up for the want of mineral materials for the arts and crafts. (This is mentioned under the account of the piranha.) The paiche's toothed tongue and other bones of the mouth serve as a rasp for wood, and as a grater for the cassaca root in the preparation of farinha.

\section{Order MICROCYPRINI \\ Family XVIII: Poeciliidae \\ Subfamily: FUNDULINAE \\ Genus 194: RIVULUS Poey}

Rivulus Poey, 1858, Mem. Hist. Nat. Cuba, 307, 383;

Eigenmann and Eigenmann, 1891, Proc. U. S. Nat. Mus., XIV, 64;

Eigenmann, 1910, Rept. Princeton Unir. Exped. Patagonia, III, 454;

Eigenmann, 1912, Mem. Carnegie Mus., V, 452;

Eigenmann, 1922, Mem. Carnegie Mus., IX, 183;

Myers, 1927, Ann. Mag. Nat. Hist, (9), XIX, 119;

Myers, 1931, Stanford Univ. Publ. Biol. Sci., VI, 10.

Type: Rivulus cylindraceus Poey

United States southward to Paraguay

All fins rounded except for notched caudals of males of some species; head wider than deep; dorsal farther back than anal, and smaller; females more brightly colored than males; sexual dimorphism very pronounced.

The area which we have under consideration lies upon the southern or southeastern fringe of the range of the family, where it is represented by few genera. Partly due to this fact, and partly due to the inundated stages of small streams, our collections of the lowland Poeciliids were seanty. Yet from the reports on other collections in the area, the same statement could be made for all. 


\section{Rivulus peruanus Regan}

Aplocheilus peruanus Regan, 1903, Ann. Mag. Nat. Hist., (7), XII, 626;

Eigenmann, 1910, Rept. Princeton Univ. Exped. Patagonia, III, 454.

Rivulus peruanus Regan, 1912, Amn. Mag. Nat. Hist., (8), X, 496;

Eigenmann, 1922, Mem. Carnegie Mus., IX, 183.

Perim, Peru, elevation $800 \mathrm{~m}$.

Simons collection taken near Huaraz, but I find no information as to the exact location of Perim, or whether it is on the Atlantic or Pacific slope; two specimens, types, $55 \mathrm{~mm}$. long.

\section{Rivulus urophthalmus Günther}

Plate XXII, figs. 1 and 2

Rivulus urophthalmus Günther, 1866, Cat. Fish. Brit. Mus., VI, 327;

Regan, 1912, Ann. Mag. Nat. Hist., (8), X, 498;

Henn, 1916, Ann. Carnegie Mus, X, 110;

Myers, 1927, Ann. Mag. Nat. Hist., (9), XIX, 126.

Rivulus brasiliensis Eigenmann (in part), 1910, Rept. Princeton Univ. Exped. Patagonia, III, 454 .

\section{Amazons and Guianas}

16185, 1, female, 47 mm., brook, Iquitos, Allen, September, 1920.

16186, 1, male, $49 \mathrm{~mm}$., Yurimaguas, Allen, November, 1920.

\section{Rivulus micropus (Steindachner)}

Fundulus micropus Steindachner, 1863, Sitzb. KK. Akad. Wiss. Wien, XLVIII, 184;

Cope, 1878, Proc. Amer. Phil. Soe, XVII, 695.

Rivulus micropus Eigenmann, 1910, Rept. Princeton Univ. Exped. Patagonia, III, 45t;

Regan, 1912, Ann. Mag. Nat. Hist., (8), X, 500;

Myers, 1927, Ann. Mag. Nat. Hist., (9), XIX, 125.

Trinidad, Venezuela, Rios Negro and Peruvian Amazon

\section{Subfamily: ORESTIATINAE}

Orestiasini, Orestiasiformes Bleeker, 1860, Ichth. Arch. Ind., II, $43 ; 483$.

Orestiinae Regan, 1911, Ann. Mag. Nat. Hist., (8), VII, 325;

Orestiatinae Myers, 1931, Stanford Univ. Publ. Biol. Sci., VI, iii, 12.

\section{Genus 195: ORESTIAS Cuvier and Valenciennes}

Oresiias Cuvier and Valenciennes, 1846, Hist. Nat. Poiss., XVIII, 221;

Garman, 1895, Mem. Mus. Comp. Zool., XIX, 147;

Pellegrin, 1904, Bull. Soc. Zool. France, XXIX, 92;

Pellegrin, 1906, Poiss. Lacs Hauts Plat. Amśr. Sud, 126.

Type: Orestias cuvieri Valenciennes

Lake Chinchaycocha southward, Titicaca basin

"Basisphenoid and opisthotic bones absent; post-temporal not forked, its upper limb joined to epiotic; parasphenoid without lateral process to alisphenoid; 
an incipient myodome; teeth conical; pelvic fins absent; larger than most Cyprinodonts, often with forked or emarginate caudal fin." (Myers' synopsis of the subfamily).

Eigenmann (1920, Copeia 110.89) studied the possible affinities of the genus to Empetrichthys, of Nevada. Mainly on the structure of the pharyngeals and the mutual lack of ventral fins he found them so nearly alike as to warrant including

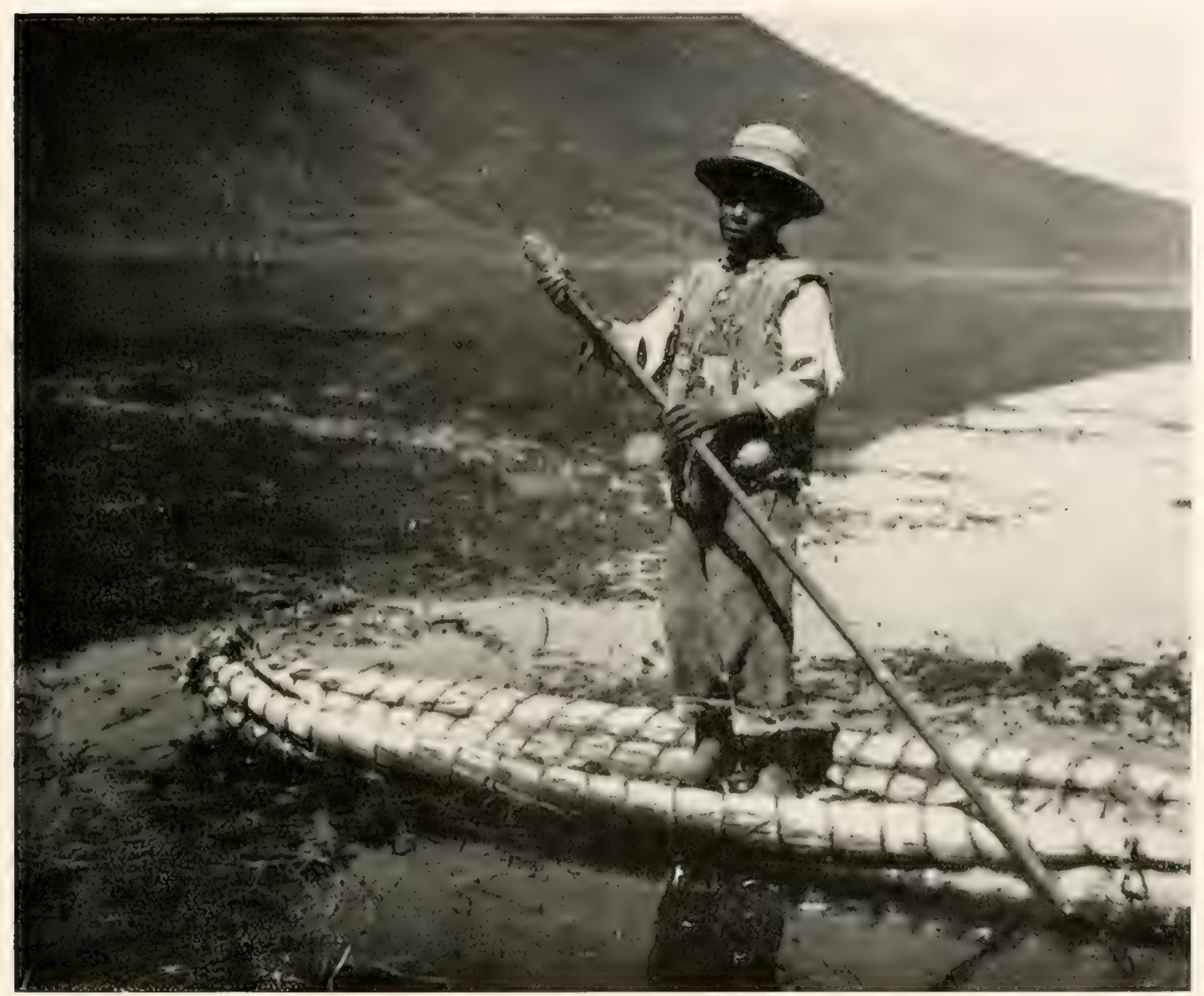

FIG. 42. Gigging for Orestias in Lake Umayo. In the highlands of Peru where no wood is produced, such poles as the boy in homespun is using must be imported from lower elevations. Hence his economy in making the pole serve both for propulsion and for fishing. His bulrush boat is of the smallest size.

them in the same genus. Both, he argues, were carried up to great elevations with the rise of their mountainous habitats from the sea. Both are the inhabitants of the quieter waters and unlikely to have invaded the highlands from below, unlike the Astroblepus and Pygidium of those waters with their great climbing ability.

The juvenile stages of all the species are convergent, funduliform, while the adult fishes diverge, tending toward an upturned mouth, a widening and angularity of the shoulder region in some species; striate scales, sometimes smooth, in other 
cases tuberculate. In $O$. luteus I find the early stages most readily identifiable by a somewhat adult-like body form.

The genus is noteworthy for the great variation of scale-form, varying with the species, with body regions, and with age. The scales of the posterior and middle parts of the body tend toward the concentrically striate form. From about the eighth scale-row posterior to the opercular aperture forward to the head and upward to the nape the seales of most species are modified. In certain species they are thickened, enlarged, and polished to a luster rather than glossy; this type is often marked in part with pores. Another type is of a granular nature, nowhere smooth. The granules are small, tend to form definite rows around the posterior margins of the scales back to about eight rows beyond the opercle; each scale with scattered granules upon its surface elsewhere. There appears to be a definite correlation between the granular scalation and the heavier types of pharyngeal teeth, as though the mollusk-eating forms were subjected to more wear from rocky shores than other species. The special scale-forms do not become evident until the juvenile stages are outgrown, and increase with age. The scales of the head, the back, and those of the posterior part of the body are often deciduous, especially in the young, becoming firmer with age, and more regularly placed in rows. The specialized scales of the anterior regions, however, increase in size and decrease in number, losing their regularity.

Branchiostegal rays appear to be always 5. Fins are usually rather uniformly placed, generally broad, rounded, with the origin of the dorsal at almost exactly the middle point between the extremity of the opercle and the caudal base; the caudal is nearly always broad, but varies from slightly rounded to slightly concave, sometimes truncate; never deeply cleft. The anal is always about two rays behind the dorsal. The pectoral generally reaches about half way from its own base to the origin of the anal. Ventrals wanting in all species.

In a few species the anal fin is often found sharply deflected in the larger specimens toward the right, enclosing a space along the right side of its base. There is a fold of skin, apparently somewhat deciduous, running along the base of the rays. The first ray is more or less surrounded by the border of the genital pore. The whole apparatus appears to be an elementary mechanism for spawning or egglaying, and is associated with a backward-directed vent in forming an almost papillose, fleshy area.

Two types of fin-structure appear to prevail: a type of fin having generally longer, more slender rays, more deeply imbedded in skin, smooth, rigid, more mucoid; the other type with fins longer, rays shorter, less glandular, more flexible, darker, harsher to the touch.

The gonad appears always to be on the right side of the abdominal cavity, single, imperceptibly divided at the tip or not at all. In all the Valenciennes species except cuvieri, his figures convey an exaggerated idea of the size of the mouth and the degree of its elevation.

The gill-membranes are more or less united, the rakers a rather uniform series, small, simple, widely spaced; the pharyngeal teeth not variable, with a shoulder. 
The alimentary canal practically without a stomach, the intestine long, much longer than the fish, sometimes twice as long.

The most obvious differences between Empetrichthys and Orestias are that the former has a double series of teeth in the jaws, the mouth is terminal (though oblique), and that the dorsal fin is in a more posterior position.

Myers points out that more deep-seated differences exist (see above) which throw Empetrichthys nearer the funduline group, the outstanding one being that in Empetrichthys parietals are found, absent in Orestias.

Cyprinodontiform fishes isolated almost altogether from all other types by the great altitude of the altiplane on which they live, upland plateaux or pampas between the great cordilleras. These extend for more than a thousand miles from near Cerro de Pasco to southwestern Bolivia and Chile, mainly at 12000 to 13500 feet above sea level. At some points the fishes have attained elevations of approximately 16000 feet, while in a few limited areas they spill over the rim of the interandine basin down the eastern slope to about 8000 feet. We found them on the western slope at only one point, a small lake near Casapalca, hanging on the precipitous rim of the divide. Co xtensive with the altiplane, the northern barrier is the great Nudo de Pasco, while southward distribution has been cut off by the rugged rolcanic terrain along the headwaters of the Pilcomayo, and the Rio Grande of Bolivia. At one point at least the genus has been hemmed off by a complete ring of active and extinct volcanoes and exists in a land-locked terrain ( L. Ascotan of Chile) cut off from another land-locked system (the Uyuni basin); the latter in turn is hemmed off by low mountains and deserts from the third land-locked system (the Titicaca basin), yet through all these metamorphoses of the land the Orestias have held their own in all three basins.

The student of the genus Orestias is confronted not only with inadequate descriptions, but with poor and often misleading figures.

All Valenciennes figures give a very erroneous conception of the mouth. The fins are inaccurate, the arrangement of scale-rows mechanical. Pentlandi, e.g., is shown as having definite rows of scales, equally with other species, while in fact they are rounded and irregular throughout the length, where other species have this irregularity upon the forward parts at most. In none does his artist show the scalation of the caudal base, vertical, broken series such as all species have. No Orestias is fully scaled below, yet three of his figures could be so understood. He describes $O$. albus as always with exposed areas alongside the back, but these areas are figured with scales, and as a matter of fact they often are scaled. His $O$. agassizii fairly well shows the appearance of a young specimen, but in no Orestias, young or adult, is the armor of thickened scales completed so far back. This caused later writers to confuse it with jussiei.

Castelnau's three figures are a much brighter green than any member of the genus, in which all greens are "olivaceous." He says the eye of $O$. tschudii is smaller and more ventral, but shows it like jussiei in his figure. His fins are untrue to life, and like Valenciennes, insists on having the scale-rows of pentlandi quite regular.

Deep-sea fishes are often brought to the top with the viscera everted under 
the diminished pressure at sea-level. Our Orestias come from a region having the atmospheric pressure two-fifths less than at sea level. This may account for the fact that they usually have the scaleless belly inverted to an unusual degree, in our collections, when transported to the greater pressures at low elevation.

Although the published history of the genus Orestias is generally dated 1846 , with the brief description, Valenciennes had first published a brief notice in the Institute, VII, p. 118, 1839. The type was not clearly stated but inferred in the Histoire Naturelle des Poissons, 1846, XVIII, at the bottom of page 225 and the top of page 226, where he says: "La première espèce de ce genre sera pour nous celle dont les individus paraissent atteindre à la plus grande taille, et qui ont dans leur dentition, dans le developpement de leurs boucliers granuleux et de leurs écailles, un ensemble de caractères dont les autres espèces n'offriront que des modifications." Thus $O$. cuvieri is well understood to be meant as his type.

Prior to this time, however, Valenciennes informs us that at least two of the species were known, $O$. pentlandii and agassizii, at least to a small world, through drawings that had been made by M. Joseph de Jussieu, and transmitted to him by the grand-nephew, MI. Adrien de Jussieu.

Following this only a few small random collections were made by Castelnau in the 1850's, Orton in the 60's, and Agassiz and Garman in the 70's. The second resulted in the publication of a few ill-considered species by Cope. The lastnamed were the basis of Garman's very incomplete revision in the Cyprinodont report of 1895. An equally unsatisfactory report of the fishes resulted from the incidental collections made by MM. Créqui-Montfort and de la Grange in 1903, published by Pellegrin (1904, and 1906). Starks (1906) describes some 37 specimens from Titicaca, belonging to five species. In 1917 Evermann and Radcliffe brought together all the literature on the genus and assembled thirteen species which they could not remove from the list considered valid.

While on the Irwin Expedition as traveling fellow of the University of Illinois my major efforts were given to the more elevated regions. It follows that Pygidium and Orestias were by far the greater part of my collections for some four months of my work in the highlands of central and southern Peru, Bolivia, and northern Chile. Some thousands of specimens of Orestias, large and small, were brought home. At intervals from that time until the death of Dr. Eigenmann I was working on them. In 1929, through error, the Orestias materials were sent to the California Academy of Sciences with the Jordan-Eigenmann collections. Other portions of the material had been sent to the University of Illinois. The following pages will show the results of the study of only a part of the entire material available.

Many specimens were dissected for parasitological materials, and for stomach examinations. The field notes on food may be summarized as follows:

Orestias agassizii. Intestine 1.5 times the length of the fish. Algal filaments, Cladocera, Amphipoda, insect fragments. No indication of shells or grit between scissor points. Specimens of small size from streams and shores with larger fragments of food, taken among water plants, than the larger species taken offshore, containing plankton. Those from shallows of Ascotan and Huancané had fed on Amphipods and insects. One specimen from R. de Eucaliptus 
had only Corixid nymphs and adults; another with lower intestine packed with Corixid remains, the rest of the gut with plankton, mainly diatoms.

Orestias milleri. Cheese-like masses containing the tests of minute Cladocera; no plant, no larger Crustacea. Some from Lake Poopó, 3.5 inches long, insects and fragments. From Moho, much red mud and grit; fragments of higher plants than algae; no shells. Intermittent rain with much mud entering through streams from the red sandstone formations of the region.

Length of intestine 1.5 times length of fish.

Orestias pentlandi. Many Cladocera, few algal filaments; mass of much finer material. Fishes more pelagic, intestine shorter than body, food finer than either of preceding.

Orestias luteus. Intestine packed with Crustacea and great numbers of small Amphipods. The smallest specimens contained the largest prey.

Orestias albus. Gastropod shells, many broken, but others entire. An older specimen, above 6 inches, with most of intestine packed with woody fragments, stems, leaves, etc., and a small portion of gut at anterior end filled with Gastropod shells.

Intestine nearly 1.5 times body length.

Zuniga, 1941, expresses the relative length of the intestine of several species as follows: $O$. pentlandii, vegetarian, $1.39 ; O$. neveui?, piscivorous, $0.5 ; O$. tschudii, crustaceans, 1.89; O. luteus, mollusks, 1.92. (From Biol. Abstr., article not seen by me.)

THE SIECIES OF ORESTIAS

As the synonymies will show there has been some confusion in the literature and numerous doubtful identifications, arising from the fewness and the imperfection of specimens, the brevity and ambiguity of descriptions, and the inadequacy of the illustrations. My study began in the hope of reducing the number of species materially. Such a number of species in waters so intimately connected seemed doubtful. But, as a matter of fact, one by one they have turned up either in our collections or, in two cases, specimens borrowed. They appear not to have had the advantage of isolation during their long history, but perhaps we can explain the evolution of so many species, mostly in one drainage area, from the long series of more or less violent changes in the habitat, their rise from sea level to as much as 12000-13000 feet, diastrophic upheavals, volcanic activity, and the change from saline to fresh water. Perhaps the species of Orestias have been the most bombarded of all fishes, with the greatest variety of external forces, some of which may have had genetic effects, even with our present understanding of genes.

Confusion of species has also arisen from the choice of characters by which to separate them. The various authors have resorted to such characters as these:

Finray counts which frequently overlap, never varying much

Position and form of fins uniform for most species

'Teeth descriptions nearly identical

Taked areas not consistently present or absent

Depth of cleft of mouth hard to determine for lack of points of reference

Striation of seales often not as given in deseriptions 



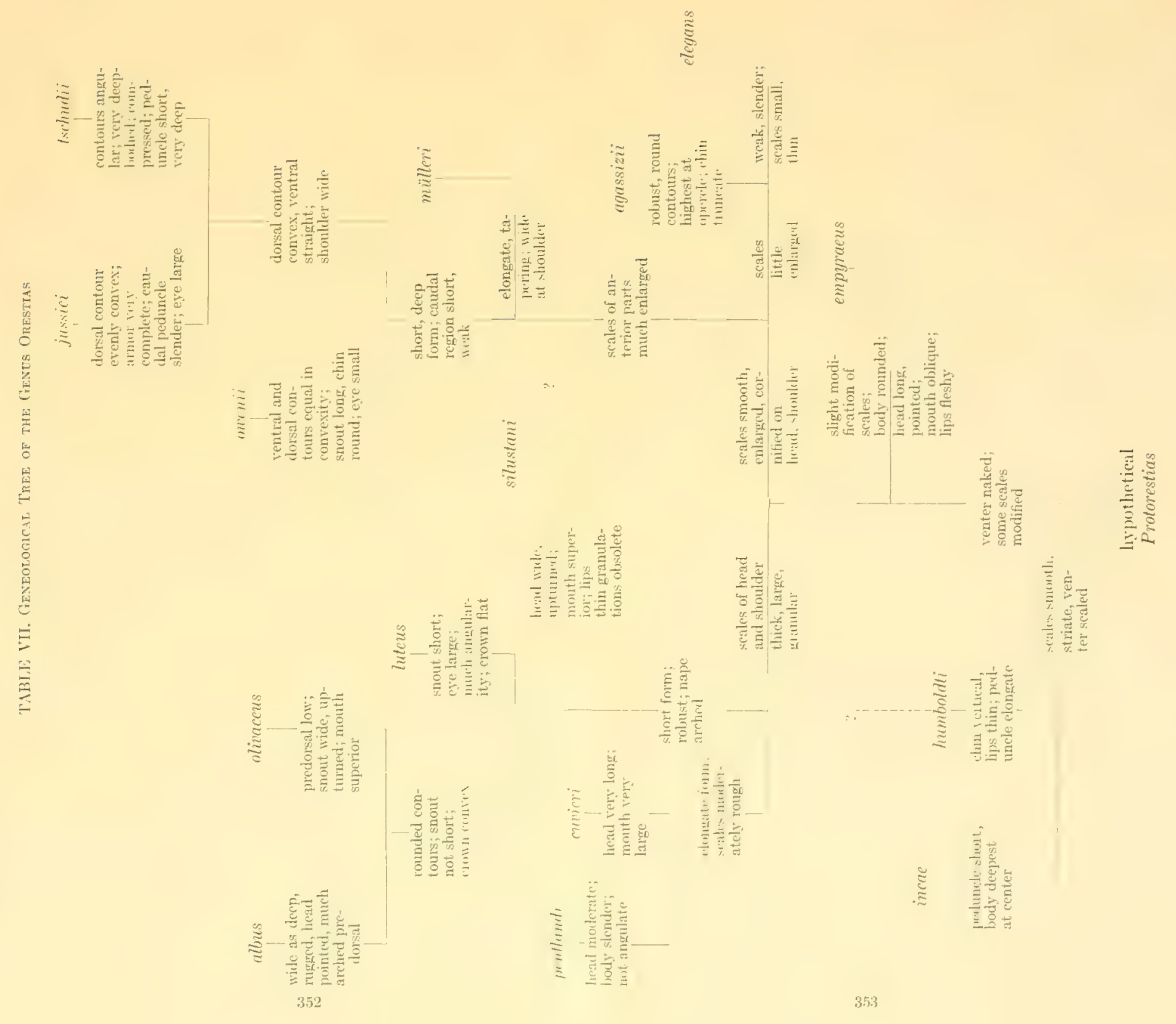




\section{KEY TO THE SPECIES OF THE GENUS ORESTIAS}

a. Scales nearly uniform throughout; venter scaled; small fishes

b. Deep, compressed, pointed equally toward head and tail; greatest depth midway; lips flestry..

bb. Elongate; vertical chin, thin-lipped; caudal peduncle long, slender; deepest above pectoral fin

aa. Scales enlarged and thickened on anterior parts

c. Scales of the head, opercle and shoulder enlarged, irregular, granular, especially in adults d. Fishes of elongate form; caudal peduncle slender

e. Mouth, teeth, and eye large (6.6 in long head); mouth wide, oblique; 20 scales in vertebral series...........................

ce. Mouth smallish, nearly vertical; snout roundly pointed; head moderate, 3.7-4.0; nape with low arch; granulations not extreme; scale rows irregular throughout length

pentlandi

dd. Fishes of short, robust form; nape arched; caudal peduncle short and deep

f. Eye large, 4.3-4.5, elevated, supraorbital jutting over eye; snout short, less than eye; mouth horseshoe-shaped, vertical, thin; head angular; lateral angle acute; crown flat................... luteus

ff. Eye smaller, round; snout equal or exceeding eye; mouth oblique, fleshy; crown more or less convex; lateral angle broad

g. Nouth uptumed, back nearly straight; roundly compressed; caudal

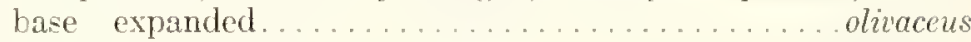

gg. Head a wide cone, moderately rugged, pointed at chin; wide as deep; abruptly compressed caudally; high predorsal arch. albus

ce. Enlarged scales on anterior parts smooth and more or less polished, without granulations

h. Seales of head and shoulder moderately thickened on small areas; little modification of general scale pattern

i. Head wide and uptumed, mouth superior, thin-lipped; dorsum straight;

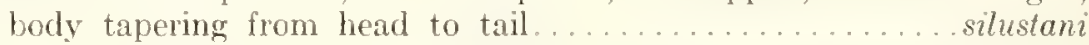

ii. Body outlines rounded; caudal peduncle abruptly constricted far back on body; head pointed; mouth oblique, lips fleshy........... cmpyraeus

hh. Scales of shoulder and head mostly thickened and cornified, forming a more or less dence armor of close-set bucklers

j. Armor of anterior parts reaching to or beyond tip of pectoral fin; seales moderately specialized; predorsal slightly or moderately arched; scalerows little disrupted or crowded; body not broadened at shoulder k. Small, elongate, scales mostly thin, little convex, deciduous. elegans kk. Larger, deeper, wider fishes; scales smooth, more permanent in older specimens

1. Arched predorsal, high above the end of operele, tapering thence to tail; robust, not expanded; chin truncate; mouth and snout wide, lips thin; fins small, fleshy.......agassizii

11. Predorsal arched equally with ventral profile; spindle-shaped forward from middle of body; chin roundly pointed, lips thick, preorbital portion of head long; tapering weakly from end of pertoral fin

oucenic

ij. Body deep and wide at level of pectoral basis; thickly and densely armored; thickened and convex scales to beyond middle level of pectoral; chin vertical

m. Elongate, mcderately deep; head in length 3.8 ; tapering gradually frcm the base of the pectoral fin to the tail. ......... mulleri $\mathrm{mm}$. Shorter form; deeper; head in length 3.3; depth in length 2.7-2.8 n. Dorsal and anal fins oblique and caudal peduncle thin and shallow; its depth in its own length $1.3 \ldots \ldots$.... jussiei

nn. Tapering gradually shoulder to tail; caudal peduncle very deep, shol't, its depth equal to itslength.........tschudii 


\section{Orestias incae Garman}

Plate XVII, fig. 1

Orestias incae Garman, 1895, Mem. Mus. Comp. Zool., XIX, 155;

Eigenmann, 1910, Rept. Princeton Univ. Exped. Patagonia, III, 461;

Evermann and Radcliffe, 1917, Bull. L. S. Nat. Mus., no. 95, 42.

\section{Lago Titicaca}

3948 IICZ, 1, 55 mm., cotype, Moho, Lake Titicaca, Garman, January, 1875.

As in the case of $O$. olvaceus the kind loan of this specimen enabled me to retain $O$. incae as a valid species, since my collections unfortunately do not include it.

The single specimen before me is extremely short, high, and compressed. The dorsal profile is rather uniformly convex from the occiput to the end of the dorsal basis, thence becoming sharply concare on the caudal peduncle; slightly concave on the head; ventral contour equally rounded from the vertical through the opercle to the caudal peduncle. Depth greater than the length of the head, 2.7 in the length of the fish without caudal fin, the point of greatest depth farther back than in any other species, being about midway of the body and toward the extremity of the pectoral (not at the first dorsal rays as stated by Garman), tapering uniformly toward head and tail. Head unusually rounded in cross-section; mouth oblique, lips fleshy, teeth scarcely perceptible; eye moderately large, greater than the snout, $3.75 \mathrm{in}$ the head, which is $3.3 \mathrm{in}$ the length. Caudal peduncle slender, 4 in the length of the fish.

(Garman) D. 16-18; A. 16-18; P. 18-20.

Scales small, striate, without granulations, belly completely scaled.

Many scattered red-brown chromatophores about over the body, and broken rows of fine markings on all fins.

Not at all closely allied to albus and luteus as believed by Garman, except as to the short form and the colors, but nearer to the primitive stock and to humboldtii, lacking the specialized forms and seales of both the major divisions of the genus. Placed here with little hesitancy, since it differs clearly from the specimens, which I have identified as humboldti, in the much less slender form, greater depth rounded head, more oblique mouth with fleshy lips, and teeth less evident.

\section{Orestias humboldti Valenciennes}

\section{Plate XVII, fig. 2}

Orestias humboldti Cuvier and Valenciennes, 1846, Hist. Nat. Poiss., XVII, 233.

Orestias curieri Eigenmann and Eigenmann, 1891, Troc. U. S. Nat. Mus., XI, 65;

Eigenmann, 1910, Rept. Princeton Univ. Exped. Patagonia, III, 461.

\section{Lake Titicaca}

16078, 31, 53-100 mm., Moho bay, Allen, December, 1918.

This species was collected for Valenciennes by Pentland, and has not since been collected. My specimens from Moho bay were long mistaken for Garman's incae until one of Garman's cotypes was sent me from the Harvard Museum, 


\begin{tabular}{|c|c|c|c|c|c|c|c|c|c|c|c|c|c|c|c|c|}
\hline$\widehat{ส ิ ~}$ & 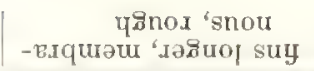 & & & $x$ & & & & & & & & & & $\times$ & $x$ & $x$ \\
\hline$\stackrel{\infty}{\sim}$ & 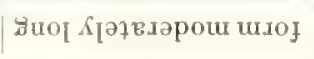 & & & & $x$ & & & $x$ & & $x$ & $x$ & $\times$ & $x$ & & & \\
\hline 太 & 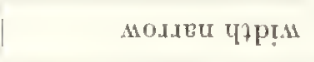 & & & & & $x$ & & $x$ & $x$ & $x$ & $x$ & & $x$ & $x$ & $x$ & \\
\hline$\because$ & 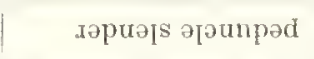 & & & & & $x$ & & $x$ & $x$ & & $x$ & & $x$ & $x$ & $x$ & \\
\hline$\because$ & 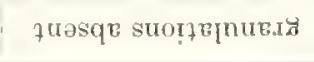 & & & & $\times$ & & & $x$ & $x$ & $x$ & $\times$ & $x$ & $x$ & $x$ & $x$ & $x$ \\
\hline$\vec{s}$ & 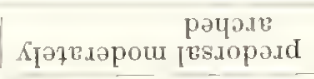 & & $x$ & & $x$ & $x$ & $\times$ & $x$ & $x$ & $x$ & $x$ & $x$ & $x$ & $x$ & & \\
\hline$\approx$ & 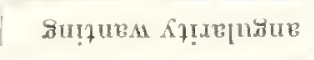 & & $x$ & & $x$ & $x$ & & & $x$ & $x$ & & $\times$ & & $\times$ & & \\
\hline a & 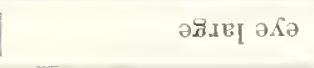 & & & $x$ & & & $\times$ & $x$ & & & $x$ & & $x$ & & $x$ & $x$ \\
\hline$\vec{a}$ & 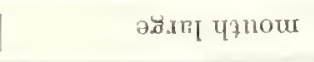 & $\times$ & & $x$ & & & $x$ & & $x$ & & & & & & & $x$ \\
\hline : & 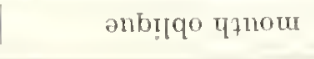 & & & & & $x$ & $x$ & $x$ & $x$ & $x$ & $x$ & $x$ & $x$ & $x$ & & $x$ \\
\hline$\stackrel{g}{-}$ & u!̣7 sdı! & $x$ & $x$ & $x$ & $x$ & $x$ & $\times$ & $x$ & $x$ & & $x$ & $x$ & $x$ & $x$ & $x$ & $x$ \\
\hline$\stackrel{\infty}{\sim}$ & प7oous soreos & & & & $x$ & & & & & $x$ & $x$ & $\times$ & $x$ & $x$ & $\times$ & $x$ \\
\hline 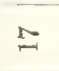 & әұєљәроนи әрэиирәd & & & & $x$ & & $x$ & & & $x$ & $x$ & $x$ & $x$ & & & \\
\hline$\stackrel{\varphi}{-1}$ & uxojฺนn હə[ซอs & & & & & & & $\times$ & $x$ & & & & & & & \\
\hline${ }_{-1}^{10}$ & 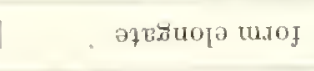 & & & & & $x$ & $\times$ & $x$ & & $\times$ & $\times$ & & & & & \\
\hline \pm & 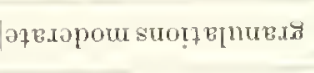 & & $x$ & & & $x$ & $x$ & & & & & & & & & \\
\hline$\stackrel{9}{-1}$ & 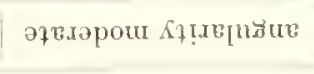 & & & & & & $x$ & $x$ & & & & & $x$ & & $x$ & $x$ \\
\hline 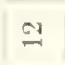 & dәวр әраипрәd & $x$ & $x$ & $x$ & & & & & & & & & & & & $x$ \\
\hline$=$ & $\begin{array}{l}\text { ypoous } \\
\text { 'Kusoy "7roys suy }\end{array}$ & $x$ & $x$ & & $x$ & $x$ & $x$ & $x$ & $x$ & $x$ & $x$ & $x$ & $x$ & & & \\
\hline 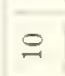 & рәนวพวอเา sd!! & & & & & & & & & $x$ & & 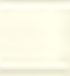 & & & & \\
\hline 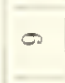 & 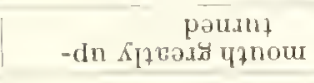 & $x$ & $x$ & $x$ & $x$ & & & & & & & & & & $x$ & \\
\hline$\infty$ & I[ซนเ ч‡nour & & $x$ & & $x$ & $x$ & & $x$ & & $\times$ & $x$ & $x$ & $x$ & $x$ & $x$ & $x$ \\
\hline r- & ไ/eus əরə & $x$ & $x$ & & $x$ & $x$ & & & $\times$ & $x$ & $\times$ & $x$ & & $x$ & & \\
\hline 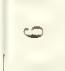 & 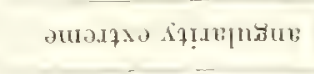 & $x$ & & $x$ & & & & & & & & & & & & \\
\hline$\therefore$ & 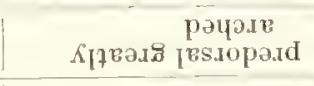 & $x$ & & $x$ & & & & & & & & & & & $x$ & $x$ \\
\hline+ & 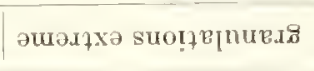 & $x$ & & $x$ & & & & & & & & & & & & \\
\hline$\infty$ & әрім Кәาв.⿻роч & & $x$ & & $x$ & & $x$ & & & & & $x$ & & & & $x$ \\
\hline a & dәәр sъ әрци & $x$ & & $x$ & & & & & & & & & & & & \\
\hline \multirow[t]{2}{*}{-1} & q.roỵs uxof & $x$ & $x$ & $x$ & & & & & $x$ & & & & & $x$ & $x$ & $x$ \\
\hline & 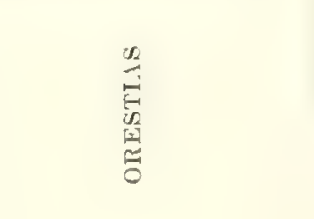 & $\stackrel{\infty}{\stackrel{\Xi}{\Xi}}$ & 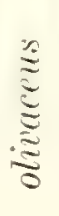 & $\underset{\Xi}{\stackrel{\Xi}{\Xi}}$ & 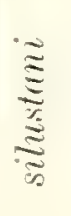 & $\underset{\underset{\Xi}{\Xi}}{\stackrel{\Xi}{\Xi}}$ & 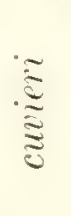 & 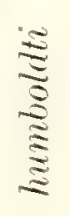 & $\Xi$ & 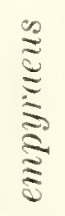 & $\stackrel{\stackrel{\Xi}{\Xi}}{\stackrel{\Xi}{\Xi}}$ & 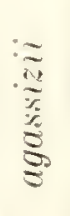 & 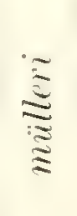 & $\frac{: \widetilde{\Xi}}{\widetilde{\Xi}}$ & 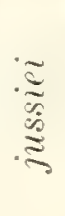 & 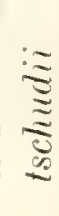 \\
\hline
\end{tabular}


showing it to be quite distinct from that species. Valenciennes was informed by Pentland that it was a favorite local food species, known as the pejerrey, noting that the name is applied in Spanish countries to the best fish of the region, and that Basitichthys also carries that complimentary epithet at Lima. I was not given that name, nor informed that it was considered a good food fish at Moho. It suggests in its general form some relationship to $O$. cuvieri, and thought to be possibly the young of that species.

Valenciennes described his $O$. humboldti in rather fuller terms than either the better-known agassizii or pentlandi. The specimens indicated above more nearly approach humboldti than any others previously reported, but do not conform perfectly to description.

Incae-like in the square tail, scaled venter, size of the eye, paucity of teeth. Unlike humboldti types apparently by being too short, head too short, dorsal profile too elevated. Similar to humboldti in the complete lack of specialized scales, the scales reaching to and including the venter, as represented in his figure (which may not be reliable), elongation of the caudal peduncle. The figure given by Valenciennes comes very close to my specimens, except for the deeply concave caudal fin, but the text describes it as truncate, which fits my specimens. His specimens were half an inch longer than my largest, and said to reach a maximum of no more than five inches. My largest were sexually mature at $82 \mathrm{~mm}$. or more.

Elongate, compressed, evenly and moderately convex from occiput to end of dorsal fin and from chin to origin of anal; caudal peduncle long, equal to head, straight; dorsal and anal bases oblique; depth moderate, 3.6. Crown convex, snout short, less than eye; eye large, elevated, slightly elongated out of round, nearly equal to interorbital space, equal to snout, nearly 4.0 in the head; mouth oblique, rather narrow; teeth few, rather large, first series complete, few in second.

Scales smooth, flat, thin, concentrically striate, the striae rather roughened, none either cornified or granulate, regular, extending well forward on snout, and on the cheek beyond the orbit; about 24 small scales on the vertebral series; sides and belly fully scaled.

D. $12-13$; A. $12-13 ;$ P. $14-16$.

Dorsal origin forward of middle of body, fin small, its base equal to depth of caudal peduncle, contained 2.5 times in the latter, the tip of fin reaching only onethird the length of peduncle; anal fin reaching a little farther; caudal fin long, narrow, truncate; pectoral rounded, reaching more than half way to the anal origin. These fin and body proportions resemble those of immature specimens and would easily be understood as such, except for finding some with well-developed gonads.

These specimens from the fjörd at Moho resemble other species collected there in the waters from the red sandstone of the region in being pale red-brown on a ground-color of silver and yellow. The scales rather uniformly and finely punctulate with chromatophores. Few fine markings on fins, not always present; the anal usually hyaline.

Locally named: hispe, hualpuche, silve. 


\section{Orestias cuvieri Valenciennes \\ Plate XVII, fig. 5}

Orestias cuvieri Valenciennes, 1839, L'Inst., VII, 118;

Cuvier and Valenciennes, 1846, Hist. Nat. Poiss., XVIII, 225, pI. 532, Lake Titicaca;

Eigenmann and Eigenmann, 1891, Proc. U. S. Nat. Mus., XIV, 65;

Garman, 1895, Mem. Mus. Comp. Zool., XIX, 147, pl. iii, fig. 11;

Starks, 1906, Proc. U. S. Nat. Mus., XXX, 779;

Eigenmann, 1910, Rept. Princeton Univ. Exped. Patagonia, III, 461 ;

Evermann and Radeliffe, 1917, Bull. U. S. Nat. Mus., no. 95, 38.

Orestias cuvierii Cope, 1877 (1878), Proc. Amer. Phil. Soc, XVIII, 44.

\section{Lake Titicaca}

3926 MICZ, 6, 170-190 mm., Puno, Lake Titicaca.

3927 MCZ, 4, 172-195 mm., Puno, Lake Titicaca.

3931 MCZ, 4, 170-180 mm., Puno, Lake Titicaca.

3951 MCZ, 1, $160 \mathrm{~mm}$., Puno, Lake Titicaca.

1461 MCZ, 1, 175 mm., Puno, Lake Titicaca.

31,112 MCZ, 1, $160 \mathrm{~mm}$. . Puno, Lake Titicaca.

Dorsal contour convex, slightly angulate or not at all above the pectoral basis, flattened or moderately convex on the head, depressed before the eye by the proportions of the mouth; ventral profile almost straight; width moderate, 1.4 in the greatest depth, 1.7-1.8 in the length of the head. Head very long, 2.8-3.2 in the length without caudal, rather angular, its bones prominent, right-angled; snout long, broad, chin prominent, rounded. Eye large, elongated, before the middle of the head, 5.2-5.7 in the latter, 1.6 in the interorbital space; mouth of extreme size, the only one not exaggerated in Valenciennes' figures, cleft far below the level of the orbit, gape exceeding interorbital space by nearly half of the latter; teeth large, hooked, in 2-3 broken series.

Caudal peduncle rather long, tapering to the middle point, widening conspicuously at the caudal basis.

D. $14-15$; A. $16-17$; P. $18-19$.

Dorsal well back, doubtless by reason of the size of the head, its origin behind the middle point from occiput to caudal base, dorsal base 1.3-1.5 in the length of the peduncle; elevation of the dorsal moderate, its tip reaching about half way to the caudal basis; dorsal and anal bases slightly elevated, naked, the former exserted, the latter oblique; pectoral wide, moderately long, reaching barely half way to the vent; caudal broad, roundly truncate. The vent fleshy, slightly protuberant.

Vertebral series of scales $22-23$, with two lateral series rather complete and continuous, the back slightly and shallowly compressed and bordered by variable naked areas, lacking in two, 3926; a large preorbital plate, infraorbital scales reduced to two or three; cheek and opercle scantily scaled, the former reduced to little more than two rows, on the latter more or less confluent; scales lacking on the prepectoral area, and in this species alone naked on the postpectoral to an extent just covered by the fin; scale-rows somewhat irregular on the largest, scales rather deciduous, granulations relatively sparse on forward parts, not very rough, sometimes worn, often pearly in appearance. 
Color in these specimens after sixty-five or more years in alcohol, upper parts pale, uniform brown, unmarked, verging into pale yellow below.

Reported by Pentland to Valenciennes under the name Umanto, a Quichua word rendered also omanto. The species was not collected by us. Valenciennes was informed by Pentland that it appears on fishing grounds only at certain seasons. This may mean that for the rest of the year it migrates into deeper water, out of reach of our collecting gear and that of the natives. By Valenciennes it was reported as the largest, the most striking in appearance, and reputedly the bestliked food fish. Garman, on the contrary, reports that its market value is less than that of $O$. pentlandii. Garman reports that dead specimens with everted stomachs

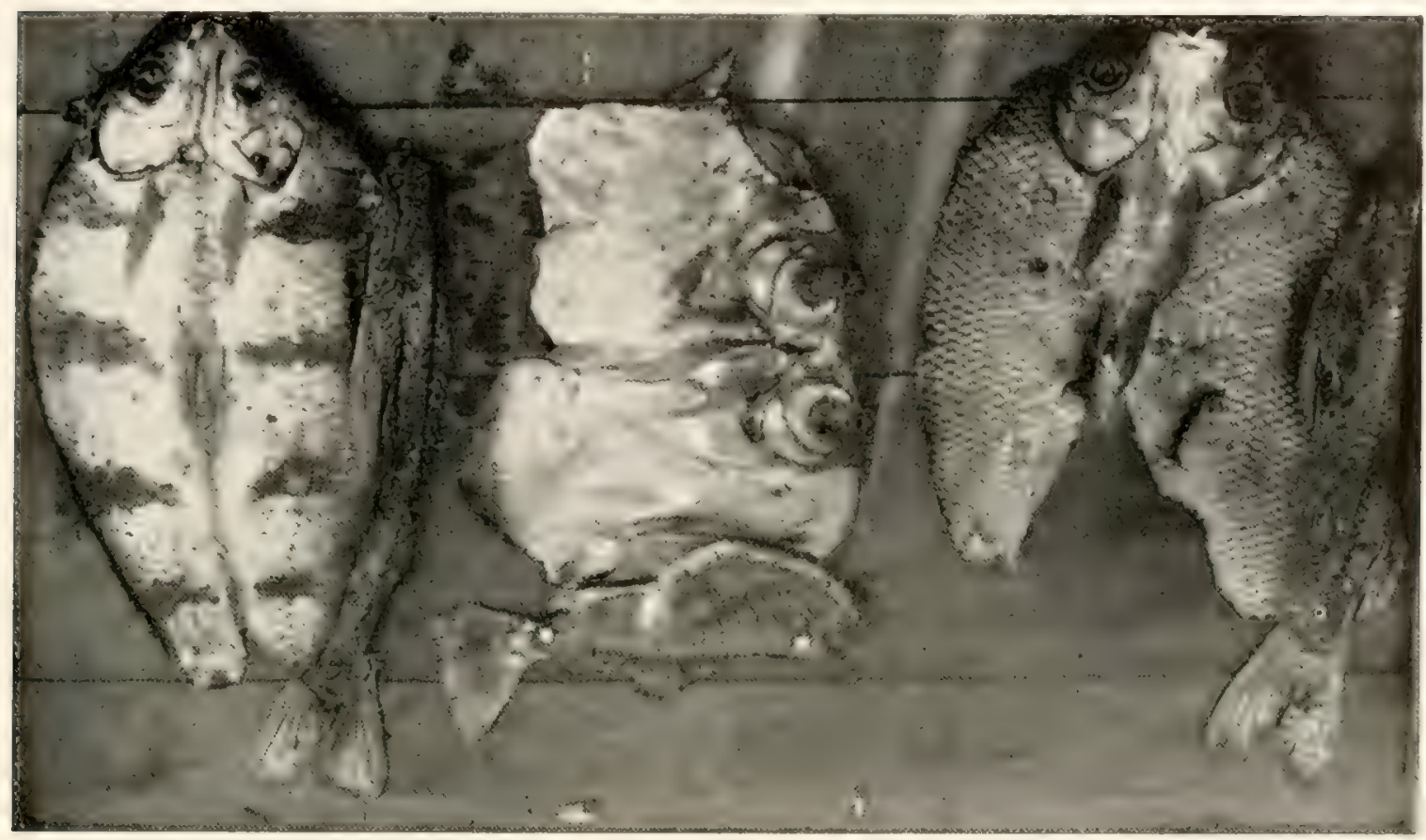

FIg. 43. Fish prepared for drying. Three of the commonest forms used for drying, the boca chica, palometa, and lisa, taken during the earlier stages of the rising waters of the rainy season in the mountains above. The Siamese-twin style of dresing small fishes is a standard procedure.

were picked up on the shores of the island of Titicaca, possibly implying their having arisen after death from considerable depths.

16077, 1, 73 mm., Moho bay, Lake Titicaca, Allen, December, 1918.

This small, somewhat emaciated, and somewhat mutilated specimen is placed here by elimination and without much certainty, as a possible juvenile. It is, however, very unlike the specimens which Garman considered young cuvieri. It is the most elongate of all my Orestias, not at all showing the robust proportions of the adult. Cuvieri-like in the depth of the mouth, but without prominent teeth and lacking width. With the irregular rows of scales and extended caudal peduncle; eye large.

Depth slight, $7.3 \mathrm{in}$ the length; the elongated head 4.7 ; the interorbital width 
just exceeding the eye; eye large, 4.0 in the head, which is everywhere narrow with no protrusion of the opercle, and little modification of the juvenile scales; about 25 in the vertebral series, a naked area on each side, elsewhere very irregular, the number small; pectoral well surrounded by scales, short, not reaching half way to anal base; opercle silvery; peduncle depth 1.25 times eye.

\section{Orestias pentlandi Valenciennes}

Plate XVII, figs. 3 and 4

Orestias pentlandii Valenciennes, 1839, L'Inst., VII, 118;

Cuvier and Valenciennes, 1846, Hist. Nat. Poiss., XVIII, 172, pl. 533;

Castelnau, 1855, Anim. Amér. Sud, Poiss., 52;

Eigenmann and Eigenmann, 1891, Proc. U. S. Nat. Mus, XIV, 65;

Garman, 1895, Mem. Mus. Comp. Zool., XIX, 148;

Steindachner, 1902, Denksch. KK. Akad. Wiss. Wien, LXXII, 58, pl. iv, fig. 4;

Pellegrin, 1904, Bull. Soc. Zool. France, XXIX, 92;

Starks, 1906, Proc. U. S. Nat. Mus., XXX, 779;

Pellegrin, 1906, Poiss. Lacs. Hauts Plat. Amér. Sud, 126, 127, 129, fig. 19i;

Eigenmann, 1910, Rept. Princeton Unir. Exped. Patagonia, III, 461 ;

Evermann and Radeliffe, 1917, Bull. U. S. Nat. Мus., no. 95, 39.

Orestias bairdii Cope, 1875, Jour. Acad. Nat. Sci. Phila., 1871-187t, 185.

\section{Lake Titicaca}

16082, 4, 180-190 mm., Capachica, Lake Titicaca, Allen, Norember, 1918.

16083, Yunguyo bay, Lake Titicaca, Allen, November, 1918.

16084, Pomata bay, Lake Titicaca, Allen, December, 1918.

16085, 3, 161-175 mm., Lake Arapa, Allen, January, 1919.

Elongated, little elevated; width in depth 1.3 ; depth in length of the head 1.3 ; head long, 3.7-4.0 in length without caudal; trunk rounded, becoming compressed toward caudal peduncle; dorsal and ventral contours uniformly and moderately convex.

Crown slightly convex, broad, flat, scaled or naked; eye in the interorbital space 2.4; snout moderately long, containing eye 1.4 times, narrowing to a moderately broad, rounded, blunt muzzle; mouth small to medium, 1.2 times eye, gape moderate, just reaching, or not reaching, lowest level of the orbit, oblique; head long, containing eye 5.4-6.0 times, opercle especially long; teeth rather few, the second series weak, deciduous.

D. 11-13, short, erect, the longest rays equal to the length of the base; $\mathrm{A}$, 13-15, its elevation greater than the length of the base; P. 18-19, broad, triangular, the last rays diminishing, the longest ones more or less half way to the anal origin; C. large, broad, slightly emarginate.

Scales of the crown rather deciduous, with a scaleless area sometimes on either side of the back; granulations of scales not extreme, rather smooth; infraorbital, lower opercle, prepectoral, and a wide area on the venter, including anal basis, without scales. A pentagonal or subrhomboidal bony plate occupies the preorbital space to the maxillary; a similar pair of narial plates, roundly triangular, overroof the snout; the first nares much reduced, pore-like. Body scales tend to be much less regular than in most species. 
Caudal peduncle slender, not extremely compressed, its lowest elevation less than interorbital width, broadening at caudal basis.

Light to dark brown above, underparts yellow, the iris bright yellow, the opercle sometimes brilliantly iridescent yellow; a green tint sometimes seen on upper parts. The Lake Arapa specimens are of bright saffron underneath, perhaps indicating a recent spawning period, since the ovaries had the empty appearance. The fins are dusky.

Garman recognizes a variety of pentlandii from the Cuzco valley, $\frac{2}{3}$ as large, much darker on the back, above the lateral line. This he names fuscus. We have no evidence of the species extending beyond the Titicaca basin; fuscus may be accounted for as a mislabeling of the locality, or possibly large specimens of $O$. milleri.

Reported by Pentland under the colloquial name boguilla; in my experience it was always called boga, without the diminutive, unless for a small specimen. Garman learned the variant form bova. This, he believed, indicated a term of contempt, such as an hidalgo might have meant in speaking of common people as "cattle."

The species is wholly lacustrine in habit, unless there should be among our specimens unrecognized jureniles from streams. Garman reports it less abundant than $O$. cuvieri, just the opposite of my experience. He considers it next to the Pygidium rivulatum of the lake as a table fish.

Pellegrin's stomach examinations of his 21 specimens of about $200 \mathrm{~mm}$. showed little but plant tissues, with few molluscan fragments, and no complete shells.

\section{Orestias luteus Valenciennes \\ Plate XVIII, figs. 1 and 2}

Orestias luteus Valencionnes, 1839, L'Inst., VII, 118;

Cuvier and Valenciennes, 1846, Hist. Nat. Poiss. XVIII, 181;

Garman, 1895, Mem. Mus. Comp. Zool., XIX, 154;

Pellegrin, 1904, Bull. Soc. Zool. France, XXIX, 96;

Starks, 1906, Proc. U. S. Nat. Mus., XXX, 781;

Pellegrin, 1906, Poiss. Laes Hauts Plat. Anér. Sud, 126, 127, 134, fig. 19iv;

Eigenmann, 1910, Rept. Princeton Univ. Exped. Patagonia, III, 461;

Evermann and Radeliffe, 1917, Bull. U. S. Nat. Mus., no. 95, 12;

Rendahl, 1937, Ark. Zool. Stockholm, 29 \11.

\section{Lake Titicaca and its basin}

16079

16080 ,

Yuno bay, tllen, Torenber, 1918.

35-91

$16090,6,46-61 \mathrm{~mm}$., same.

$16091,39,32-54 \mathrm{~mm}$., same.

16095, 16, 33-172 mm., Lago Umaro, Alen, January, 1919.

16100 ,

16104

16105 ,

16110 ,

16123 ,

16127 ,
Guaqui, Lake Titicaca, Allen, December, 1918.

Yunguyo bay, Lake 'Titicaca, Allen, December', 1918. same.

ke Arapa, Allen, Decemler, 1918

Chupa, Lake Arapa, Allen, December, 1918.

Juliaca, Rio de Lampa, Allen, January, 1919.

Rio de Azángaro, Azángaro, Allen, Jànary, 1919. 
Widely disseminated within its narrower boundaries which appear to be about the northern fringe of Lake Titicaca and its more lacustrine tributaries, but not so generally distributed as $O$. agassizii or mulleri. One of the most extreme and distinctive species. The following paragraphs are descriptive mainly of my largest specimen, $172 \mathrm{~mm}$. in length, part of 16095, collected in Lake Umayo, at the foot of the mountain Atuncolla with its ancient ruins. (Fig. 42).

D. 13 ; A. 13 ; P. 20 ; C. 28 ; vertebral series 12 .

Head in length 3.3 and equal to greatest depth; its width slightly less, 3.5 in length; crown strongly convex, depressed at occiput; snout slightly greater than diameter of eye, which, although large, is contained in the large head 5.8 times; more than 2.0 in the broad interorbital; the orbit tangent to the crown, with a slightly prominent overhang; snub-nosed; head extremely angular; mandible vertical, gape horseshoe-shaped, front view, the rictus reaching little below the orbit; width of gape 1.0-1.4 in the interorbital.

Dorsal profile strongly arched from occiput to dorsal fin; chin blunt, mouth superior, thin-lipped, edentulous. Postorbital portion of head 1.7 times greater than snout plus eye, the broad opercle terminating in an almost right angle.

Scalation complete, no naked area on back; a row of bucklers elevated into a ridge above the opercle; well-developed granulations on the bucklers to the middle of the pectoral, more or less worn off at shoulder; remaining scales outlined with a brown, faintly granulate zone, which gives to the trunk a reticulate appearance; prepectoral with three rows of scales extending well below the base of the fin; sides also well-scaled, except for a naked patch extending from the belly up to the pectoral basis; dorsal, anal, and pectoral fin bases elevated and naked.

A large, fleshy, protuberant area encloses the vent, the openings prominent.

The fins are of the flexible, membranous, harsh type, with a brown membrane between rays. Dorsal and anal short, erect, rounded; caudal broader than long, slightly rounded; pectoral broad, rounded.

Younger specimens down to $30 \mathrm{~mm}$. in length show the predorsal hump and enlarged scales, without granulations. Width of the head only moderate, $1.3-1.5$ in its length, compared to 1.0 in the largest specimens, in which width, depth, and length are about equal. The smaller ones have a maximum body depth of around 3.3 as compared with 2.8 in the larger.

Profile of head nearly straight above, the frontal eminence not appearing in specimens of less than $150 \mathrm{~mm}$. Eye in head 4.0-4.8; in snout 1.0; in interorbital 1.8 ; those of intermediate size flat on the crown.

Caudal peduncle greatly elevated and compressed, equal to the postorbital part of the head; opercle more acutely angular in the young; mouth smaller, two rows of teeth still present and well developed up to the $100-\mathrm{mm}$. specimens, more or less obsolescent in those of $130 \mathrm{~mm}$. or larger.

D. $13-16 ;$ A. $14-15 ;$ P. $19-22 ;$ C. $27-28$.

General ground color at all ages a flat yellow, locally silvered, the scales becoming outlined in brown (in alcohol), and the general color darker above increasingly with age. 


\title{
479. Orestias olivaceus Garman
}

\author{
Plate XVIII, fig. 3
}

Orestias otivaceus Garman, 1895, Mem. MIs. Comp. Zool., XIX, 152;

Eigenmann, 1910, Rept. Prinecton Univ. Exped. Patagonia, III, 461;

Evermann and Radcliffe, 1917, Bull. U. S. Nat. Mus., no. 95, 42.

\section{Lake Umayo}

$3946 \mathrm{MCZ}, 1,84 \mathrm{~mm}$, cotype, Lake Tmayo, E. G. Squier, 1865.

My collections from this body of water contain no olivaceus, and Garman's description is ambiguous on the separation of olvaceus from albus. I experienced much confusion as to the boundaries of the two until Dr. Barbour kindly placed the above specimen at my disposal, when I was pleased to find what a clear-cut species olivaceus is after all. Despite its 76 years in alcohol, it is well preserved.

Of all the Orestias species this has the most horizontal dorsal profile, flattened on the crown, depressed slightly at the occiput, the predorsal gently convex, dorsal basis slightly elevated, peduncle a little concave; ventral profile greatly bent upward on the elevated chin and throat, leveling off on the belly, slightly concave from anus to base of caudal. General form short, moderately deep, depth equal to the length of the head, 3.0 in body length; compressed roundly, nowhere more than slightly angular; width at opercle 1.3 in length of head, the latter slightly broader than deep; head pointed and narrowly rounded at the chin. Mouth conspicuously superior, cleft to middle level of the eye; teeth small, a complete, clear-cut series in each jaw; eye rather small, elevated, equal to the short snout, 2.0 in the interorbital, 5.0 in the head. Caudal peduncle short, deep.

Infraorbital area without scales; cheek and opercle fully scaled; pre-pectoral area well-scaled to much below the level of the base of the fin, belly only narrowly naked; no desquamated areas on the back or sides; vertebral series complete with 13 ; body scales show growth-lines rather well, but roughened along these lines; granulations on scales of forward parts very moderate and rather scattered. Not as harsh to the touch as Garman's description would be understood to imply.

D. $15 ;$ A. $16 ;$ P. 21.

Fins short like body dimensions, but dorsal tip nearly reaching caudal base; anal almost as long; caudal peduncle and fin short and deep, fin subtruncate; pectoral broad, short, but reaching more than half way to the anal.

Color pale, yellowish-green; tinged with brown on the back, about fin-bases, snout, and thin lips. Few chromatophores anywhere, or at least few remain.

\section{Orestias albus Valenciennes}

Plate XIX, figs. 2-5

Orestias albus Valenciennes, L'Inst, 1839, VII, 118;

Cuvier and Valenciennes, 1846, Hist. Nat. Poiss., XVIII, 180, pl. 537;

Garman, 1895, Mem. Mus. Comp. Zool., XIX, 153;

Pellegrin, 1904, Bull. Soc. Zool. France, XXIX, 94;

Starks, 1906, Proc. U. S. Nat. MIus., XXX, 780; 
Pellegrin, 1906, Poiss. Laes Hauts Plat. Amér. Sud, 126, 136, fig. 19iii;

Eigenmann, 1910, Rept. Princeton Univ. Exped. Patagonia, III, 461;

Evermann and Radcliffe, 1917, Bull. U. S. Nat. Mus., no. 95, 42;

Rendahl, 1937, Ark. Zool. Stockholm, 29 A11.

Orestias neveui Pellegrin, 1904, Bull. Soe. Zool. France, XXIX, 95;

Eigenmann, 1910, Rept. Princeton Univ. Exped. Patagonia, III, 461;

Evermann and Radeliffe, 1917, Bull. U. S. Tat. Mus., no. 95, 42.

Lake Titicaca and affluents

16081 Puno bay, Lake 'Titicaca, Allen, November, 1918.

16091, 18, 3t-53 mm., Bay of Huancané, Allen, December, 1918.

$16120,1,76 \mathrm{~mm}$., Rio Caminaque, Allen, December, 1918.

16127, 4, 26-69 mm., Rio de Azángaro, Allen, January, 1918.

One of the species at least locally known as carache, but less numerous according to Garman, and less numerous in my collection than nearby luteus. Called also silgo according to the Indians of Moho, Garman reports.

Garman amplifies the original brief description as follows: "snout large, wide, and deep...teeth not as numerous nor as strong as those of O. cuvieri," which makes it doubtful if his specimens were albus. Further on he says: "the large snout ... distinguish it from $O$. luteus, breadth at the mouth makes the head less pointed," just the reverse of what I find in my specimens. I fear that either Garman or myself has interchanged these two species. Here as elsewhere much confusion has been injected into the literature by Valenciennes' figure and description. In fact, it is doubtful that he, himself, had $O$. luteus and albus clearly in mind, for he comments that Jussieu's drawing would fit the one about as well as the other.

Pellegrin separated his neveui from albus largely on the want of naked patches on the back. Since such areas appear occasionally on many species and with constancy in few or none, it is not of diagnostic value. Starks either considered this character important, or was "thinking aloud" about them in describing their variations at some length. His description of $O$. luteus is such as to make it clear that he had correctly separated the two species, except that he says the mouth is smaller.

In my collections I find four specimens of large size, and several smaller, which conform fairly well to previous concepts of albus, while my material on $O$. luteus is quite abundant, and from many localities, forming an unbroken series up to the blunt-nosed, 200-mm. specimens from Lake Umayo.

My specimens from the Azángaro, 61-67 mm., correspond very well to Valenciennes' figure in general form, length of head, shape of opercle, etc., differing in the form of the mouth, in the scalation of the pre-pectoral area and sides of the belly. They have the "clouded blotches" of Garman's younger specimens. 16120, a little larger, has the head wider, width equal to depth, and 1.3 in the length of the head; mouth narrower.

Rather strongly but evenly arched on the dorsal profile, highest above the pectoral base, depth 1.3 in the length of the head, slightly depressed at the occiput. Shorter, more robust, more rounded than $O$. luteus of equal size, nowhere as angular, 
wider at the opercle ( 1.4 compared with 1.6 ); head 3.0 in the length, as wide as long and equal to greatest depth of the body; eye smaller (4.6 as against 4.2), slightly oval, equal to snout (while in luteus of this size the eye exceeds the snout); eye in the interorbital width $1.7-2.0$ as compared to 1.3 . The mouth in these specimens is, as the authors state, vertical, wider than in luteus, the gape equal to the interorbital width; teeth much fewer, and in a single series, compared with a double rank in luteus. Opercle of about equal extent, but ending in a much less acute angle. Caudal peduncle shorter, squarely truncate rather than expanded at the base of the fin.

Preorbital scaled; cheek scales reaching to the anterior vertical from the eye, or nearly so; three vertebral series rather regular, 12 scales in middle series; granulations of anterior scales beginning to appear.

Numerous clumps of chromatophores falling into 2-3 longitudinal rows, forming a reticulate pattern. Dorsal and caudal fins from nearly hyaline to several broken rows of fine punctulations, very few on anal and pectoral. Head and shoulder scales darker about margins, with lighter centers.

Turning to the bay of Huancané, we find a series of smaller specimens, some of which are more slender, and may be luteus. In this age range the scales are more deciduous, the vertebral series more regular, 12-14, only the largest beginning to show any granulation of scales, the opercle often showing silvery through the still-thin scales. Colors similar. O. luteus of this size more arched on the nape, less robust, with more tapering caudal peduncle, lateral angle more acute, mouth more vertical and more deeply cleft, eye more elevated, larger, 4.3 in the head; crown flatter, overhanging the larger eye; snout shorter, 0.5 times the eye; more granulations begun on the enlarged scales; finrays all separated by a dark membrane; reticulated patches wanting.

16080, 4, 97-120 mm.. Puno, Allen, Norember, 1918

Separable from nearby $O$. luteus by the extreme breadth of the opercle, the pointed head, small, narrow much upturned mouth with fleshy lips, pointed snout, often greater convexity of the predorsal arch; shorter body, abruptly compressed. The chunkiest of all the species, with the most pointed head, the contours of a plummet.

Postorbital portion of the head 1.4-1.7 greater than the anterior moiety (end of snout to posterior border of orbit); opercle acutely angular; body becoming compressed rapidly from opercle to anus; caudal peduncle deep (but less so than $O$. luteus), its depth nearly equal to the postorbital portion of the head, shorter than the peduncle of luteus, widening less at the base of the caudal.

Mouth usually described as larger than that of luteus. This should be interpreted as meaning wider, but with the gape crescentic and not curved sharply downward into a horseshoe. Except possibly for $O$. olivaceus, the most superior mouth of all Orestias species; thick-lipped, almost without teeth, as described by Valenciennes.

These specimens may at least be reconciled with the much smaller ones above, 
since the difference might be accounted for by age; the mouth is similar, a rather unique character, the light-centered scales of the shoulder, size of eye, paucity of teeth.

Eye small, 5.5 in the head, rounded, equal to luteus in its distance from the end of the snout; eye without the protuberant supraorbital; width of head surpassing its depth; head 2.7 in body length; interorbital 2.7 times the eye; crown considerably elevated and convex in both dimensions, with a short, flatter area at the occipital; snout sometimes expanded to give the effect of a proboscis.

Scales similar to luteus in the extent and form of the granulations; resembling it also in the naked infraorbital, outlined by a row of pores, and snout naked; surpassing it in the investiture of the prepectoral, represented by Valenciennes with pectoral fin surrounded by a scaleless area, which Starks makes a diagnostic character; cheek scales barely reaching, not passing, the anterior level of the orbit. Vertebral series three, regular, as described by Garman, without lateral desquamated areas.

D. 14 ; A. $13-14$; P. 19 ; C. 28.

While $O$. luteus belongs to the parchment-finned group of species, those of albus are smaller, fleshier, more rigid in alcohol, thick-skinned, and heavily coated in mucus. Garman says they are medium, I should say small, with the dorsal basis less than its distance from the first caudal finray; pectoral broad; caudal deeper than long, its depth half that of trunk, while luteus exceeds half, and is conspicuously larger; I am unable to find 35 rays as did Valenciennes.

Sharing with $O$. luteus the extensible, muscular, unscaled vent region, as though used for oviposition.

Colors in alcohol varying from red-brown to gray-green and nearly black; fins colorless or nearly uniformly brown.

Garman was in error as to Lake Umayo, type locality, being without outlet. It drains by a small stream, the Rio Ilpa, to the bay of Puno.

481. Orestias silustani Allen, sp. nov.

Plate XIX, fig. 1

16097, 5, 55-86 mm., Lago Umayo, Allen, January, 1919.

Catalogued as 0 . olivaceus. Comparison with the cotype of the latter brings out numerous differences. They resemble one another in the extremely superior mouth and convexity of the ventral surface of the head. My type has an even straighter dorsal profile with less indication of a predorsal hump; like olivaceus the mouth and cheeks widely and roundly expanded, without the angularity of luteus, but the width of the head not equal to that of olivaceus; differing from it in the smooth, moderately thickened scales of opercle, without the granulations. Differing in the lack of the almost uniform green color of olvaceus. The type is of the same size as the olivaceus cotype, is more compressed, more tapering, with a slenderish caudal peduncle, body form much less expanded and robust.

My paratypes are sufficiently unlike the type to be mistaken easily for luteus 
or albus at first, and a considerable metamorphosis must be assumed between the stages here represented. They cast some doubt upon the validity, otherwise satisfactory, of the assortments of genes by which my two main branches of the genus are separated.

Dorsal profile very slightly and uniformly elevated from snout to dorsal fin, thence very slightly concave; ventral profile very convex from the elevated mouth to the throat, thence slightly convex, anal basis a little oblique; general form tapering from head to tail; caudal peduncle thinly compressed, rather short, not deep nor expanded at the caudal basis; width at opercle moderate, 1.6 in the depth, which is equal to the length of the head and $3.3 \mathrm{in}$ the length to the base of the caudal. Head much shorter than in olivaceus, 3.6 compared to 3.0.

Eye rather small, circular, elevated, 5.0 in the head, 2.0 in the interorbital space; mouth very superior, rather small, less than interorbital space; lips thin, teeth in one weak series in each jaw.

Scales striate, infraorbital sparsely scaled, scales of shoulder, cheek, and opercle only moderately thickened, lustrous; 15 scales in vertebral series; those of prepectoral area sparse, but postpectoral well scaled downward to a narrow naked band on the belly.

D. $14 ;$ A. $15 ;$ P. 20.

Origin of dorsal midway from occiput to caudal basis; fins small, thin, membranous, not roughened or fleshy.

Light gray to light brown above; whitish ventrally; conspicuously yellow on opercle; numerous small patches of minute chromatophores on the body; fins with staggered rows of fine, elongate punctulations, more regular on caudal, united into larger spots on the dorsal.

The smaller specimens, paratypes, were at first mistaken for luteus or albus, being more convex on the back, but are of more elongate form, and begin to show the smooth-scaled epaulettes of the miilleri group at the age when albus and luteus are taking on the granulate form of scale. Differing from albus of equal size in the color and much more compressed rather than rounded; unlike luteus in the less pointed lateral angle, more pointed and not truncate head, oblique gape, smaller eye, more elongate caudal peduncle.

The name silustani is that of the nearby Inca ruin on the shore of Lake Umayo, overlooking the weedy habitat from which the species was collected.

\section{Orestias empyraeus Allen, sp. nov.}

Plate XX, fig. 2

Central Peru; upland pampas, upper Mantaro

15232, many, 20-115 mm., Huancayo, Eigenmann, September, 1918.

15233, many, Jauja, Peru, Eigenmann, September, 1918.

15234, many, Pachachaca, Eigenmann, September, 1918.

15235, 1, 35 mm., R. Mantaro, Eigenmann and Allen, September, 1918.

15236, many, 25-63 mm., Zigzag, Allen, September, 1918.

$15237,22,27-94 \mathrm{~mm}$., 'Tilarnioc, Eigenmann, September, 1918.

15238, many, 16-150 mm., Lago Chinchaycocha, Allen, October, 1918. 
15239, 38, 18-114 mm., Rio de Junin, Allen, October, 1918.

15241, many, 24-78 mm., Lago Yanamate, Eigenmann, September, 1918.

15244, 6, 21-34 mm., Tuctu, near Morococha, Miss Heywood and Mr. A. S. Kalenborn, September, 1918 (elevation about 14400).

15245, Challhuacocha, near Quishuarcancha, Mr. Murdock, September, 1918 (elevation 13200 feet).

15246, Pocobamba, Adele Eigenmann and Mr. Emerson, September, 1918 (elevation 13700 feet).

15248, many, 25-65 mm., railway to Goyllarisquisga, Eigenmann, September, 1918.

Although impressed by the intense coloration and finely modeled form of these fishes while collecting them in the crystal waters of Chinchaycocha, against the

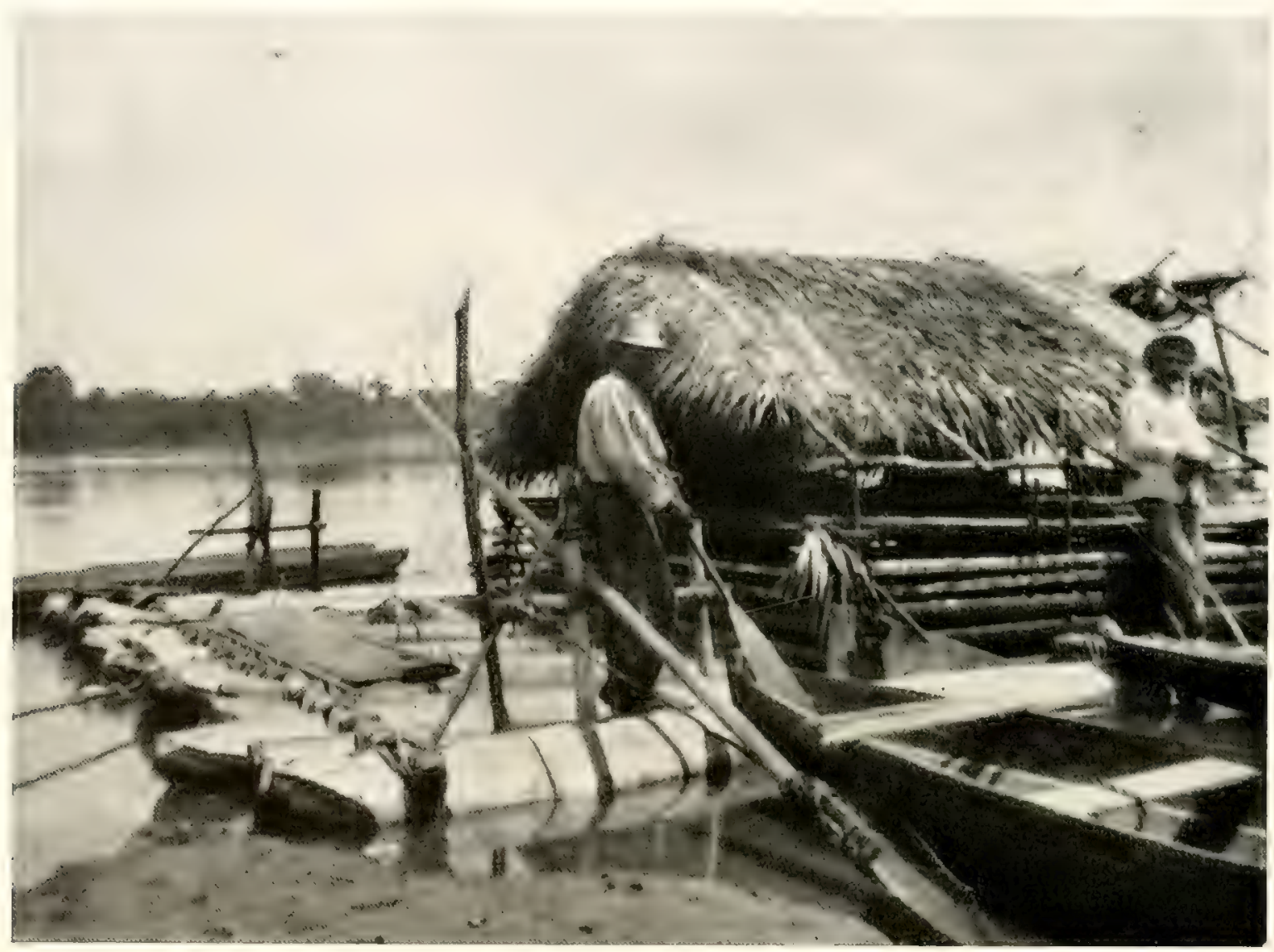

Fig. 44. The Colombian Charapero, or turtle-dealer, on the upper Peruvian Amazon. His raft is of Balsa-wood; his turtle-pen forms the ground-floor, his dwelling the upper story.

equally vivid green aquatic plants and sponge of the false bottom of that lake, I had been content to catalogue them as a variety of $O$. agassizii. Evermann and Radcliffe had so regarded the younger specimens of the nearby streams at La Fundición. Resuming the study of Orestias more recently I find these fishes very distinct from agassizii, or any other species, showing more resemblance to the specimens of intermediate size of var. inornata Pellegrin than to any other.

Comparing adult specimens with those of $O$. agassizii of equal range in size, I find them:

More elongate, narrower, with more rounded contours transversely; the width 
only slightly exceeding the length of the head, the dorsal profile straight, or nearly straight, on the head, while convex in agassizii; head pointed, its depth through center of eye less than that of caudal peduncle; mouth wider, equal to interorbital, lips thickened, fleshy; little enlargement or convexity of the shoulder scales; median fins more rectilinear, but caudal more rounded. Colors in alcohol, redbrown upper parts, merging into maroon below; fins unmarked or with dark band at base of dorsal and anal.

A comparison of smaller specimens reveals such differences as the following:

More elongate than $O$. agassizii, head more pointed; more rounded form; dorsal profile less convex; crown and snout narrower, interorbital space narrower; eye less oval; chin less vertical; fins larger in both dimensions, pectoral especially broad, median fins considerably broader, but caudal not so elongate in extreme young; colors begin early to differentiate as above. Thick lips are a good character for separating adults, but I do not find this consistent in the smaller specimens.

Considering the small size and juvenile character of the Valenciennes types, less than 4 inches, our young specimens of this species could readily be confused with them, especially with their great variation and the metamorphoses through which they pass.

I find the present species, by reason of its more minnow-like form and less specialized scales, to be nearer than 0 . agassizii to the primitive Orestias stock. Since nowhere in the northern range of the genus have we collected large specimens similar to the 0 . agassizii of Lake Titicaca, and since all the larger specimens taken in the north are identical with the present type, I am convinced of their complete isolation geographically. The great gorges of the Apurimac and other streams appear to be an effective barrier between them.

Description of the type, $120 \mathrm{~mm}$. long, Lake Chinchaycocha, (15238).

Dorsal contour straight on the head, faintly arched above the opercle, slightly convex to origin of the dorsal fin, descending slightly along its base to rectilinear caudal peduncle. Contours rounded, never angular. Caudal peduncle slightly longer than dorsal basis.

Width in depth 1.5, slightly greater than length of head, and 3.5 in body length; eye 4.8 in the head, equals snout, 1.4 in the interorbital space; head 3.7 in the body length; snout narrow, equals width of mouth and length of opercle; chin roundly pointed, mouth oblique, crescentic in front view, lips thickened and Heshy; teeth sparse.

Scales showing striae, becoming moderately thickened on forward parts, but well-embedded, not deciduous anywhere; scale-rows somewhat irregular on nape, head, and shoulder; nowhere polished or granular; few scattered scales on suborbital area; smooth, tightly embedded, but not dense, on cheek; similar, but eloser, on opercle; very few on pre-pectoral area; preventral widely exposed, more narrowly on post-ventral to anus.

D. $15 ;$ A. $14 ;$ C. 28.

The fins somewhat thickened, but scarcely fleshy, with coarse rays, somewhat roughened; dorsal and anal more rounded than in young; caudal somewhat broadened fanwise; pectoral broad, fan-shaped. 
Colors as mentioned above, most readily confused with O. agassizii var. inornata, such as those of Maravillas, but readily distinguished when brought together.

Garman's description of $O$. agassizii collected at Puno applies to larger specimens than the types of Valenciennes, and was intended to supplement the original description. This it does very satisfactorily as applied to my larger specimens. His description and that of Evermann and Radcliffe, the latter taken from small specimens in central Peru, and large specimens from southern Peru, fail to take into account larger specimens from central Peru, such as the present species.

The name empyraeus is in allusion to the extremely elevated habitat, mostly 10000-14000 feet, the species being at its best in Lake Chinchaycocha, elevation 13500 feet.

\section{Orestias elegans Garman Plate XX, fig. 1}

Orestias elegans Garman, 1895, Mem. MIus. Comp. Zool., XIX, 149;

Eigenmann, 1910, Rept. Princeton Univ. Exped. Patagonia, III, 461;

Evermann and Radeliffe, 1917, Bull. U. S. Nat. Mus., no. 95, 40;

Eigenmann, 1922, Mem. Carnegie Mus., IX, 184.

\section{Central Peruvian Andes}

15242, 46, 37-102 mm., small glacial lake, 15000-15500 feet elevation, near Casapalca, Peru, Eigenmann, September, 1918.

The only known Orestias of the Pacific slope; small lakes at the headwaters of the Rio Santa Eulalia, a small precipitous river arising just west of the continental divide near Casapalca; flowing into the Rimac above 3000 feet elevation and above the flume of the Chosica hydroelectric plant. Although populated at the sources, I found no fish life in the lower courses of the stream, near Chosica.

D. 15 ; A. 16 ; P. $16-18$; Ll. $34-36$.

Elongate, minnow form, ventral contour nearly straight, dorsal uniformly and moderately arched; head rounded above; eye usually circular equal to snout, more than 4 in the length of the head; H. 4.3 in length without caudal; greatest depth equals or exceeds length of head, and 3.75-4.3 in the length to the caudal.

Mouth small, nearly vertical, the cleft reaching below the level of the eye, its width 1.4 in the interorbital space; teeth small, hooked, in a complete single series.

$P$. short, not attaining to the midpoint from its origin to that of the anal; caudal only about the length of the head.

In form like an elongate $O$. agassizii, with the shoulder scalation more like that of $O$. mülleri, but without the widening of the body at that point; all other scales discernible small, weak, thin, mostly smooth; scales of cheek extending forward of the eye; few or none found in infraorbital region, which is encircled by a row of pores.

Specimens badly preserved, fins badly broken, all nearly devoid of scales, emaciated. Naked skin pale yellow, with red chromatophores on dorsal areas. 
Garman reports a $2 \frac{1}{2}$-inch specimen with well-developed eggs; some of mine had developed gonads at $70 \mathrm{~mm} .,(23$ inches).

15238 (part), 2, 85 and 92 mm., Chinchaycocha, Allen, Septemlser, 1918.

Two poor specimens of quite different nature from any other, at least near their own size, having somewhat the general form of mature $O$. agassizii, but much less robust, and differing in various respects; close to elegans in a number of ways, and since they were taken in contiguous territory to that of elegans, and are difficult to separate without better material, I place them here not too confidently.

Similar to elegans in the proportions of the head regions, mouth, teeth, eye, size of head, shoulder scalation, finray counts. Rather less slender and less circular in cross section, compressed; caudal peduncle measurably deeper.

Scales thin, flat, not much striated, deciduous, regular except upon the back; shoulder scales somewhat thickened, polished; in one specimen a dense group of scales in the infraorbital area; cheek well filled with close scales extending before eye; opercle similar except anterior horn.

Fins moderately long.

Yellowish-white below, sides yellow-brown, nearly uniform; fins hyaline without markings.

\section{Orestias agassiziI Valenciennes \\ Plate XX, figs. $3-8$}

Orestias agassizii Curier and Valenciennes, 1St6, Hist. Nat. Poiss., XVIII, 238, Corocoro, Bolivia;

Eigenmann and Eigenmann, 1891, Proc. U. S. Nat. Mus., XIV, 65;

Garman, 1895, Men. Mus. Comp. Zool., XLX, 150;

Steindachner, 1902, Denksch. KK. Akad. Wiss. Wien, LXXII, 58, pl. iii, fig. 3;

Pellegrin, 1904, Bull. Soc. Zool. France, XXIX, 93;

Starks, 1906, Proc. U. S. Nat. Mus., XXX, 780;

Pellegrin, 1906 (1907), Poiss. Laes Hauts Plat. Amér. Sud, 19, pl. xiv, figs. A-D;

Evermann and Radcliffe, 1909, Proc. Biol. Soc. Wash., XXII, 165;

Evermann and Radeliffe, 1917, Bull. U. S. Nat. Mus., no. 95, 40;

Rendahl, 1937, Ark. Zool. Stockholm, XXIX, A. 11;

Eigenmann, 1927, Mem. Nat. Acad. Sci., XXII, 52, pl. xiii, fig. 8.

Orestias agassizi Eigenmann, 1910, Rept. Princeton Univ. Exped. Patagonia, III, 461.

Orestias ortonii Cope, 1875, Jour. Acad. Nat. Sci. Phila,, 186.

Orestias frontosus Cope, 1875, Jour. Acad. Nat. Sci. Phila, 187.

Orestias owenii Garman (part), 1895, Mem. Mus. Comp. Lool., XIX, 152.

Orestias albus Garman (part), 1895, Mem. Mus. Comp. Zool., XIX, 153.

Orestias tirapatae Boulenger, 1902, Ann. Mag. Nat. Hist., (7), X, 153;

Eigenmann, 1910, Rept. Princeton Univ. Exped. Patagonia, III, 461.

Higher Andes of southern Peru to northern Chile

15239 (dupl. number), 22, 43-84 mm., Rio MIauri, Calacoto, Bolivia, Allen, February, 1919, (type locality Pellegrin's var. typica).

15219, many, Rio Mauri, Desaguadero, Allen, February, 1919.

15250, many, 50-85 mm., Rio Mulato, Bolivia, Allen, February, 1919.

15347, many, Lago Ascotan, Chile, Allen, February, 1919.

16060, many, same data.

16067, many very small, Lago Huaypo, Eigenmann, November, 1918. 
16089, 5, four small, 58-73 mm., one large, $180 \mathrm{~mm}$., bay of Huancané, Allen, December, 1918. 16093, many, Calacoto, Bolivia, Allen, March, 1919.

16101, many, small to minute, R. Colorado; Viacha, Allen, March, 1919.

16106, many, Rio de Juli, saline, Allen, December, 1918.

16108, many, Rio Colorado, Viacha, Bolivia, Allen, March, 1919.

16112, many, wet meadows, Pampa de Acora, Allen, December, 1918.

16114, many, 28-8 8 mm.,R. de Eucaliptus, Bolivia, Allen, January, 1919.

$16116,13,56-74 \mathrm{~mm}$, roadside pool near Juli, Allen, December, 1918.

16117, many,

16118,15 ,

16119, many, pools and creek, Ilave, Allen, December, 1919.

Rio de Ilave, Ilave, Allen. December, 1918

16121, many, millrace, Naravillas, R. de Lampa, Allen, November, 1918.

16122, many, 29-74 mm., Lagunillas, Allen, March, 1919.

16124, 20, 28-82 mm., R. de Lampa and lagoons, Allen, January, 1919.

16125, 18, 31-94 mm., Rio Grande de Lipez, Bolivia, Allen, February, 1919.

16126, 11, 40-103 mm., R. de Tiahuanáco, pond, Allen, March, 1919.

17867, many, 40-100 mm., R. de Santa Rosa, Eigenmann, December, 1918.

Puno mole, Allen, November, 1918
$-, 2,86$ and $117 \mathrm{~mm}$., Chucuito, Allen, November, 1919.

Puno mole, Allen, November, 1918.
$-, 2,86$ and $117 \mathrm{~mm}$. , Chucuito, Allen, November, 1919.

Of all the members of the genus this is the most widely dispersed and the most given to variation, a circumstance which has been a constant incitement to the creation of species and varieties. It has the greatest range, from the mountains about Cuzco and the passes of the western cordillera, throughout the Titicaca basin southward farther than other species to the southern extremity of the Bolivian and Chilean altiplano.* With two exceptions it is the nearest the primitive ancestral form, being little specialized from the ancestral minnow-like form, especially in the younger stages, and resembling in its juvenile stages those of other species, most if not of all. I have found it the most adaptable of all the Orestias, occurring in all types of marshy lands, streams and lakes. It has the greatest range in latitude, is found at higher and lower altitudes than any other, and has adjusted itself to all degrees of salinity and freshness of the waters of the interandine valleys. Hence the variations of form and color, especially of color. In some of the intermediate areas agassizii is replaced locally by other species, such as mülleri, their distribution being reminiscent of that of the two dominant tribes of the land, the Quichuas and the Aymarás.

Although not esteemed for food to the degree I have indicated for $O$. cuvieri and pentlandi, yet among the aborigines it is a food fish of considerable importance, despite its small size. The larger ones are marketed fresh, while the smaller ones are dried entire and are a reserve food for use when the fresh ones are unavailable. In the shops at Puno, Cuzco, La Paz, and elsewhere I encountered large burlap bags of dried Orestias agassizii (and the other small species) displayed with the tops of the bags rolled back, and standing about on the earthen floors among the still larger bags of the dried leaf of the coca plant.

Known today as in Pentland's time as the carache. This name Pentland varied as carachito, but I did not encounter the diminutive form except when young

* Eigenmann, 1927, page 5, correctly states that this species was found in Lake Ascotan. His caption under fig. 3 is in error in stating that 0 . agassizii extends down the western slope to the Rio Loa at Calama, which I found devoid of fishes now, although from the extensive tampering with that stream some former population may have been exterminated. 
specimens were implied. On Lake Titicaca I heard it called carache blanco to differentiate it from O. mülleri. Elsewhere the name challhua (meaning fish) appears to be sufficient. According to Garman carache, like bova, is a term of opprobrium, signifying also scab; a scabby sheep and its parasite both bear the name. Pentland reported from Corocoro the name purus, and locally I was given the name corbinita (of course borrowed).

One specimen of $63 \mathrm{~mm}$. contained a tapeworm of more than $100 \mathrm{~mm}$.

O. agassizii, and doubtless other related species, were frequently collected, upon which the frontal region bulged out in a very prominent manner. I dissected many of these in the fresh state, and found that the bulging affected the cranial bones, leaving an unusually large cranial cavity, and that the cavity was inhabited by swarms of minute larval trematodes, all about the brain. Many hundreds were collected and prepared by parasitological methods for the University of Illinois. Cope's description of his Orestias frontosus leaves no doubt in my mind that he was dealing with parasitized specimens of agassizii.

Garman found a number of specimens in Lake Umayo which he considered a "variety," and which he named O. affimis. They were small (up to $3 \frac{1}{4}$ inches), short and stout, light olive, but "spotted, freckled, blotched, and streaked" in the young, predorsal scales irregular, teeth in a band, outer series larger. In this description he forecast all the varieties soon to appear under the pen of Pellegrin.

Pellegrin described four "rarieties." They may be left at that, since they point out certain more or less definite types of color variation. His four categories are as follows:

Var. inornata, with uniform, solid greenish color and no punctulations on the fins.

Var. typica (from Corocoro, type locality of the species); color as in the preceding, but dorsal and caudal finely punctulate; a dark lateral streak, at least on the caudal peduncle.

Var. seneschali, with general color as in inornata, but with about ten dark blotches above the lateral line.

Var. crequii, with many small, deep, irregular blotches in 3-5 rows, parallel and longitudinal; they often touch, or coalesce along the lateral line; D. and C. punctulate; A. and P. whitish.

My examination of many hundred specimens brought to light all the types described by Pellegrin. Seneschali was rarely met with, the other three very commonly. But I am unable to accord them taxonomic value in any case. Intermediates were also frequent, obliterating the outlines between rarieties.

All the largest specimens could be assigned to inornata. The smallest specimen of inornata was $58 \mathrm{~mm}$. long, and that was very unusual, few of them falling under $70-80 \mathrm{~mm}$. Those found to be sexually mature were almost always inomata. All the small or minute specimens were spotted, usually crequii-like. The specimens of var. typica were usually intermediate in size.

Specimens taken in the red waters of muddy streams during the rainy season invariably were reddish in appearance, lightly pigmented, from saffron to pale 
brown. In these the fins were always lightly punctulate or not at all. Specimens collected from the clearer waters of Lakes Titicaca, Umayo, etc., were the most deeply colored and rich in var. inornata.

In large series it was often possible to arrange the specimens in order of size, and find that there was a rather regular transition from the crequii type through var. typica to inornata, the largest. One specimen of $70 \mathrm{~mm}$. still bore faint traces of the crequii spots, while the ovaries were becoming enlarged. The $70-90 \mathrm{~mm}$. specimens (one from Lake Ascotan at $65 \mathrm{~mm}$.) appear to be at the threshold of sexual maturity. The immature specimens are commoner in the smaller streams.

Resume: the study of numerous populations shows that Pellegrin's varieties are without the geographic isolation necessary to rank as subspecies. They are open to both genetic and ecological interpretation, and a definite correlation with age.

My collections from about Tirapata, Pucará, etc., reveal no trace of forms which I could identify as Boulenger's $O$. tirapatae, the region yielding only $O$. agassizii varieties and mülleri. His description, scale count, etc. would indicate that he had agassizii. Boulenger was influenced by the fact that his specimens attained sexual maturity at about $65 \mathrm{~mm}$., but my own specimens of agassizii (see above) were beginning to pass into the adult stage at little greater size.

Fishes of minnow form, elongate, moderately convex dorsal and ventral profiles, in older specimens highest at the occiput and tapering thence caudally; becoming much compressed with age; only moderate in width, without strong angularities. Width 1.4 in depth, the latter 3.3 in the length; head short, 3.4-3.7 in the length; eye 1.7-2.0 in the interorbital space; eye in head (smaller specimens) $3.7-4.4,4.8-5.3$ (in larger ones); the posterior margin of the eye midway of the head. Head convex both ways, mouth wide, vertical, thin-lipped, teeth sparse; snout both long and wide, containing the eye 1.5 times; the eye small and round. Tightly scaled except snout, no naked areas, little irregularity in scale rows except across the shoulders and predorsal; vertebral series $17-20$, usually irregular; narrow scaleless portion of venter often bridged by several rows of scales before vent; bucklers of cheek and opercle becoming thickened and denser with age; infraorbital with few or none in the young, but outlined by a row of pores; in older 6-12 close-set bucklers extending forward well beyond the orbit; bases of fins without scales. Opercle short with a wide lateral angle.

D. 13-15 (exceptionally 17); A. 15-16; caudal broad and truncate.

Colors as described above, and by Pellegrin; oldest specimens as described by Garman; darkest and lightest specimens equally devoid of spots or stripes

485. Orestias Mülleri Valenciennes

Plate XXI, fig. 1

Orestias mülleri Cuvier and Valenciennes, 1816, Hist. Nat. Poiss., XVIII, 179;

Garman, 1895, Mem. Mus. Comp. Zool., XIX, 149;

Eigenmann, 1910, Rept. Princeton Univ. Exped. Patagonia, III, 461;

Evermann and Radeliffe, 1917, Bull. U. S. Nat. Mus., no. 95, 40. 


\section{Lake Titicaca and adjoining waters}

1606t, 19, 30-80 mm., Rio Urubamba, Urcos, Eigenmann, December, 1918.

16071, 6, 70-90 mm., R. Huatanay, Iscuchaca, Eigenmann, November, 1918.

16073, 16, 38-84 mm., Rio de Langui, Eigenmann, November, 1918.

16075, 8, 70-83 mm., Rio Huatanay, Cuzco valley, Eigenmann, December, 1918.

$16076,14,23-139 \mathrm{~mm}$., Moho Bay, L. Titicaca, Allen, December, 1918.

16092, 11, 48-83 mm., R. Porque, Tirapata, Allen, January, 1919.

16095, 1, 109 mm., Lago Umayo, Allen, January, 1919.

16098, 48, 32-103 mm., Lago Poopó, Bolivia, Allen, February, 1919.

16099, many, 30-127 mm., Guaqui, Bolivia, Allen, January, 1919.

16110, many, 49-102 mm., Chupa, R. de Chupa, Allen, January, 1919.

16111, many, Rio de Chupa, 3 leagues up, Allen, January, 1919.

16115, many, 32-105 mm., R. de Huancané, Nllen, January, 1919.

16124, many, Juliaca, R. de Lampa, bayoux, Allen, January, 1919.

$16125,42,27-110 \mathrm{~mm}$., Juliaca, R. de Lampa, Allen, January, 1919.

$16127,18,42-82 \mathrm{~mm}$. R. de Molino, near Juli, Allen, December, 1918.

16128, 121, 25-80 mm., Azángaro, R. de Azángaro, Allen, January, 1919.

A wide-spread species resembling 0 . agassizu, although in younger stages usually darker, often much darker than any agassizii except the var. inornata, and similar in form; differing in the smaller mouth, striate scales, and flatter crown, not so evident in the young, the rotundity of the crown being doubtless sometimes a matter of trematode parasitism. The older specimens tend to be more compressed, with thickened scales more conspicuous on the shoulder, and not so widely distributed; head rather angulate.

I found $O$. mülleri most abundant in and about the southern extremity of Lake Titicaca, less so along the western border or in Puno bay, but found in many localities about the upper end of the lake with its northern tributaries, and across the divide in the upper Urubamba valley.

Known as the carache negro.

Dorsal and ventral contours rather regularly convex, caudal peduncle compressed, but not very deep, widening at the caudal basis; crown slightly convex or flat; head roundly compressed at the opercle, its breadth 1.4 in its length; snout roundly pointed; head medium length, 3.6-3.8 in maturer specimens, and nearly equal to depth which is $3.3-3.4$ in the length of the fish without the caudal; eye medium, 4.2 in the head, 2.0 in the interorbital space, just within the forward half of the head, slightly oval, 1.0 in the snout; the supraorbital forming a slight bony eyebrow; opercular opening forming approximately a right angle. Larger mülleri with a distinct, but rounded, ridge along the upper margin of the opercle and to the end of the pectoral fin.

Mouth rather small, oblique, gape a flattish crescent seen from front, becoming more horseshoe-shaped in the larger; lips present, not conspicuous; teeth rather few, dark, mostly in the first series.

Scales mostly faintly striate, those of the crown, cheeks, opercle, shoulder thickened, cornified, smooth; few infraorbital scales, irregular; scales of cheek roughly three rows; prepectoral area finely scaled or desquamated. Preventral naked between bases of pectorals, thence narrowly to anus; some individuals with a bridge of fine scales before the anus; upper and lower surfaces of caudal peduncle with several rows of fine, irregular scales; fins closely invested with scales; the 
specialized scales of the shoulder more or less identifiable in young specimens down to 30 or $40 \mathrm{~mm}$.

As in other species, scales are more easily shed in early life and become more regular and more firm in later life, especially after reaching maturity. A few specimens were found to have the naked patches on either side of the back, described for several other species. In many streams most specimens, especially the young, were taken with fins mutilated.

D. $13 ;$ A. 15 .

Dorsal base long, equal to its remoteness from the first caudal ray; its first rays short, increasing up to the eighth, the fin rounded posteriorly; the anal of similar form. Belonging to the group with thin, flexible, parchment-like fins, whose rays are light, the membrane dark between rays. In younger specimens the caudal is somewhat less elongate than in agassizii young, but similar in its being squarely truncate.

Younger specimens up to about $50 \mathrm{~mm}$. show considerable spotting, often with a lateral band, the irregular blotches falling into three longitudinal rows, the rows becoming concealed or broken in those of $60-80 \mathrm{~mm}$. Sexually mature individuals were found at $90 \mathrm{~mm}$. The older specimens become more compressed, and broader at the shoulder, and more uniformly colored with olivaceous or brown, some with fins clear, others not so dark, with four or five fine cross bars on the caudal. This series of color changes is very similar to that of 0 . agassizii. Also like the latter, specimens from muddy water tend to be much lighter, from saffron to light brown. Most specimens are bright silvery on the lower opercle, prepectoral, and preventral areas.

I found $O$. mülleri more abundant in lakes and less common in streams than O. agassizii. Also on more occasions I seem to have collected good series of all ages in a single locality. Are they less migratory in habit?

486. Orestias owenil Valenciennes

Plate XXI, fig. 2

Orestias owenii Cuvier and Valenciennes, 1846, Hist. Nat. Poiss., XVIII, 180;

Garman, 1895, Nem. Mus. Comp. Zool., XIX, 152;

Eigenmann, 1910, Rept. Princeton Univ. Exped. Patagonia, III, 461;

Evermann and Radcliffe, 1917, Bull. U. S. Nat. Mus., no. 95, 12.

Orestias agassizii Eigenmann and Eigenmann, 1891, Proc. U. S. Nat. Mus., XIV, 65.

Lake Urcos and Cuzco valley, upper Urubamba

15075, 8, 69-86 mm., Rio Guatanai, Cuzco, Eigenmann, December, 1918.

16063, 19, 35-112 mm., Lake Urces, type locality, Eigenmann, December, 1918.

Resembling $O$. mülleri, with similar smooth bucklers on the infraorbital, cheek, opercle, crown, and shoulder, but shorter and chubbier, more rounded about the anterior parts; chin more elevated; caudal peduncle moderate in depth, equal to the postorbital part of the head; like müller in color, light olivaceous above to light brown, yellowish below, all but the smallest uniformly colored. 
Dorsal profile rather strongly and uniformly convex to end of dorsal basis, and rentral profile to end of anal base; shoulder the widest part of the body, 1.4 in the length of the head; depth greater than head length, containing it 1.25 times; depth in length 2.8-3.4. A specimen of mülleri of equal length has the head about 0.8 as long, depth about 0.8 as great; in both the eye equals snout, and is contained 2.0 in the interorbital space, but this equality is due to the actually smaller eye of milleri, whose crown is considerably narrower. Eye 3.75-4.75 in the head, which slightly exceeds 3 in the short body length. Mouth broader, more oblique, gape flatter than in mülleri, crown equally convex.

Bony rather than scaled occiput; few scales on infraorbital; cheek scaled far in adrance of eye; finely scaled or desquamated on pre-pectoral; little regularity of vertebral series; a broad band of the belly fully scaled, otherwise naked; fin bases well enclosed by scales.

D. and A. $13-14 ;$ C. $23-25$, not 31 .

Fins rather short and erect, long-rayed, dorsal and anal appearing to be notched into the contours of the body, with oblique bases, and directed backward.

All but the smallest uniformly olivaceous above shading to yellowish below, and a silver-saffron on cheeks and opercles. A broad lateral band seen on some specimens freshly taken.

The species strongly developed along the lines of mülleri forward, weaker caudally, a short-hitched modification of the former with more rounded contours generally.

\section{Orestias jussiei Valenciennes \\ Plate XXI, fig. 3}

Orestias jussiei Curier and Valenciennes, 1846, Hist. Nat. Poiss., XVIII, 176, pl. 535;

Castelnau, 1855, Anim. Amér. Sud, Poiss., 51, 52, pl. xxrii, fig. 3;

Günther, 1866, Cat. Fish. Brit. Mus., VI, 329;

Eigenmann and Eigenmann, 1891, Proc. U. S. Nat. Mus., XIV, 65;

Eigenmann, 1910, Rept. Princeton Univ. Exped. Patagonia, III, 461;

Evermann and Radcliffe, 1917, Bull. U. S. Nat. Mus., no. 95, 42.

Orestias jussieui Garman, 1895, Mem. Mus. Comp. Zool., IIX, 155.

Rio Guasacona; Rio Chinchero, near Cuzco

15066, 42, 30-85 mm., Lago Chinchero, Adele Eigenmann, December, 1918.

A clear-cut and striking species of the smooth-scaled division of the genus, characterized by the shorter, deeper form, the vertical chin, great and uniform convexity above, and the more complete, closer investiture of scales on anterior parts.

The author's description is clearer than nearly any other, although his figure is inaccurate in some respects.

In its general configuration $O$, jussici appears to be easily derived from mülleri which it resembles: in the specialized scales of the head and shoulder, except as to their extent; in the regularity of the scale rows on the latter half of the body; in the slender proportions of the caudal peduncle; in the narrow snout and mouth. 
They differ in the depth; the verticality of mouth and chin; the greater size of the eye in jussiei; the extension of the enameled bucklers to enclose nearly all the anterior half of the fish. Our specimens more consistently dark than the dark carache negro.

Dorsal profile strongly and evenly arched from the eye to the end of the dorsal basis, thence slightly concave; ventral profile only perceptibly convex to the origin of the anal fin, whose base forms a reëntrant angle with the straight, elongate caudal peduncle. The box-like form of the forward parts, with the rudder-like caudal apparatus is reminiscent of some of the trunk- or box-fishes. The greatest depth in the vertical through the pectoral base, nearly equal to the length of the head in the smaller specimens, exceeding that measurement in the good-sized ones, 2.7-3.5 in the length. Little expanded at the shoulder, contours rounded, width 1.2-1.4 in the head, 4.2-4.6 in the length. Caudal peduncle short, but narrow, its depth equal to the postorbital portion of the short head.

Head rather short, although but 3.3-3.7 in the moderate length; crown convex in cross section, slightly to considerably depressed before the eye; snout narrow, rather pointed; chin deep, truncate, vertical, mandible equal to interorbital space; mouth vertical, not usually cleft so deeply as indicated by Garman; teeth numerous, close-set in double ranks; eye large, elevated, round or but slightly oval, 4.0-4.3 in the head, orbital bones forming a prominent ring; cheek more squarely angulate below than other species; opercle wide-angled, slightly eared.

Scales thickened, cornified, smooth, close-set; crown completely armored; 3-6 infraorbital scales, variable; cheek scaled in three rows; naked areas sometimes along sides of back; vertebral series 13-14; prepectoral scales generally dehiscent, and differing also from Valenciennes' figure in that the naked preventral area extends to the base of the pectoral fin; many with more or less complete scalation on venter, with the flattened preventral area back of the isthmus bearing a band of scales.

Fins of the flexible, parchment type; origin of the dorsal fin slightly nearer the caudal basis than to occiput; dorsal and anal rather small, both 13-14; caudal rather long, especially in the young, 28-30; pectoral 15-16, long, narrow, reaching considerably beyond half way to the origin of the anal fin.

The young begin to be identifiable at $40 \mathrm{~mm}$., lighter, more slender, less elevated.

This species and $O$. owenii share between them the property of having the anterior half more developed, the caudal half weak; differing in the longer, more rounded snout, less elevation, smaller eye, rounded chin and convex ventral contours, feeble armament, of owenii.

Colors uniform dark brown on dorsal and caudal parts, a faint lateral stripe, greenish-yellow below, brightest on cheek, opercle, and shoulder; fins uniformly light-rayed with darkened membrane between rays.

Valenciennes' record from Lake Titicaca is doubtful.

Known to inhabitants as Ispi, or Hispe. 


\section{Orestias tschudi Castelnau \\ Plate XXI, fig. 4}

Orestias tschudii Castelnau, 1855, Anim. Amér. Sud, Poiss., 51, pl. xxrii, fig. 1;

Pellegrin, 1904, Bull. Soe. Zool. France, XXIX, 92;

Pellegrin, 1906, Poiss. Lacs Hauts Plat. Amér. Sud, 127, 129, fig. 19ii;

Evermann and Radcliffe, 1917, Bull. U. S. Nat. Mus., no. 95, to.

Orestias agassizii Eigenmann, 1910, Rept. Princeton Univ. Exped. Patagonia, III, 461.

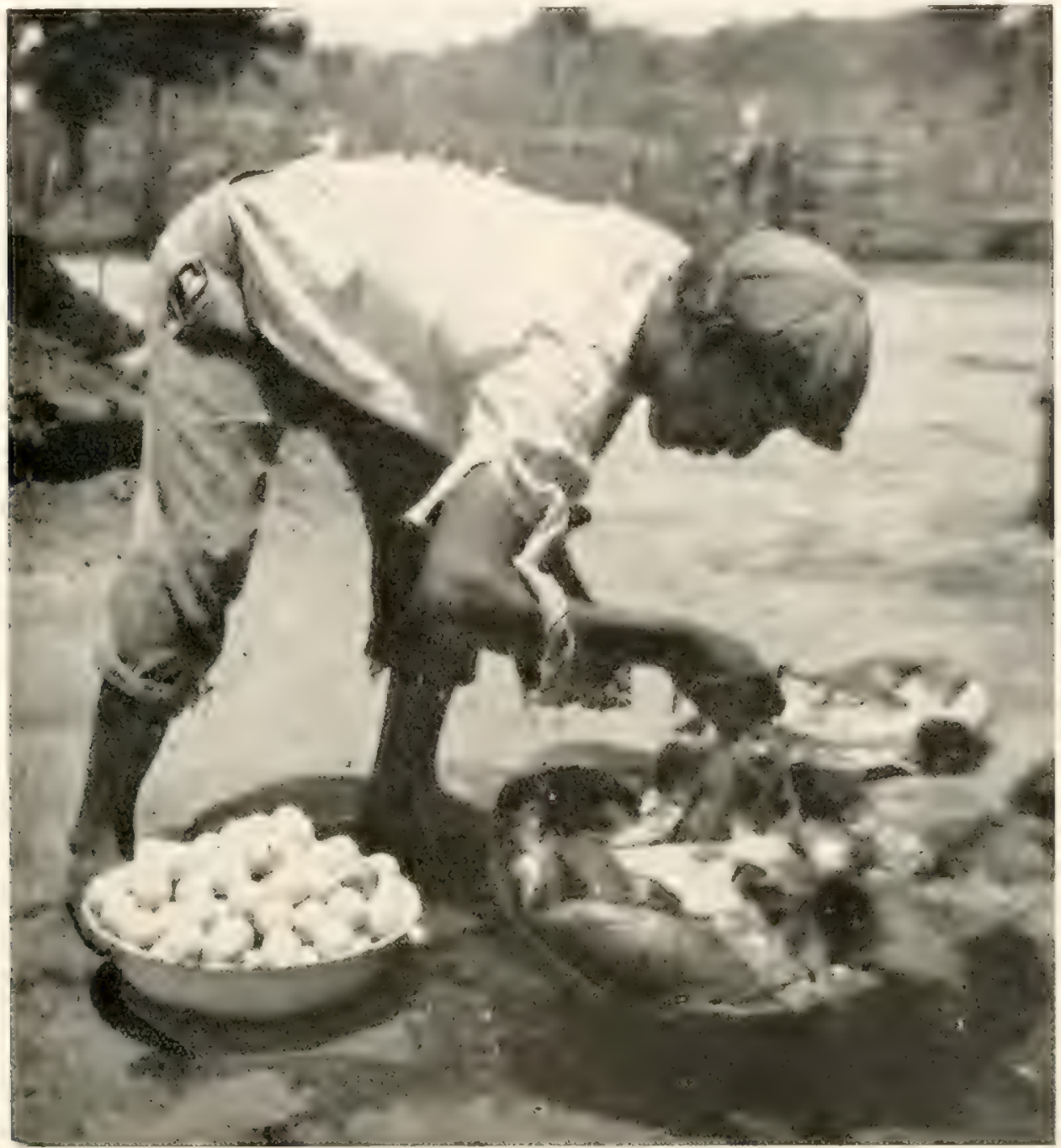

Fig. 45. Foraging for fresh meat and turtle eggs to be used aboard the steam-launch. Hercules.

Lakes Titicaca and Umayo

16095, part, 8, 52-114 mm., Lake Umayo, Allen, January, 1919, $16097,5,67-102 \mathrm{~mm}$., Lake Umayo, Allen, January, 1919.

Specimens collected by a Mr. Weddell in Lake Titicaca were named and very briefly described by Castelnau, and not seen in subsequent collections. Most 
writers have not recognized the species as more than a variant of the versatile agassizii. I have one specimen, the largest named above, which corresponds definitely to the brief synopsis and to the figure of Castelnau, a fine specimen for which I take pleasure in reviving the name tschudii.

Two of the 16095 are of moderately erect form, the largest extremely elevated. Taking my description from the largest we find it:

Much compressed, well-armored in large, close-set scales, regular on the after parts, and enlarged, less regular, cornified on the forward parts. Dorsal contour straight on head, greatly arched and highest above the pectoral basis, nearly straight thence to the caudal peduncle; ventral profile of uniformly slight convexity to the anal basis, thence obliquely by the anal basis to the straight caudal peduncle.

Depth 2.8-3.5; width moderate, 1.4-1.7 in the depth, 1.3-1.4 in the length of the head; caudal peduncle deep, exceeding considerably the length of the postorbital head region. Head rather large, 3.3-3.5 in the length; eye well in advance of the center of the head, elevated, large, slightly elongated, its bony orbit prominent, equal to snout, $4.5-5.0$ in the length of the head, 1.8 in the interorbital space; snout angular, pointed roundly in profile; mouth narrow, cleft deeply below orbit, horseshoe-shaped in front aspect, thin-lipped, with a series of unusually prominent teeth; cheeks not at all swollen.

Scales nowhere conspicuously striate, becoming thickened, cornified, irregular on head and 6-7 scale-rows on and about the lateral line beyond the opercle; investiture complete. Few scattered scales on the infraorbital space; cheek to beyond the eye, and the opercle, except its anterior horn, heavily scaled; prepectoral only lightly and incompletely so; preventral broadly, and postventral narrowly scaleless; vertebral series 13-15, three series regular. Smaller specimens more müller-like, more deciduous.

D. $13-15$; A. $13-15 ;$ P. 17.

Fins of exceptionally large size, longer than deep, not rounded as in most species; dorsal basis, beginning at midway-point of the trunk, exceeds its distance from the first caudal ray; pectoral more rounded, and reaching beyond the midwaypoint to the anal origin.

Alcoholic specimens still show an olivaceous color, especially on the bucklers, shading into yellow-green, and then yellow on the opercle, and to brown on the back, brown on the scale-margins of the sides and after-parts. Many scales of the dorso-lateral area with lighter centers, bordered with dark. Fins darkened between radii, especially near the bases; no spotting of fins except, slightly, the pectoral.

The smallest of the three best specimens differs from the other two in the much more rounded back, more pointed snout, fewer teeth, fleshy lips, and smaller, more circular eye. The largest is notable:

In the size and position of the eye, form of the mouth, scalation, fin-characters, colors, there is much resemblance to jussiei; differing from the latter in the greater compression, more moderate width at the shoulder, deeper, shorter caudal peduncle, and in the largest specimen, the abrupt angle in the dorsal contour above the base of the pectoral fin. 
489. Orestias Rospigliosir Eigenmann and Allen, sp. nor.

12290, 5, largest, type, 53 mm., Rio Languí, Peru (above 12,000 feet) Eigenmann, December 8, 1918

Head 4.0-4.2; depth 5.33-5.5; D. 13-14; A. 14-15; eye 2.4-2.75; interorbital 4 in the head, snout rery little more than half the eye in length; mouth small, very oblique; mandible vertical, forming a right angle with the lower surface of the head, equal to snout and half the eye.

Scales small, mostly lost, about 15 between the middle of the anal fin and dorsal; origin of the dorsal fin nearer to the base of the caudal than to the eye; origin of the anal fin about opposite to the origin of the dorsal; depth of the caudal peduncle $2.5-3.0 \mathrm{in}$ its length.

For our friend Dr. Carlos Rospigliosi y Vigil, director of the Zoological Museum of the University of San Marcos, leader of the University's expeditions into the Chanchomayo, member of the army medical corps, and of the army hospital staff.

Having been unable to find the types, the description is incomplete, and I do not know where the species belongs.

\section{Order SYNENTOGNATHI}

\section{Family XIX: Belonidae}

\section{Genus 196: POTAMORRHAPHIS Günther}

Potamorrhaphis Günther, 1866, Cat. Fish. Brit. Mus., VI, 234;

Eigenmann and Eigenmann, 1891, Proc. U. S. Nat. Mus, XIV, 66;

Eigenmann, 1910, Rept. Princeton Univ. Exped. Patagonia, III, 463;

Eigenmann, 1912, \Iem. Carnegie Mus., $V, 461$.

Type: Belone taeniata Günther = B. guianensis Schomburgk

Guiana to Peru and Paraguay

Greatly elongated, needle-shaped fishes of small size, with snout greatly prolonged; dorsal rays subequal in length, anterior ones not forming a lobe.

\section{Potamorrhaphis guianensis (Schomburgk)}

Belone guianensis Schomburgk, 1843, Fish. Brit. Guiana, II, 131, pl. i.

Potamorrhaphis guianensis Eigenmann and Eigenmann, 1891, Proc. U. S. Nat. Mus., XIV, 66;

Eigenmann, 1910, Rept. Princeton Univ. Exped. Patagonia, III, 463;

Eigenmann, 1912, Mem. Carnegie \Ius., V, t61;

Fowler, 1919, Proc. Acad. Nat. Sci. Phila., LXXI, 6, Yauta;

Fowler, 1939 (1940), Proc. Acad. Tat. Sci. Phila., XCI, 278, two, 146 and $195 \mathrm{~mm}$., Contamana.

Belone scolopacina Cuvier and Valenciennes, 1846, Hist. Nat. Poiss., XVIII, 428;

Günther, 1866, Cat. Fish. Brit. Mus., VI, 256.

Belone taeniata Günther, 1866, Cat. Fish. Brit, Mus, VI, 256;

Cope, 1878, Proc. Amer. Phil. Soc., XVII, 695, Rio Maranon. 


\section{The Guianas to Peruvian Amazon; Rio Paraguay}

15811, 1, $220 \mathrm{~mm}$., Rio Morona, Allen, October, 1920.

15815, 1, 161 mm., Rio Pacaya, Allen, August, 1920.

A marine relict reaching the extreme western margin of the Amazonian flood plain and the fringes of the Andean highlands.

\section{Genus 197: TYLOSURUS Cocco}

Tylosurus Cocco, 1833, Giom. Sci. Lett. Sicilia, XLII, no. 124;

Eigenmann and Eigenmann, 1891, Proc. U. S. Nat. Mus., XIV, 65;

Jordan and Gilbert, 1882, Bull. U. S. Nat. Mus., XVI, 372;

Eigenmann, 1910, Rept. Princeton Univ. Exped. Patagonia, III, 462.

Type: Tylosurus cantraini Cocco $=T$. acus Lacépède and Esox imperialis Rafinesque

Both coasts of the Americas; West Indies; rivers

Greatly elongate, subcylindrical; both jaws extended into a beak, the lower somewhat the longer; teeth of both jaws in bands, one band of small, sharp teeth, another of larger, unequal, conical ones; maxillaries and premaxillaries united; scales small, deciduous; lateral line along the belly, median on the tail; separated from Belone by lack of gill-rakers and vomerine teeth.

\section{Tylosurus amazonicus (Steindachner)}

Belone amazonicus Steindachner, 1875, Sitzb. KK. Akad. Wiss. Wien, LXXI, 66.

Tylosurus amazonicus Eigenmann and Eigenmann, 1891, Proc. U. S. Nat. Mus., XIV, 65;

Jordan and Evermann, 1896, Bull. U. S. Nat. Mus., XLVII, i, 712;

Eigenmann, 1910, Rept. Princeton Univ. Exped. Patagonia, III, 462.

Para to Peru

15812, 2, 180 and 212 mm., Rio Paranapura, Yurimaguas, Allen, November, 1920.

15813, 2, 95 and $110 \mathrm{~mm}$., Gosulimacocha, Allen, October, 1920.

16161, 2, 40 and 52 mm., Rio Pichis, Pto. Bermudez, Allen, July, 1920.

None of the familiars of the frontier post at Puerto Bermudez, so far as could be ascertained, had ever seen a specimen until they were shown my collections. At this point they are separated by more than three thousand miles of fresh water from their salt-water kindred.

\section{Order ACANTHOPTERI \\ Family XX: Nandidae}

\section{Genus 198: MONOCIRRHUS Heckel}

Monocirrhus Heckel, 18t0, Ann. Wien. Mus., II, 439;

Günther, 1861, Cat. Fish. Brit. Mus., III, 371;

Eigenmann and Eigenmann, 1891, Proc. U. S. Nat. Mus., XIV, 66;

Eigenmann, 1910, Rept. Princeton Univ. Exped. Patagonia, III, 466. 
Type: Monocirrhus polyacanthus Heckel

Rios Negro, Cupai; Guiana; Marañon

Spiny rayed fishes of small size; body extremely compressed; dorsal and anal fins long with serrate margins, erect; soft dorsal and soft anal fins with vertical bases and hyaline, similar in both shape and color to the caudal; snout very long and sharply pointed; the mandible extending beyond snout, with a barbel; premaxillary with a long spine equal in length to the mandible; eye large, 4 in the head.

\section{Monocirrhus mimophyluds Eigenmann and Allen}

Monocirrhus mimophyllus Eigenmann and Allen, 1921, Biol. Bull., XLI, 5, 301-305, figs. 1-3.

Monocirrhus polyacanthus Fowler, 1939 (1940), Proc. Acad. Nat. Sci. Phila., XCI, 279, one, $71 \mathrm{~mm}$. Contamana.

This specimen may belong here, as should be expected.

$15715,3,44-51 \mathrm{~mm}$, to base of caudal, brook near Rio Itaya, Iquitos, Allen, September, 1920.

A leaf-mimicking species of spiny-rayed fishes was described by Heckel in 1840 (Johann Natterer's Neue Flussfische Brasiliens). It was given the name Monocirrus polyacanthus, and later joined with Polycentrus to form the family Polycentridae, by Günther. Scientifically it then went into complete desuetude for eighty years, although Dr. Myers informs me it was later rediscovered in Guiana and reported in certain aquarium journals, he himself having noted its occurrence at Rockstone and in the Essequibo.

On account of the imperfect original description, without any illustration, we were uncertain as to the exact identity of our specimens with Heckel's species. The wide distance separating our locality from the original source on the Rio Negro, a thousand miles to the eastward, made reasonable the assumption that they were not identical, even though similar. Hence the paper of 1921 describing our three specimens as M. mimophyllus. As far as one could tell from Heckel's account, the identity might still be uncertain.

Meanwhile, since 1921, the leaf-mimic has again come to light in the collections of dealers in tropical fishes, imported into Germany and thence to the United States. Here it is reported as having been successfully propagated in aquaria, and its habits much more fully described. I have unsuccessfully attempted to procure specimens of these importations for comparison with our types. Mr. Innes's halftone of polyacanthus appears very similar (Innes, 1933; ibid, 1935). However, the source of his material is not made known. The source of commercial collections is usually very indefinite. Whether the commercial species of unknown source is the same as $M$. polyacanthus or mimophyllus, or both, or neither, is not yet positively demonstrated.

Dr. Myers has examined a good series of Monocirrhus from the dealers. He assures me that there is but one species, polyacanthus. He does not state where the specimens came from originally. He is sure our specimens are not different in any respect.

However, the Innes photographs (1933, p. 7, and 1935, p. 335) both clearly 
show about 16-17 spinous rays in the anal fin, where our specimens have but 12 (at most 13). His description does not allude to the ashen markings seen in mimophyllus, nor do they appear in the photograph from life.

Mr. Innes's illustrations show a specimen with mouth distended, clarifying better than our fig. 2 (1921 paper) the significance of the unusual visceral skeleton.

It is of interest to note here that the Agassiz in their book, A Journey in Brazil, pages 161 and 238, make allusion to certain fishes of the Amazon which are mimics of dead leaves. These they assign to a family Folhidae, a Portuguese word latinized. The derivation of the name is quite appropriate, but I have found no evidence that it ever attained proper standing.

THE PRESENT STATUS OF THE THEORY OF MIMICRY

McAtee and others have recently held up for much adverse criticism the entire matter of mimicry in animals. The ground for their antagonism seems to be the fact that animals possessing it do not appear to enjoy a measurably higher survival rate in Nature than others. We are constrained, they say, to reject the doctrine entirely. If other animals not so protected live as long on the average, the species has not been subjected to the operation of Natural Selection, and no mechanism other than random selection has brought about the infringement of copyright.

So far as it reaches, the argument mentioned is very convincing, and doubtless completely satisfying to many good zoologists. However, should the term mimicry fall into complete disuse and be forgotten, we still have a phenomenon needing a name, one of the most vivid and interesting in all the realm of Nature. Perhaps a better name will be forthcoming, but likely not if we are looking for a term which will explain the phenomenon to the general satisfaction of the zoological world.

We do have a well-known phenomenon. Certain animal forms do show a clear-cut resemblance to other objects in their environment. We do have a masquerading act whether we like it or not, and whether we can explain it or not. This masquerade goes on in the immediate vicinity of the object which is imitated, and not at remote, unrelated points. Perhaps the greatest objection to the word mimicry is the fact that it seems to imply psychic factors, that the imitator exercises a voluntary control of its own evolution. We are unable to understand the intermediate steps by which the mimic has arrived at perfection, except as a long line of consciously-directed mutations or gradations.

This phylogeny cannot be shown to have had psychic elements; it has not been demonstrated that mimicry has effective selection value; its processes are not known, nor are the respective cases of mimicry known to have arisen in the same manner. $\mathrm{My}$ thesis here is to defend the use of the name until its true name shall have been revealed.

At this juncture it would appear that what we need is a new definition rather than a new provisional name, since no new explanation is available.

We might raise some inquiry as to the occurrence in Nature of intermediate stages in the evolution of this at least quasi-mimicry. For such mimicry-in-the- 
making we might consider the numerous classical examples of protective form, such as that of the walking-stick, and protective coloration, applied in some measure to most animals. In none of these cases would we speak of them as mimicry. These factors exist in greater or less perfection, either protective form alone, protective coloration alone, or in varying degrees in combination. Species with colors blending with those of the background, and more or less unusual body form also resembling the animal's background, are not at all uncommon. We may still be unable to consider them as good examples of mimicry. They may be only good cases of protective resemblance.

Protective resemblance may be thought of as a good name for a phenomenon consisting of elements in varying degrees of perfection called protective coloration and protective form, which are doubtless associated with discrete genes.

In the most perfect cases of protective resemblance it might be argued that they have reached the threshold of actual mimicry, but for the sake of a definition let us say that they fall just short of it, that they lack the psychic element. Yet Nature affords examples in which the psychic factor is as evident as in the small boy in the policeman's costume. Many animals assume attitudes and go through movements similar to the models after which they are formed. A third factor climaxes the whole drama, that of protective behavior. An animal species resembling some other object in its environment in form, color, and behavior is a very good mimic, whether or not we have a sufficiently broad view of its evolution to understand the steps by which it came into being. Whether or not we may say that the species as a whole has responded to the model after which it is patterned, or that its evolution has been directive, still the individual member of the species does consciously imitate the model in its behavior. The psychic factor is the "priceless ingredient" which finishes our definition of mimicry.

We might put the meaning of the above paragraphs as follows:

Protective form

Protective coloration. Protective resemblance Protective behavior... Mimicry

Monocirrhus is a form which admirably exemplifies all the factors of mimicry. It is true that a photograph, a dead specimen, or a drawing may not be especially convincing, even to an open mind. The scholar in the museum, the laboratory, or the library might well remain skeptical as to this performance. We may concede that seeing the living fish in an aquarium might also fail to convince. But in the natural background of the forest pool, with its bottom strewn with dead leaves, and the fish in the midst of them, there is no room for doubt as to the actuality of the phenomenon.

Dr. Julian Huxley recently wrote (Cott; Adaptive Coloration in Animals, Preface): "Among a certain section of experimental biologists, any time in these last thirty years, it has been fashionable, and indeed almost a matter of professional conscience to display a radical skepticism on the subject of adaptations, especially 
colour adaptations, and most particularly mimetic adaptations. Upholders of the theories of protective and warning coloration and of mimicry have often been attacked as 'armchair theorists' (whereas they have in fact almost invariably been first and foremost field naturalists) insufficiently acquainted with modern work in genetics, which for some unexplained reason is held to do away with adaptive interpretations. Dr. Cott has .. . shown that it is they who are the armchair critics...."

It is not my purpose here to enter the debate among worthier contenders, but rather to bear witness as to the validity of a natural phenomenon which few men have been privileged to see at its best, a phenomenon which even the unclad savage has observed, and given his testimony in calling the fish "pira-caá-a," or leaf-fish.

\section{Family XXI: Sciaenidae}

\section{Genus 199: PLAGIOSCION Gill}

Plagioscion Gill, 1861, Proc. Acad. Nat. Sci. Phila., 82;

Jordan and Eigenmann, 1886 (1889), Rept. U. S. Fish Comm., 380;

Eigenmann and Eigenmann, 1891, Proc. U. S. Nat. Mus., XIV, 67;

Eigenmann, 1910, Rept. Princeton Univ. Exped. Patagonia, III, 467;

Eigenmann, 1912, Mem. Carnegie Mus., V, 471.

Type: Sciaena squamosissima Heckel

Atlantic drainage from R. Magdalena to La Plata

Skull not excessively cavernous nor lacking in firmness; preorbital not turgid, interorbital space moderate; teeth not villiform, more or less unequal, upper teeth in two series, the inner somewhat the larger teeth; pseudobranchiae small; lateral line scales the largest and overlapped by the smaller ones.

\section{Plagioscion squamosissimum (Heckel)}

Sciaena squamosissima Heckel, 1840, Ann. Wiener Mus., II, 132.

Diplolepis squamosissima Steindachner, 1863, Sitzb. KK. Akad. Wiss. Wien, XLVII, 2;

Steindachner, 1882 (1883), Denksch. KK. Akad. Wiss. Wien, XLVI, 1.

Pachyurus squamosissimus Günther, 1860, Cat. Fish. Brit. Mus., II, 526.

Plagioscion squamosissima Gill, 1861, Proc. Acad. Nat. Sci. Phila., 82;

Jordan and Eigenmann, 1886 (1889), Rept. U. S. Fish Comm., 381;

Jordan and Evermann, 1898, Bull. U. S. Nat. Mus., no. 47, II, 1418;

Eigenmann, 1910, Rept. Princeton Univ. Exped. Patagonia, III, 468;

Fowler, 1939 (1940), Proc. Acad. Nat. Sci. Phila., XCI, 280, five, 140-210 mm., Contamana.

Plagioscion squamosissimum iquitensis Nakashima, 1941, Bol. Mus. Hist. Nat. Lima, V, 68.

Johnius crowina Castehau, 1855, Anim. Amér. Sud, Poiss., 11, pl. v, fig. 1.

Johnius amazonicus Castelnau, 1855, Anim. Amér. Sud, Poiss., 12, pl. iv, fig. 1.

Peruvian Amazons to Guiana

16146, 1, 125 mm., Gosulimacocha, Allen, October, 1920.

16147,3 ,

$161+8,1,180$ mm., Manaos, Allen, December, 1920.

16149,1 ,

16150,5 ,

, creek near Yurimaguas, Allen, November, 1920.

, Iquitos, R. Nanay, Allen, September, 1920.

- Iquitos, Amazon, Allen, September, 1920. 
The largest of the above specimens was $250 \mathrm{~mm}$. The species is known throughout the Amazons, the Orinoco basin, and the Guianas. It is another of the relict marine ichthyfauna of the Amazon.

\section{Plagioscion auratum (Castelnau)}

.Jolnius auratus Castelnau, 1855, Anim. Amér. Sud, Poiss., 12, pl. iv, fig. 2, Rio Ucayali.

Sciaena aumata Günther, 1860, Cat. Fish. Brit. Mus., II, 287.

Plagioscion auratus Jordan and Eigenmann, 1886 (1889), Rept. U. S. Fish Comm., 383;

Eigenmann and Eigenmann, 1891, Proc. U. S. Nat. Mus., XIV, 67;

Eigenmann, 1910, Rept. Princeton Univ. Exped. Patagonia, III, 468;

Eigenmann, 1912, Mem. Carnegie Mus., V, 472.

Plagioscion auratus iquitensis Nakashima, 1941, Bol. Mus. Hist. Nat. Lima, V, 67.

Guianas, Rios Apuré, São Francisco, Peruvian Amazons

\section{Family XXII: Cichlidae}

\section{Genus 200: CHAETOBRANCHUS Heckel}

Chactobranchus Heckel, 1810, Ann. Wiener Mus., II, 401;

Günther, 1862, Cat. Fish. Brit. MIus., IV, 309;

Eigenmann and Eigenmann, 1891, Proe. U. S. Nat. Mus., XIV, 70;

Pellegrin, 1904, Bull. Soe. Zool. France, XXIX, 200;

Eigenmann, 1910, Rept. Princeton Univ. Exped. Patagonia, II, 469;

Eigenmann, 1912, Mcm. Carnegie Mus., V, 483.

\section{Type: Chactobranchus flavescens Heckel}

The Guianas to the Rio Guaporé

Most readily to be distinguished from other Cichlidae by the exceptional length of the numerous, setiform gill-rakers.

\section{Chaetobranchus flavescens Heckel}

Chaetobranchus flavescens Heckel, 1840, Ann. Wiener MIus., II, 401;

Müller and Troschel in Schomburgk, 1848, Reisen, III, 625;

Günther, 1862, Cat. Fish. Brit. Mus., IV, 310;

Eigenmann and Eigenmann, 1891, Proc. U. S. Nat. Mus., XIV, 70;

Pellegrin, 1902, I3ull. Mus. Hist. Nat., VIII, 182;

Pellegrin, 1903 (1904), Mém. Soc. Zool. France, XVI, 190, 200;

Eigenmann, 1910, Rept. Princeton Univ. Exped. Patagonia, III, 469;

Eigenmann, 1912, Mem. Carnegie Mus., V, 485;

Fowler, 1939 (1940), I'roc. Acad. Nat. Sci. Phila., XCI, 280, one, 118 mm., Contamana.

Equidens flavescens? Haseman, 1911c, Ann. Carnegie Mus., VII, 338.

Chromys ucayalensis Castelnau, 1855, Anim. Amér. Sud, Poiss., 15, pl. vi, fig. 2, one, Sarayacu.

Geophagus badiipinnis Cope, 1871, Proc. Acad. Nat. Sci. Phila., XXIII, 251, pl, xi, fig. 1, R. Ambyiacu.

Widely dispersed Guianas to the Guaporé

17750, 6, 115-195 mm., Lago Cashiboya, Allen, August, 1920.

17751, 2, 102 and $105 \mathrm{~mm}$., pond, Iquitcs, Allen, September, 1920. 
17752, 1, $132 \mathrm{~mm}$. , Rio Itaya, Allen, September, 1920.

17753, 5, 126-215 mm., Contamana, Allen, August, 1920.

1775t, 3, 132-188 mm., Yarinacocha, Allen, August, 1920.

17755, 1, $240 \mathrm{~mm}$. . Iquitos, Morris, 1922.

17756, 1, 220 mm., Manaos, Allen, December, 1920.

17757, 1, $180 \mathrm{~mm}$., Marañon, Allen, October, 1920.

In general form Chaetobranchus may be thought of as bearing the same relationship to Cichla as does the croppie to the black basses of North America.

\section{Genus 201: ACARONIA Myers}

Acaropsis Steindachner, 1875, Sitzb. KK. Akad. Wiss. Wien, LXXI, 281;

Eigenmann and Eigenmann, 1891, Proc. U. S. Nat. Mus., XIV, 68;

Pellegrin, 1903 (1904), Mém. Soc. Zool. France, XVI, 144;

Eigenmann, 1910, Rept. Princeton Univ. Exped. Patagonia, III, 470;

Eigenmann, 1912, Mem. Carnegie Mus., V, 485.

Acaronia Myers, 1940, Stanford Ichth. Bull., I, 170.

Type: Acaropsis nassa Heckel

Amazonia, Orinoco drainage, Guianas

The characters are largely those of Equidens; the maxillary exposed to the extremity, the premaxillary highly protractile, mouth very large.

\section{Acaronia nassa (Heckel)}

Acara nassa Heckel, 1840, Ann. Wiener Mus., II, 353, R. Guaporé;

Müller and Troschel, in Schomburgk, 1848, Reisen, III, 624;

Günther, 1862, Cat. Fish. Brit. Mus., IV, 281.

Acara (Acaropsis) nassa Steindachner, 1875, Sitzb. KK. Akad. Wiss. Wien, LXXI, 81;

Pellegrin, 1902, Bull. Mus. Hist. Nat., VIII, 182.

Acaropsis nassa Eigenmann and Bray, 1894, Ann. N. Y. Acad. Sci., VII, 613;

Pellegrin, 1903 (1904), Mém. Soc. Zool. France, XVI, 180;

Regan, 1905, Ann. Mag. Nat. Hist., (7), XV, 345;

Eigenmann, 1910, Rept. Princeton Univ. Exped. Patagonia, III, 470;

Eigenmann, 1912, Mem. Carnegie Mus., V, 485.

Acaronia nassa Myers, 1940, Stanford Ichth. Bull., I, 170.

\section{Guianas, Orinoco, Amazons}

17794, 1, 240 mm., Manaos, Allen, December, 1920.

This specimen, larger than any described from the Guianas, shows some departures from type.

Scales deeply embedded; spines of dorsal and anal fins very stout, and arranged alternately with one another; the membranes of these fins and of the caudal much thickened, dark, and opaque; markings obscured, except for a caudal ocellus; posterior border of operculum with about twenty small, irregular, dark spots; vertical bands faintly perceptible; the lateral line decurved just before its interruption, and separated from the dorsal fin by $5-7 \frac{1}{2}$ rows of scales. 
497. Acaronia trimaculata Allen, sp. nov.

Plate XXII, fig. 8

17794, 5, 110-162 mm., the largest the type, Iquitos; Morris, 1922.

An Acaronia of very different form from the genotype, nassa, appears in the material assembled by Morris at Iquitos.

Head 2.6-2.8; depth 2.0-2.3; D. XIV or XV, 9-10; A. III, 7; scales 23-25 along the middle line, lateral line scales separated by a scale and a half from the soft dorsal fin; lateral line $17-18+9-9$; eye $3.3-3.6$ in the head, $1.3-1.7$ in the interorbital space.

Snout as in Equidens; mouth slightly oblique, jaws equal; mouth only moderately large, but maxillary not reaching the eye; several rows of conical teeth; rakers of first gill-arch few, large, and fungiform; on remaining arches 9-10, stout, not closely set.

Dorsal and anal fins naked, but base of caudal fin sealed; pectorals mostly hyaline, reaching to the origin of the anal fin; ventrals inserted slightly behind the origin of the dorsal fin; soft dorsal and anal fins drawn out to a filament reaching the middle of the caudal, black-tipped; ventrals also tipped with black, and with a filament reaching the caudal peduncle; fins elsewhere mottled, almost taking shape as oblique bands on the caudal; dorsal spines graduated, the last the longest, equal to the snout before the orbit, caudal peduncle about as long as deep.

Eye at the middle of the head, three rows of scales on the cheek. Approaching the venter the body scales become bordered with silver.

Three distinct black spots as follows: (1) a double one bordering the cheek on its caudal margin, contrasted sharply with silvery preopercle, and broadening at the level of the eye so as nearly to reach the orbit; (2) a spot four scales long by two broad, just beneath the lateral line scales, at the level of the tenth to twelfth spines of the dorsal fin; (3) the usual ocellus bordered with yellow at the base of the upper caudal rays.

Most clearly separated from A. nassa, the genotype, by the following characters: more elongated dimensions generally (spines, lateral line, ete.); stouter head, maxillary not reaching the eye, snout not pointed; number and form of the gillrakers; longer peduncle; no ocellated spot on the head; only a suggestion of a complete longitudinal band; lateral line more widely separated from the dorsal line.

Genus 202: UARU Heckel

Uaru Heckel, 1810, Ann. Wiener Mus., II, 330;

Pellegrin, 1903 (1904), Mém. Soc. Zool. France, XVI, 212, 219;

Eigenmann, 1910, Rept. Princeton Univ. Exped. Patagonia, II I, 469.

\section{Type: Uaru amphiacanthoides Heckel \\ Brazilian and Peruvian Amazon}

Body of very short, vertical form; teeth of the form of talons or claws, the anterior and outside series the larger, compressed, with rounded cusps; maxillary 
exposed; branchial spines short and few in number, 7-8; scales ctenoid, moderate in size, 44-51 on the lateral line; lateral line scales larger than others adjacent; dorsal fin with 15-16 spines, anal 8-10.

\section{UARU AMPHIACANTHOIDES Heckel}

Uam amphiacanthoides Heckel, 18t0, Amn. Wiener Mus., II, 331;

Günther, 1862, Cat. Fish. Brit. Mus., IV, 302;

Eigenmann and Bray, 1894, Ann. N. Y. Acad. Sci., VII, 612;

Pellegrin, 1903 (1904), Mém. Soc. Zool. France, XVI, 249;

Eigenmann, 1910, Rept. Princeton Univ. Exped. Patagonia, III, 469.

Acara (Heros) amphiacanthoides Steindachner, 1875, Sitzb. KK. Akad. Wiss. Wien, LXXI, 94.

Astronotus (Uaru) amphiacanthoides Eigenmann and Eigenmann, 1891, Proc. U. S. Nat. Mus., XIV, 69 .

\section{Peruvian and Brazilian Amazons}

$15989,3,93-100 \mathrm{~mm}$., Iquitos, Morris, 1922.

$17776,3,130-185$ mm., Manaos, Allen, December, 1920.

17788, 2, 111 and $144 \mathrm{~mm}$., Contamana, Allen, August, 1920.

17791, 1, 148 mm., Lago Cashiboya, Allen, August, 1920.

\section{Uaru imperialis (Steindachner)}

Acara (Heros) imperialis Steindachner, 1879, Sitzl). KK. Akad. Wiss. Wien, LXXX, 161;

Uam imperialis Pellegrin, 1903 (1904), Mem. Soc. Zool. France, XVI, 249;

Eigenmann, 1910, Rept. Princeton Univ. Exped. Patagonia, III, 469.

\section{Middle course of the Amazon}

17777, 6, 1+2-170 mm., Manaos, Allen, December, 1920.

Not in our territory.

\section{Genus 203: ASTRONOTUS Swainson}

Astronotus Swainson, 1839, Fish. Amph. Rept., II, 229;

P'ellegrin, 1903 (1904), Mlém. Soc. Zool. France, XVI, 146;

Eigenmann, 1910, Rept. Princeton Univ. Exped. Patagonia, III, 470.

Astronotus (Astronotus) Eigenmann and Ligenmamn, 1891, Proc. U. S. Nat. MIus., XIV, 68.

Acara (in part) Heckel, 1840, Ann. Wiener XIus., II, 338.

\section{Type: Lobotes ocellatus Spix}

The Guianas to the Paraguay basin

Body oval, broad; head obtuse, mouth large, opening obliquely, the lower jaw longer; teeth strong in front, small on the sides; dorsal, anal, and caudal fins scaled; pectoral and caudal rounded, ventral pointed; lateral line interrupted; preopercle crenated.

\section{Astronotus ocellatus (Spix)}

Lobotes ocellatus Spix, 1829, Sel. Gen. et Spec. Pise. Bras., 129, pl. lxviii. Astronotus ocellatus Swainson, 1839, Fish. Amph. Rept., II, 229;

Pellegrin, 1903 (1904), Mém. Soc. Zool. France, XVI, 182;

Eigenmann, 1910, Rept. Princeton Univ. Exped. Patagonia, III, 470; 
Fowler, 1939 (1940), Proc. Acad. Nat. Sci. Phila., XCI, 284, two, 128 and 135 mm.,

Contamana.

Astronotus (Astronotus) ocellata Eigenmann and Eigenmann, 1891, Proc. I. S. Nat. MIus, XIV, 68. Acara ocellata Steindachner, 1875. Sitzh. KK. Akad. Wiss. Wien, I.XXI, 77

Acara compressus Cope, 1871, Proe. Acad. Nat. Sei. Phila, XXIII, 256, R. Ambyiacu.

Acara hyposticta Cope, 1878, Proc. Amer. Phil. Soc, XVII, 697, Rio Mirañon;

Pellegrin, 1903 (1901), Mém. Soc. Hist. Nat., XVI, 183.

IJygrogonus ocellatus Günther, 1862, Cat. Fish. Brit. MIs., IV, 303.

Acara (Hygrogoms) ocellata Steindachner, 1882 (1883), Denksch. KK. Akad. Wiss. Wien, LXVI, 2 , R. Huallaga, one specimen.

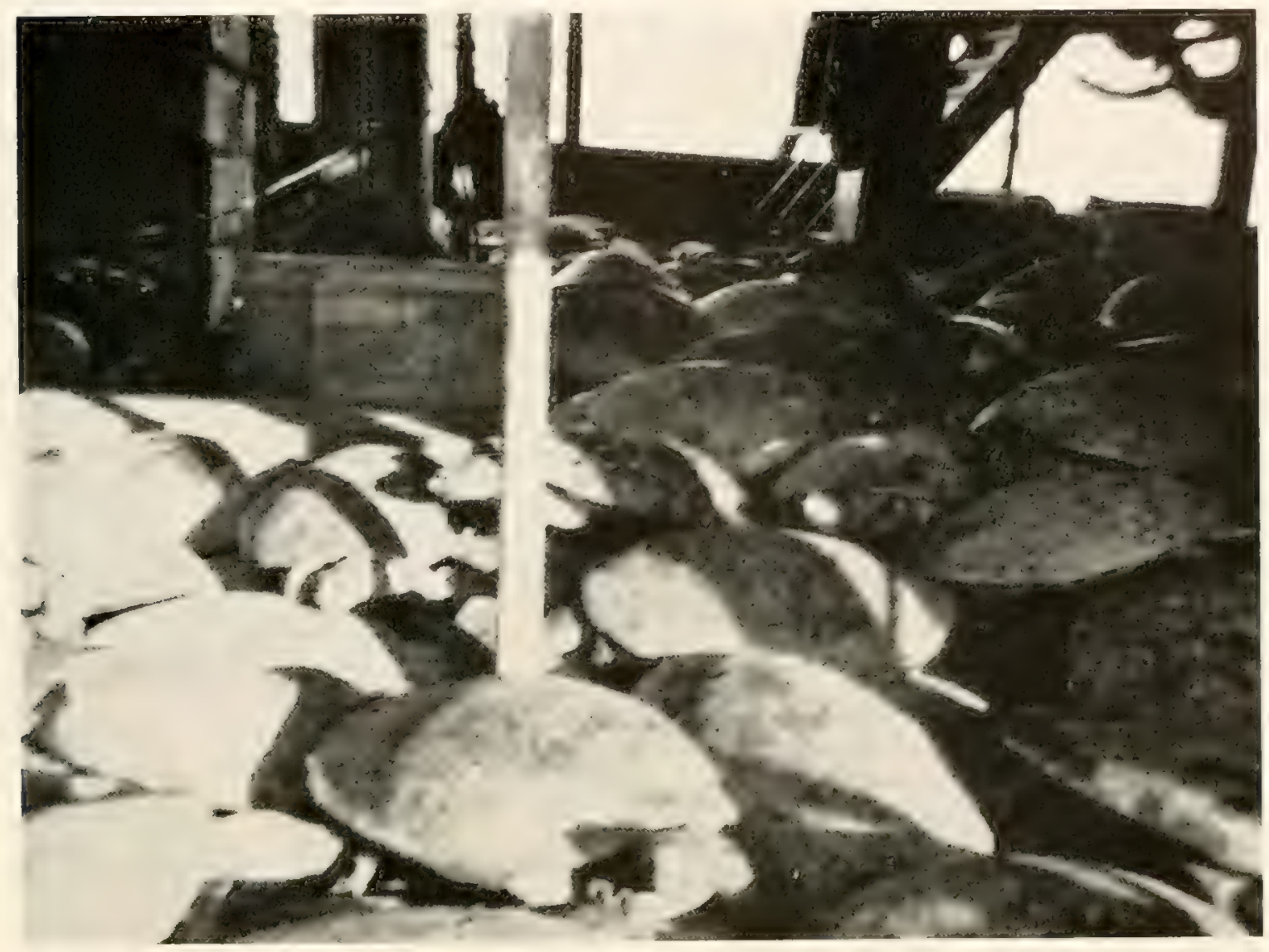

Fig. 46. Deck-load of charapa (turtle) for the Manas market. Stored four or five deep across the entire deck of the São Salvador: crude rubber in the boxes at the left.

Amazons and R. Paraguay

The vernacular name Acarahugsu applied by Fowler.

Genus 204: AEQUIDENS Eigenmann and Bray

Acara (in part) Heckel, 1810, Ann. Wiener Mus., II, 338.

Equidens Eigenmann and Bray, 1894, Ann. X. I. Acad. Sci. VII, 616;

Eigenmann, 1910, Rept. Princeton Univ. Exped. Patagonia, III, 470;

Eigenmann, 1912, Mem. Carnegie Mus., V, 487;

Eigenmann, 1922, Mem. Camegie Mus., IX, 196. 


\section{Type: Acara tetramerus Heckel \\ All South America Panama to La Plata}

Gills without a lobe, rakers small; mouth small and moderately protractile; lateral line low; soft fins scaled slightly or not at all; lateral line scales of the same size as others.

\section{Fouidens Tetramerus (Heckel)}

Acara tetramerus Heckel, 1840, Ann. Wiener Mus., II, 341;

Müller and Troschel in Schomburgk, 1848, Reisen, III, 624;

Günther, 1862, Cat. Fish. Brit. Mus., IV, 277;

Cope, 1871, Proc. Acad. Nat. Sei. Phila., XXIII, 255, R. Ambyiacu;

Steindachner, 1882 (1883), Denksch. KK. Akad. Wiss. Wien, XLVI, 2, Iquitos; Rio Huallaga;

Pellegrin, 1902, Bull. Mus. Hist. Nat., VIII, 182;

Pellegrin, 1903 (1904), Mém. Soc. Zool. France, XVI, 171;

Regan, 1913, Ann. Mag. Nat. Hist., (8), XII, 282, Rio Ucayali.

Astronotus tetramerus Eigenmann and Eigenmanu, 1891, Proc. U. S. Tat. MIs., XIV, 68.

Astronotus (Equidens) tetramerus Eigenmann and Bray, 1894, Ann. N. Y. Acad. Sci., VII, 617.

Equidens tetramerus Eigenmann and Kennedy, 1903, Proc. Acad. Nat. Sci. Phila., LV, 534;

Eigenmann, 1910, Rept. Princeton Univ. Exped. Patagonia, III, 171;

Eigenmann, 1912, Mem. Carnegie Mus., V, 191.

Chromys uniocellata Castelnau, 1855, Anim. Amér. Sud, Poiss., 15, pl. vi, fig. 1, Rio Ucayali.

Acara flavilabris Cope, 1870, Proc. Amer. Phil. Soc., XI, 570, Pebas;

Cope, 1871 (1872), Proc. Acad. Tat. Sci. Phila., XXIII, 255, pl. x, fig. 4, Rio Ambyiacu;

Cope, 1878, Proc. Amer. Phil. Soc, XVII, 696, R. Marañon.

British Guiana, Amazons, Rio de Janeiro, Paraguay

17735, 11, 19-80 mm., creek, Rio Itaya, Allen, September, 1920.

17738, 2, 26 and $37 \mathrm{~mm}$., Gosulimacocha, Allen, October, 1920.

17739, 3, 21-45 mm., brook, Iquitos, Allen, November, 1920.

$17740,12,22-41 \mathrm{~mm}$., Yarinacocha, Allen, August, 1920.

One of these juveniles has a complete longitudinal band.

$17741,7,79-121 \mathrm{~mm}$., Iquitos pond, Allen, September, 1920.

17742, 79, 22-138 mm., creek, Pto. Bermudez, Allen, July, 1920.

Apparently this number is incorrectly recorded.

17742 , 4, 46-126 mm., Iquitos, Morris, 1922.

17743, 4, 95-163 mm., Lago Cashiboya, Allen, August, 1920.

17744, 3, 71-94 mm., creek, Yurimaguas, Allen, November, 1920.

$17745,4,103-138$ mm., creek, Rio Morona, Allen, October, 1920.

$-, 2,175$ and $185 \mathrm{~mm}$., Yarinacocha, Allen, August, 1920.

17789, 2, 165, $232 \mathrm{~mm}$., Nanaos, Allen, December, 1920.

The pond specimens, especially 17741, deeply colored. They show faintly the vertical color bands and a lateral band from the eye to the caudal basis. This is interrupted by the lateral spot.

Of the specimens from the Itaya, 17735, one of three largest has four anal spines, otherwise the same.

Color notes made in the field on the Puerto Bermudez specimens, 17742, show the dorsal half of the body deep blue, shading to grey ventrally. Ocellated spot on the peduncle blue-black, bordered with yellow; irregular blue-black markings on the caudal fin; fins washed with yellow; five or six longitudinal stripes of yellow on 
the head from the snout to the eye and cheek. In alcohol a longitudinal color-band can be seen in many.

\section{EQUIDENS DORSIGERUS (Heckel)}

Acara dorsigera Heckel, 1840, Ann. Wiener Mus., II, 348;

Steindachner, 1875, Sitzh. KK. Akad. Wiss. Wien, LXXI, 66.

Equidens dorsigerus Pellegrin, 1903 (1901), Mém. Soc. Zool. France, XVI, 174;

Eigenmann, 1910, Rept. Princeton Univ. Exped. Patagonia, III, 472.

Nannacara dorsigera Ribeiro, 1918, Comm. Linhas Telegr. de Matto Grosso as Amazonas, 14.

Astronotus (Acara) dorsigera Eigenmann and Eigenmann, 1891, Proc. U. S. Nat. MIus., XIV, 68.

Amazonia to Paraguay basin

17733, 7, 78-115 mm., creek, Rio Itaya, Allen, September, 1920.

$17737,13,15-38 \mathrm{~mm}$., creeks, Iquitos, Allen, November, 1920.

$17749,16,45-103 \mathrm{~mm}$, creeks, Yurimaguas, Nllen, November, 1920.

$17779,1,60 \mathrm{~mm}$., Iquitos, Morris, 1922.

\section{EQUidens mariae Eigenmanm}

Equidens mariae Eigenmann, 1922, Mem. Carnegie Mus., IX, 240, pl. xxx, fig. 1, supplement on Rio Meta.

\section{Peruvian Amazon and Rio Meta}

$17734,2,88$ and $95 \mathrm{~mm}$., Yarinacocha, Allen, August, 1920.

$17746,4,112-135 \mathrm{~mm}$, Rio Morona, Allen, October, 1920.

$17747,1,146 \mathrm{~mm}$., Rio Itaya, Iquitos, Allen, September, 1920.

$177+8,13,30-68$ mm., creeks, Yurimaguas, Allen, November, 1920.

Known here and in eastern Colombia, having been collected by Brother Apolinar Maria and Manuel Gonzales on the Meta.

\section{Equidens freniferus (Cope)}

Acara freniferus Cope, 1871, Proc. Acad. Nat. Sei. Phila., XXIII, 255, Rio Ambyiacu;

Pellegrin, 1903 (1904), Mém. Soc. Zool. France, XVI, 177.

Equidens freniferus Eigenmann, 1910, Rept. Princeton Univ. Exped. Patagonia, III, 472.

Equidens dorsigera Haseman, 1911c, Ann. Carnegie Mus., VII, 337.

Astronotus (Acara) freniferus Eigenmann and Eigenmann, 1891, Proe. U. S. Nat. Mus., XIV, 68.

\section{Peruvian Amazon}

Haseman studied the Cope material in the Philadelphia Academy and found none which could not be retained within the limits of A. dorsigerus.

\section{Equidens vittatus (Heckel)}

Acara villatus Heckel, 1840, Ann. Wiener Mus., I, 346.

Acara vittata Pellegrin, 1903 (1904), Mém. Soc. 'Lool. France, XVI, 173.

Equidens vittatus Eigenmann, 1910, Rept. Princeton Univ. Exped. Patagonia, III, 472;

Haseman, 1911c, Ann. Carnegie Mus., VII, 335;

Eigenmann, 1912, Mem. Carnegie Mus., V, 489 ;

Fowler, 1939 (1940), Proe. Acad. Nat. Sei. Phila., XCI, 280, four, 80-129 mm., Contamana. 
Acara syspilus Cope, 1871, Proc. Acad. Nat. Sci. Phila., XXIII, 255, pl. xi, fig. 3, Rio Ambyiacu; Cope, 1878, Proc. Amer. Phil. Soc., XVII, 690;

Boulenger, 1887, Proc. Zool. Soc. London, 275, Canelos.

Equidens syspilus Pellegrin, 1903 (1904), Mém. Soc. Zool. France, XVI, 138;

Eigenmann, 1910, Rept. Princeton Univ. Exped. Patagonia, III, 472.

\section{Peruvian and Ecuadorean Amazon}

Haseman examined the types of Cope, and unhesitatingly places his Acara syspitus under E. vittatus of Heckel.

\section{6. ÆQuidens subocularis (Cope)}

Acara subocularis Cope, 1878, Proc. Amer. Phil. Soc., XVII, 696.

Equidens subocularis Eigenmann, 1910, Rept. Princeton Univ. Exped. Patagonia, III, 472;

Haseman, 1911c, Ann. Carnegie Mus., VII, 338.

Geophagus thayeri Pellegrin, 1903 (1901), Mém. Soc. Zool. France, XVI, 189.

Peruvian Amazons

507. Equidens hercules Allen, sp. nov.

Plate XXII, figs. $4-7$

17736, 13, 38-132 mm., the largest the type, creek, Rio Morona, Allen, October, 1920.

These thirteen specimens from near the Peruvian-Ecuadorean frontier and taken within only a few miles of the foothills of the Andes, exhibit many resemblances to known species of Equidens, but fail to conform to the descriptions of any of them, and are unlike any specimens available for comparison.

Head 3.15-3.3; depth 2.4-2.7; D. XVI-XVII, 8; A. III, 6-7; lateral line $18+8$ to 11 ; scales $27-29$ along a middle line from the end of the opercular opening; eye 2.8-3.4 in the head, exceeds the preorbital space, and interorbital in the young; eye in the middle of the head except in the smallest, in which it is in front of the middle; dorsal profile more arched than the ventral, especially with age, depressed, or at least flattened, between the eyes, in a plane tangent to the orbit in younger specimens, and more depressed with age.

The fish is elongated in shape; the caudal peduncle a fifth longer than deep.

Mouth small, maxillary not reaching eye; maxillary-premaxillary border $2.6-$ 2.8 in the head; lower gill-arch with 8-9 small, papillose gill-rakers; cheeks with three rows of scales, preopercle naked; one and one-half to two and one-half scales above the lateral line; fins naked except the caudal, which is scaled at the base; lateral line has only an indication of forking on the caudal fin in the younger specimens.

Dorsal spines are subequal from the fourth, and about half the length of the head; pectorals and ventrals longer than the head; caudal fin rounded at the end.

A series of six sub-rhomboidal dark areas along the middle of the body to the base of the caudal; four or five additional blotches of more shadowy character from the base of the dorsal fin to the lateral line scales, alternating with the above; verti- 
cal rows of pencilled lines alternate with hyaline zones on the fins, especially pronounced on the caudal, and growing more distinct with age; markings on the body coalescing somewhat, and more faded, with age.

Resembling $E$. mariae; body contours more elongate; greater number of spiny rays in the dorsal fin; two or three more gill-rakers; markings in a double series, without special emphasis upon one or two spots, as in $\mathbb{E}$. dorsigera or tetramerus.

The allusion of the name of this species is to the river-"launch" Hércules, of the fleet of Casa Israel, Iquitos, my headquarters during a month's cruise of the upper Marañon, Morona, Pastaza, and Tigre rivers, where it was making its semiannual calls upon the military posts. I was guest of the Peruvian government during this period.

\section{Genus 205: CICHLAURUS Swainson}

Cichlaurus Swainson, 1839, Fish. Amph. Rept., II, 173;

Jordan, Evermann and Clark, 1928 (1930), Rept. U. S. Comm. Fish., Part II, 416.

Cichlasoma Swainson, 1839, Fish. Amph. Rept., II, 230;

Regan, 1905, Ann. Mag. Nat. Hist., (7), XVI, 60-77, 225, 243, 316-340;

Eigenmann, 1910, Rept. Princeton Univ. Exped. Patagonia, III, 473;

Eigenmann, 1912, Mem. Carnegie Mus., V, 494;

Eigenmann, 1922, Mem. Carnegie Mus., IX, 201;

Hubbs, 1936, Carnegie Inst. Publ. no. 457, 254.

Acara (in part) Heckel, 1840, Ann. Wiener Mus., II, 338.

Heros Heckel, 1840, Ann. Wiener Mus., II, 338.

Theraps Günther, 1862, Cat. Fish. Brit. Mus., IV, 28t, irregularis.

Archocentrus Gill, 1877, Proc. Acad. Nat. Sci. Phila., 186, centrarchus;

Jordan, Evermann and Clark, 1928 (1930), Rept. U. S. Comm. Fish., Part II, 420.

Astatheros Pellegrin, 1903 (1904), Mém. Soc. Zool. France, XVI, 203;

Jordan, Evermann and Clark, 1928 (1930), Rept. U. S. Comm. Fish., Part II, 420.

Astronotus (Heros) Eigenmann and Eigenmann, 1891, Proc. U. S. Nat. Mus., XIV, 68.

(The Cichlasoma of authors generally, replaced by Jordan, Evermann, and Clark by reason of the appearance of Cichlaurus on an earlier page of Swainson's Part II.)

Type: Labrus punctatus Bloch

Mexico to Rio de la Plata

Anal with more than three spines; lateral line depressed; gill-rakers short; mouth small, premaxillary moderately protractile.

Predominating in Central America, diminishing southward through South America.

\section{Cichlaurus bimaculatus (Linnaeus)}

Acara Piso, 1658, Hist. Nat. Med., 67.

Labrus no. 87 Gronow, 1754, MIus. Ichth., 36.

Spames no. 227 Gronow, 1763, Zoophyl., 64, pl. v, fig. 4.

Sciaena bimaculata Linnaeus, 1754, Mus. Adolphi Fred., I, 66.

Labrus punctatus Linnaeus (in part), 1758, Syst. Nat., ed. x, 285. 
Labrus bimaculatus Linnaeus, 1758, Syst. Nat., ed. x, 285;

Linnaeus, 1766, Syst. Nat., ed. xii, I, 477.

Perca bimaculata Bloch, 1792, Ausl. Fische, VI, 82, pl. ceex, fig. 1.

Cichla bimaculata Bloch and Schneider, 1801, Syst. Ichth., 338.

Acara bimaculata Günther, 1862, Cat. Fish. Brit. Mus., IV, 276;

Pellegrin, 1899, Bull. Mus. Hist. Nat., V, 158.

Heros bimaculatus Cope, 1871, Proc. Acad. Nat. Sci. Phila., XXIII, 254, Rio Ambyiacu;

Cope, 1878, Proc. Amer. Phil. Soc., XVII, 696, Rio Marañon.

Acara (Heros) bimaculatus Steindachner, 1875, Sitzb. KK. Akad. Wiss. Wien, LXXI, 82, Pebas;

Steindachner, 1882 (1883), Denksch. KK. Akad. Wiss. Wien, XLVI, 2, Rio Huallaga, one, $100 \mathrm{~mm}$.

Astronotus (Heros) bimaculata Eigenmann and Eigenmann, 1891, Proc. U. S. Nat. Mus., XIV, 68.

Cichlasoma bimaculatum Pellegrin, 1903 (1904), Mém. Soc. Zool. France, XVI, 204;

Regan, 1905, Ann. Mag. Nat. Hist., (7), XVI, 68;

Eigenmann, 1910, Rept. Princeton Univ. Exped. Patagonia, III, 473;

Eigenmann, 1912, Mem. Carnegie Mus., V, 495;

Fowler, 1939 (1940), Proc. Acad. Nat. Sci. Phila., XCI, 280, two, 85 and 88 mm., Contamana.

\section{Amazons to Paraguay basin and Trinidad}

17781, 28, 25-177 mm., pond, Yurimaguas, Allen, November, 1920.

17782, 1, 87 mm., Yarinacocha, Allen, August, 1920.

17783, 2, 89 and $177 \mathrm{~mm}$., Rio Huallaga, Yurimaguas, Allen, November, 1920.

17784, 2, 92 and 111 mm., Lago Cashibova, Allen, August, 1920.

Fowler finds acara employed as the common name.

\section{Cichlaurus severus (Heckel)}

Heros severus Heckel, 1840, Ann. Wiener Mus., II, 362.

Astronotus (Heros) severus Eigenmann and Eigenmann, 1891, Proc. U. S. Nat. Mus., XIV, 68;

Eigenmann and Bray, 1894, Ann. N. Y. Acad. Sci., VII, 619.

Cichlasoma severum Regan, 1905, Ann. Mag. Nat. Hist., (7), XVI, 322;

Eigenmann, 1910, Rept. Princeton Univ. Exped. Patagonia, III, 475;

Haseman, 1911c, Ann. Carnegie Mus., VII, 343;

Eigenmann, 1912, Nem. Carnegie Mus., V, 497;

Fowler, 1939 (1940), Proc. Acad. Nat. Sci. Phila., XCI, 281, two, 100 and $105 \mathrm{~mm}$, Contamana.

Chromys fasciata Castelnau, 1855, Anim. Amér. Sud, Poiss., 17, pl. ix, fig. 2.

Chromys appendiculata Castelnau, 1855, Anim. Amér. Sud, Poiss., 15, pl. vii, fig. 3, Rio Ucayali.

Acara (Heros) spuria Steindachner, 1874, Sitzb. KK. Akad. Wiss. Wien, LXIX, 9, pl. iv;

Steindachner, 1875, Sitzb. KK. Akad. Wiss. Wien, LXX, 507, pl, iv;

Steindachner, 1882 (1883), Denksch. KK. Akad. Wiss. Wien, XLVI, 2, Rio Huallaga, three specimens.

Heros spurius Pellegrin, 1903 (1904), Mém. Soc. Zool. France, XVI, 236, Rio Ucayali and Tabatinga to Tocantins.

Uarus centrarchoides Cope, 1871, Proc. Acad. Nat. Sci. Phila., XXIII, 253, pl. xi, fig. 2, R. Ambyiacu.

\section{Amazons to Guiana and the Parahyba}

17785, 5, 85-172 mm., Yarinacocha, Allen, August, 1920.

$17786,1,165 \mathrm{~mm}$., Iquitos, Morris, 1922.

17787, 15, 80-103 mm., Lago Cashiboya, Allen, August, 1920. 


\section{Cichlaurus temporalis (Günther)}

Heros temporalis Günther, 1862, Cat. Fish. Brit. Mus., IV, 287.

Cichlasoma temporale Pellegrin, 1903 (1904), Mém. Soc. Zool. France, XVI, 218;

Eigenmann, 1910, Rept. Princeton Univ. Exped. Patagonia, III, 473.

Acara crassa Steindachner, 1882 (1883), Denksch. KK. Akad. Wiss. Wien, XLVI, 2, Rio Huallaga.

Cichlasoma coryphacnoides Haseman, 1911c, Ann. Carnegie Mus., VII, 312.

Amazons to Huallaga and Guiana

\section{Cichlaurus autochthon (Günther)}

Heros autochthon Günther, 1862, Cat. Fish. Brit. Mus., IV, 299;

Pellegrin, 1903 (1904), Mém. Soc. Zool. France, XVI, 235.

Acara (Heros) autochthon Steindachner, 1874, Sitzb. KK. Akad. Wiss. Wien, LXX, 502, pl. i;

Cope, 1878, Proc. Amer. Phil. Soc., XVII, 695, R. Marañon.

Cichlasoma autochthon Eigenmann, 1910, Rept. Princeton Univ. Exped. Patagonia, III, 473.

Cichlasoma facetum Haseman, 1911c, Ann. Carnegie Mus., VII, 340.

\section{La Plata basin, Brazilian coastal streams, Peru}

Cope appears to doubt the identity of his specimens with those from the coast. While Pellegrin's $H$. autochthon material closely resembles $C$. facetus, he believes that it should be assigned to $C$. oblongus Castelnau, which also Haseman reduces to C. facetus on the ground that the folding of the lips is a variable character.

\section{Genus 206: MESONAUTA Günther}

Mesonauta Günther, 1862, Cat. Fish. Brit. Mus., IV, 300;

Eigenmann, 1912, Mem. Carnegie Mus., V, 498.

Cichlasoma (Mesonauta) Eigenmann, 1910, Rept. Princeton Univ. Exped. Patagonia, III, 473.

Astronotus (Mesonauta) Eigenmann and Eigenmann, 1891, Proc. U. S. Nat. MIus., XIV, 69.

\section{Type: Heros insignis $=$ Heros festivus Heckel}

Peruvian Amazon to Brazilian Amazon and the Guianas, Orinoco, Paraguay

Separable most readily by its contours, compressed and increasing in width to the posterior half of the dorsal fin; scales of the lateral line not larger than those adjacent; lower lip with frenum; origin of the dorsal fin behind that of the ventral.

\section{Mesonauta festivum (Heckel)}

Heros festivus Heckel, 1840, Ann. Wiener Mus., II, 376, R. Guaporé.

Acara festiva Steindachner, 1875, Sitzb. KK. Akad. Wiss. Wien, LXXI, 93.

Astronotus (Mesonauta) festivus Eigenmann and Eigenmann, 1891, Proc. U. S. Nat. MIus., XIV, 69.

Mesonauta festivus Eigenmann and Bray, 1894, Ann. N. Y. Acad. Sci., VII, 619;

Eigenmann, 1912, Mem. Carnegie Mus., V, 498.

Cichlasoma festivum Regan, 1905, Ann. Mag. Nat. Hist., (7), XVI, 69;

Eigenmann, 1910, Rept. Princeton Univ. Exped. Patagonia, III, 473;

Haseman, 1911c, Ann. Carnegie Mus., VII, 340;

Fowler, 1939 (1940), Proc. Acad. Nat. Sci. Phila., XCI, 280, one, 95 mm., Contamana. 
Chromys acara Castelnat, 1855, Anim. Amér. Sud, Poiss., 17, pl. ix, fig. 1.

Heros (Heros) insignis Heckel, 1810, Ann. Wiener Mus., II, 379.

Mesonauta insignis Günther, 1862, Cat. Fish. Brit. Mus., IV, 300;

Pellegrin, 1902, Bull. Mus. Hist. Nat., VIII, 182.

Cichlasoma insigne Pellegrin, 1903 (1904), Mém. Soc. Zool. France, XVI, 221.

Uanus insignis Cope, 1871, Proc. Acad. Nat. Sci. Phila., XXIII, 253, Rio Ambyiacu.

Brazilian and Peruvian Amazons, Guiana, Paraguay

17778, 10, 69-101 mm., Yarinacocha, Allen, August, 1920.

\section{Genus 207: ACARICHTHYS Eigenmann}

Acarichthys Eigenmann, 1912, Mem. Carnegie Mus., V, 500.

Type: Acara heckelii Müller and Troschel

British Guiana, Brazilian and Peruvian Amazons

A genus of a form intermediate between Equidens and Geophagus, with a feeble development of the dorsal lobe of the first gill-arch, and its small number of rakers, about two; mouth small and feebly protractile; caudal emarginate, its base scaled; eye posterior on head.

\section{Acarichthys heckeli (Müller and Troschel)}

Acara heckelii Müller and Troschel, 18t8, in Schomburgk, Reisen, III, 624;

Günther, 1862, Cat. Fish. Brit. Mus., IV, 279.

Acarichthys heckeli Eigenmann, 1912, Mem. Carnegie Mus., V, 500.

Geophagus thayeri Steindachner, 1875, Sitzb. KK. Akad. Wiss. Wien, LXXI, 48, pl. iii, fig. 2;

Pellegrin, 1902, Bull. Mus. Hist. Nat., VIII, 182, Tabatinga;

Pellegrin, 1903 (1904), Mém. Soc. Zool. France, XVI, 189.

Acara subocularis Cope, 1878, Proc. Amer. Phil. Soc., XVII, 696, Peruvian Amazon.

\section{Peruvian Amazon to the Guianas}

\section{Genus 208: BIOTODOMA Eigenmann and Kennedy}

Mesops Günther, 1862, Cat. Fish. Brit. Mus., IV, 311, preoccupied.

Geophagus (1/esops) Steindachner, 1875, Sitzb. Kí. Akad. Wiss. Wien, LXXI, 47.

Geophagus (part) Pellegrin, 1903 (1904), Mém. Soc, Zool. France, XVI, 189.

Biotodoma Eigenmann and Kennedy, 1903, Proc. Acad. Nat. Sci. Phila., LV, 533;

Eigenmann, 1912, Mem. Carnegie Mus., V, 501.

Type: Geophagus cupido Heckel

Amazons, Guiana, Rio Guaporé

With a downward-projecting lobe on the upper gill-arch, the gill-rakers along its border; upper lateral line well separated from the dorsal fin; lateral line not forked on the caudal fin; preorbital space about equal to the eye in the adult fish. 


\section{Biotodoma cupido (Heckel)}

Gcophagus cupido Heckel, 1840, Ann. Wiener Mus., II, 399;

Cope, 1878, Proc. Amer. Phil. Soc., XVII, 697, Peruvian Amazon;

Pellegrin, 1903 (190t), Mém. Soc. Zool. France, XVI, 189;

Regan, 1906, Ann. Mag. Nat. Hist., (7), XVII, 5t;

Eigenmann, 1910, Rept. Princeton Univ. Exped. Patagonia, III, 479;

Haseman, 1911c, Ann. Carnegie Mus., VII, 367.

Mesops cupido Günther, 1862, Cat. Fish. Brit. Mus., IV, 311.

Geophagus (Mesops) cupido Steindachner, 1875, Sitzb. KK. Akad. Wiss. Wien, LXXI, 147;

Eigenmann and Eigenmann, 1891, Proc. U. S. Nat. Mus., XIV, 70.

Biotodoma cupido Eigenmann and Kennedy, 1903, Proc. Acad. Nat. Sci. Phila., LV, 533;

Eigenmann, 1912, Mem. Carnegie \us., I, 501;

Fowler, 1939 (1940), Proc. Acad. Nat. Sci. Phila., XCI, 281, six, 95-108 mm., Contamana.

The Amazons to the Essequibo and Guaporé

\section{Genus 209: GEOPHAGUS Heckel}

Geophagus Heckel, 1840, Ann. Wiener Mus., II, 383;

Eigenmann and Eigenmann, 1891, Proe. U. S. Nat. Mus., XIV, 70;

Pellegrin, 1903 (1904), Mém. Soc. Zool. France, XVI, 189;

Eigenmann, 1910, Rept. Princeton Univ. Exped. Patagonia, III, 478;

Eigenmann, 1912, Mem. Carnegie Mus., V, 502, and authors generally.

Type: Geophagus altifrons = Sparus surinamensis Bloch, according to Eigenmann; logotype: Geophagus megasema Heckel, according to Jordan

\section{Panama to Argentina}

Similar to Biotodoma in the downward-projection of a lobe of the upper ramus of the gill-arch, with the rakers at its margin; also in the wide separation of the lateral line from the dorsal fin; unlike in that the lateral line is bifurcated on the caudal fin, and that the snout is longer, the ratio of the preorbital to the eye being about $2: 1$.

Haseman found Geophagus nesting on the sand in the manner of North American Centrarchids; eggs small and numerous, unlike the latter or mouth-breeders, but young were seen to take shelter in the mouth of the parent, evidently the female.

\section{Geophagus surinamensis (Bloch)}

Sparus surinamensis Bloch, 1791, Ausl. Fische., pl. 277, fig. 2.

Geophagus surinamensis Müller and Troschel, 1848, in Schomburgk, Reisen, III, 625;

Steindachner, 1875, Sitzb. KK. Akad. Wiss. Wien, LXII, 122;

Pellegrin, 1902, Bull. Mus. Hist. Nat,, VIII, 182;

Pellegrin, 1903 (1904), Mém. Soc. Zool. France, XVI, 198, two specimens, R. Ucayali, Castelnau collection;

Regan, 1906, Ann. Mag. Nat. Hist., (7), XVII, 55;

Eigenmann, 1910, Rept. Princeton Univ. Exped. Patagonia, III, 478 ;

Haseman, 1911c, Ann. Carnegie Mus., VII, 362;

Eigenmann, 1912, Mem. Carnegie Mus., V, 503, pl. lxvi, fig. 3. 


\section{Most of the Amazon basin northward}

17764, 1, 94 mm., Rio Itaya, Allen, September, 1920.

17765, 2, 76 and $86 \mathrm{~mm}$., Yarinacocha, Allen, August, 1920.

$17766,1,120 \mathrm{~mm}$. ., Iquitos, Allen, September, 1920.

$17767,1,102 \mathrm{~mm}$. , Iquitos, Morris, 1922.

\section{Geophagus Jurupari Heckel}

Geophagus jurupari Heckel, 18t0, Ann. Wiener Mus., II, 392;

Cope, 1871, Proc. Acad. Nat. Sci. Phila., XXIII, 251, R. Ambyiacu;

Steindachner, 1875, Sitzb. KK. Akad. Wiss. Wien, LXXI, 120;

Steindachner, 1882 (1883), Denksch. KK. Akad. Wiss. Wien, XLVI, 2, three poor specimens, Iquitos, R. Huallaga;

Pellegrin, 1899, Bull. Mus. Hist. Nat, V, 405;

Pellegrin, 1903 (1905), Mém. Soc. Zool. France, XVI, 189, 195;

Regan, 1906, Ann. Mag. Nat. Hist., (7), XVII, 56;

Eigenmann, 1910, Rept. Princeton Univ. Exped. Patagonia, III, 479;

Haseman, 1911c, Ann. Carnegie Mus., VII, 370;

Eigenmann, 1912, Mem. Carnegie Mus., V, 504;

Fowler, 1939 (1940), Proc. Acad. Nat. Sci. Phila., XCI, 281, twenty-three, 38-173 mm., Contamana.

\section{Peruvian and Brazilian Amazons, Guiana}

15990, 10, 42-161 mm., Iquitos, MIorris, 1922.

17758, 3, 127-167 mm., Contamana, Allen, August, 1920.

17759, 1, 118 mm., Lago Cashiboya, Allen, August, 1920.

17760, 1, 140 mm., Iquitos, Allen, September, 1920.

17761, 4, 21-105 mm., brook, Rio Itaya, Allen, September, 1920.

17762, 1, $148 \mathrm{~mm}$., Rio Morona, Allen, October, 1920.

17763, 3, 95-122 mm., Yarinacocha, Allen, August, 1920.

17790, 6, 170-200 mm., Manaos, Allen, December, 1920.

\section{Genus 210: APISTOGRAMMA Regan}

Mesops (in part) Günther, 1862, Cat. Fish. Brit. Mus., IV, 311.

Heierogramma Regan, 1906, Ann. Mag. Nat. Hist., (7), XVII, 63, preoccupied;

Eigenmann, 1910, Rept. Princeton Univ. Exped. Patagonia, III, 478;

Eigenmann, 1912, Mem. Carnegie Mus., V, 506.

Apistogramma Regan, 1913, Ann. Mag. Nat. Hist., (8), XII, 282.

\section{Type: Heterogramma borellii Regan}

\section{Amazons, Rio Paraguay}

First branchial arch with its upper ramus bearing a lobe fringed with feeble rakers; upper lateral line closely approaching the dorsal fin.

\section{Apistograma amoenum (Cope)}

Geophagus amoenus Cope, 1871, Proc. Acad. Nat. Sci. Phila., XXIII, 250, Rio Ambyiacu. Apistogramma amoenus Regan, 1913, Ann. Mag. Nat. Hist., (8), XII, 283.

Mesops taeniatus Günther, 1862, Cat. Fish. Brit. Mus., IV, 312.

Geophagus taeniatus Cope, 1878, Proc. Amer. Phil. Soc., XVII, 697, Peruvian Amazon; Steindachner, 1875, Sitzb. KK. Akad. Wiss. Wien, LXXI, 115. 
Heterogramma taeniatum Regan, 1906, Ann. Mag. Nat. Hist., (7), XVII, 60;

Eigenmann, 1910, Rept. Princeton Univ. Exped. Patagonia, III, 478;

Haseman, 1911c, Ann. Carnegie Mus., VII, 357.

Biotodoma taeniatum Pellegrin, 1903 (1904), Mém. Soc. Zool. France, XVI, 187.

Peruvian Amazon to Paraguay

518. Apistograma ambloplitoides Fowler

A pistogramma ambloplitoides Fowler, 1939 (1940), Proc. Acad. Nat, Sci. Phila., XCI, 281, fig. 63.

\section{Contamana, Rio Ucayali}

Two specimens of the Morrow collection of the Philadelphia Academy of Sciences, type and paratype, 108 and $105 \mathrm{~mm}$., were described as having a narrow preorbital space, $\frac{2}{5}$ the eye diameter; with two rows of large scales on the cheek; fins long and pointed; similar to Cope's $A$. amoenum with its 3-4 large scales on the cheek.

\section{Genus 211: CICHLA Bloch and Schneider}

Cichla Bloch and Schneider, 1801, Syst. Ichth., 336;

Eigenmann and Eigenmann, 1891, Proc. U.S. Nat. Mus., XIV, 69;

Pellegrin, 1903 (1904), Mém. Soc. Zool. France, XVI, 148;

Eigenmann, 1910, Rept. Princeton Univ. Exped. Patagonia, III, 469;

Eigenmann, 1912, Mem. Carnegie Mus., V, 509.

\section{Type: Cichla ocellaris Bloch and Schneider Guianas, Amazons, La Plata}

"Perciform; lateral line unbroken in the earlier stages, usually interrupted in the adult, and forked at the base of the caudal fin; soft dorsal, caudal, and anal fins scaled at the base; gill-arch normal, the rakers long and heavy; spinous and soft dorsal subequal, separated by a notch; each jaw with a band of broad, villiform teeth."

Our material does not indicate that there are more than one species, the variability with age exceeding that between adult specimens.

\section{Cichla ocellaris Bloch and Schneider}

Cichla ocellaris Bloch and Schneider, 1801, Syst. Ichth., 340, pl. lxvi;

Mialler and Troschel, 1848, in Schomburgk, Reisen, III, 625;

Günther, 1862, Cat. Fish. Brit. Mus., IV, 304;

Cope, 1878, Proc. Amer. Phil. Soc., XVII, 697, Nauta;

Steindachner, 1882 (1883), Denksch. IK Akad. Wiss. Wien, XLVI, 3, Rio Huallaga, one specimen, $220 \mathrm{~mm}$;

Eigenmann and Eigenmann, 1891, Proc. U. S. Nat. Mus., XIV, 69;

Pellegrin, 1902, Bull. Mus. Hist. Nat, VIII, 182;

Pellegrin, 1903 (1904), Mém. Soc. Zool. France, XVI, 18t;

Eigenmann, 1910, Rept. Princeton Univ. Exped. Patagonia, III, 469; 
Eigenmann, 1912, Mem. Carnegie Mus., V, 509;

Fowler, 1939 (1940), Proc. Acad. Nat. Sci. Phila., XCI, 283, three, 130-205 mm., Contamana. Cichla multifasciata Castelnau, 1855, Anim. Amér. Sud, Poiss., 17, pl. x, fig. 2.

Cichla bilineatus Nakashima, 1941, Bol. Mus. Hist. Nat. Lima, V, 73.

Amazons northward

17728, 1, 280 mm., Peruvian Amazon, Allen, 1920.

17729, 3, 195-287 mm., Manaos, Allen, December, 1920.

17730, 4, 246-280 mm., Contamana, Allen, August, 1920.

17731, 3, 228-343 mm., Yarinacocha, Allen, September, 1920.

$17732,2,205$ and $210 \mathrm{~mm}$. , locality record lost, Allen, 1920.

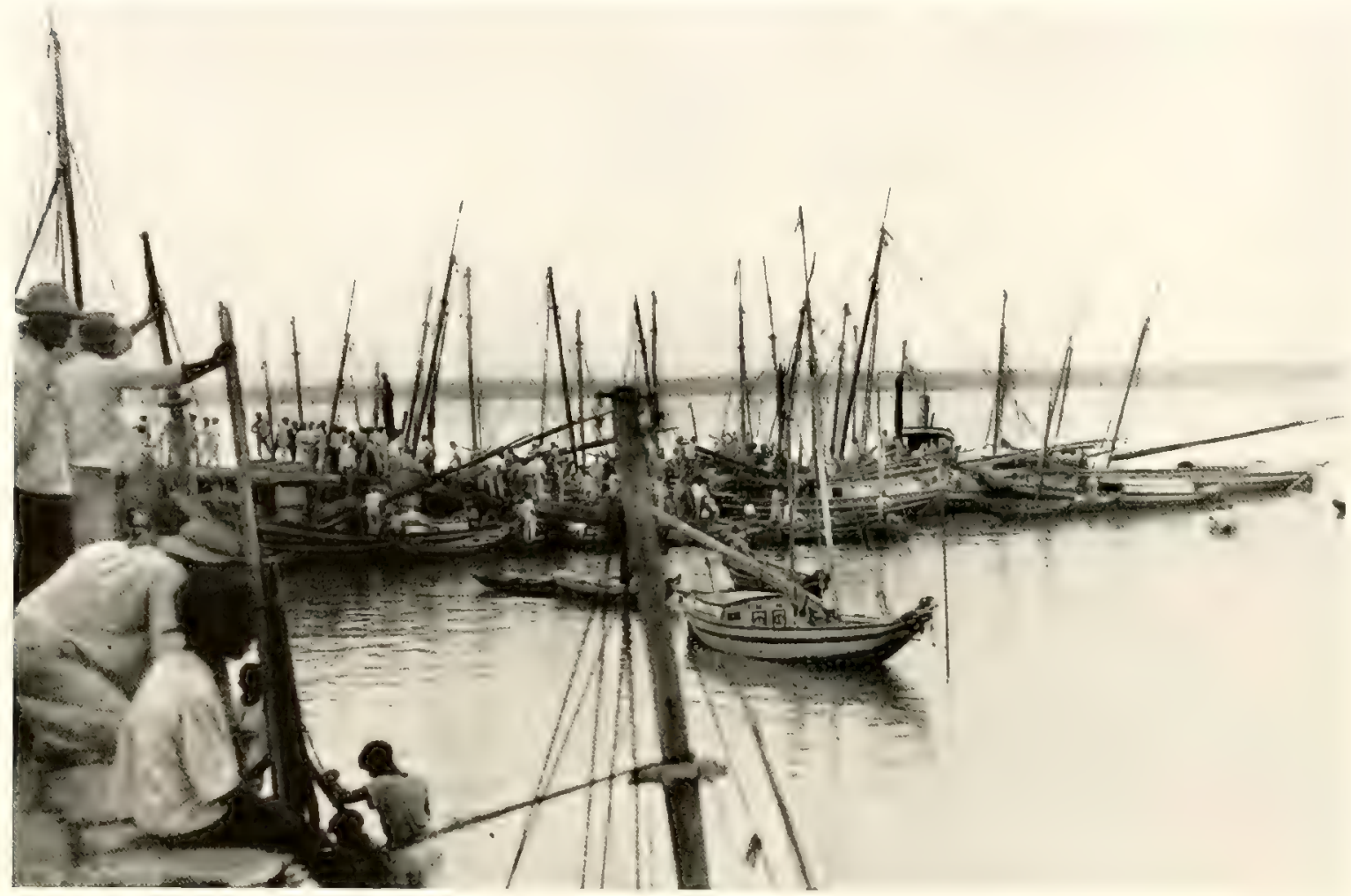

Fig. 47. The fishing and merchant fleet at Para, on the Rio de Para, one of the mouths of the Amazon.

Eigenmann, in the 1912 Guiana report, names Cichla ocellaris as the best food-fish of that country. After much experimentation I believe that this holds also for the upper Amazon. This opinion is not concurred in by the people born there, however. While the flesh is firmer and sweeter than that of most Amazonian fishes, and the bright colors and game qualities have an appeal of their own, the inhabitants judge a fish by other criteria. They have acquired a taste for fishes most easily obtained. Among our sportsmen, on the contrary, their liking is inversely proportional to the ease of catching.

Our specimens were mostly taken from the clearer waters of the oxbow lakes and bayoux. They prefer to lurk in the shade of overhanging banks, or among the brush and trees fallen into the water. This makes them difficult to collect with ordinary gear, such as I had. Most of them were taken by borrowing the light 
javelin, or gig, used by the inhabitants. This consisted of a two-tined iron head and a handle of caña brava, whose flower-stalk reaches a length of ten feet or more, and is extremely light in weight.

Known in oriental Peru as the tucunari.

\section{Cichla temensis Humboldt}

Cichla temensis Humboldt, 1833, Rec. d'Obs. Zool. Anat., II, 169;

Heckel, 1840, Ann. Wiener Mus., II, 413 ;

Günther, 1862, Cat. Fish. Brit. Mus., IV, 304;

Steindachner, 1882 (1883), Denksch. KK. Akad. Wiss. Wien, XLVI, 3, pl. i, fig. 3 (juv.), Rio Huallaga;

Eigenmann and Eigenmann, 1891, Proc. U. S. Nat. Mus., XIV, 69;

Eigenmann and Bray, 1894, Ann. N. Y. Acad. Sci., VII, 611;

Pellegrin, 1903 (1904), Mém. Soc. Zool. France, XVI, 149;

Eigenmann, 1910, Rept. Princeton Univ. Exped. Patagonia, III, 469.

Cichla conibos Castelnau, 1855, Anim. Amér. Sud, Poiss., 18, pl. x, fig. 3;

Günther, 1862, Cat. Fish. Brit. Mus., IV, 305.

\section{Rios Orinoco and Amazons}

\section{Genus 212: BATRACHOPS Heckel}

Batrachops (non Bibron) Heckel, 1840, Ann. Wiener MIus., II, 432;

Günther, 1862, Cat. Fish. Brit. Nus., IV, 306;

Regan, 1905, Proc. Zool. Soc. London, 156;

Eigenmann, 1910, Rept. Princeton Univ. Exped. Patagonia, III, 177;

Eigenmann, 1912, Mem. Carnegie Mus., V, 512.

Crenicichla Eigenmann and Eigenmann, 1891, Proc. U. S. Nat. Mus., XIV, 69.

$$
\begin{aligned}
& \text { Type: Batrachops reticulatus Heckel } \\
& \text { Upper Amazons and British Guiana }
\end{aligned}
$$

Crenicichla-like, but differing in the fact that the inner teeth are not depressible.

\section{Batrachops Cyanonotus (Cope)}

Crenicichla cyanonotus Cope, 1870 (1871), Proc. Amer. Phil. Soc., XI, 569;

Eigenmann and Eigenmann, 1891, Proc. U. S. Nat. Mus., XIV, 70;

Pellegrin, 1903 (1904), Mém. Soc. Zool. France, XVI, 378.

Batrachops cyanonotus Regan, 1905, Ann. Mag. Nat. Hist., (7), XV, 156;

Eigenmann, 1910, Rept. Princeton Univ. Exped. Patagonia, III, 477.

Lower Marañon

One specimen collected by John Hauxwell at Pebas.

\section{Batrachops nemopterus Fowler}

Batrachops nemopterus Fowler, 1939 (1940), Proc. Acad. Nat. Sci. Phila., XCI, 283, fig. 64. 


\section{Bajo Ucayali}

Three specimens, type and paratypes, 129-185 mm., Contamana, Morrow collection; characterized by the deep body, large scales, and the prolonged soft dorsal and anal fins.

\section{Batrachops Reticulatus Heckel}

Batrachops reticulatus Heckel, 1840, Ann. Wiener Mus., II, 433, Guiana;

Regan, 1905, Proc. Zool. Soc. London, 155;

Eigenmann, 1910, Rept. Princeton Univ. Exped. Patagonia, III, 477.

Crenicichla reticulata Günther, 1862, Cat. Fish. Brit. MIus., IV, 309;

Eigenmann and Eigenmann, 1891, Proc. U. S. Nat. Mus., XIV, 70.

Crenicichla elegans Steindachner, 1882 (1883), Denksch. KK. Akad. Wiss. Wien, XLIV, 15, "Hoch Peru":

Pellegrin, 1903 (1904), Além. Soc. Zool. France, XVI, 378, "Haut-Perou."

Amazons and the Guianas

\section{Genus 213: CRENICICHLA Heckel}

Crenicichla Heckel, 1840, Ann. Wiener Mus., II, 416;

Eigenmann and Eigenmann, 1891, Proc. U. S. Nat. Mus., XIV, 69;

Regan, 1905, Ann. Mag. Nat. Hist., (7), XVI, 158;

Eigenmann, 1910, Rept. Princeton Univ. Exped. Patagonia, III, 477;

Eigenmann, 1912, גem. Carnegie Mus, V, 513.

\section{Type: Crenicichla vittata Heckel \\ Guianas to Rio de la Plata}

Maximum extension of the mandible among the cichlids; preopercle serrate; inner series of teeth depressible; scales of lateral line larger than those adjacent; body form elongate.

\section{Crenicichla saxatilis (Linnaeus)}

Sciaena Linnaeus, 175t, Mus. Adolphi Fred., 65, pl. xxxi, fig. 1.

Sparus Gronow, 1756, MIus. Ichth., II, 29, pl. vi, fig. 3.

Sparus saxatilis Linnaeus, 1758, Syst. Nat., ed. x, 279.

Sparus rufescens Gronow, 1763, Zoophyl., 67, pl, vi., fig. 3.

Perca saxatilis Bloch, 1792, Ausl. Fische, VI, 79, pl. 309.

Cichla labrina Agassiz, 1829, Sel. Gen. et Spec. Pisc. Bras., 99, pl. lxii, fig. 1.

Crenicichla saxatilis Heckel, 1840, Ann. Wiener Mus, II, 432;

Günther, 1862, Cat. Fish. Brit. MIus., IV, 308;

Boulenger, 1887, Proc. Zool. Soc. London, 275, Canelos;

Eigenmann and Bray, 1894, Ann. N. Y. Acad. Sci., VII, 620;

Pellegrin, 1903 (1904), IIém. Soc. Zool. France, XVI, 373;

Regan, 1905, Proc. Zool. Soc. London, 159;

Eigenmann, 1910, Rept. Princeton Univ. Exped. Patagonia, III, 477;

Haseman, 1911c, Ann. Carnegie Mus., VII, 350;

Eigenmann, 1912, Mem. Carnegie MIus, V, 513. 
Crenicichla argynnis Cope, 1871 (1872), Proc. Acad. Nat. Sci. Phila., XXIII, 253, Rio Ambyiacu; Pellegrin, 1903 (1904), Mém. Soc. Zool. France, XVI, 373.

Crenicichla proteus Cope, 1871 (1872), Proc. Acad. Nat. Sei. Phila., XXII, 252, Rio Ambyiacu; Pellegrin, 1903 (1904), Mém. Soc. Zool. France, XVI, 373.

Trinidad to Rio Grande do Sul, Paraguay and Peru

17768, 6, 67-100 mm., brook, Puerto Bermudez, R. Pichis, Allen, July, 1920.

$17769,5,115-170 \mathrm{~mm}$. circa, Lago Cashiboya, Allen, August, 1920.

$17770,1,134 \mathrm{~mm}$., brook, Rio Itava, Allen, September, 1920.

$17771,9,82-190 \mathrm{~mm}$., creek, Rio Morona, Allen, October, 1920.

17774,3 , pond, Iquitos, Allen, September, 1920.

$17792,2,245$ and $280 \mathrm{~mm}$., Manaos, Allen, December, 1920.

\section{Crenicichla lucius Cope}

Crenicichla lucius Cope, 1871, Proc. Amer. Phil. Soc., XI, 570;

Cope, 1878, Proc. Amer. Phil. Soc., XVII, 697, Rio Cachiyacu, Huallaga basin, near Ioyobamba;

Eigenmann and Eigenmann, 1891, Proc. U. S. Nat. Mus., XIV, 70;

Pellegrin, 1903 (1904), Mém. Soc. Zool. France, XVI, 377;

Regan, 1905, Ann. Mag. Yat. Hist., (7), XV, 160;

Eigenmann, 1910, Rept. Princeton Univ. Exped. Patagonia, III, 477.

\section{Basin of Rio Huallaga}

One specimen, six inches long, in the Hauxwell collection at the Philadelphia Academy of Sciences.

\section{Crenicichla anthurus Cope}

Crenicichla anthurus Cope, 1871 (1872), Proc. Acad. Nat. Sci. Phila., XXIII, 252, pl. x, fig. 1, Rio Ambyiacu;

Eigenmann and Eigenmann, 1891, Proc. U. S. Nat. Mus., XIV, 70;

Pellegrin, 1903 (1904), Mém. Soc. Zool. France, XVI, 377.

Crenicichla lucius (in part) Regan, 1905, Ann. \Iag. Nat. Hist., (7), XV, 160;

Eigenmann, 1910, Rept. Princeton Univ. Exped. Patagonia, III, 477.

\section{Amazons of Peru and Ecuador}

15986, 4, 111-138 mm., Iquitos, Morris, 1922.

This material is sufficiently unlike $C$. lucius to allow its withdrawal from the synonymy of that species, placing it with the Ambyiacu species, anthurus, which is nearby both taxonomically and geographically.

\section{Crenicichla geayi Pellegrin}

Crenicichla gcayi Pellegrin, 1903, Bull. Mus. Hist. Nat., IX, 123;

Pellegrin, 1903 (1904), Mém. Soc. Zool. France, XVI, 375;

Regan, 1905, Proc. Zool. Soc. London, 161;

Eigenmann, 1910, Rept. Princeton Univ. Exped. Patagonia, III, 477.

\section{Rio Orinoco, Peruvian Amazon}

15986, 6, 114-188 mm. to end of middle caudal rays, Iquitos, Morris, 1922.

17772, 1, 170 mm., creek, Pto. Bermudez, R. Pichis, Allen, July, 1920. 
Middle series of scales 55 ; D. XXII, $10 ; \mathrm{A}$. III, 8 , 3, 117-138 mm., creek, Yurimaguas, Allen, November, 1920.

If hybridization were known to occur among the species of Crenicichla, both $C$. geayi and $C$. saxatilis might be thought to have contributed to the pedigree of the three uncatalogued specimens.

\section{Crenicichla Johanna Heckel}

Crenicichla johanna Heckel, 1840, Ann. Wiener Mus., II, 417, R. Guaporé;

Steindachner, 1882 (1883), Denksch. KK. Akad. Wiss. Wien, LXVI, 3, Rio Huallaga, one, $250 \mathrm{~mm}$;

Regan, 1905, Proc. Zool. Soc. London, 168;

Eigenmann, 1910, Rept. Princeton Univ. Exped. Patagonia, III, 478;

Haseman, 1911c, Ann. Carnegie Mus., VII, 356;

Eigenmann, 1912, Mem. Carnegie Mus., V, 520.

Crenicichla joanna Cope, 1878, Proc. Amer. Phil. Soc., XVII, 697, Rio Marañon.

Crenicichla johanna johanna Günther, 1862, Cat. Fish. Brit. Mus., IV, 307.

Crenicichla brasiliensis johanna Eigenmann and Eigenmann, 1891, Proc. U. S. Nat. Mus., XIV, 69;

Pellegrin, 1902, Bull. Mus. Hist. Nat., VIII, 182;

Pellegrin, 1903 (1904), Mém. Soc. Zool. France, XVI, 383, fig. 42, 6.

\section{Venezuela and the Guianas to upper Amazons}

17773, 3, 192-282 mm., Rio Pacaya, Allen, August, 1920.

\section{Genus 214: PTEROPHYLLUM Heckel}

Pterophyllum Heckel, 1840, Ann. Wiener Mus., II, 334;

Günther, 1862, Cat. Fish. Brit. Mus., IV, 316;

Eigenmann and Eigenmann, 1891, Proc. U. S. Nat. Mus., XIV, 71;

Pellegrin, 1903 (1904), Mém. Soc. Zool. France, XVI, 215;

Eigenmann, 1910, Rept. Princeton Univ. Exped. Patagonia, III, 479 ;

Eigenmann, 1912, Mem. Carnegie Mus., V, 520;

Ahl, 1928, Zool. Anz., LXXVI, 319.

Type: Platax scalaris Cuvier and Valenciennes

Orinoco, Guiana, Amazons

Extremely compressed and deep; spines of dorsal and anal graduated, the first rays prolonged into long filaments; gill-arch not modified, the rakers $11-14$, moderate, stiff; teeth conical, in bands, the outer ones in each jaw larger than the inner; maxillary but slightly visible.

\section{Pterophylum scalare (Cuvier and Valenciennes)}

Platax scalaris Cuvier and Valenciennes, 1831, Hist. Nat. Poiss, VII, 237, Brazil. Pterophyllum scalaris Heckel, 1840, Ann. Wiener Mus., II, 335, R. Yegro;

Günther, 1862, Cat. Fish. Brit. MIus., IV, 316;

Cope, 1871, Proc. Acad. Nat. Sci. Phila., XXIII, 250, R. Ambyiacu;

Steindachner, 1875, Sitzb. KK. Akad. Wiss. Wien, LXXI, 136. 
Pterophyllım scalare Eigenmann and Eigenmann, 1891, Proc. U. S. Nat. Mus., XIV, 71;

Pellegrin, 1902, Bull. Mus. Hist. Nat., VIII, 183;

Pellegrin, 1903 (1904), Xém. Soc. Zool. France, XVI, 251, "Haut-Perou," 8 specimens, 2 from "Haut-Amazone";

Regan, 1905, Ann. Mag. Nat. Hist., (7), XVI, 441;

Eigenmann, 1910, Rept. Princeton Univ. Exped. Patagonia, III, 479;

Eigenmann, 1912, Mem. Carnegie Mus., V, 521;

Ahl, 1928, Zool. Anz., LXXVI, 319.

Range that of the genus

15988, 6, 60-99 mm. to end of middle caudal rays, Iquitos, Morris, 1922.

$17780,3,65-78 \mathrm{~mm}$., Yarinacocha, Allen, August, 1920.

\section{Order HETEROSOMATA Family XXIII: Soleidae}

\section{Genus 215: ACHIRUS Lacépède}

Achirus Lacépède, 1803, Hist. Nat. Poiss., IV, 658;

Cuvier, 1829, Règne Anim., ed. ii, II, 343;

Eigenmann, 1910, Rept. Princeton Univ. Exped. Patagonia, III, 483;

Eigenmann, 1912, Mem. Carnegie Mus., V, 526;

Myers, 1929, Copeia, no. 171, 36, 37;

Hubbs, 1936, Carnegie Inst. Publ., 457, 284.

Trinectes Rafinesque, 1832, Atlantic Jour., I, scabra.

Grammichthys, Monochirus Kaup, 1858, Arch. Naturg., XXIV, 94.

Baiostoma Bean, 1882, Proc. U. S. Nat. Mus., V, 413.

Barostoma Jordan and Gilbert, 1883, Bull. U. S. Nat. Mus., XVI, 965.

Anathyridium Chabanand, 1928, Bull. Inst. Océanogr., no. 523, 25.

\section{Type: Pleuronectes achirus Linnaeus}

Jamaica to Buenos Aires and Amazons

Jaws equal; ventrals nearly equally developed and not continuous with the anal fin, their origin remote from chin; scales ctenoid; a margin about the blind side of the head with profuse fringes; lateral line straight.

\section{Achirus achirus (Linnaeus)}

"Passer lineis transversis notatus" Sloane, 1725, Jamaica, II, 277, pl. cexlvi, fig. 2.

Pleuronectes lineatus Linnaeus, 1758, Syst. Nat., ed. x, I, 268.

Achirus lineaus Valenciennes, 18t7, in d'Orb. Voy. Amẻr. Merid., V, pl. xvi, fig. 2;

Eigenmann and Eigenmann, 1891, Proc. U. S. Nat. Mus., XIV, 73;

Jordan and Evermann, 1898, Bull. U. S. Nat. Mus., no. 47, II I, 2697;

Eigenmann, 1910, Rept. Princeton Unir. Exped. Patagonia, III, 183;

Eigenmann, 1912, Mem. Carnegie Mus., V, 526;

Fowler, 1914, Proc. Acad. Nat. Sci. Phila., LXVI, 283;

Hubbs, 1936, Carnegie Inst. Publ., no. 457, 284.

Baeostoma (Anathyridium) maculipinnis Chabanaud, 1935, Bull. Inst. Océanogr., no. 523, 25.

Achims achirus Chabanaud, 1935, Bull. Inst. Océanogr., no. 661, 1-24;

Fowler, 1939 (1940), Proc. Acad. Nat, Sci. Phila., XCI, 278, two, 150 and $17 t \mathrm{~mm}$., Contamana. 
Florida keys, West Indies to Uruguay, La Plata, and the Peruvian Amazon 16155, 5, 28-163 mm., Gosulimacocha, Allen, October, 1920.

16156, 2, 103-157 mm., Iquitos, Morris, 1922.

$16157,8,27-120 \mathrm{~mm} .$, R. Huallaga, Yurimaguas, Allen, November, 1920.

16163, 4, 16-27 mm., Yarinacocha, Allen, September, 1920.

\section{Genus 216: ACHIROPSIS Steindachner}

Achiropsis Steindachner, 1876, Sitzb. KK. Akad. Wiss. Wien, LXXIV, 158;

Eigenmann and Eigenmann, 1891, Proc. U. S. Nat. Mus., XIV, 73;

Eigenmann, 1910, Rept. Princeton Univ. Exped. Patagonia, III, 483.

\section{Type: Solea nattereri Steindachner}

Rio Negro to the Huallaga

Gill-openings small, narrow slits on both sides of the head; snout produced in the form of a pendant to the origin of the ventral fins; scales well-developed, without fringes; both ventral fins well developed.

\section{Achiropsis Nattereri Steindachner}

Solea (Achiropsis) nattereri Steindachner, 1876, Sitzb. KK. Akad. Wiss. Wien, LXXIV, 158.

Achiropsis nattereri Jordan and Goss, 1886 (1889), Rept. U. S. Fish Comm., XIV, 318;

Eigenmann and Eigenmann, 1891, Proc. U. S. Nat. Mus., XIV, 73;

Eigenmann, 1910, Rept. Princeton Univ. Exped. Patagonia, III, 483;

Chabanaud, 1927, Ann. Mag. Nat. Hist., (9), XX, 528, note;

Chabanaud, 1928, Ann. Mag. Nat. Hist., (10), I, 640;

Fowler, 1939 (1940), Proc. Acad. Nat. Sci. Phila., XCI, 279, one, 225 mm., Contamana.

Rio Negro to the Huallaga basin

16158, 1, 209 mm., Rio Huallaga, Yurimaguas, Allen, November, 1920.

$16159,2,150$ and $165 \mathrm{~mm}$., Iquitos, Morris, 1922.

$16160,3,129-193$ mm., Iquitos, Allen, 1920.

The present and preceding species are members of that not insignificant marine relict fauna which extends up the Amazon and its Peruvian affluents for three thousand miles or more.

\section{Order PLECTOGNATHI Family XXIV: Tetraodontidae}

Genus 217: COLOMESUS Gill

Tetrodon Bloch and Schneider, 1801, Syst. Ichth., 505;

Günther, 1870, Cat. Fish. Brit. Mus., VIII, 286.

Les Batrachopes Bibron, 1855, Rev. Zool., (2), VII, 279, psittacus.

Batrachops Bibron, 1855, Rev. Mag. Zool., VIII, 280, preoccupied.

Colomesus Gill, 188t, Proe. U. S. Nat. Nus., VII, 422, psittacus;

Eigenmann and Eigenmann, 1891, Proc. U. S. Nat. Mus., XIV, 73;

Eigenmann, 1910, Rept. Princeton Univ. Exped. Patagonia, III, 184;

Eigenmann, 1912, Mem. Carnegie Mus., V, 528. 
Type: T'etrodon psittacus Bloch and Schneider

Marine and fresh waters of South America

Puffers with narrow frontals, not reaching to the orbit of the eye, and united with the prefontals; snout rounded, obtuse; dorsal and anal fins short and rounded.

\section{Colomesus psittacus (Bloch and Schneider)}

Ostracion tetraodon Seba, 1748, Locupl. Rer. Nat., III, pre-Linnaean.

Tetrodon psittacus Bloch and Schneider, 1801, Syst. Ichth., 505;

Günther, 1870, Cat. Fish. Brit. Mus., VIII, 286;

Cope, 1878, Proc. Acad. Nat. Sci. Phila., XVII, 695, Marañon.

Colomesus psittacus Gill, 1884, Proc. U. S. Nat. NIus., VII, 422 ;

Eigenmann and Eigenmann, 1891, Proc. U. S. Nat. Mus., XIV, 73;

Jordan and Evermann, 1898, Bull. U. S. Nat. MIus., no. 47, 1740;

Eigenmann, 1910, Rept. Princeton Univ. Exped. Patagonia, III, 484;

Eigenmann, 1912, Mem. Carnegie Mus., V, 529.

West Indies and Guianas to Para and Peru

16140 ,

16141 ,

16142 ,

16143, many,

16144 ,

\footnotetext{
Rio Paranapura, Yurimaguas, Allen, November, 1920. , Iquitos, Allen, September, 1920.

, I urimaguas, Allen, November, 1920. Rio Morona, Allen, October, 1920

, Gosulimacocha, Allen, October, 1920.
}

Many specimens were taken, of considerable range in size. This is still another of the relict fauna of an area once oceanic. They also reach to the fringes of the Andes, a distance probably exceeding three thousand miles from salt water at the mouth of the Amazon. Like their marine relatives they continue the habit of swallowing water or air, whichever may be the more convenient, and taking on an almost spherical outline.

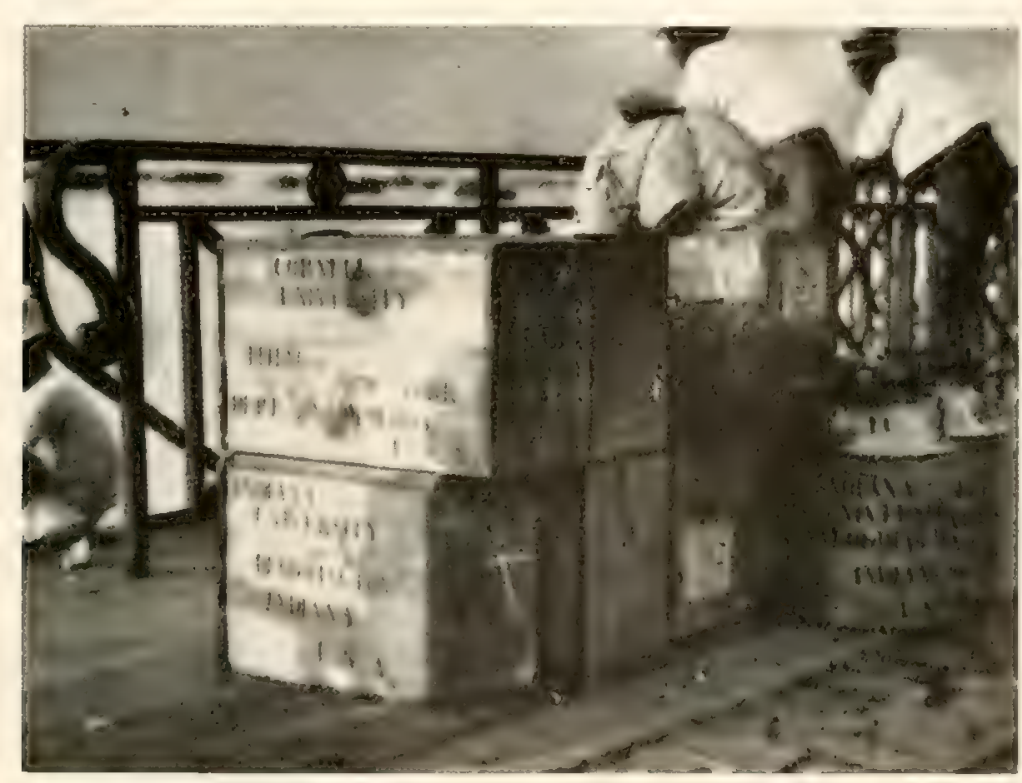

- Fis. 48. Farewell to South America on the docks at l'ara. 



\section{BIBLIOGRAPHY}

\section{POPULAR WORKS WHICH CONTAIN ALLUSIONS TO FISHES}

\section{André, Eugene.}

1904. Naturalist in the Guianas. London: Smith Elder of Co.

Bandelier, Adolph F.

1910. The Islands of 'Titicaca and Koati. New York; Hispanic Soc.

Bates, Henry W.

1861. A Naturalist on the River Amazons, ed. 2. London, John Murray.

Beals, Carleton.

193-t. Fire on the Andes. Philadelphia; J. B. Lippincott \& Company.

Beebe, William.

1917. Tropical Wild Life (Chap. $3 \pm$ by Rev. Walter G. White on fishes). New York; $N . Y$. Zoological Soc.

\section{Bowman, Isaiah.}

1916. The Andes of Southern Peru. New York; Henry Holt and American Geographical Soc.

\section{Bowman, Isaiah.}

1921. Desert Trails of Atacama. New York; American Geographical Soc., Special Publ. no. 5 .

Castelnau, Francois de.

1855. Animaux Nouveaux ou Rares de L'Amerique du Sud, Tome I. Paris; P. Bertrand.

Cherrie, George K.

1930. Dark Trails. New York; G.P. Putnam's Sons.

Church, Col. G. E.

1912. The Aborigines of South America. London; Chapman and Hall.

Cutright, Paul Russell.

1910. The Great Taturalists Explore South America. New York; The Macmillan Co.

Daniel, Hawthorne. (See Dickey, H. S.)

Dell, Anthony. 1926. Llama Land. New York and London; Geoffrey Bles.

Dent, Charles Hastings.

1886. A Year in Brazil. London; Kegan Paul Trench.

Dickey, Herbert Spencer, and Hawthorne Daniel.

1929. The Misadventures of a Tropical Medico. New York; Dodd, Mead of Co.

Domville-Fife, Charles W.

n. d. The United States of Brazil. New York: James Pott \& Co.

1924. Among the Wild Tribes of the Amazons. London; Secley, Service \& Co.

Duguid, Julian.

1931. Green Hell. New York; Century Co.

Dyott, G. M.

1930. Man Hunting in the Jungle. Indianapolis; Bobbs-Merrill Co.

Enock, C. Reginald.

1907. The Andes and the Amazon. London: T. Unwin Fisher.

Ewhank, Thomas.

1856. Life in Brazil. New York; Harper and Bros.

Fleming, Peter.

1934. The Brazilian Adventure. New York: Chas. Seribner's Sons Co. 


\section{Franck, Harry A.}

1922. Working North from Patagonia. New York; Century Co.

Gibbon, Lardner (See Herndon).

Grubb, Kenneth G.

1930. The Amazon and the Andes. New York; Lincoln Macveagh.

Guenther, Konrad.

1931. A Naturalist in Brazil. Boston; Houghton, Mifflin Co.

Hartt, Charles Frederick.

1870. Geology and Geography of Brazil (Scientific Results of a Voyage in Brazil). Boston; Fields, Osgood \& Co.

Herndon, William Lewis, Lieut. and Lieut. Lardner Gibbon.

1854. Exploration of the Valley of the Amazon, vols. I and III, and Atlases, vols. II and IV. Robert Armstrong, Public Printer; A. O. P. Nicholson, Public Printer.

Humboldt, Alexander von, and Aimé Bonpland (Trans. Thomasina Ross).

1852. Travels to the Equinoctial Regions of America during the Years 1799-1804; vols. I-III. London: Bohn \&: Co.

Johnson, George R., Lieut.

1930. Peru from the Air. New York; American Geographical Soc. Special Publ. no. 12.

Kahn, Morton C.

1931. Djuka. New York; Viking Press.

Kingston, W. H. G.

1872. On the Banks of the Amazon. London; T. Nelson and Sons.

Koebel, W. H.

1915. The South Americans. London: Methuen \& Co.

Koebel, W. H. ed.

n. d. Enciclopedia de la America del Sur, Tomos I-IV. Buenos Aires y London; Anglo \& Latin

Lange, Algot.

American Publishing Co.

1912. In the Amazon Jungle. New York; G. P. Putnam's Sons Co.

Lange, Algot.

1914. The Lower Amazon. New York: G. P. Putnam's Sons Co.

MacCreagh, Gordon.

1926. White Waters and Black. New York; Century Co.

McGovern, William Montgomery.

1927. Jungle Paths and Inca Ruins. New York; Century $C_{0}$.

Marcoy, Paul.

1875. Travels in South America, vols. I and II. New York; Scribner, Armstrong \& Co.

Martin, Percy F.

1905. Through Five Republics. London; William Heinemann.

May, Earl Chapin.

1924. 2000 Miles through Chile. New York; Ceniury Co.

Means, Philip Ainsworth.

1931. Ancient Civilizations of the Andes. New York; Chas. Scribmer's Sons.

Medina, José Toribio. (Trans. Bertram T. Lee.)

1934. The Discovery of the Amazon. New York; American Geographical Soc., Special Publ.no. 1\%.

Miller, Leo E.

1919. In the Wilds of South America. London; T. Fisher Unwin.

Mozans, H. J.

1910. Up the Orinoco and down the Magdalena. New York; D. Appleton \& Co.

1911. Along the Andes and down the Amazon. New York; D. Appleton \& Co. 
Nash, Roy.

1926. The Conquest of Brazil. New York; Harcourt, Brace do Co.

Ogilvie, Alan G.

1922. Geography of the Central Andes. New York; Americal Geographical Soc. IIap of Hispanic America, Publ. no. 1.

Orton, James.

1875. The Andes and the Amazon. New York; Harper d. Bros.

Paez, Ramon.

1873. Travels and Adventures in South and Central America. Harlford; Belknap Co.

Prodgers, C. H.

1922. Adventures in Bolivia. London; The Bodley Hcad.

Prodgers, C. H.

1925. Adventures in Peru. New York: E. P. Dutton if Co.

Raimondi, Antonio.

1874-1879. El Perú, 'Tomos I-III. Lima; Imprenta del Estado.

Roosevelt, Theodore.

1914. Through the Brazilian Wilderness. New York; Chas. Seribner's Sons Co.

Roth, Walter E.

1929. Additional Studies of Guiana Indians. Washington; Gov't. Printing Office; Bull. 91, Bur. Amer. Ethnology.

Rudolph, William E.

1940. Bolivia's Water-Power Resources. Geogr. Rev., XXY, 41-63, figs. 1-24, tables I-II.

Savage-Landor, A. Henry.

1913. Across Unknown South America. Boston; Little, Brown if Co.

Shelford, V. E. et al. (O. E. White, Amazon valley.)

1926. Naturalists' Guide to the Americas. Baltimore; Williams \& Wilkins.

Spruce, Richard.

1908. Notes of a Botanist. London; Macmillan.

Squier, E. George.

1877. Peru: Incidents of Travel and Exploration in the Land of the Incas. New York; Harper and Bros.

Im Thurn, Everard F.

1883. Among the Indians of Guiana. London; Kegan Paul, Trench of Co.

Tolten, Hans.

1936. Enchanting Wilderness. London; Selwyn \& Blount.

Up de Graff, F. W.

1923. Head Hunters of the Amazon. London: Herbert Jenkins.

Waterton, Chas. (Ed. Rev. J. G. Wood.)

1889. Wanderings in South America. London; Wacmillan.

Whitbeck, R. H.

1926. Economic Geography of South America. New York; McGraw Hill Co.

White, Ernest William.

1881-1882. The Young Naturalist in the Argentine Republic. London; John Van Voorst.

White, Walter G. (See Beebe.)

Whitney, Caspar.

1912. The Flowing Road. Philadelphia; J. B. Lippincott \& Co.

Whymper, Edward.

1891. Travels among the Great Andes of Ecuador, vol. I, text, and II, Appendix (Fishes by F. Day.) London; John Murray.

Woodroffe, Joseph $\mathbf{F}$.

1914. Upper Reaches of the Amazon. London; Methuen \& Co. 


\section{BOOKS AND ARTICLES ON SOUTH AMERICAN ICHTHYOLOGY}

For additional titles consult (1) Eigenmann and Eigenmann, 1890, The South American Catfishes; (2) Eigenmann, 1912, Freshwater Fishes of British Guiana; and (3) Dean, Bibliography of Fishes.

\section{Agassiz, Louis.}

1829. Selecta Genera et Species Piscium quos in itinere per Brasiliam annis $1817-20 \ldots$ collegit et pingendos curavit J. B. de Spix. Wunich.

\section{Agassiz, Louis and Agassiz, Mrs. Louis.}

1868. A Journey in Brazil. Boston; Ticknor \& Fields.

\section{Allen, William Ray.}

1920. The Irwin Expedition about Cerro de Paseo and Lake Titicaca. Transactions Illinois Academy of Science, XIII, 28-36.

1921a. The Centennial Expedition to Peru. Indiana University Alumni Quarterly, VIII, $111-140$.

1921b. The Centennial Expedition of Indiana University to Peru. Science, LIII, 377-379.

1921c. The Birds of Lake Poopó, Bolivia. The Auk, XXXVIII, 340-344. (With a discussion of the ecology of the region.)

1921d. (With C. H. Eigenmann). A Leaf-Mimicking Fish. Biological Bulletin, XLI, 301-305.

1922a. Notes on the Andean Frog, Telmatobius culeus. Copeia, no. 105, 52-54.

1922b. Keeping Photographic Material in the Tropics. The Camera, March, 1922, $74-81$. (Reprinted entire in the British Journal of Photography, April, 1922).

Anonymous.

1940. Ictiología del Perú. Bol. Mus. Hist. Nat. "Javier Prado," IV (1), 69-84; IV (2), $257 ; I V(3), 898-403 ; I V(4), 518-528$.

Artedi, Petrus.

1738. Ichthyologia sive Opera Omnia de Piscibus. (Edidit Carolus Linnaeus). Lugdini Batavorum.

Azevedo, P. de.

1938. O Cascudo dos Açudes Tordestinos Plecostomus plecostomus. Arquiros Instituto Biologia, São Paulo, IX, 211-224, pl. i, figs. 1-14.

\section{Bibron, Gabriel.}

1855. Note sur un travail inédit de Bibron relatif aux poissons plectognathes gymnodontes.

\section{Bleeker, Pieter.}

$$
\text { Rev. Mag. Zool., VIII, 279-281. }
$$

1858. Ichthyologiae Archipelagi Indici Prodromus; vol. I, Siluri. Batavia.

1862a. Descriptions de quelques Espèces Nouvelles de Silures de Suriname. Koninklijke Akademie Wetenschappen, XIV, 371-389, Amsterdam.

1862b. Notice sur les genres Trachelyopterichthys, Hemicetopsis, et Psendocetopsis. Verslagen en Mededeelingen Koninklijke Akademie Wetenschappen, Amsterdam, XIV, 402-404.

1863a. Sur quelques Genres Nouveaux du Groupe des Doras. Nederlandsch Tijdsch. voor de Dierkunde, I, 10-18, Amsterdam.

1863b. Systema Silurorum Revisum. Nederlandsch Tijdschrift voor de Dierkunde, Amsterdam, $I, 7 \%-122$.

1864. Deseription des Espèces de Silures de Suriname conservées aux Musées de Leide et d'Amsterdam. Natuurhundige Verhandelingen Hollandsche Maatschappij der IVetenschappen, (2), XX, 1-104.

\section{Bloch, Mark Eliezer.}

1785-1795. Naturgeschichte der Ausländischen Fische; parts I-IX, atlas. Berlin. 
Bloch, Mark Eliezer and J. G. Schneider.

1801. Systema Ichthyologiae iconibus ex illustratum, rols. I-II. Berlin.

Bonnaterre, Joseph (L'Abbé).

1788. 'Tableau Encyclopedique et Methodique des Trois Règnes de la Nature; Ichthyologie. Paris. 1-215, pls. $i-c$.

Borodin, N. A.

1929. Totes on Some Species and Subspecies of the Genus Leporimus Spix. Memoirs Muscum Comparative \%oology, L, 268-290, pl. $i$-xizi, text-fig. 1.

1931. On the Genus Anostomus (Family Characinidae). Bulletin Uuscum Comparative Zoology, LXXII, $3 \%-52, p l s . i-i v$.

Boulenger, G. A.

1887a. Descriptions of New South American Characinoid Fishes. Ammals and Magazine of Natural History, (5), $\mathrm{N} I \mathrm{X}, 17 \mathrm{\gamma}-174$.

1887b. An account of the Fishes Collected by Mr. C. Buckley in Eastern Ecuador. Proceedings Zoological Society of London, 1887, 274-283, pls. $x$-x-xiv.

1890. Deseriptions of 'Two New Species of the Siluroid Genus Arges. Procedings Zoological Socicty London, 1890, 450-452, pl. xli.

1898a. Description of Two New Siluroid Fishes from Brazil. Annals and Magazine Natural History, (7), $11,477-478$.

1898b. On a Collection of Fishes from the Rio Jurua, Brazil. Transactions Zooloaical Sociely London, $\mathrm{XIT}, 421-428$.

1898c. Viaggio del Ir. Enrico Festa nell' Ecuador e Regione Vicine; Poisions de l'Equateur. I. Bollettino dei Musei di Zoölogia ed Anatomia Comparata della R. Universita Torino, XIII, $829,1-13$.

1902. Description of a New Cyprinodontid Fish from Eastem Peru. Annals and Magazine of Natural History, (7), I, 153-154.

\section{Castelnau, Francois de.}

1855. Animaux Nouveaux ou Rares Recueillis pendant l'Expedition dans les Parties Cen-

\section{Chabanaud, Paul.} trales de l'Amérique du Sud....; II, Poissons, Paris, 12 and 1-112, pls. $i-l$.

1929. Revision des P'oissons Hétérosomes de la Sous-famille des Achirinae, d'après les Types de Kaup, de Günther et de Steindachner. Bullctin de l'Institute d'Océanographic, no. 523, 1-53.

1930. Sur la Taxonomie des Soléidés du Nouveau-Monde. Bulletin Musée Histoire Naturelle Paris, (2), II, 260-268.

1935. Achiridae nec Trinectidae Caractères et Synonymie de Deux Génotypes Systématiques Certains; Achirus achirus Linné 1758 et Trinectes maculatus Bloch et Schneider 1801. Bulletin de l'Institute d'Océanographie, no. 661, 1-24.

1939. Catalogue Systématique et Chorologique des Téléostéens Dyssymetriques du Globe. Bulletin de l'Institute d'Océanographic, no. 768, 1-31.

\section{Coates, Christopher.}

1939. What We Know about the Electric Eel. Bulletin New York Zoological Socicly, XLII, 80-83, figs. 1 and 2 .

Coates, C. W. and R. T. Cox.

1936. Preliminary Note on the Nature of the Flectric Discharges of the Flectric Ecl, Electrophorus electricus (Linnaeus). Zoologica, New York, XXI, 125-128, text-fig. 1.

Coates, C. W., R. T. Cox, and L. P. Granath.

1937. The Electric Discharge of the Electric Eel, Electrophorus clectricus (Linnaeus). New York, Zoologica, XXII, 1-80, pls. i-ii, text-figs. 1-6.

\section{Cockerel, T. D. A.}

1913 (1915). The Scales of the South American Characinid Fishes. Annals Carnegie Muscum, IX, 92-113, pls. xxiit-xxvii. 


\section{Cope, Edward D.}

1870. Contribution to the Ichthyology of the Marañon. Procecdings American Philosophical Society, $\mathrm{XI}, 559-570$.

1871 (1872). On the Fishes of the Ambyiacu River. Proccedings Academy Natural Sciences Philadelphia, XXIII, 250-294, pls. iii-xvii.

1874. On Some Batrachia and Nematognathi Brought from the Upper Amazon by Prof. Orton. Proceedings Academy Natural Sciences, Philadelphia, XXVI, 120-13\%.

1877 (1878)a. Synopsis of the Cold-blooded Vertebrata Procured by Prof. James Orton during his Exploration of Peru in 1876-77. Proceedings American Philosophical Society, XVII, 33-49.

1877 (1878)b. Synopsis of the Fishes of the Peruvian Amazon, Obtained by Professor Orton during his Expeditions of 1873 and 1877. Proceedings American Philosophical Society, XVII, 673-701.

1894a. On the Fishes Obtained by the Naturalist Expedition in Rio Grande do Sul. Procecdings American Philosophical Society, XXXIII, 84-118, pls. iv-ix.

1894b. On Three New Genera of Characinidae. American Naturalist, XLVIII, 6\%.

Cox, R. T. (See also Coates).

1938. The Electric Eel at Home. Bulletin New York Zoological Society, XLI, ii, 59.

Cuvier, Georges.

1817. La Règne Animal Distribué d'après son Organisation, II, 1-532. Paris.

Cuvier, Georges, et Achille Valenciennes.

1828-1849. Histoire Naturelle des Poissons. Vols. I-XXII, text, and 4 vols. atlas. Paris.

Day, Francis (in Whymper, q. v.)

1891. Supplementary appendix to Travels amongst the Great Andes of the Equator. II,

Driver, Charles.

$$
\text { 137-139. London; John Murray. }
$$

1919. On the Luciopimelodinae, a New Subfamily of the South American Siluridae. Proceedings American Philosophical Society, LVIII, 448-456, pls. ii and iii, text figs. 1 and 2.

Dumeril, André Marie Constant.

1856. Ichthyologie Analytique ou Classification des Poissons, Suivant la Méthode Naturelle, à l'Aide de Tableaux Synoptiques. Mémoires de l'Academie des Sciences de l'Institut Imperial de France, XXVIII, 1-511.

1865, 1870. Histoire Naturelle des Poissons, ou Ichthyologie Générale, vols. I and II, text and atlas. Paris.

Durbin, Marion Lee (Ellis).

1908 (1909). A New Genus and Twelve New Species of Tetragonopterid Characins. Reports on the Expedition to British Guiana of the Indiana University and the Carnegie

\section{Eigenmann, Carl H.} Museum, Report no. 2. Annals Carnegie Museum, VI, 55-7D.

1885. A Review of the Genera and Species of Diodontidae Found in American Waters. Annals New York Academy of Sciences, III, 297-311.

1890. The Evolution of the Catfishes. Zoë, I, 10-15.

1892. On the Presence of an Operculum in the Aspredinidae. American Naturalist, XXVI, 70. (Abstracted in Proceedings Indiana Academy of Science, 1891, 175.)

1893. Catalogue of the Fresh-water Fishes of Central America and Southern Mexico. Proceedings U. S. National Museum, XVI, 53-60.

1894. Notes on Some South American Fishes. Annals New York Academy of Sciences, $X I I, 625-68 \%$.

1903. New Genera of South American Fresh-Water Fishes, and New Names for Some Old Genera. Smithsonian Iiscellaneous Collections, Quarterly Issue, XLV, 114-148.

1905a. The Fishes of Panama. Science, n.s. XXII, 1S-20. 
1905h). Divergence and Convergence in Fishes. Biological Bulletin, TIII, $59-66$.

1905e. The Mailed Catfishes of South America (Loricaridae). Science, n.s. XXII, 792-795.

1900. The Fresh-Water Fishes of South and Middle Ameriea. I'opulat Scionce Monthly, L. IVIII, 515-530, figs. 1-14, map.

1907a. Fowler's "Heterognathous Fishes," with a Tote on the Stethaprioninae. American Naturalist, $\mathrm{ILI}, 76 \gamma-\tau \gamma \mathrm{\gamma}$.

19075. On a Collection of Fishcs from Bucnos Aires. Procedings Itashington Acatemy of Sciences, VIII, 4h9-4,s, pls. xxi-xizii.

1907c. On Further Collections of Fishes from Paraguay. Innals Camegie Museum, IV, $110-1.5 \%$, pls. $i-x v$.

1907d. The Poecilid Fishes of Rio Crande do Sul and the Ita Plata Basin. Procedings U.S. National Musenm, XXIII, 425-438, figs. $1-11$.

1908. Preliminary Descriptions of New Genera and Species of Tetragonopterid Characins; Zoologieal Results of the Thayer Brazilian Expedition. Bulletin Musen Comparative Zoology, LII, 93-106.

1909a. The Fresh-Water Fishes of Patagonia and an Examination of the Archiplata-Archhelenis Theory. Reports Princeton University Lxpedition to Palagonia. III, $225-374, p l s . x x-x x x+i$.

1909b. Some New Genera and Species of Fishes from British Gimm (Reports on the Expedition to British Guiana of the Indiana University and the Carnegie Iuseum, 1908, no. 1.) Innals Carnegie Museum, VI, /45.

1910. Catalogue of the Fresh-IVater Fishes of Tropical and South Temperate America. Reports Princeton Lniversity Expeditions to Patagonia, III, 376-511.

1911a. The Localities at Which Mr. Haseman Made Collections. Amnals Carnegie Museum, $V I I, 299-81 / 4$.

1911b. Description of a New Species of Pygidium. Lnnals Carnegie Museum, VII, ii, 214, p?. xaxii.

1911e. Descriptions of Two New Tetragonopterid Fishes in the British Museum. Annals and Magazine of Natural History, (8), VII, 215-210.

1911d. New Characins in the Collections of the Carnegie Museum. Annals Carncgie Museum, VIII, i, 104-181, pls. iv-ix, text figs. 1 and 2.

1912a. The Cuban Blind Fishes. Procecdings Seventh Internationa? Zoslogica! Congress, Boston, 1907, 697-698.

19121). The Fresh-Water Fishes of British Guiana, Including a Study of the Ecological Grouping of Species, and the Relation of the Fauna of the Platean to That of the Lowlands. Memoirs Carnegic Muscum, V, 1-57s, pls.i-ciii.

1912c. The Origin of the Fish-Fauna of the Fresh Waters of South America. Procecdings Seventh International Zoological Congress, Boston, 1907, 958-959.

1912d. Some Results from an Ichthyological Reconnaissance of Colombia, South America, I. Indiana University Studics, no. 16, 1-27.

1913a. The Fishes of South America. Bulletin Pan-American Union XXXVII, vi, 781-800, figs. $1-18$.

1913b. On Two Species of Fishes Collected by Miss Lola Vance in Peru. Innals Carnegie Museum, VIII, 421-422.

1913c. Some Results from an Ichthyological Recomaisince of Colombia, South America, II. Indiana University Studies, no. 18, 7-32.

191 ta. I Los Peces de Sud América. Boletin de la Unión Panamericana, XXYYIII, i, 1-21, illus.

1914h. On New Species of Fishes from the Rio Meta Basin of Eastern Colombia, and on Albino, or Blind Fishes from near Bogotá. Indiana University Studies, no. 23, $299-230$. 
1914c. Some Results from Studies of South American Fishes. Indiana University Studies, no. $20,20-48$.

1914d. New Fishes from Western Colombia, Ecuador, and Peru. Indiana University Studies, no, $19,1-15$.

191te. The Gymnotidae of Trans-Andean Colombia and Ecuador. Indiana University Studies, no. 25, 235-28\%.

1914f. Report of the Curator of Fishes in the Carnegie Museum (in 1\%th Annual Report of the Director), 19-22.

1915a. The Cheirodontinae, a Subfamily of Minute Characid Fishes of South America. Memoirs Carnegie Muserm, VII, 1-99, map, pls. ii-xvii, and text figs. 1-36.

1915b. The Serrasalminae and Mylinae. Annals Carnegie Museum, IX, 226-272, pls. xliv-lviii.

1916a. New and Rare Fishes from South American Rivers. Annals Carnegie Museum, $X$, ry-86, pls. xiii-xvi, lext figs. 1-3.

1916b. Descriptions of Three New Species of Characid Fishes. Annals Carnegie Museum, X, $87-90$.

1916e. On Aparciodon, a New Genus of Characid Fishes. Annals Carnegie Museum, I, $71-76, p l s, x i-x i i$.

1916d. On the Species of Salminus. Annals Carnegie Museum, X, 91-92.

1917a. Eighteen New Species of Fishes from Northwestern South America. Proceedings American Philosophical Socicty, LVI, 673-689.

1917b. Pimelodella and Typhlobagrus. Memoirs Carnegie Museum, VII, 229-258, pls. xix-xixt.

1917c. Descriptions of Sixteen New Species of Pygidiidae. Proceedings American Philosophical Society, LVI, 690-703.

1917d-1929. The American Characidae. Memoirs Muscum Comparative Zoology, XLIII, parts $i-v$

1917, part i, 1-102, pls. i-viii, xii, xiv-xvi, xev, xeviii, e, and ci.

1918, part ii, 103-108, pls. ix-xi, xiii, xvii-xxix, xxxiii, lxxviii-lxxx, xciii.

1921, part iii, 209-310, pls. xxx-xxxii, xl-lv, lxi-lxii, lxiv, lxvi, lxix, lxxxv, lxxxvii, lxxxix, xci.

1927, part iv, 311-428, pls. xxxiv-xxxix, lvi, lviii-lx, lxv, lxvii, lxviii, lxxv-lxxvii, lxxxiv, lxxxvi, lxxxviii, xe, xei, xevi, xevii, xeix.

1929, and Myers, part v, 429-558, pls. lvii, lxiii, lxx-lxxiv, lxxxi-lxxxiii, xeiv.

1918a. The Pygidiidae. Proceedings Indiana Academy of Science, 1917, 59-66.

1918b. The Pygididae, a Family of South American Catfishes. Memoirs Carnegie Museum, VII, 259-369, pls. xxxvi-lvi, text figs. 1-39.

1919a. The Irwin Expedition. Science, L, 100-102.

19191-1922. Peces Colombianas de las Cordilleras y de los Llanos al Oriente de Bogotá. Boletin Sociedad Colombiana Ciencias Naturales, VII-IX, 126-136, 159-168, 191-199.

1920a. The Irwin Expedition to Peru, Bolivia, and Chile. Indiana University Alumni Quarterly, 1-16.

1920b. The Fishes of Lake Valencia, Caracas, and of the Rio Tuy at El Concejo, Venezuela. Indiana University Studies, VII, no. 44, 1-13, pls. $i-i i$.

1920c. South America West of the Maracaibo, Orinoco, Amazon, and Titicaca Basins, and the Horizontal Distribution of its Fresh-Water Fishes. Indiana University Studies, $V I I$, no. $45,1-24$.

1920d. The Fishes of the Rivers Draining the Western Slope of the Cordillera Occidental of Colombia, Rios Atrato, San Juan, Dagua, and Patia. Indiana University Studies, VII, no. 46, 1-19, map.

1920e. The Fish Fauna of the Cordillera of Bogotí. Joumal Washington Academy of Sciences, X, 460-468. 
1920 (1921)f. A. The Fresh-Water Fishes of Panama East of Longitude $80^{\circ}$ West. B. The Magdalena Basin and the Horizontal and Vertical Distribution of Its Fishes. Indiana University Studies, no. 47, 1-34, maps.

$1920 \mathrm{~g}$. On the Genera Orestias and Empetrichthys. Copeia, no. $89,108-100^{\circ}$, fig. 1.

1920h. On a New Species of Hatcheria and a New Species of Pygidium. Revista Chilena Historia Natural Santiago, X XIII, 53-54.

19201. Iimits of the Genera Fandellia and Urinophilus. Science, LI, 441.

1921. The Origin and Distribution of the Genera of the Fishes of South America West of the Maracaibo, Orinoco, Amazon, and Titicaca Basins. Procedings American Philosophical Socicty, LX, $\mathrm{X}, 1-6$.

1922a. On a New Genus and Two New Species of Pygididae, a Family of South American Nematognaths. Bijdragen Tot de Dierkunde, Amsterdam, Aflevering $\mathrm{X} X I$, 113-114, pls. iii-iv.

1922b. Fishes of Northwestem South America, Part I. Memoirs Carnegie Museum, IX, 1-218, (with Appendix on Fishes of the Meta, 219-277), pls. i-xxxviii, text figs. 1-20.

1922c. Yellow Fever and Fishes. Procedings American Philosophical Socicty, LXI, 204-211.

1922d. The Nature and Origin of the Fishes of the Pacific Slope of Ecuador, Peru, and Chili. Procecdings American Philosophical Society, L X, 503-523, pls. viii-ix.

1923a. The Fishes of the Pacific Slope of South America and the Bearing of Their Distribution on the History of the Development of the Topography of Peru, Ecuador, and Western Colombia. American Naturalist, LVII, 193-210.

1923b. Vellow Fever and Fishes. Amorican Naturatist, LVII, 448-4/8.

1923c. The Andes of Northern P'eru. Science, LVIII, 532.

1924. Yellow Fever and Fishes in Colombia. Procedings American Philosophical Socicty, $L \mathrm{XIII}, 236-238, p l . i$.

1925. A Review of the Doradidae, a Family of South American Nematognathi, or Catfishes. Transactions Imerican Philosophical Society, n. s. X YII, v, 279-366, pls. i-xxvii, text figs. 1-22.

1927. The Fresh-Water Fishes of Chili. Memoirs National Academy of Sciences, XYII, ii, $1-63$, pls. $i-x v i$, text figs. $1-7$.

Eigenmann, Carl H. and William Ray Allen.

1921. A Leaf-Mimicking Fish. Biological Bulletin, ILI, 301-30i), figs. 1-3.

Eigenmann, C. H. and Barton A. Bean.

1907. An Account of the Amazon River Fishes Collected by J. B. Stecre; with a Note on Pimelodus Clarias. Procedings $U$. S. National Muscum, IXXI, 659-668, figs. $1-5$.

Eigenmann, C. H. and William L. Bray.

1894. A Revision of the American Cichlidae. Annals Vew York Academy of Science, VII, 607-624.

Eigenmann, Carl H. and Rosa Smith Eigenmann.

1888a. Preliminary Notes on South American Nematognathi. Proccedings California Academy of Scicnecs, (2), I, 119-172.

1888b. South American Nematognathi. American Naturalist, XXIII, 647-649.

1889a. Descriptions of New Nematognathoid Fishes from Brazil. I'est American Scicntist, $I, 8-10$.

1889b. Preliminary Description of New Species and Genera of Characinidae. West Imerican Scientist, $Y I, \gamma-S$.

1889c. A Revision of the Erythrininat. Procedings California Academy of Sciences, (2), $I I, 100-110, p l . i$.

1889d. A Revision of the Edentulous Genera of the Curimatinae. Annals Vew York Acadcmy of Sciences, $I V, 409-440$. 
1889e. Preliminary Notes on South American Nematognathi, II. Proccedings California Academy of Sciences, (2), $I I, 28-56$.

1890a. A Revision of the South American Nematognathi, or Catfishes. Occasional Papers California Academy of Sciences, I, 1-508, text figs. 1-57, map.

1890b. The Evolution of the Catfishes. Zoë, I, March, 1890.

1891. A Catalogue of the Fresh-Water Fishes of South America. Proccedings U. S. National Museum, XIV, 1-S1.

Eigenmann, C. H. and Homer G. Fisher.

1914. The Gymnotidae of Trans-Andcan Colombia and Ecuador. Indiana University Studies, no. 25, 235-23\%.

Eigenmann, C. H. (John D. Haseman and).

1911. A Brief Report upon the Expedition of the Carnegie Museum to Central South America, together with a List of Localities at Which Mrr. Haseman Collected. Annals Carnegie Muscum, VII, 287-314.

Eigenmann, C. H. and Arthur W. Henn.

1914. On New Species of Fishes from Colombia, Ecuador and Brazil. Indiana University Studies, no. 24, 231-234.

1916. Description of Three New Species of Characid Fishes. Annals Carnegie Museum, $X$, $87-90, p l$. xvii.

Eigenmann, C. H., Arthur W. Henn and Charles E. Wilson.

1914. New Fishes from Western Colombia, Ecuador, and Peru. Indiana University Studies, no. $19,1-15$.

Eigenmann, C. H. and Clarence H. Kennedy.

1903. On a Collection of Fishes from Paraguay, with a Synopsis of the American Genera of Cichlids. Proceedings Academy Natural Scionces Philadelphia, 1903, LV, 497-587.

Eigenmann, C. H., Waldo L. McAtee, and D. P. Ward.

1907. On Further Collections of Fishes from Paraguay. Annals Carnegie Muserm, IV, 110-157, pls. $x x x i-x l$.

Eigenmann, C. H. and Allen A. Norris.

1900. Sobre alguns Peixes do São Paulo, Brazil. Revista M uscu Paulista, IV, 3/9-362.

Eigenmann, C. H. and George Sprague Myers.

1927. A New Genus of Brazilian Characin Fishes Allied to Bivibranchia. Procedings National Academy of Sciences, XIII, 565-566.

1929. See Eigenmann, 1917-1929, The American Characidae, Part v.

Eigenmann, C. H. and Fletcher Ogle.

1907. An Annotated List of Characin Fishes in the U. S. National Museum and the Museum of Indiana University, with Deseriptions of New Species. Proccedings U.S. National Museum, XXXIII, 1-S6, figs. 1-S.

Eigenmann, C. H. and David Perkins Ward.

1905. The Gymnotidae. Procectings Washington Academy of Scicnces, VII, 159-188, pls. lii $x i$.

Eigenmann, C. H., Waldo L. McAtee, and David P. Ward.

1907. On Further Collections of Fishes from Paraguay. Annals Carncgie Muscum IV, 110-157, pls, $x x x i-x l v$.

Ellis, Marion Durbin (Mrs. M. M.)

1913. The Plated Nematognaths. Annals Carnegic Museum, III, 383-418, pl.xxv-xxxi.

Ellis, Max Mapes.

1913. The Gymnotid Eels of Tropical America. Memoirs Carnegic Museum, VI, 109-195, pls, $x v-x$ xiii.

Evermann, Barton Warren, and William Converse Kendall.

1905. An Interesting Species of Fish from the High Andes of Central Ecuador. Proceedings Biological Socicty of Washington, XYIII, 91-106. 
Evermann, Barton Warren, and Iewis Radcliffe.

1909. Notes on a Cyprinodont (Orestias Agassizii) from Central Peru. Procedings Biological socicty of II'ashinglon, X XII, 105-170.

1917. The Fishes of the West Coast of Peru and the Titicaca Basin. Bulletin U. S. Nalional Museum, no. 9i, i-xii, 1-15\%, pls. $i-x i v$.

Filippi, Filippo di.

1853. Nouvelles Fispeces de P'oissons. Revue et Magazin de Zoologie, (2), V, 161-171.

\section{Fisher, Homer G.}

1917. A List of the Hypophthalmidae, ete, in the Camegie MIsseum. Annals Camegie Muscum, II, 40i5-42\%, pl. xlii.

\section{Fowler, Henry Weed.}

1904. Note on the Characinidae. Procedings Academy Nalural Sciences Philadelphia, $L V I, 119$.

1907. Further Knowledge of Some Heterognathous Fishes, I, II. Procedings Acadcmy Natural Sciences P'hiladelphia, 1900, LVIII, 293-351, 431-183, figs. 1-60.

1911. Some Fishes from Venezuela. Proccedings Academy Natural Sciences Philadelphia, 1.9 133 .

1914. Fishes from the Rupununi River, British Guiana. Proceedings Academy Natural Sciences Ihiladelphia, L XVI, 229-284.

1915. Notes on Nematognathous Fishes. Procedings Academy Natural Sciences Philadelphia, LIVII, 203-244.

1926. Fishes from Florida, Brazil, Bolivia, Argentina, and Chile. Proceedings Academy Natural Sciences Philadelphia, L X Y VIII, 249-285, fig.

1939 (1940). A Collection of Fishes Obtained by Mr. William C. Norrow in the Ucayali River Basin, Peru. Procectings Academy Natural Sciences Philadelphia, XCI, 219-289, figs. 1-64.

Garman, Samuel W. (in Agassiz, Alexander, and Garman, S. W.)

1875. Exploration of Lake 'Titicaca; Fishes and Reptiles. Bulletin Muscum Comparative Zoology, 1871-1876, III, 273-270.

\section{Garman, Samuel W.}

1890a. On the Species of the Genus Chalcinus in the Muscum of Comparative Zoology at Cambridge, Mass., U. S. A. Bulletin Essex Institute, X XII, 1-7.

1890b. On the Species of Gasteropelecus. Bulletin Essex Institute, X XII, S-10.

1890c. On the Species of Cynopotamus. Bullctin Essex Institute, I YII, 11-14.

1890d. On the Species of the Genus Anostomus. Bulletin Essex Institute, XXII, 1, 23.

1895. The Cyprinodonts. Mcmoirs II useum Comparative Zoology, XI X, 1-179, pls. i-xii.

\section{Gill, Theodore.}

1858. Synopsis of the Fresh-Water Fishes of the Western Portion of the Island of Trinidad, IV. I. Annals Lyceum Natural History Now York, VI, S6S-480.

1859. Description of a New South American Type of Siluroids, Allied to Callophysus. Procecdings Academy Natural Sciences Philadelphia, 196-197.

1870. Some New Species of Fishes Obtained by Prof. Orton from the Marañon, or Upper Amazon, and Napo Rivers. Iroccedings Academy Nahural Sciences Philadelphia, X $\mathrm{YII}, 92-96$.

1895 (1896). The I)ifferential Characters of Characinoid and Erythrinoid Fishes. Proceetings U. S. National Museum, XVIII, 205-209.

1896a. Notes on Characinoid Fishes with Ctenoid Seales; with a Description of a Yew Psectrogaster. Procedings U.S. National Museum, XVIII, 199-2018.

1896b. The Nomenclature of the Fishes of the Characinoid Gens Tetragonopterus. Proccedings $U$. S. National Huseum, XIIII, 225-227.

\section{Girard, Charles Frederic.}

1855. The United States Naval Astronomical Expedition to the Southern IIemisphere during 
the Years 1849-1852, II; Fishes. Washington, House of Represcntatives, Executive Document no. 121, 230-953, pls. xxix-xxi.

\section{Gmelin, Johann Friedrich.}

1788. Linnaei Systema Naturae, ed. xii. I, iii, Pisces, 1126-1516.

\section{Gosline, William A.}

1940a. Rediscovery and Redescription of Pariolius armillatus, a Genus and Species of Pimelodid Catfishes. Copeia, 1940, 2, $78-80$.

1940b. A Revision of the Neotropical Catfishes of the Family Callichthyidae. Stanford Ichthyological Bulletin, II, $i, 1-36$.

\section{Gregory, William K.}

1933. Fish Skulls: A Study of the Evolution of Natural Mechanisms. Transactions American Philosophical Society, XXIII, ii, 75-481, figs. 1-302.

\section{Gregory, William K., and G. Miles Conrad.}

1938. The Phylogeny of the Characin Fishes. Zoologica, XXII, iv, 319-360, figs. 1-37.

\section{Gronow, Lorenz Theodor.}

1754. Museum Ichthyologicum, I. Lugdini Batavorum, 8 and $1-70, p l s . i-i v$.

1763. Zoophylaceum Gronovianum. Lugdini Batavorum; 1-136.

185t. Catalogue of Fish Collected and Described by Laurence Theodore Gronow, now in the British Museum. London.

\section{Gudger, Eugene W.}

1930a. On the Alleged Penetration of the Human Urethra by an Amazonian Catfish Called Candiru. American Journal of Surgery, $n . s ., V I I I, i, 170-188 ; i i, 448-45 \%$.

1930b. The Candirú; the Only Vertebrate Parasite of Man. New York, Paul W. ILocber.

\section{Günther, Albert.}

1859-1870. Catalogue of the Fishes in the British Museum; I-VIII. I, 1859, xxi, j24; II, $1860, x x i, 548 ; I I I, 1861, x x v, 586 ; I V, 1861, x x x i, 584 ; \mathrm{T}, 1864, x x i i, 45 \pi ; 1 T$ $1866, x v, 368 ; V I I, 1868, x x, 512 ; V I I I, 1870, x x v, 549$.

1863. On New Species of Fishes from the Essequibo. Annals and Magazine of Natural History, (3), $\mathrm{XII}, 441-443$.

1866. Remarks on Some Fishes from the River Amazons in the British Museum. Annals and Magazine Natural History, (3), XVIII, 30-31.

1868. Descriptions of Freshwater Fishes from Surinam and Brazil. Procedings Zoological Society London, 229-217, pls. $x x-x$ xii, text figs. $1-8$.

1869. Descriptions of Some Species of Fishes from the Peruvian Amazons. Proceedings Zoological Socicty London, 423-429, text figs. $1-6$.

1880. An Introduction of the Study of Fishes. Edinburgh, 1-790, illus.

Hancock, John.

1828. Notes on Some Species of Fishes and Reptiles from Demarara, Presented to the Society

\section{Haseman, John D.}

by John Hancock, Esq. Zoological Journal, IV, 240-247.

1911a. A Brief Report upon the Expedition of the Carnegie Museum to Central South America. Annals Carnegie Muscum, VII, 287-299.

1911b. Descriptions of Some New Species of Fishes and Miscellaneous Notes on Others Obtained on the Expedition to Central South America. Annals Carnegie II useum, VII, 315-328, pls, xlvi-lii.

1911c. An Annotated Catalog of the Cichlid Fishes Collected by the Expedition of the Carnegie Museum to Central South America, 1907-1910. Annals Carnegie Uuscum, VII, 329-379, pls. 58-72.

1912. Some Factors of Geographical Distribution in South America. Annals New Fork Academy of Sciences, XXII, 9-112.

\section{Heckel, Jakob.}

1840. Johann Natteres Flussfische Brasiliens nach den Beobachtungen und Mittheilungen 
des Entdeckers, Beschrieben von Jakob Heckel. Annalen des Wiener Museums der Naturgeschichte, II, 397-470.

Henn, Arthur William.

1914. Indiana University Expeditions to Northwestem South America. Scicnce, XL, $602-606$.

1916a. On Various South American Poecilid Fishes. Annals Carnegie Museum, X, 93-142, pl. $x$ vizi-xxi.

1916b. The Voracity of the South American Hoplias. Copcia, no. 33, 53-54.

Hubbs, Carl L.

1926. Studies of the Fishes of the Order Cyprinodontes, VI. University of Michigan Miscellaneous Publications, no. 16, $1-87, p l s . i-i v$.

1936. Fishes of the Yucatan Peninsula. Carnegie Institution of Washington Publication, no. $457,15 \%-28 \%$.

1939. Hepsetus to Replace Hydrocynoides and Sarcodaces for a Genus of African Fresh-IVater Fishes. Copcia, 1989, iii, 168.

Humboldt, Alexander von.

1806. Ueber den Eremophilus und den Astroblepus, Zwei Neue Fisch-Gattungen. Observationes Zoologicae; and Philosophical Magazine, XXIV.

Humboldt, Alexander von, and A. J. A. Bonpland.

1811. Recueil d'Observations de Zoologie et d'Anatomie Comparée, vol. I. (Vol. II, 1833). Paris.

Humboldt, Alexander von, and Achille Valenciennes.

1833. Recherches sur les Poissons Fluviatiles de l'Amérique Equinoxiale. Recueil d'Observations de Zoologie et d'Anatomie Comparée, II, 145-210.

Ihring, von. (See von lhring)

Innes, William $\mathrm{T}$.

1933a. New Importations; The Leaf Fish. The Aquarium, May, 6-9, two figs.

1933b. New Importations; Acaropsis nassa (Heckel). The Aquarium, II, (4) S6, one fig.

1935. Exotic Aquarium Fishes. Philadelphia. Pp. 457.

1939. Cichlasoma festivum (Heckel). The Aquarium, Dec., 132, fig. '1.

Jenyns, Leonard.

1842. The Zoology of the Voyage of H. II. S. Beagle; Part IV, Fish. London, Pp. 172, 29 pls.

Jordan, David Starr.

1886. A Preliminary List of the Fishes of the West Indies. Proceedings U.S. National II useum, I X, $554-608$.

Jordan, David Starr, and Barton Warren Evermann.

1896-1900. The Fishes of North and Middle America, Parts I-IV. Bulletin U. S. National Museum, no, 47, 1-3313, pls. i-cccxcii.

1917-1920. The Genera of Fishes, Parts I-IV. Stanford University Press.

Jordan, David Starr, Barton Warren Evermann, and Howard Walton Clark.

1930. A Check List of the Fishes and Fishlike Vertebrates of North and Middle America, North of the Northern Boundary of Venezuela and Colombia. Report U.S.Commissioner of Fisheries, 1928, ii, 1-670 (Document no. 1055); Washington; Government Printing Office.

Jordan, David Starr, and Alvin Seale.

1925. Analysis of the Genera of Anchovies, or Engraulidae. Copeia, 1925, no. 141, 27-32.

Kaup, J. J.

1856a. Uebersicht der Gymnotidae. Archiv. fü Naturgeschichte, i, 78-87, pl. $i$.

1856b. Catalogue of Apodal Fish in the Collection of the British Museum. London.

Kner, Rudolf.

185ta. Die Panzerwelse des KK. Hofnaturalien-Cabinetes zu Wien. Denkschriften Kaiscrlichen Akademie der Wissenschaften, Wien, $1 T, i, 65-98, p l s . i-v i i i$. 
1854b. Die Hypostomiden; Zweite Hauptgruppe der Familie der Panzerfische. Denkschriften Kaiserlichen Akadomie der Wissenschaften, Wicn, VII, 251-286, pls. $i-v$.

1855. Ichthyologische Beitrüge. Sitzungsberichte Kaiserlichen Akademie der Wissenschaften, Wien, XVII, 92-162, pls. $i-v i$.

1857 (1858). Ichthyologische Beiträge, II Abtheilung. Sitzungsberichte Kaiscrlichen Akademie der Wissenschaften, Wien. X̃XVI, 378-448, pls. $i-i x$.

1859a. Zur Familie der Characinen, III Folge der Ichthyologischen Beiträge. Denkschriften Kaiserlichen Akademie der $\mathrm{W}^{\mathrm{i}}$ ssenschaften, Wien, XVII, i, 137-182, pls. $i-i x$.

1859b. Zur Familie der Characinen, III Folge der Ichthyologischen Beiträge, II Abtheilung. Denkschriften Kaisertichen Akademie der Wisscnschaften, Wion, XVIII, i, 9-62, pls. $i$-viii.

Koelreuter, J. Theophilus.

1761. Piscium Rariorum e Museo Petropolitano Excerptorum Deseriptiones Novi. Commentarii Academiae Scientiarum Imperialis Petropolitanae, VIII, 404-430.

Lacépède, Bernard Germain Etienne de la Ville.

1798-1803. Histoire Naturelle des Poissons, vols. I-V. P'aris.

Ladiges, W.

1938. Drei Neue Fische der Gattungen Hyphessobrycon und Hemigrammus aus dem Peru-

Lahille, F. anischen T'eil des Amazonas. Zoologischer Anzeiger, CXXIV , 49-52.

1929. El Pejerrey. Boletin Ministerio Agricultura Nacional Argentina; Buenos Aires,

\section{Lichtenstein, K. M. H.} XXVIII, 261-395, figs. 1-31.

1819. Ueber Einige Neue Arten von Fischen aus den Gattung Silurus. Wiedomanns Zoologisches Magazin, I, iii, $57-63$.

1826 (1829). Die Werke von Maregrave und Piso neber die Naturgeschichte Brasiliens, erläutert aus den Original-Abbildungen; IV, Fische. Abhandlungen der Königlichen Akademie der Wisscnschaften, Berlin, 49-65.

\section{Linnaeus, Carolus.}

1749-1790. Amoenitates Academicae, vols. I-X.

175t. Museum Regis Adolphi Frederici. Stockholm, $i-x x x$ and $1-96$.

1758. Systema Naturae, ed. x. Holmiac. Pisces, I, 239-338.

1766. Systema Naturae, ed. xii. Holmiae. Pisces, $1,419-582$.

\section{Luitken, Christian Frederik.}

1874 (1875). Characinae Novae Brasiliae Centralis. Oversigt Kongelige Danske Videnskabernes Selskabs Forhandlinger, 127-148.

1891 (1892). Om en Med Stegophiler og Trichomycterer Besloegtet Sydamerikansk Mallefisk

McAtee, Waldo I. (Acanthopoma Annectens). Videnskabelige Naturhistorisle Forening $i$ Kjobenhavn, 58-60.

1938. Carl H. Eigenmann - an Appreciation. Indiana University Alumni Quarlerly, Autumn, 1988.

\section{Marcgravius, Georgius.}

1618. Historiae Rerum Naturalium Brasiliae; Liber Quartus Qui Agit de Piscibus Brasiliae.

\section{Marherr, A.} Lugdini Bataronu, 142-181.

1937. Bemerkungen über Einige Seltener Gepflegte Corydoras-Arten. Blaetter AquarienTerrarienkunde, Stuttgart, XLVIII, 287-2, 40 , lext figs. 1-3.

\section{Meyen, Franz Julius Ferdinand.}

1835. Reise im Peru, I.

Müller, Johannes, and Franz Hermann Troschel.

1844. Synopsis Generum et Specierum Familiae Characinorum. Archiv für Naturgeschichte, I, 81-99. 
1845. Horac Ichthyologicac. IBeschriebung und Abbildung Neuer Fische; Heft I, II. Familie der Characinen. 1-24, pls. $i-x i$.

1S49. Heft III. 1-2s, pls. i-v, Berlin.

Myers, George Sprague.

1926. Deseriptions of a New Pygidid Catfish from the Amazon Basin. Copeia, no. 156, $150-152$.

1927a. An Analysis of the Genera of Neotropical Killifishes Allied to Rivulus. Annals and Magazine Natural History, (9), XIX, 115-129.

1927b. Descriptions of Tew South American Fresh-Water Fishes Collected by Ir. Carl T'ernetz. Bulletin Muscum Comparative Zoology, LAVIII, iii, 107-135.

1928. New Fresh-Water Fishes from Peru, Venezuch and Brazil. Amals and Magazine Natural-IIistory, (10), II, vii, $89-90$.

1929. Notes on Soles Related to Achirus. Copcia, no. 171, 2pp.

1931. The Primary Groups of Oviparous Cyprinodont Fishes. Stanford University Publications; Biological sciences, $11,1-1 \%$.

1934. Corrections of the Type Localities of Metezia mescmbrina, a Formosan Cyprinid, and of Othonocheirodus cigenmanni, a Peruvian Characin. Copeia, 1934, 48.

1936a. A New Characid Fish of the Genus Hyphessobrycon from the Peruvian Amazon. Proceclings Biological Society ITashinglon, XLLX, $97-98$.

1936b. A Tew Genus of Gymnotid Eels from the Peruvian Amazon. Procectings Biological Society Washington, XLIT, 115-116.

1940a. Suppression of Acaropsis and Chalcinus, 'Two Preoceupied Generic Names of South American Fresh-Water Fishes. Stanford Ichthyological Bulletin, I, v, 170.

1940h. The Neotropieal Anchovies of the Cienus Amplova. Procedings California Academy of Sciences, (4), XXIII, $487-442$.

Myers, George S., (C. H. Eigenmann and) See Eigenmann.

Nakashima, Shoji.

1941. Algunos Peces del Oriente Peruano. Boletin Museo Mistoria Natural Javior Prado, Lima, $\mathrm{V}$, xvi, 61-78, figs. 1-14.

Nichols, John T.

1930. Speculation on the History of the Ostariophysi. Copcia, 148-151.

Nigrelli, Ross F.

1939. Fish out of Water. Bullctin New York Zoological Socicty, XLII, ii, 54-01, illus.

Norman, J. R.

1928. The South American Characid Fishes of the Subfamily Serrasalmoninae, with a Revision of the Genus Serrasalmus Lacépède. Proccedings Zoological Socicty London, 781-829, pl. i, text figs. 1-20.

1935. Description of a New Loricariid Catfish from Eenador. Amals and Magazine Natural

Oken, L. History, $\mathrm{NY}^{\mathrm{r}}, 627-629, \mathrm{fig} .1$.

1817. Isis, 1182-1183. (Supplies latinized form of Curier's genera.)

\section{Pallas, Petrus Simon.}

1767-1780. Spicilegia \%oologica, Quibus Novae Imprimis et Obseurae Animalium Species

Pearson, Nathan Everett.

Iconibus, Descriptionibus atque Commentaris Illustrantur, vols. I and II. Berlin.

1924. The Fishes of the Eastern Slope of the Andes; I, The Fishes of the Rio Beni Basin, Bolivia, Collected by the Mulford Expedition. Indiana University Studies, XI, no. 64, 1-58, pls. $i-x i$.

1937a. The Fishes of the Atlantic and Pacific Slopes near Cajamarea, Peru. Procedings California Academy of Sciences, (4), XXIII, vii, $87-98, p l s$, xii-xii, text fig. 1.

1937b. The Fishes of the Beni-Mamoré and Paraguay Basins, and a Discussion of the Origin of the Paraguayan Fauna. Proccedings California Lcademy of Sciences, (4), IXII, viii, 99-11/. 


\section{Pellegrin, Jacques.}

1899. Note sur les Poissons Recueillis par MI. F. Geay dans l'Apuré et ses Affluents. Bulletin Musée d'Histoire Naturelle, Paris, $V, 156-159$.

1902. Cíchlidés du Brésil Rapportés par M. Jobert. Bulletin Musće d'Histoire Naturelle, Paris, VIII, 181-184.

1904a. Sur les Pharyngiens Inferieurs chez les Poissons du Genre Orestias. Comptes Rendues Academic Sciences, CXYXIX, 682-684.

1904b. Mission de G. de Crequi-Montfort et E. Sénéschal de la Grange. Note sur les P'oissons des Lacs Titicaca et Poopó. Bulletin Société Zoölogique de France, XXIX, 90-96.

190tc. Contribution à l'Etude Anatomique, Biologique, et Taxonomique des Poissons de la Famille des Cichlidés. Himoires Sociêté Zoologique de France, XVI, 41-402, pls. iv-vii, text figs. $1-49$.

1907. Les Poissons des Lacs des Hauts Plateaux de l'Amérique du Sud. Mission Scientifique G. de Crequi-Montfort et E. Sénéschal de la Grange (extract), pp. 25, pl. xiv, text figs. $17-18$.

1931. Description d'un Poisson Nouveau de l'Equateur Appartenant à la Famille des Loricariidés. Revue Suisse Zoologique, XXXVIII, 113-115, fig.1.

\section{Perugia, Alberto.}

1897. Di Alcuni Pesci Raccolti in Bolivia dal Prof. Luigi Balzan. Annali Museo Civico di Storia Naturale di Genova, (2), XVIII, 16-27.

\section{Peters, Wilhelm.}

1877. Ủber die von Herm Dr. C. Sachs in Venezuela Gesammelten Fische. Monatsberichte Königliche Akademie der Wissenschaften Berlin, 469-479.

\section{Piso, Guilielmus.}

1658. Indiae Utriusque Re Naturali et Mediea; Liber 'Tertius. Amsterdam, pp. 47-7/4.

\section{Putnam, F. W.}

1871. Note on the Pimelodus Cyclopum of Humboldt. American Naturalist, V, 694.

\section{Quoy, J. R. C., and P. Gaimard.}

1824. Voyage autour du Monde....sur les Corvettes de S. MI. l'Uranie et la Physicienne, pendant les Années 1817-1820; Zoologie, Chap. IX, Poissons, 192-101. I'aris.

\section{Regan, C. Tate.}

1903. Deseriptions of New South-American Fishes in the Collection of the British Museum. Annals and Magazine of Natural History, (\%), XII, 621-630.

1904. A Monograph of the Fishes of the Family Loricariidae. Transactions Zoological Society London, XYII, 191-32/, pls. ix-xxi.

1905a. A Revision of the South-American Cichlid Genera Acara, Nannacara, Acaropsis, and Astronotus. Annals and Magazine of Natural History, (7), XV, 329-347.

1905b. The Systematic Arrangement of the Fishes of the Genus Arges. Annals and Magazine Natural History, (7), $\mathrm{XV}, 529-534$.

1905c. A Revision of the Fishes of the American Cichlid Genus Cichlasoma and of the Allied Genera. Annals and Magazine Natural History, (7), XVI, 60-67; 225-243; $316-340 ; 488-445$.

1905d. A Revision of the South-American Cichlid Genera Crenicara, Batrachops, and Crenicichla. Proceedings Zoological Society London, i, 152-168, pls. 14-15.

1906. A Revision of the South-American Cichlid Genera Retroclus, Heterogramma, and Biotoecus. Annals and Magazine Natural History, (7), XVII, 49-66.

1906-1908. Biologia Centrali-Americana; Pisces. London, $i-x x x i i i ; 1-203 ; 7$ maps, pls. $i-x+2 i$.

1909. The Classification of Teleostean Fishes. Annals and Magazine Natural History, (8), III, $75-86$.

1911. The Classification of the Teleostean Fishes of the Order Ostariophysi; I, Cyprinoidea. Annals and Magazine Natural History, (S), VIII, 13-32, pl. ii. 
1912a. A Rerision of the South-American Siluroid Fishes of the Genus Corydoras, with a List of Specimens in the British Museum. Annals and Magazine Natural History, (8), I, 209-220.

1912b. A Revision of the South-American Characid Fishes of the Genera Chalceus, Pymhulina, Copeina, and Pogonocharax. Annals and Magazine Natural History, (8), I. $887-395$.

1912c. A Revision of the Poeciliid Fishes of the Genera Rivulus, Pterolebias, and Cynolebias. Annals and Magazine Tatural History, (8), X, 494-50S.

1913a. Fishes of Peru, Collected by Dr. H. O. Forbes. Amnals and Magazine Natural History, (8), XII, 278-280.

1913b. Fishes from the River Ucayali, Peru, Collected by Mr. Mounsey. Annals and Magazine Natural History, (8), NII, 281-28S.

\section{Reinhardt, Johann Theodor.}

1858. Stegophitus Insidiosus, en ny Mallefisk fra Brasilien og dens Levemaade. Fidenskabelige Meddelelser fra den Naturhistoriste Forening $i$ Kjobenhavn, nos. 5-7, $79-97, p l . i i$.

1866. Om Trende, forementlig Ubeskrevne Fish af Charaeinernes eller Karpelaxenes Familie. Oversigt ouer det Kongelige Danske Tidenskabernes Selskabs Forhandlinger og dets Medlemmers Arbeider, 49-68, pls. 1-2.

Rendahl, H.

1937. Einige Fische aus Ecuador und Bolivia. Arkiv Zoologie Stockholm, XXIX, A11, $1-11$, text figs. $1-3$.

\section{Ribeiro, Alipio de Miranda.}

1918. Historia NaturaI; Zoologia; Cichlidae. Commissão Linhas T'clegraph do Matto Grosso ao Imazonas, $\mathrm{X} L I, 1-18$, pls. $i-x v i$.

\section{Ridewood, W. G.}

1913. Notes on the South American Freshwater Flying-fish, Gastropelecus, and the Common

\section{Schindler, 0 .}

Flyingfish, Exococtus. Annals and Magazine Natural History, (8), XII, 544-548.

\section{Schomburgk, Robert Hermann.}

$$
\text { 19-25, text figs. } 1-11 \text {. }
$$

1811. Fishes of British Guiana, I. Jardine's Vaturalisls' Library, XXXIX, 81-263; II,

\section{Seba, Albert.} Jardine's Naturalists' Library, IL, 13.4-214.

1758. Locupletissimi Rerum Taturalium Thesauri Accurata Descriptio, III. Amsterdam, $1-212$.

Spix, Johann Baptist de.

1829-1831. Selecta Genera et Species Piscium Quos in Itinere per Brasiliam Annis 1817-1820

\section{Starks, Edwin Chapin.} Collegit. Munich, XII, 1-138, pls. i-ci.

1906. On a Collection of Fishes Made by P. O. Simons in Ecuador and Peru. Proceedings

\section{Steindachner, Franz.}

$$
\text { U. S. National Museum, IX I, no. 1468, 761-800, pls. lvi-lvii, figs. 1-10. }
$$

1868. Die Gymnotidae des Hof-Naturaliencabinetes zu Wien. Sitzungsberichte $K K$. Alademie der IVissenschaften, Wien, LVIII, $i, 249-264, p l s . i-i$.

1875a. Beiträge zur Kenntuiss der Chromiden des Amazonenstromes. Sitzungsberichte $K K$. Alademie Wissenschaften, Wien, LXXI, i, 61-13\%, pls. i-vizi.

1875b. Uber einige Neue Brasilianische Siluroiden aus der Gruppe der Doradinen. Sitzungsberichte $K K$. Akademie Wissenschaften Wien, LXXI, i, 1s8-154, pls. $i-i v$.

1875c. Die Süsswasserfische des Südöstlichen Brasilien, II. Sitzungsberichte $K K$. Akadcmic Hissenschaften Wien, LI XI, i, 211-245, pls. i-vi. 
1875d. Ichthyologische Beiträge, II. Sitzungsberichte $K K$. Akadcmie Wissenschaften Wien, $L X X I, 448-480, p l . i$.

1875e. Beiträge zur Kenntniss der Characinen des Amazonenstromes. Sitzungsberichte $K K$. Akademie der Wissenschaften Wien, $L_{X} X I I, i, 6-24, p l s$. i-ii.

1875f. Ichthyologische Beiträge, IV. Sitzungsberichte KK. Akademic Wissenschaften Wien, LXXXI, i, 551-616, pls. i-xii讠.

1876. Ichthyologische Beiträge, V. Sitzungsberichte $K K$. Akademie Wissenschaften Wien, $L X X I V, i, 49-240, p l s . i-x v$.

1878a. Ichthyologische Beiträge, VI. Sitzungsberichte $K K$. Akademie Wissenschaften Wien, LXXYII, i, 379-392, pls. $i-i i i$.

1878b (1879). Zur Fischfauna des Magdalenen-Stromes. Denkschriften $K K$. Akademic Wissenschaften Wien, $X X X I X, i, 19-\gamma 8$, pls. $i-x$.

1879a. Ueber einige Teue und Seltene Fisch-Arten aus den KK. Znölogischen Museen zu Wien, Stuttgart, und Warschau. Denkschriften KK. Akademie Wissenschaften ITien, $X L I, 1-52, p l s . i-i x$.

1879b. Beiträge zur Kenentniss der Flussfischen Südamerikas. Denkschriften $K K$. Akademio Wissenschaften Wien, XLI, i, 151-172, pls. $i-i v$.

1880a. Zur Fisch-Fauna des Cauea und der Flüsse bei Guayaquil. Denkschriften $K K$. Akademie Wissenschaften Wien, XLII, i, 55-104, pls. $i-i x$.

1880b. Beitrüge zur Kenntniss der Flussfische Südamerikas, II. Denkschriften $K K$. Akademie Wissenschaften Wien, XLIII, $i, 103-144$, pls. $i$-vii.

1880 (1882). Ichthyologische Beitrage, $I X$. Sitzungsberichte $K K$. Akademic Wissenschaften Wien, LXXXII, 288-262.

1881 (1882). Beiträge zur Kenntniss der Flussfische Südamerikas, III. Denkschriften $K K$. Akademie Wissenschaften Itien, $L \mathrm{X} I V, i, 1-18$, pls. $i-v$.

1882 (1883). Beiträge zur Kenntniss der Flussfische Südamerikas, IV. Denkschriften $K K$. Akademie Wissenschaften Wien, XLYI, i, 1-42, pls. $i$-vii.

1891. Ichthyologische Beiträge, XV. Sitzungsberichte KK. Aliademie Wissenschaften Wion, $C, i, 343-374, p l s, i-i i$.

1902. Herpetologische-Ichthyologische Ergebnisse einer Reise nach Südamerika. Denkschriften $K K$. Akademie Wissenschaften Wien, $L X X I I, 88-1 / 49$, pls. $i-v$.

Stoye, F. H.

1934. Corydoras Paleatus (Jenyns): Care and Breeding. The Aquarium, Iay, 1934, 12-14, illus.

\section{Swainson, William.}

1838-1839. On the Natural History and Classification of Fishes, Amphibians and Reptiles. The Cabinet Cyclopedia, I and II.

\section{Tschudi, J. J. von.}

18t5. Untersuchungen über die Fauna Peruana; Ichthyologie. St. Gallen; pp. 35, pls. i-vi.

\section{Ulrey, Albert B.}

1895. South American Characinidae Collected by Charles Frederick Hartt. Amnals New York Academy Sciences, TIII, 258-800.

Valenciennes, Achille. (In d'Orbigny.)

1847. Voyage dans l'Amérique Meridionale; $\mathrm{V}$, Poissons. 1-11, pls. $i-x v i$.

Valenciennes, Achille (Georges Cuvier et.)

See Curier and Valenciennes.

\section{Von Ihring, Rodolpho.}

1937. Oviducal Fertilization in the South Américan Catfish, Trachycorystes. Copcia, $1987,4,201$. 
Willughby, Francis.

1686. De Historia I'iscium. Oxonii, 1-8/s (and Appendix S0), pls. i clxxavi.

\section{Wilson, Charles Earl.}

1916. Some Marine Fishes from Colombia and Ecuador. Annals Carnegie Museum, X, $i$ and ii, $5 \gamma-\gamma 0, p l . x$.

Wilson, Charles Earl, (Eigenmann, Wilson and Henn, q. v.)

Zuñiga, Enrique.

1941. Regimen alimentico y Longitud del Tubo Digestico en los Peces del Genero Orestias. Bol. Mus. Hist. Nat. "Javier Prado," Y, 78-86. 

PLATES 


\section{PLA'TE II}

Fig. 1. Bunocephalus haggini Eigenmann and Allen, sp. nov. 15t08, type, $94 \mathrm{~mm}$., Amazon, Iquitos.

FIG. 2. Bunocephalus bifidus Eigenmann, sp. nov. 15 412 , type, $47 \mathrm{~mm}$, Yurimaguas.

FIG. 3. Bunocephalus retropinnis Eigenmann, sp. nov. 14332, type, 86 mm., Cacequi, Brazil, Haseman coll. 

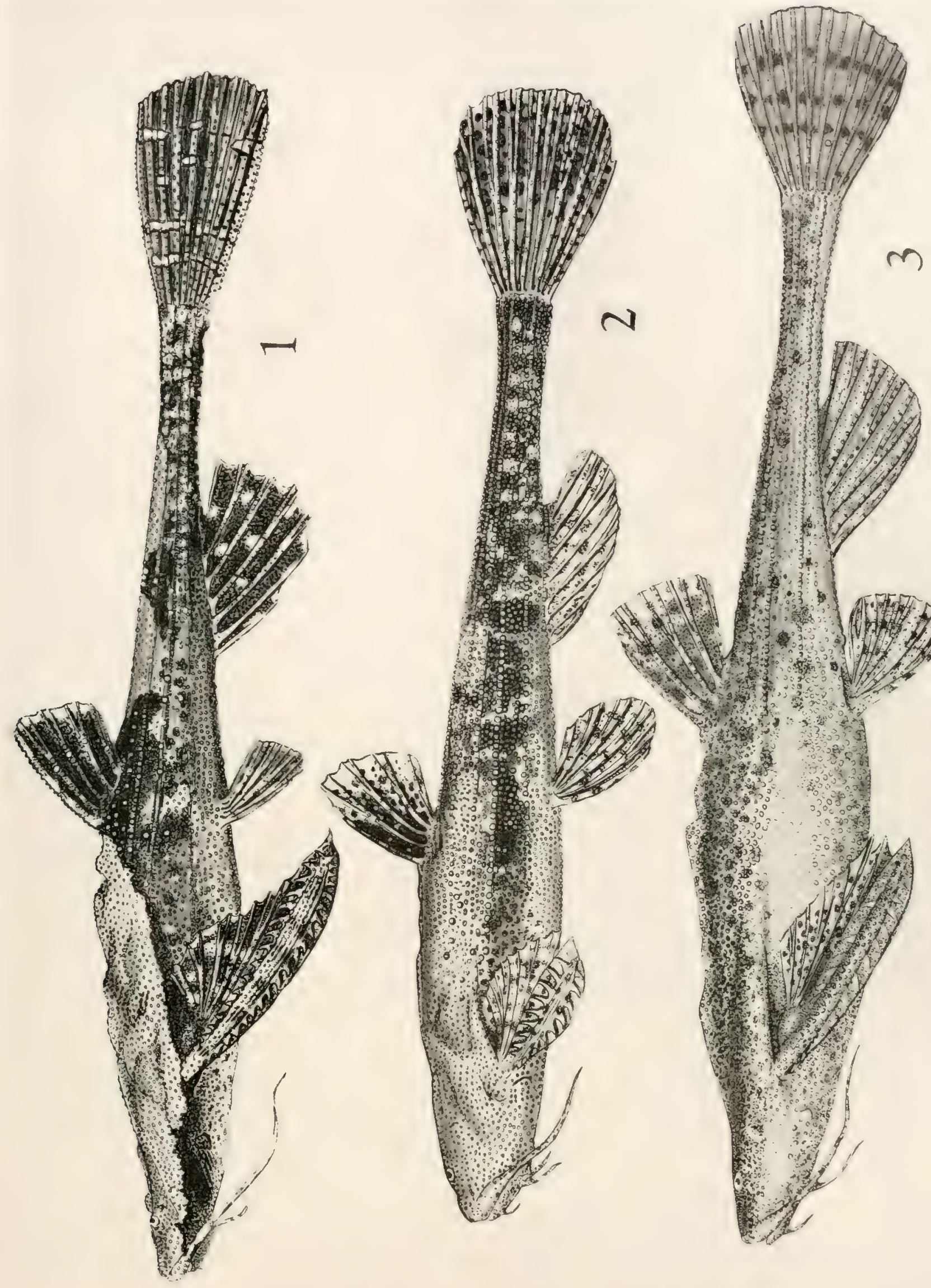

(n)
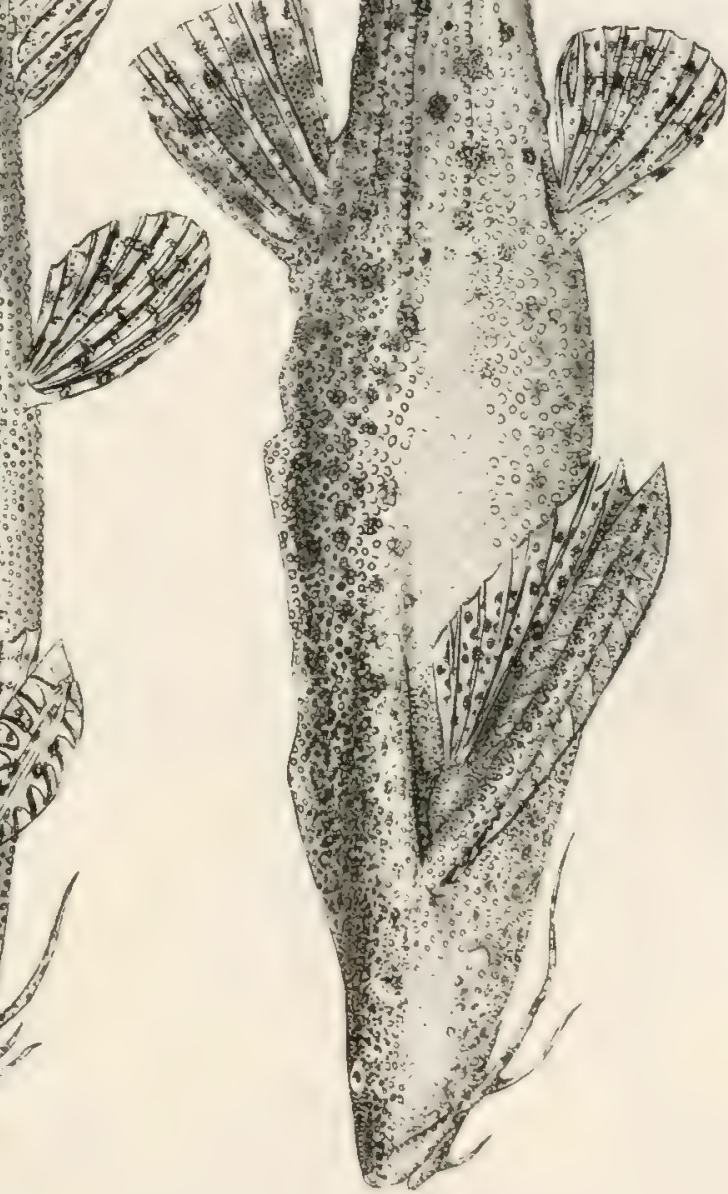


\section{PLATE III}

FIG. 1. Microglanis zonatus Eigenmann and Allen, sp. nov. 15890, type, $24 \mathrm{~mm}$., Rio Morona.

FIG. 2. Pectoral spine of the same.

Figs. 3 ANd 4. Chasmocranus peruanus Eigenmann and Pearson, sp. nov. 15869, type and paratype, 60 and $63 \mathrm{~mm}$., Puerto Melendez.

FIG. 5. Pimelodella peruana Eigenmann and Myers, sp. nov. 15868, type, $52 \mathrm{~mm}$., Inahuaya, R. Ueayali. 


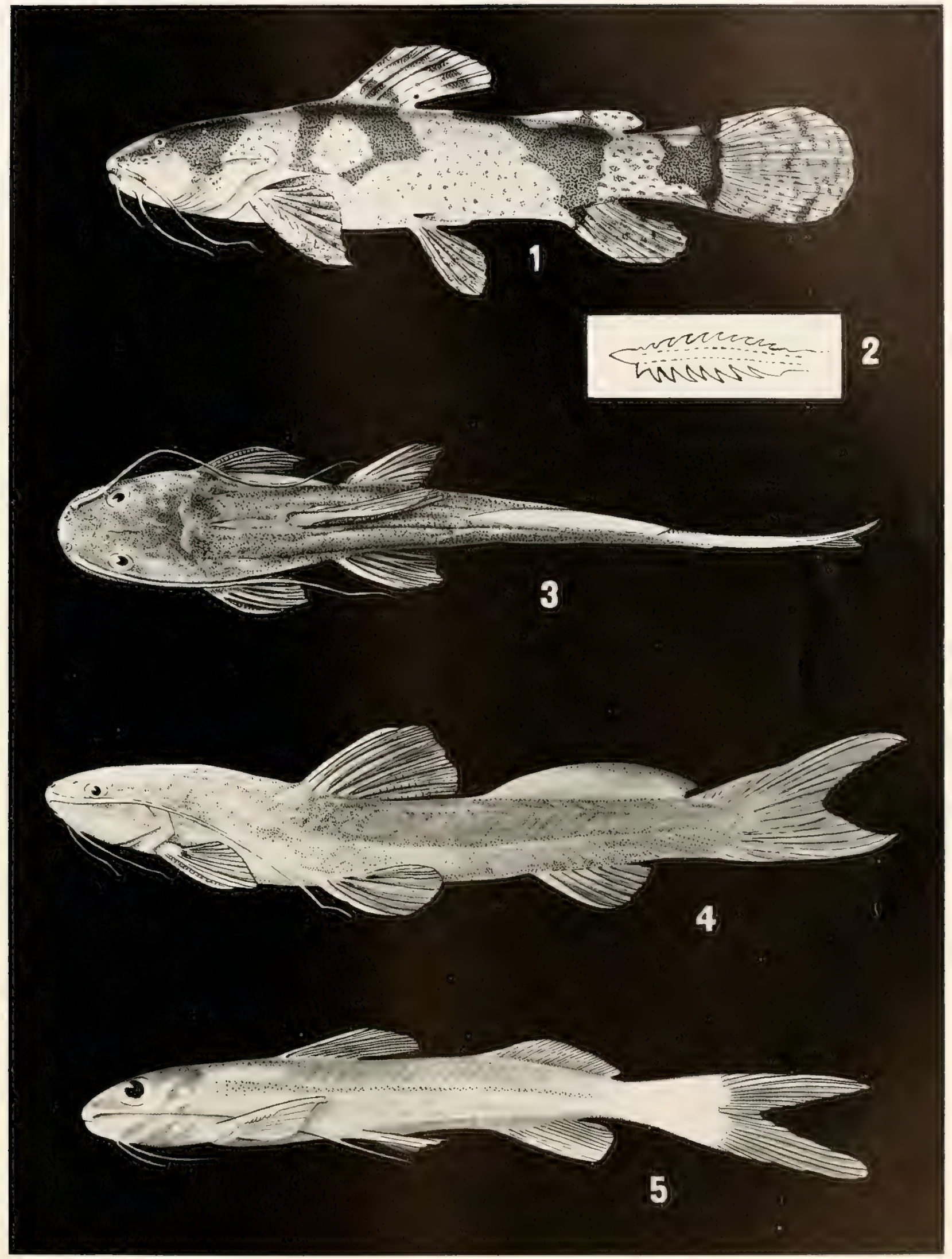

[1 135$]$ 
PLATE IV

FiG. 1. Brachyplatystoma juruense (Boulenger), 15953, $286 \mathrm{~mm}$. to end of middle caudal rays, Iquitos.

Fig. 2. Pimelodus jivaro Eigenmann and Pearson, sp. nov. 15859, paratype, $105 \mathrm{~mm}$., creek, Rio MIorona.

Fig. 3. Pimelodus leptus Eigenmann and Pearson, sp. nov. 1585s, type, $175 \mathrm{~mm}$., R. Pachiten.

FIG. 4. Duopalatinus peruanus Eigenmann and Allen, sp. nov. 15798, type, $176 \mathrm{~mm}$. to end of middle caudal rays, R. Puinagua, mouth of R. Pacaya. 

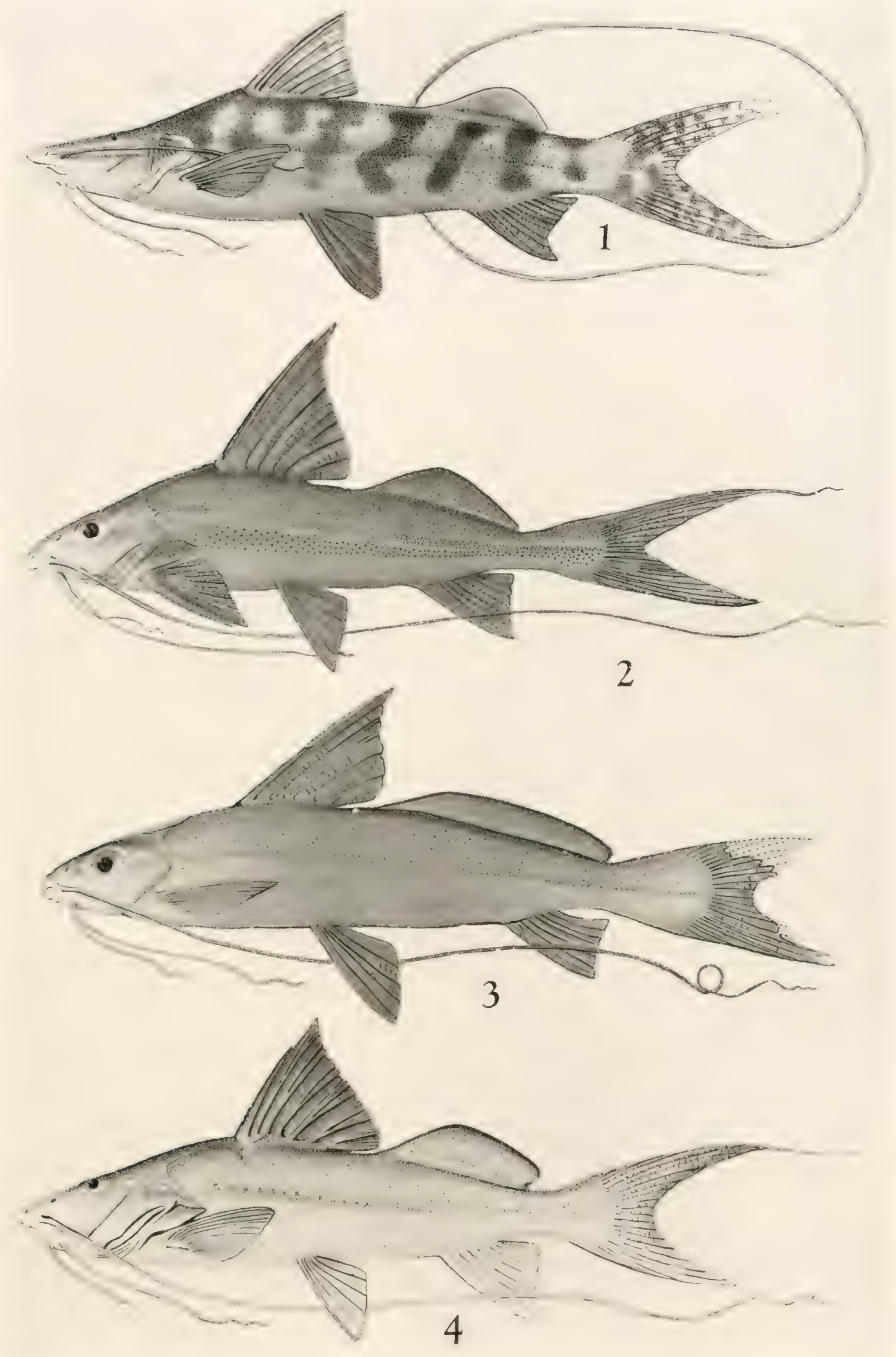


\section{PLATE V}

FIG. 1. Trachycorystes galcatus Linnaeus, 15796, creek, Yurimaguas.

FIG. 2. Tympanopleura nigricollis Eigenmann and Allen, sp. nov. 15789, paratype, female, $95 \mathrm{~mm}$., R. Ucayali.

FIG. 3. Tympanopleura nigricollis Eigenmann and Allen, sp. nov. 15788, type, male, $106 \mathrm{~mm}$. to tip of upper caudal ray, Iquitos. (See also pl. vi, fig. 3.)

FiG. 4. Centromochlus gyrinus Eigenmann and Allen, sp. nov. 15795, type, $55 \mathrm{~mm}$, brook near R. Itaya, Iquitos.

Fig. 5. Pimelodus altissimus Eigenmann and Pearson, sp. nov. 15797, type, $182 \mathrm{~mm}$. to end of middle caudal rays, R. Ucayali, near Orellana. 


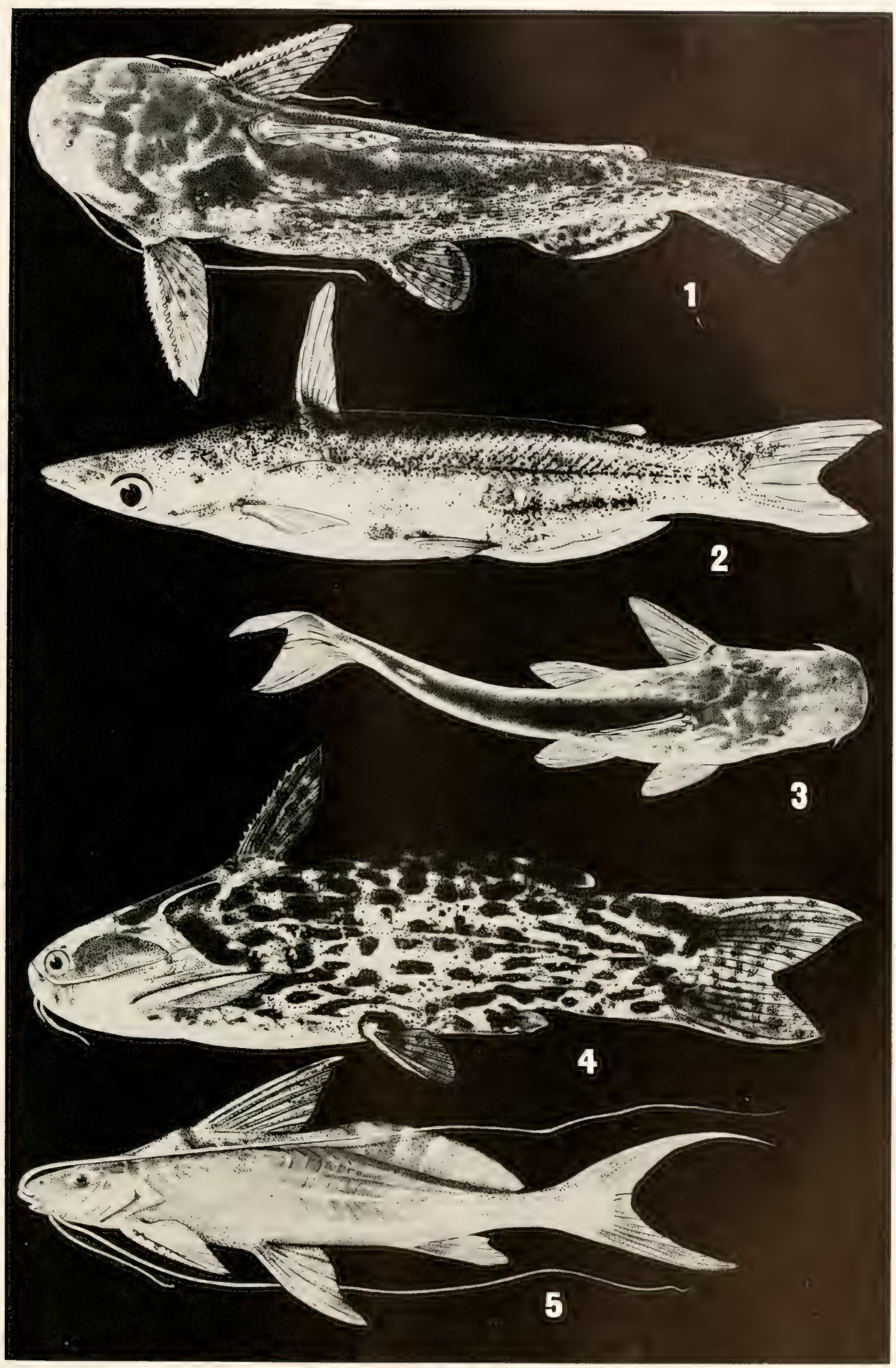




\section{PIATE VI}

FIG. 1. Chactostoma lincopunctata Eigenmann and Allen, sp. nov. 15373, type, $143 \mathrm{~mm}$. , R. Azupizú.

FIG. 2. Hemiancistrus arenarius Eigenmann and Allen, sp. nov. 15356 , type, $93 \mathrm{~mm}$. to end of middle caudal rays, Yurimaguas.

Fig. 3. Tympanopleura nigricollis Eigenmann and Allen, sp. nov. 15788, type, male, $106 \mathrm{~mm}$., to tip of upper caudal ray, Icquitos. (See also pl. v, fig. 3.)

Fig. 4. Tympanopleura alta Eigenmann and Myers, 15790, type, 128 mm., Iquitos. 


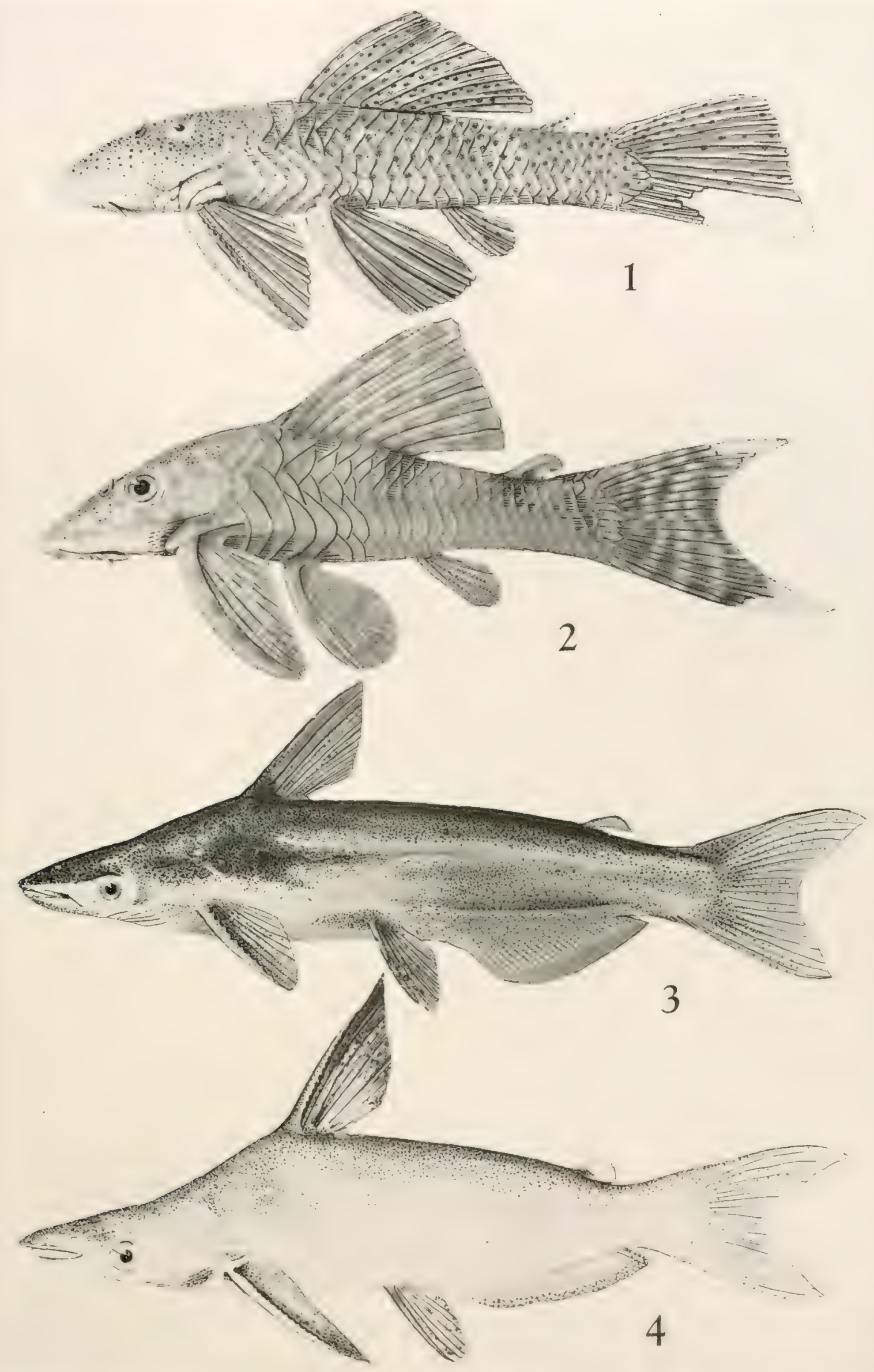


PIATE VII

Figs. 1 AND 2. Canthopomus agassizii (Steindachner). Gen. nov., 15970, $154 \mathrm{~mm}$. to end of plates at base of caudal fin, Iquitos. 


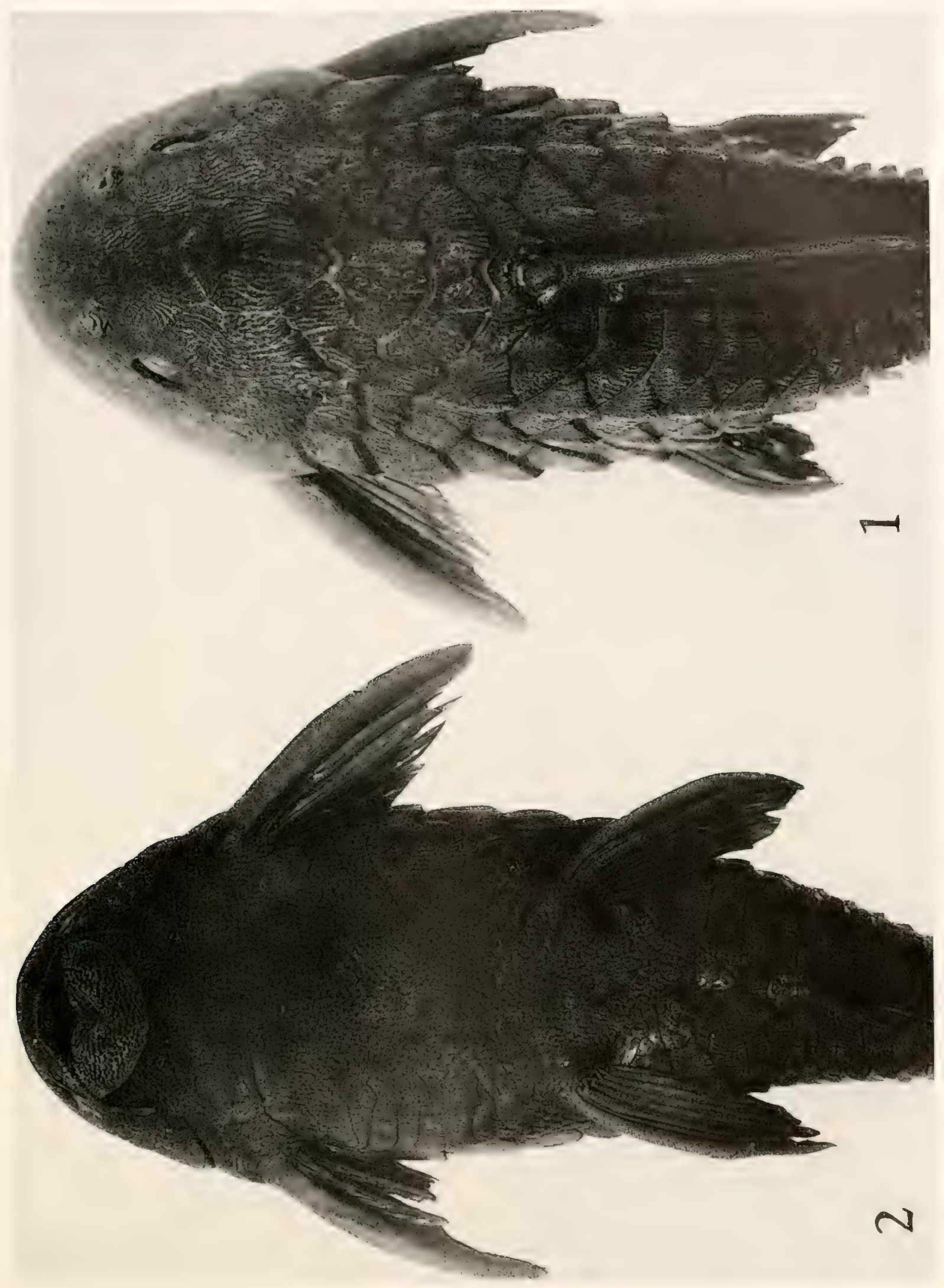

[4.3] 
PLATE VIII

FIGS. 1 AND 2. Harttia filamentissima Eigenmann and Allen, sp. nov. 15378 , type, $170 \mathrm{~mm}$., T'urimaguas.

Figs. 3 AND t. Harttia microps Eigenmann and Allen, sp. nov. 15380, type, $150 \mathrm{~mm}$., Iquitos. (See also pl. ix.) 

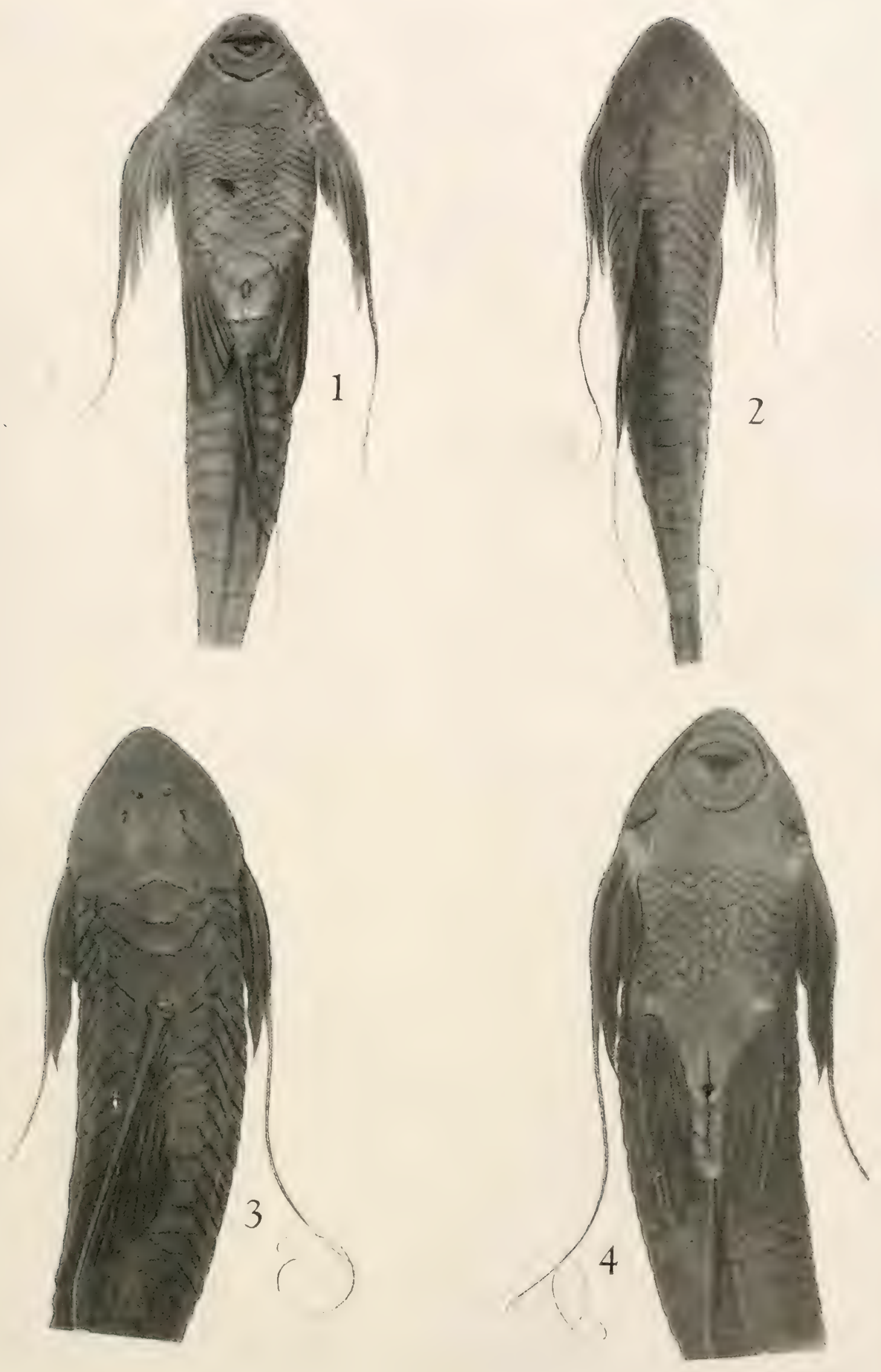


\section{PLATE IX}

Harttia microps Eigenmann and Allen, sp. nov. 15380, type, $150 \mathrm{~mm}$. to end of middle caudal rays, Iquitos. (See also pl. viii.) 


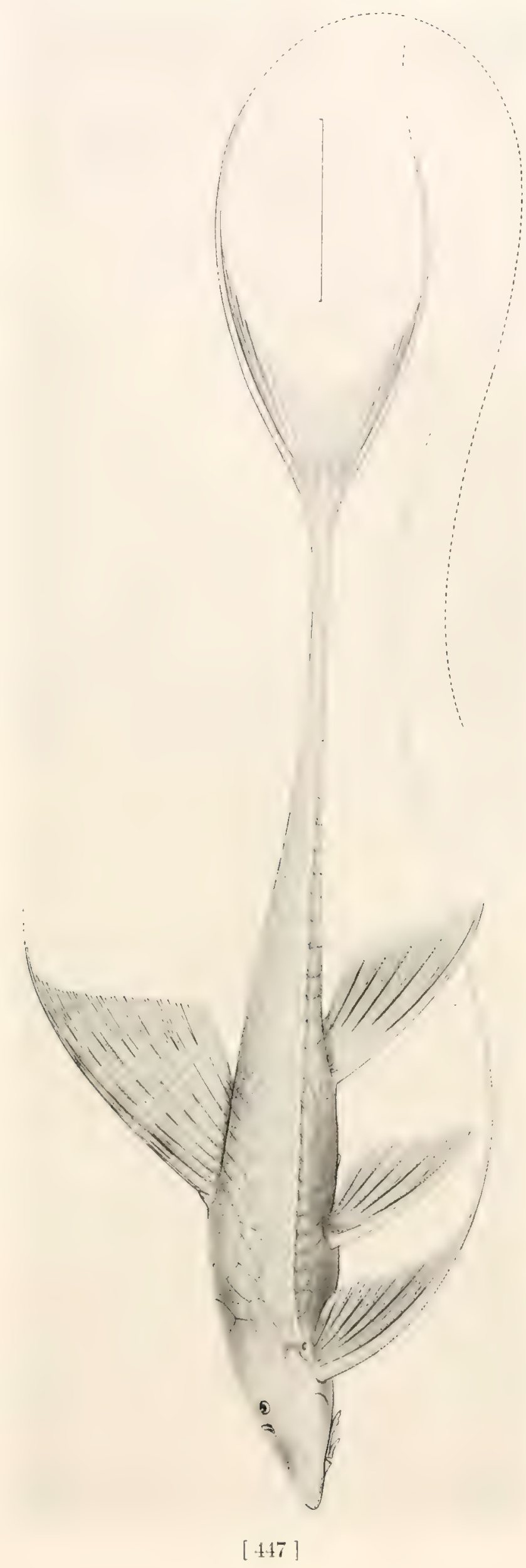




\section{PLATE $\mathrm{X}$}

Figs. 1 And 2. Ancistrus occloi Eigenmann and Myers. 15067, type, 115 mm., Ollantaitambo, Heller coll.

FIG. 3. Rhamdia riojae Fowler. Upper Urubamba, Heller coll.

FIG. 4. Pimelodella roccae Eigenmann. Rio Comberciato, Heller coll.

Fig. 4a. Pectoral spine of the same. 

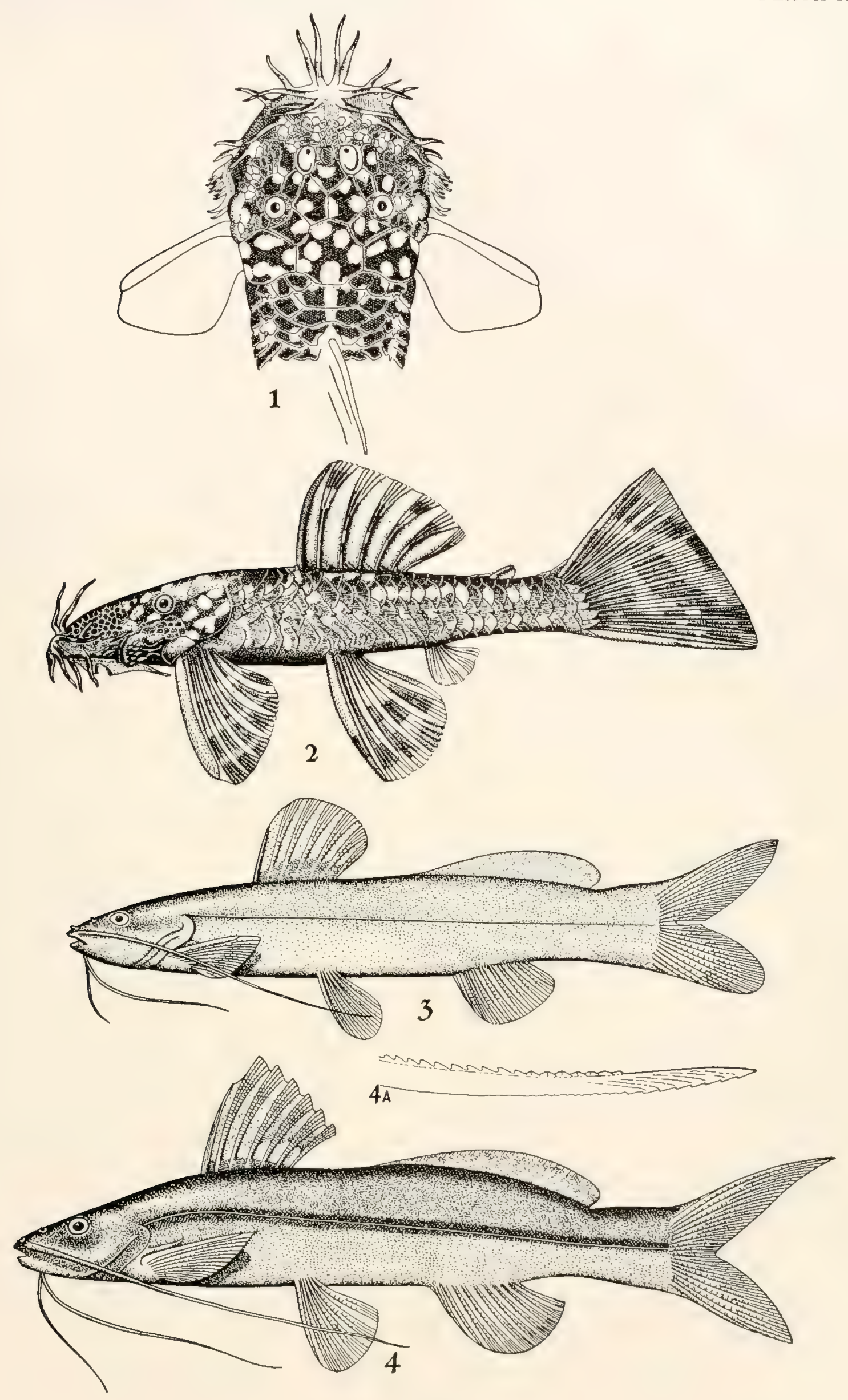


\section{PLATE XI}

FIGs, 1-7. Astroblepus mancoi Eigenmann and Myers. Type and paratypes, Ollantaitambo, upper Urubamba, Heller coll. Variations in markings. 


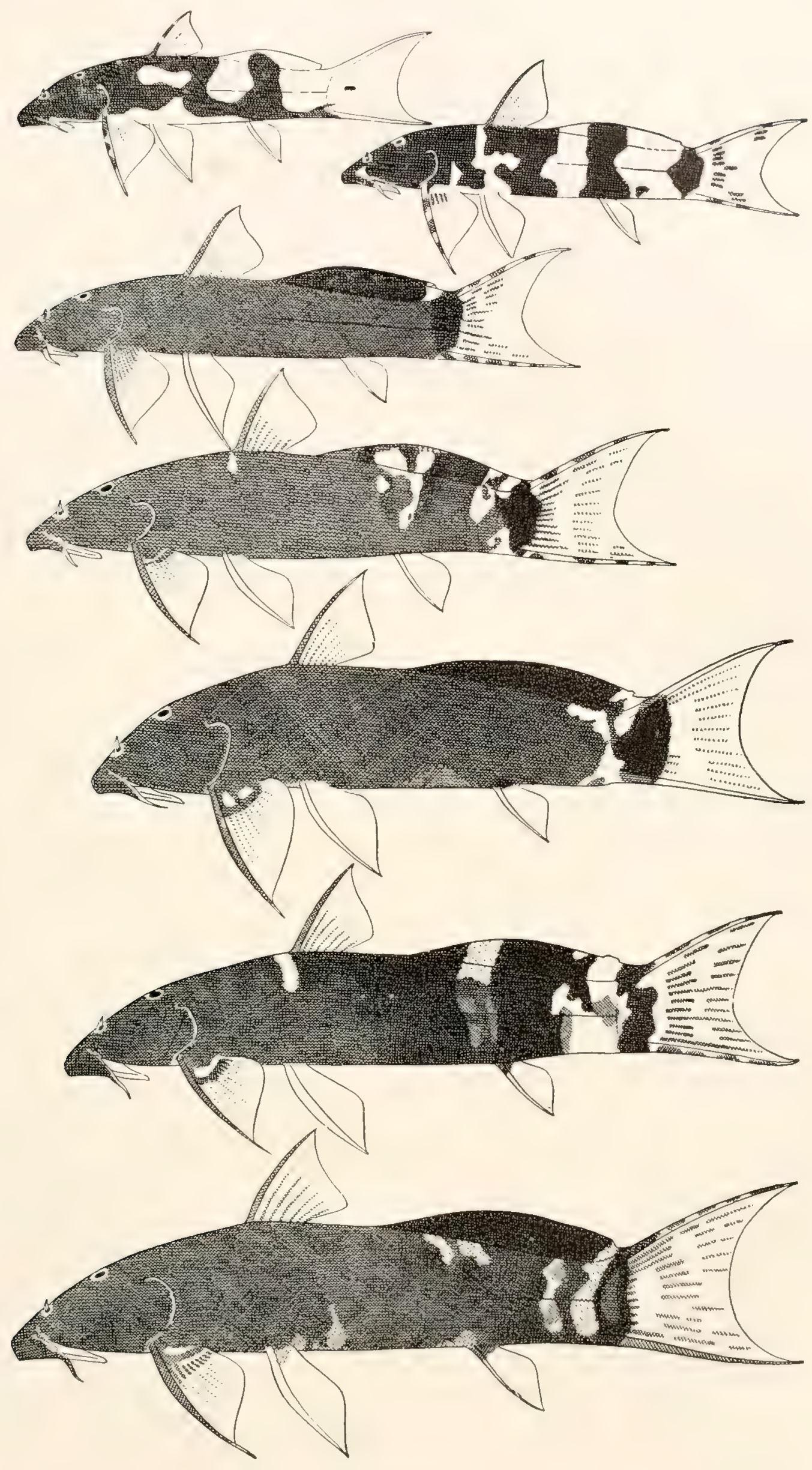




\section{PLATE XII}

Fig. 1. Corydoras zygatus Eigenmann and Allen, sp. nov. 15704, type, $77 \mathrm{~mm}$., creek, Yurimaguas.

Fig. 2. Corydoras stenocephalus Eigenmann and Allen, sp. nov. 15817, type, $59 \mathrm{~mm}$., Yarinacocha.

FIG. 3. Corydoras episcopi Eigenmann and Allen, sp. nov. 15605, type, $33 \mathrm{~mm}$., R. Morona.

Fig. 4. Corydoras leucomelas Eigenmann and Allen, sp. nov. 15818, type, $39 \mathrm{~mm}$., Yarinacocha. 


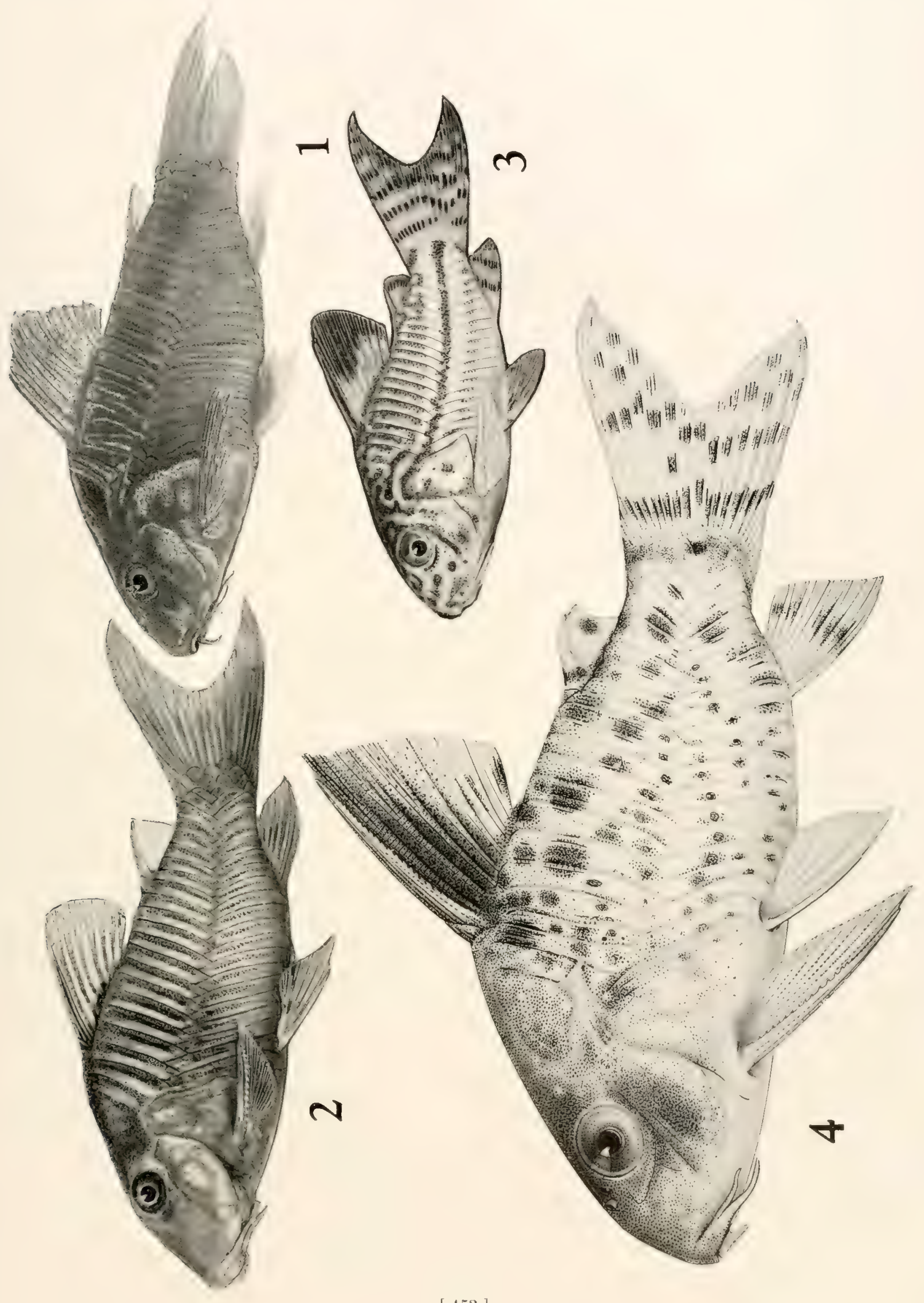




\section{PLATE XIII}

FIG. 1. Otocinclus macrospilus Eigenmann and Allen, sp. nov., paratype, 15606, $30 \mathrm{~mm}$., R. Morona.

FIG. 2. Pimelodella montana Allen, sp. nov., type. 17830, $93 \mathrm{~mm}$., Rio Huallaga, Huánuco.

Figs. 3-5. Pygidium atochae Allen, sp. nov., types. 17819, 64, 85, and 93 mm., R. de Atocha, Bolivia.

FIGs. 6-7. Astroblepus praetionum Allen, sp. nov., types, 17829, 38 and 58 mm., Huánuco. 

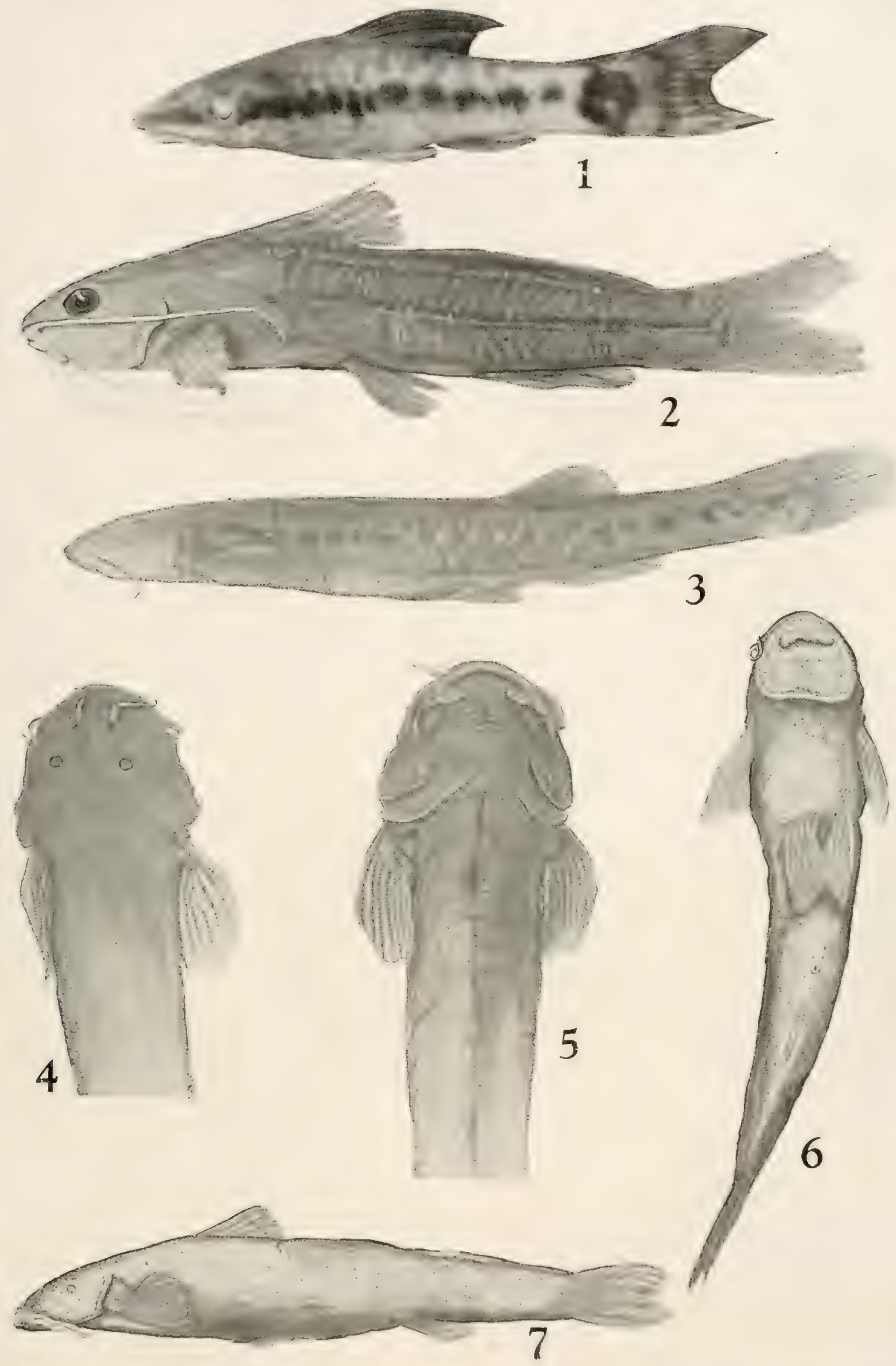


\section{PLATE XIV}

FIG. 1. Curimata muricli Allen, sp. nov, 178t3, type, $80 \mathrm{~mm}$., Contamana.

FIG, 2. Curimata reticulata Allen, sp. nov. 17857, type, $113 \mathrm{~mm}$., L. Cashibova.

FIG, 3. Psectrogaster cisandinus Allen, sp. nov. 1583t, type, $135 \mathrm{~mm} ., \mathrm{R}$. Paranapura.

FIG. t. Gasteropelecus coronatus Allen, sp. nov. —, 35 mm., R. Huallaga, Yurimaguas.

FIG. 5. Carnegiella strigata (Linnaeus). - - $35 \mathrm{~mm}$., Iquitos.

Fig. 6. Bryconamericus osgoodi Eigenmann and Allen, sp. nov. 15915, type, $63 \mathrm{~mm}$., Moyobamba.

Fig. 7. A pareiodon pongoense Allen, sp. nov. - - type, $67 \mathrm{~mm}$., Pongo de Manseriche. 


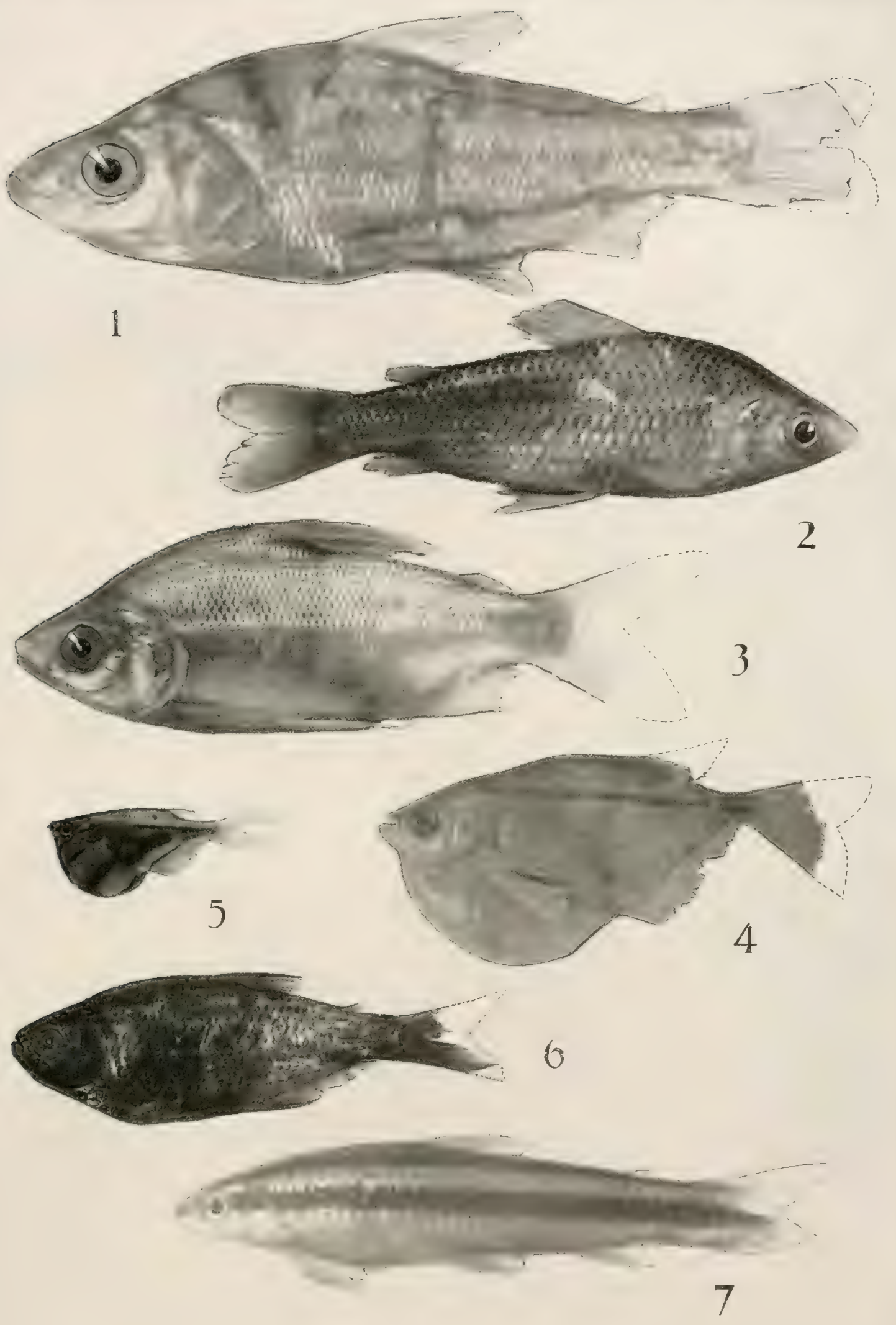




\section{PIATE XV}

Fig. 1. Apteronotus anas Eigenmann and Allen, sp. nov. 15433, type, $365 \mathrm{~mm}$., Iquitos.

Fig. 2. Ocdemognathus exodon Myers. $15421,92 \mathrm{~mm}$. to base of caudal fin, Iquitos.

Fig. 3. Lips and teeth of same. 

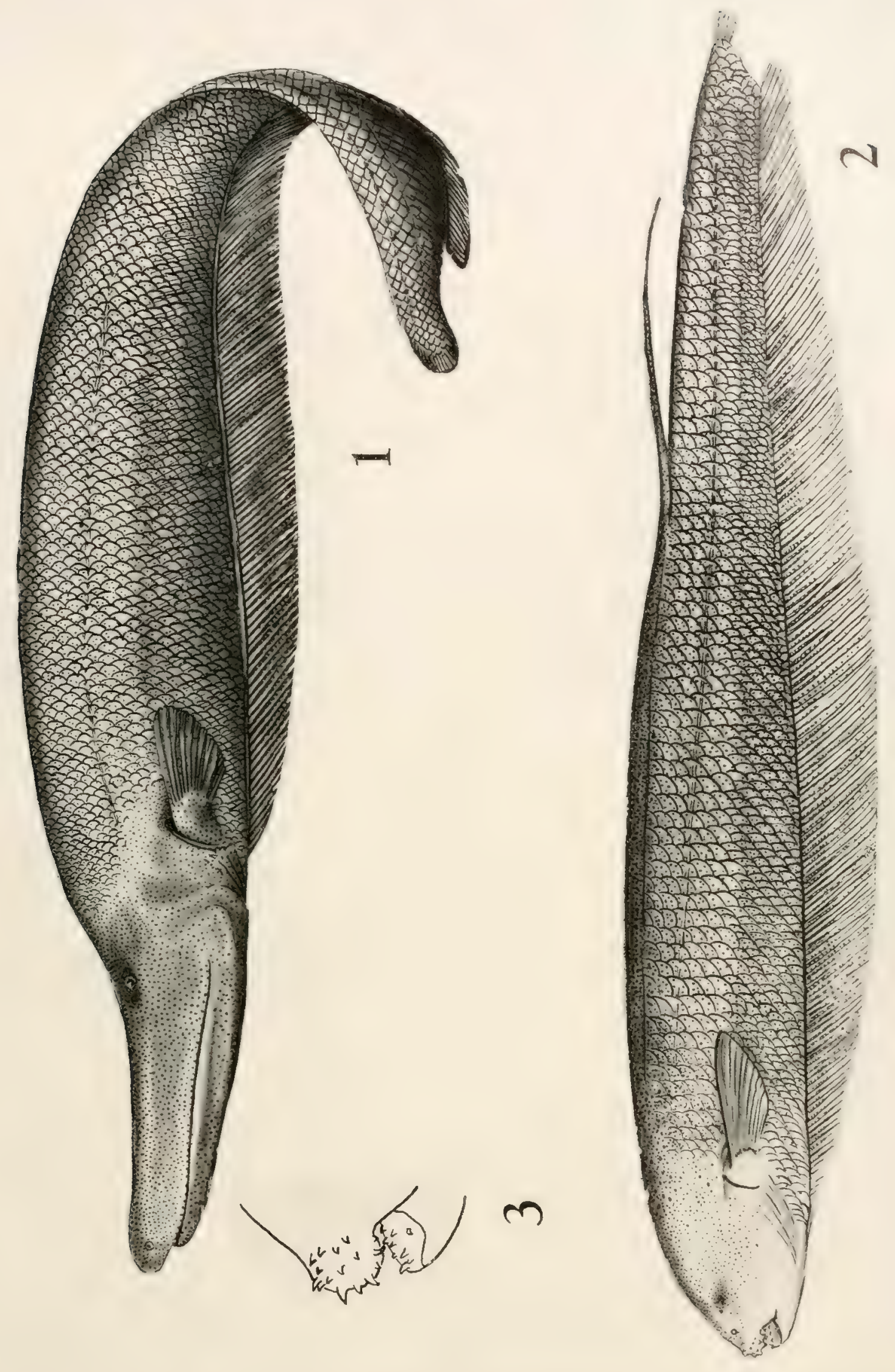


\section{PLATE XVI}

FIG. 1. Sternarchogiton porcinum Eigenmann and Allen, sp. nov. 15740, $300 \mathrm{~mm}$. , Yurimaguas.

Figs. 2 AND 5. Eigenmannia conirostris Eigenmann and Allen, sp. nov. 15739, paratype, $26 t \mathrm{~mm}$. ., Iquitos.

FIGS. 3 AND 4. Rhabdolichops longicaudatus Eigenmann and Allen, sp. nov. $15996,630 \mathrm{~mm}$., total length, Iquitos. 


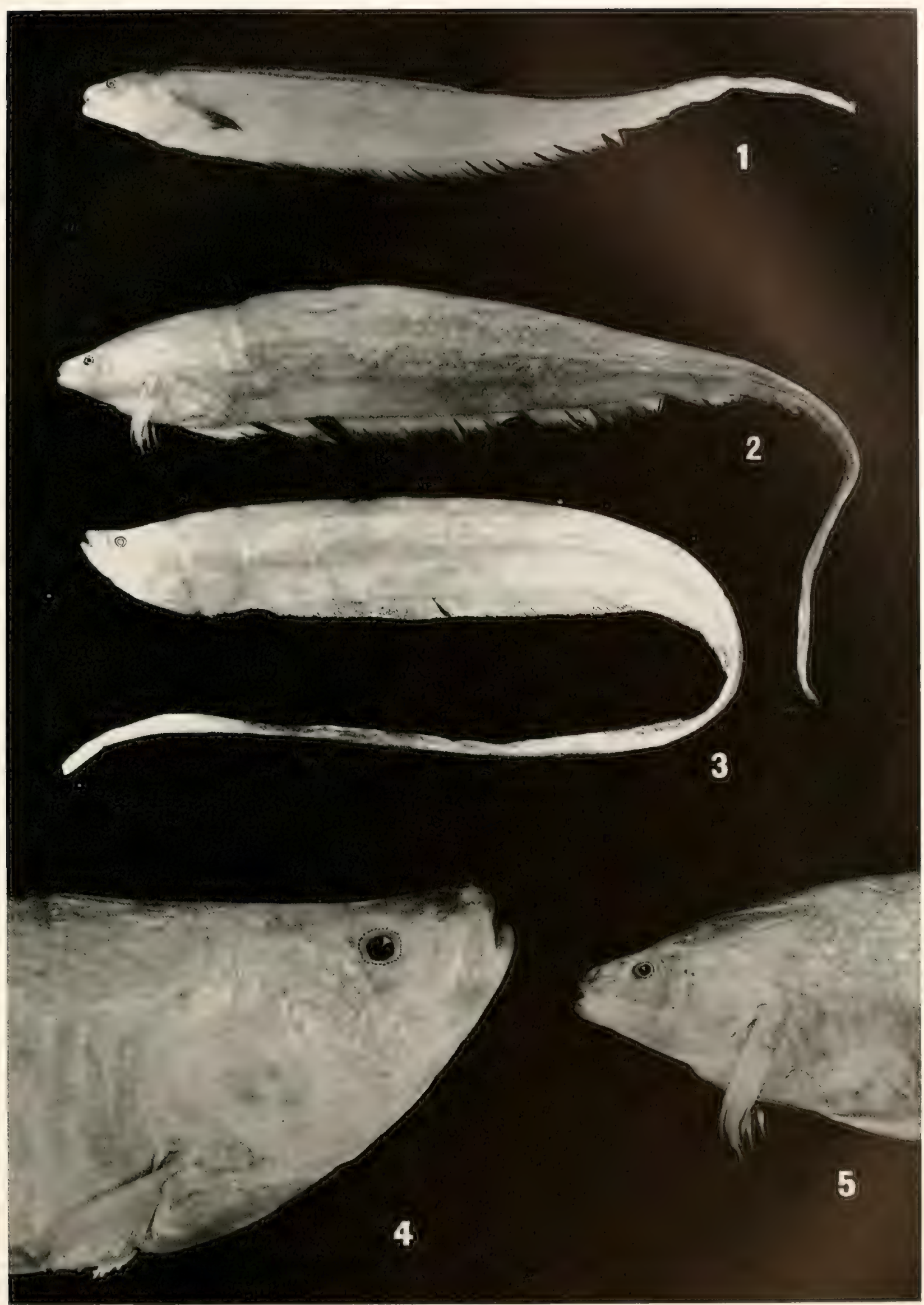

[461] 


\section{PLATE XVII}

FIG. 1. Orestias incae Garman, $3948 \mathrm{MCZ}$, cotype, $55 \mathrm{~mm}$., Moho, I. Titicaca.

FIG. 2. Orestias humboldti Valenciennes, 16078, $78 \mathrm{~mm}$., MIoho fjörd, L. Titicaca.

Figs. 3 And 4 . Orestias pentlandi Valenciennes, 16082, $155 \mathrm{~mm}$. to caudal basis, Capachica, L. Titicaca.

FIG. 5. Orestias cuvieri Valenciennes, 3927 IICZ, $195 \mathrm{~mm}$., Puno, L. Titieaca. 


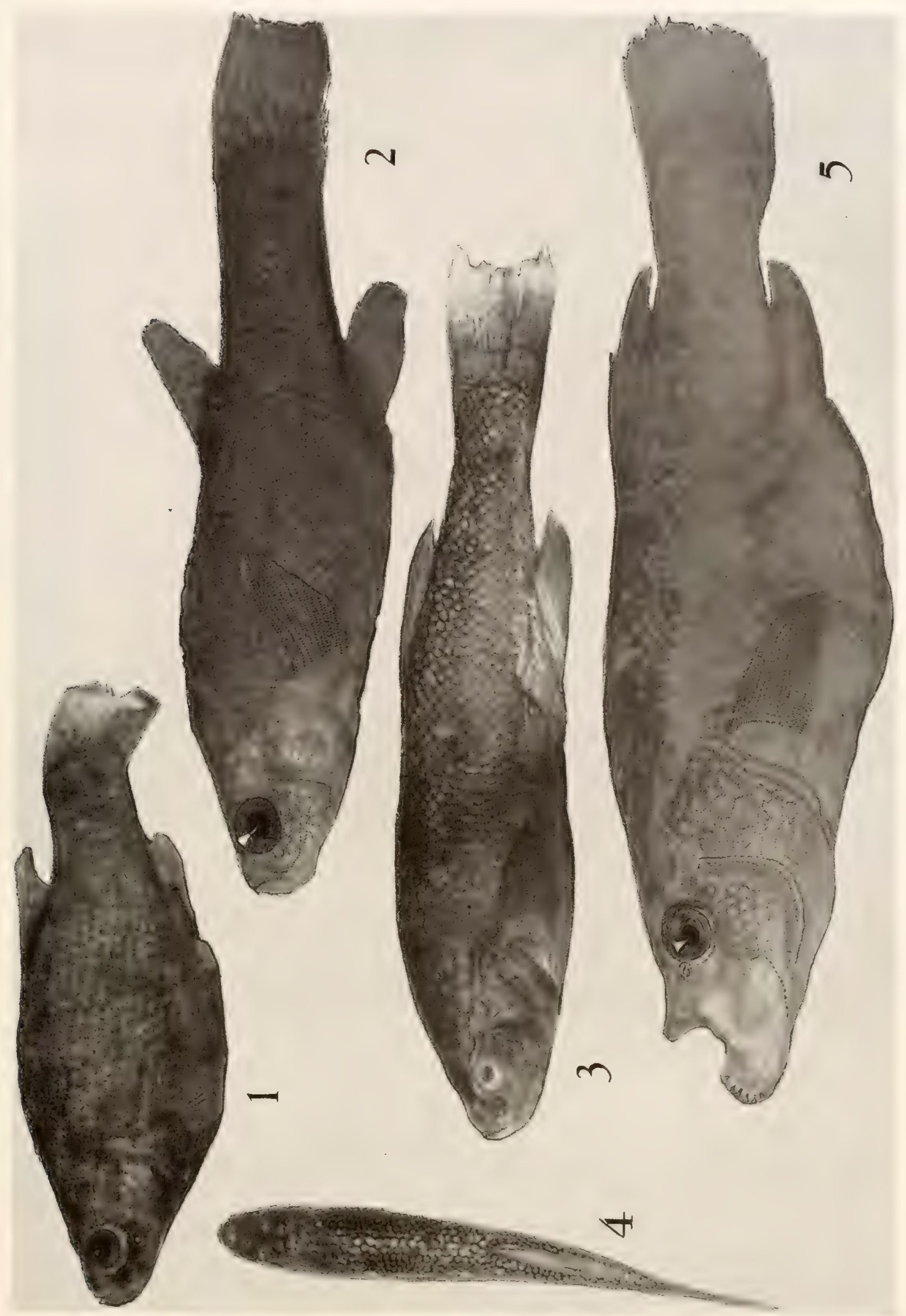




\section{PIATE XVIII}

Figs. 1 ANd 2. Orestias luters Valenciennes, 16095, part, $172 \mathrm{~mm}$., L. Umayo.

Fig. 3. Orestias olivaceus Garman, $3946 \mathrm{MICZ}, 8+\mathrm{mm}$., L. Umayo.

Fra. t. Radiograph of one of the shorter species, Orestias agassizii, 105 $\mathrm{mm}$. to caudal basis.

Fig. 5. Radiograph of a longer species, Orestias pentlandi, $172 \mathrm{~mm}$. to caudal basis. 


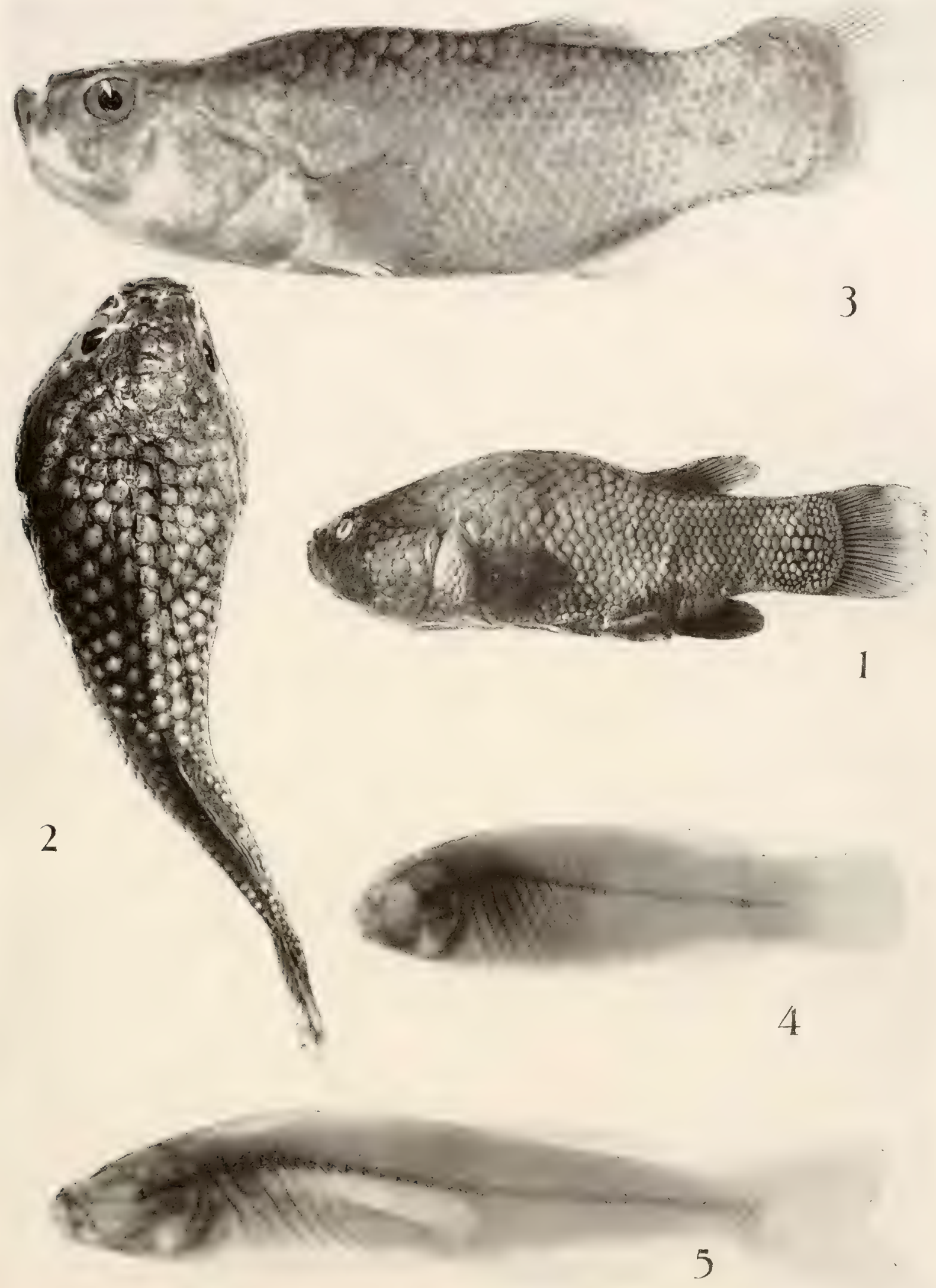




\section{PLATE XIN}

Fig. 1. Orestias silustani Allen, sp. nov., type, 16097, part, $80 \mathrm{~mm}$., L. Umayo.

Figs. 2-5. Orestias albus Valenciennes. Figs. 2 and 3, 16095, part, 115 mm., L. Umayo; figs. 4 and 5, 16127, part, 63 and $68 \mathrm{~mm}$., R. Azángaro. 

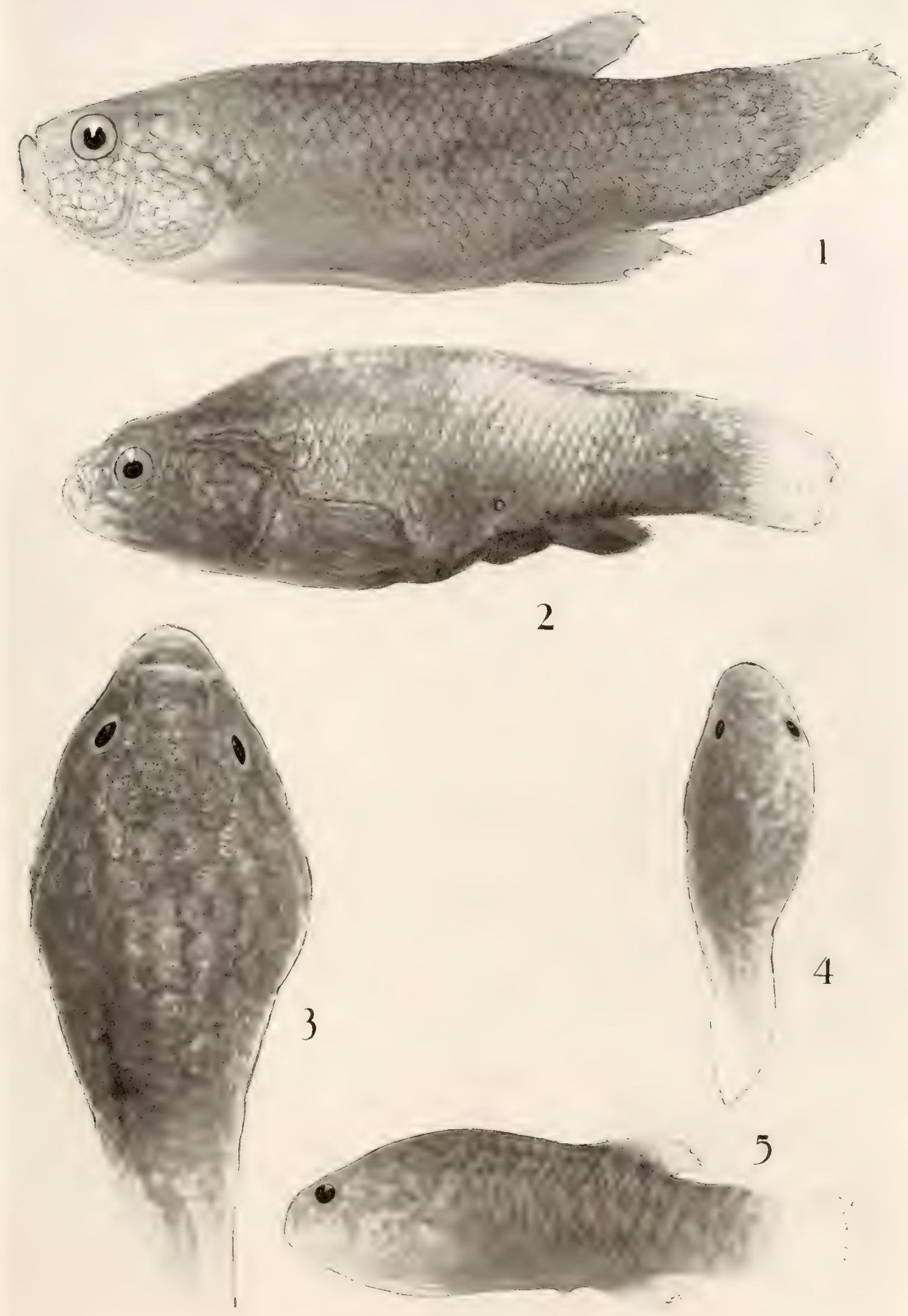


\section{PLATE XX}

FIG. 1. Orestias clegans Garman, 15238, part, $95 \mathrm{~mm}$., L. Chinchaycocha.

FIG. 2. Orestias empyraeus Allen, sp. nov. 15238, part, $120 \mathrm{~mm}$., L. Chinchaycocha.

Figs. 3-8. Orestias agassizii Valenciennes. Fig. 3, the largest, $120 \mathrm{~mm}$., Puno, L. Titicaca; fig. 4, dorsal aspect; figs. 5-7, juvenile, showing variation in color; fig. 8 , about $90 \mathrm{~mm}$., metamorphosis to adult form. 

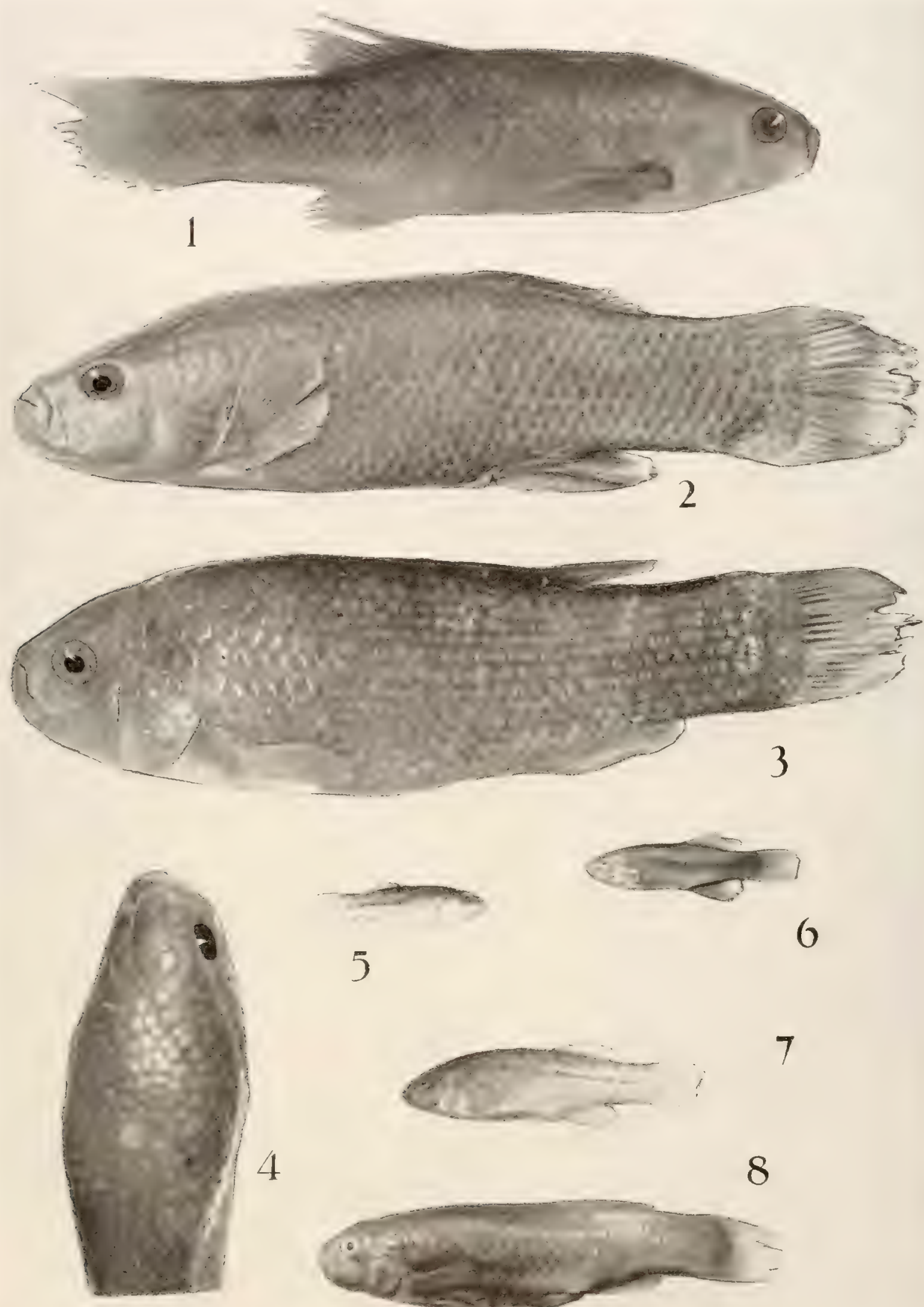

5

6

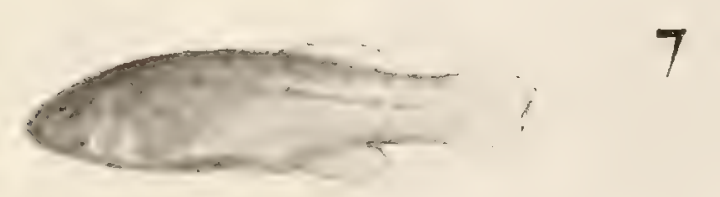

4

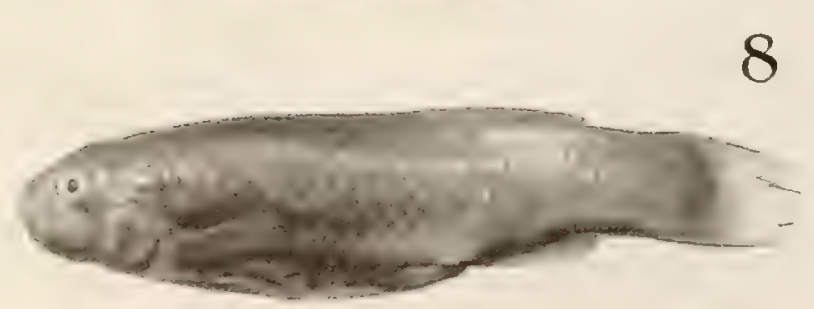

[ 469$]$ 


\section{PLATE XXI}

Fis. 1. Orestias mülleri Valenciennes, 17098, 79 mm., L. Poopó, Bolivia, at Challapata.

FIr. 2. Orestias owenii Valenciennes, $16063,87 \mathrm{~mm}$., L. Ureos.

FIg. 3. Orestias jussiei Valenciennes, 16066, $81 \mathrm{~mm}$., L. Chinchero.

Fig. 4. Orestias tschudii Castelnau, 16095, part, $114 \mathrm{~mm}$., L. Umayo. 

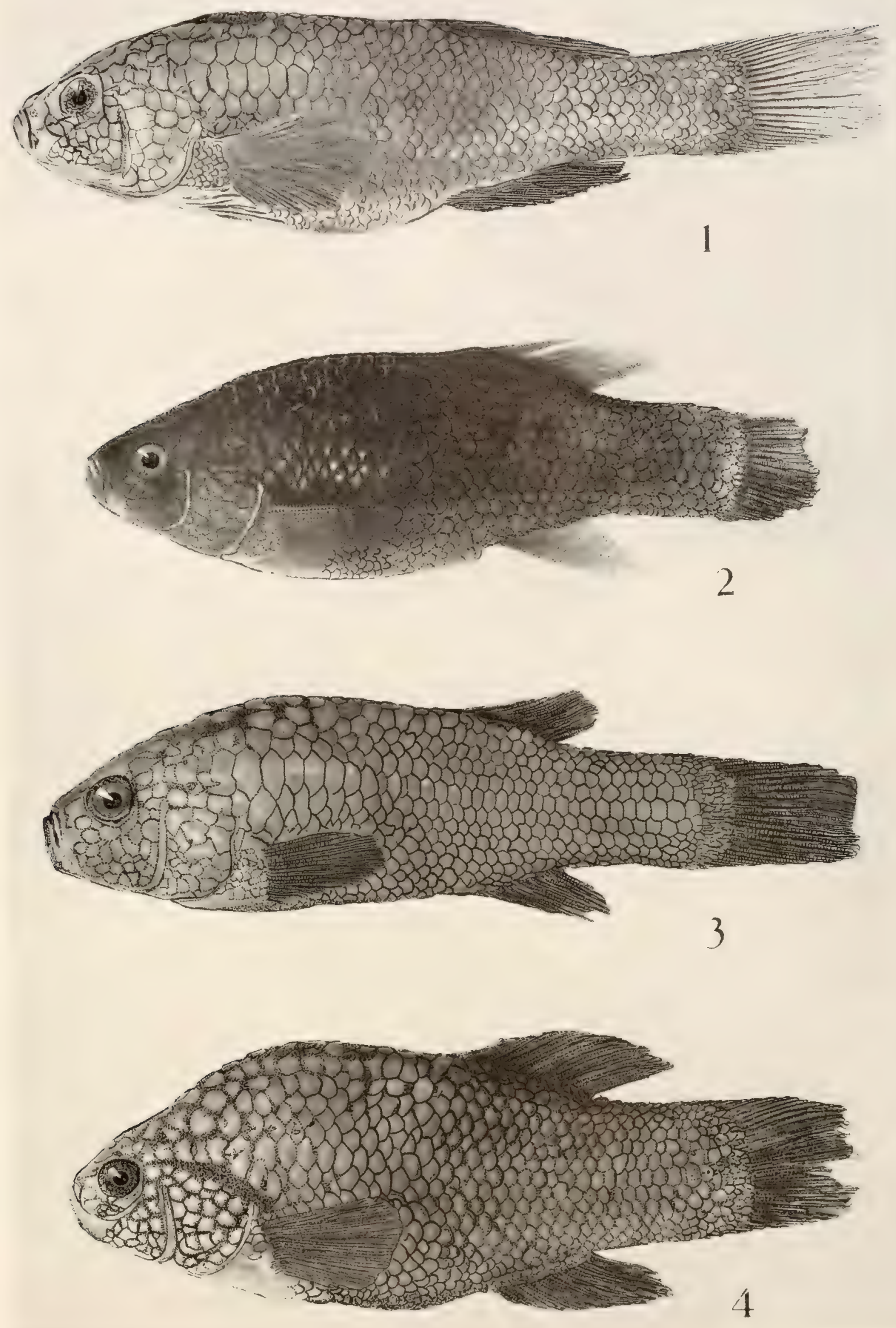


\section{PIATE XXII}

Figs. 1 AND 2. Rivulus urophthalmus Günther, 16185, female, $47 \mathrm{~mm}$., Iquitos; 16186, male, $49 \mathrm{~mm}$., Y'urimaguas.

Fig. 3. Amplova alleni Myers, $67 \mathrm{~mm}$., Contamana.

Figs. 4-7. Equidens hercules Allen, sp. nor., types, 17736, 34, 43, 45, and $132 \mathrm{~mm}$., Rio Morona.

FIG. 8. Acaronia trimaculata Allen, sp. nov, type, 1769t, $162 \mathrm{~mm}$., Iquitos. 

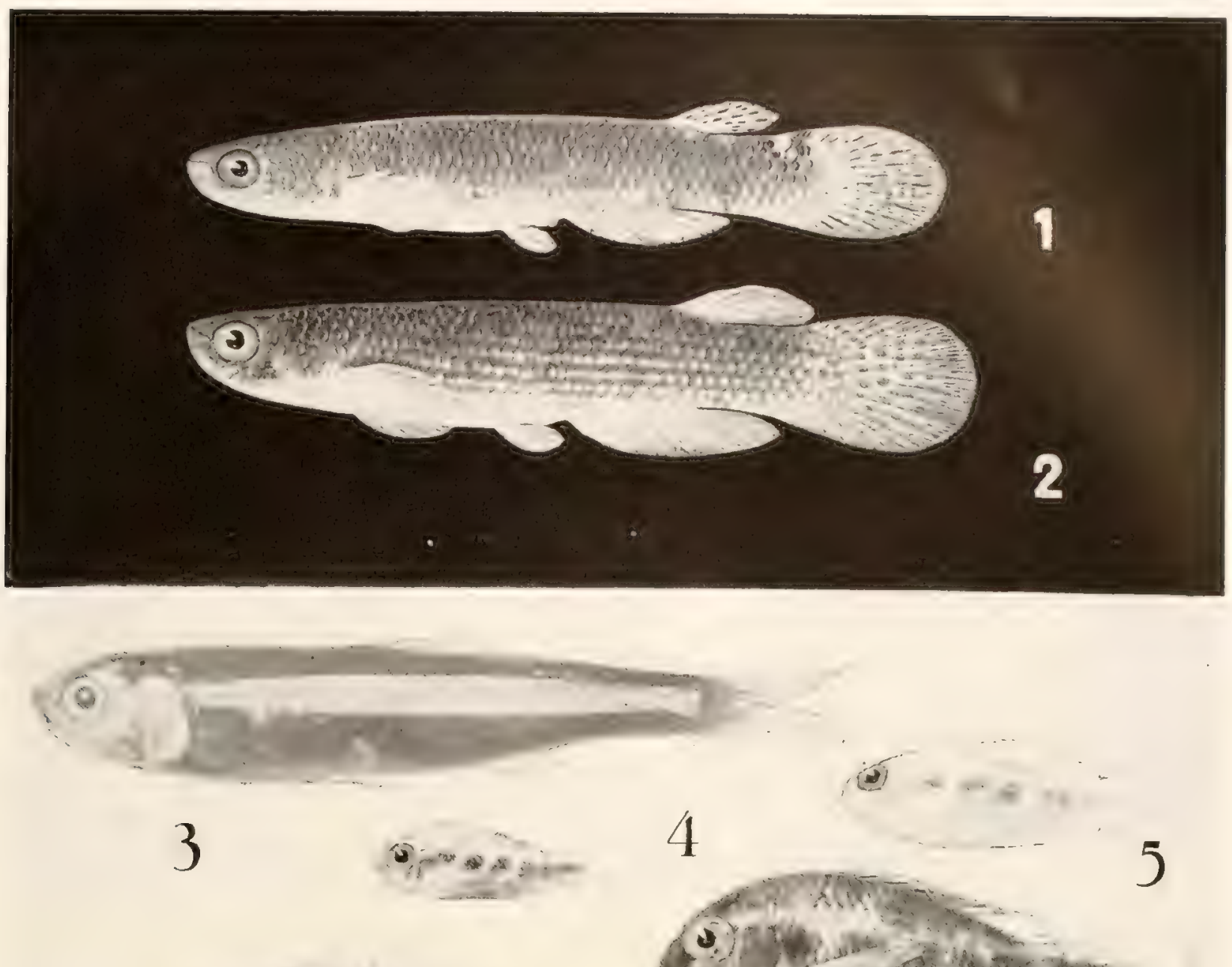

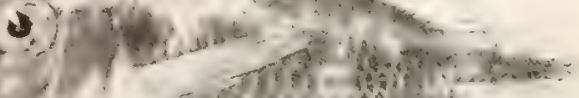

6

(2) Whinen

7

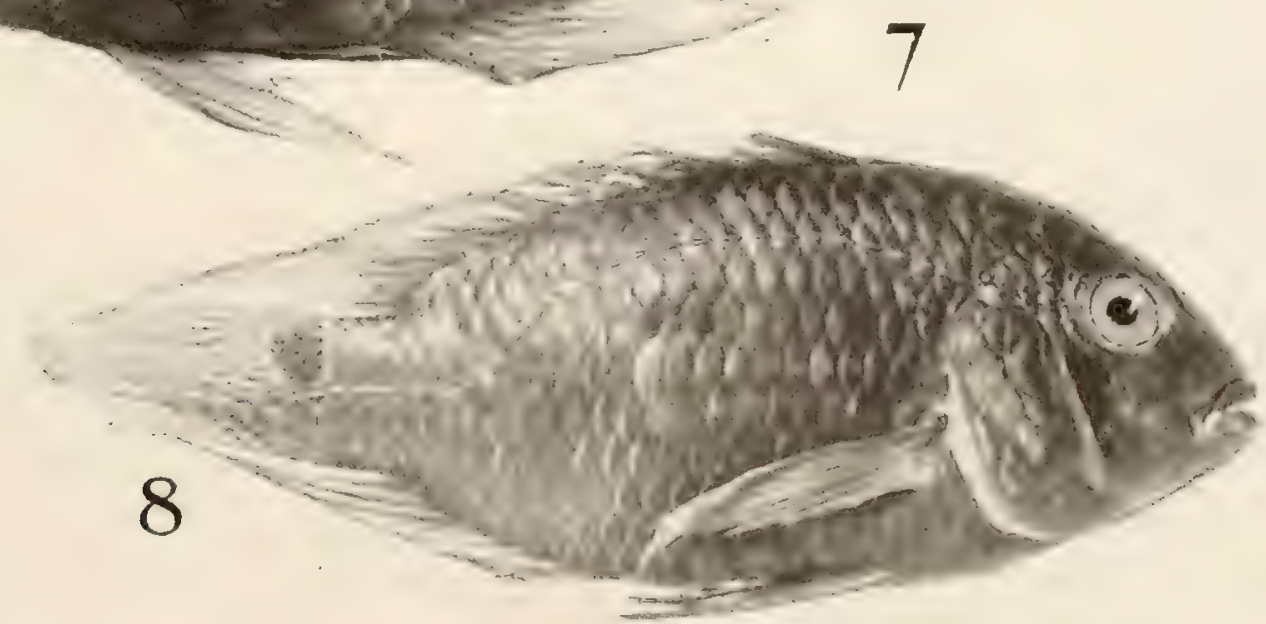





\section{INDEX}

1

abbreviatus, Acestrorhamphus.. 275 Acestrorhynchus.......45,48, 275 Xiphorlamphus,........... 275 abnormis, Ilisha.

abramis, Astyanax

Tetragonopterus

Abramites

hypselonotus

ACANTHICUS

genibarbis

hystrix.

Acanthodoras

ACANTHOPOMA

annectens

\section{ACANTHOPTEIR}

Acara

ACARA

$41,55,228$ 222

$305,307,308$

$30 \mathrm{~s}$

189

183

$49,54,189$

126

$1+2,159$

$49,144,159$

352

396

Acara (Heros) amphiacanthoides 390 autochthon.............. 3917

himaculata............... 396

compressus ............... 391

crassa . . . . . . . . . . . . . . . 397

dorsigera . . . . . . . . . . . . . 393

festiva .................. 397

flavilabris . . . . . . . . . . $39^{\circ}$

freniferus .......... $39^{\circ}$

heckelii.................. 398

hyposticta. . . . . . . . . . . . 391

imperialis................. 390

nassa............... 35s

spuria....................396

subocularis.............394, 398

syspilus. .............51, 394

tetramerus ............... $39^{2}$

vittata, vittatus . . . . . . . . . . 393

Acara (Acaropsis) nassa........ 388

ocellata.................. 391

Acara (Hygrogonus) ocellata... 391

Acarahugsu................ 391

acara, Chromys .............. 398

ACARICHTHYS . . . . . . . . . . . 398

heckelii.............46, 58, 398

ACARONIA................ 388

nassa................ 58,388

trimaculata........... 46,389

Acaropsis.................. 358

nassa. . . . . . . . . . . . . 35

I'EMTRA

acus.................. 213

amazonum.............. 214

knerii.................21t

ACESTRORHAMPHINAE_... 27 t

ACESTRORHAMPHUS. . . . . . . . . 275

abbreviatus
ACFATRORHYNCHINAE

ACESTRORHYXCHUS

ahbreviatus.

cachorro.

faleatus

falcirostris

lieterolepis

microlepis.

ACHIROPSIS

nattereri.

ICHIRU:

achirus.

lincatus

achirus, Achirus.

Pleuronectes.

teipenser plecostomus

acipenserinus, Hemidoras

Hemiodon.

Hemiodontichthys

Leptodoras.

Joricaria.

Oxydoras

ACROBRYCON

ipanquianus

$41,52,60,65,218,219,22,7$

acus, Acestra

'Tylosurus

$45,45,275$

$48,2 \gamma 6$

$4 !, 56,276$

$45,48,49,275$

45,276

$49,56,276$

408

$46,48,50,55,403$

........ 407

........ 407

$46,48,50,58,407$

\section{7}

$18 t$

136

210

cuta. Loricaria

$14,55,210$

49,136

210

136

218

$44.55,203,2114$

acutidens, Curimatus. ........ 305

acutus, Corydoras......44, 175,177

ADONTOSTERNARCHUA. . . . . . 318, 926

balaenops.

$6,318,326$
$6,36,327$

sachisi

$46,48,57,326$

adspersum, Decapogon $44,49,54,178$

adspersus, Callichthys.....172, 173

Decapogon

aeneum, Hoplosoma

173

aeneus, Callichthys.

Corydoras...47, 52, 5t, 59,173, 174

EQUIDENS. . . . . . . . . . . . . 391

dorsigera

dorsigerus.

Havesecus.

..... 50

freniferus

$46,58,393$

hercules.

46,393

mariae.

16,394

subocularis. ............. 16, 394

syspilus. . . . . . . . . . . . 394

tetramerus $46,48,50,52,58,61,392$

vittatus...........46,48,50, 393

affinis, Anacyrtus. ........... 25 s

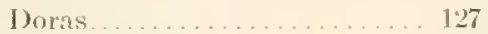

Doras (Amblydoras) ......... 127

Otocinclus.............. 20.2

Rophoirles............. 49.258
Rocboides (Cynochax)

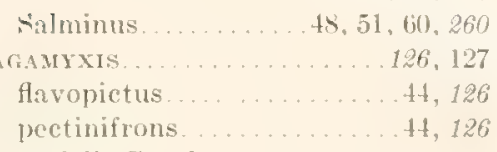

gassizii, Canthopomus

$14,49,54,183$

Luciopimelodus

117

Orestias

$16,52,61,349,350,353$ $354,356,362,371,376,379$

Perugia.......44, $47,48,53,117$

Pimelodus

100

Pinirampus

116,117

Rhinclepis........... 183

Tetragonopterus. .......... 231

ACEXFIOSIDAE .......... 136

AgENEIOSUS. . . . . . . 137, 138, 134

armatus. . . . . . . . . . . . . 137

brevifilis............ 41, 54, 138

ucavalensis .......44, 47, 51,137

Ageneiosus (Pseudagenciosus) .. 138

brevifilis .............49, 138

AGONIATINAE

270

albifrons, Apteronotus

$16,50,51,52,57,60,320$

Gymnotus.

320

Sternarchus.

$.51,320$

albiscopum, Mylossoma

$15,47,49,56,250$

albiscopus, Myletes.......... 250

Mylosoma ............... 250

Mylossoma................ 250

Albula maculata . . . . . . . . . . 220

alburna, Curimatella

$45,45,57,291,292$

allournus, Anodus ............ 2!1

Aphyocharax. ......45,56,266

Chirolon...............266

Curimatella .............. 291

Curimatus. . . . . . . . . . . . . 291

Paragoniates $\quad 45,50,56,270$

albus, Chalcinus $\quad 45,49,56,26 \%$

Orestins

$52,61,349,351,352$, $354,355,356,363,371$

Triportheus........ 262 aleuropsis, Bunocephalus $\quad 43,8$; alfredae, Bryconamericus

$50,52,60,225$

nlgu, Chactostomus........... 197

alleni, Amplova........46, 48,833

Apomatoceros...........4, 160

alosa, Tetragonopterus........221 


\begin{tabular}{|c|c|}
\hline & \\
\hline & ANADORAS \\
\hline Rooseveltiella......45,47,49, 242 & $44,47,54,128$ \\
\hline Tympanopleura..........44,139 & nauticus. \\
\hline altamazonica, Hisha......46,58, 334 & anas, Apteronotus.......46,320, 321 \\
\hline Pellona................. 334 & añaschallua.................274 \\
\hline altamazonicus, Curimatus...... & Anathyridium. \\
\hline alternans, Leporinus........... & anallo........ \\
\hline altifrons, Geophagus. . & anchoeta................. \\
\hline altipinnis, Liposareus. & anchoveoides, Clupeacharax \\
\hline Pimelodus................ 106 & $45,56,263$ \\
\hline altissimus, Pimelodus .....t7, 104, $106^{\circ}$ & anchoveta.... \\
\hline altus, Pygocentrus........... 242 & ANCHOVIELLA. \\
\hline Rooseveltiella ............ 242 & AXCISTRUS \\
\hline amazona, Farlowella......47, 55, 214 & $65,185,186,187,188,190,191,196$ \\
\hline amazonensis, Prochilodus & aurantiacus............. 189 \\
\hline $46,48,57,311$ & bachi........ \\
\hline amazonica, Loricaria........... 205 & bufonius.........51,54,50,197 \\
\hline Psectrogaster......... & cirrhosus \\
\hline amazonicus, Belone........... 382 & $47,49,50,54,194,198,199$ \\
\hline Johnius . ............... 396 & duodecimalis............ 187 \\
\hline Psectrogaster & gibbiceps...... \\
\hline $45,48,49,56,289,290$ & heteraeanthus.. \\
\hline Tylosurus & $\ldots t 4,49,54,196$ \\
\hline $46,48,50,52,58,61,382$ & medians...... \\
\hline imazonum, Acestra............ 214 & multiradiatus. . \\
\hline Anacyrtus (Cynopotamus).... 257 & oceidentalis...........50, 198 \\
\hline Anisitsia ...........45,56, 285 & occloi............52,59,197 \\
\hline Charax ............ 49.257 & pictus................... 191 \\
\hline Curimatus. & punctatus............... 188 \\
\hline Farlowella. & temminckii $\ldots 17,49,52,54,59,198$ \\
\hline Hemiodus... & anguila electrica............. 330 \\
\hline ambiacus, Corydoras... & angulatus, Chalceus........260, 261 \\
\hline mphlacts, corycoris... & Chalcinus ......45, 48, 49,56,261 \\
\hline amblophtoldes, Apistogramma & angulatus vittatus, Chalcinus \\
\hline 18,401 & $48,56,262$ \\
\hline AMBLY DORAS... & ANISITSIA ..... \\
\hline hancockii.........4, $47,54,127$ & amazonum............ $45,56,285$ \\
\hline monitor...............4, 128 & annectens, Acanthopoma \\
\hline amboinensis, Coregonus :...... 237 & $49,144,159$ \\
\hline Amia ..................279, 280 & ANODINAE,.. \\
\hline amoenum, Apistogramma & ANODUS..............285, 300 \\
\hline $46,58,400,401$ & alburnus ............... 291 \\
\hline amocnus, Geophagus.......... 400 & ciliatus...... \\
\hline amphiacanthoides, Acara..... & elongatus... ...45, 48, 57, 300, 301 \\
\hline Acara (Heros) ............. & laticeps.....45, 18, $19,57,300,301$ \\
\hline Astronotus (Uaru) .......... 390 & latior $\ldots \ldots \ldots \ldots 45,48,49,57,300$ \\
\hline Uaru .......46, 48,58, 389,390 & melanopogon. \\
\hline amphibelus, Corydoras.......44, 175 & notatus...... \\
\hline AMPLOVA. . ........... & steatops.............. \\
\hline$\ldots 46,48,333$ & anomalus, Chaetostoma. \\
\hline balboae. & Anostomatidae ........ \\
\hline Anacyrtus. & ANOSTOMATINAE..... \\
\hline 258 & Anostomatine subfamilies...... 289 \\
\hline 257 & ANostouUs . . . . . . . . . . 302, 303 \\
\hline 257 & fasciatus................ 304 \\
\hline 258 & taeniatus ...... \\
\hline 259 & trimaculatus.... \\
\hline 256 & ucaynlensis.... . \\
\hline 258 & anostomus, Salmo....... \\
\hline pauciradiatus. & anthurus, Crenicichla ....... 46,405 \\
\hline sanguineus... & APAREIODON ... . . . . . . 286 \\
\hline$\ldots \ldots \ldots \ldots \ldots 256$ & ecuadoriensis. \\
\hline
\end{tabular}

itapicuruensis . . . 286

pongoense $\quad 45,286$

terminalis ....... 286

APHYOCHARACINAE 265

APHYOCHARAX

alburnus $\quad \ldots 45,56,266$

filigerus $\quad 45,266$

pusillus.........45, 49, 265, 266

APISTOGRAMIMA - 400

ambloplitoides..........48, 401

amoenum.......46,58,400,401

amoenus.......... 400

Aplocheilus peruanus $\quad 316$

IPOMATOCEROM $\quad 160$

alleni...............44, 160

appendiculata, Chromys........ 396

APTERONOTINAE .......312, 318

APTERONOTUS _.64, 320,323

albifrons.....46, 50,52,57,60, 320

anas.................46, 321

bonapartii ........46, $48,57,921$

hasemani........46,51,60, 322

leptorhynchus.......46,57,321

arahuana . 335

Arapaema gigas $\quad 338$

arapaima.................. 338

ARAPAIMA . . . . . . . . . 2 28, 336

gigans.................. 338

gigas.......46, 48, $58,337,338$

ARAPAMIIDAE ............ 336

Archocentrus................ 395

arenarius, Hemiancistrus. $44,19,185$

argentatus, Astyanax......... 220 argenteofuscus, Rhytiodus

$46,57,304$

argenteus, Hydrocyon. . . . . . . . 259

Prochilodus................ 309

Tetriagonopterus

$45,47,49,52,55,60,64,236$

argentina, Piabuca,......... 255

argentinus, Salmo ............ 255

Arges $\quad 164$

boulengeri................ 165

longifilis............... 166

peruanus.................... 166

prenadilla................ 165

sabalo.................164, 167

simonsii ................ 166

taczanowskii 167

Argiidne ................. 163, 164

Argiinae.................. 163

argynnis, Creniciehla.......... 405

argyrops, Copeina..........45, 264

Pyrrhulina.............. 263, 264

Arius nodosus . . . . . . . . . . 12:

nrmatus, Ageneiosus............ 137

Callichthys .............. 17/4

Corydoras

$47,49,54,174,175,177$

Gastrodermus.............. 174

armatulus, Doras............... 126

armillatus, Pariolius....... 4 , 150 


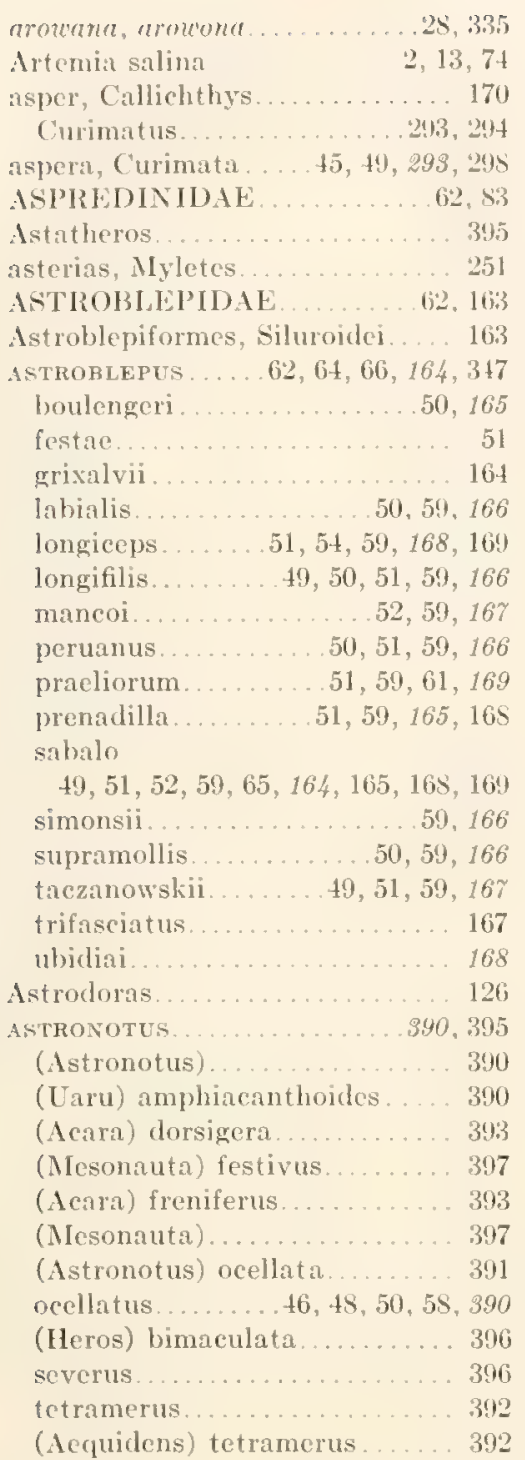
ASTYANAX

$64,65,216,21 \mathrm{~s}$ $219,223,224,226,231$

abramis...........44,55, 222

argentatus.............. 220

asymmetricus...........44, 220

atahualpianus............. 232

bartletti................ 220

bimaculatus

$44,47,50,51,52,55,60,220,222$ carolinae................222 diaphanus . . . . . . . . . . 224 fasciatus .......44,50,55,222 hauxwellianus............ 229 ipanquiants 215 lacustris 220 longior .........49,51, 60, 221 maximus

$44,47,49,50,51,52,60,221$ pectinatus

phoenicopterus.

simulatus.

asymmetricus, Astyanax

atulualpiana, Astyanax.

Moenkhausia

atochae, P'ygidium

atranalis, Pterohemiodus

atricaudatus, Brycon

atripes, Trachydoras. $44,54,131,132$

ACCHENIPTERINAE....... 117

AUCHENIPTERU, . . . . . . 121, 123

brachyurus

brevibarbus.

44,122

galeatus

heckelii.

isacanthus

nodosus

nuchalis.

$4,49,53,121$

Chaetostomus............ 189

Hypostomus . . . . . . . . . . . 189

Parancistrus ........... 47, 189

aurata, Sciaena............. 387

auratum, Plagioscion.. 46, $48,58,387$

auratus, Johnius............. 387

iquitensis, Plagioscion ........3\$ 387

aurcum, Mylossoma......47,56, 249

aurcus, Myletes. . . . . . . . . . . 249

autochthon, Acara (Heros).... 397

Cichlasoma ... . ........... 397

Cichlaurus..........46,58, 397

Heros.

397

13

bachi, Ancistrus

badiipinnis, Geophagus

186

Bacostoma (Anathyridium) maculipinnis ...............4 407

bagre .............. 1, 153, 155

Bagrus pictus.............. 111

piramuta................ 97

Baiostumal. . . . . . . . . . . . W W

bairdi, Phenacogaster......... 219

bairdii, Orestias. . . . . . . . . . 360

Tetragonopterus........... 219

balacnops, Adontosternarchus

$46,326,327$
Sternarchella ........... 327

Sternarchus..................... 327

balbone, Amplova . . .......... 333

barbasso

barbatula, Trichomycterus..... 153

BARIO . . . . . . . . . . . . . . 61, 235

steindachneri...45, 55, 232, 233, 235

Barostoma ............... 407

bartlettii, Astyanax.......... 220

Tetragonopterus ........... 220

Basilichthys . . . . . . . . . 357

batesii, Lycengraulis. . 46, 50, 58, 332

bathyurus, Pimelodus........ 01

Rhamdia..............43, 94
BATOIDEI .............. $\mathrm{s} 2$

Batrachoglanis pulcher....... 91 raninus ................. 91

Batrachopes, Les............ $40 s$

BATRACHOPS. . . . . . . . . 403, 40.

cyanonotus. . . . . . . . 46, 40,3

nemopterus........... $\$ 5,403$

reticulatus.......59, 55, 40:3,404

Belone amazonicus.......... 382

guianensis . . . . . . . . . . . 381

seolopacina.............. 381

taeniata .................. 381

BELONIDAE . . . . . . . . . 381

beni, Creagrutus.......50,60,228

bertoni, Corycloras............. $17 \%$

bicarinatus, Chaenothorax....44, 180

Brochis (Chaenothorax) ....... 180

bicirrhosum, Osteoglossum

$46,48,50,58,335$

hicirrhosus, Plecostomus....... 18t

bicolor, Bunocephalus.... 48, 84, 87

I'hractocephalus ............ 110

hicornis, Roeboides.....45, 47,258

Roeboides (Cynocharax) ..... 258

bidens. Colosoma . . . . . . . . . 249

Colossoma......45, 47,56, 248, 249

Myletes................. 245

Reganina.............. 248

bifidus, Bunocephalus.....48, 53, 86

bilineatus, Cichla........... 402

hilobatum, Hypoptopoma...... 200

bimaculata, Acara........... 396

Astronotus (Heros) . ......... 396

Cichla................ 390

Curimata......55, 49, 57, 292, 293

Lebiasina . . . . . .....60, 249

Perea .................. 396

sciacna. . . . . . . . . . . . . 395

bimaculatum. Cichlasoma...... 396

bimaculatus, Acara (Heros) . . . 390 Astyanax

$41,47,50,51,52,55,60,220,222$ Cichlaurus. $\quad 46,48,50,58,395$

('harax 2:-1)

Curimatus $\quad 2912,294$

Heros

Labrus $3 ! 94$

Leporinus $\quad 46,57,30.5$

Salmo ................. 220

binghami, Ceratobranchia..52, 60, 223 віотоDом. ................. 398 cupido ..........46, 48, 58, 399 taeniatum . 401

biseriatus, l'lecostomus........ 184 bocachica........ 34, 207, 310, 359 boga, boguilla........22, 153,36! boliviana, Pimelodella....47,53, 100 bolivianus, Imparfinis...50, 53, 5!, 97 bonapartii, Apteronotus

$46,48,57,320,321$ sternathus..............321 bondi, Noenkhausia ...45, 49, 55, 232 
bondi-Contimued

Phenacogaster

borellii, Heterogramma

boulengeri, Arges

Astroblepus

Cyelopium

bor'a

brachiatus, Centrodoras

$$
4,47,53,124
$$

Doras

124

brachiurus, Auchenipterus

Gymnotus.

BRACHYPLATYSTOMA

filamentosum

goeldii

juruense.

brachypomus, Chalcinus.260, 261, 262

Myletes.

Brachyrhamphichthys brevirostris

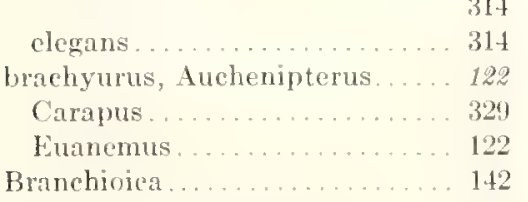

branickii, Chactostoma 49,51,59, 194

Chaetostomus............. 194

brasiliensis, Rivulus......... 346

Crenicichla .............. 406

brevibarbus, Auchenipterus. . . 120

Trachycorystes..........t4, 120

brevicauda, Lrythrinus. . . . . . . 282

breviceps, Bryconamericus..... $23 t$

Iinodus...........51,60,234

brevidens, Hydrocyon......... 260

brevifilis, Ageneiosus...44, 49, 54, 138

Agenejosus (Pseudageniosus). 138

Pseudageneiosus. ........... 138

brevipes, Curimata........45, 299

Curimatus................ 299

brevirostris, Brachyrhamphichthys

Hartia

(4ia..............4, 212

Hypopomus......46,50,57, 314

Loricaria................. 212

Oxyloricaria............... 212

Rhamphichthys............ 314

brevis, Chactostoma.....50,59, 195

Chaetostomus............. 195

Pyrrhulina................. 264

BROCHIS $\quad 173,179,180,181$

coeruleus...........4, 180, 181

dipterus................ 180

semiscutatus. 180

Brochis (Chaenothorax) bicarinatus

Brontes................... 160

prenadilla.............. 165

brunnea, Loricaria . . 44, 47, 55, 203

brunneus, Lorieariichthys. . 203, 204 ниясох $\quad$. 258, 276, 277 atricaudatus.............. 51 capito..............45,253 cephalus

$45,25.3$

$45,47,254$

254

erythropterum

erythropterus

falcatus

melampterum

253

melampterus

$45,47,52,60,953$

siebenthatae iquitensis.

stolzmanni

$51,60,254$

striatulus

stübelii .

BRYCONACIDNUS

ellisi

45,253

225

$51,60,226$

BRYCONAMERICUS

$$
6+, 65,216,223,226,228,230
$$

alfredae.

breviceps

$50,52,60,225$

eaucanus

diaphanus

$50,60,224$

15, 224

exodon

2.3

grosvenori

$52,60,223$

moenkhausii

234

osgoodi

pachacuti.

$49,51,60,225$

peruanus

$52,60,224$

phoenicopterus.

mutilus.

BRYCONINAL

buckleyi, Parodon

Pimelodus................ 99

bufonius, Ancistrus. ...51, 54, 59, 197

Chactostomus............. 197

Hypostomus............65, 197

Pimclodus.

Xenocara...

90

BUNOCEPHALUS

197

aleuropsis

bicolor

43,84

bifidus

corneoideus

$18,84,87$

laggini

knerii

melas

retropinnis

BUNOCEPHALINAE

$48,53,86$

43,87

$43,53,86$

$48,50,53,84$

43,85

85

St

\section{()}

cabezón

cachorro.

cachorro, Acestrorhynchus

calamita, Hypostomus

CALLICHTHYIDAE

Callich thyoidei

CALLICHTHYS

adspersus

aeneus

armatus

asper

callichthys

lacvigatus

littoralis

melampterus

171

172 paleitus

175

punctatus............... 175

splendens................ 181

tamoata................ 170

thoracatus............... 171

callichthys, Callichthys

$44,47,49,54,170$

Cataphractus............. 170

silurus.................. 170

CALLOPHYSINAE . ........ 87

Callophysus ............... 87

lateralis

macropterus.......43, $46,53,88$

camerone................. 25

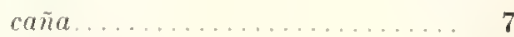

caña brata.................. 403

candira.................... 148

candiru

$10,142,143,144$

$145,146,147,149,190$

candiru, Cetopsis $\quad 142,146,148$

Hemicetopsis... 44, $47,49,54,148$

Silurus. . . . . . . . . . . 148

canero................... 275

CANTHOPOMUS. . ...........182, 183

agassizii .........44, $49,54,183$

genibarbis ............... 183

cantraini, 'Tylosurus. . . . . . . 382

capito, Brycon...........45,253

carachama................. 182

carachama, Monistiancistrus

$17,186,187$

carache

$.5,364,372$

curachilo $\quad \ldots \ldots \ldots, 5,372$

carapo, Gymnotus $46,50,57,328,329$

Sternopygus............... 329

carapus, Gymnotus........... 329

Sternopygus............. 313

brachyurus . . . . . . . . . . 329

Carapus................... 493

fasciatus . . . . . . . . . . 329

rostratus . . . . . . . . . . 327

sanguinolentus............. 313

caribe..........239, 242, 243, 245

carinata, Farlowella........... 214

Loricaria............47,55,208

Loricaria (Loricaria)........ 203

276 carinatum, Hypoptopoma. 47, 55, 201

carinatus, Hypoptopoma... . 201

Silurus. $\quad 132$

CARNEGIELLA $\quad \ldots 267,269$

strigata $\quad 45,56,269$

carnero

$10,142,143,144,145,149,162,275$

rarocha de brada 185

carolinae, Astyanax . 222

cashibo, Loricaria.......47,205, 200

cataphracta, Loricaria

$44,49,55,202,208$

Cataphractops melampterus.... 172 
Cataphractus
callichthys, callichthis..
costatus
catucanus, Bryconamoricus. 50, 60, 22
caudimaculata. Curimatella
caudofasciatus, Prochilodus

$18,51,60,311$

\section{cayanus, Pristigaster} $46,48,50,58,339$

centrarchoides, Carus 390

CENTRODORAS 121

brachiatus.......44, 47, 53, 1294

CFNTROMOCHLUS ............. 117

gyrinus . . . . . . . . . 4,118

heckelii .......44, 47, $48,53,117$

intermedius .............. 118

megalops................ 117

perugize.............50, 118

steindachneri...........44,118

Centrophorus.

157

cephalotes, Prochilodus.....44, 310

cephalus, Brycon..........45, 258

Cyprinus

Megalobrycon

CERATOBRANCHIA

binghami

obtusirostris

252
253

$64,65,222$

$52,60,223$

CETOPSINAE

$51,60,222,223$

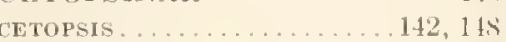

candira................ I ts

candiru............142,146,145

"nerutichs 112

gobioides.

macroteronema

plumbeus.

ventralis

119

51

$14 !$

$1+9$

Cetopsis (Hemicetopsis).. 1 ts

('scudocetopsis) 14!

CHAENOTHORAX , ............ 1 हi

bicarinatus.............4, 1,80

semiscutatus ........44,180,181

ChaETOBRANCHUS.........387, 388

flavescens........46, 48, 58, 387

CHAETOSTOMA.........64, 191, 196

inomalus 192

branickii.........49,51,59,194

brevis $50,59,195$

dermorhyncha.......50,51, 194

furcata...............47, 191

latifrons

196

lincopunctata......47,52,59, 192

loborhyncha.........191, 192, 194

maculata.............59, 195

marcapatae............. 195

marmorescens........51,59, 193

microps......44,50,51,59, 195

mollinasa ............50, 59, 195

platycephalus............ 51

sericea..................4, 194

taczanowskii . 49, 51, 52, 59, 191, 192

variola ..............4, 194

Chactostomus ............185, 191 itluit

aurantiacus

bufonius

cirrhosus

dentex

furcatus

gibbiceps

heteracanthus

hoplogenys

emeostictus

maculatus

malacops

nigricans

nigrolineatus

punctatus

tectirostris

CHALCES

angulatus

erythrurus

fasciatus.

macrolevidotus

rotundatus.

iquitensis. .... 277

chalceus, Tetragonopterus

$4, \pi, 3,234,232$

CHAI.CININAE

$$
\text { ...... 260 }
$$

\section{CHALCINUS}

albus .

$252,260,261,262$

$45,49,56,262$
angulatus. vittatus $\quad 49,56,262$ brachypomus......260, 261, 262 culter..............262, 263 elongatus

..$\quad$ iquitensis......... 262
nematurus.

$45,45,49,56,262$

rotundatus

$45,56,262$

iquitensis .......2 262

challhua.........70, 271, 304, 373

chambira-challhua............ 271

chanjoo, Loricaria.........47,204

Parahemiodon

CHARACIDAE

CHARICIDIUM

etheostoma

$62,214,215$

288

(Poecilosomatops) etheostoma. 28

fasciatum.........50, 56, 288

steindachneri

45,288

CHARACINAE ... 214, 256, 276, 277

Characini..................214

CHARACINIDAE ......... 214

CHARACINUS. . . . . . . . . . . . 256

cyprinoides............... 295

charapa .................. 391

(HAk. .................256

amazonum............49,257

bimaculatus. . . . . . . . . . 2?

gibbosus ..........47,56,257

limaesquamis ........45,47,256

pauciradiata........45,50,256

tectifer............45, 256,257

Chasmocephalus............. 91

CHASMOCRANUS. ..........91,97 longior . . . . . . . . . . . . 91

peruanus............... $+4,91$

quadrizonatus.........50,59,91

CHEIRODOX ....

CHEIRODONTINAE: 21:5

chilio

Chirodon alburnus Lthiti

Chorimycterus

Chromys acara

appendiculatal :;!Hi

fasciata :3!ti

ucayalensis $\quad 3 \times 7$

uninecllata 302

chryseum, Stethaprion.......45, ‥3

chullu-coclla 113

chupadora 311

Cichlat...............358, 4't

bilineatus $\{1)^{2}$

bimaculata 396;

conibos 40:3

labrina $\quad 104$

multifasciati $\quad 102$

ocellaris $\quad 46,48,50,58,401,402$

temensis ............50, 58, 408

Cichlasoma................ 395

autochthon .............. 397

bimaculatum.............. 396

coryphaenoides. ........... 397

faectum . . . . . . . . . . . . 397

factus . . . . . . . . . . . . . 397

festivum .................. 397

insigne ....... . . . . . . . 395

oblongus . . . . . . . . . . . . 397

severum . .......... 396

(Mesonauta) . . . . . . . . . 397

temporale ................. 397

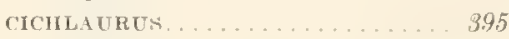

autochthon $\quad$ 46.58,397

bimaculatus $\quad 46,48,50,58,395$

severus $\quad 46,48,50,55,396$

temporalis $\quad 58,397$

CICHLIDAE 387

ciliata, Curimata $\quad 45,48,289,295$

Curimata (Curimata) ....... 295

ciliatus, Anodus............. 295

Curimatus................295

Psectrogaster...........289, 295

cirhosa, Vtmdellia........... 161

Xenocarn................ 194

cirrhosus, Ancistrus

$47,49,50,51,194,198,199$

Chactostomus.............. 199

Hypostomus............196, 199

Aenocara.................. 199

cisandinus, P'sectrogaster

$45,48,49,290$

clarias, Pimelodus

$$
13,47,48,53,104,105
$$

silurus.

101

clavipinna, Ioricaria........t7, 210

Loricaria (Fusiloricaria) ..... 210)

Clibadium aspersum.......... 30 


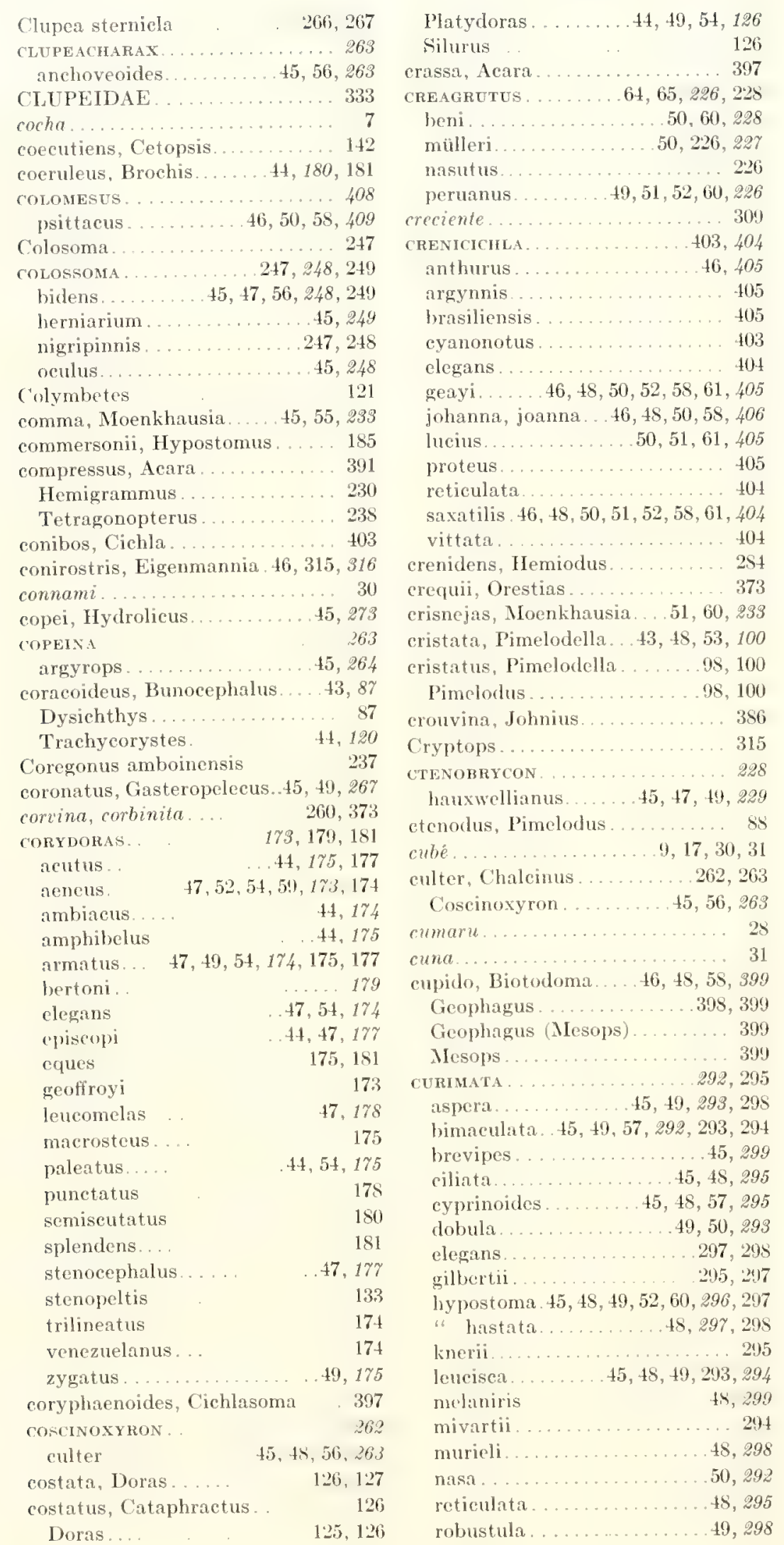

rutiloides........49,57,293, 294

simulata.............49, 298 spilura........45,57,292, 294

trachystetha . .........45,293

(Curimata) ciliata......... 295

(Steindachnerina) melaniris ... 299 (Steindachnerina) trachystethus 293

(Cyphocharax) spilura...... 292

CURIMATELLA . . . . . . . . . . . 291

alburna.......45,45,57,291, 292

alburnus, ...............291

caudimaculata $\quad .292$

lepidurus 291

meyeri...........45, 49, 291

Curimates, Les............... 292

CURIMATINAE ............ 289

Curimatoides................ 299

ucayalensis . . . . . . . . . . . 48, 299

Curimatus ..........289, 291, 292

acutidens. . . . . . . . . . . . 305

alburnus................. 291

altamazonicus............ 300

amizonum 2 295

asper..............293, 294

bimaculatus...........292, 294

bimaculatus trachystethus.... 293

brevipes .................. 299

ciliatus................ 295

cyprinoides 295

dobula ................. 293

elongatus................. 301

fasciatus.............. 303

hypostonus $\quad 296$

laticeps.................. 300

latior .................. 300

lenciscus. . ............... 294

meyeri.................. 291

nasus.................. 292

pristigaster .............. 259

rutiloides. .............294, 295

simulatus. . . . . . . . . . . . 298

spilurus................ 292

trachystethus.............. 293

curvirostris, Sternarchus (Rhamphostemarchus) ............. 310

Sternarchorhynchus $\quad 310$ cuvicri, Orestias

$52,61,346,350,352$ $354,355,356,358,361$

Xiphostoma.............. 274

cuvierii, Orestias..............358

cyanonotus, Batrachops.....46, 409

Crenicichla............. 403

cyanostigma, Pimelodella....43, 101

Pimelodus............... 101

Rhandia 101

Cyclopium................. 161

boulengeri.............. 165

cyclopum............... 165

longifile................ 166

peruanus................. 166

prenadilla.............. 165 
Cyclopium-Continued sabalo ................ 16 simonsii................ 166 taczanowskii.............. 167 ubidiai . . . . . . . . . . 168

cyelopum, Cyclopium.......... 165

Cyclorhamphus culeus........ 2

evlindraceus, Rivulus......... 345

cylindricus, Cyprinus......... 282

Cynocharax................257

CYNODON..............2\%2, 273

gibbum......... 45, $19,56,272$

gibbus.

pectoralis .

scomberoides.

vulpinus.

CYNODONTINAE

CYNOPOTAMUS.

gibbosus.

gulo.

knerii

$45,49,56,272$

273

273

271

259,271

259

257

cyprinoides, Characinus....... 295 Curimata.......45,48,57, 295

Curimatus

Salmo

$\ldots \ldots, 295$

292, 295

Cyprinus cephalus

cylindricus......

Cyrtocharax limaesquamis

\section{D}

dariensis, Hemibrycon

DASTATIDAE

82

deaurata, deauratus, Ilisha. 46, 334 DECAPOGON .............172, 179

adspersum, adspersus $44,49,54,173$

dentata, Trutta............ 255

dentatus, Piabucus......45, 56, 255

dentex, Chactostoma.......... 186

Panaque.............49, 186

dentón................. 272

dermorhyncha, Chaetostoma

$50,51,194$

dermorhynchus, Chactostomus

51,194

diabolicus, Urinophilus. .44, 143, 162

DIANEMA. . . . . . . . . . 173, 179

longibarbis.........4, 173, 179

diaphanus, Astyanax......... 224

Bryconamericus.........45, 224

Tetragonopterus........... 224

Diplolepis squamosissima . . . . 386

dipterus, Brochis

dispar, Pygidium $52,59,65,151,152,154,155$

Trichomycterus.

152,153 dispilurus, Epapterus. 44, 47, 53, 128 dobula, Curimata.......49, 50, 293 doncella................ 162 DORAS.......125, 126, 127, 128, 192 affinis................ 127 armatulus................. 126 brachiatus.............. 124 costata (costatus)

$1: 5,1: 26,1: 27$

granulosus

irypus

hancockii

humeralis

monitor

nauticus

niger.

pectinifrons

punctatus

weddellii

(Agamyxis)

(Agamyxis) flavopictus

(Astrodoras) monitor.

(Astrodoras) nauticus

dorme-ilorme

dorsalis, Rhamdia

dorsigerus, Acara

Equidens

Astronotus (Acara)

Nannacara

duodecimalis, Ancistrus

Hypostomus

DUOPALATINUS

peruanus

duquei, Rhamdia

dura, Loricaria.

duriventre, Myletes

Iylossoma $45,47,49,56,219,950$

DYSICHTHYS.

coracoideus.

$5,47,49,56,249,250$

$$
\text { Hi) }
$$

ecuadoriensis, Apareiodon.

edentatus, Hypophthalmus

$$
44,47,49,54,140
$$

edentulus, Hypophthalmus

141

Salmo

295

eigenmanni, Othonocheirodus

$51,60,215$

EIGENMANNIA . . . . . 313, $915,316,317$

conirostris.........46,315, 316

macrops.................. 315

troscheli.....46, 48, 315, 316,318

virescens....46, 48,50,57,315, 316

EIGENMANNINA . . . . . . . . . . . 301

melanopogon ...........45, 302

eleanora, Pyrrhulina...... \$5, 264

electricus, Electrophorus

$$
48,52,57,60,330
$$

Gymnotus................ 330

ELECTROPHORINAE . . . 312, 329

ELECTROPHORUS. . . . . . . . $\$ 99,330$ electricus.....44,52,57,60,330

clegans, Brachyrhamphichthys. . 314

Corydoras

$17,54,174$

Crenicichla

. 404

Curimata .............297, 295

Orestias......60, 353, 35t, 356, 370

Rhamphichthys........... 314

Stentogenes.........46,57,314

Steatogenys ellisi, Bryconacidnus $\quad 51,60,226$

Hyphessobrycon $\quad 226$

elongata, Piabucina......50,51,27 8

elongatus, Anodus $45,45,57,300,301$

Chalcinus..... $45,48,49,56,262$

Curimatus.

Elopomorphus ............ 301

Serrasalmo............... 240

Serrasalmus........47,49,55,240

Elopomorphus.................. 300

elongatus. . . . . . . . . . . . . . 301

jordani...............301

emarginatum, Platystoma..... 107

emarginatus, Hypostomus

$44,47,49,54,184$

Plecostomus

181

Empetrichthys.......... . . 347, 349

empyraeus, Orestias

$51,61,353,354,356,36 \gamma$

ENGRALIDAE . . . . . . . . . 332

Engraulis grossidens. . . . . . . . . 332

iquitensis. . . . . . . . . . . . . . 332

Entomolepis................. 235

steindachneri............ 235

EPAPTERUS . . . . . . . . . . . . 122

dispilurus.......44, 17,53,128

EPHIPPICHARAX . . . . . . . . 232, 238

orbicularis........... $15,55,239$

Epicyrtus................. 250

gibbosus. ................. 257

episcopi, Corydoras .....44,47,17\%

eques, Corydoras.......... 175, 181

Goeldiella..........43,53,107

Pimelodus............... 107

Nannostomus . . . . . . . . . . 298

Poccilobrycon.......... 45, 288

erinaceus, Hypostomus. ....... 195

EIITHIRIN INAE . . . . 276, 279, 283

Erythrinine group of subfamilies 276

erythrinoides, Piabucina....... 278

ERYTHRINUS. . . . . . . . . 282, 283, 284

brevicauda. . . . . . . . . . . 2\$2

erythrinus . . . . . . . $45,49,56,282$

macrodon. . . . . . . . . . . . . 280

salmoneus. . . . . . . . . . . . . . . 282

trahira ................ 2\$0

unitaeniatus .............. 281

(Ophiocephalops) unitaeniatus 281

erythrinus, Erythrinus .45, 49, 56, 282

Salmo..................... 282

Synodus. . . . . . . . . . . . . 282

erythrops, Stethaprion

$45,47,49,55,23,5$

erythropterum, Brycon $45,47,254$

Megalobrycon 251

erythropterus, Brycon 25t

erythrurus, Chalceus $27 x$

Plethodectes. 45, 56, 32.

Urinophilus $44,47,49,54,143,16 ?$

Isox imperialis

malabaricus 240 

etheostoma, Characidium..... 45, 288
Characidium (Poecilosomatops)

Euanemus brachyurus. nuchalis

Eucynopotamus gulo. kncrii

Evanemus.

evansii, Loricaria

Exocoetus.

exodon, Bryconamericus

Oedemognathus

\section{F}

facetum, facetus, Cichlasoma ... 397

falcatus, Acestrorhynchus. 49, 56, 276

Brycon ................ 253

Salmo............... 276

Xiphorhamphus............ 277

Xiphorhynchus

falcirostris. Acestrorhynchus

$45,48,49,275$

Hydrocyon............... 275

Xiphorhamphus........... 275

Xiphorhynchus............. 275

FARLOWELLA . . . . . . . . . . . 918

amazona............47,55,214

amazonum ............... 214

carinata

kneri, knerii,.........50,55,214

smithi.............44, 49, 214

fasciata, Chromys........... 390

fasciatum, Characidium....50,56, 288

Pimelodus ................. 108

Platystoma ............... 10s

Pseudoplatystoma

$43,47,48,53,108,109$

Schizodon.....46,48,49,57, 303

fasciatus, $\Lambda$ nostomus......... $30 t$

Astyanax........44,50,55, 222

Carapus.................. 329

Chalceus................... 222

Curimatus................. 303

Gasteropelecus............. 269

Giton.................. 320

Gymnotus................ 329

Nannoglanis............ 50,92

Schizodon ............... 303

Silurus . . . . . . . . . . . . . 108

Tetragonopterus ........... 222

feitorias. ................ 342

Felichthys.................. 122

nodosus . . . . . . . . . . . . . 122

ferox, Niphorhamphus ....... 276

festae, Astroblepus............ 51

festiva, Acara. . . . . . . . . . . . 397

festivum, Cichlasoma......... 397

Mesonauta........46,48, 58, 397 festivus, Astronotus (Mesonauta)

Heros ................. 397

Mesonauta. . . . . . . . . . 397 filamentissima, Hartia $\quad 47,49,211$ filamentosa, Loricaria .50, 55, 202, 208 Pyrrhulina. $26 \mathrm{t}$ filamentosum, Brachyplatystoma 112 filigerus, Aphyocharax $\quad .45,266$ fisga 27 Havescens, Lquidens $\quad 387$ Chatobranchus $\quad 46,48,58,38 \%$ flavilabris, Acara $\quad$... 392 flavipinnis, Pimelodina. $\quad 43,53,88$ flavopictus, Agamyxis . . . 44,126 Doras

Doras (Agamyxis)

flavus, Triportheus

Folhidie

forficulatus, Hypodoras

Fowlerina

orbicularis

freniferus, Acara

Equidens.

Astronotus (Acara)

friderici, Leporinus $46,45,49,57,305$ Salmo

frontosus, Orestias

fugitiva, Odontostilbe

Fundulinae

Fundulus

$$
\text { micropus. }
$$

furcata. Chactostoma

furcatus, Chactostomus

fuscum, Pygidium

fuscus, Orestias

(i)

galeatus, Auchenipterus

Pimelodus

Silurus

Trachycorystes $44,48,53,119,121$

Garmanina

garza-challhua

Gastrodermus

armatus

GASTEROPELECINAE

CASTEROPELECUS . . 252, 266, 267, 269 coronatus

fasciatus

pectorosus

securis

stellatus

sternicln

strigatus

gasteropelecus, Salmo

Gasterotomus latior

geayi, Crenicichla $46,48,50,52,58,61,405$

genibarbis, $\Lambda$ canthicus

Canthoponus

Plecostomus.

Rhinelepis

geoffroyi, Corydoras

GEOPHAGUS

altifrons

amoenus..................400

badiipinnis............... 387

eupido. . . . . . . . . . . . 398, 399

jurupari.......46,48,50,58, 400

megasema

surinamensis......... $46,48,58,399$

taeniatus. . . . . . . . . . . . . 400

thayeri. . . . . . . . . . . 394, 398

(Mesops) ...............398, 399

gibbiceps, Ancistrus........... 187

Chaetostomus.............. 187

Hemiancistrus , . . . . . . . . . 187

Pterygoplichthys....44, 47,54, 187

gibbosus, Anacyrtus. .......... 257

Charax...........47,56,257

Cynopotamus............ 257

Epicyrtus. . . . . . . . . . . 257

Salmo . . . . . . . . . 256, 257

gibbum, Cynodon 45, 49, 56, 271, 27\%

Raphiodon.............. 272

gigans, Arapaima........... 338

gigas, Arapaima...46, 48, 58, 837,338

Platystoma............. 115

Primodontos................ 338

Sorubimichthys.........48, 115

Sudis................ 337, 338

Vastres..................... 338

gilherti, Curimata..........295, 297

gilbertii, Curimata........... 295

gimbeli, Porotergus. . 46, 57, 323, 324

Giton fasciatus. . . . . . . . . 329

GLANHNOHELI . . . . . . . . . . 311

gobioites, Cetopsis.......... 149

G(IEHELIA 106

eques..............43,53, $10 \%$

goeldii, Brachyplatystoma...44, 112

Goniodontes................ 181

gordillo.................. 291

gracilis, Pimelodella . . 50, 53, 59, 102

Pimelodus ................ 102

Pygidium.............. 65

Trichonycterus............ 153

Grammichthys.............. 407

granulosus, Doras............. 125

P'terodoras.......44,47,53,125

grixalvii, Astroblepus......... 164

grossidens, Engraulis.......... 332 grosvenori, Bryeonamericus

$52,60,223$

268,260

48. 56.267

$$
269
$$

266.267

301

grypus, Anadoras.....44, 47, 54,128

Doras................... 128

guacari, Hypostomus..........18t, 185

Plecostomus................ 185

guatemalensis, Anacyrtus ...... 258

guianensis, Belone............ 381

Potamorrhaphis.....46, 48, 58, 381

gulare, Hypoptopoma.........44, 200 gulo, Cynopotamus . 45, 47, 51, 60, 259

Cynopotamus (Eucynopotamus)

398,899 309

Eucynopotamus............. 259 
güntheri, Oxylorienria

Sturisoma

GMINONOTI

GYMNOTIDAE

GMNOTINAE

GYMNOTUN

alhifrons

brachiurts

carapo, carapus $46,50,57,328,329$

electricus $\quad 330$

fasciatus

macrurus

rostratus

$44,49,55,218$

312,328

$313,327,328,329$

3211

329

313

327

gymnotus, Porotergus $\quad 322,323,324$

gyrinus, Centromochlus ..... $\$ 4,118$

\section{$\mathrm{H}$}

haggini, Bunocephalus .....43, 53, 86

haiari................... 30

hancockii, Amblydoras $44,47,54,12 \gamma$

Doras

harrisoni, Poecilobryeon

127

hartii, Pimelodella

IIARTTIA

brevirostris.

21

filamentissima

loricariformes.

microps

platystoma

hartwelli, Pimelodella

hasemani, Apteronotus

$46,51,60,320,322$

Pimelodella.......43,48,53,100

Sternarchus............... 321

IIASSAK.........

135

ucayalensis. . .

47,135

hastata, Curimata

297

Curimata hypostoma

296

hanxwellianus, Astyanax, ... 229

Ctenobrycon ......45, 47, 49, 229

Tetragonopterus

. $\ldots, 228$

heckeli, Acarichthys. . . . . . . 398

heckelii, Acara

Acarichthys........ $46,58,398$

Auchenipterus............ 117

Centromochlus . . 44, 47, 48, 53, 117

helleri, Hemibryeon

$50,52,60,61,216,218$

HEMIANCISTRUS. ......... 185, 189 arenarius .......... $44,49,185$ gibbiceps.

$44,49,185$

leteracanthus

190

ucayalensis.

47,185

HEMURRCON

$62,63,64,65,215,218,223$

dariensis................ 218

helleri .....50, 52, 60,61, 216, 218

huambonicus

$$
50,51,52,55,60,216,21 \mathrm{~s}
$$

ipanquianus. ............ 216 jelskii......49, 50, 51, 60, 216, 218 pectinatus

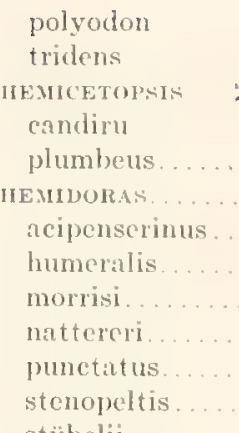

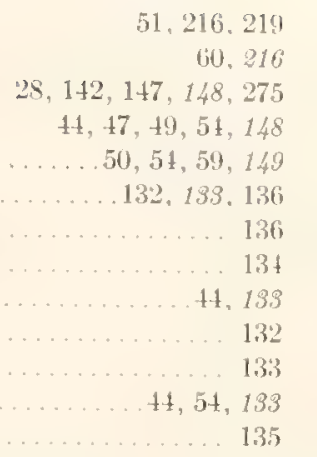

Hemidoras (Leptodoras) linneli 136

Hemidoras (Oxydoras) stenopeltis

H, 133

HEMIGRAMUUUS

$229,230,231$

compressus

paipayensis

2330

pulcher

$50,60,230$

robustulus

45,230

schmardae

230

hemiliopterus, Phractocephalus

\section{Silurus}

$43,53,110$

Hemiodon

acipenserinus

HEMIODONTICHTHYS

acipenserinus.

Hemiodontidae

HENIODONTINAE

. 110

210

210

210

$4+, 55,210$

284

amazonum

crenidens.

, $2 \times 5$

285

(Hemiodopsis) microlepis

284

$45,48,56,284$

hemipeltis, Opsodoras........17, 134

Hemiplatystoma ............ 108

HEMISORUBIM ............... 11 t

platyrhynchos.....44, $47,53,114$

platyrhynchus........... 114

HENONEMUS, ............... 158, 159

macrops.........49, 51, 158,159

punctatus.....44, 49,50,54,158

HEPSETINAE . . . . . . 271

Hepsetine Group of Subfamilies. 271

Hepsetus . . . . . . . . . . . . . 271

hercules, Equidens.........46,394

herniarium, Colossoma...... 45, 249

herniarius, Myletes. . . . . . . . . 249

Starksina ............... 24?

Heros . . . . . . . . . . . . 395

autochthon .............. 397

bimaculatus . . . . . . . . . 396

festivus. . . . . . . . . . . 397

insignis . . . . . . . . . . . 397

severus . . . . . . . . . . . . 390

spurius................ 390

temporalis................ 397

Heros (Heros)insignis. ....... 398 heteracanthus, Ancistrus (Iasiancistrus) ................ 190

Chaetostomus ............ 190

Hemiancistrus . . . . . . . . . 190

Lasiancistrus . . . . . . . 4. 44, 190

Hetererythrinus .... . . . . . . . 282

HETEROGXATHI ....

Heterogramma ..............4 400

borellii.... 400

taeniatum................. t01

heterolepis, Acestrorhynchus. 45, 276 Pellegrinina............ 277

Xiphorhamphus ........... 270

IETEROSOMATA . . . . . 407

hilarii, salminus. . . . . . . . 260

hispe..............5, 357,378

Holobrycon iquitensis......... 260

Holosthenes. ................ 215

holostictus, Leporinus.......46, 307

Holotaxis ........ $26 t$

laetus .................. 26t

melanostoma.............. 26t

Homodiaetus . . . . . . . . . . 159

HOPLERXTHRINU'S. . . . . 280, 283, 284

unitaeniatus.......45,48,56, 281

HOPLAS. . 279, 280, 281, 282, 283, 281

malabaricus....45, 48, 49,56, 280

Hoplisoma............... 173

hoplogenys, Ancistrus 44, 19,54,196

Chaetostomus ............ 196

Xenocara................ 197

Hoplosoma ................. 173

aeneum................. 173

HOPLOGTERNUM........170, 172, 179

littorale......44, 49,54,171, 172

longifilis ............... 171

melanopterum...........4.172

melanopterus.............. 172

shirui............... 47,172

thoracatum......4, $47,49,54,171$

thoracatum...... 171

hualpuche................. 357

huambonicus, Hemibryeon

$50,51,52,55,60,216,218$

Tetragonopterus ............ 216

huascachallhua............. 155

huimba-shitari.............. 294

huito-challhua................. 304

humboldti, Orestias...... 353, 355

humboldtii, Orestias

$52,61,354,356,357$

Prstinaca............... \&3

Potamotrygon ............. 83

Stemopygus ............. 315

S'tyogenes.................. 165

humeralis, Doras.............. 131

Hemidoras ................. 134

Opsodoras.....44, 47,54, 184, 135)

Oxydoras ................. 131

Scrrasalmo. Serrasalmus

$45,47,49,52,55, ?: 1$ 


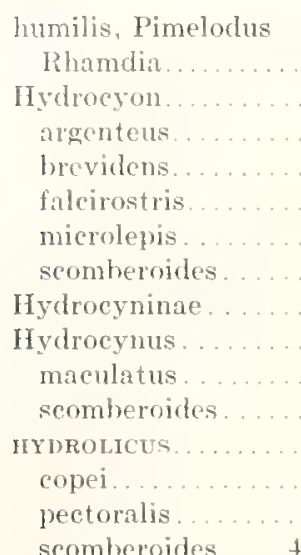

94,05 $43,51,53,94,96$ 274 259 260 275 276 273 273 274 274 273 259, 272 45, 973 $45,49,273$ scombernides $\quad 45,48,49,56,278$

Hygrogonus ocellatus

HYPHESSOBRYCON.

… 391

ellisi.................. 226

innesi ................. 45,231

loretoensis............45,231

peruvianus............45, 231

robustulus...............45,280

HY PODORAS.

forficulatus

129

.4, 129

HYPOPHTHALMIDAE

62,140

137,140

HY POPITHA LMUS

cdentatus......44, $47,49,54,140$

edentulus.

nuchalis.

perporosus

IIYPOPOMUS

brevirostris.

HY POPTOPOAR.

bilobatum.

carinatum .

carinatus

gulare

joberti.

thoracatum.

121

141

313,314

$46,50,57,314$

200

200

$47,55,201$

... 201

44,200

$47,55,200$

HYPOPTOPOMATINAE . . . 199

hyposticta, Acara............ 391

hypostoma, Curimata

$45,48,49,52,60,296,297$ hastata .....48,297, 298

IIypostomatina ............. 181

HYPOSTONIATINAE ...... 182, 283 HYPOSTOMUS

$183,184,185,187,188,191$

aurantiacus. . . . . . . . . . . 189

bufonius..............65, 197

calamita................. 65

cirrhosus ................. 196. 199

commersonii............... 185

duodecimalis............. 187

emarginatus.....44, 47,49,54, 184

erinaceus............... 195

guacari.............184, 185

multiradiatus............. 188

nigricans................. 189

pardalis.................. 188

phrixosoma

47,185 pictus

plecostomus

punctatus

temminekii

vicinus.

hypsanchen, Metynnis

Myletes.

hypselonotus, Abramites

.

hystrix, Acanthicus .....49,5 4,189

Potamotrygon .......46, 48, 53, 89

Trygon

I

IGUANODECTES.

tenuis.

IGUANODECTINAE

....2.254

abnormis

altamazonica

deaurata

iquitensis

immaculatus, Serrasalmo

$45,56,255$

254

.334

334

$6,58,394$

46,334

46,394

IMPARFINIS.

bolivianus .......50,53,59,97

piperatus

imperialis, Acara (Heros)

Esox.

Uaru

incae, Orestias $52,61,353,354,355,356,357$

Pygidium............... 65

Trichomycterus............ 153 innesi, Hyphessobrycon.....45, 231 inornata, Orestias............. 368 insidiosus, Stegophilus........ 144 insigne, Cichlasoma........... 398 insignis, Heros............ 397

Heros (Heros) . . . . . . . . . . . . 398

Mesonauta . . . . . . . . . . . 398

Prochilodus .......46,57,310,311

Uarus ................... 398

intermedius, Centromochlus.... 118

Stegophilus............... 15s

ipanquianus, Acrobrycon $41,52,60,65,218,219,225$

Astyanax................ 218

Hemibrycon............. 210

Tetragonopterus ...........218

iquitensis, Bryeon siebenthali... 251

Chalceus macrolepidotus..... 277

Chalcinus elongatus. . . . . . . 262 rotundatus .............. 262

Engraulis................ 332

Holobrycon................ 260

Ilisha.

Plagioscion auratus

46,394

.

iridopsis, Serrasalmo.......... 241

irwini, Megalodoras....44, 53, 124

isacanthus, Auchenipterus. . . . 120

Trachycorystes

4,120
ISOSPONDYII

ispi. $\quad 37 \mathrm{~s}$

itapicuruensis, Apareioton $2 \mathrm{st}$

\section{$\mathbf{J}$}

jamesi, Moenkhausia

jeanesianus, Liposarcus

Pterygoplichthys

jelskii, Hemibrycon

$49,50,51,60,216,218$

Tetragonopterus

jivaro, Pimelodus

218

joanna, Crenicichla

joberti, Hypoptopoma

43. 105

Otreinclus

$47,55,200$

johanna, Crenicichla

$46,48,50,54,406$

Crenicichla brasiliensis $\quad 406$

Crenicichla johanna $\quad+06$

Johnius amazonicis $380^{\circ}$

jordani, Elopomorphus 301

juruense, Brachyplatystoma

$44,53,111$

Platystoma

111

jurupari, Geophagus

$46,48,50,58,400$

jussici, Orestias

$52,61,349,352,354,356,3 \gamma \gamma$

jussicui, Orestias

377

$\mathrm{K}$

kneri, Curimata

295

Pygidium.

157

Trichomyeterus

157

linerii, Acestra

Anacyrtus

214

Bunocephalus

Cynopotamus

$48,50,53,84$

Eucynopotamus

$50,56,259$

Forlowella

Pygidium

'Trichomyeterus

$50,55,21$,

$51,54,157$

KNoDES

breviceps

megalops

meridas

moenkhausii

konopickyi, Loricaria

Rhineloricatia

kutschin

157

330,234

$51,60,234$

47. 52, 235

231

51,234

$+4,55,204$

204

155

I.

labialis, Astroblepus

$50,59,166$

labrina, Cichla

Iabrus punctatus

bimaculatus

lacustris, Astyanax

LAEMOLYTA

taeniata

lacta, Pyrrhulina.

lnetus. Holotaxis xis

sis (1)

6

00

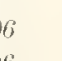

01

1

1

00




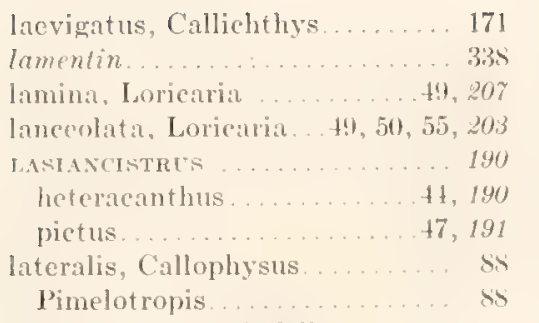

lateristriga, Pimelodella $43,53,99,100$ Pimelodus

lateristrigus, Pimelodus

laticeps, Anodus

$45,48,49,57,300,301$

Curimatus, Curimata ......300

Semitipicis

latifrons, Chaetostomus

Xenocara

latior, Anodus

Curimata

Ginsterotomus

$45,48,49,57,300$

196
4.196
57,300
300

300

latissima. Moenkhausia

lativirgatus, Microgenys .

232

$50,60,228$

I.EBIASINA ...........278, 979

bimaculati.

(60, 279

I.EBIASININAE

leoidurus, Curimatella

IJPOREILINAE .

HAPORELUS

vittatus

276

291

$30 \mathrm{~s}$

308

I.EPORINUS ... 252, $305,307,30 \mathrm{~s}, 309$ alternans ................ 300

bimaculatus........46,57,305

fritlerici......46, 48, 49,57,305

holostictus .............46, 307

hypselonotus

$46,49,57,308$

$46,57,307$

$57,305,306$

magelepis .

$46,57,227,306$

mülleri

46. 307

multifasciatus

305

novemfasciatus.

305

pictus. . . . . . . . .

$50,57,305$

trifasciatus.........49,57,307

vittatus.

$30 \mathrm{~s}$

wolfei.

48,306

270

IEPTAGONIATES

steindachneri

LEPTODORAS

$.50,270$

135,136

acipenserinus

49,136

linnelli

$47,54,136$

leptorhynchus, Aptcronotus

$16,57,320,321$

Sternarehus

. . 321

leptus, Pimelodus

47,104

leucisca, Curimata

$45,48,49,293,294,297$

leuciscus, Curimatus.

294

leucomelas, Corydoras

$47,1 \% 8$

Ieucostictus, Chaetostomus

197

levis, Myleus

252

\begin{tabular}{|c|c|}
\hline Myloplus... & $47,56,252$ \\
\hline Pterodiseus... & $\ldots \ldots 267$ \\
\hline ima, Platystoma & 113 \\
\hline silurus......... & 113 \\
\hline Sorubim........t4, 47 . & $+5,53,113$ \\
\hline limaesquamis, Inacyrtus. & $\ldots \ldots 256$ \\
\hline Charax ............... & $45,47,256 i$ \\
\hline Cyrtocharax... & $\ldots \ldots 256$ \\
\hline inentus, Achirus. & 407 \\
\hline Pleuronectes .. & 407 \\
\hline Khamphichthys... & 325 \\
\hline Tetragonopterus...... & 235 \\
\hline
\end{tabular}

lineopunctata, Chaetostoma

limnelli, Hemidoras

$47,52,59,192$

Leptodoras.

$17,54,186$

LIOSOMADORA

... 127

morrowi...............47, 127

Liposarcus................. 187

altipinnis................. 187

jeanesianus.............. 18s

multiradiatus............. 18s

pardalis .................. 18s

scrophus................ 187

varius................... 1ss

lisa $\quad 207,302,305,35 !$

LITIIODORAS

littorale, Hoplosternum

littoralis, Callichthys......... 171

$44,49,54,171,172$

loborlyncha, Chaetostoma

$191,193,194$

loborhynchus, Chactostomus

$191,193,194$

Lobotes ocellatus

390

Lonchocarpus densiftorus....... 30

longibarbis, Dianema $\quad$ 4. 173.179

longicauda, Nannorhamdia. 50, 59, 9i P'imelodus

Rhamdia . . .

97

longicandatus, Rhabdolichops 46,317

longiceps, Astroblepus

longifile, Cyclopium

$$
51,54,59,168,169
$$

longifilis, Arges 166

Astroblepus $\quad 49,50,51,59,166$

Hoplosternum

171

longior, Astyanax $\quad$. $19,51,60,221$

Chasmocranus

Tetragonopterus . 221

loretoensis, Hyphessobrycon 45, 231

LORTCARIA 202,205,212

acipenserinus 210

ilcutil $\quad .44,55,203,204$

amazonica. $\quad 205$

brevirostris 212

brunnea.........44, 47, 55,203

carinata. $\quad+7,55,208$

cashibo. 47,205, 2016

cataphracta $\quad 41,49,55,202,209$

chanjoo $\quad 47,204$ clavipinna...........47,210

lura 202,208

evinsii ............ 44,55,200

filamentosa . . . 50,55, 202,2018

konopickyi ......... 4 t, 55, 204

laminat. . . ... .........49. 207

lanecolata..... 49.50.55.203

macromystax ...........4, 408

maculata . . 44, 47, 55, 201, 205,206

morrowi............47,208

mulirostris. . . . . . . . . H, 55, 206

petleyi...............47, 208

plecostomus. ............ 181

puganensis..........50,60,202

punctata......44,49,55, 188, 206

rostrata...........2 212, 213

simillima.............55), 207

spixii.................... 204

stiubelii ...............49, 20 t

typus ............5.55, 204, 205

ucayalensis ............47,205

wolfei...........47,203,300

Ioricariformis, Harttia ........211

IORICARIII)AH . . . . . . 62, 181

Loricariichthys brunneus. . 203, 20t maculatus................ 205

neaynlensis............... 205

LORICARIINAE . . . . . . . 20.2

Loricnroidei ............... 181

Loricata................. 181

Ion-10u ..................... 339

LUCIOPLIELODINAE _... 115

Luciopimelodus ..........116, 117 agassizii ............... 117

lucius, Crenicichla....50,51,61,405

lugubris, Pyruhulina ..... $45,56,265$

Iuna, Metynnis . . . . 45, 47, 49,246

Luteus, Orestias

$52,61,3.51,352,351,355,356,345$

LYCENGRATLIS. . . . . . . . . . . 392

batesii.........46,50,58, 332

lyra, l'hysopyxis

41,129

\section{II}

Macrodon................. 279

malabaricus ............... 280

trahira.................... 280

macrodon, Erythrinus.......... 280

macrolcpidotus, Chalceus

$45,48,56,277,27 \mathrm{~s}$

macromystax, Loricaria..... .44, 209

macrops, Eigenmannia....... 315

Henonemus . . . . . 49, 54, 158, 15!

Sterophilus. ............. 15is

macopterus, Callophysus

$43,46,53,88$

Pimelodus.................. sis macrospilus, Otocinclus......4t,201 macrostcus, Corydoris......... 175 macrostoma, Sternarchorhynchus 319

sternarchus............. $31 !$ 
macrostomus, Rhamphosternarchus

319

Sternarchorhamphus....46,50,819

macroteronema, Cetopsis

macrurus, Gymnotus.

Sternopygus

$46,48,50,51,52,57,60,313,328$

maculata, Albula

.. 220

Chactostoma

$.59,195$

Loricaria. 4t, $47,55,204,205,200$

maculatum, Pygidium

Xiphostoma.

maculatus, Chactostomus.

Hydrocynus

Ieporinus.

Loricariichthys

Pimelodus.

Plecostomus

Serrasalmo, Serrasalmus

$45,49,55,241$

Tetragonopterus

maculipinnis, Basostoma

Maius osteoglossum.

malabaricus, Esox

Hoplias

$45,48,49,56,280$

Macrodon

Synodus

malncops, Chaetostomus

mancoi, Astroblepus

$45,49,274$

195

$27+$

$6,57,30$

205

102

205

220

220
407

338

280

mapara

maparacui

maparate

marcapatae, Chaetostoma...... 195

Chactostomus............ 195

maregravii, Salmo........... 292

marginatus, Serrasalmo ........241

mariae, Equidens. . 46, 48, 50, 58, 393 marmoratus, Rhamphichthys

$46,48,57,327,328$

Sciades

43,111

Symbranchus...46,50,58, 331, 33. marmorescens, Chaetostoma

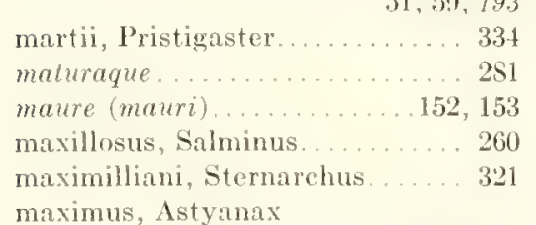

maximus, Astyanax $44,47,49,50,51,52,60,221$

Tetragonopterus........... 221 medians, Ancistrus............. 185 meeki, Pimelodella............ 101 megalepis, Leporinus....57, 305, 306 Megalobrycon cephalus..... 253 erythropterum............ $25 t$ melampterum.............. 253 MEGALODORAS............124, 125 irwini. $\quad 14,53,124$ megalops, Centromochlus...... 117

Knodus .........47,52,60,235 megasema, Geophagus........ 399 melampterum, Brycon

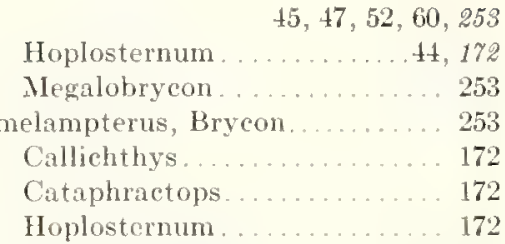

melaniris, Curimata.........48, 299

Curimata (Steindachnerina)...299

melanopogon, Anodus.......301, 302

Eigenmannina............ 45, 302

melanops, Tridens.........44, 163

melanostoma, Pyrrhulina..... 45,264

melanostomus, Holotaxis....... 264

melas, Bunocephalus......... 43,85

meridae, Knodus.............. 234

MESONAUTA...... 397

festivum, festivus....46, $48,58,397$

insignis. . . . . . . . . . . . . . 398

Mesops ...............398, 399, 400

cupido.

taeniatus

METYNNIS

hypsauchen

luna

meyeri, Curimatella

...... 399

400

246,252

$49,55,246$

$45,47,49,246$

$45,49,291$

Curimatus

291

Curimatus (Curimatella)..... 291

micayi, Rhamdia ............ 93

MICROCYPRINI. .......... 345

MCROGENYS 208

lativirgatus ........50, 60, 228

minutus. . . . . . . . . . . . 228

MICROGLANIS . . . . . . . . . . 89

poecilus............... 89

zonatus.

43,89

microlepis, Acestrorhynchus

$49,56,276$

Hemiodus.........45, 48, 56, 284

Hemiodus (Hemiodopsis)..... 284

Hydroeyon .............276

Rhytiodus.......46,48,57, 304

Xiphorhamphus...........276

microps, Chaetostoma . $49,51,59,195$

('hactostomus $50,51,195$

Hartia................44, 211

Pareiodon..........44, 157, 158

micropus, Fundulus ........... 346

Rivulus...........46,58, 346

mijano................ 9

mimicry .................. 384

mimophyllus, Nonocirrhus 46, 48, 383

minutus, Microgenys. . . . . . . . 228

mivartii, Curimata. . . . . . . . . . 294

MOENKHAUAIA........291, 231, 235

atahualpiana...........45, 232

bondi......... 45, 49,55, 232

comma.............45, 55,233

crisnejas...........51, 60, 233

jamesi................. 235

latissima ................. 232 oligolepis........45,55,291, 232 ovalis.............45,47,49,234

profunda................ 232

simulata........47,52,60, 232

steindachneri.............. 235

moenkhausii, Bryconamericus... 234

Knodus ............51, 60, 284

Poecilurichthys............ 234

mollinasa, Chaetostoma ...50, 59, 195

mollinasus, Chaetostomus...... 195

MONISTIANCISTRUS .......... 186

carachama........47, 186, 187

monitor, Amblydoras.......44, 128

Doras................... 128

Doras (Astrodoras)......... 128

Zathorax................. 128

Monochirus............... 407

MONOCIRRHUS ............... 382

mimophyllus .........46, 48, 388

polyacanthus............. 383

Monotocheirodon............215

montana, Pimelodella.....51, 59, 100

mormyrus, Sternarchorhynchus. . 319

Sternarchus.............. 319

morrisi, Hemidoras. . . . . . . .44, 193

morrowi, Liosomadoras......47, 127

Loricaria..............47, 208

Rhineloricaria............. 208

mounseyi, Rhamdia $\quad 46,94$

II üllera moniliformis.......... 30

mülleri, Creagrutus......50, 226, 227

Leporinus.......46,57,227, 306 Orestias

$52,61, \quad 351, \quad 352$ $354,356,362,367,374$

Rhamphichthys........... 314

Sternarchorhamphus....48, 57,320

Sternarchorhynchus . . 318, 319, 320

Sternarchus.............. 319

Sternarchus (Rhamphostern-

archus) ............... 320

Trygon................. 83

multifasciata, Cichla.......... 402

multifasciatus, Leporinus.....46, 307

multiradiatus, Ancistrus....... 188

Hypostomus ............... 188

Liposarcus................ 188

Pterygoplich thys $44,47,49,54,188$ murieli, Curimata.........48, 298 myersii, Anacyrtus........... 258

Roeboides........45, 47, 49,258

Myletes.................. 251

albiscopus............... 250

nsterias................. 251

nureus............... 249

bidens.................24s

brachypomus............. 247

duriventris............... 240

herniarius ............... 249

hypsauchen.............. 246

nigripinnis............. 247

oculus ......... 


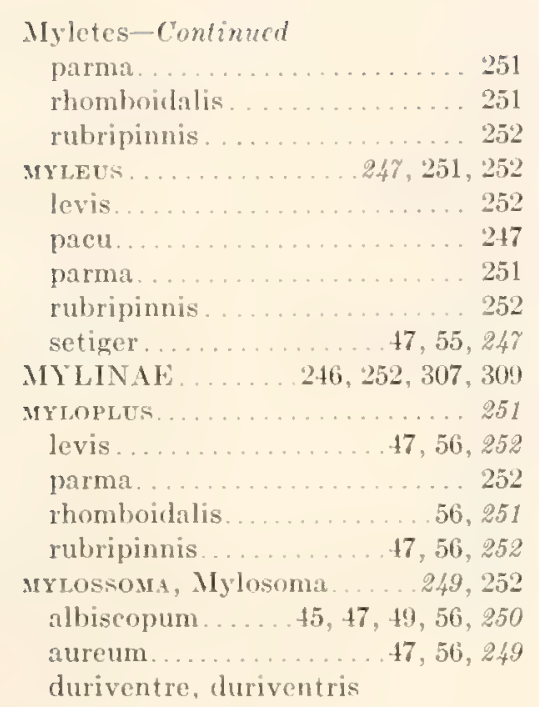

$45,47,49,56,249,250$

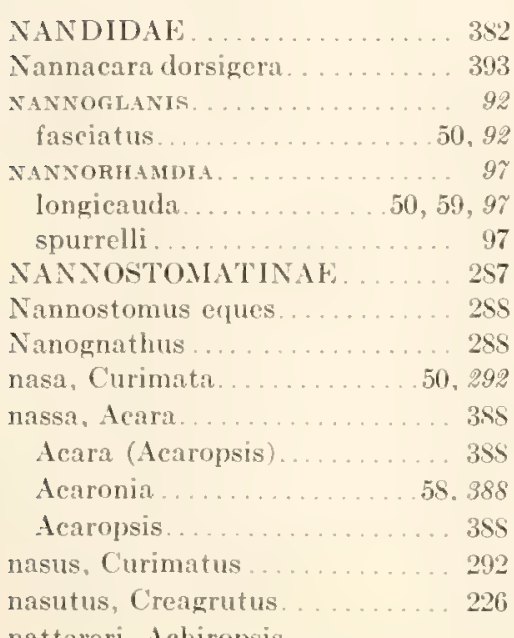

nattereri, Achiropsis

$46,48,50,58,408$

IIemidoras . . . . . . . . . . . . 132

Oxydoras. ............... 131

Pygocentrus ............. 242

Pyrrhulina..............264

Rooseveltiella.....45, 47, 55, 242

Serrasalmo, Serrasalmus.... 242

Solea................... 408

Solea (Achiropsis) . . . . . . . 408

Sternarchogiton

$$
46,57,323,324,325,326
$$

Sternarchus.............. 321

Trachydoras....44, 47, 54, 131, 132

nauticus, Anadoras..........4, 128

Doras ..................... 129

Doras (Anadoras) ........... 128

(Astrodoras) .............. 128

Zathorax ................ 128

NEMATOGNATHI nematurus, Chalcinus.

261

nemopterus, Batrachops......48, 403

nemurus, Pseudostegophilus

$44,47,54,159$

stegophilus

Neceratodus

neveui, Orestias

150

Oxydoras.

P'seudodoras .44, 17, 51, 54, 59, 130

IRhinodoras.

nigricans, Chaetostomus

Hypostomus

Parancistrus

Prochilodus

$46,48,50,51,52,57,60,909,310$ nigricollis, Tympanopleura...44, 139 nigripinnis, Colosoma (Waiteina) 248

Colossoma . . . . . . . . . 247

Myletes................ 247

Piarctus......45, 47,56, 247, 248

nigrolineatus, Chaetostomus .... IS6

nigrorostrum, Sturisoma.....47, 213

nodosus, Arius . . . . . . . . . . 122

Auchenipterus ............. 122

Felichthys............. 122

Pseudauchenipterus.... 47,53,122

Silurus ................ 122

notatus, Anodus ............ 285

novemfasciatus, Leporinus.... 305

nuchalis, Auchenipterus

$44,47,49,53,121$

Evanemus ................ 121

Hypophthalmus . . . . . . . . 121

nudirostris, Loricaria..... $44,55,206$

nulilla.

304

\section{o}

obermülleri, P'yrrhulina

oblongus, Cichlasoma.

obtusirostris, Ceratobranchia $51,60,222,223$

oceidentalis, Ancistrus......50,198

Xenocara........................ 198

oceloi, Ancistrus........52,59, 197

ocellaris, Cichla $16,48,50,58,401,402$

ocellata, Acara.............. 391

Acara (Hygrogonus)........ 391

Astronotus............... 391

ocellatus, Astronotus

$46,48,50,58,390$

Hygrogonus. . . . . . . . . . . . 391

Lobotes. . . . . . . . . . . . 390

oculus, Colossoma.........45, 248

Myletes. . . . . . . . 248

ODONTOSTHABE..........215, 265

fugitiva. . . . . . . . . 45,265

OEDEMOGNATHUS. .........318, 325

exodon...............46, 325

oesopus, Serrasalmo.......... 240

Serrisalmus. oligolepis, Astyantx. . . . . . 231

Moenkhausia . 45, 55, 231,232

T'etragonopterus............ 231

olivacens, Orestias

$52,61,352,354,355,356,363$

cmanto................. 359

Ophiocephalops.............. 2\$n

ophthalmicus, Pimelodus....... 100

OPSODORAS.............134, 135

hemipeltis............47, 134

humeralis ......4t, $47,54,134,135$

orthacanthus ......44, 47, 13t, 13.5

parallelus............4, 134

stübelii................49, 135

orbicularis, Ephippicharax 45, 5.5, 299

Fowlerina............. 239

'Tetragonopterus. . . . . . . . . . 239

ORESTIAS... … 1, 3, 5, 19, 21 . $28,61,65,71,72,78,142,150,154$. 346

agassizii . 16, 51, 61, 65, 66, 77, 349. $350,353,354,356,362,371,379$ crequii............... 373 inornata............368, 373 seneschali. . ........... 373 typica. . . . . . . . . . . . . . 373

affinis. . . . . . . . . . . 373

albus $\quad 52,61,349$,

$351,352,354,355,356,363,371$

bairdii............... 360

cuvieri, cuvierii...52, 61, 346, 3HS, $350,352,354,355,356,357,358,361$ elegans.....60, $353,354,356,330$ empyraeus . 51, 61, 353, 354, 356, 367 frontosus.............371.373 humboldti, humboldtii

$52,61,353,354,355,356,357$ incae . 52, 61, 353, 351, $355,356,357$ jussiei, jussieui

$52,61,65,349,352,354,356,3 \gamma \gamma$ luteus................52,61.

$348,351,352,354,355,356,361$ mülleri.

$351,352,354,356,361,362,374$ neveui ............. 351, 361 olivaceus

$52,61,352,351,355,356,393$ ortonii.

owenii

$52,61,65,352,354,356,371,3 \% 6$ pentlandi, pentlandii

$52,61,71,349,350,351,352,354$, $356,357,35 \%, 360$

fuscus.

65,361

rospigliosii..........52,61, 381 silustani . . 52, $61,352,354,356,366$ tirapatae ............371,37t tschudii

$52,61,349,351,352,354,356,8 \% 9$ Orestiasini, Orestiasiformos. .... 346 


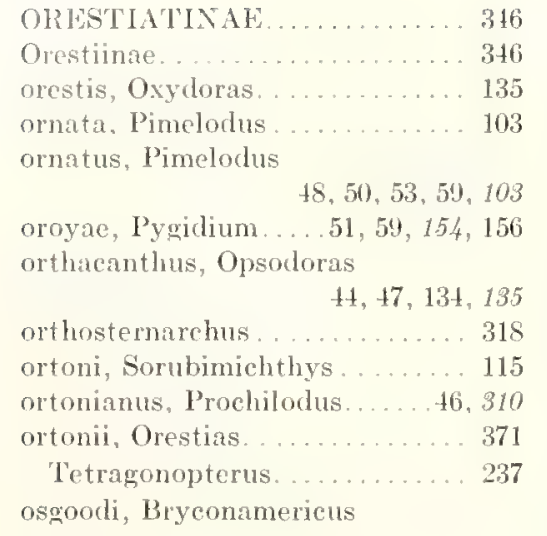

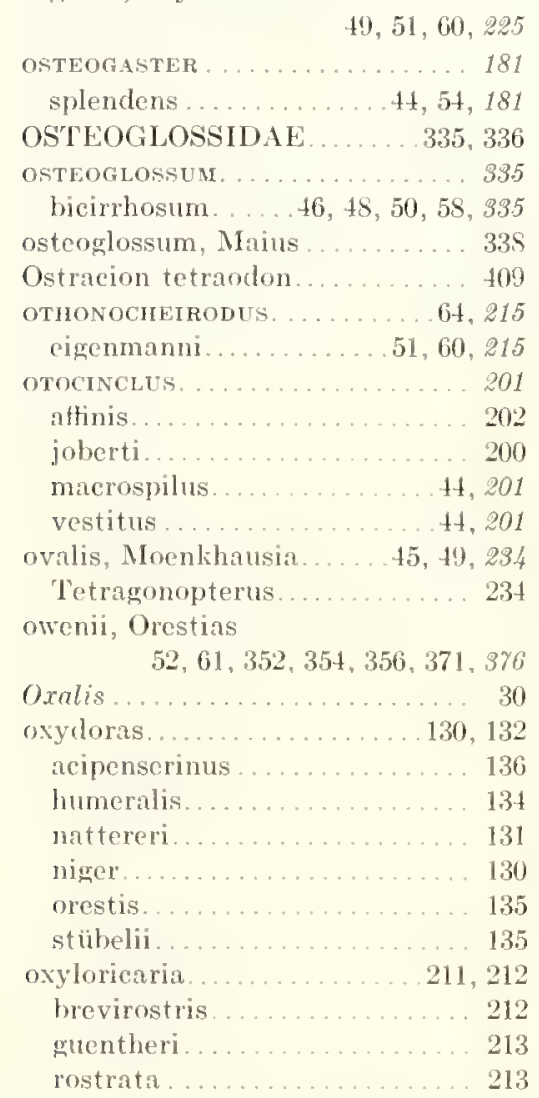

oxyrhynchus, Stemarchorhyne\}us $46,50,57,318,319$

Sternarchus

\section{$P$}

pachacuti, Bryconamericus $52,60,224$

Pachyurus squamosissimus..... 386 peco, pacu

250. 252 pacu, Myleus. 247 paiche ...........9, 24, 336, 338 paipayensis, Henigrammus paleatus, Callichthys......... 175 Corydoras..........44,54, 175 palometa, palometo

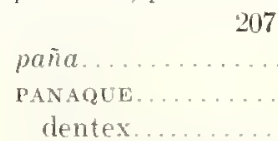

$207,250,251,252,359$

$239,242,243$

dentex

49,186

pantherinus, Rhamphichthys... 328

PARAGONIATES. . . . . . . . . . 270 alburnus.........45,50,56, 270

Parahemiodon chanjoo........ 204 spixii ....................... 205

typus. . . . . . . . . . . 204

parallelus, Opsodoras .......4t, 134

PARANCISTRUS............ 188, 190

aurantiacus........... 47,189

nigricans.

pardalis, Hypostomus.

Liposareus

Plecostomus (Liposarcus)

Pterygoplichthys.

pardus, Trichomycterus.

PAREIODON.............157, 158

microps...........44, 157, 158

PARIOLIUS.

armillatus

parma, Myletes

Myleus

Myloplus

PARODON.

buckleyi.

piracicabae

suborbitalis

PARODONTINAE

parvus, Rhamdia

Pastinaca humboldtii

pauciradiata, Anacyrtis .

Charax.

Paullinia pinnata

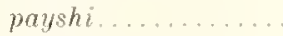

pectinatus, Astyanax.

Hemibrycon.

Phenacogaster.

Tetragonopterus

pectiniflons, Agamyxis

Doras.

pectoralis, Cynodon

Hydrolicus.

157,158
150

44,150

251

251

252

50,286

256

265

285

51

8.3

256

$45,50,256$

ectorosus, Gasteropelecu

Thoracocharax

peje-perro.

pejervey.

......

...........

pellegrini, Plecostomus.

Pellegrinina.

heterolepis

Pellona

altamazonica.

pentlandi Orestias . $52,61,71,340$ $350,351,352,354,356,357,359,360$ Pinclodus.

Rhamdia...........51,59,96

'I'richomyeterus. . . . . . . . . . 153

perai ............... 239, 242

Perea saxatilis. bimaculata.

396

perporosus, Hypophthalmus.... 141

peruana, Piabina. .......... 226

Pimelodella.............47, 101

peruanus, Aplocheilus......... 346

Arges . . . . . . . . . . . . . 166

Astroblepus........50,51,59, 166

Bryconamericus............ 225

Chasmocranus.......... 43,91

Creagrutus .... 49,51,52,60,226

Cyclopium............... 166

Duopalatinus...........47, 107

Rivulus . . . . . . . . . 60, 346

PERUGIA . . . . . . . . . . . . . . . 115

agassizii......44, $47,48,53,117$

perugiae, Centromochlus.....50, 118

peruvianus, Hyphessobrycon. 45, 281

petleyi, Loricaria.............47,208

Rhineloricaria............. 208

PHENACOGASTER. ...............219

bairdi.................. 219

bondi................ 232

pectinatus..........44,55, 219

phoenicopterus, Astyanax...... 224

Bryconamericus ......... 45, 224

Tetragonopterus ............ 224

PHRACTOCEPHALYS.......... 110

bicolor ................ 110

hemiliopterus........43,53,110

phrixosoma, Hypostomus .....47, 185

Plecostomus .............. 185

PHITSOPYXIs.................. 129

Iyra.................44, 129

Piabina peruana ............. 226

Piabuca ................... 255

argentina................ 255

PIABUCINA . . . . . . 276, 277, 278, 279

clongata ............50,51, 278

crythrinoides . . . . . . . . . . 278

unitueniata.........50,50, 278

PIABtCtis ................. 255

dentatus .........45,56, 255

piabuques, les............. 257

PIARCTL's . . . . . . . . . . . . . 247

nigripinnis ......45,56,247, 248

pictus, Ancistrus (Lasiancistrus) 191

Bagrus .................. 111

Hypostomus . . . . . . . . . . . 191

Lasiancistrus ............47.191

Leporinus............... 308

l'imelodus . . . 43, 47, 48,53,102, 104

'Trichomyeterus. . . . . . . . . 153

Pimelodas lateristriga......... 99

PIMELODELLA . . . . . . . . 65, 98, 107

boliviana.........47,53,100

buckleyi .......43, 48, 50,53, 99

cristata, cristatus ...43,48,53,100

cyanostigma........... 43,101

gracilis ...........50,53,59, 109

hartii ................. 101

hartwelli ..............47,99

hasemani.........43,48,53,100 
PIMbededitat-Continued

lateristriga _... $43,53,99,100$

meeki......

montana.

peruani

puruense, puruensis

rocente

transitoria

PIMLIODID AI"

PIMEJ,ODINA.

flavipinnis

I'IMEI,OININA

PIMELODLS

agassizii

altipinnis.

altissimus.

bathyurus

buekleyi.

bufonius.

clarias.

cristafus

ctenodus.

cyanostigma

eques.

fasciatum, fasciatus

galeatus.

$3,53,99,100$
$\ldots \ldots, 101$

$51,59,100$

47,101

$13,53,95$

$52,59,98$

. 101

27,87

88

$43,53,88$

63.85

92,102

100

106

17, 104, 106

91

gracilis .

humilis. .

jivaro.

lateristrigus

leptus.

longicauda.

macropterus

maculatus

ophthalmicus

$43,47,48,53,104,105$

pentlandi

pictus..... $43,47,48,53,102,104$

(Pseudopimelodus) pulcher.... 91

quelen, queleni.......... 92, 93

raninus. . . . . . 90. 91

schae. .

westermanni

94

zungaro................. 90

Pimelotropis................ . $8 \mathrm{~s}$

lateralis. ................. Ss

Pinirampus agassizii........116, 117

piperata, Tympanopleura...... 135

piperatus, Imparfinis . . . . . . . 96

pira-ca $a-a \ldots \ldots \ldots \ldots . . . \ldots . . . .386$

piracicabae, Parodon ......... 286

piramuta, Bagrus.

Piramutana .........46,53,97

IIRAMLTANA ............. $9 \gamma$

piramuta..........46,53,97

pirana, piranha

$143,239,242,243,244,245,271,330$

pirarocon, pirarucu. $\quad 9,27,63,33 \mathrm{~s}$

pirarucu, Sudis . . . . . . . . . 337

piraya ............ 234, 242, 245

piscatrix, I'seudorhamdia . . . . . 101

Pithecocharax ... . . . . . . . . 303 ucayalensis

PLAGIOSClOS

auratum

auratus iquitensis.

squamosissima, squamosissimum $46,+8,58,896$

squamosissimum iquitensis. . . 380

planiceps, Platystoma........ 115

Sorubimichthys .......4, 53, 115

Platax sealaris.

$+406$

platycephalus, Chactostomus... 51

PLATYDORAS

costatus

$44,49,54,126$

Platygaster.

platyrhynchos, Inemisorubim

334

$$
\begin{array}{r}
44,47,53,114 \\
\text { Platystoma ............ } 114
\end{array}
$$

P'atystacus verrucosus......... 84

Platystoma....108, 111,112, 113, 114

emarginatum

fasciatum

gigas.

jurtuense

lima.

planiceps

platyrhynchos

punctifer

spatula

sturio.

vaillanti

platystoma, Hartia

. 107

107
108

115

111

113

115

114

109

115

113,114

PI ATYTOMATICHTHYS .

sturio

$44,47,53,113,114$

plazai, plazaii, Vandellia..47, 54, 161

plecostomus. .........182, 183, 185

bicirrhosus.

biscriatus.

cmarginatus

genibarbis

guacari.

maculatus

pardalis

pellegrini .

phrixosoma

plecostomus

scopularius.

virescens.

wer theimeri

Loricaria . . . . . . . . . . . 184

Pleenstomus

PIECTOGNATHI

T'LETIODECTLE

erythrurus

Pleuronectes achirus

lineatus. ............... 407

plumbeus, Cetopsis ........... 149

Hemicetopsis . ......50,54,59,149

Poecilosomatops ............. 288

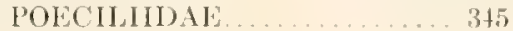

POECILOBRYCON . . . . . . . . . 28Y eques

45. 289

harrisoni 280

Poccilurichthys moenkhausii . 234

unilineatus 220 !

poccilus, Microglanis

Pogronopona 183

polyacanthus, Monoeirrhus $\quad 343$

Polyeentrus $38 \% 3$

polyodon, Hemibryeon ..51, 216, 214

polystictus, Tympanopleura 13!)

pongo 7

pongoense, Apareiodon ......45, 286;

poraqué

porcinum, Sternarehogiton

$46,50,324,325$

POROTLRGUS. . 318, 322, 323, 325, 326

gimbeli .........4 46,57,328,324

gymnotus ..........32:, 32:3, 324

terminalis.........46,323,324

POTAMORHINA 289

pristigaster $\quad 45,56,289$

POTAMORRHAPHIS 381

guianensis $\quad 46,48,58,381$

POTAMOTRYGON 82

humboldtii.

hystrix...... 46, 48, 53, 83

PO'AMOTRVGONINAE

praclionum, Astroblepus

prenadilla, Arges

Astroblepus....5.51,59, 165, 168

Brontes 16.5

Cyclopium 165

Primodontos gigas 338

prionomus, Rhinodoras 1.30

PHISTIGASTER 393

cilyanus $\quad 46,48,50,58,338$

martii 334

pristigaster, Curimatus 289

Potamorhina $\quad 45,56,289$

PROCHIIODINAF

PROCHILODUS 252,307, 309

amazonensis, amazonicus

$16,48,57,311$

argenteus............. 309

caudofasciatus.....48,51,60, 311

cephalotes.............46, 810

insignis.........46,57,310, 311

nigricans

$46,48,50,51,52,57,60,809,310$

ortonianus

16. 310

rubrotaeniatus $\quad 16,57,309,311$

theraponeura $\quad 46,48,310,311$

profunda, Moenkhausia 2032

protective behavior $\quad 3,55$

coloration ins.

form

resemblaner 355

Proteropodes, Siluridae.... . 163, 166

proteus, Creniciclila 105

PSBCThOGASTER 28? 


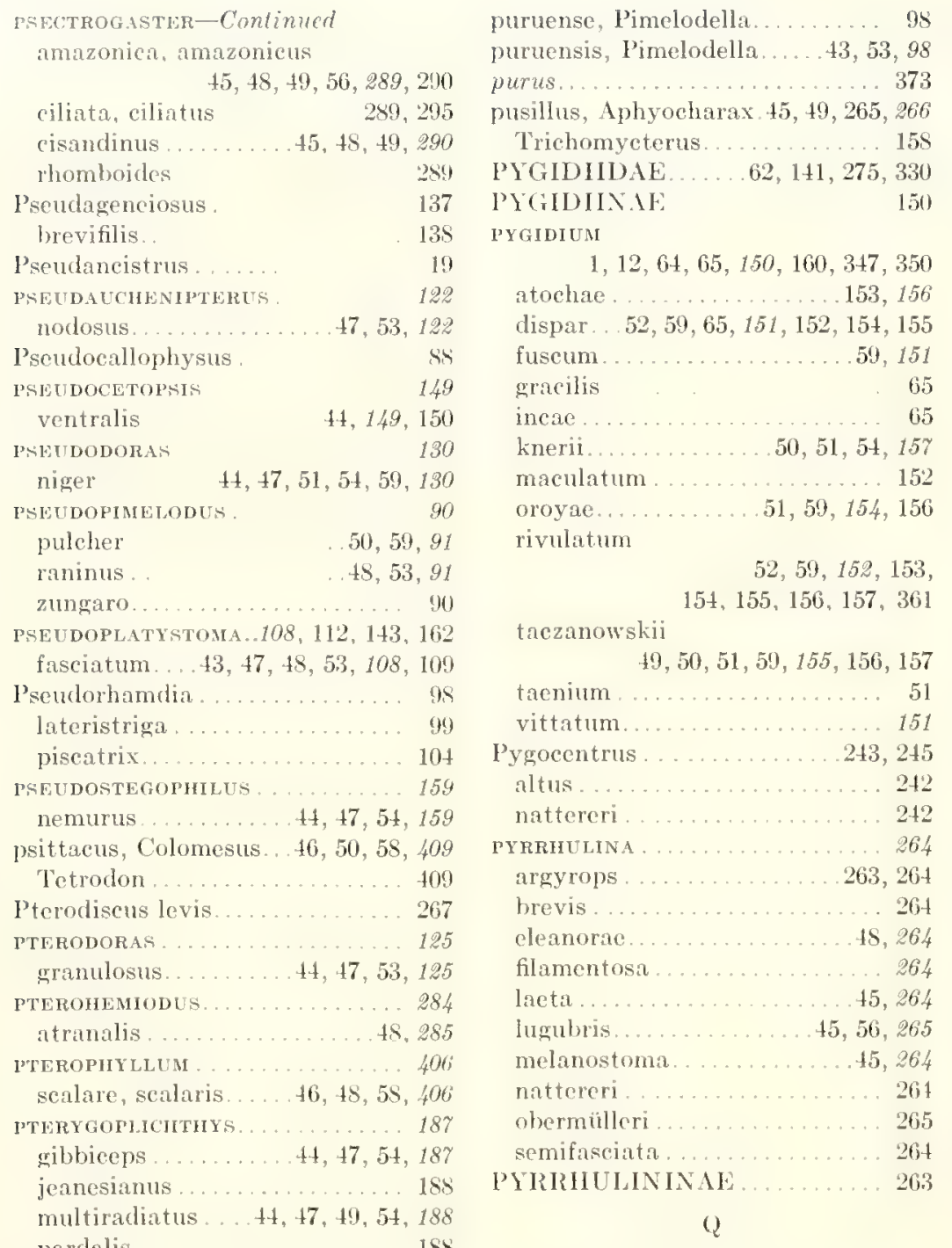

puruense, Pimelodella

$\ldots .98$
$43,53,98$ puruensis, Pimelodella.....43,53, 98 purus..................... 373

Trichomycterus............155 PYGIDIIDAE .....62, 141, 275, 330 P'TGIDISTA

I'YGIDIUM

$1,12,64,65,150,160,347,350$

atochae ...............153, 156

dispar . 52, 59, 65, 151,152, 154, 155

fuscum ............. 59,151

gracilis

incae.

knerii.

maculatum

oroyae.....

rivulatum

$50,51,54,157$

57

$51,59,154,156$

$52,59,152,153$ $154,155,156,157,361$

taczanowskii

$19,50,51,59,155,156,157$

taenium

vittatum.

Pygocentrus

altus

nattereri .

PYRRHULINA.

argyrops

hrevis .

eleanorae.

filamentosa

laeta.

lugubris

melanostoma

nattereri.

obermülleri

semifasciata

PYRRHULININAF

$Q$

quadrimaculatus, Silurus. . . . . 102 quadrizonatus, Chasmocranus

quelen, queleni, Pimelodus..... 92

Rhandia ......43, 48,51, 53,59,93 R

raninus, Batrachoglanis

Pimelodus .............90,91

Pseudopimelodus.......48,53,91

IReganina ................ 248

bidens................ 248

reticulata, Crenicichla........ 401

Curimata...... . 48, 295

reticulatus, Batrachops $50,58,403,404$

retropinnis, Bunocephalus..... 85 IRHABDOLICHOPS........312, 313, 816

Rhamdella............... 97 RHAMDIA .............. 98,97

bathyurus..............43,94
$50,59,91$

longicaudatus .........46, 917 cyanostigma

dorsalis

duquei.

humilis.

longicauda.

micayi.

mounseyi. .

parvus.

pentlandi

.... 101

$43,95,96$

$52,59,93$

$43,51,53,94,96$

\section{7}

93

46,94

quelen, queleni $43,48,51,53,59,93$

riojae..........51,52,59,95

sebae ..............46,53,94

RHAMPHICHTHY INAE . 312,327

RHAMPHILTHYS. . . . . . . . . 327

brevirostris $\quad . \quad 314$

elegins $\quad 314$

lineatur.... 328

marmoratus ....46, 48, 57, 327, 328

mülleri................ 314

pantherinus .............. 328

rostratus ......4.46,57, 327,328

Rhamphosternarchus ......... 318 macrostomus.............. 319

RHAPHIODON 271

gibbus................ 272

vulpinum, vulpinus

$45,48,49,56,271$

rhinelepis................. 183

agassizii ............... 183

genibarbis ............... 183

Ihineloricaria konopickyi ..... 204

morrowi ................... 208

petleyi 208

wolfei .................. 203

lihinodoras ............... 130

niger................. 130

prionomus................ 130

rhombeus, Salmo .........229, 240

Serrasalmo, Serrasalmus $45,49,55,240,241$

rhomboidalis, Myletes......... 251

Myloplus.............56, 251

rhomboides, Psectrogaster..... 289

RHYTIODUS................. 304

argenteof uscus .......46,57,304

microleps $\quad \quad 46,48,57,304$

riojae, Rhamdia.....51,52,59,95

rivulatum, Pygidium

$52,59,152,153$ $154,155,156,157,361$

rivulatus, Trichomycterus ..... 152

RIVULUS ............... 345

brasiliensis .............. 346

cylindraceus .............. 345

micropus... $\quad 46,55,846$

peruants..... $\quad 60,346$

urophthalmus.... .46,50,58, 346

robador $\quad 27$

robustula. Curimata........49, 298

robustulus, Hemigrammus. . . . 230

Hyphessobryeon.........45,230

Tetragonopterus ............ 230 


\begin{tabular}{|c|c|}
\hline \multicolumn{2}{|l|}{ rocene, Pimelodella } \\
\hline ROEBOIDES . . ....... & $.242,257$ \\
\hline affinis.... & $47,49,56,258$ \\
\hline bicornis. & $\ldots 45,47,258$ \\
\hline myersii .... & $45,47,49,258$ \\
\hline rubrivertex & $25 \mathrm{~s}^{\circ}$ \\
\hline rondoni, 'Tympanopleu & $13 ! 9$ \\
\hline ROOSEVELTIELLA ..... & 241 \\
\hline alta, altus & $45,47,49,242$ \\
\hline nattereri & $45,47,55,242$ \\
\hline rospigliosii, Orestias... & $\ldots \ldots 52,61,381$ \\
\hline rostrata, Loricaria.... & $\ldots \ldots 212,213$ \\
\hline Oxyloricaria & 213 \\
\hline Sturisona $\quad 44,47$, & $49,55,212,213$ \\
\hline rostratus, Carapus & 327 \\
\hline Gymnotus & $327,32 \mathrm{~s}$ \\
\hline IRhamphichthys & $46,57,327,32 \mathrm{~s}$ \\
\hline rotundatus, Chalcinus & $45,56,262$ \\
\hline rotundatus, Chalceus & 262 \\
\hline rubripinnis, Myletes & 252 \\
\hline Myleus & 252 \\
\hline Myloplus & $47,56,252$ \\
\hline Mylosoma & 252 \\
\hline rubrivertex, Roeboides & 258 \\
\hline
\end{tabular}

rubrotreniatus, Prochilodus

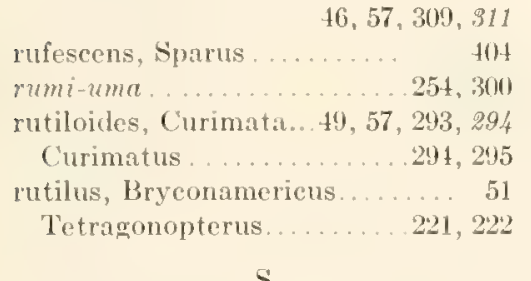

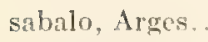

sanguinea, Urinophilus........ 162

Yandellia............... 162

sanguineus, Anacyrtus......256, 257

sanguinolentus, Carapus ....... 313

San Pedro................. 308

sapo mama. 261

areodaces

SAIRCODACINAE

saxatilis, Crenicichla

271, 274

$46,48,50,51,52,58,61,404$

Perca.

Sparus .................. 404

scalare, Pterophyllum....46, 58, 400

scalaris, Platax............. 406

P'terophyllum

SCHIZODON.

400

fasciatum, fasciatus

sagittarius.

$46,48,49,57,303$

treniatus

trimaculatus.

Schizodontopsis.

304

304

schmardae, Hemigrammus 45, 55, 229

Tetragonopterus ...........229

schotti, Sternarchella . $46,48,57,322$ Sternarchus .............. 322

SCIADES................... 111

marmoratus .......... 43,111

SCIAENIIDAE . . . . . . . . . . 386

Sciaena.................... 395

squamosissima............. 386

scolopacina, Belone............ 381

scomberoides, Cynodon ........ 273

Hydrolicus .....45, 48, 49, 56, 273

Hydrocynus . . . . . . . . . . . . 273

Hydrocyon ............... 273

scopularius, Plecostomus...... 181

scrophus, Liposareus.......... 187

Sealeina .................. 246

sebae, Pimelodus............ 94

Pimelodus (Rhamdia)........ 94

Rhamdia..........46,53,94

securis, Gasteropelecus........ 268

seiche ................... 4

SELACHII .......... 82

semifasciata, Pyrrhulina.......264

semiscutatus, Brochis......... 180

Brochis (Chaenothorax)...... 180

Chaenothorax.......44, 180,181

Corydoras ................ 180

Semitipicis................. 300

laticeps.................. 300

seneschali, Orestias ........... 373

sericea, Chaetostoma .......44, 194

Xenocara.................. 194

sericeus, Chatostomus......... 191

Serrasalmo, SERRASALMUS

$147,239,241$

elongatus... . $47,49,55,240$

humeralis $\quad 45,47,49,52,55,241$

immaculatus .210

iridopsis

241 maculatus

marginatus

$45,49,55,241$

241

nattereri 242

vesopus

rhombeus......45, 49,55,240,241

spilopleura....45,55, 299, 240,241

SEIRIRASALMONINAE . 239, 245, 246

setiger, Myleus........47, 55, 247

severum, Cichlnsoma 396

severus, Astronotus (Heros) 396

Cichlaurus .....46, 48,50,58, 896

shirui, Hoplosternum ....... 47, 17\%

shitari................135, 202

siebenthalae iquitensis $\quad 254$

silgo. $\quad 364$

Siluridae Proteropodes $\quad 163,169$

Siluroidei Astroblepiformes $\quad 163$

Trichomyeteriformes 141

Siluroides. 181

Silurus callichthys $\quad 170$

candiru. 148

carinatus 132

clarias 104

costatus. $\quad 126$

fasciatus 108

galeatus... 119

hemiliopterus $\quad 110$

lima.. $\quad 113$

nodosus....... 122

quadrimaculatus $\quad 102$

silustani, Orestias

$52,61,352,354,356,366$

silve ............... 357

simillima, Loricaria.......50, 207

simonsii, Arges ............. 166

Astroblepus...........59, 166

Cyclopium............... 166

simulata, Curimata.........49, 298

Moenkhausia.....47,52,60,232

simulatus, Astyanax $\quad, 232$

Curimatus. 298

smithi, Farlowella $\quad 44,49,214$

Solea nattereri........ tos

(Achiropsis) nattereri $\quad 408$

SOLEIDAE $\quad 407$

solyman $\quad 30$

SORUBIM. . $112,114,115,144$

$\operatorname{lima} \ldots \ldots \ldots \ldots .44,47,48,53,118$

SORUBIMICHTHYS 115

gigas $\mathrm{ti}, 115$

ortoni 115

planiceps... $11,53,115$

Sparus $\quad 40$

rufescens . 404

saxatilis. 404

surinamensis $\quad 3(99$

spatula, Platystoma 115

Sphyraenocharax $\quad 275$

spilopleura, Serrasalmo........ 239

Serrasalmus $\quad 45,55,289,240,241$

spilura, Curimata....45, 57, 292, 2914

Curimata (Cyphocharax) 292 
spilurus, Curimatus........... 292

spixii, Loricaria.............. 204

Parahemiodon .............. 205

splendens, Callichthys ......... 181

Corydoras ................ 181

Osteogaster..........4t,54,181

spuria, Acara (Heros)........., 396

spurius, Heros ................ 396

spurrelli, Nannorhamdia....... 97

squamosissima, Diplolepis..... 386

Pachyurus................ 386

Plagioscion ................ 386

S'ciaena................. 386

squamosissimum, Plagioscion

$46,48,58,386$

Starksina................. 249

herniarius.............. 249

Steatogenes, steatogenys..... 313

elegans............46,57,314

steatops, Anodus............. 301

STEGOPHILINAE . . . _ . 158

STEGOPHILUS .......... 142, 158, 159

insidiosus.............. 14

intermedius................ 158

macrops ............... 158

nemurus................. 159

punctatus................ 155

steindachneri, Bario

$45,55,232,233,235$

Centromochlus ..........44, 118

Characidium..........45, 288

Entomolepis............... 235

Leptagoniates...........50, 270

Moenkhausia.............. 235

Tetragonopterus ............. 235

stellatus, Gasteropelecus.... 265, 269

Thoracocharax . 45, 49,56, 268,269

stenocephalus, Corydoras....47, 177

stenopeltis, Corydoras......... 133

Hemidoras ..........4, 54, 133

Hemidoras (Oxydoras) ....... 133

STERNARCHELLA .......... 318, 922

balaenops................ 327

schotti.........46, 48,57, 322

Sternarehinae

318

STERNARCHOGITON .....318, 324, 325

nattereri $\ldots 46,57,323,324,325,326$

porcinum......4.46,50,324,325

sachsi

STERNARCHORHAMPHUS 318,319

macrostomus. $\quad 46,50,319$

mülleri. $\quad 48,57,320$

WTERNARCHORHYNCHUS. . 318

curvirostris 319

macrostoma. . 319

mormyrus 319

miilleri $\quad 318,319,320$

oxyrhynchus $\quad 46,50,57,318,310$

Stermarchus

albifrons ..............51, 320

balaenops

327

bonapartii hascmani

322

leptorhynchus

321

macrostoma

maximilliani

mormyrus

mülleri

mattereri

oxyrhynchus

sachsi

schotti.

virescens

(Rhamphosternarchus) curvirostris

$$
\text { mülleri }
$$

sternicla, Clupea

Gasteropelecus

266,267

TEIRNOPYGINAE

$48,56,267$

STLRNOPYGUS

carapo, carapus

humboldtii.

maturus

$16,48,50,51,52,57,60,318,323$

troscheli

virescens

STETHAPRION

chryseum

erythrops

STH'HAPRIONINA

$64,312,31$

312

313,315

313,329

315

stolzmanni, Brycon.......51, 60, 254

striatulus, Auchenipterus....... 119

Brycon

Trachycorystes

striatus, Leporinus

51
110

strigata, Carnegiella

$50,57,305$

strigata, Carnegiela

$45,56,269$

strigatus, Gasteropelecus.

- 269

stubelii, Brycon

45, 253

Hemidoras

135

Ioricarin

Opsodoras.

Oxydoras

49,204

49,135

135

sturio, Platystom

113,114

l'latystomatichthys

$$
44,47,53,113,114
$$

STURISOMA ........... 211, 212

güntheri.........4t, $49,55,213$

nigrorostrum ........... 47,213

rostrata. .

55

rostratum,

$44,47,49,212,213$

Styogenes...

humboldtii

subocularis, Acara

165

Equidens

394,398

suborbitalis, Parodon

46, 394

suche, suchi.......5, 22, 152, 153

Sudis

gigas

337,338

pirarueu

337

supramollis, Astroblepus. $.50,59,166$

surinamensis, feophagus

Sparus

$46,48,58,399$

SYMBIRA YCIIIA
STMBRANCHIDAF... 331

symbranchus, Synbranchus . . . 831

marmoratus ....46,50,58, 331, 332

SYNENTOGNATHI 351

Synodus.. . $\quad 282$

erythrinus $\quad 282$

malabaricus . . . . . . . . . . . 280

syspilus, Acara..........51, 394

Equidens

394

I

tabatingae, Tetragonopterus . 219

taczanowskii, Arges $\quad 167$

Astroblepus . . $\quad \ldots 49,51,59,167$

Chactostoma, Chaetostomus

$49,51,52,59,191,193$

Cyelopium............. 167

Pygidium 49, 50, 51, 59, 155, 156, 157

Trichomycterus 155

taedo, Xiphostoma... . 274

taeniata, Belone _ . . 381

Laemolyta

$45,49,302$

taeniatum, Biotodoma . 401

Heterogramma.. _. 401

taeniatus, Anostomus . $\quad 302$

Geophagus . $\quad .400$

Mesops $\quad 400$

Schizodon _... 302

Tetragonopterus . $\quad 231$

taenium, Pygidium.... . 5l

Taeniura , 82

tamoata, Callichthys. $\quad 170$

Larafa, taraya ......25, 199, 207, 307

Tareira . 280

tectifer, Anaeyrtus .. $\quad 256$

Charax $45,256,257$

tectirostris, Chactostomus .... 197

Telmatobius culeus .......... ¿2

temensis, Cichla .......50,58, 409

temminckii, Ancistrus

Hypostomus 198

Xenocara......... 198

temporale, Cichlasoma..... . 397

temporalis, Cichlaurus......58, 397

Heros................ 397

tenuis, Iguanodectes.... 45, 56, 255

terminalis, Aparciodon........ 286

Porotergus.........46,323, 324

TETRAGONOPTERINAE . 215

TETRAGONOPTERUS. . . . . 218, 219, 235

abramis $\quad 222$

agassizii . $\quad 231$

alosa ... 221

argenteus

$45,47,49,52,55,60,64,236$

bardii 219

bartlettii. . 20

chalceus.........45,55, 234, 237

compressus $23 \mathrm{~K}$

diaphanus $\quad 224$

fasciatus $\quad 222$ 
TETRAGONOPTERUS-Conlinued

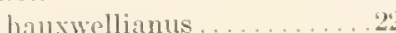

huambonicus.............. 216

ipanquianus............... 218

jelskii...................218

lineatus............... 235

Iongior . . . . . . . . . . . . . . 21

maculatus ................ 220

maximus . . . . . . . . . . . . 221

oligolepis ............... 231

orbicularis. ............. 2. 231

ortonii ................. 237

ovalis. ... . . . . . . . . . . 231

pectinatus . . . . . . . . . . . 210

phoenicopterus............ 221

robustulus. . . . . . . . . . . . . 230

rutilus . . . . . . . . . . . . 221, 22,2

schmardae............... . 22y

steindachneri............. 235

tabatingae ................ 219

taeniatus ............... 231

xinguensis . . . . . . . . . . . 231

tetramerus, Acara........... $33^{2}$

Equidens . 46, 48, 50,52, 58, 61, 392

Astronotus . . . . . . . . . . 39. $39^{2}$

Astronotus (Equidens) . . . . . 392

tetraodon, Ostracion........... 400

TETTAODONTID.1L ........ 408

letrodon ................... tos psittacus

thayeri, Geophagus

theraponeura, Prochilodus

$46,48,910,311$

Theraps 395

thoraentum, Hoplosternum

$44,47,49,171$

Hypoptopoma...44, 47, 49, 55, 200 thoracatum thoracatum, Hoplosternum ..........5t, 171

thoracatus, Callichthys

171

THORACOCHARAX

pectorosus.

266,268

stellatus $\quad 45,49,56,268,269$

Thrichomycterus . . . . . . . . . 150

timbó..................... 30

timminckii, Ancistrus. .

tirapatae, Orestias .......371, 374

toro .................. 131

TRACHYCORYSTES............. 118

breviharbus ............44, 120

coracoideus ...........4, 120

galcatus......4t, $45,53,119,121$

isacanthus...........44, 120

striatulus. . . . . . . . . . . . 119

typus.................... 118

TRACHY DORAS .............. 181

atripes..........44,54,131, 182

nattereri.....44,47,54, 131, 132

trachystetha, Curimata.....45, 293

trachystethus, Curimatus ...... 293

Curimatus bimaculatus ...... 293

trahira, Erythrinus............ 280
Macrodon.

Iraira

transitoria, Pimelodella

Trichomycteridae.

lriehomycteriformes Siluroitei 141

Trichomycterus. ............ 150

barbatula.

dispar.

gracilis

incae

knerii

pardus

pentlandi.

pictus.

pusillus.

rivulatus

taczanowskii.

vittatus.

TRIDENS.

melanops.

tridens, Hemibryeon.

trifasciatus, Astroblepus .

Ieporinus.

trilineatus, Corydoras

trimaculata, Acaronia

trimaculatus, Anostomus

Schizodon.

Trinectes

Triportheus

albus.

Havus.

152,153

153
.153

153

157

$15: 3$

153

158

158

152

155

2161

$142,163,216$

44,163

60,216

167

$49,57,307$

$17 t$

46,389

$16,57,30.3$

303

407

260

200
262

troscheli, Eigenmannia

$46,48,315,316,318$

Sternopygus .............. 316

troschelii, Sternopygus....... 316

Trutta dentatus............. 255

Trygon hystrix .............. 83

miilleri

tschudii, Orestias $61,349,351,352,354,356,379$

lucunari ................. 40 .

TYLostrú. . . . . . . . . . . . . 388

ncus................. 35

amazonicus $46,48,50,52,58,61,382$ cantraini ............... 35?

TYMPANOPLEURA ........... 138

alta ...............4, 189

nigricollis ...........4, 199

piperata .

polystictus

rondoni.

138

rondoni

139

tyea, Orestias.

typus, Loricaria.

Parahemiodon.

'I'rachyeorystes.

$55,204,205$

373

UARU . . . . . . . . . . $\$ 89$

amphiactunthuicles

$46,48,58,359,390$

imperialis ............. 390

Uarus centrarchoides. ......... 396 insignis. . . . . . . . . . . . . 395

uhidiai, Astroblepus. ........ 168

Cyclopium............... 168

ucayalensis, Ageneiosus. $44,47,54,137$

Anostonus .............48, 303

Chromys................ 357

Curimatoides............48.299

Hassar .............. 47, 185

Hemiancistrus . . . . . . . . 17. 185

Loricaria............ 47,205

Loricarichthys. . . . . . . . . 205

Pithecocharax ........... . 303

cmanto ................ 350

unilineatus, Poecilurichthys. . . 220

unimaculatus, Salmo.......... 284

uniocellata, Chromys......... 392

unitaeniata, Piabueina ...50,56,278

unitaeniatus, Erythrinus.......281

Erythrinus (Ophiocephalops).. 281

Hoplerythrinus ......45,48,56, 281

URINOPHLUS, . . . . 142, 143, 145, 161

diabolicus .........44, 143, 162

crythrurus. . . 44, $47,49,54,143,162$

sanguineus . . . . . . 162

urophthalmus, Rivulus $46,50,55,346$

\section{V}

vaillanti, Platystoma

111

YANDEIA $112,147,16$

cirthosa ............. 161

plazaii............47,54, 161

sanguinea . . . . . . . . 162

VANDELLIINAE ............ 161

variola, Chaetostoma.......44, 194

variolus, Chactostomus ........ 194

varius, Liposarcus . . ........... 18s

Vastres................... 330

gigas .................. 338

venezuelanus, Corydoras........ 174

ventralis, Cetopsis............ 119

Pseudncetopsis .........149,150

verrucosus, Platystacus....... 81

vestitus, Otocinclus .......4, 201

vicinus, Hypostomus. . . . . . . . . 189

virescens, Eigenmannia

$46,48,50,57,315,316$

Plecostomus .............. 18

Sternarchus .............. 315

Sternopygus ............. 315

vittata, Acara . . . . . . . . . . . . 393

Crenicichla.............. 101

vittatum, Pygidium .......... 151

vittatus, Acara.... 393

Aquidens........46, 18, 50, 89.3

Chalcinus...........49,56,262

Leporellus ..........46,57, 808

Icporinus. . . . . . . . . . . . . . . 300

"l'richomycterus. ............ 151

vulpinum, Rhaphiodon

$45,48,49,56,271$

vulpinus, Cynodon..........271 
IV

Waiteina.................. 248

warapaima................. 330

weddellii, Doras.............. 128

wertheimeri, Plecostomus ....... 18.3

westermanni, Pimelodus........ 104

wolfei, Leporinus. ....... . . . 48, 306

Loricaria. . . . . . . . . . 47, 208

Rhineloricaria . ........... 203

$\mathrm{X}$

XENOCARA ............... 196

bufonia................. 197

cirrhosa ...............194, 199

hoplogenys ................ 197

latifrons................44, 196

occidentalis................. 195

sericea................... 194

temminckii................. 198 xinguensis, Tetragonopterus

Niphorhamphus

abbreviatus.

falcatus.

falcirostris

ferox.

heterolepis. .

microlepis

Xiphorhynchus

falcatus

falcirostris.

XIPHOSTOMA

cuvieri...

maculatum

taedo.

XIPHOSTONIDAE

IIPHOSTONINAE
231

274

275

276

275

276

276

276

274

276

275

274

274

$45,49,274$

274

274

274 yahnarache, yanarache.. . . 300

yavarachi, llavarachi... . . . 294

yulilla

301

athorax $\quad 127$

monitor... 128

nauticus $\quad 128$

zonatus, Microglanis.. . 43,89

zungaro, Pimelodus.... . . 90

l'seudopimelodus. ... $\quad 90$

Zungaro. . . ........ 90

zungaro... $43,46,53,90$

ZUNGARO .... .... 90

zungaro $\quad 43,46,53,90$

zygatus, Corydoras... . .49, 175 


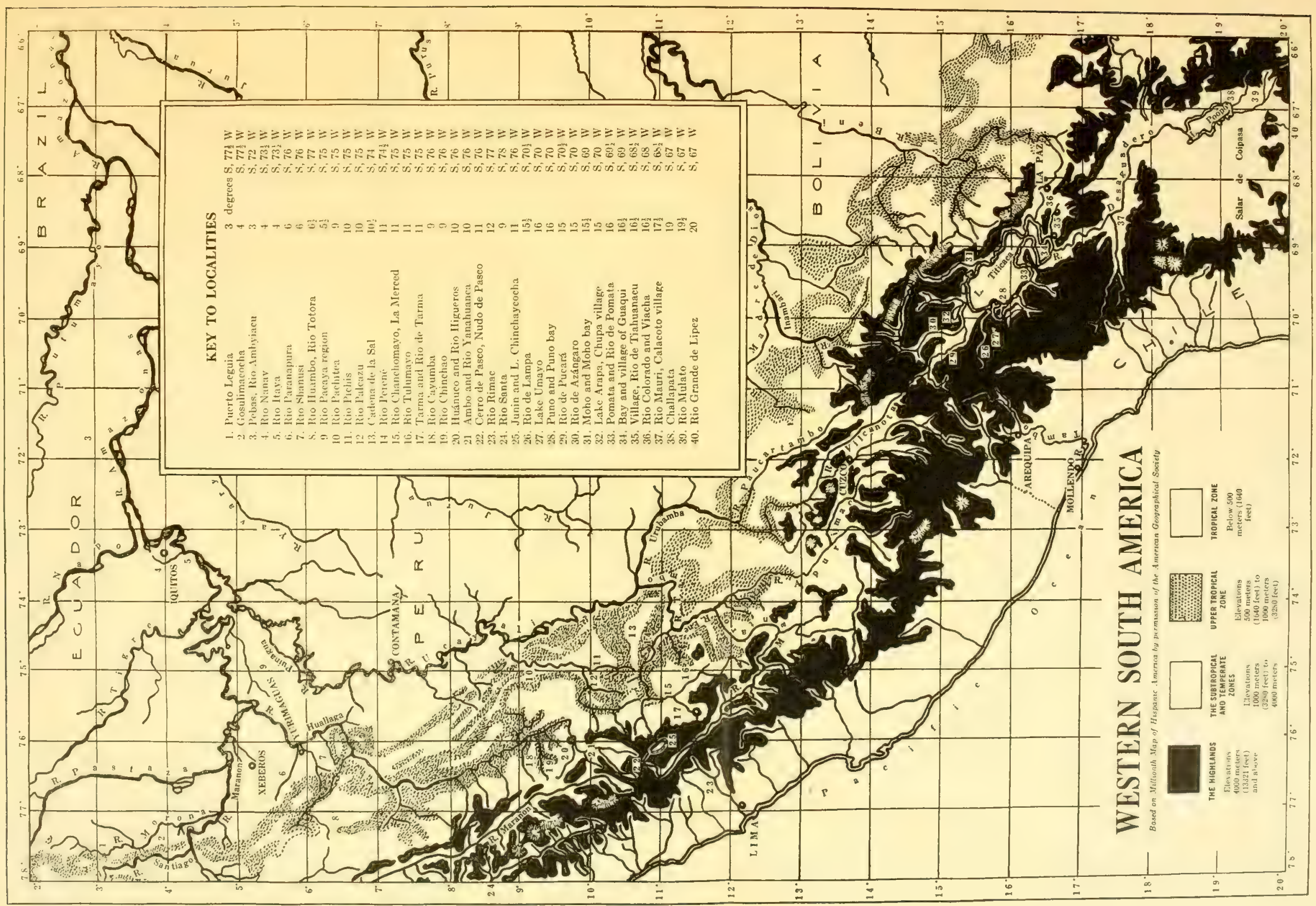









